\begin{tabular}{|c|c|}
\hline \multicolumn{2}{|l|}{$\begin{array}{l}\text { 2. ECN Category } \\
\text { (mark one) }\end{array}$} \\
\hline $\begin{array}{l}\text { Supplemental } \\
\text { Direct Revision } \\
\text { Change ECN } \\
\text { Temporary } \\
\text { Standby } \\
\text { Supersedure } \\
\text { Cancel/Void }\end{array}$ & $\begin{array}{r}{[]} \\
{[x]} \\
{[]} \\
{[]} \\
{[]} \\
{[]} \\
{[]}\end{array}$ \\
\hline
\end{tabular}

12a. Modification Work

[] Yes (fill out Blk. 12b)

[X] No (NA Blks. 12b, 12c, 12d)

13a. Description of Change

3. Originator's Name, Organization, MSIN, and Telephone No.

D.L. Sherre11, R3-86, 376-0937

6. Project Title/No./Work Order No. SNF Project

9. Document Numbers Changed by this ECN (includes sheet no. and rev.) WHC-SD-SNF-TI-009 ReV OA

\begin{tabular}{|l|l|l|l}
\hline 12b. Work Package & 12c. Modification Work Complete & $\begin{array}{l}\text { 12d. Restored to Original Condi- } \\
\text { tion (Temp. or Standby ECN only) }\end{array}$
\end{tabular}
No.

N/A $N / A$ N/A

1) Incorporate ECN 645035 (which revised the tables to reflect: improved cross section data, a decision to use accountability data as the basis for total $\mathrm{Pu}$, a corrected methodology for selection of the heat generation basis feed, and a revised decay date);

2) Add section 3.3.3.1 ("Limitations of the Methodology") to expand the description of the approach used to calculate the inventory values and explain why that approach yields conservative results;

3) Change the pre-irradiation braze beryllium value (in sec 3.3.1) from $137 \mathrm{~g}$ per assembly to $1.37 \mathrm{~g}$ per assembly (this was a "type-0"--the $142 \mathrm{~kg}$ value remains unchanged in Table 3.4). Revised chemical tables (Tables 2.1 and 3.4 )

4) Incorporate miscellaneous, non-substantive, editorial changes throughout the document, including elimination of Fig. 3.2 ("Fuel Storage Areas...")

14a. Justification (mark one)

Criteria Change [] Design Improvement [] . Environmental

As-Found

[] Facilitate Const

[]

Const. Error/Omission

[]

Facility Deactivation Design Error/Onission

[]

14b. Justification Details

Availability of improved neutron cross section data justified changes to tables -- See ECN 645035 for additional details. Typographical error on beryilium value in section 3.3.1 required correction. Fig. 3.2 conveyed no unique information. The quantities listed for fission products in the "chemical tables" (Tables 2.1 and 3.4) were not consistent with results from the ORIGEN2 calculations.

15. Distribution (include name, MSIN, and no. of copies) 


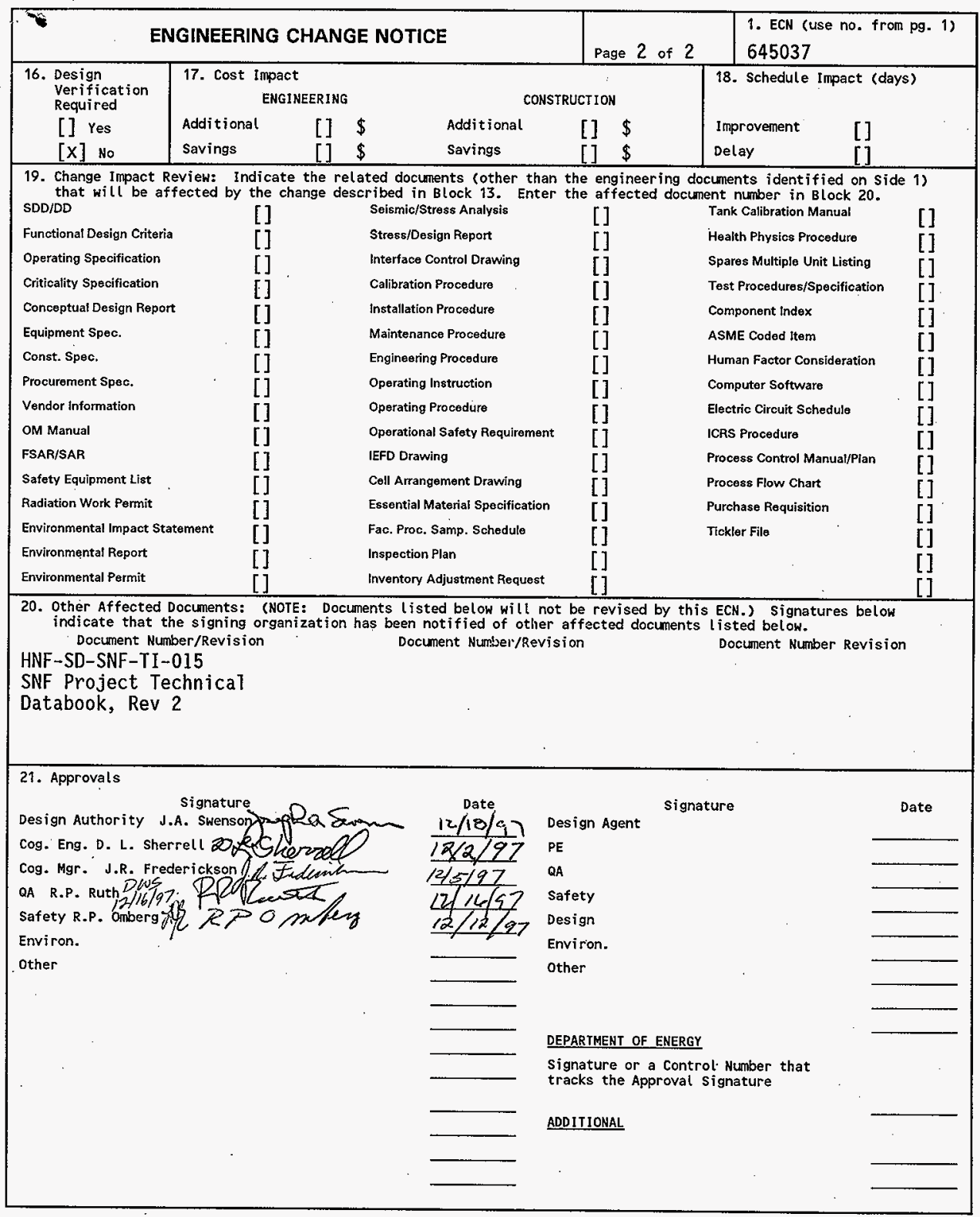




\title{
105-K BASIN MATERIAL DESIGN BASIS FEED DESCRIPTION FOR SPENT NUCLEAR FUEL PROJECT FACILITIES
}

A. N. Praga and *W. L. Will is

DE\&S Hanford, Richl and, WA 99352

U.S. Department of Energy Contract DE-AC06-96RL13200

\author{
EDT/ECN: $645037 \quad$ UC: 510 \\ Org Code: 2T710 Charge Code: LB05I \\ B\&R Code: EW3135040 Total Pages:/77
}

Key Words: N-Reactor fue T, 105-K Basin, SNF Project, spent nuclear fuel, fuel inventory, sludge inventory, design basis feed, radionuclide inventory, chemical inventory, shielding basis, heat generation basis, safety/regutatory basis.

Abstract: Revisions 0 and $O A$ of this document provided estimated chemical and radionuclide inventories of spent nuclear fuel and sludge currently stored within the Hanford Site's 105-K Basins. This Revision (Rev. 1) incorporates the following changes into Revision $0 A$ : 1) updates the tables to reflect: improved cross section data, a decision to use accountability data as the basis for total Pu, a corrected methodology for selection of the heat generation basis fee, and a revised decay date; 2) adds section 3.3.3.1 to expand the description of the approach used to calculate the inventory values and explain why that approach yields conservative results; 3 ) changes the pre-irradiation braze beryllium value (in Sec. 3.3.1) from $137 \mathrm{~g}$ per assembly to $1.37 \mathrm{~g}$ per assembly to correct a typographical error (the $142 \mathrm{~kg}$ value remains unchanged in Table 3.4).

*Numatec Hanford Company, Richland, Washington.

TRADEMARK DISCLAIMER. Reference herein to any specific commercial product, process, or service by trade name, trademark, manufacturer, or otherwise, does not necessarily constitute or imply its endorsement, recommendation, or favoring by the United States Government or any agency thereof or its contractors or subcontractors.

Printed in the United States of America. To obtain copies of this document, contact: Document Control Services, P.0. Box 950, Mailstop H6-08, Richland WA 99352, Phone (50́9) 372-2420; Fax (509) 376-4989.
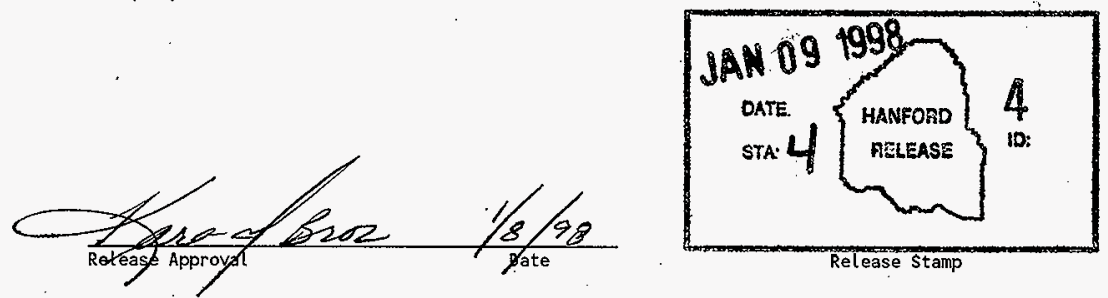
(2) Title

105-K Basin Material Design Basis.Feed Description for Spent Nuclear Fuel Project Facilities

\begin{tabular}{|c|c|c|c|c|}
\hline \multirow{2}{*}{ (3) } & \multirow{2}{*}{ Revision } & \multirow{2}{*}{ (4) Description of Change - Replace, Add, and Delete Pages } & \multicolumn{2}{|c|}{ Authorized for Release } \\
\hline & & & (5) Cog. Engr. & (6) Cog. Mgr. \\
\hline & 0 & (7) Initial Release EDT\# $613002(8 / 01 / 95)$ & $\begin{array}{l}\text { WL Wi11 is } \\
7 / 31 / 95\end{array}$ & $\begin{array}{l}\text { JR Frederickson } \\
7 / 31 / 95\end{array}$ \\
\hline & $O A$ & $\begin{array}{l}\text { Released via ECN\# } 191383(12 / 20 / 95) \text { : } \\
\text { Replace }{ }^{60} \mathrm{Co} \text { and }{ }^{244} \mathrm{Cm} \text { values in tables } 2.2 \text {, } \\
2.4,2.5,2.7,3.5,3.6,3.7,3.8,3.9 \text {, and } \\
3.10 \text { to reflect better estimates of actual } \\
\text { inventory. } \\
\text { Change wording as shown on pages } 29 \text { and } \mathrm{D}-3 \\
\text { to account for change in }{ }^{50} \mathrm{Co} \text { inventory } \\
\text { numbers. }\end{array}$ & $\begin{array}{l}\text { WL Wi11 is } \\
12 / 12 / 95\end{array}$ & $\begin{array}{l}\text { JR Frederickson } \\
12 / 20 / 95\end{array}$ \\
\hline RS & 1 & $\begin{array}{l}\text { Released via ECN\# } 645037(12 / 12 / 97) \text { : } \\
\text { Incorporate ECN } 645035 \text { (which revised the } \\
\text { tables to reflect: improved cross section } \\
\text { data; a decision to use accountability data } \\
\text { as the basis for total Pu; a corrected } \\
\text { methodology for selection of the heat } \\
\text { generation basis feed; and a revised decay } \\
\text { date). } \\
\text { Replace RADNUC output listings in Appendix } \\
\text { B with updated runs for revised decay date. } \\
\text { Add section } 3.3 .3 .1 \text { ("Limitations of the } \\
\text { Methodology"). } \\
\text { Change the pre-irradiation braze beryllium } \\
\text { value (in sec } 3.3 .1 \text { ) from } 137 \mathrm{~g} \text { per } \\
\text { assembly to } 1.37 \mathrm{~g} \text { per assembly (this was a } \\
\text { "type-0"-the } 142 \text { kg value remains } \\
\text { unchanged in Table } 3.4 \text { ). } \\
\text { Remove Figure } 3.2 \text {, "Fuel Storage Areas..." } \\
\text { and renumber subsequent figures in sec } 3 \text {. } \\
\text { Incorporate miscellaneous, non-substantive } \\
\text { editorial changes throughout the document. } \\
\text { Revise chemical tables (Tables } 2.1 \text { \& } 3.4 \text { ). }\end{array}$ & $\begin{array}{l}\text { DL Sherre11 } \\
12 / 1 \text { / } / 97 \\
\text { DL Steernel }\end{array}$ & $\begin{array}{l}\text { JR Frederickson } \\
12 / 14 / 97 \\
\text { REveduri } \\
1211 / 97\end{array}$ \\
\hline & & $\cdot$ & & \\
\hline & & & & \\
\hline
\end{tabular}


HNF-SD-SNF-TI-009, Rev. 1

W.L. Willis and A.N. Praga

NOVEMBER 1997 
HNF-SD-SNF-TI-009, Rev. 1

\section{Table of Contents}

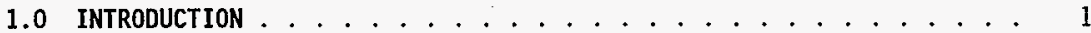

1.1 BACKGROUND ............................ 1

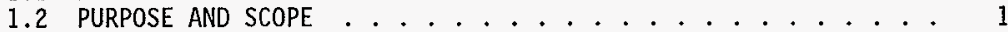

1.2.1 Purpose and Scope of Revision 1 ......... 2

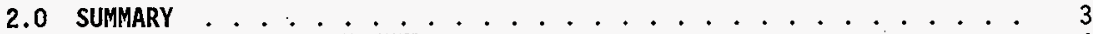

2.1 NOMINAL DESIGN FEED . . . . . . . . . . . . . . . 4

2.1.1 Inventory Totals .............. 4

2.1.2 Unit Mass Uranium Inventory ........... 6

2.2 SHIELDING DESIGN FEED BASES ............. 8

2.3 SAFETY/REGULATORY ASSESSMENT FEED ............ 8

2.4 HEAT GENERATION BASIS FEED . . . . . . . . . . . . 9

2.5 CRITICALITY ASSESSMENT FEED . . . . . . . . . . 10

3.0 N REACTOR FUEL . . . . . . . . . . . . . . . . . . . . . . . . . . . 11

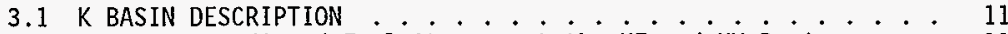

3.1.1 Irradiated Fuel Storage at the KE and KW Basins ... 11

3.2 N REACTOR FUEL DESCRIPTION . . . . . . . . . . . 13

3.2.1 Fuel Fabrication ............... 16

3.2.2 Burnup and Time Since Discharge . . . . . . . . . . 17

3.3 NOMINAL N REACTOR DESIGN BASIS FEED ......... . . 20

3.3.1 N Reactor Fuel Chemical Content Methodology . . . . . 20

3.3 .2 N Reactor Fuel Chemical Inventory .......... 21

3.3.3 N Reactor Fuel Radionuclide Content Methodology . . . 22

3.3.3.1 Limitations of the Methodology . . . . . . . 22

3.3.4 N Reactor Fuel Radionuclide Content . . . . . . . . . 23

3.4 SHIELDING DESIGN BASIS FEED . . . . . . . . . . . 27

3.5 SAFETY/REGULATORY ASSESSMENT DESIGN BASIS FEED . . . . . . 27

3.6 HEAT GENERATION BASIS FEED . . . . . . . . . . . . 28

3.7 CRITICALITY DESIGN BASIS FEED ............ 28

4.0 SINGLE PASS REACTOR FUEL . . . . . . . . . . . . . . 33

4.1 BACKGROUND . . . . . . . . . . . . . . . . . . . . 33

4.2 FUEL DESCRIPTION . . . . . . . . . . . . . . . . 34

4.2.1 Fuet Fabrication . . . . . . . . . . . . 36

4.3 FUEL INVENTORY . . . . . . . . . . . . . 37

4.4 RADIONUCLIDE CONTENT . . . . . . . . . . . . . . . . . . 38

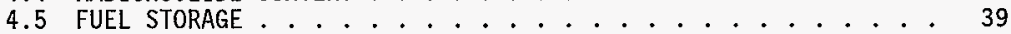

5.0 105-K BASIN SLUDGE . . . . . . . . . . . . . . . . . . 40

5.1 SLUDGE SOURCES . . . . . . . . . . . . . . . . 40

5.2 SLUDGE LOCATION . . . . . . . . . . . . . . . . 40

5.3 SLUDGE DEPTH ........................ 43

5.4 CURRENT INVENTORY BASIS . . . . . . . . . . . . 43

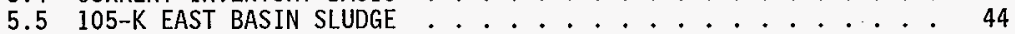

$5.6105-K$ WEST BASIN SLUDGE ................ 48

6.0 REFERENCES . . . . . . . . . . . . . . . . . . 49

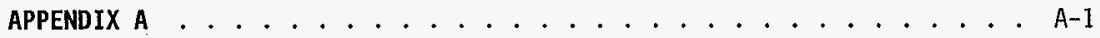

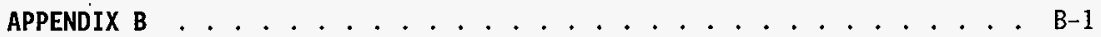


APPENDIX C

APPENDIX D

APPENDIX E

APPENDIX $\mathbf{F}$

APPENDIX G

\section{List of Figures}

Figure 3.1: 105-K Basins ................. 12

Figure 3.2: N Reactor Fuel Storage Canisters ............ 14

Figure 3.3: N Reactor Mark IV Fuel Assembly . . . . . . . . . . . 15

Figure 3.4: K Basin N Reactor Fuel Inventory Characteristics . . . . . . 19

Figure 3.5: ${ }^{137} \mathrm{Cs}$ Shielding Design Basis Selection ............. 29

Figure 4.1: Single Pass Reactor Fuel Elements . . . . . . . . . . 35

Figure 5.1: S1udge Location in the 105-K Basins .......... 42

\section{List of Tables}

Table 1.1:

Table 2.1:

Table 2.2:

TabTe 2.3:

Table 2.4:

Table 2.5:

Table 2.6:

Table 2.7:

Table 3.1:

Table 3.2:

Table 3.3:

Table 3.4:

Table 3.5:

Table 3.6:

Table 3.7:

Table 3.8:

Table 3.9:

Table 3.10:

Table 4.1:

Table 4.2:

Table 4.3:

Table 4.4:

Table 4.5:

Table 5.1:

Table 5.2:

Table 5.3:

Table 5.4:

Table 5.5:

Table 1.1:

Table 2.1:

Table 2.2:

Table 2.3:

Table 2.4:
Spent Fuel Project Facility Design Feeds

Summary Chemical Constituents .

Summary Radionuclide Constituents

Average Chemical Inventory/Unit Mass Uranium Summary :

Average Radionuclide Inventory/Unit Mass Uranium Summary .

Shielding Design Basis Summary

Safety/Regulatory Assessment Design Bas is Summary

Heat Generation Basis Summary

105-N Reactor Fuel Element Description

N Reactor Mark IV Fuel Burnup Summary

N Reactor Mark 1 A Fue1 Burnup Summary

N Reactor Fuel Chemical Inventory

Radionuclide Inventory of the Co . . . . . . 21

K-East Basin Radionuci of the Combined K Basins...... 24

K-East Basin Radionuclide Inventory . . . . . . . . . . 24

K-West Basin Radionuclide Inventory . . . . . . . . . 25

Shielding Design Basis ................. 30

Safety/Regulatory Assessment Design Basis . . . . . . 31

Safety/Regulatory Assessment Bas is . . . . . . . . 32

Operating Periods of the Hanford Single Pass Reactors . . . 33

Physical Characteristics of Single Pass Reactor Fuel :.: 36

Total Chemical Inventory in Single Pass Reactor Fuel Metals: 36

Single Pass Reactor Fuel Elements Stored in the K Basins . . 38

Total Activity of Selected Radionuclides in SPR Fuel . . . 38

Physical Properties of 105-K East Basin STudge . . . . . . 45

Chemical Constituents in 105-K East Basin ........ 46

Radionuclides in 105-K East Basin Sludge . . . . . . . 46

105-K East Basin Radionuclide Totals ......... . 47

Physical Properties of 105-K West Basin S1udge . . . . . 48

Spent Fue 1 Project Facility Design Feeds ........ 2

Summary Chemical Constituents . . . . . . . . . . . . 5

Summary Radionuclide Constituents . . . . . . . . . . . 6

Average Chemical Inventory/Unit Mass Uranium Summary . . . . 7

Average Radionuclide Inventory/Unit Mass Uranium Summary : 7 
Table 2.5: Shielding Design Basis Summary . . . . . . . . . . . . . . 8

Table 2.6: Safety/Regulatory Assessment Design Basis Summary . . . . . . 9

Table 2.7: Heat Generation Bas is Summary . . . . . . . . . . . . . . . . 10

Table 3.1: 105-N Reactor Fuel Element Description . . . . . . . . . . 17

Table 3.2: N Reactor Mark IV Fuel Burnup Summary . . . . . . . . . . . . 18

Table 3.3: N Reactor Mark 1A Fuel Burnup Summary . . . . . . . . . . . . 18

Table 3.4: N Reactor Fuel Chemical Inventory . . . . . . . . . . . . . . 21

Table 3.5: Radionuclide Inventory of the Combined K Basins . . . . . . . 24

Table 3.6: K-East Basin Radionuclide Inventory . . . . . . . . . . . . . 25

Table 3.7: K-West Basin Radionuclide Inventory . . . . . . . . . . . . 26

Table 3.8: Shielding Design Basis . . . . . . . . . . . . . . . . . 30

Table 3.9: Safety/Regulatory Assessment Design Basis . . . . . . . . . 31

Table 3.10: Safety/Regulatory Assessment Basis . . . . . . . . . . . . . 32

Table 4.1: Operating Periods of the Hanford Single Pass Reactors . . . . 33

Table 4.2: Physical Characteristics of Single Pass Reactor Fuel . . . . 36

Table 4.3: Total Chemical Inventory in Single Pass Reactor Fuel Metals . 37

Table 4.4: Single Pass Reactor Fuel Elements Stored in the K Basins . . 38

Table 4.5: Total Activity of Selected Radionuclides in SPR Fuel . . . . 38

Table 5.1: Physical Properties of 105-K East Basin Sludge . . . . . . . 45

Table 5.2: Chemical Constituents in 105-K East Basin . . . . . . . . . 46

Table 5.3: Radionuclides in 105-K East Basin STudge . . . . . . . . . . 47

Table 5.4: 105-K East Basin Radionuclide Totals . . . . . . . . . . . . 47

Table 5.5: Physical Properties of 105-K West Basin Sludge . . . . . . . 48 
HNF-SD-SNF-TI-009, Rev. 1

\section{List of Acronyms}

$\begin{array}{ll}\text { CEDE } & \text { cumulative effective dose equivalents } \\ \text { DESH } & \text { DE\&S Hanford Inc. } \\ \text { DOE } & \text { U.S. Department of Energy } \\ \text { EIS } & \text { Environmental Impact Statement } \\ \text { GEA } & \text { gamma energy analysis } \\ \text { I\&E } & \text { internally and externally cooled } \\ \text { MCO } & \text { multi-canister overpack } \\ \text { MWD } & \text { megawatt-day(s) } \\ \text { MT } & \text { metric ton(s) } \\ \text { MTHM } & \text { metric ton(s) heavy metal } \\ \text { MTU } & \text { metric ton(s) uranium } \\ \text { PUREX } & \text { plutonjum uranium extraction } \\ \text { SPR } & \text { single pass reactor } \\ \text { SNF } & \text { spent nuclear fuel } \\ \text { USQ } & \text { unreviewed safety question }\end{array}$




\section{5-K BASIN MATERIAL DESIGN BASIS FEED DESCRIPTION FOR SPENT NUCLEAR FUEL PROJECT FACILITIES}

\section{0 - INTRODUCTION}

\subsection{BACKGROUND}

Metallic uranium Spent Nuclear Fuel (SNF) is currently stored within two water filled pools, 105-KE Basin (KE Basin) and 105-KW Basin (KW Basin), at the United States Department of Energy (U.S. DOE) Hanford Site, in south eastern Washington State. DE\&S Hanford Inc. (DESH) Spent Nuclear Fuel Project (SNF Project) is responsible to DOE for operation of these fuel storage pools and for the 2100 metric tons of SNF materials that they contain. The SNF Project mission includes safe removal and transportation of a71 SNF from these storage basins to a new storage facility in the 200 East Area. To accomplish this mission, the SNF Project modifies the existing KE Basin and KW Basin facilities and constructs two new facilities: the $100 \mathrm{~K}$ Area Cold Vacuum Drying Facility (CVDF), which drains and drys the SNF; and the 200 East Area Canister Storage Building (CSB), which stores the SNF.

\subsection{PURPOSE AND SCOPE}

The purpose of this document is to describe the design basis feed compositions for materials stored or processed by SNF Project facilities and activities. This document is not intended to replace the Hanford Spent Fuel Inventory Baseline (WHC 1994b), but only to supplement it by providing more detail on the chemical and radiological inventories in the fuel and siudge.

A variety of feed definitions is required to support evaluation of specific facility and process considerations during the development of these new facilities. Six separate feed types have been identified for development of new storage or processing facilities. The approach for using each feed during design evaluations is to calculate the proposed facility flowsheet assuming each feed. The process flowsheet would then provide a basis for material compositions and quantities which are used in follow-on calculations.

Table 1-1 provides a list of the proposed feeds and the intended purpose of each feed definition. 
Table 1.1: Spent Fuel Project Facility Design Feeds

\begin{tabular}{|c|c|}
\hline Design Feed & Description/Purpose \\
\hline $\begin{array}{l}\text { Nominal } \\
\text { Feed }\end{array}$ & $\begin{array}{l}\text { Average feed to the facility over the plant life. Used to design systems that provide } \\
\text { suitable performance over the entire plant life. Among other things, this feed is used } \\
\text { to design shielding that will maintain radiation doses to workers as low as reasonably } \\
\text { achievable (ALARA). }\end{array}$ \\
\hline $\begin{array}{l}\text { Shielding } \\
\text { Basis Feed }\end{array}$ & $\begin{array}{l}\text { A } 1 \text { fed with the highest gamma shielding requirements as compared to the nominal feed } \\
\left({ }^{3} \text { Cs is the doninate gamma contributor in either case). This feed is used to evaluate }\right. \\
\text { gamma shielding provided by the plant structure and equipment to determine if potential } \\
\text { peak radiation dose rates are acceptable. This feed represents material which would be in } \\
\text { the facility for short campaigns and would not be used for evaluations of performance } \\
\text { over the entire plant life. }\end{array}$ \\
\hline $\begin{array}{l}\text { Safety/ } \\
\text { Regul'atory } \\
\text { Assessment } \\
\text { Feed }\end{array}$ & $\begin{array}{l}\text { A feed with bounding }{ }^{241} \text { Am, plutonium isotopes, and }{ }^{90} \mathrm{Sr} \text { radionuclides which, if } \\
\text { released, dominate the estimate of dose to personnel (both onsite and offsite). This feed } \\
\text { is used to analyze design basis accidents and support definition of mitigation. systems. } \\
\text { This feed represents material which. would be in the facility for short campaigns and } \\
\text { would not be used for evaluations of performance over the entire plant life. }\end{array}$ \\
\hline $\begin{array}{l}\text { Heat } \\
\text { Generation } \\
\text { Bas is Feed }\end{array}$ & $\begin{array}{l}\text { A feed with bounding amounts of those isotopes that dominate heat dissipation } \\
\text { requirements. This feed is used to define heat removal requirements provided by the } \\
\text { facility systems. The Heat removal basis feed represents the upper bound of the operating } \\
\text { envelope for feed material which can be handled by the facility without special operating } \\
\text { procedures or evaluations to determine if supplemental heat removal is required. This } \\
\text { feed represents material which would be in the facility for short campaigns and would not } \\
\text { be used for evaluations of performance over the entire plant life. }\end{array}$ \\
\hline $\begin{array}{l}\text { Criticality } \\
\text { Assessment } \\
\text { Feed }\end{array}$ & $\begin{array}{l}\text { A feed with bounding fissile material content used to define criticality controls (e.g., } \\
\text { geometric favorable equipment designs) which may impact the system design. This feed } \\
\text { represents an upper bound of the operating envelope for material fissile content which } \\
\text { could be introduced into the facility without special operating procedures or additional } \\
\text { criticality safety evaluations. The feed represents material which would be in the } \\
\text { facility for short campaigns and would not be used for evaluations of performance over } \\
\text { the entire plant life: (Analysis to be completed in future revision). }\end{array}$ \\
\hline
\end{tabular}

\subsubsection{Purpose and Scope of Revision 1}

The primary purpose of Revision 1 is to incorporate changes into the radionuclide tables that result from: 1) the availability of improved cross section data, 2) a decision to use the accountability data as the basis for total $\mathrm{Pu}$, and 3 ) additional radioactive decay that would accrue between the original project startup date (12/31/97) and a May 31, 1998 startup date. Most of the radionuclide concentrations have been reduced with the exception of $239,240 \mathrm{Pu}$ and $\mathrm{Am}$, which have increased in some tables.

In addition to incorporation of the adjusted inventory values, Revision 1 also provides additional references for certification of the computer programs used to calculate the inventory values and adds a section (3.3.3.1) to explain the limitations of the calculation method.

Finally, Revision 1 incorporates miscellaneous editorial changes. 


\subsection{SUMMARY}

Chemical and radionuclide inventories are estimated for fuel and sludge stored in the KE and KW Basins. Inventory estimates are presented for the nominal (or overall average) inventory, selected shielding design basis, shielding design basis, selected safety/regulatory assessment design basis, selected heat generation basis, and selected criticality assessment basis materials. This document is intended to be revised as needed to support the Spent Nuclear-Fuel Project.

The nominal design basis is presented as a total material inventory in the combined basins and as an average inventory per metric ton uranium (MTU). Bounding design basis feed compositions-are also presented on a unit mass of uranium basis. The bounding feeds were selected by considering the range of radionuclide compositions in $\mathrm{N}$ Reactor and Single Pass Reactor fuel predicted to exist within the basins as a result of varying exposures and decay periods reported for each key (or group of fuel assemblies) in the accountabitity database.

Accountability records were used as a basis for the quantity, exposure variation, and decay time variation of stored fuel. Chemical constituents were estimated from the mid-point of fuel fabrication material impurity specification ranges. Variation of the chemical constituents over the specification ranges was not incorporated in the current design basis feed estimates. Radionuclide estimates were effectively derived from the following two computer models:

1) ORIGEN2 runs for $\mathrm{N}$ Reactor fuel provided radionuclide compositions for discharged fuel at selected exposure leve?s.

2) RADNUC $2 A$ combined the ORIGEN2 fuel compositions at the selected points with accountability data on exposure and decay time to generate a composite radionuclide inventory decayed to a common date.

Interpolations were used to estimate radionuclides in blocks of fuel irradiated to exposure levels between the ORIGEN 2 point projections.

Tests of the radionuclide estimate method indicate the interpolation results are within $2 \%$ of the ORIGEN2 projections for exposures near the interpolation points and within 10\% of expected results for exposures between interpolation points. A comparison of ORIGEN2 and RADNUC outputs is included in the RADNUC documentation (WHC 1995a).

The sludge inventory is currently 1 imited to estimates of components in the K-East Basin. The component estimates are based on chemical and radionuclide analyses of four samples, two samples from the weasel pit, one sample from the sandfilter backwash pit, and one sample from the approximate center of the basin floor. While not quantified, significant uncertainty in the sludge component estimates should be expected.

Development of the feed basis data emphasized best estimates of the actual bounds of material compositions, with a minimum of conservatism. This approach was used in order to allow future designs based on the bounds to apply known safety factors and avoid excessive over-design. Some conservatism is currently included in the radionuclide design basis bounds as a result of 
the following:

1) The decay date selected for presenting radionuclide inventories and bounds is May 31, 1998. This is conservative (i.e., early) in view of the July, 1999 official project startup date, and therefore, radionuclide inventories (and associated heat loads) could be reduced to reflect additional decay.

2) The radionuclide inventories were developed using the computer codes as described above. The plutonium inventory predicted was larger than that reported in the accountability data. While, the plutonium 239 and 240 isotope values in the overall total tables have been adjusted to reflect the accountability plutonium inventory numbers, no adjustment has been made to the other isotope numbers in the tables (see section 3.3.3.1).

3) The shielding design basis includes a limited degree of conservatism due to selecting $16 \%$. ${ }^{240} \mathrm{Pu}$ content fuel, aged 13.5 years to $5 / 31 / 1998$, as the composition basis. This represents material containing approximately $6.5 \%$ more ${ }^{137} \mathrm{Cs}$ and ${ }^{90} \mathrm{Sr}$ per MTU than the highest actual fuel content identified in the basin inventory (15.7\% ${ }^{240} \mathrm{Pu}$ content Mark IV fuel, aged 14.5 years to $5 / 31 / 1998$ ).

\subsection{NOMINAL DESIGN FEED}

The nominal design feed is an average of the current inventory of spent fuel stored in the $K$ Basins. Tables in this section provide a summary of the current nominal design basis feed.

\subsubsection{Inventory Totals}

Tables 2.1 and 2.2 contain a summary of the nominal design basis feed information estimated for the entire inventory of fuel and sludge in the combined $K$ Basins. Table 2.1 includes the chemical inventories, and Table 2.2 contains a summary of the radionuclide inventory for $\mathrm{N}$ Reactor fuel, Single Pass Reactor (SPR) fuel, $K$ Basin sludge, and totals for each constituent. 
Table 2.1: Summary Chemical Constituents

\begin{tabular}{|c|c|c|c|c|}
\hline Chemical & $\begin{array}{l}\text { N Reactor } \\
\text { Fuel } \\
\text { (kg) }\end{array}$ & $\begin{array}{l}\text { SPR } \\
\text { Fuel } \\
\text { (kg) } \\
\end{array}$ & $\underset{(\mathrm{kg})}{\text { sludge }}$ & $\begin{array}{l}\text { Total } \\
(\mathrm{kg})\end{array}$ \\
\hline $\begin{array}{c}\mathrm{Al} \\
\mathrm{As} \\
\mathrm{B} \\
\mathrm{Ba} \\
\mathrm{Be} \\
\mathrm{C} \\
\mathrm{Ca} \\
\mathrm{Cd} \\
\end{array}$ & $\begin{array}{l}1.70 e+03 \\
6.05 e-01 \\
1.63 e+02 \\
1.20 e+03 \\
6.05 e-01 \\
\end{array}$ & $\begin{array}{l}1.20 \mathrm{e}+02 \\
1.20 \mathrm{e}-03 \\
2.54 \mathrm{e}+00 \\
3.60 \mathrm{e}-03 \\
\end{array}$ & $\begin{array}{l}4.32 \mathrm{e}+02 \\
8.06 \mathrm{e}-01 \\
2.19 \mathrm{e}+00 \\
2.00 \mathrm{e}-01 \\
8.34 \mathrm{e}+01 \\
1.77 \mathrm{e}+00 \\
\end{array}$ & $\begin{array}{l}2.25 \mathrm{e}+03 \\
8.06 \mathrm{e}-01 \\
6.06 \mathrm{e}-01 \\
2.19 \mathrm{e}+00 \\
1.63 \mathrm{e}+02 \\
1.20 \mathrm{e}+03 \\
8.34 \mathrm{e}+01 \\
2.38 \mathrm{e}+00\end{array}$ \\
\hline $\begin{array}{l}\mathrm{Co} \\
\mathrm{Cr} \\
\mathrm{Cu} \\
\mathrm{Fe} \\
\mathrm{H} \\
\mathrm{Hf} \\
\mathrm{K} \\
\mathrm{Li} \\
\end{array}$ & $\begin{array}{l}1.54 \mathrm{e}+00 \\
2.88 \mathrm{e}+02 \\
1.66 \mathrm{e}+02 \\
9.41 \mathrm{e}+02 \\
8.06 \mathrm{e}+00 \\
3.02 \mathrm{e}+01\end{array}$ & $\begin{array}{l}1.20 \mathrm{e}-03 \\
2.20 \mathrm{e}-01 \\
1.86 \mathrm{e}-01 \\
1.38 \mathrm{e}+00 \\
9.60 \mathrm{e}-03 \\
\end{array}$ & $\begin{array}{l}4.11 \mathrm{e}-01 \\
1.72 \mathrm{e}+01 \\
6.81 \mathrm{e}+00 \\
4.51 \mathrm{e}+03 \\
\\
2.93 \mathrm{e}+00 \\
1.44 \mathrm{e}+00 \\
\end{array}$ & $\begin{array}{l}1.95 e+00 \\
3.05 e+02 \\
1.73 e+02 \\
5.45 e+03 \\
8.06 e+00 \\
3.02 e+01 \\
2.93 e+00 \\
1.45 e+00 \\
\end{array}$ \\
\hline $\begin{array}{c}\mathrm{Mg} \\
\mathrm{Mn} \\
\mathrm{Mo} \\
\mathrm{N} \\
\mathrm{Na} \\
\mathrm{Nd} \\
\mathrm{Ni} \\
\mathrm{O} \\
\end{array}$ & $\begin{array}{l}5.58 e+01 \\
6.03 e+01 \\
7.54 e+00 \\
1.70 e+02 \\
3.02 e+00 \\
2.94 e+02 \\
6.53 e+00 \\
\end{array}$ & $\begin{array}{l}8.45 e-02 \\
8.45 e-02 \\
3.38 e-01 \\
1.74 e+00\end{array}$ & $\begin{array}{l}1.84 \mathrm{e}+01 \\
7.02 \mathrm{e}+00 \\
6.91 \mathrm{e}-01 \\
3.80 \mathrm{e}+00 \\
2.51 \mathrm{e}+00 \\
1.75 \mathrm{e}+00\end{array}$ & $\begin{array}{l}7.43 e+01 \\
6.74 \mathrm{e}+01 \\
8.23 \mathrm{e}+00 \\
1.70 \mathrm{e}+02 \\
6.82 \mathrm{e}+00 \\
2.51 \mathrm{e}+00 \\
2.97 \mathrm{e}+02 \\
6.53 \mathrm{e}+00 \\
\end{array}$ \\
\hline $\begin{array}{l}\mathrm{P} \\
\mathrm{Pb} \\
\mathrm{S} \\
\mathrm{Sb} \\
\mathrm{Si} \\
\mathrm{Sn} \\
\mathrm{Sn} \\
\mathrm{Sr}\end{array}$ & $\begin{array}{l}1.52 e+01 \\
2.77 e+02 \\
6.54 e+00 \\
2.19 e+03 \\
7.33 e+01 \\
\end{array}$ & $4.58 \mathrm{e}-01$ & $\begin{array}{l}7.84 \mathrm{e}+00 \\
9.43 \mathrm{e}+00 \\
6.42 \mathrm{e}+00 \\
4.04 \mathrm{e}+00 \\
3.64 \mathrm{e}+01 \\
8.97 \mathrm{e}+00 \\
6.10 \mathrm{e}-01\end{array}$ & $\begin{array}{l}7.84 \mathrm{e}+00 \\
2.51 \mathrm{e}+01 \\
6.42 \mathrm{e}+00 \\
4.04 \mathrm{e}+00 \\
3.13 \mathrm{e}+02 \\
1.55 \mathrm{e}+01 \\
2.19 \mathrm{e}+03 \\
7.39 \mathrm{e}+01 \\
\end{array}$ \\
\hline $\begin{array}{l}\mathrm{Ti} \\
\mathrm{Tl} \\
\mathrm{V} \\
\mathrm{W} \\
\mathrm{Kr} \\
\mathrm{Xe} \\
\end{array}$ & $\begin{array}{l}7.54 e+00 \\
7.54 e+00 \\
7.68 e+00 \\
7.71 e+01 \\
1.04 e+03 \\
\end{array}$ & . & $\begin{array}{l}2.58 \mathrm{e}+00 \\
2.87 \mathrm{e}+00 \\
6.97 \mathrm{e}+00\end{array}$ & $\begin{array}{l}1.01 \mathrm{e}+01 \\
2.87 \mathrm{e}+00 \\
1.45 \mathrm{e}+01 \\
7.68 \mathrm{e}+00 \\
7.71 \mathrm{e}+01 \\
1.04 \mathrm{e}+03\end{array}$ \\
\hline $\begin{array}{l}\mathrm{Zn} \\
\mathrm{Zr} \\
\mathrm{U} \\
\mathrm{Np} \\
\mathrm{Pu} \\
\mathrm{Am} \\
\mathrm{Cm} \\
\mathrm{Se} \\
\end{array}$ & $\begin{array}{l}1.48 \mathrm{e}+05 \\
2.10 \mathrm{e}+06 \\
8.11 \mathrm{e}+01 \\
4.12 \mathrm{e}+03 \\
1.09 \mathrm{e}+02 \\
1.78 \mathrm{e}-02 \\
1.20 \mathrm{e}+01 \\
\end{array}$ & $3.38 \mathrm{e}+03$ & $\begin{array}{l}1.92 e+01 \\
3.22 \mathrm{e}+00 \\
1.46 \mathrm{e}+03 \\
4.88 \mathrm{e}+00 \\
2.28 \mathrm{e}-01\end{array}$ & $\begin{array}{l}1.92 \mathrm{e}+01 \\
1.48 \mathrm{e}+05 \\
2.10 \mathrm{e}+06 \\
8.11 \mathrm{e}+01 \\
4.12 \mathrm{e}+03 \\
1.09 \mathrm{e}+02 \\
1.78 \mathrm{e}-02 \\
1.20 \mathrm{e}+01 \\
\end{array}$ \\
\hline $\begin{array}{c}\text { Tc } \\
\text { Pd } \\
I \\
\text { Cs } \\
\text { Pm } \\
\text { other } \\
\end{array}$ & $\begin{array}{c}1.70 e+02 \\
1.33 e+02 \\
4.61 e+01 \\
4.65 e+02 \\
5.0 e+01\end{array}$ & & 1.73è+04 & $\begin{array}{c}1.70 \mathrm{e}+02 \\
1.33 \mathrm{e}+02 \\
4.61 \mathrm{e}+01 \\
4.65 \mathrm{e}+02 \\
5.0 \mathrm{e}-01 \\
1.73 \mathrm{e}+04\end{array}$ \\
\hline Total & $2.26 e+06$ & $3.51 \mathrm{e}+03$ & $2.40 \mathrm{e}+04$ & $2.29 e+06$ \\
\hline
\end{tabular}


Table 2.2: Summary Radionuclide Constituents (Decay date basis: May 31. 1998)

\begin{tabular}{|c|c|c|c|c|}
\hline Isotope & $\begin{array}{l}\text { N Fuel } \\
\text { (Ci) }\end{array}$ & $\begin{array}{c}\text { SPR Fuel } \\
\text { (Ci) }\end{array}$ & $\begin{array}{l}\text { sludge } \\
\text { (Ci) }\end{array}$ & $\begin{array}{l}\text { Total } \\
\text { (Ci) }\end{array}$ \\
\hline $\begin{array}{l}H-3 \\
\mathrm{C}-14 \\
\mathrm{Fe}-55 \\
\mathrm{Co}-60 \\
\end{array}$ & $\begin{array}{l}3.66 \mathrm{e}+04 \\
6.93 \mathrm{e}+02 \\
1.84 \mathrm{e}+03 \\
3.96 \mathrm{e}+03 \\
\end{array}$ & $5.94 \mathrm{e}+02$ & $2.30 \mathrm{e}+01$ & $\begin{array}{l}3.72 \mathrm{e}+04 \\
6.93 \mathrm{e}+02 \\
1.84 \mathrm{e}+03 \\
3.98 \mathrm{e}+03 \\
\end{array}$ \\
\hline $\begin{array}{l}\mathrm{Ni}-63 \\
\mathrm{Kr}-85 \\
\mathrm{Se}-79 \\
\mathrm{Sr}-90 \\
\mathrm{Y}-90 \\
\end{array}$ & $\begin{array}{l}4.49 \mathrm{e}+03 \\
5.90 \mathrm{e}+05 \\
8.62 \mathrm{e}+01 \\
1.01 \mathrm{e}+07 \\
1.01 \mathrm{e}+07\end{array}$ & $\begin{array}{l}6.62 \mathrm{e}+01 \\
6.04 \mathrm{e}+02 \\
1.27 \mathrm{e}+04 \\
1.27 \mathrm{e}+04\end{array}$ & $\begin{array}{l}1.28 \mathrm{e}+03 \\
1.28 \mathrm{e}+03 \\
\end{array}$ & $\begin{array}{l}4.56 \mathrm{e}+03 \\
5.91 \mathrm{e}+05 \\
8.62 \mathrm{e}+01 \\
1.01 \mathrm{e}+07 \\
1.01 \mathrm{e}+07\end{array}$ \\
\hline $\begin{array}{l}Z r-93 \\
\text { Nb-93m } \\
\text { Tc-99 } \\
\text { Ru- } 106\end{array}$ & $\begin{array}{l}4.00 \mathrm{e}+02 \\
2.47 \mathrm{e}+02 \\
2.88 \mathrm{e}+03 \\
1.82 \mathrm{e}+03\end{array}$ & $6.76 e+00$ & & $\begin{array}{l}4.00 \mathrm{e}+02 \\
2.47 \mathrm{e}+02 \\
2.89 \mathrm{e}+03 \\
1.82 \mathrm{e}+03\end{array}$ \\
\hline $\begin{array}{l}\text { Rh-106 } \\
\text { Sn-126 } \\
\text { Sb-125 } \\
\text { Te-125m }\end{array}$ & $\begin{array}{l}1.82 e+03 \\
1.56 e+02 \\
3.35 e+04 \\
8.18 e+03\end{array}$ & & & $\begin{array}{l}1.82 \mathrm{e}+03 \\
1.56 \mathrm{e}+02 \\
3.35 \mathrm{e}+04 \\
8.18 \mathrm{e}+03\end{array}$ \\
\hline $\begin{array}{l}1-129 \\
c s-134 \\
C s-135 \\
c s-137\end{array}$ & $\begin{array}{l}6.37 e+00 \\
1.59 e+04 \\
7.75 e+01 \\
1.32 e+07\end{array}$ & $\begin{array}{l}2.47 e+00 \\
3.25 e+04\end{array}$ & $9.72 \mathrm{e}+02$ & $\begin{array}{l}6.37 \mathrm{e}+00 \\
1.59 \mathrm{e}+04 \\
7.75 \mathrm{e}+01 \\
1.32 \mathrm{e}+07\end{array}$ \\
\hline $\begin{array}{l}\text { Ba- } 137 m \\
\text { Ce- } 144 \\
\text { Pr-144 } \\
\text { Pm- } 147 \\
\end{array}$ & $\begin{array}{l}1.25 e+07 \\
9.14 e+02 \\
9.03 e+02 \\
4.62 e+05 \\
\end{array}$ & $3.08 \mathrm{e}+04$ & $9.20 \mathrm{e}+02$ & $\begin{array}{l}1.25 \mathrm{e}+07 \\
9.14 \mathrm{e}+02 \\
9.03 \mathrm{e}+02 \\
4.62 \mathrm{e}+05 \\
\end{array}$ \\
\hline $\begin{array}{l}\text { Sm-151 } \\
E u-152 \\
E u-154 \\
E u-155 \\
\end{array}$ & $\begin{array}{l}1.76 e+05 \\
9.45 e+02 \\
1.07 e+05 \\
2.21 e+04 \\
\end{array}$ & $\begin{array}{l}3.97 \mathrm{e}+02 \\
3.69 \mathrm{e}+02 \\
7.40 \mathrm{e}+01 \\
\end{array}$ & $\begin{array}{l}2.61 \mathrm{e}+01 \\
1.35 \mathrm{e}+01 \\
\end{array}$ & $\begin{array}{l}1.76 \mathrm{e}+0.5 \\
9.45 \mathrm{e}+02 \\
1.07 \mathrm{e}+0.5 \\
2.22 \mathrm{e}+04 \\
\end{array}$ \\
\hline $\begin{array}{l}U-234 \\
U-235 \\
U-236 \\
U-238 \\
\end{array}$ & $\begin{array}{l}8.74 \mathrm{e}+02 \\
3.37 \mathrm{e}+01 \\
1.27 \mathrm{e}+02 \\
6.96 \mathrm{e}+02 \\
\end{array}$ & & & $\begin{array}{l}8.74 \mathrm{e}+02 \\
3.37 \mathrm{e}+01 \\
1.27 \mathrm{e}+02 \\
6.96 \mathrm{e}+02 \\
\end{array}$ \\
\hline $\begin{array}{l}\mathrm{Np}-237 \\
\mathrm{Pu}-238 \\
\mathrm{Pu}-239 \\
\mathrm{Pu}-240\end{array}$ & $\begin{array}{l}5.72 e+01 \\
1.11 e+05 \\
2.18 e+05 \\
1.19 e+05\end{array}$ & $\begin{array}{l}1.42 \mathrm{e}+02 \\
4.06 \mathrm{e}+02 \\
6.42 \mathrm{e}+02\end{array}$ & $\begin{array}{l}6.51 \mathrm{e}+01 \\
2.60 \mathrm{e}+02 \\
1.43 \mathrm{e}+02\end{array}$ & $\begin{array}{l}5.72 \mathrm{e}+01 \\
1.11 \mathrm{e}+05 \\
2.19 \mathrm{e}+05 \\
1.20 \mathrm{e}+05\end{array}$ \\
\hline $\begin{array}{l}\text { Pu-241 } \\
\text { Pu-242 } \\
\mathrm{Am}-241 \\
\mathrm{Cm}-242\end{array}$ & $\begin{array}{r}6.68 \mathrm{e}+06 \\
5.49 \mathrm{e}+01 \\
3.75 \mathrm{e}+05 \\
1.62 \mathrm{e}+02\end{array}$ & $\begin{array}{l}1.46 \mathrm{e}+04 \\
1.52 \mathrm{e}+03\end{array}$ & $\begin{array}{l}5.22 \mathrm{e}+03 \\
4.36 \mathrm{e}-02 \\
7.82 \mathrm{e}+02\end{array}$ & $\begin{array}{l}6.70 \mathrm{e}+06 \\
5.49 \mathrm{e}+01 \\
3.77 \mathrm{e}+05 \\
1.62 \mathrm{e}+02\end{array}$ \\
\hline $\mathrm{Cm}-244$ & $1.44 \mathrm{e}+03$ & & . & $1.44 \mathrm{e}+03$ \\
\hline
\end{tabular}

Note: This table provides a sumary of key radionuclides for $N$ Reactor fuel. A complete listing of estimated radionucl ides in $\mathrm{N}$ Reactor fuel is provided in Table 3.3 .

\subsubsection{Unit Mass Uranium Inventory}

Tables 2.3 and 2.4 contain an estimate of the chemical and radionuclide nominal design basis inventory on a uranium mass basis. Table 2.3 is a summary of the chemical composition of the fuel on a uranium mass basis. - Table 2.4 is a summary of the radionuctide inventory on a uranium mass basis. 
HNF-SD-SNF-TI-009, Rev. I

Table 2.3: Average Chemical Inventory/Unit Mass Uranium Summary

\begin{tabular}{|c|c|c|c|}
\hline chemicat & $\begin{array}{c}\text { Mass } \\
(\mathrm{kg} / \mathrm{MTU})\end{array}$ & chemical & $\begin{array}{c}\text { Mass } \\
(\mathrm{kg} / \mathrm{MTU})\end{array}$ \\
\hline aluminum & $8.1 \mathrm{e}-01$ & beryllium & $7.8 \mathrm{e}-02$ \\
\hline carbon & $5.7 \mathrm{e}-01$ & cesium & $1.0 \mathrm{e}-01$ \\
\hline chromium & $1.4 \mathrm{e}-01$ & copper & $7.9 \mathrm{e}-02$ \\
\hline iron & $4.5 \mathrm{e}-01$ & manganese & $2.9 \mathrm{e}-02$ \\
\hline molybdenum & $4.6 \mathrm{e}-03$ & nitrogen & $8.1 \mathrm{e}-02$ \\
\hline nickel & $1.4 \mathrm{e}-01$ & plutonium & $1.9 \mathrm{e}+00$ \\
\hline silicon & $1.3 \mathrm{e}-01$ & strontium & $3.5 \mathrm{e}-02$ \\
\hline technetium & $7.6 \mathrm{e}-02$ & tin & $1.0 \mathrm{e}+00$ \\
\hline uranium & $1.0 \mathrm{e}+03$ & zirconium & $7.0 \mathrm{e}+01$ \\
\hline
\end{tabular}

Table 2.4: Average Radionuclide Inventory/Unit Mass Uranium Summary

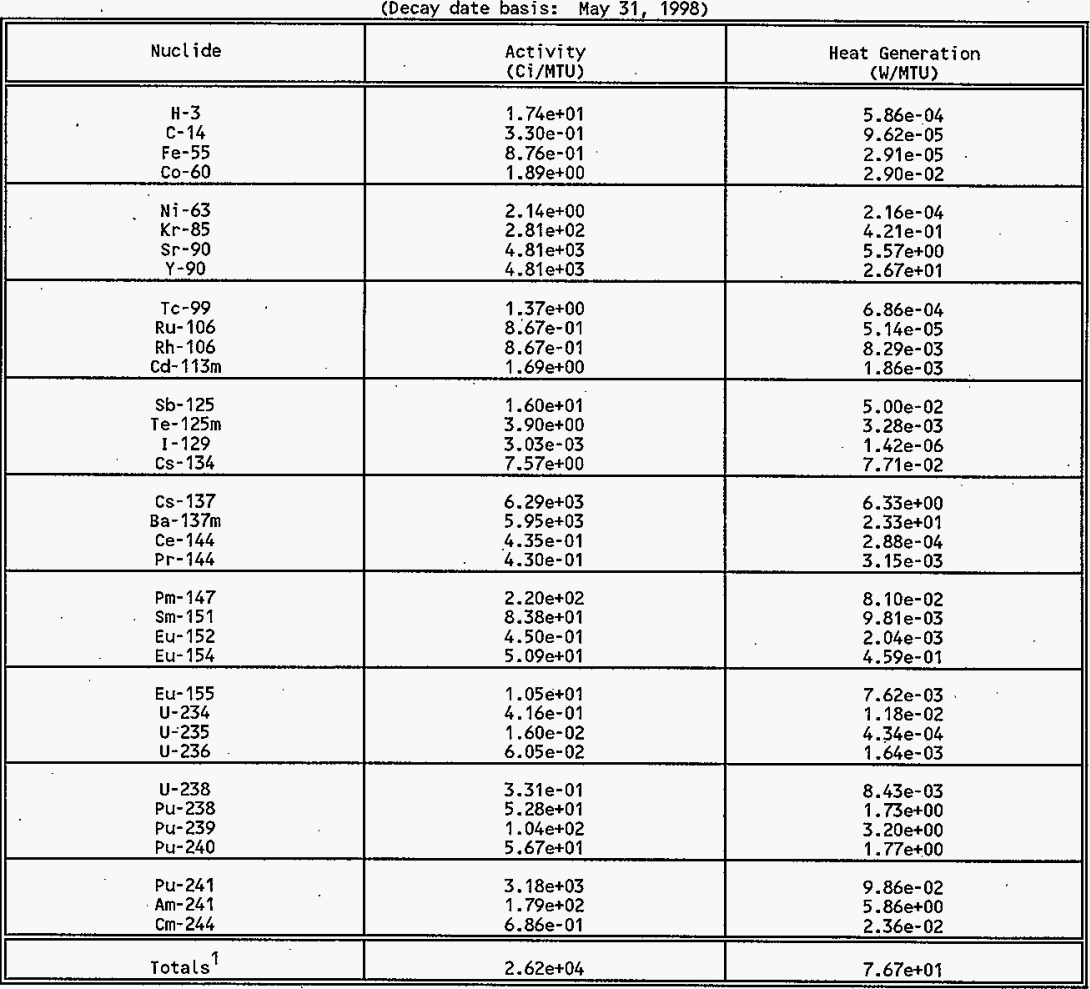

Totals include additional nuclides which are not itemized in this summary table. A complete listing of the estimated radionuclide inventory can be derived from Table $3: 3$. 


\subsection{SHIELDING DESIGN FEED BASES}

The shielding design basis is defined here as Mark IV fuel, irradiated to $16 \%{ }^{240} \mathrm{Pu}$ content, that has been discharged from the reactor for 13.5 years. This fuel was chosen for the shielding basis because it represents a bounding limit to the ${ }^{137} \mathrm{Cs}$ concentration. The shielding design basis radionuclide concentrations are summarized in Table 2.5 .

The shielding basis ${ }^{137} \mathrm{Cs}$ content is approximately 1.7 times the average ${ }^{137} \mathrm{Cs}$ content in the basins. The shielding basis allows any combination of fuel canisters which may be encountered within the $K$ Basins to be loaded into an $\mathrm{MCO}$ without concern for exceeding shielding requirements to 1 imit peak (as opposed to average) dose rates.

Table 2.5: Shielding Design Basis Summary

(Based on MK IV fuel at $16 \%{ }^{240} \mathrm{Pu}$ content, aged 13.5 years)

\begin{tabular}{|c|c|c|}
\hline Isotope & $\begin{array}{c}\text { Activity } \\
\text { (Ci/MTU) }\end{array}$ & $\begin{array}{c}\text { Heat Generation } \\
\text { (W/MTU) }\end{array}$ \\
\hline \hline Cobalt-60 & $6.27 \mathrm{e}+00$ & $9.64 \mathrm{e}-02$ \\
\hline Cesium-137 & $1.13 \mathrm{e}+04$ & $1.14 \mathrm{e}+01$ \\
\hline Barium-137m & $1.07 \mathrm{e}+04$ & $4.18 \mathrm{e}+01$ \\
\hline Samarium-151 & $1.08 \mathrm{e}+02$ & $1.26 \mathrm{e}-02$ \\
\hline Europium-154 & $2.02 \mathrm{e}+02$ & $1.81 \mathrm{e}+00$ \\
\hline
\end{tabular}

Note: This summary table is limited to key isotopes which are important for gamma shielding calculations. Table 3.8 provides a complete list.

\subsection{SAFETY/REGULATORY ASSESSMENT FEED}

The safety/regulatory assessment design basis was selected by identifying the isotopic mixture of components expected to yield the 1 argest dose to people per unit of material released. The selection process used to compare the isotopic mixtures focused on radionuclides that are anticipated to dominate dose calculations for accident scenarios. These included: all plutonium isotopes, ${ }^{241} \mathrm{Am},{ }^{90} \mathrm{Sr}$, and ${ }^{137} \mathrm{Cs}$. The dose from a unit release of material was summed for these nuclides assuming dose conversion factors modelling an inhalation exposure pathway. N Reactor fuel that was irradiated to $16.72 \%{ }^{240} \mathrm{Pu}$ and discharged from the reactor during the month of February 1979 was selected as the safety/regulatory assessment basis from this comparison. The safety design basis is summarized on a unit mass basis in Table 2.6.

Safety Analysis documentation will identify accident scenarios and potential exposure pathways to establish a safety basis for new facilities. The intent of this document is not to present the accident scenarios or exposure pathways, but only to supply worst case information to be used in the development of the safety documentation. 
Table 2.6: Safety/Regulatory Assessment Design Basis Summary (Based on MK IV fuel at $16.72 \%{ }^{240} \mathrm{Pu}$, aged approximately 19 years)

\begin{tabular}{|c|c|c|}
\hline Isotope & $\begin{array}{c}\text { Activity } \\
\text { (Ci/MTU) }\end{array}$ & $\begin{array}{c}\text { Heat Generation } \\
\text { (W/MTU) }\end{array}$ \\
\hline Plutonium-238 & $1.33 \mathrm{e}+02$ & $4.34 \mathrm{e}+00$ \\
\hline Plutonium-239 & $1.73 \mathrm{e}+02$ & $5.28 \mathrm{e}+00$ \\
\hline Plutonium-240 & $1.37 \mathrm{e}+02$ & $4.19 \mathrm{e}+00$ \\
\hline Plutonium-241 & $6.82 \mathrm{e}+03$ & $2.11 \mathrm{e}-01$ \\
\hline Plutonium-242 & $8.71 \mathrm{e}-02$ & $2.55 \mathrm{e}-03$ \\
\hline Americium-241 & $4.34 \mathrm{e}+02$ & $1.42 \mathrm{e}+01$ \\
\hline Curium-242 & $3.08 \mathrm{e}-01$ & $1.11 \mathrm{e}-02$ \\
\hline Curium-244 & $4.47 \mathrm{e}+00$ & $1.54 \mathrm{e}-01$ \\
\hline Strontium-90 & $6.93 \mathrm{e}+03$ & $8.03 \mathrm{e}+00$ \\
\hline Cesium-137 & $9.66 \mathrm{e}+03$ & $9.78 \mathrm{e}+00$ \\
\hline This summary is limited to key dose contributors. Table 3.9 provides a complete list.
\end{tabular}

\subsection{HEAT GENERATION BASIS FEED}

Whereas the Table 2.7 values in Revisions 0 and $O A$ of this document were based on selection of the shielding basis fuel material to also represent the heat generation basis feed material, those values have been. adjusted downward in this revision (Revision 1) to reflect selection of the safety/regulatory assessment basis fuel material to replace the shielding basis fuel to represent the heat generation basis feed material.

The heat generation basis feed material selected for Revision 1 by choosing the fuel lot capable of generating the most heat within a fully loaded MCO, as opposed to the most heat per MTU. A comparison was made of different groups of fuel in the basins including the most recently discharged fuel, the shielding design basis fuel, the safety/regulatory assessment fuel, and a $13.4 \%{ }^{240} \mathrm{Pu}$ key which has been discharged for approximately 8.5 years.

Although the shielding design basis fuel has the largest heat production on a per mass basis, the safety/regulatory assessment fuel has the highest heat generation on a per element basis. The reason for this apparent discrepancy is that the safety/regulatory assessment fuel is longer than the shielding basis fuel (E length vs S length \{see table 3.1\}). Current plans call for loading the Multi-canister Overpacks (MCO) with a given number of fuel pieces rather than a given mass of fuel. An MCO loaded with the safety/regulatory assessment fuel will produce more heat than an MCO loaded with the shielding basis fuel. The safety/regulatory assessment basis fuel was therefore selected to represent the heat generation basis fuel.

Table 2.7 provides a listing of important heat generating isotopes in the heat generation basis feed. 
Table 2.7: Heat Generation Bas is Summary (Based on MK IV fuel at $16.72 \%{ }^{240} \mathrm{Pu}$ content, aged approximately 19 years)

\begin{tabular}{|c|c|c||}
\hline \multicolumn{1}{|c|}{ Isotope } & $\begin{array}{c}\text { Activity } \\
\text { (Ci MTU) }\end{array}$ & $\begin{array}{c}\text { Heat Generation } \\
\text { (W/MTU) }\end{array}$ \\
\hline Co-60 & $2.09 \mathrm{e}+00$ & $3.23 \mathrm{e}-02$ \\
\hline $\mathrm{Kr}-85$ & $3.70 \mathrm{e}+02$ & $5.53 \mathrm{e}-01$ \\
\hline $\mathrm{Sr}-90$ & $6.93 \mathrm{e}+03$ & $8.03 \mathrm{e}+00$ \\
\hline$\gamma-90$ & $6.93 \mathrm{e}+03$ & $3.84 \mathrm{e}+01$ \\
\hline $\mathrm{Cs}-134$ & $6.47 \mathrm{e}+00$ & $6.59 \mathrm{e}-02$ \\
\hline $\mathrm{Cs}-137$ & $9.66 \mathrm{e}+03$ & $9.78 \mathrm{e}+00$ \\
\hline $\mathrm{Ba}-137 \mathrm{~m}$ & $9.14 \mathrm{e}+03$ & $3.59 \mathrm{e}+01$ \\
\hline $\mathrm{Eu}-154$ & $1.13 \mathrm{e}+02$ & $1.01 \mathrm{e}+00$ \\
\hline $\mathrm{Pu}-238$ & $1.33 \mathrm{e}+02$ & $4.34 \mathrm{e}+00$ \\
\hline $\mathrm{Pu}-239$ & $1.73 \mathrm{e}+02$ & $5.28 \mathrm{e}+00$ \\
\hline $\mathrm{Pu}-240$ & $1.37 \mathrm{e}+02$ & $4.19 \mathrm{e}+00$ \\
\hline $\mathrm{Am}-241$ & $4.34 \mathrm{e}+02$ & $1.42 \mathrm{e}+01$ \\
\hline $\mathrm{Cm}-244$ & $4.47 \mathrm{e}+00$ & $1.54 \mathrm{e}-01$ \\
\hline
\end{tabular}

Notes: This sumary is limited to key heat contributors. Table 3.9 provides a complete list.

\subsection{CRITICALITY ASSESSMENT FEED}

The primary purpose of constructing a criticality assessment design basis feed is to identify special equipment geometries or operating limits which may be imposed by criticality safety evaluations. The criticality assessment feed is chosen as unirradiated fuel. Unirradiated Mark IA fuel has an outer element with a ${ }^{235} \mathrm{U}$ enrichment of $1.25 \%$, and an inner element ${ }^{235} \mathrm{U}$ enrichment of $0.947 \%$. Unirradiated Mark IV fuel has ${ }^{235} \mathrm{U}$ enrichments of $0.947 \%$ in both inner and outer elements. The criticality assessment feed is therefore unirradiated Mark $1 \mathrm{~A}$ fuel. 


\subsection{N REACTOR FUEL}

\subsection{K BASIN DESCRIPTION}

The 105-K East and 105-K West (referred to as KE and KW) Reactors are located in the 100 Area of the Hanford Site, $0.4 \mathrm{~km}(0.25 \mathrm{mi})$ from the Columbia River. The two reactors, built in the early 1950's, were graphitemoderated plutonium-production reactors using once-through (single-pass) cooling. Each reactor was provided with a large basin for underwater storage of its irradiated fuel. The KW Reactor was shut down in February 1970, and the KE Reactor was shut down in February 1971. Essentially all stored fuel was shipped to the 200 East Area for processing, Teaving the 105-KE and 105-KW fuel storage basins idle but filled with water. The two basins are nearly identical. A three dimensional representation of one basin is depicted in Figure 3.1.

In the mid 1970 's, need for additional storage space for irradiated N Reactor fuel was identified. Projects H-50I (Gydesen 1977) and H-508 (Gydesen 1975) modified the KE and KW Basins, respectively, so that the basins could be used for storage and handling of irradiated $N$ Reactor fuel.

\subsubsection{Irradiated Fuel Storage at the KE and KW Basins}

The fuel at the KE and KW Basins is stored in canisters on the bottom of the basins in single stacked storage racks. Each canister consists of two 20 $\mathrm{cm}$ ( 8 in.) I.D. by $70 \mathrm{~cm}$ (28 in.) long open top cylinders, welded together in binocular fashion. Spacers at each end of the assembly, between the two cylinders, serve as lifting lugs. Each cylinder holds up to seven fuel assemblies, i.e., seven inner elements and seven outer elements. Three different types of canisters (Mark 0, Mark I, and Mark II) are currently deployed within the basins (see Figure 3.2). Mark 0 canisters have perforated bottoms and open tops, and are made of aluminum. Mark I and Mark II canisters have solid bottoms and sealable tops; however, Mark I and Mark II canisters located in the KE Basin do not have the tops installed. Mark I canisters are made of either aluminum or stainless steel. All Mark II canisters are made of stainless steel. There are approximately 3050 Mark II canisters, 2925 Mark I stainless steel canisters, and 1415 Mark 0 or Mark I aluminum canisters in the $\mathrm{K}$ Basins. There are 93 canisters in the KE Basin that were covered with debris and not identified as Mark 0, Mark I, or Mark II. In addition to the $\mathrm{N}$ Reactor fuel, there are approximately 30 containers of SPR fuel; see section 4.3 below. (Pitner 1995 and WHC 1995b)

The KE Basin stores 3,672 canisters containing 51,073 fuel assemblies, elements, or pieces. The KW Basin stores 3,841 canisters containing 53,964 fuel assemblies, elements, or pieces (WHC 1994b). The total mass of fuel elements at the KE Basin is approximately 1,233 metric tons. The total mass of fuel elements in the $K W$ Basin is approximately 1,038 metric tons. Of this total mass, there are approximately $1,143,600 \mathrm{~kg}$ of uranium and $2,155 \mathrm{~kg}$ of plutonium in the KE Basin and approximately $951,900 \mathrm{~kg}$ of uranium and 1,875 kg of plutonium in the KW Basin. 


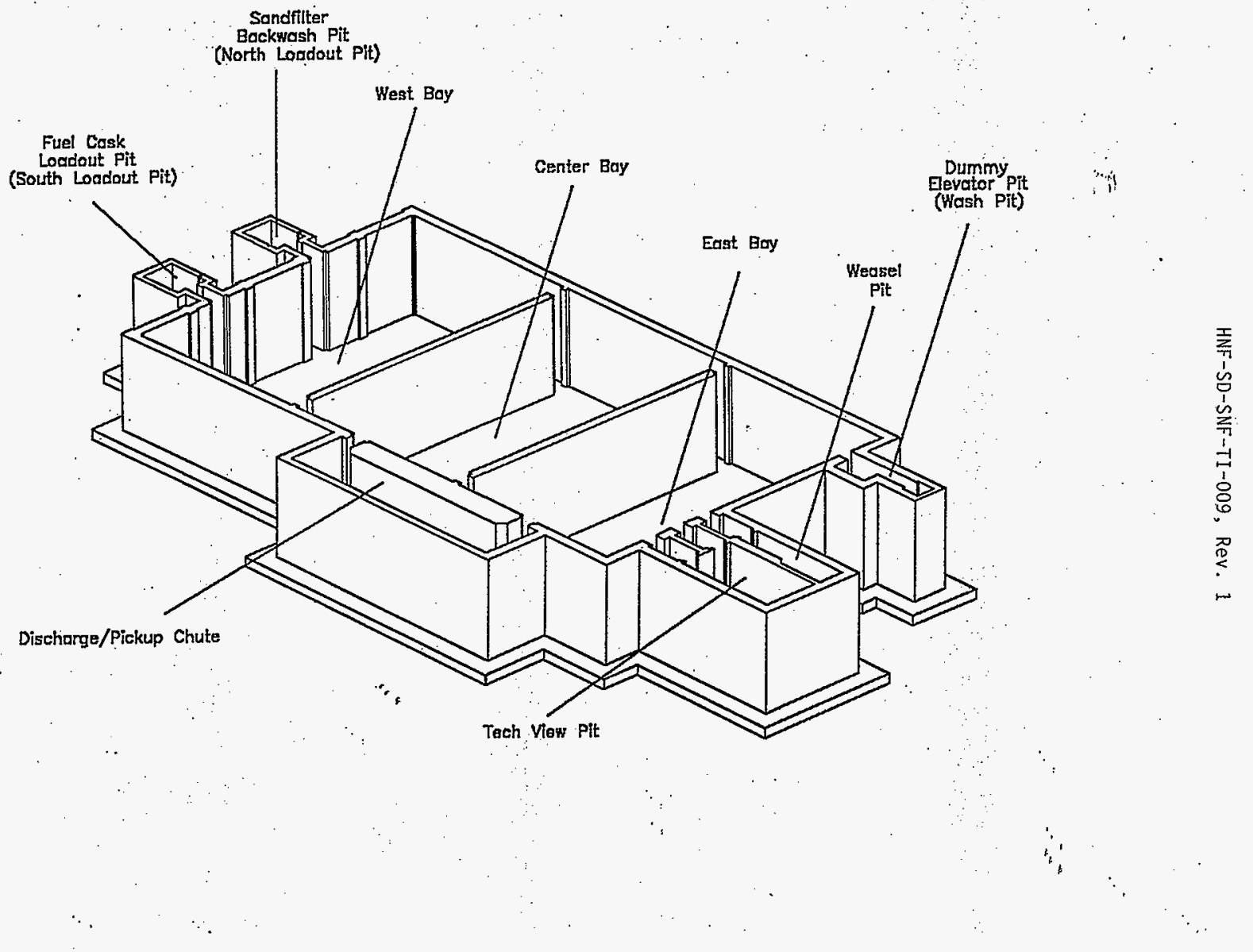


The cladding on a significant fraction of the fuel was damaged at reactor discharge or during subsequent fuel handling. Video imaging done in the summer of 1994 indicates that approximately $40 \%$ of the outer elements and $20 \%$ of the inner elements have breached cladding (Pitner 1995). As a result of the cladding damage, the uranium in some elements was exposed to the water and has oxidized during storage. The uranium oxidation causes the fuel elements to swell and leads to further damage of the cladding, thus exposing fresh uranium to the basin water. The loss of cladding integrity and oxidation of the uranium allows soluble and gaseous fission products to dissolve into the canister water. The open canisters used in the KE Basin allow free exchange of water between the canister and the basin; therefore, soluble and gaseous fission products are continually released to the water of the KE Basin.

All of the canisters in the $\mathrm{KW}$ Basin have closed lids and bottoms; therefore, with the exception of gaseous products, contamination resulting from damaged and/or oxidized fuel has been contained within the canisters. As compared to the KE Basin, the water in the $\mathrm{KW}$ Basin is relatively free of contamination.

In 1983 and 1984, Mark IV fuel in the KE Basin was segregated into fuel grade and weapons grade inventories. The segregation process involved retrieving the fuel canisters from the storage racks, removing the fuel from the canisters, separating the inner elements from the outer elements, measuring the ${ }^{240} \mathrm{Pu}$ content of the elements, reassembiing similar grade elements, repackaging the fuel into canisters, and returning the canisters to the storage racks. Although some of the segregated fuels were later moved to the $\mathrm{KW}$ Basin no Targe scale segregation was undertaken at that faciljty.

A significant amount of sludge has accumulated on the KE Basin's floor. The composition of the sludge is described in Section 5.0 of this document.

\subsection{N REACTOR FUEL DESCRIPTION}

The $\mathbf{N}$ Reactor fuel assemblies consist of two concentric tubes (termed inner and outer elements) made of uranium metal co-extruded into Zircaloy-2 cladding. There are two basic types of fuel assemblies differentiated by their uranium enrichment. Mark IV fuel assemblies have a pre-irradiation enrichment of $0.947 \%{ }^{235} \mathrm{U}$ in both elements and an average uranium weight of $22.7 \mathrm{~kg}$ (50 7b). The Mark IV assemblies have an outside diameter of $6.1 \mathrm{~cm}$ ( $2.42 \mathrm{in})$ and lengths of $44.2,58.9,62.5$, or $66.3 \mathrm{~cm}(17.4,23.2,24.6$, or 26.1 in). Mark IA fuel assemblies have a pre-irradiation enrichment of $1.25 \%{ }^{235} \mathrm{U}$ in the outer element and $0.947 \%{ }^{235} \mathrm{U}$ in the inner element. The Mark $1 \mathrm{~A}$ assemblies have an average uranium weight of $16.3 \mathrm{~kg}(35.9 \mathrm{lb})$. Mark IA fuel assemblies have an outside diameter of $6.1 \mathrm{~cm}(2.40 \mathrm{in})$ and lengths of $37.8,49.8,53.1$, or $66.3 \mathrm{~cm}(14.9,19.6,20.9$, or 26.1 in). A Mark IV fuel assembly is shown schematically in Figure 3.3. Mark IA fuel assemblies are similar. There is also a small amount of fuel with $0.71 \%{ }^{235} \mathrm{U}$ content that

was designated as Mark IVB fuel. The Mark IVB fuel has the same dimensions and weights as the $66.3 \mathrm{~cm}$ (26.1 in) Mark IV fuel. 


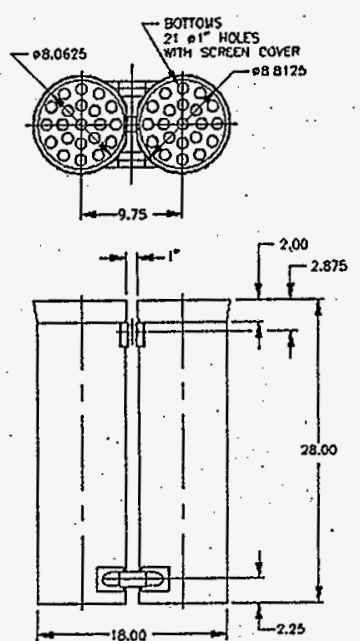

MARK O CANISTERS

$(\mathrm{H}-1-36935)$
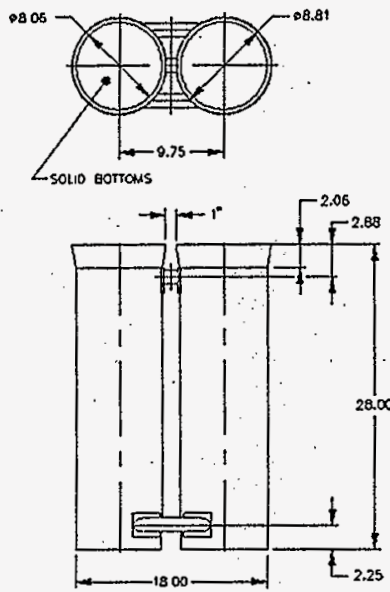

MARK I CANISTERS

(H-1-42793)
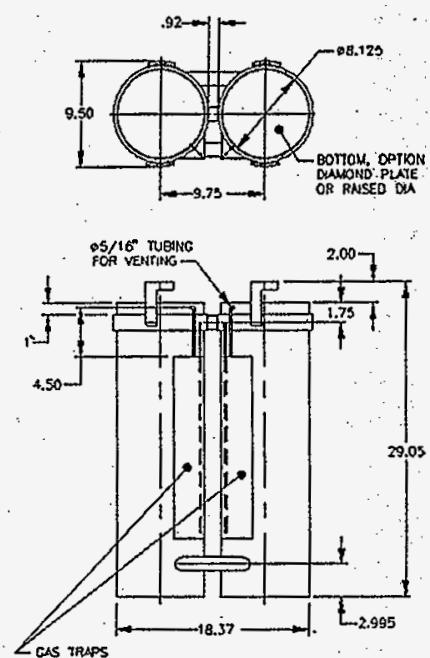

MARK I I CANISTERS ( $H-1-46215)$

\section{5-N REACTOR FUEL STORAGE CANISTERS}


HNF-SD-SNF-TI-009, Rev. 1

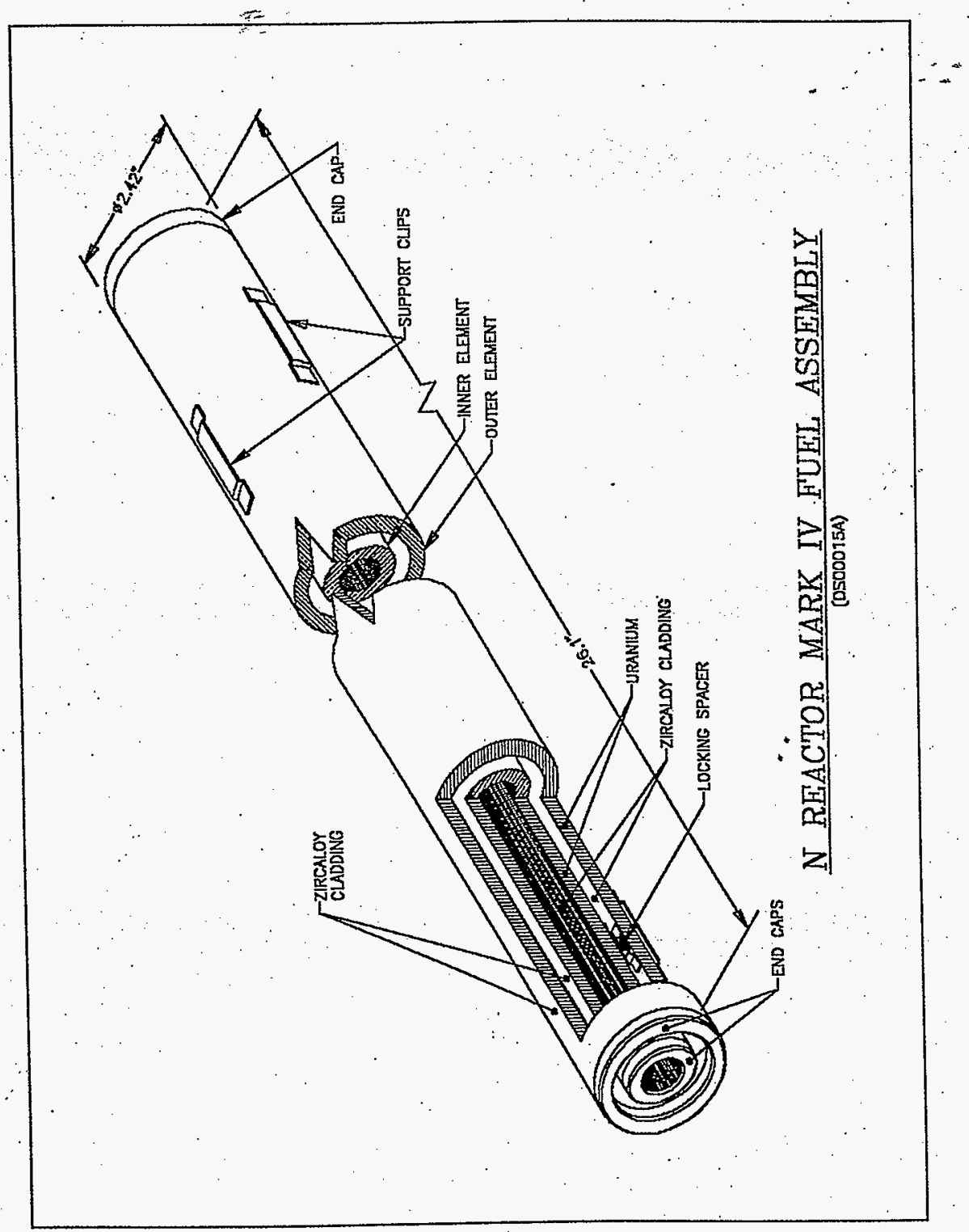

Figure 3.3: N Reactor Mark IV Fuet Assembiy 


\subsubsection{Fuel Fabrication (WHC 1984, WHC 1989)}

In the co-extrusion fabrication process, a tubular billet of uranium was encased in an inner and outer sleeve of Zircaloy-2 with an outer sheath of copper. This billet/cladding assembly was evacuated and sealed to prevent oxidation during preheating and extrusion. As the billet/cladding assembly was extruded under high pressure and elevated temperature, a solid state diffusion bond formed between the uranium core and the Zircaloy- 2 cladding.

The extruded fuel was cut to the desired lengths and a recess was machined into the uranium at each end of the fuel section. The copper sheath was then stripped off by an acid bath, after which an acid etching process was used to remove residual uranium from the cladding. The tube ends were closed by placing a Zircaloy $-2 / 5 \%$ beryllium braze ring and a Zircaloy-2 end cap into the recess in each end of the fuel and then induction heating the assembly to brazing temperature (approximateTy $1050^{\circ} \mathrm{C}$ ) in a vacuum. The junction of the end cap, braze, and cladding was fusion welded to alloy the braze material with the cladding, improving corrosion resistance and providing a hermetic seal. The fuel was then heat treated and cleaned with an abrasive grit blast and acjd baths.

Six spacers were welded to the outside of the inner element to ensure proper alignment and engagement with the outer element when the two elements were assembled together. Eight Zircaloy-2 support clips were welded to the outside of the outer tube to ensure proper alignment of the fuel when inserted into the $N$ Reactor core. Low-carbon steel "shoes" were crimped onto these Zircaloy-2 clips to minimize the tendency for galling to occur between the assemblies and the reactor tubes during fuel insertion and removal. The shoes vary in thickness from $0.25 \mathrm{~mm}$ to $0.46 \mathrm{~mm}$ (10 to $18 \mathrm{mils}$ ) and contain 0.42 to 0.74 grams of iron. Finishing operations on each tube included nondestructive testing, heating in an autoclave, inspecting, and inserting an inner element into an outer element to produce the finished fuel assembly. Table 3.1 provides additional details concerning the two fuel assembly types (the Mark IV and Mark IA) that are prevalent in the basins. 
Table 3.1: 105-N Reactor Fuel Element Description

\begin{tabular}{|c|c|c|c|c|c|c|c|}
\hline & \multicolumn{3}{|r|}{ Mark IV } & \multicolumn{4}{|c|}{ Mark IA } \\
\hline $235_{u}^{-i r r a d i a t i o n ~ e n r i c h m e n t ~ o f ~}$ & \multicolumn{3}{|c|}{$0.947 \%$ Enriched } & \multicolumn{4}{|c|}{$1.25-0.947 \%$ Enriched } \\
\hline Type-Length code ${ }^{1}$ & E & $s$ & A & $\mathbf{E}$ & $M$ & $\mathbf{T}$ & $F$ \\
\hline Length $(\mathrm{cm})$ & 66.3 & 62.5 & $58.9 \quad 44.2$ & 66.3 & 53.1 & 49.8 & 37.8 \\
\hline \multicolumn{8}{|l|}{ Element diameter $(\mathrm{cm})$} \\
\hline 1. Outer of outer & \multicolumn{3}{|r|}{6.15} & \multicolumn{4}{|c|}{6.10} \\
\hline 2. Inner of outer & \multicolumn{3}{|r|}{4.32} & \multicolumn{4}{|c|}{4.50} \\
\hline 3. Outer of inner & \multicolumn{3}{|r|}{3.25} & \multicolumn{4}{|c|}{3.18} \\
\hline 4. Inner of inner & \multicolumn{3}{|r|}{1.22} & \multicolumn{4}{|c|}{1.11} \\
\hline cladding mass $(\mathrm{kg})$ & \multicolumn{3}{|c|}{. } & & & & \\
\hline 1. Outer element & 1.09 & 1.04 & $0.99 \quad 0.79$ & 1.07 & 0.88 & 0.83 & 0.66 \\
\hline 2. Inner element & 0.55 & 0.52 & $0.50 \quad 0.40$ & 0.66 & 0.54 & 0.51 & 0.40 \\
\hline \multicolumn{8}{|l|}{ Mass of uranitum in outer $(\mathrm{kg})$} \\
\hline 1. $\quad\left(0.947 \%^{235} \mathrm{U}\right)$ & \multirow{2}{*}{\multicolumn{3}{|c|}{$16.0 \quad 15.0 \quad 14.1 \quad 10.5$}} & & & & \\
\hline 2. $\left(1.25 \%{ }^{235} \mathrm{U}\right)$ & & & & 13.8 & 11.1 & 10.4 & 7.85 \\
\hline $\begin{array}{l}\text { Mass of } 2 \text { uganium in inner }(\mathrm{kg}) \\
0.947 \%{ }_{\mathrm{U}}\end{array}$ & 7.48 & 7.03 & $6.62 \quad 4.94$ & 6.84 & 5.49 & 5.12 & 3.90 \\
\hline $\begin{array}{l}\text { Weighted average of uranium in } \\
\text { element (kg) }\end{array}$ & \multicolumn{3}{|r|}{22.7} & \multicolumn{4}{|c|}{16.3} \\
\hline $\begin{array}{l}\text { Ratio of Zircaloy-2 to uranium } \\
\text { (kg/MTU) }\end{array}$ & 70.0 & 70.8 & $71.6 \quad 77.1$ & 83.8 & 85.5 & 86.3 & 90.4 \\
\hline Weighted ave. (kg/MTU) & \multicolumn{3}{|r|}{70.3} & \multicolumn{4}{|c|}{85.7} \\
\hline$\%$ of total elements & \multicolumn{3}{|r|}{63} & \multicolumn{4}{|c|}{37} \\
\hline$\%$ of length type of each fuel & 78 & 10 & 7 . & $0.03^{2}$ & 87 & 10 & 3 \\
\hline Displacement volume (L/MTU) & \multicolumn{3}{|r|}{67} & \multicolumn{4}{|c|}{67} \\
\hline
\end{tabular}

1. Letter code differentiates the different lengths of the Mark IV or Mark IA fuet elements, i.e. a.

type "E" element is 66.3 centimeters long.

2. There are only 12 of the $66.3 \mathrm{~cm}$ Mark $1 \mathrm{~A}$ assemblies.

\subsubsection{Burnup and Time Since Discharge}

Fuel burnup (or exposure level) and time since discharge determine the radionuclide content of a fuel assembiy or group of assemblies. The K Basin inventory of $\mathrm{N}$ Reactor fuel is composed of elements which experienced a range of burnups and were discharged from the reactor between January 1971 and Apri1 1987. The burnups range from 0 to approximate $7 y$ 6000 megawatt-days (MWD) per MTU (Roblyer 1995).

Accountability records have been used as the basis for estimating $\mathrm{N}$ Reactor fuel radionuclide content. The accountability. record run data 1isting, dated November 17, 1994, includes discharge date, fuel type, and other information for 497 groups of fuel elements (the groups are also known as keys). Each group (or key) includes elements of the same type, and with the same burnup, that were discharged from the reactor at the same time. The 
mass of uranium associated with each key varies from $2.37 \times 10^{-3}$ to 67.4 MTU. Appendix A.lists the accountability database that forms the inventory basis. Tables 3.2 and 3.3 present breakdowns of the fuel burnups 1 isted in the accountability database for Mark $1 \mathrm{~A}$ and Mark IV fue 1.

Table 3.2: N Reactor Mark IV Fuel Burnup Summary

\begin{tabular}{|c|c|c|}
\hline \multicolumn{2}{|c|}{ Mark IV Fuel Burn-up Surmary } \\
\hline$\%^{240}$ Pu Range & Mass & $\%$ of total mass \\
\hline$\leq 5 \%$ & 166.94 MTU & $11.35 \%$ \\
\hline$>5 \%-7 \%$ & 125.25 MTU & $8.51 \%$ \\
\hline$>7 \%-9 \%$ & 0.059761 MTU & $0.00 \%$ \\
\hline$>9 \%-11 \%$ & 62.988 MTU & $4.28 \%$ \\
\hline$>11 \%-13 \%$ & 270.56 MTU & $18.39 \%$ \\
\hline$>13 \%-15 \%$ & 714.01 MTU & $48.54 \%$ \\
\hline$>15 \%$ & 131.29 MTU & $8.92 \%$ \\
\hline Total & 1471.1 MTU & $100 \%$ \\
\hline
\end{tabular}

Table 3.3: N Reactor Mark 1A Fuel Burnup Summary

\begin{tabular}{|c|c|c|}
\hline \multicolumn{2}{|c|}{ Mark 1A Fuel Burn-up summary } \\
\hline$\%^{240}$ Pu Range & Mass & $\%$ of - total mass \\
\hline$\leq 5 \%$ & 36.124 MTU & $5.75 \%$ \\
\hline$>5 \%-7 \%$ & 3.3729 MTU & $0.54 \%$ \\
\hline$>7 \%-9 \%$ & 0 MTU & $0.00 \%$ \\
\hline$>9 \%-11 \%$ & 68.008 MTU & $10.83 \%$ \\
\hline$>11 \%-13 \%$ & 118.59 MTU & $18.88 \%$ \\
\hline$>13 \%-15 \%$ & 401.88 MTU & $64.00 \%$ \\
\hline$>15 \%$ & 0 MTU & $0.00 \%$ \\
\hline Total & 627.98 MTU & 100 \\
\hline
\end{tabular}




\section{F}

Pu-240 content

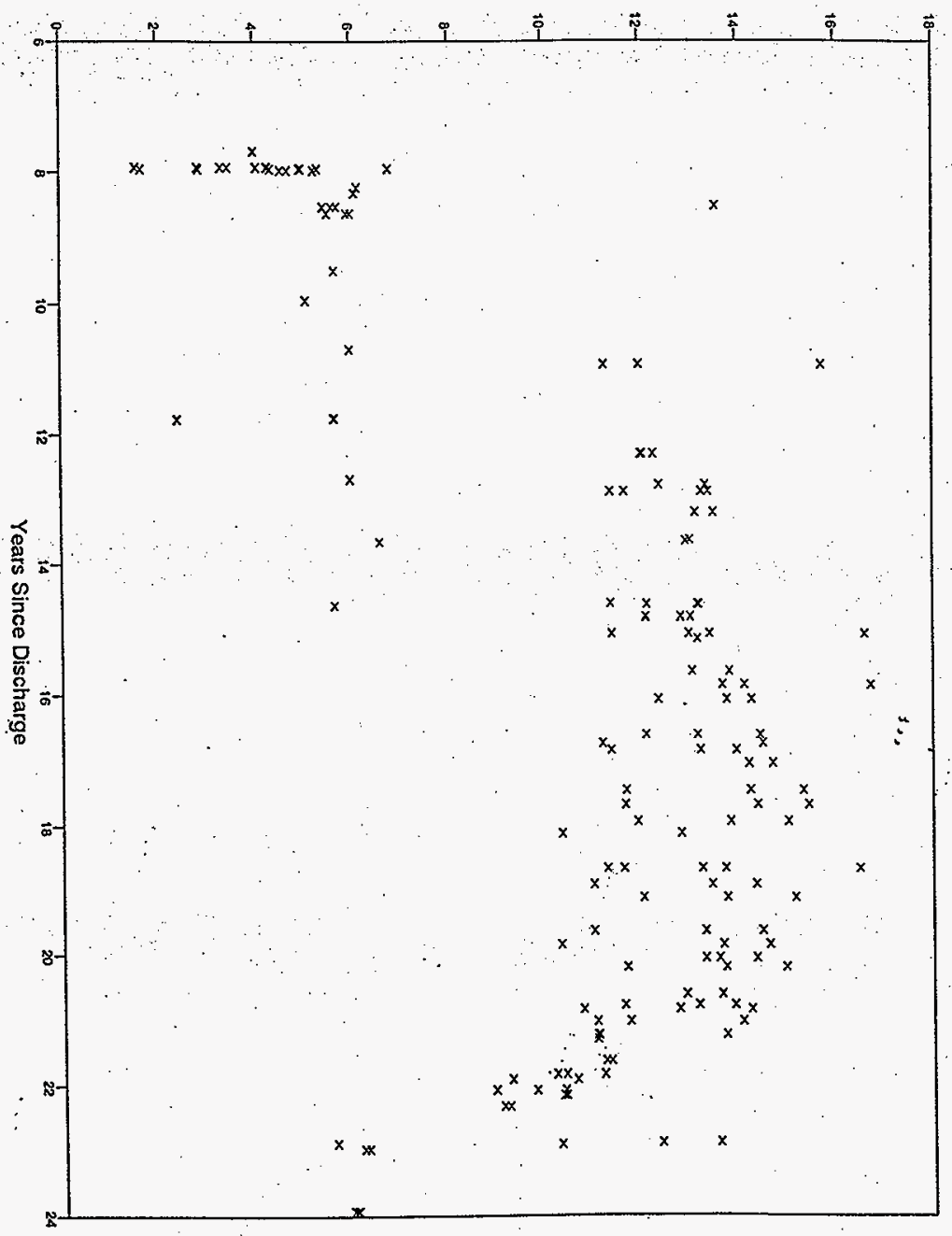

Figure 3.4: K Basin N Reactor Fuel Inventory Characteristics 


\subsection{NOMINAL N REACTOR DESIGN BASIS FEED}

\subsubsection{N Reactor Fuel Chemical Content Methodology}

The chemical content of the fuel is taken from concentration ranges and maximums found in the Hanford Spent Fuel Inventory Baseline (WHC 1994b) and totaled for all of the $\mathrm{N}$ Reactor fuel in the K Basins. The chemical content of the fuel is on a pre-irradiation basis derived by applying the reported pre-irradiation concentration range to the uranium, zirconium, and braze filling total in N Reactor fuel of approximately 2,100,000, 145,000, and 3000 $\mathrm{kg}$, respectively. The pre-irradiation uranium and zircaloy-2 cladding quantities are based on information in the fuel inventory baseline (WHC 1994b). The pre-irradiation braze quantity is based on a totál of $1.37 \mathrm{~g}$ of berylijum per assembly (Weakley 1994) in the braze, and the braze component listing in the fuel inventory baseline (WHC 1994b). In the post irradiated fuel, a small percentage of the uranium will have been fissioned or converted to plutonium, and some of the other constituents will have been activated by neutron bombardment, this is particulariy true for the boron and hafnium which have relatively high neutron capture cross sections. Major actinide and fission product amounts were derived using the specific activities of the nuclides and the nuclide amounts calculated in section 3.3.4 of this report. The specific activities and half lives of the nuclides listed in this document are found in appendix $C$. The overall total chemical inventory is a composite of the uranium fue 1 , the zircaloy 2 cladding and the zirconium/beryllium braze filler material using the midpoint where a range is listed. 
HNF-SD-SNF-TI-009, Rev. I

\subsubsection{N Reactor Fuel Chemical Inventory}

Table 3.4 lists kilogram quantities of the chemical inventory of $\mathrm{N}$ Reactor fuel currently stored in the K Basins.

Table 3.4: N Reactor Fuel Chemical Inventory

\begin{tabular}{|c|c|c|c|c|}
\hline Element & $\begin{array}{c}\text { Uranium Alloy } 601 \\
(\mathrm{~kg})\end{array}$ & $\begin{array}{c}\text { Zircaloy-2 cladding } \\
(\mathrm{kg})\end{array}$ & $\begin{array}{c}\text { Braze Fjller } \\
(\mathrm{kg})\end{array}$ & $\begin{array}{l}\text { Totals } \\
(\mathrm{kg})^{2}\end{array}$ \\
\hline $\begin{array}{c}\mathrm{Al} \\
\mathrm{B} \\
\mathrm{Be} \\
\mathrm{C}\end{array}$ & $\begin{array}{c}1,480-1,900 \\
0.530 \\
21.0 \\
769-1,550 \\
\end{array}$ & $\begin{array}{r}11.1 \\
0.074 \\
- \\
40.7 \\
\end{array}$ & $\begin{array}{c}0.411 \\
0.00142 \\
142 \\
1.42 \\
\end{array}$ & $\begin{array}{c}1,700 \\
0.605 \\
163 \\
1,200 \\
\end{array}$ \\
\hline $\begin{array}{l}\mathrm{Cd} \\
\mathrm{Co} \\
\mathrm{Cr} \\
\mathrm{Cu} \\
\end{array}$ & $\begin{array}{c}0.530 \\
- \\
137 \\
158 \\
\end{array}$ & $\begin{array}{c}0.074 \\
1.48 \\
74=222 \\
7.40 \\
\end{array}$ & $\begin{array}{c}0.00142 \\
0.0567 \\
1.42-4.26 \\
0.170 \\
\end{array}$ & $\begin{array}{l}0.605 \\
1.54 \\
288 \\
166 \\
\end{array}$ \\
\hline $\begin{array}{c}\mathrm{Fe} \\
\mathrm{H} \\
\mathrm{Hf} \\
\mathrm{Mg}\end{array}$ & $\begin{array}{c}632-843 \\
4.22 \\
-- \\
52.7\end{array}$ & $\begin{array}{c}104-296 \\
3.70 \\
29.6 \\
2.96 \\
\end{array}$ & $\begin{array}{c}1.70-5.96 \\
0.142 \\
0.567 \\
0.170 \\
\end{array}$ & $\begin{array}{r}941 \\
8.06 \\
30.2 \\
55.8 \\
\end{array}$ \\
\hline $\begin{array}{c}\text { Mn } \\
\text { Mo } \\
N \\
\text { Na }\end{array}$ & $\begin{array}{c}52.7 \\
- \\
158 \\
- \\
\end{array}$ & $\begin{array}{l}7.40 \\
7.40 \\
11.8 \\
2.96 \\
\end{array}$ & $\begin{array}{l}0.170 \\
0.142 \\
0.567 \\
0.0567 \\
\end{array}$ & $\begin{array}{l}60.3 \\
7.54 \\
170 \\
3.02 \\
\end{array}$ \\
\hline $\begin{array}{c}\mathrm{Ni} \\
\mathrm{O} \\
\mathrm{Pb} \\
\mathrm{Si}\end{array}$ & $\begin{array}{c}211 \\
= \\
261 \\
\end{array}$ & $\begin{array}{c}44.4-118 \\
14.8 \\
14.8 \\
\end{array}$ & $\begin{array}{c}0.851-2.27 \\
6.53 \\
0.369 \\
0.709 \\
\end{array}$ & $\begin{array}{l}294 \\
6.53 \\
15.2 \\
277 \\
\end{array}$ \\
\hline $\begin{array}{l}\text { Sn } \\
T i \\
V \\
W \\
Z r \\
\end{array}$ & $\begin{array}{r}- \\
- \\
- \\
- \\
753 \\
\end{array}$ & $\begin{array}{c}1,780-2,520 \\
7.40 \\
7.40 \\
7.40 \\
145,000 \\
\end{array}$ & $\begin{array}{c}32.3-48.2 \\
0.142 \\
0.142 \\
0.284 \\
2.780 \\
\end{array}$ & $\begin{array}{r}2,190 \\
7.54 \\
7.54 \\
7.68 \\
148,000 \\
\end{array}$ \\
\hline \multicolumn{5}{|l|}{ Actinides } \\
\hline $\begin{array}{l}\mathrm{U} \\
\mathrm{Np} \\
\mathrm{Pu} \\
\mathrm{Am} \\
\mathrm{Cm}\end{array}$ & $\begin{array}{c}2,100,000 \\
81.1 \\
4,120 \\
109 \\
0.018\end{array}$ & $\begin{array}{c}0.518 \\
- \\
- \\
- \\
=\end{array}$ & $\begin{array}{c}0.0113 \\
= \\
- \\
-\end{array}$ & $\begin{array}{c}2,100,000 \\
81.1 \\
4,120 \\
109 \\
0.018\end{array}$ \\
\hline \multicolumn{5}{|c|}{ Fission Products $2 a$} \\
\hline $\begin{array}{l}\mathrm{Se} \\
\mathrm{Sr} \\
\mathrm{TC} \\
\mathrm{Pd} \\
\mathrm{Kr}\end{array}$ & $\begin{array}{c}12.0 \\
152 \\
170 \\
133 \\
77.1 \\
\end{array}$ & $\begin{array}{ll}- & \\
- & \\
- & \end{array}$ & $\begin{array}{l}- \\
\overline{-}\end{array}$ & $\begin{array}{l}12.0 \\
152 \\
170 \\
133 \\
77.1 \\
\end{array}$ \\
\hline $\begin{array}{l}\text { I } \\
\mathrm{Cs} \\
\mathrm{Pm} \\
\mathrm{Sm} \\
\mathrm{Xe} \\
\end{array}$ & $\begin{array}{r}46.1 \\
4.65 \\
0.50 \\
176 \\
1040 \\
\end{array}$ & 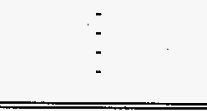 & $\begin{array}{l}- \\
-\end{array}$ & $\begin{array}{l}46.1 \\
4.65 \\
0.50 \\
176 \\
1040 \\
\end{array}$ \\
\hline
\end{tabular}

2

For the values with a range, the midpoint of the range is used

2a stable fission product are based on the ratio of ${ }^{99} \mathrm{Tc}$ in Table 3.5 and the relative concentration of stable fission products from ORIGEN2 for $12 \% 240$ Pu Mark IV assembl ies. 
HNF-SD-SNF-TI-009, Rev, 1

\subsubsection{N Reactor Fuel Radionuclide Content Methodology}

Enabling assumptions used in the development of these data are 1isted in appendix $D$ of this document. The basis for the radionuclide content estimates in the $\mathrm{N}$ Reactor fuel, with the exception of the plutonium 239 and 240 , is the "RADNUC" computer program (WHC 1995a). The plutonium 239 and 240 data were taken from the Westinghouse Hanford Company 1996 Materials Management. Plan (WHC 1996).

The RADNUC program was origina $71 y$ written to estimate the radionuclide content in tank waste. This code was selected for adaptation to the K Basin inventory estimates because it represented an available tool for taking multiple discharge dates and burnups of $\mathrm{N}$ Reactor fuel and developing a composite radionuclide inventory at a common decay date. The code has also maintained a quality assurance pedigree. RADNUC's fuel burnup estimates are based on the spent fueT's ${ }^{240} \mathrm{Pu}$ content, which increases with increasing burnup. The K Basin N Reactor fuel inventory, which includes fuel with burnups from 0 to $6000 \mathrm{MWD} / \mathrm{MTU}$ (Roblyer 1995), ranges from 0 to almost 17 percent ${ }^{240} \mathrm{Pu}$.

Data are input to RADNUC from the output of the "ORIGEN2" program (Schwarz 97). ORIGEN2 estimates total radionuclide content of fuel with a given burnup in the reactor, and then decays the nuclides and predicts future radionuclide amounts. The results produced by ORIGEN2 are somewhat unwieldy because ORIGEN2 tracks a very large number of nuclides. Additionally, one ORIGEN2 run only produces results for one burnup leve1, and so a large number of runs would be required to directly estimate the radionuclide content in the $\mathrm{N}$ Reactor Fuel in the $\mathrm{K}$ Basins. For these reasons, a complete set of ORIGEN2 runs has not been thought to be practical for the $N$ Reactor fuel. Instead, runs for burnups corresponding to ${ }^{240} \mathrm{Pu}$ contents of $6 \%, 9 \%, 12 \%$, and $16 \%$ have been completed and used to estimate radionuclides in the fuel.

RADNUC uses ORIGEN2 estimates of eighty-nine nuclides that have been decayed to levels that would be present one year after discharge from the reactor. The one year decay period was introduced to reduce the number of nuclides to a manageable size by eliminating the short half life nuclides which would have decayed completely after one year. Tables of the eighty-nine nuclides for burnups corresponding to ${ }^{240} \mathrm{Pu}$ contents of $6 \%, 9 \%, 12 \%$, and $16 \%$, are included in the code for both Mark $1 \mathrm{~A}$ and Mark IV fuel. The RADNUC user specifies a data file for each run. The data file must have at least one line, but may have any number of lines. Each line in the data file contains; the date the fuel was discharged from the reactor, fuel type (Mark IV or Mark $1 \mathrm{~A}),{ }^{240} \mathrm{Pu}$ content, and total mass of uranium in the fuel. RADNUC uses a logarithmic interpolation scheme to compute the amount of each of the eightynine nuclides. RADNUC then decays the nuclides to a date selected by the user. The output includes a summation of the total curies and heat production for each nuclide as well as overall totals.

The $\mathrm{N}$ Reactor fuel radionuclide activity and heat generation rates were derived directly from RADNUC output using the accountability records presented in Appendix A as input data and selecting a common decay date of May 31, 1998 . The database was converted into RADNUC input files, which are presented in Appendix B. The RADNUC output files are presented in Appendix $B$ as well. The output files were reformatted to generate the tables in this document.

3.3.3.1 Limitations of the Methodology. The method used to calculate radionuclide inventories (see section 3.3.3) produces conservative results because: 1) the calculations are based on irradiation at a single exposure 
value, whereas the actual fuel keys are blends of higher and lower exposure fuel; and 2) the ${ }^{240} \mathrm{Pu}$ content of the spent fuel is not a liner function of exposure. Consequently, a burnup calculation that treats the average ${ }^{240} \mathrm{Pu}$ concentration of a high/low burnup blend as if it resulted from a single exposure level overestimates the average burnup of the blend.

The resulting conservatism is acceptable for establishing the bounding case, but the more accurate accountability values for ${ }^{239,240} \mathrm{Pu}$ have been used, in the tables for basin totals. The accountability data for the combined basin result in an estimate that is 5\% less than the ORIGEN2 based estimate. The information used to calculate the accountability concentration of $\mathrm{Pu}$ is not readily available for use in calculating other radionuclides, which, therefore, remain overstated. The decay heat is also overstated due to the same conservatism.

\subsubsection{N Reactor Fuel Radionuclide Content}

Tables 3.5, 3.6, and 3.7. list the radionuclide inventory of the $\mathrm{N}$ Reactor Fuel in storage at the $\mathrm{K}$ Basins. Table 3.5 provides an inventory estimate for the combined total for both basins. TabTe 3.6 provides an inventory estimate specific to the KE Basin, and table 3.7 provides an inventory estimate specific to the $\mathrm{KW}$ Basin. The ${ }^{85} \mathrm{Kr}$ data provided in both tables assume there has been no release of this gaseous nuclide from the fuel. 
Table 3.5: Radionuclide Inventory of the Combined $K$ Basins $^{3}$

\begin{tabular}{|c|c|c|c|c|c|c|c|}
\hline Isotope & $\begin{array}{l}\text { Activity } \\
\text { (Ci) }\end{array}$ & $\begin{array}{l}\text { Mass } \\
(\mathrm{Kg})\end{array}$ & $\begin{array}{c}\text { Heat } \\
\text { Generation } \\
\text { (W) }\end{array}$ & Isotope & $\begin{array}{l}\text { Activity } \\
\text { (Ci) }\end{array}$ & $\begin{array}{l}\text { Mass } \\
(\mathrm{Kg})\end{array}$ & $\begin{array}{c}\text { Heat } \\
\text { Generation } \\
\text { (W) }\end{array}$ \\
\hline \multicolumn{8}{|c|}{ Fission and Activation Products } \\
\hline $\begin{array}{l}\mathrm{H}-3 \\
\mathrm{C}-14 \\
\mathrm{Fe}-55 \\
\mathrm{Co}-60 \\
\end{array}$ & $\begin{array}{l}3.66 \mathrm{e}+04 \\
6.93 \mathrm{e}+02 \\
1.84 \mathrm{e}+03 \\
3.96 \mathrm{e}+03 \\
\end{array}$ & $\begin{array}{l}3.79 \mathrm{e}-03 \\
1.55 \mathrm{e}-01 \\
7.36 \mathrm{e}-04 \\
3.50 \mathrm{e}-03\end{array}$ & $\begin{array}{l}1.23 e+00 \\
2.02 e-01 \\
6.12 e-02 \\
6.09 e+01 \\
\end{array}$ & $\begin{array}{l}S n-123 \\
S n-126 \\
S b-124 \\
S b-125 \\
\end{array}$ & $\begin{array}{l}1.74 \mathrm{e}-05 \\
1.56 \mathrm{e}+02 \\
3.03 \mathrm{e}-18 \\
3.35 \mathrm{e}+04\end{array}$ & $\begin{array}{l}2.12 \mathrm{e}-12 \\
5.50 \mathrm{e}+00 \\
1.73 \mathrm{e}-25 \\
3.24 \mathrm{e}-02 \\
\end{array}$ & $\begin{array}{l}5.42 e-08 \\
4.78 e-02 \\
4.01 e-20 \\
1.05 e+02 \\
\end{array}$ \\
\hline $\begin{array}{l}\mathrm{Ni}-59 \\
\mathrm{Ni}-63 \\
\mathrm{Se}-79 \\
\mathrm{Kr}-85 \\
\end{array}$ & $\begin{array}{l}4.10 \mathrm{e}+01 \\
4.49 \mathrm{e}+03 \\
8.62 \mathrm{e}+01 \\
5.90 \mathrm{e}+05 \\
\end{array}$ & $\begin{array}{l}5.41 \mathrm{e}-01 \\
7.28 \mathrm{e}-02 \\
1.24 \mathrm{e}+00 \\
1.50 \mathrm{e}+00 \\
\end{array}$ & $\begin{array}{l}1.63 e-03 \\
4.54 e-01 \\
2.66 e-02 \\
8.85 e+02 \\
\end{array}$ & $\begin{array}{l}s b-126 \\
s b-126 \mathrm{~m} \\
T e-123 \mathrm{~m} \\
T e-125 \mathrm{~m} \\
\end{array}$ & $\begin{array}{l}2.18 e+01 \\
1.56 e+02 \\
2.76 e-11 \\
8.18 e+03 \\
\end{array}$ & $\begin{array}{l}2.61 e-07 \\
1: 99 e-09 \\
3.11 e-18 \\
4.54 e-04\end{array}$ & $\begin{array}{l}3.96 \mathrm{e}-01 \\
2.00 \mathrm{e}+00 \\
3.98 \mathrm{e}-14 \\
6.89 \mathrm{e}+00 \\
\end{array}$ \\
\hline $\begin{array}{l}S r-89 \\
S r-90 \\
\gamma-90 \\
\gamma-91 \\
\end{array}$ & $\begin{array}{r}0.00 \\
1.01 e+07 \\
1.01 e+07 \\
2.23 e-14 \\
\end{array}$ & $\begin{array}{r}0.00 \\
7.40 \mathrm{e}+01 \\
1.86 \mathrm{e}-02 \\
9.09 \mathrm{e}-22 \\
\end{array}$ & $\begin{array}{r}0.00 \\
1.17 \mathrm{e}+04 \\
5.60 \mathrm{e}+04 \\
8.00 \mathrm{e}-17 \\
\end{array}$ & $\begin{array}{l}\text { Te-127 } \\
\text { Te-127m } \\
\text { Te-129 } \\
\text { Te-129m } \\
\end{array}$ & $\begin{array}{r}9.49 \mathrm{e}-07 \\
9.69 \mathrm{e}-07 \\
0.00 \\
0.00 \\
\end{array}$ & $\begin{array}{r}3.60 \mathrm{e}-16 \\
1.03 \mathrm{e}-13 \\
0.00 \\
0.00 \\
\end{array}$ & $\begin{array}{r}1.28 \mathrm{e}-09 \\
4.81 \mathrm{e}-10 \\
0.00 \\
0.00 \\
\end{array}$ \\
\hline $\begin{array}{l}2 r-93 \\
2 r-95 \\
\mathrm{Nb}-93 \mathrm{~m} \\
\mathrm{Nb}-95\end{array}$ & $\begin{array}{l}4.00 \mathrm{e}+02 \\
1.69 \mathrm{e}-12 \\
2.47 \mathrm{e}+02 \\
3.74 \mathrm{e}-12 \\
\end{array}$ & $\begin{array}{l}1.59 e+02 \\
7.85 e-20 \\
8.74 e-04 \\
9.55 e-20 \\
\end{array}$ & $\begin{array}{l}4.61 \mathrm{e}-02 \\
8.49 \mathrm{e}-15 \\
4.42 \mathrm{e}-02 \\
1.79 \mathrm{e}-14 \\
\end{array}$ & $\begin{array}{l}I-129 \\
\text { Cs- } 134 \\
\text { Cs-135 } \\
\text { Cs-137 } \\
\end{array}$ & $\begin{array}{l}6.37 e+00 \\
1.59 e+04 \\
7.75 e+01 \\
1.32 e+07 \\
\end{array}$ & $\begin{array}{l}3.61 e+01 \\
1.23 e-02 \\
6.73 e+01 \\
1.52 e+02\end{array}$ & $\begin{array}{l}2.99 e-03 \\
1.62 e+02 \\
2.59 e-02 \\
1.33 e+04\end{array}$ \\
\hline $\begin{array}{l}\mathrm{Nb}-95 \mathrm{~m} \\
\mathrm{Tc}-99 \\
\mathrm{Ru}-103 \\
\mathrm{Ru}-106 \\
\end{array}$ & $\begin{array}{r}1.25 \mathrm{e}-14 \\
2.88 \mathrm{e}+03 \\
0.00 \\
1.82 \mathrm{e}+03 \\
\end{array}$ & $\begin{array}{r}3.29 \mathrm{e}-23 \\
1.70 \mathrm{e}+02 \\
0.00 \\
5.44 \mathrm{e}-04 \\
\end{array}$ & $\begin{array}{r}1.65 \mathrm{e}-17 \\
1.44 \mathrm{e}+00 \\
0.00 \\
1.08 \mathrm{e}-01 \\
\end{array}$ & $\begin{array}{l}\mathrm{Ba}-137 \mathrm{~m} \\
\mathrm{Ce}-141 \\
\mathrm{Ce}-144 \\
\mathrm{Pr}-143 \\
\end{array}$ & $\begin{array}{r}1.25 \mathrm{e}+07 \\
0.00 \\
9.14 \mathrm{e}+02 \\
0.00 \\
\end{array}$ & $\begin{array}{r}2.32 \mathrm{e}-05 \\
0.00 \\
2.86 \mathrm{e}-04 \\
0.00 \\
\end{array}$ & $\begin{array}{r}4.89 e+04 \\
0.00 \\
6.04 e-01 \\
0.00 \\
\end{array}$ \\
\hline $\begin{array}{l}\mathrm{Rh}-103 \mathrm{~m} \\
\mathrm{Rh}=106 \\
\mathrm{Pd}-107 \\
\mathrm{Ag}-110\end{array}$ & $\begin{array}{r}0.00 \\
1.82 \mathrm{e}+03 \\
1.63 \mathrm{e}+01 \\
2.84 \mathrm{e}-04 \\
\end{array}$ & $\begin{array}{r}0.00 \\
5.11 \mathrm{e}-10 \\
3.17 \mathrm{e}+01 \\
6.81 \mathrm{e}-17 \\
\end{array}$ & $\begin{array}{r}0.00 \\
1.74 e^{+01} \\
8.94 e^{-04} \\
2.13 e-09 \\
\end{array}$ & $\begin{array}{l}\mathrm{Pr}-144 \\
\mathrm{Pr}=144 \mathrm{~m} \\
\mathrm{Pm}=147 \\
\mathrm{Pm}-148\end{array}$ & $\begin{array}{r}9.03 \mathrm{e}+02 \\
1.10 \mathrm{e}+01 \\
4.62 \mathrm{e}+05 \\
0.00 \\
\end{array}$ & $\begin{array}{r}1.20 \mathrm{e}-08 \\
6.06 \mathrm{e}-11 \\
4.98 \mathrm{e}-01 \\
0.00\end{array}$ & $\begin{array}{r}6.62 \mathrm{e}+00 \\
3.69 \mathrm{e}-03 \\
1.70 \mathrm{e}+02 \\
0.00\end{array}$ \\
\hline $\begin{array}{l}\text { Ag- } 110 m \\
\mathrm{Cd}-113 \mathrm{~m} \\
\mathrm{Cd}-115 \mathrm{~m} \\
\mathrm{In}-113 \mathrm{~m}\end{array}$ & $\begin{array}{r}2.14 \mathrm{e}-02 \\
3.55 \mathrm{e}+03 \\
0.00 \\
2.14 \mathrm{e}-07 \\
\end{array}$ & $\begin{array}{r}4.50 \mathrm{e}-09 \\
1.64 \mathrm{e}-02 \\
0.00 \\
1.28 \mathrm{e}-17 \\
\end{array}$ & $\begin{array}{r}3.55 \mathrm{e}-04 \\
3.90 \mathrm{e}+00 \\
0.00 \\
4.95 \mathrm{e}-10 \\
\end{array}$ & $\begin{array}{l}\text { Pm- } 148 m \\
\text { Sm-151 } \\
\text { Eu-152 } \\
\text { Eu-154 } \\
\end{array}$ & $\begin{array}{r}0.00 \\
1.76 \mathrm{e}+05 \\
9.45 \mathrm{e}+02 \\
1.07 \mathrm{e}+05 \\
\end{array}$ & $\begin{array}{r}0.00 \\
6.69 \mathrm{e}+00 \\
5.46 \mathrm{e}-03 \\
3.96 \mathrm{e}-01 \\
\end{array}$ & $\begin{array}{r}0.00 \\
2.06 \mathrm{e}+01 \\
4.28 \mathrm{e}+00 \\
9.64 \mathrm{e}+02 \\
\end{array}$ \\
\hline $\begin{array}{l}\$ n-113 \\
\$ n-119 m \\
\$ n-121 m \\
\end{array}$ & $\begin{array}{l}2.14 \mathrm{e}-07 \\
2.97 \mathrm{e}-01 \\
7.96 \mathrm{e}+01 \\
\end{array}$ & $\begin{array}{l}2.13 e-14 \\
6.62 e-08 \\
1.35 e-03 \\
\end{array}$ & $\begin{array}{l}3.55 \mathrm{e}-11 \\
1.53 \mathrm{e}-04 \\
8.36 \mathrm{e}-02 \\
\end{array}$ & $\begin{array}{l}\text { Eu-155 } \\
\text { Gd-153 } \\
\text { Tb- } 160 \\
\end{array}$ & $\begin{array}{r}2.21 e+04 \\
1.28 e-04 \\
2.77 e-15 \\
\end{array}$ & $\begin{array}{l}4.75 \mathrm{e}-02 \\
3.63 \mathrm{e}-11 \\
2.45 \mathrm{e}-22 \\
\end{array}$ & $\begin{array}{r}1.60 e+01 \\
1.15 e-07 \\
2.21 e-17 \\
\end{array}$ \\
\hline \multicolumn{5}{|c|}{ Fission and Activation Product Totals } & $4.74 \mathrm{e}+07$ & $7.07 \mathrm{e}+02$ & $1.32 \mathrm{e}+05$ \\
\hline \multicolumn{8}{|c|}{ Actinides } \\
\hline $\begin{array}{l}U-234 \\
U-235 \\
U-236 \\
U-238 \\
\end{array}$ & $\begin{array}{l}8.74 \mathrm{e}+02 \\
3.37 \mathrm{e}+01 \\
1.27 \mathrm{e}+02 \\
6.96 \mathrm{e}+02 \\
\end{array}$ & $\begin{array}{l}1.40 \mathrm{e}+02 \\
1.56 \mathrm{e}+04 \\
1.96 \mathrm{e}+03 \\
2.07 \mathrm{e}+06\end{array}$ & $\begin{array}{l}2.47 \mathrm{e}+01 \\
9.14 \mathrm{e}-01 \\
3.40 \mathrm{e}+00 \\
1.73 \mathrm{e}+01\end{array}$ & $\begin{array}{l}\mathrm{Pu}-241 \\
\mathrm{Pu}-242 \\
\mathrm{Am}-241 \\
\mathrm{Am}-242 \\
\end{array}$ & $\begin{array}{l}6.68 \mathrm{e}+06 \\
5.49 \mathrm{e}+01 \\
3.75 \mathrm{e}+05 \\
1.95 \mathrm{e}+02 \\
\end{array}$ & $\begin{array}{l}6.48 \mathrm{e}+01 \\
1.44 \mathrm{e}+01 \\
1.09 \mathrm{e}+02 \\
2.41 \mathrm{e}-07 \\
\end{array}$ & $\begin{array}{r}2.07 \mathrm{e}+02 \\
1.60 \mathrm{e}+00 \\
1.23 \mathrm{e}+04 \\
1.62 \mathrm{e}+00 \\
\end{array}$ \\
\hline $\begin{array}{l}\mathrm{Np}-237 \\
\mathrm{Pu}-238 \\
\mathrm{Pu}-239 \\
\mathrm{Pu}-240 \\
\end{array}$ & $\begin{array}{l}5.72 \mathrm{e}+01 \\
1.11 \mathrm{e}+05 \\
2.18 \mathrm{e}+05 \\
1.19 \mathrm{e}+05 \\
\end{array}$ & $\begin{array}{l}8.11 \mathrm{e}+01 \\
6.48 \mathrm{e}+00 \\
3.51 \mathrm{e}+03 \\
5.22 \mathrm{e}+02 \\
\end{array}$ & $\begin{array}{l}1.65 e+00 \\
3.63 e+03 \\
6.72 \mathrm{e}+03 \\
3.71 \mathrm{e}+03 \\
\end{array}$ & $\begin{array}{l}\mathrm{Am}-242 \mathrm{~m} \\
\mathrm{Am}-243 \\
\mathrm{Cm}-242 \\
\mathrm{Cm}-244 \\
\end{array}$ & $\begin{array}{l}1.96 \mathrm{e}+02 \\
1.20 \mathrm{e}+02 \\
1.62 \mathrm{e}+02 \\
1.44 \mathrm{e}+03 \\
\end{array}$ & $\begin{array}{l}2.02 \mathrm{e}-02 \\
6.02 \mathrm{e}-01 \\
4.90 \mathrm{e}-05 \\
1.78 \mathrm{e}-02 \\
\end{array}$ & $\begin{array}{l}2.99 \mathrm{e}-01 \\
3.81 \mathrm{e}+00 \\
5.86 \mathrm{e}+00 \\
4.95 \mathrm{e}+01 \\
\end{array}$ \\
\hline \multicolumn{5}{|c|}{ Actinide Totals } & $7.51 \mathrm{e}+06$ & $2.09 e+06$ & $2.66 \mathrm{e}+04$ \\
\hline
\end{tabular}

Table 3.6: K-East Basin Radionuclide Inventory ${ }^{4}$

3

06/02/1997 RADNUC2A run for combined $K$ Basins, with Results decayed to 05/31/1998. Total fuel mass in the combined basins $2.10 \mathrm{e}+03 \mathrm{MTU}$. Total fuel activity in the combined basins $5.50 \mathrm{e}+07 \mathrm{Ci}$. Total fuel heat generation in the combined basins $1.61 \mathrm{e}+05 \mathrm{~W}$. Pu-239 and Pu-240 have been adjusted to ensure consistency with data previously reported by Safeguards.

4 06/02/1997 RADNUC2A run for K-East Basin fuel. Results decayed to 05/31/1998. Total fuel mass in K-East $1.15 \mathrm{e}+03 \mathrm{MTU}$. Total fuel activity in $\mathrm{K}$-East $2.73 \mathrm{e}+07 \mathrm{Ci}$. Total fuel heat generation in $\mathrm{K}$-East $8.06 \mathrm{e}+04 \mathrm{~W}$. Pu-239 and Pu-240 have been adjusted to ensure consistency with data previously reported by safeguards. 
HNF-SD-SNF-TI-009, Rev. 1

\begin{tabular}{|c|c|c|c|c|c|c|c|}
\hline Isotope & $\begin{array}{l}\text { Activity } \\
\text { (Ci) }\end{array}$ & $\begin{array}{l}\text { Mass } \\
(\mathrm{Kg})\end{array}$ & $\begin{array}{c}\text { Heat } \\
\text { Generation } \\
\text { (W) }\end{array}$ & I sotope & $\begin{array}{l}\text { Activity } \\
\text { (Ci) }\end{array}$ & $\begin{array}{l}\text { Mass } \\
(\mathrm{Kg})\end{array}$ & $\begin{array}{c}\text { Heat } \\
\text { Generation } \\
\text { (W) }\end{array}$ \\
\hline \multicolumn{8}{|c|}{ Fission and Activation Products } \\
\hline $\begin{array}{l}\mathrm{H}-3 \\
\mathrm{C}-14 \\
\mathrm{Fe}-55 \\
\mathrm{CO}-60 \\
\end{array}$ & $\begin{array}{l}1.80 \mathrm{e}+04 \\
3.62 \mathrm{e}+02 \\
9.64 \mathrm{e}+02 \\
1.86 \mathrm{e}+03 \\
\end{array}$ & $\begin{array}{l}1.86 e-03 \\
8.12 e-02 \\
3.86 e-04 \\
1.64 e-03 \\
\end{array}$ & $\begin{array}{l}6.04 \mathrm{e}-01 \\
1.06 \mathrm{e}-01 \\
3.22 \mathrm{e}-02 \\
2.86 \mathrm{e}+01 \\
\end{array}$ & $\begin{array}{l}s n-123 \\
S n-126 \\
S b-124 \\
s b-125\end{array}$ & $\begin{array}{l}1.46 e-05 \\
8.07 e+01 \\
2.49 e-18 \\
1.69 e+04 \\
\end{array}$ & $\begin{array}{l}1.78 \mathrm{e}-12 \\
2.84 \mathrm{e}+00 \\
1.42 \mathrm{e}-25 \\
1.64 \mathrm{e}-02 \\
\end{array}$ & $\begin{array}{l}4.57 \mathrm{e}-08 \\
2.48 \mathrm{e}-02 \\
3.28 \mathrm{e}-20 \\
5.31 \mathrm{e}+01 \\
\end{array}$ \\
\hline $\begin{array}{l}\mathrm{Ni}-59 \\
\mathrm{Ni}-63 \\
\mathrm{Se}-79 \\
\mathrm{Kr}-85\end{array}$ & $\begin{array}{l}2.11 e+01 \\
2.30 e+03 \\
4.35 e+01 \\
2.84 e+05\end{array}$ & $\begin{array}{l}2.79 e-01 \\
3.73 e-02 \\
6.24 e-01 \\
7.24 e-01 \\
\end{array}$ & $\begin{array}{l}8.38 \mathrm{e}-04 \\
2.33 \mathrm{e}-01 \\
1.34 \mathrm{e}-02 \\
4.25 \mathrm{e}+02\end{array}$ & $\begin{array}{l}\$ b-126 \\
\$ b-126 m \\
T e-123 m \\
T e-125 m \\
\end{array}$ & $\begin{array}{l}1.13 e+01 \\
8.07 e+01 \\
2.33 e-11 \\
4.13 e+03\end{array}$ & $\begin{array}{l}1.35 e-07 \\
1.03 e-09 \\
2.63 e-18 \\
2.29 e-04\end{array}$ & $\begin{array}{l}2.05 e-01 \\
1.03 e+00 \\
3.37 e-14 \\
3.46 e+00\end{array}$ \\
\hline $\begin{array}{l}S r-89 \\
S r-90 \\
Y-90 \\
Y-91 \\
\end{array}$ & $\begin{array}{r}0.00 \\
4.96 \mathrm{e}+06 \\
4.97 \mathrm{e}+06 \\
1.78 \mathrm{e}-14 \\
\end{array}$ & $\begin{array}{r}0.00 \\
3.64 e+01 \\
9.13 e-03 \\
7.26 e-22 \\
\end{array}$ & $\begin{array}{r}0.00 \\
5.77 e+03 \\
2.75 e+04 \\
6.39 e-17 \\
\end{array}$ & $\begin{array}{l}\text { Te-127 } \\
\text { Te-127m } \\
\text { Te-129 } \\
\text { Te-129m }\end{array}$ & $\begin{array}{r}7.90 \mathrm{e}-07 \\
8.07 \mathrm{e}-07 \\
0.00 \\
0.00 \\
\end{array}$ & $\begin{array}{r}2.99 e-16 \\
8.55 e-14 \\
0.00 \\
0.00 \\
\end{array}$ & $\begin{array}{r}1.07 \mathrm{e}-09 \\
3.98 \mathrm{e}-10 \\
0.00 \\
0.00\end{array}$ \\
\hline $\begin{array}{l}\mathrm{Zr}-93 \\
\mathrm{Zr}-95 \\
\mathrm{Nb}-93 \mathrm{~m} \\
\mathrm{Nb}-95\end{array}$ & $\begin{array}{l}2.01 e+02 \\
1.35 e-12 \\
1.26 e+02 \\
3: 01 e-12 \\
\end{array}$ & $\begin{array}{l}7.98 e+01 \\
6.30 e-20 \\
4.46 e-04 \\
7.69 e-20 \\
\end{array}$ & $\begin{array}{l}2.30 e-02 \\
6.83 e-15 \\
2.25 e-02 \\
1.44 e-14 \\
\end{array}$ & $\begin{array}{l}I-129 \\
C s-134 \\
c s-135 \\
c s-137 \\
\end{array}$ & $\begin{array}{l}3.26 \mathrm{e}+00 \\
6.95 \mathrm{e}+03 \\
3.96 \mathrm{e}+01 \\
6.55 \mathrm{e}+06 \\
\end{array}$ & $\begin{array}{l}1.85 e+01 \\
5.37 e-03 \\
3.44 e+01 \\
7.53 e+01 \\
\end{array}$ & $\begin{array}{l}1.52 \mathrm{e}-03 \\
7.09 \mathrm{e}+01 \\
1.32 \mathrm{e}-02 \\
6.62 \mathrm{e}+03\end{array}$ \\
\hline $\begin{array}{l}\text { Nb-95m } \\
\text { Tc-99 } \\
\text { Ru-103 } \\
\text { Ru-106 }\end{array}$ & $\begin{array}{r}1.00 \mathrm{e}-14 \\
1.45 \mathrm{e}+03 \\
0.00 \\
1.39 \mathrm{e}+03 \\
\end{array}$ & $\begin{array}{r}2.64 e-23 \\
8.55 e+01 \\
0.00 \\
4.15 e-04 \\
\end{array}$ & $\begin{array}{r}1.33 e-17 \\
7.27 e-01 \\
0.00 \\
8.26 e-02 \\
\end{array}$ & $\begin{array}{l}\mathrm{Ba}-137 \mathrm{~m} \\
\mathrm{Ce}-141 \\
\mathrm{Ce}-144 \\
\mathrm{Pr}-143 \\
\end{array}$ & $\begin{array}{r}6.19 \mathrm{e}+06 \\
0.00 \\
7.56 \mathrm{e}+02 \\
0.00 \\
\end{array}$ & $\begin{array}{r}1.15 \mathrm{e}-05 \\
0.00 \\
2.37 \mathrm{e}-04 \\
0.00 \\
\end{array}$ & $\begin{array}{r}2.43 \mathrm{e}+04 \\
0.00 \\
4.98 \mathrm{e}-01 \\
0.00 \\
\end{array}$ \\
\hline $\begin{array}{l}\mathrm{Rh}-103 \mathrm{~m} \\
\mathrm{Rh}-106 \\
\mathrm{Pd}-107 \\
\mathrm{Ag}-110 \\
\end{array}$ & $\begin{array}{r}0.00 \\
1.39 e+03 \\
8.59 e+00 \\
2.28 e-04 \\
\end{array}$ & $\begin{array}{r}0.00 \\
3.90 \mathrm{e}-10 \\
1.67 \mathrm{e}+01 \\
5.47 \mathrm{e}-17 \\
\end{array}$ & $\begin{array}{r}0.00 \\
1.32 e+01 \\
4.72 e-04 \\
1.71 e-09 \\
\end{array}$ & $\begin{array}{l}\mathrm{Pr}-144 \\
\mathrm{Pr}-144 \mathrm{~m} \\
\mathrm{Pm}-147 \\
\mathrm{Pm}-148 \\
\end{array}$ & $\begin{array}{r}7.47 \mathrm{e}+02 \\
9.07 \mathrm{e}+00 \\
2.45 \mathrm{e}+05 \\
0.00 \\
\end{array}$ & $\begin{array}{r}9.89 e-09 \\
5.00 e-11 \\
2.64 e-01 \\
0.00 \\
\end{array}$ & $\begin{array}{r}5.48 \mathrm{e}+00 \\
3.05 \mathrm{e}-03 \\
9.00 \mathrm{e}+01 \\
0.00 \\
\end{array}$ \\
\hline $\begin{array}{l}\mathrm{Ag}-110 \mathrm{~m} \\
\mathrm{Cd}-113 \mathrm{~m} \\
\mathrm{Cd}-115 \mathrm{~m} \\
\mathrm{In}-113 \mathrm{~m} \\
\end{array}$ & $\begin{array}{r}1.71 \mathrm{e}-02 \\
1.80 \mathrm{e}+03 \\
0.00 \\
1.77 \mathrm{e}-07 \\
\end{array}$ & $\begin{array}{r}3.60 \mathrm{e}-09 \\
8.30 \mathrm{e}-03 \\
0.00 \\
1.06 \mathrm{e}-17 \\
\end{array}$ & $\begin{array}{r}2.84 e-04 \\
1.98 e+00 \\
0.00 \\
4.10 e-10 \\
\end{array}$ & $\begin{array}{l}\text { Pm- } 148 m \\
S m-151 \\
\text { Eu- } 152 \\
\text { Eu-154 } \\
\end{array}$ & $\begin{array}{r}0.00 \\
8.92 \mathrm{e}+04 \\
4.67 \mathrm{e}+02 \\
5.30 \mathrm{e}+04 \\
\end{array}$ & $\begin{array}{r}0.00 \\
3.39 \mathrm{e}+00 \\
2.70 \mathrm{e}-03 \\
1.96 \mathrm{e}-01 \\
\end{array}$ & $\begin{array}{r}0.00 \\
1.04 \mathrm{e}+01 \\
2.11 \mathrm{e}+00 \\
4.75 \mathrm{e}+02 \\
\end{array}$ \\
\hline $\begin{array}{l}S n-113 \\
S n-119 m \\
S n-121 m \\
\end{array}$ & $\begin{array}{l}1.77 \mathrm{e}-07 \\
2.50 \mathrm{e}-01 \\
4.01 \mathrm{e}+01 \\
\end{array}$ & $\begin{array}{l}1.76 e-14 \\
5.57 e-08 \\
6.78 e-04 \\
\end{array}$ & $\begin{array}{r}2.93 e-11 \\
1.28 \mathrm{e}-04 \\
4.20 \mathrm{e}-02 \\
\end{array}$ & $\begin{array}{l}E u-155 \\
\mathrm{Gd}-153 \\
\mathrm{~Tb}-160 \\
\end{array}$ & $\begin{array}{l}1.12 e+04 \\
9.59 e-05 \\
2.29 e-15 \\
\end{array}$ & $\begin{array}{l}2.41 e-02 \\
2.72 e-11 \\
2.03 e-22 \\
\end{array}$ & $\begin{array}{l}8.12 e+00 \\
8.64 e-08 \\
1.83 e-17 \\
\end{array}$ \\
\hline \multicolumn{5}{|c|}{ Fission and Activation Product Totals } & $2.34 \mathrm{e}+07$ & $3.55 e+02$ & $6.53 e+04$ \\
\hline \multicolumn{8}{|c|}{ Actinides } \\
\hline $\begin{array}{l}U-234 \\
U-235 \\
U-236 \\
U-238 \\
\end{array}$ & $\begin{array}{l}4.66 e+02 \\
1.77 \mathrm{e}+01 \\
6.61 \mathrm{e}+01 \\
3.80 \mathrm{e}+02 \\
\end{array}$ & $\begin{array}{l}7.46 \mathrm{e}+01 \\
8.19 \mathrm{e}+03 \\
1.02 \mathrm{e}+03 \\
1.13 \mathrm{e}+06 \\
\end{array}$ & $\begin{array}{l}1.32 e+01 \\
4.81 e-01 \\
1.77 e+00 \\
9.46 e+00 \\
\end{array}$ & $\begin{array}{l}\mathrm{Pu}-241 \\
\mathrm{Pu}-242 \\
\mathrm{Am}-241 \\
\mathrm{Am}-242 \\
\end{array}$ & $\begin{array}{l}3.42 e+06 \\
3.07 e+01 \\
2.06 e+05 \\
1.13 e+02 \\
\end{array}$ & $\begin{array}{l}3.32 e+01 \\
8.04 e+00 \\
6.00 e+01 \\
1.40 e-07 \\
\end{array}$ & $\begin{array}{l}1.06 e+02 \\
8.94 e-01 \\
6.74 e+03 \\
9.43 e-01 \\
\end{array}$ \\
\hline $\begin{array}{l}\text { Np-237 } \\
\text { Pu-238 } \\
\text { Pu-239 } \\
\text { Pu-240 } \\
\end{array}$ & $\begin{array}{l}3.02 \mathrm{e}+01 \\
6.05 \mathrm{e}+04 \\
1.16 \mathrm{e}+05 \\
6.37 \mathrm{e}+04 \\
\end{array}$ & $\begin{array}{l}4.28 \mathrm{e}+01 \\
3.53 \mathrm{e}+00 \\
1.87 \mathrm{e}+03 \\
2.80 \mathrm{e}+02 \\
\end{array}$ & $\begin{array}{l}8.70 \mathrm{e}-01 \\
1.97 \mathrm{e}+03 \\
3.59 \mathrm{e}+03 \\
1.98 \mathrm{e}+03 \\
\end{array}$ & $\begin{array}{l}\mathrm{Am}-242 \mathrm{~m} \\
\mathrm{Am}-243 \\
\mathrm{Cm}-242 \\
\mathrm{Cm}-244 \\
\end{array}$ & $\begin{array}{l}1.14 \mathrm{e}+02 \\
7.12 \mathrm{e}+01 \\
9.40 \mathrm{e}+01 \\
8.71 \mathrm{e}+02 \\
\end{array}$ & $\begin{array}{l}1.17 \mathrm{e}-02 \\
3.57 \mathrm{e}-01 \\
2.84 \mathrm{e}-05 \\
1.08 \mathrm{e}-02 \\
\end{array}$ & $\begin{array}{l}1.74 \mathrm{e}-01 \\
2.25 \mathrm{e}+00 \\
3.40 \mathrm{e}+00 \\
2.99 \mathrm{e}+01 \\
\end{array}$ \\
\hline \multicolumn{5}{|c|}{ Actinide Totals } & $3.87 \mathrm{e}+06$ & $1.14 e+06$ & $1.45 \mathrm{e}+04$ \\
\hline \multicolumn{8}{|c|}{ Table 3.7: K- } \\
\hline Isotope & $\begin{array}{l}\text { Activity } \\
\text { (Ci) }\end{array}$ & $\begin{array}{l}\text { Mass } \\
(\mathrm{Kg})\end{array}$ & $\begin{array}{c}\text { Heat } \\
\text { Generation } \\
\text { (W) }\end{array}$ & Isotope & $\begin{array}{l}\text { Activity } \\
\text { (Ci) }\end{array}$ & $\begin{array}{l}\text { Mass } \\
(\mathrm{Kg})\end{array}$ & $\begin{array}{c}\text { Heat } \\
\text { Generation } \\
\text { (W) }\end{array}$ \\
\hline \multicolumn{8}{|c|}{ Fission and Activation Products } \\
\hline
\end{tabular}

5

06/02/1997 RADNUC2A run for $K$-West Basin. Results decayed to 05/31/1998. Total fuel mass in $K$ West $9.53 \mathrm{e}+02$ MTU. Total fuel activity in K-West $2.77 \mathrm{e}+07 \mathrm{Ci}$. Total Heat Generation of fuel in $\mathrm{K}$-West $8.03 e+04 \mathrm{~W}$. Pu-239 and Pu-240 have been adjusted to ensure consistency with data previously reported by Safeguards. 


\begin{tabular}{|c|c|c|c|c|c|c|c|}
\hline $\begin{array}{l}H-3 \\
C-14 \\
F e-55 \\
C o-60 \\
\end{array}$ & $\begin{array}{l}1.86 \mathrm{e}+04 \\
3.31 \mathrm{e}+02 \\
8.75 \mathrm{e}+02 \\
2.10 \mathrm{e}+03 \\
\end{array}$ & $\begin{array}{l}1.93 e-03 \\
7.43 e-02 \\
3.50 e-04 \\
1.86 e-03 \\
\end{array}$ & $\begin{array}{l}6.24 \mathrm{e}-01 \\
9.67 \mathrm{e}-02 \\
2.92 \mathrm{e}-02 \\
3.22 \mathrm{e}+01 \\
\end{array}$ & $\begin{array}{l}\mathrm{Sn}-123 \\
\mathrm{Sn}-126 \\
\mathrm{sb}-124 \\
\mathrm{sb}-125\end{array}$ & $\begin{array}{l}2.75 \mathrm{e}-06 \\
7.50 \mathrm{e}+01 \\
5.45 \mathrm{e}-19 \\
1.66 \mathrm{e}+04\end{array}$ & $\begin{array}{l}3.35 e-13 \\
2.64 e+00 \\
3.12 e-26 \\
1.61 e-02 \\
\end{array}$ & $\begin{array}{l}8.58 \mathrm{e}-09 \\
2.30 \mathrm{e}-02 \\
7.21 \mathrm{e}-21 \\
5.23 \mathrm{e}+01 \\
\end{array}$ \\
\hline $\begin{array}{l}\mathrm{Ni}-59 \\
\mathrm{Ni}-63 \\
\mathrm{Se}-79 \\
\mathrm{Kr}-85 \\
\end{array}$ & $\begin{array}{l}1.99 \mathrm{e}+01 \\
2.19 \mathrm{e}+03 \\
4.28 \mathrm{e}+01 \\
3.06 \mathrm{e}+05 \\
\end{array}$ & $\begin{array}{l}2.63 e-01 \\
3.55 e-02 \\
6.14 e-01 \\
7.80 e-01 \\
\end{array}$ & $\begin{array}{l}7.88 \mathrm{e}-04 \\
2.21 \mathrm{e}-01 \\
1.32 \mathrm{e}-02 \\
4.60 \mathrm{e}+02 \\
\end{array}$ & $\begin{array}{l}\text { sb- } 126 \\
\text { sb-126m } \\
\text { Te-123m } \\
\text { Te-125m }\end{array}$ & $\begin{array}{l}1.05 \mathrm{e}+01 \\
7.50 \mathrm{e}+01 \\
4.28 \mathrm{e}-12 \\
4.05 \mathrm{e}+03\end{array}$ & $\begin{array}{l}1.26 \mathrm{e}-07 \\
9.55 \mathrm{e}-10 \\
4.82 \mathrm{e}-19 \\
2.25 \mathrm{e}-04 \\
\end{array}$ & $\begin{array}{l}1.90 \mathrm{e}-01 \\
9.61 \mathrm{e}-01 \\
6.21 \mathrm{e}-15 \\
3.40 \mathrm{e}+00 \\
\end{array}$ \\
\hline $\begin{array}{l}S r-89 \\
S r-90 \\
Y-90 \\
Y-91 \\
\end{array}$ & $\begin{array}{r}0.00 \\
5.17 e+06 \\
5.17 e+06 \\
4.47 \mathrm{e}-15 \\
\end{array}$ & $\begin{array}{r}0.00 \\
3.79 \mathrm{e}+01 \\
9.50 \mathrm{e}-03 \\
1.82 \mathrm{e}-22 \\
\end{array}$ & $\begin{array}{r}0.00 \\
6.011 e+03 \\
2.86 e+04 \\
1.60 e-17 \\
\end{array}$ & $\begin{array}{l}\text { Te-127 } \\
\text { Te-127m } \\
\text { Te-129 } \\
\text { Te-129m } \\
\end{array}$ & $\begin{array}{r}1.59 \mathrm{e}-07 \\
1.62 \mathrm{e}-07 \\
0.00 \\
0.00\end{array}$ & $\begin{array}{r}6.02 \mathrm{e}-17 \\
1.72 \mathrm{e}-14 \\
0.00 \\
0.00 \\
\end{array}$ & $\begin{array}{r}2.14 \mathrm{e}-10 \\
8.03 \mathrm{e}-11 \\
0.00 \\
0.00 \\
\end{array}$ \\
\hline $\begin{array}{l}\mathrm{Zr}-93 \\
\mathrm{Zr}-95 \\
\mathrm{Nb}-93 \mathrm{~m} \\
\mathrm{Nb}-95\end{array}$ & $\begin{array}{l}2.01 \mathrm{e}+02 \\
3.30 \mathrm{e}-13 \\
1.22 \mathrm{e}+02 \\
7.33 \mathrm{e}-13\end{array}$ & $\begin{array}{l}7.98 \mathrm{e}+01 \\
1.54 \mathrm{e}-20 \\
4.32 \mathrm{e}-04 \\
1.87 \mathrm{e}-20 \\
\end{array}$ & $\begin{array}{l}2.30 e-02 \\
1.66 e-15 \\
2.18 e-02 \\
3.52 e-15\end{array}$ & $\begin{array}{l}1-129 \\
C s-134 \\
C s-135 \\
C s-137\end{array}$ & $\begin{array}{l}3.11 e+00 \\
8.96 e+03 \\
3.79 e+01 \\
6.64 e+06\end{array}$ & $\begin{array}{l}1.76 \mathrm{e}+01 \\
6.92 \mathrm{e}-03 \\
3.29 \mathrm{e}+01 \\
7.63 \mathrm{e}+01\end{array}$ & $\begin{array}{l}1.46 \mathrm{e}-03 \\
9.14 \mathrm{e}+01 \\
1.27 \mathrm{e}-02 \\
6.71 \mathrm{e}+03\end{array}$ \\
\hline $\begin{array}{l}\mathrm{Nb}-95 \mathrm{~m} \\
\mathrm{Tc}-99 \\
\mathrm{Ru}-103 \\
\mathrm{Ru}-106 \\
\end{array}$ & $\begin{array}{r}2.45 \mathrm{e}-15 \\
1.43 \mathrm{e}+03 \\
0.00 \\
4.34 \mathrm{e}+02 \\
\end{array}$ & $\begin{array}{r}6.44 \mathrm{e}-24 \\
8.43 \mathrm{e}+01 \\
0.00 \\
1.30 \mathrm{e}-04 \\
\end{array}$ & $\begin{array}{r}3.23 \mathrm{e}-18 \\
7.18 \mathrm{e}-01 \\
0.00 \\
2.58 \mathrm{e}-02 \\
\end{array}$ & $\begin{array}{l}\text { Ba- } 137 \mathrm{~m} \\
\mathrm{Ce}-141 \\
\mathrm{Ce}-144 \\
\mathrm{Pr}-143 \\
\end{array}$ & $\begin{array}{r}6.28 \mathrm{e}+06 \\
0.00 \\
1.58 \mathrm{e}+02 \\
0.00 \\
\end{array}$ & $\begin{array}{r}1.17 \mathrm{e}-05 \\
0.00 \\
4.95 \mathrm{e}-05 \\
0.00 \\
\end{array}$ & $\begin{array}{r}2.46 \mathrm{e}+04 \\
0.00 \\
1.04 \mathrm{e}-01 \\
0.00 \\
\end{array}$ \\
\hline $\begin{array}{l}\text { Rh-103m } \\
\text { Rh-106 } \\
\text { Pd-107 } \\
\mathrm{Ag}-110 \\
\end{array}$ & $\begin{array}{r}0.00 \\
4.34 \mathrm{e}+02 \\
7.68 \mathrm{e}+00 \\
5.66 \mathrm{e}-05 \\
\end{array}$ & $\begin{array}{r}0.00 \\
1.22 \mathrm{e}-10 \\
1.49 \mathrm{e}+01 \\
1.36 \mathrm{e}-17 \\
\end{array}$ & $\begin{array}{r}0.00 \\
4.13 e+00 \\
4.22 e-04 \\
4.25 e-10 \\
\end{array}$ & $\begin{array}{l}\mathrm{Pr}-144 \\
\mathrm{Pr}-144 \mathrm{~m} \\
\mathrm{Pm}-147 \\
\mathrm{Pm}-148 \\
\end{array}$ & $\begin{array}{r}1.56 \mathrm{e}+02 \\
1.90 \mathrm{e}+00 \\
2.17 \mathrm{e}+05 \\
0.00 \\
\end{array}$ & $\begin{array}{r}2.06 e-09 \\
1.05 e-11 \\
2.34 \mathrm{e}-01 \\
0.00 \\
\end{array}$ & $\begin{array}{r}1.15 \mathrm{e}+00 \\
6.39 \mathrm{e}-04 \\
7.97 \mathrm{e}+01 \\
0.00 \\
\end{array}$ \\
\hline $\begin{array}{l}\mathrm{Ag}-110 \mathrm{~m} \\
\mathrm{Cd}-113 \mathrm{~m} \\
\mathrm{Cd}-115 \mathrm{~m} \\
\mathrm{In}-113 \mathrm{~m}\end{array}$ & $\begin{array}{r}4.26 \mathrm{e}-03 \\
1.75 \mathrm{e}+03 \\
0.00 \\
3.74 \mathrm{e}-08 \\
\end{array}$ & $\begin{array}{r}8.97 e-10 \\
8.07 e-03 \\
0.00 \\
2.24 e-18 \\
\end{array}$ & $\begin{array}{r}7.06 \mathrm{e}-05 \\
1.92 \mathrm{e}+00 \\
0.00 \\
8.64 \mathrm{e}-11 \\
\end{array}$ & $\begin{array}{l}P m-1.48 m \\
S m-151 \\
\text { Eu- } 152 \\
\text { Eu- } 154 \\
\end{array}$ & $\begin{array}{r}0.00 \\
8.66 e+04 \\
4.77 \mathrm{e}+02 \\
5.44 \mathrm{e}+04 \\
\end{array}$ & $\begin{array}{r}0.00 \\
3.29 \mathrm{e}+00 \\
2.76 \mathrm{e}-03 \\
2.02 \mathrm{e}-01 \\
\end{array}$ & $\begin{array}{r}0.00 \\
1.01 \mathrm{e}+01 \\
2.16 \mathrm{e}+00 \\
4.89 \mathrm{e}+02 \\
\end{array}$ \\
\hline $\begin{array}{l}S n-113 \\
S n-119 m \\
S n-121 m\end{array}$ & $\begin{array}{l}3.74 \mathrm{e}-08 \\
4.75 \mathrm{e}-02 \\
3.95 \mathrm{e}+01 \\
\end{array}$ & $\begin{array}{r}3.73 e-15 \\
1.06 e-08 \\
6.68 e-04 \\
\end{array}$ & $\begin{array}{l}6.21 e-12 \\
2.45 e-05 \\
4.15 e-02 \\
\end{array}$ & $\begin{array}{l}\text { Eu- } 155 \\
\text { Gd- } 153 \\
\text { Tb- } 160 \\
\end{array}$ & $\begin{array}{l}1.08 \mathrm{e}+04 \\
3.23 \mathrm{e}-05 \\
4.77 \mathrm{e}-16 \\
\end{array}$ & $\begin{array}{r}2.32 \mathrm{e}-02 \\
9.16 \mathrm{e}-12 \\
4.23 \mathrm{e}-23 \\
\end{array}$ & $\begin{array}{l}7.85 e+00 \\
2.91 e-08 \\
3.81 e-18 \\
\end{array}$ \\
\hline \multicolumn{5}{|c|}{ Fission and Activation Product Totals } & $2.40 \mathrm{e}+07$ & $3.52 \mathrm{e}+02$ & $6.72 \mathrm{e}+04$ \\
\hline \multicolumn{8}{|c|}{ Actinides } \\
\hline $\begin{array}{l}U-234 \\
U-235 \\
U-236 \\
U-238 \\
\end{array}$ & $\begin{array}{l}4.08 \mathrm{e}+02 \\
1.60 \mathrm{e}+01 \\
6.11 \mathrm{e}+01 \\
3.16 \mathrm{e}+02 \\
\end{array}$ & $\begin{array}{l}6.53 \mathrm{e}+01 \\
7.40 \mathrm{e}+03 \\
9.44 \mathrm{e}+02 \\
9.40 \mathrm{e}+05 \\
\end{array}$ & $\begin{array}{l}1.15 \mathrm{e}+01 \\
4.34 \mathrm{e}-01 \\
1.63 \mathrm{e}+00 \\
7.85 \mathrm{e}+00 \\
\end{array}$ & $\begin{array}{l}\mathrm{Pu}-241 \\
\mathrm{Pu}-242 \\
\mathrm{Am}-241 \\
\mathrm{Am}-242 \\
\end{array}$ & $\begin{array}{l}3.26 \mathrm{e}+06 \\
2.42 \mathrm{e}+01 \\
1.69 \mathrm{e}+05 \\
8.15 \mathrm{e}+01 \\
\end{array}$ & $\begin{array}{l}3.16 \mathrm{e}+01 \\
6.34 \mathrm{e}+00 \\
4.92 \mathrm{e}+01 \\
1.01 \mathrm{e}-07\end{array}$ & $\begin{array}{l}1.01 e+02 \\
7.03 e-01 \\
5.54 e+03 \\
6.77 e-01\end{array}$ \\
\hline $\begin{array}{l}\mathrm{Np}-237 \\
\mathrm{Pu}-238 \\
\mathrm{Pu}-239 \\
\mathrm{Pu}-240 \\
\end{array}$ & $\begin{array}{l}2.70 \mathrm{e}+01 \\
5.10 \mathrm{e}+04 \\
1.01 \mathrm{e}+05 \\
5.53 \mathrm{e}+04 \\
\end{array}$ & $\begin{array}{l}3.83 \mathrm{e}+01 \\
2.98 \mathrm{e}+00 \\
1.63 \mathrm{e}+03 \\
2.42 \mathrm{e}+02 \\
\end{array}$ & $\begin{array}{l}7.79 e-01 \\
1.66 e+03 \\
3.13 e+03 \\
1.72 e+03 \\
\end{array}$ & $\begin{array}{l}A m-242 m \\
A m-243 \\
C m-242 \\
C m-244 \\
\end{array}$ & $\begin{array}{l}8.19 \mathrm{e}+01 \\
4.89 \mathrm{e}+01 \\
6.76 \mathrm{e}+01 \\
5.72 \mathrm{e}+02 \\
\end{array}$ & $\begin{array}{r}8.43 e-03 \\
2.45 e-01 \\
2.04 \mathrm{e}-05 \\
7.07 \mathrm{e}-03 \\
\end{array}$ & $\begin{array}{l}1.25 \mathrm{e}-01 \\
1.54 \mathrm{e}+00 \\
2.45 \mathrm{e}+00 \\
1.97 \mathrm{e}+01 \\
\end{array}$ \\
\hline \multicolumn{5}{|c|}{ Actinide Totals } & $3.64 \mathrm{e}+06$ & $9.50 \mathrm{e}+05$ & $1.22 \mathrm{e}+04$ \\
\hline
\end{tabular}




\subsection{SHIELDING DESIGN BASIS FEED}

The shielding design basis feed material was selected to include the fuel with the highest ${ }^{137} \mathrm{Cs}$ content. The ${ }^{137} \mathrm{Cs}$ content was used as the criterion because of that isotope's relative abundance in the fuel and its significant gamma radiation. The lines in figure 3.6 represent the burnup levels required at different times to obtain the $1 / 1 / 1995{ }^{137} \mathrm{Cs}$ concentrations shown in the table. The accountability key data are also included in figure 3.6. As in figure 3.5, each " $x$ " in Table 3.6 represents one key from the accountability database. The key nearest the highest ${ }^{137} \mathrm{Cs}$ concentration 1 ine is the key with the highest ${ }^{137} \mathrm{Cs}$ concentration. The fuel with the highest actual cesium content is Mark IV fuel with a ${ }^{240} \mathrm{Pu}$ Content of $15.74 \%$ discharged from the reactor in 1984. For the sake of conservatism, the design basis was selected as Mk IV fuel with $16 \%{ }^{240} \mathrm{Pu}$ content aged ten years to $1 / 1 / 1995$. The bounding case chosen here has a ${ }^{137} \mathrm{Cs}$ content approximately $6.5 \%$ higher than the maximum fuet in inventory. RADNUC was used to estimate the radionuclide content and heat generation rates of the $16 \%{ }^{240} \mathrm{Pu}$ content fuel. Table 3.8 is a tabulation of the results. The RADNUC input and output files in their raw form are listed in Appendix B.

\subsection{SAFETY/REGULATORY ASSESSMENT DESIGN BASIS FEED}

The safety/regulatory assessment design basis feed material was selected by determining which fuel would result in the highest estimated dose to people if exposed to a unit of material. A potential dose was obtained using cumulative effective dose equivalents (CEDE) (DOE 1988) and nuclide levels generated by RADNUC to estimate a dose resulting from each nuclide. The potential dose resulting from inhalation and ingestion pathways was evaluated, and the inhalation pathway was selected as most likely. Americium, plutonium, strontium, and cesium are estimated to dominate the dose impacts of other nuclides in the fuel, therefore only these isotopes were included in the safety/regulatory assessment basis development.

Two parameters were considered in selecting the fuel with the highest concentration of the isotopes used for determining the safety/reguTatory assessment design basis. The first is burnup; all else being equal, the concentrations of radionuclides increase with increasing burnup. The second is age (time since discharge); with the notable exception of ${ }^{241} \mathrm{Am}$, radionuclide concentrations decrease with increasing time since discharge from the reactor. Because it results in the largest dose, ${ }^{241} \mathrm{Am}$ is the most important nuclide for development of the safety/regulatory assessment basis.

A small amount of ${ }^{241} \mathrm{Am}$ is produced directly as an activation product in the irradiated fuel, but a far larger amount results from the decay of ${ }^{241} \mathrm{Pu}$. Because al1 of the ${ }^{241} \mathrm{Pu}$ wi11 eventually decay to ${ }^{241} \mathrm{Am}$, and because ${ }^{241} \mathrm{Am}$ has a half 1 ife of approximately 433 years whereas the half 1 ife of ${ }^{241} \mathrm{Pu}$ is only 14 years, the concentration of ${ }^{241} \mathrm{Am}$ continues to increase for approximately 60 years following reactor discharge. With half 1 ives of 24,100 and 6,560 years respectively, ${ }^{239} \mathrm{Pu}$ and ${ }^{240} \mathrm{Pu}$ are also among the most important radionuclides for the safety/regulatory assessment design basis. Over a 50 year time scale, the concentration of $239,240 \mathrm{Pu}$ wi17 be nearly constant. Considering the two factors above, the highest burnup, oldest fuels should contain the largest concentration of the most important radionuclides for the safety/regulatory assessment design basis.

Single Pass Reactor and $N$ Reactor fuels were both considered in the evaluation. In the case of the single pass reactor fuel, the americium, 
cesium, plutonium, and strontium were taken from the fuel inventory baseline document (WHC 1994b). The results of the evaluation indicate that $N$ Reactor Mark IV fuel discharged from the reactor $2 / 20 / 1979$ with a ${ }^{240} \mathrm{Pu}$ content of $16.72 \%$ represents the mix of isotopes with the largest potential dose impact on people. There are 6.9 MTU total of this $16.72 \%$ fuel stored at $\mathrm{K}$ Basins. The selected safety/regulatory assessment basis fuel is shown in Table 3.9. Through decay, the safety/regulatory assessment basis radionuclide content. changes over time. Table 3.10 lists the radionuclide content of the safety/regulatory assessment basis fuel decayed to 05/31/2038 (approximately 40 years after the projected date of first fuel movement from the $K$ Basins).

Appendix B lists the RADNUC input and output files in their raw form. Appendix $F$ provides comparisons of the safety basis fuel $\left(16.72 \%{ }^{240} \mathrm{Pu}\right.$ Mk IV N Reactor fuel aged 19 years) with other fuels and provides additional details regarding its selection.

\subsection{HEAT GENERATION BASIS FEED}

The heat generation basis feed material was selected by choosing the fuel lot capable of generating the most heat within a fully loaded MCO, as opposed to the most heat per MTU. A comparison was made of different groups of fue 1 in the basins including: the most recently discharged fuel, the shielding design basis fuel, the safety/regulatory assessment fuel, and a $13.4 \%{ }^{240} \mathrm{Pu}$ key which has been discharged for approximately 8.5 years. The heat generation from the most recently discharged fuel was 29 W/MTU; the shielding basis fuel was 147 W/MTU; the safety/regulatory assessment fuel was 137 W/MTU; and the 8.5 year old $13.4 \%{ }^{240} \mathrm{Pu}$ fuel was 113 W/MTU. AT though the shielding design basis fuel has a higher heat generation rate per MTU, the shielding design basis fuel keys include only $S$ and $C$ length fuel. The safety/regulatory assessment fuel keys contain the longer $E$ length fue 1 . The safety/regulatory assessment fuel has the highest heat generation on a per assembly basis. The current strategy is to load up to 270 assemblies into an MCO. Therefore, an MCO fully loaded with the safety/regulatory assessment fuel would generate more heat than an MCO fully loaded with the shielding basis fuel. The heat generation basis fuel is therefore the same as the safety/regulatory assessment basis fuel already listed in Tables 3.9 and 3.10.

\subsection{CRITICALITY DESIGN BASIS FEED}

The criticality design basis feed was determined by selecting the fuel with the highest reactivity. In a conventional 1 ight water reactor such as the Hanford site production reactors (we11 moderated non-breeder reactor), more fissile atoms are used up than are created. The reactivity of the fuel therefore decreases with increasing burn-up. The highest reactivity fuels are the unirradiated Mark $1 \mathrm{~A}$ fuels. Current planning calls for the fuel to be segregated by type so that a given MCO may contain ejther Mark $1 \mathrm{~A}$ or Mark IV fuel, but not a mixture of the two. In the MCOs with Mark IV fuel, the criticality design basis is again un-irradiated Mark IV fuel. 


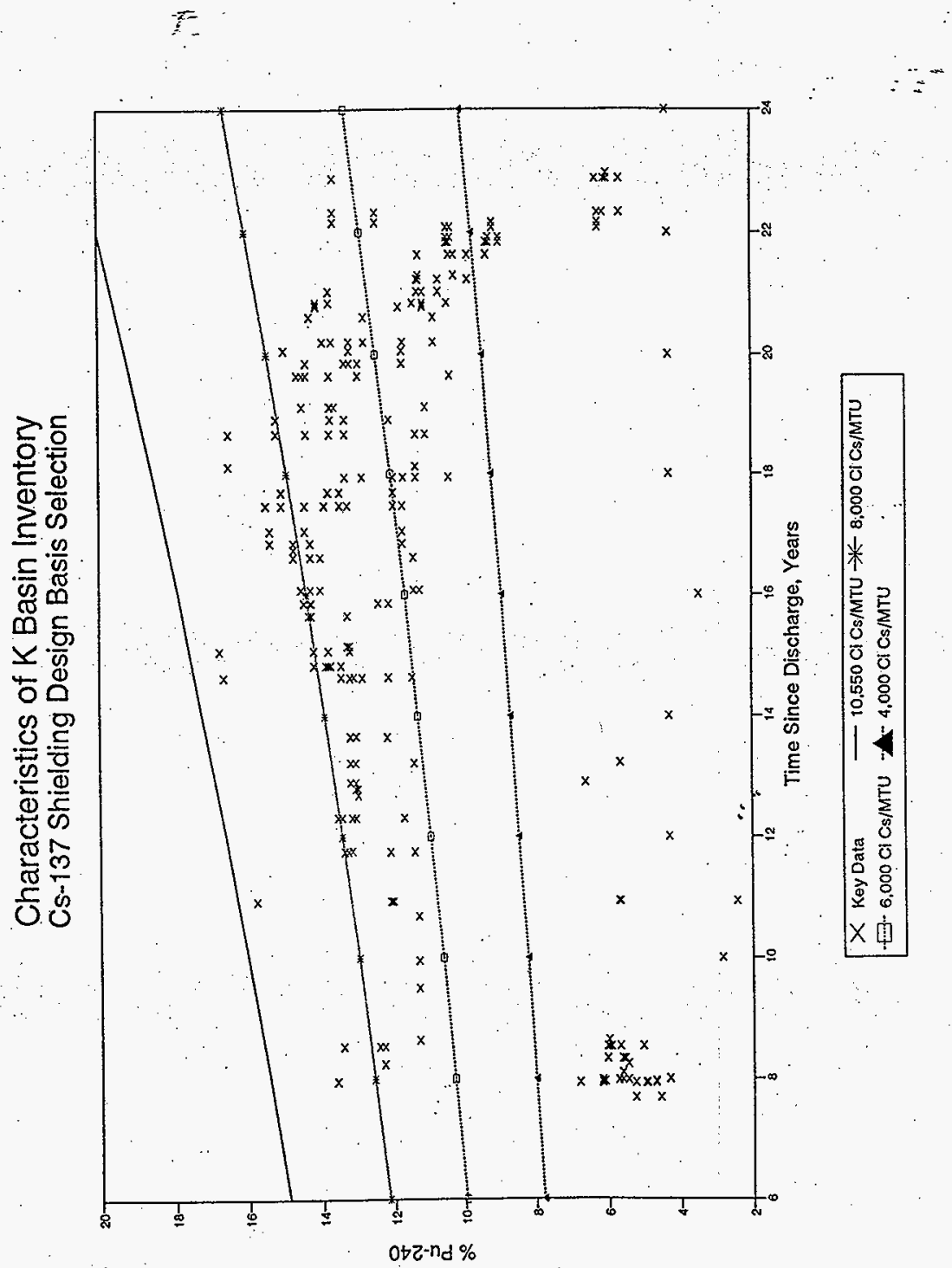

Figure 3.5: ${ }^{137} \mathrm{Cs}$ Shielding Design Basis Selection 
Table 3.8: Shielding Design Basis ${ }^{6}$

(Based on MK IV fuel at $16 \%$ Pu- 240 aged 13.5 years)

\begin{tabular}{|c|c|c|c|c|c|}
\hline I sotope & $\begin{array}{l}\text { Activity } \\
\text { (Ci/MTU) }\end{array}$ & $\begin{array}{c}\text { Heat } \\
\text { Generation } \\
\text { (W/MTU) } \\
\end{array}$ & Isotope & $\begin{array}{l}\text { Activity } \\
\text { (Ci/MTU) }\end{array}$ & $\begin{array}{c}\text { Heat } \\
\text { Generation } \\
\text { (W/MTU) }\end{array}$ \\
\hline \multicolumn{6}{|c|}{ Fission and Activation Products } \\
\hline $\begin{array}{l}H-3 \\
C=14 \\
\text { Fe }-55 \\
\text { Co- } 60 \\
\end{array}$ & $\begin{array}{l}4.03 \mathrm{e}+01 \\
5.27 \mathrm{e}-01 \\
5.23 \mathrm{e}+00 \\
6.27 \mathrm{e}+00 \\
\end{array}$ & $\begin{array}{l}1.36 e-03 \\
1.54 e-04 \\
1.75 e-04 \\
9.64 e-02 \\
\end{array}$ & $\begin{array}{l}S n-123 \\
S n-126 \\
S b-124 \\
S b-125 \\
\end{array}$ & $\begin{array}{r}4.08 \mathrm{e}-09 \\
1.22 \mathrm{e}-01 \\
0.00 \\
0.00 \\
\end{array}$ & $\begin{array}{r}1.26 \mathrm{e}-11 \\
3.75 \mathrm{e}-05 \\
0.00 \\
0.00 \\
\end{array}$ \\
\hline $\begin{array}{l}\mathrm{Ni}-59 \\
\mathrm{Ni}-63 \\
\mathrm{Se}-79 \\
\mathrm{Kr}-85 \\
\end{array}$ & $\begin{array}{l}3.03 e-02 \\
3.53 e+00 \\
6.23 e-02 \\
6.23 e+02 \\
\end{array}$ & $\begin{array}{l}1.21 e-06 \\
3.57 e-04 \\
1.93 e-05 \\
9.33 e-01 \\
\end{array}$ & $\begin{array}{l}S b-126 \\
S b-126 m \\
T e-123 m \\
T e-125 m\end{array}$ & $\begin{array}{r}1.71 e-02 \\
1.22 e-01 \\
1.19 e-13 \\
0.00 \\
\end{array}$ & $\begin{array}{r}3.10 \mathrm{e}-04 \\
1.57 \mathrm{e}-03 \\
1.72 \mathrm{e}-16 \\
0.00 \\
\end{array}$ \\
\hline $\begin{array}{l}s r-89 \\
\$ r-90 \\
Y-90 \\
Y-91 \\
\end{array}$ & $\begin{array}{r}0.00 \\
8.19 e+03 \\
8.19 e+03 \\
0.00 \\
\end{array}$ & $\begin{array}{r}0.00 \\
9.50 \mathrm{e}+00 \\
4.53 \mathrm{e}+01 \\
0.00 \\
\end{array}$ & $\begin{array}{l}\text { Te-127 } \\
\text { Te-127m } \\
\text { Te-129 } \\
\text { Te-129m } \\
\end{array}$ & $\begin{array}{r}1.16 \mathrm{e}-10 \\
1.19 \mathrm{e}-10 \\
0.00 \\
0.00 \\
\end{array}$ & $\begin{array}{r}1.57 \mathrm{e}-13 \\
5.88 \mathrm{e}-14 \\
0.00 \\
0.00 \\
\end{array}$ \\
\hline $\begin{array}{l}\mathrm{Zr}-93 \\
\mathrm{Zr}-95 \\
\mathrm{Nb}-93 \mathrm{~m} \\
\mathrm{Nb}-95 \\
\end{array}$ & $\begin{array}{l}2.83 e-01 \\
4.20 e-18 \\
1.38 e-01 \\
9.33 e-18 \\
\end{array}$ & $\begin{array}{l}3.25 e-05 \\
2.12 e-20 \\
2.47 e-05 \\
4.48 e-20 \\
\end{array}$ & $\begin{array}{l}\mathrm{I}-129 \\
\mathrm{Cs}=134 \\
\mathrm{Cs}-135 \\
\mathrm{Cs}-137 \\
\end{array}$ & $\begin{array}{l}4.88 e-03 \\
1.07 e+02 \\
5.77 e-02 \\
1.13 e+04 \\
\end{array}$ & $\begin{array}{l}2.29 \mathrm{e}-06 \\
1.10 \mathrm{e}+00 \\
1.93 \mathrm{e}-05 \\
1.14 \mathrm{e}+01 \\
\end{array}$ \\
\hline $\begin{array}{l}\mathrm{Nb}-95 \mathrm{~m} \\
\mathrm{Tc}-99 \\
\mathrm{Ru}-103 \\
\mathrm{Ru}-106 \\
\end{array}$ & $\begin{array}{r}3.12 \mathrm{e}-20 \\
2.08 \mathrm{e}+00 \\
0.00 \\
9.38 \mathrm{e}+00 \\
\end{array}$ & $\begin{array}{r}4.12 \mathrm{e}-23 \\
1.05 \mathrm{e}-03 \\
0.00 \\
5.59 \mathrm{e}-04 \\
\end{array}$ & $\begin{array}{l}\text { Ba-137m } \\
\text { Ce-141 } \\
\text { Ce-144 } \\
\mathrm{Pr}-143 \\
\end{array}$ & $\begin{array}{r}1.07 \mathrm{e}+04 \\
0.00 \\
1.75 \mathrm{e}+00 \\
0.00 \\
\end{array}$ & $\begin{array}{r}4.18 \mathrm{e}+01 \\
0.00 \\
1.15 \mathrm{e}-03 \\
0.00 \\
\end{array}$ \\
\hline $\begin{array}{l}\mathrm{Rh}-103 \mathrm{~m} \\
\mathrm{Rh}-106 \\
\mathrm{Pd}-107 \\
\mathrm{Ag}=110 \\
\end{array}$ & $\begin{array}{r}0.00 \\
9.38 e+00 \\
1.44 e-02 \\
4.15 e-06 \\
\end{array}$ & $\begin{array}{r}0.00 \\
8.97 e-02 \\
7.94 e-07 \\
3.11 e-11 \\
\end{array}$ & $\begin{array}{l}\mathrm{Pr}-144 \\
\mathrm{Pr}-144 \mathrm{~m} \\
\mathrm{Pm}-147 \\
\mathrm{Pm}-148 \\
\end{array}$ & $\begin{array}{r}1.73 e+00 \\
2.10 \mathrm{e}-02 \\
1.06 \mathrm{e}+03 \\
0.00 \\
\end{array}$ & $\begin{array}{r}1.26 e-02 \\
7.05 e-06 \\
3.88 e-01 \\
0.00 \\
\end{array}$ \\
\hline $\begin{array}{l}\mathrm{Ag}-110 \mathrm{~m} \\
\mathrm{Cd}-113 \mathrm{~m} \\
\mathrm{Cd}-115 \mathrm{~m} \\
\mathrm{In}-113 \mathrm{~m} \\
\end{array}$ & $\begin{array}{r}3.12 e-04 \\
3.96 e+00 \\
0.00 \\
2.59 e-11 \\
\end{array}$ & $\begin{array}{r}5.18 \mathrm{e}-06 \\
4.35 \mathrm{e}-03 \\
0.00 \\
5.98 \mathrm{e}-14 \\
\end{array}$ & $\begin{array}{l}P m-148 m \\
S m-151 \\
E u-152 \\
E u-154 \\
\end{array}$ & $\begin{array}{r}0.00 \\
1.08 e+02 \\
1.22 e+00 \\
2.02 e+02 \\
\end{array}$ & $\begin{array}{r}0.00 \\
1.26 e^{-02} \\
5.50 \mathrm{e}-03 \\
1.81 \mathrm{e}+00 \\
\end{array}$ \\
\hline $\begin{array}{l}s n-113 \\
s n-119 m \\
\$ n-121 m \\
\end{array}$ & $\begin{array}{r}2.59 e-11 \\
0.00 \\
0.00 \\
\end{array}$ & $\begin{array}{r}4.30 \mathrm{e}-15 \\
0.00 \\
0.00 \\
\end{array}$ & $\begin{array}{l}E u-155 \\
G d-153 \\
T b-160 \\
\end{array}$ & $\begin{array}{r}3.42 \mathrm{e}+01 \\
3.92 \mathrm{e}-06 \\
2.22 \mathrm{e}-19 \\
\end{array}$ & $\begin{array}{r}2.48 \mathrm{e}-02 \\
3.53 \mathrm{e}-09 \\
1.78 \mathrm{e}-21 \\
\end{array}$ \\
\hline \multicolumn{4}{|c|}{ Fission and Activation Product Totals } & $4.05 e+04$ & $1.12 \mathrm{e}+02$ \\
\hline \multicolumn{6}{|c|}{ Actinides } \\
\hline $\begin{array}{l}U-234 \\
U-235 \\
U-236 \\
U-238 \\
\end{array}$ & $\begin{array}{l}3.92 \mathrm{e}-01 \\
1.31 \mathrm{e}-02 \\
7.12 \mathrm{e}-02 \\
3.35 \mathrm{e}-01 \\
\end{array}$ & $\begin{array}{l}1.11 e-02 \\
3.54 e-04 \\
1.89 e-03 \\
8.35 e-03\end{array}$ & $\begin{array}{l}\mathrm{Pu}-241 \\
\mathrm{Pu}-242 \\
\mathrm{Am}-241 \\
\mathrm{Am}-242 \\
\end{array}$ & $\begin{array}{l}9.42 \mathrm{e}+03 \\
7.46 \mathrm{e}-02 \\
2.92 \mathrm{e}+02 \\
3.19 \mathrm{e}-01 \\
\end{array}$ & $\begin{array}{l}2.92 \mathrm{e}-01 \\
2.16 \mathrm{e}-03 \\
9.57 \mathrm{e}+00 \\
2.66 \mathrm{e}-03 \\
\end{array}$ \\
\hline $\begin{array}{l}\text { Np-237 } \\
\text { Pu-238 } \\
\text { Pu-239 } \\
\text { Pu-240 } \\
\end{array}$ & $\begin{array}{l}4.42 \mathrm{e}-02 \\
1.28 \mathrm{e}+02 \\
1.68 \mathrm{e}+02 \\
1.28 \mathrm{e}+02 \\
\end{array}$ & $\begin{array}{r}1.27 \mathrm{e}-03 \\
4.16 \mathrm{e}+00 \\
5.14 \mathrm{e}+00 \\
3.90 \mathrm{e}+00 \\
\end{array}$ & $\begin{array}{l}\mathrm{Am}-242 \mathrm{~m} \\
\mathrm{Am}-243 \\
\mathrm{Cm}-242 \\
\mathrm{Cm}-244 \\
\end{array}$ & $\begin{array}{l}3.21 \mathrm{e}-01 \\
2.22 \mathrm{e}-01 \\
2.65 \mathrm{e}-01 \\
4.62 \mathrm{e}+00 \\
\end{array}$ & $\begin{array}{r}4.91 e-04 \\
7.02 e-03 \\
9.59 e-03 \\
1.59 e-01 \\
\end{array}$ \\
\hline \multicolumn{4}{|c|}{ Actinide Totals } & $1.01 \mathrm{e}+04$ & $2.33 e+01$ \\
\hline
\end{tabular}


Table 3.9: Safety/Regulatory Assessment Design Basis ${ }^{7}$

\begin{tabular}{|c|c|c|c|c|c|}
\hline Isotope & $\begin{array}{l}\text { Activity } \\
\text { (Ci/MTU) }\end{array}$ & $\begin{array}{c}\text { Heat } \\
\text { Generation } \\
(W / M T U) \\
\end{array}$ & Isotope & $\begin{array}{l}\text { Activity } \\
\text { (Ci/MtU) }\end{array}$ & $\begin{array}{c}\text { Heat } \\
\text { Generation } \\
\text { (W/MTU) }\end{array}$ \\
\hline \multicolumn{6}{|c|}{ Fission and Activation Products } \\
\hline $\begin{array}{l}\mathrm{H}-3 \\
\mathrm{C}-14 \\
\mathrm{Fe}-55 \\
\mathrm{C} 0-60 \\
\end{array}$ & $\begin{array}{l}2.61 e+01 \\
5.53 e-01 \\
5.41 e-01 \\
2.09 e+00 \\
\end{array}$ & $\begin{array}{l}8.77 e-04 \\
1.62 e-04 \\
1.80 e-05 \\
3.23 e-02 \\
\end{array}$ & $\begin{array}{l}s n-123 \\
s n-126 \\
s b-124 \\
s b-125 \\
\end{array}$ & $\begin{array}{r}1.72 \mathrm{e}-16 \\
1.29 \mathrm{e}-01 \\
0.00 \\
0.00 \\
\end{array}$ & $\begin{array}{r}5.35 \mathrm{e}-19 \\
3.97 \mathrm{e}-05 \\
0.00 \\
0.00 \\
\end{array}$ \\
\hline $\begin{array}{l}\mathrm{Ni}-59 \\
\mathrm{Ni}-63 \\
\mathrm{Se}-79 \\
\mathrm{Kr}-85 \\
\end{array}$ & $\begin{array}{l}3.18 e-02 \\
3.47 e+00 \\
6.54 e-02 \\
3.70 e+02 \\
\end{array}$ & $\begin{array}{l}1.26 e-06 \\
3.51 e-04 \\
2.02 e-05 \\
5.53 e-01 \\
\end{array}$ & $\begin{array}{l}s b-126 \\
s b-126 m \\
T e-123 m \\
T e-125 m \\
\end{array}$ & $\begin{array}{r}1.81 \mathrm{e}-02 \\
1.29 \mathrm{e}-01 \\
1.50 \mathrm{e}-21 \\
0.00 \\
\end{array}$ & $\begin{array}{r}3.28 \mathrm{e}-04 \\
1.66 \mathrm{e}-03 \\
2.18 \mathrm{e}-24 \\
0.00 \\
\end{array}$ \\
\hline $\begin{array}{l}S r-89 \\
5 r-90 \\
Y-90 \\
Y-91 \\
\end{array}$ & $\begin{array}{r}0.00 \\
6.93 e+03 \\
6.93 e+03 \\
0.00 \\
\end{array}$ & $\begin{array}{r}0.00 \\
8: 03 \mathrm{e}+00 \\
3.84 \mathrm{e}^{+}+01 \\
0.00 \\
\end{array}$ & $\begin{array}{l}\text { Te-127 } \\
\text { Te-127m } \\
\text { Te-129 } \\
\text { Te-129m } \\
\end{array}$ & $\begin{array}{r}2.12 \mathrm{e}-19 \\
2.16 \mathrm{e}-19 \\
0.00 \\
0.00 \\
\end{array}$ & $\begin{array}{r}2.85 e-22 \\
1.07 e-22 \\
0.00 \\
0.00 \\
\end{array}$ \\
\hline $\begin{array}{l}\mathrm{Zr}-93 \\
\mathrm{Zr}-95 \\
\mathrm{Nb}-93 \mathrm{~m} \\
\mathrm{Nb}-95\end{array}$ & $\begin{array}{r}2.95 e-01 \\
0.00 \\
1.93 e-01 \\
0.00 \\
\end{array}$ & $\begin{array}{r}3.40 \mathrm{e}-05 \\
0.00 \\
3.45 \mathrm{e}-05 \\
0.00 \\
\end{array}$ & $\begin{array}{l}I-129 \\
C s-134 \\
C s-135 \\
C s-137\end{array}$ & $\begin{array}{l}5.16 e-03 \\
6.47 \mathrm{e}+00 \\
6.04 \mathrm{e}-02 \\
9.66 \mathrm{e}+03 \\
\end{array}$ & $\begin{array}{l}2.41 e-06 \\
6.59 e-02 \\
2.02 e-05 \\
9.78 e+00 \\
\end{array}$ \\
\hline $\begin{array}{l}\text { Nb-95m } \\
\text { Tc-99 } \\
\text { Ru-103 } \\
\text { Ru-106 } \\
\end{array}$ & $\begin{array}{r}0.00 \\
2.19 \mathrm{e}+00 \\
0.00 \\
2.56 \mathrm{e}-02 \\
\end{array}$ & $\begin{array}{r}0.00 \\
1.10 \mathrm{e}-03 \\
0.00 \\
1.52 \mathrm{e}-06 \\
\end{array}$ & $\begin{array}{l}\mathrm{Ba}-137 \mathrm{~m} \\
\mathrm{Ce}=141 \\
\mathrm{Ce}-144 \\
\mathrm{P}_{\mathrm{r}}-143 \\
\end{array}$ & $\begin{array}{r}9.14 \mathrm{e}+03 \\
0.00 \\
7.91 \mathrm{e}-04 \\
0.00 \\
\end{array}$ & $\begin{array}{r}3.59 \mathrm{e}+01 \\
0.00 \\
5.23 \mathrm{e}-07 \\
0.00 \\
\end{array}$ \\
\hline $\begin{array}{l}\mathrm{Rh}-103 \mathrm{~m} \\
\mathrm{Rh}-106 \\
\mathrm{Pd}-107 \\
\mathrm{Ag}-110 \\
\end{array}$ & $\begin{array}{r}0.00 \\
2.56 \mathrm{e}-02 \\
1.56 \mathrm{e}-02 \\
7.17 \mathrm{e}-10 \\
\end{array}$ & $\begin{array}{r}0.00 \\
2.45 \mathrm{e}-04 \\
8.56 \mathrm{e}-07 \\
5.38 \mathrm{e}-15 \\
\end{array}$ & $\begin{array}{l}P r-144 \\
P r-144 m \\
P m-147 \\
P m-148 \\
\end{array}$ & $\begin{array}{r}7.82 \mathrm{e}-04 \\
9.48 \mathrm{e}-06 \\
1.09 \mathrm{e}+02 \\
0.00 \\
\end{array}$ & $\begin{array}{r}5.73 \mathrm{e}-06 \\
3.18 \mathrm{e}-09 \\
4.02 \mathrm{e}-02 \\
0.00 \\
\end{array}$ \\
\hline $\begin{array}{l}\mathrm{Ag}-110 \mathrm{~m} \\
\mathrm{Cd}-113 \mathrm{~m} \\
\mathrm{Cd}-115 \mathrm{~m} \\
\mathrm{In}-113 \mathrm{~m} \\
\end{array}$ & $\begin{array}{r}5.39 \mathrm{e}-08 \\
2.78 \mathrm{e}+00 \\
0.00 \\
1.36 \mathrm{e}-19 \\
\end{array}$ & $\begin{array}{r}8.94 \mathrm{e}-10 \\
3.06 \mathrm{e}-03 \\
0.00 \\
3.13 \mathrm{e}-22 \\
\end{array}$ & $\begin{array}{l}P m-148 m \\
S m-151 \\
E u-152 \\
E u-154 \\
\end{array}$ & $\begin{array}{r}0.00 \\
1.02 e^{+02} \\
8.45 e-01 \\
1.13 e+02 \\
\end{array}$ & $\begin{array}{r}0.00 \\
1.19 \mathrm{e}-02 \\
3.81 \mathrm{e}-03 \\
1.01 \mathrm{e}+00 \\
\end{array}$ \\
\hline $\begin{array}{l}s n-113 \\
s n-119 m \\
s n-121 m \\
\end{array}$ & $\begin{array}{r}1.36 e-19 \\
6.14 e-08 \\
6.27 e-02 \\
\end{array}$ & $\begin{array}{l}2.26 \mathrm{e}-23 \\
3.16 \mathrm{e}-11 \\
6.59 \mathrm{e}-05 \\
\end{array}$ & $\begin{array}{l}\text { Eu-155 } \\
\mathrm{Gd}-153 \\
\mathrm{~Tb}-160 \\
\end{array}$ & $\begin{array}{r}1.06 \mathrm{e}+01 \\
5.19 \mathrm{e}-10 \\
0.00 \\
\end{array}$ & $\begin{array}{r}7.65 \mathrm{e}-03 \\
4.67 \mathrm{e}-13 \\
0.00 \\
\end{array}$ \\
\hline \multicolumn{4}{|c|}{ Fission and Activation Product Totals } & $3.34 \mathrm{e}+04$ & $9.38 \mathrm{e}+01$ \\
\hline \multicolumn{6}{|c|}{ Actinides } \\
\hline $\begin{array}{l}U-234 \\
U-235 \\
U-236 \\
U-238 \\
\end{array}$ & $\begin{array}{l}3.84 e-01 \\
1.27 e-02 \\
7.16 e-02 \\
3.31 e-01 \\
\end{array}$ & $\begin{array}{l}1.09 e-02 \\
3.44 e-04 \\
1.91 e-03 \\
8.23 e-03\end{array}$ & $\begin{array}{l}\mathrm{Pu}-241 \\
\mathrm{Pu}-242 \\
\mathrm{Am}-241 \\
\mathrm{Am}-242\end{array}$ & $\begin{array}{l}6.82 e+03 \\
8.71 e-02 \\
4.34 e+02 \\
3.71 e-01 \\
\end{array}$ & $\begin{array}{r}2.11 e-01 \\
2.55 e-03 \\
-1.42 e+01 \\
3.08 e-03 \\
\end{array}$ \\
\hline $\begin{array}{l}\text { Np-237 } \\
P u-238 \\
\text { Pu-239 } \\
\text { Pu-240 } \\
\end{array}$ & $\begin{array}{l}4.66 \mathrm{e}-02 \\
1.33 \mathrm{e}+02 \\
1.73 \mathrm{e}+02 \\
1.37 \mathrm{e}+02 \\
\end{array}$ & $\begin{array}{l}1.34 \mathrm{e}-03 \\
4.34 \mathrm{e}+00 \\
5.28 \mathrm{e}+00 \\
4.19 \mathrm{e}+00 \\
\end{array}$ & $\begin{array}{l}\mathrm{Am}-242 \mathrm{~m} \\
\mathrm{Am}-243 \\
\mathrm{Cm}-242 \\
\mathrm{Cm}-244 \\
\end{array}$ & $\begin{array}{l}3.72 e-01 \\
2.78 \mathrm{e}-01 \\
3.08 \mathrm{e}-01 \\
4.47 \mathrm{e}+00 \\
\end{array}$ & $\begin{array}{l}5.71 e-04 \\
8.82 e-03 \\
1.11 e-02 \\
1.54 e-01 \\
\end{array}$ \\
\hline \multicolumn{4}{|c|}{ Actinide Totals } & $7.70 \mathrm{e}+03$ & $2.85 e+01$ \\
\hline
\end{tabular}


Table 3.10: Safety/Regu7atory Assessment Basis ${ }^{8}$

\begin{tabular}{|c|c|c|c|c|c|}
\hline Isotope & $\begin{array}{l}\text { Activity } \\
\text { (Ci/MTU) }\end{array}$ & $\begin{array}{c}\text { Heat } \\
\text { Generation } \\
\text { (W/MTU) } \\
\end{array}$ & Isotope & $\begin{array}{l}\text { Activity } \\
\text { (Ci/MTU) }\end{array}$ & $\begin{array}{c}\text { Heat } \\
\text { Generation } \\
\text { (W/MTU) }\end{array}$ \\
\hline \multicolumn{6}{|c|}{ Fission and Activation Products } \\
\hline $\begin{array}{l}H-3 \\
C-14 \\
F e-55 \\
C O-60 \\
\end{array}$ & $\begin{array}{l}3.32 \mathrm{e}+00 \\
5.64 \mathrm{e}-01 \\
2.72 \mathrm{e}-05 \\
1.61 \mathrm{e}-02 \\
\end{array}$ & $\begin{array}{l}1.11 e-04 \\
1.65 e-04 \\
9.09 e-10 \\
2.47 e-04 \\
\end{array}$ & $\begin{array}{l}S n-123 \\
S n-126 \\
S b-124 \\
S b-125 \\
\end{array}$ & $\begin{array}{r}0.00 \\
1.33 \mathrm{e}-01 \\
0.00 \\
1.10 \mathrm{e}-03 \\
\end{array}$ & $\begin{array}{r}0: 00 \\
4.08 \mathrm{e}-05 \\
0.00 \\
3.44 \mathrm{e}-06 \\
\end{array}$ \\
\hline $\begin{array}{l}\mathrm{Ni}-59 \\
\mathrm{Ni}-63 \\
\mathrm{Se}-79 \\
\mathrm{Kr}-85 \\
\end{array}$ & $\begin{array}{l}3.25 \mathrm{e}-02 \\
2.68 \mathrm{e}+00 \\
6.68 \mathrm{e}-02 \\
3.41 \mathrm{e}+01 \\
\end{array}$ & $\begin{array}{l}1.29 \mathrm{e}-06 \\
2.71 \mathrm{e}-04 \\
2.06 \mathrm{e}-05 \\
5.10 \mathrm{e}-02 \\
\end{array}$ & $\begin{array}{l}\text { sb-126 } \\
\text { sb-126m } \\
T e-123 \mathrm{~m} \\
T e-125 \mathrm{~m} \\
\end{array}$ & $\begin{array}{r}1.86 \mathrm{e}-02 \\
1.33 \mathrm{e}-01 \\
0.00 \\
2.68 \mathrm{e}-04 \\
\end{array}$ & $\begin{array}{r}3.36 \mathrm{e}-04 \\
1.70 \mathrm{e}-03 \\
0.00 \\
2.25 \mathrm{e}-07 \\
\end{array}$ \\
\hline $\begin{array}{l}S r-89 \\
S r-90 \\
Y-90 \\
Y-91 \\
\end{array}$ & $\begin{array}{r}0.00 \\
2.91 \mathrm{e}+03 \\
2.91 \mathrm{e}+03 \\
0.00 \\
\end{array}$ & $\begin{array}{r}0.00 \\
3.38 \mathrm{e}+00 \\
1.61 \mathrm{e}+01 \\
0.00 \\
\end{array}$ & $\begin{array}{l}\text { Te-127 } \\
\text { Te-127m } \\
\text { Te-129 } \\
\text { Te-129m } \\
\end{array}$ & $\begin{array}{l}0.00 \\
0.00 \\
0.00 \\
0.00 \\
\end{array}$ & $\begin{array}{l}0.00 \\
0.00 \\
0.00 \\
0.00 \\
\end{array}$ \\
\hline $\begin{array}{l}\mathrm{Zr}-93 \\
\mathrm{Zr}-95 \\
\mathrm{Nb}-93 \mathrm{~m} \\
\mathrm{Nb}-95\end{array}$ & $\begin{array}{r}3.02 e-01 \\
0.00 \\
2.73 e-01 \\
0.00 \\
\end{array}$ & $\begin{array}{r}3.47 \mathrm{e}-05 \\
0.00 \\
4.88 \mathrm{e}-05 \\
0.00 \\
\end{array}$ & $\begin{array}{l}I-129 \\
C s-134 \\
C s-135 \\
C s-137\end{array}$ & $\begin{array}{l}5.29 \mathrm{e}-03 \\
2.52 \mathrm{e}-05 \\
6.19 \mathrm{e}-02 \\
4.19 \mathrm{e}+03 \\
\end{array}$ & $\begin{array}{l}2.48 e-06 \\
2.58 e-07 \\
2.07 e-05 \\
4.23 e+00 \\
\end{array}$ \\
\hline $\begin{array}{l}\mathrm{Nb}-95 \mathrm{~m} \\
\mathrm{Tc}-99 \\
\text { Ru- } 103 \\
\text { Ru- } 106 \\
\end{array}$ & $\begin{array}{r}0.00 \\
2.23 \mathrm{e}+00 \\
0.00 \\
2.06 \mathrm{e}-13 \\
\end{array}$ & $\begin{array}{r}0.00 \\
1.12 \mathrm{e}-03 \\
0.00 \\
1.22 \mathrm{e}-17 \\
\end{array}$ & $\begin{array}{l}\text { Ba-137m } \\
\text { Ce-141 } \\
\text { Ce-144 } \\
\mathrm{Pr}-143 \\
\end{array}$ & $\begin{array}{r}3.96 \mathrm{e}+03 \\
0.00 \\
0.00 \\
0.00 \\
\end{array}$ & $\begin{array}{r}1.55 \mathrm{e}+01 \\
0.00 \\
0.00 \\
0.00 \\
\end{array}$ \\
\hline $\begin{array}{l}\mathrm{Rh}-103 \mathrm{~m} \\
\mathrm{Rh}-106 \\
\mathrm{Pd}-107 \\
\mathrm{Ag}-110 \\
\end{array}$ & $\begin{array}{r}0.00 \\
2.06 \mathrm{e}-13 \\
1.61 \mathrm{e}-02 \\
0.00 \\
\end{array}$ & $\begin{array}{r}0.00 \\
1.96 e-15 \\
8.87 e-07 \\
0.00 \\
\end{array}$ & $\begin{array}{l}\mathrm{Pr}-144 \\
\mathrm{Pr}-144 \mathrm{~m} \\
\mathrm{Pm}-147 \\
\mathrm{Pm}-148 \\
\end{array}$ & $\begin{array}{r}0.00 \\
0.00 \\
5.97 \mathrm{e}^{-03} \\
0.00 \\
\end{array}$ & $\begin{array}{r}0.00 \\
0.00 \\
2.19 \mathrm{e}-06 \\
0.00 \\
\end{array}$ \\
\hline $\begin{array}{l}\text { Ag- } 110 \mathrm{~m} \\
\mathrm{Cd}-113 \mathrm{~m} \\
\mathrm{Cd}-115 \mathrm{~m} \\
\mathrm{In}-113 \mathrm{~m} \\
\end{array}$ & $\begin{array}{r}0.00 \\
4.87 \mathrm{e}-01 \\
0.00 \\
0.00 \\
\end{array}$ & $\begin{array}{r}0.00 \\
5.35 \mathrm{e}-04 \\
0.00 \\
0.00 \\
\end{array}$ & $\begin{array}{l}\text { Pm- } 148 m \\
\text { Sm-151 } \\
\text { Eu-152 } \\
\text { Eu-154 } \\
\end{array}$ & $\begin{array}{r}0.00 \\
7.67 e+01 \\
1.32 e-01 \\
5.93 e+00 \\
\end{array}$ & $\begin{array}{r}0.00 \\
8.96 e-03 \\
5.94 \mathrm{e}-04 \\
5.31 \mathrm{e}-02 \\
\end{array}$ \\
\hline $\begin{array}{l}s n-113 \\
s n-119 m \\
s n-121 m \\
\end{array}$ & $\begin{array}{r}0.00 \\
0.00 \\
3.84 \mathrm{e}-02 \\
\end{array}$ & $\begin{array}{r}0.00 \\
0.00 \\
4.04 \mathrm{e}-05 \\
\end{array}$ & $\begin{array}{l}\mathrm{Eu}-155 \\
\mathrm{Gd}-153 \\
\mathrm{~Tb}-160 \\
\end{array}$ & $\begin{array}{r}5.94 \mathrm{e}-02 \\
0.00 \\
0.00 \\
\end{array}$ & $\begin{array}{r}4.29 e-05 \\
0.00 \\
0.00 \\
\end{array}$ \\
\hline \multicolumn{4}{|c|}{ Fission and Activation Product Totals } & $1.41 e+04$ & $3.94 e+01$ \\
\hline \multicolumn{6}{|c|}{ Actinides } \\
\hline $\begin{array}{l}U-234 \\
U-235 \\
U-236 \\
U-238 \\
\end{array}$ & $\begin{array}{r}3.81 \mathrm{e}-01 \\
1.25 \mathrm{e}-02 \\
7.19 \mathrm{e}-02 \\
3.29 \mathrm{e}-01 \\
\end{array}$ & $\begin{array}{l}1.08 \mathrm{e}-02 \\
3.38 \mathrm{e}-04 \\
1.92 \mathrm{e}-03 \\
8.20 \mathrm{e}-03 \\
\end{array}$ & $\begin{array}{l}\text { Pu-241 } \\
\text { Pu-242 } \\
\text { Am-24i } \\
\text { Am-242 }\end{array}$ & $\begin{array}{l}1.19 \mathrm{e}+03 \\
9.39 \mathrm{e}-02 \\
6.17 \mathrm{e}+02 \\
3.42 \mathrm{e}-01 \\
\end{array}$ & $\begin{array}{l}3.69 e-02 \\
2.73 e-03 \\
2.03 e+01 \\
2.85 e-03 \\
\end{array}$ \\
\hline $\begin{array}{l}\mathrm{Np}-237 \\
\mathrm{Pu}-238 \\
\mathrm{Pu}-239 \\
\mathrm{Pu}-240 \\
\end{array}$ & $\begin{array}{l}4.77 \mathrm{e}-02 \\
1.04 \mathrm{e}+02 \\
1.75 \mathrm{e}+02 \\
1.41 \mathrm{e}+02 \\
\end{array}$ & $\begin{array}{l}1.37 \mathrm{e}-03 \\
3.40 \mathrm{e}+00 \\
5.35 \mathrm{e}+00 \\
4.33 \mathrm{e}+00 \\
\end{array}$ & $\begin{array}{l}\text { Am-242m } \\
\text { Am-243 } \\
C m-242 \\
C m-244 \\
\end{array}$ & $\begin{array}{l}3.43 e-01 \\
3.09 e-01 \\
2.84 e-01 \\
1.24 e+00 \\
\end{array}$ & $\begin{array}{l}5.27 e-04 \\
9.77 e-03 \\
1.03 e-02 \\
4.25 e-02 \\
\end{array}$ \\
\hline \multicolumn{4}{|c|}{ Actinide Totals } & $2.23 e+03$ & $3.35 e+01$ \\
\hline
\end{tabular}


HNF-SD-SNF-TI-009, Rev. 1

\subsection{SINGLE PASS REACTOR FUEL}

The information included in this section was taken from the Hanford Spent Fuel Inventory Base7ine (WHC 1994b).

\subsection{BACKGROUND}

Eight single-pass, water-cooled, graphite moderated reactors, commonly referred to as single pass reactors (SPR), operated at Hanford to produce plutonium, beginning in 1944 with the 105-B Reactor start-up and ending in 1971 with the 105-KE Reactor shut down (HAPO 1944, HAPO 1961, HAPO 1963a, HAPO $1963 \mathrm{~b}$, PNL 1991). The reactors and their operating periods are listed in Table 4.1.

Table 4.1: Operating Periods of the Hanford Single Pass Reactors

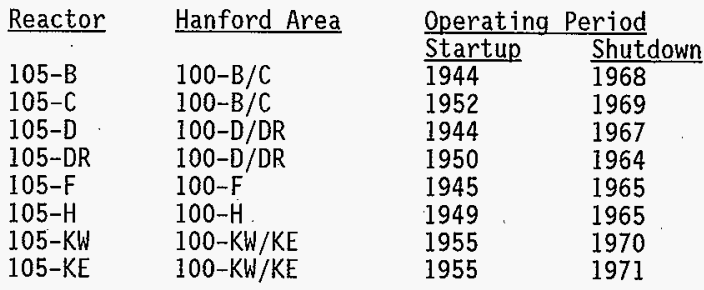

The older reactors (105-B, 105-C, 105-D, 105-DR, 105-F, and 105-H) were similar in design. Their graphite block cores were 11 meters ( $36 \mathrm{ft}$ ) high by 11 meters $(36 \mathrm{ft})$ wide by 8.5 meters $(28 \mathrm{ft})$ long. A total of 2004 aluminum horizontal process tubes held the fuel and contained the cooling water. Most of the older reactors had nine horizontal, boron-containing, water-cooled control rods running perpendicular to the process tubes. The $105-\mathrm{C}$ and $105-\mathrm{H}$ Reactors each had 15 of these control rods. The control rods entered the reactor from the side and provided operating reactivity control, neutron flux shaping, and emergency shutdown control. A completely independent emergency shutdown control was provided by vertical channels penetrating the core which could be gravity filled with either boron-containing safety rods or boroncontaining steel balls.

The basic design of the 105-KE and 105-KW Reactors was similar to the older reactors, with the following exceptions. Their graphite cores were 12.5 meters (41 ft) high by 12.5 meters ( $41 \mathrm{ft}$ ) wide by 10.7 meters ( $35 \mathrm{ft}$ ) long. There were 3220 aluminum horizontal process tubes, 2400 of which were later replaced with zirconium tubes. There were 20 horizontal control rods. 


\subsection{FUEL DESCRIPTION (HAPO 1955, DUN 1967)}

The single pass reactor fuel consisted of a machined uranium core that was sealed within, and metallurgically bonded to, an aluminum can. There were three basic designs for SPR fuel elements; solid core cylinders, hollow core cylinders, and tubes. All three types are shown in Figure 4.1. The solid cylinder fuel was used from 1944 until the late 1950s. This design was adequate unti] 1951, when increasing reactor power levels and fuel exposure began to result in significant fuel failures. The hollow cored fuel was used concurrently with the solid fuel from late-1954 until 1957 in an attempt to reduce fuel failures, but this strategy was unsuccessfut. Beginning in late1955 , the fuel failure rate was successfulty reduced by introduction of a tubular fuel design called an internally and externally cooled (I\&E) fueT.

Many variations of these basic designs were created in attempts either to improve cooling of the fuel element during irradiation or to simplify the fabrication process. In one successful variation, called the tru-line design, one end of the fuel element had a raised face while the other end had a recessed face. The raised face mated with the recessed face of the adjacent fuel element in the tube to improve cooling through better alignment of the fuel elements within the reactor tubes. Tru-line features are shown on the I\&E fuel element in Figure 4.1 .

The SPR fuel was made primarily in two ${ }^{235} \mathrm{U}$ concentrations, natural $(0.71 \%)$ and $0.947 \%$; although other enriched fuel (including $1.25 \%, 1.7 \%$, and $2.1 \%{ }^{235} \mathrm{U}$ ) and depleted fuel (including $0.14 \%$ and $0.22 \%{ }^{235} \mathrm{U}$ ) were aiso made. The lengths of the fuel elements range from approximately $12 \mathrm{~cm}$ (4.7 in) to 23 $\mathrm{cm}$ ( $9.0 \mathrm{in})$, with specific lengths generally associated with specific ranges of enrichment. The diameters of most of the fuel elements vary from $3.45 \mathrm{~cm}$ (1.36 in) to $3.63 \mathrm{~cm}(1.43 \mathrm{in})$ to accommodate slight differences in the process tubes of different reactors. The fuel for the KE and KW Reactors was generally the largest, and even included some $5.1 \mathrm{~cm}$ (2 in) diameter elements. The fuel for the 105-C Reactor was larger than that used in the other five older reactors. These variations in length, diameter, and secondary features, such as tru-line ends, lead to a large number of similar, but distinct, fuel element types. To allow for easy differentiation, each fuel element is stamped with a six character code. The second letter of the code identifies the specific model of fuel element, including the enrichment, dimensions, and group of reactors to receive it.

The physical characteristics of some SPR fuel element types are listed in Table 4.2 and reference drawings $\mathrm{H}-3-7350$ and $\mathrm{H}-3-7352$ (HAPO 1963b). Additional details are available in the reference drawings. 


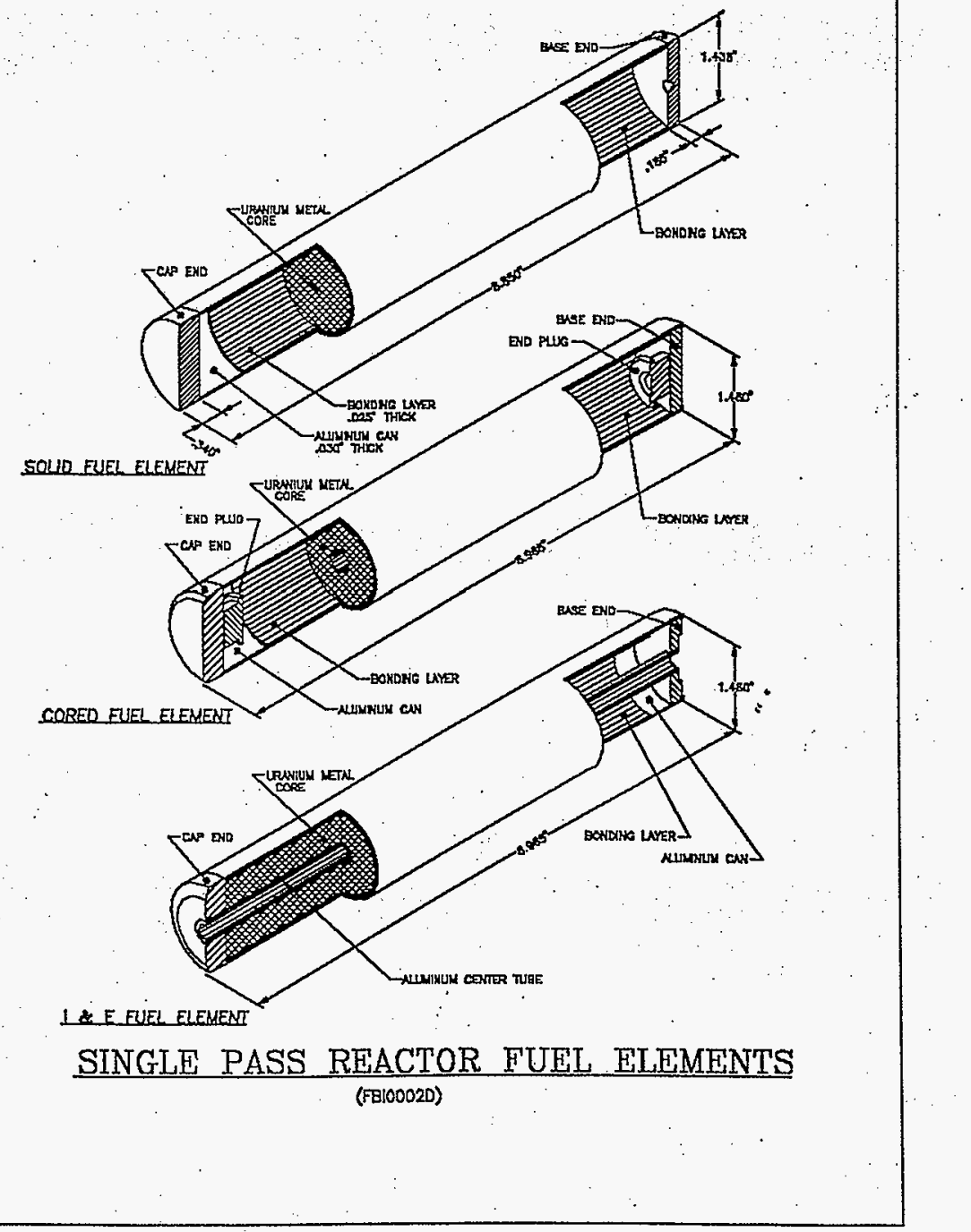

Figure 4.1: Single Pass Reactor Fuel Elements 
HNF-SD-SNF-TI-009, Rev. 1

Table 4.2: Physical Characteristics of Single Pass Reactor Fuel ${ }^{1}$

\begin{tabular}{|c|c|c|c|c|c|c|c|c|c|c|c|}
\hline \multirow[b]{3}{*}{ Code $^{2}$} & \multirow[b]{3}{*}{$\%^{235} \mathrm{u}$} & \multicolumn{5}{|c|}{ Fuel Element } & \multicolumn{4}{|c|}{ Uranium Core } & \multirow{3}{*}{$\frac{\text { Cap }}{\text { Length }}$} \\
\hline & & \multirow[t]{2}{*}{ Length } & \multicolumn{2}{|c|}{ Diameter } & \multicolumn{2}{|c|}{$\begin{array}{c}\text { Cladding Wall } \\
\text { Thickness }\end{array}$} & \multirow[t]{2}{*}{ Length } & \multicolumn{2}{|c|}{ Diameter } & \multirow[t]{2}{*}{ Weight } & \\
\hline & & & Outer & Inner & Outer & Inner & & Outer & Inner & & \\
\hline $\mathrm{C} 2 \mathrm{~N}$ & 0.714 & 22.8 & 3.72 & 0.953 & 0.10 & 0.114 & 21.3 & 3.48 & 1.22 & 3.34 & 0.635 \\
\hline $\mathrm{K} 4 \mathrm{~N}$ & 0.714 & 22.8 & 3.71 & 0.978 & 0.094 & 0.13 & 21.3 & 3.48 & 1.26 & 3.30 & 0.635 \\
\hline $\mathrm{K} 5 \mathrm{~N}$ & 0.714 & 22.5 & 3.86 & 1.07 & 0.094 & 0.13 & 21.1 & 3.63 & 1.35 & 3.56 & 0.635 \\
\hline O3N & 0.714 & 22.8 & 3.67 & 0.787 & 0.094 & 0.13 & 21.3 & 3.44 & 1.07 & 3.37 & 0.635 \\
\hline $\mathrm{CGN}$ & 0.714 & 22.5 & 5.04 & 0.848 & 0.11 & 0.13 & 21.1 & 4.78 & 1.15 & 6.75 & 0.635 \\
\hline C3E & 0.947 & 16.9 & 3.71 & 0.953 & 0.094 & 0.13 & 15.4 & 3.48 & 1.24 & 2.40 & 0.635 \\
\hline K5E & 0.947 & 16.6 & 3.83 & 1.10 & 0.094 & 0.13 & 15.2 & 3.60 & 1.38 & 2.49 & 0.635 \\
\hline O3E & 0.947 & 16.9 & 3.67 & 0.787 & 0.094 & 0.13 & 15.4 & 3.44 & 1.07 & 2.43 & 0.635 \\
\hline $\mathrm{K} 4 \mathrm{~W}$ & 0.714 & 16.9 & 3.71 & 1.02 & 0.094 & 0.13 & 15.4 & 4.48 & 1.30 & 2.36 & 0.635 \\
\hline $\mathrm{K} 5(1.25)$ & 1.25 & 14.1 & 3.82 & 1.12 & 0.094 & 0.13 & 12.7 & 3.61 & 1.38 & 2.08 & 0.635 \\
\hline
\end{tabular}

1. All dimensions are in centimeters, except that the uranium core weight is in kilograms.

2. The first letter of the code indicates in which reactors the fuel was used. "K" designates the 105-KE and 105-KW Reactors. "C" designates the 105-C Reactor. "O" designates the other five reactors. The number indicates the number of times the design has been modified. The third character indicates the general uranium conte $355^{\text {and }}$ other features. "N" indicates natural uranium content $\left(0.714 \%{ }^{235} \mathrm{U}\right)$. "E" indicates $0.947 \% 235 \mathrm{U}$ enrichment. "W" indicates natural enrichment with 23 inch cooling water mixing attachment. "D" indicates depleted uranium. Enrichments above $0.947 \%$ $U$ are indicated by the specific enrichment enclosed within parentheses.

\subsubsection{Fuel Fabrication (HAPO 1955, HAPO 1958)}

In the lead dip fabrication process used since 1954, a machined uranium core was sealed within, and metallurgically bonded to, an aluminum can. The core was first subjected to a degreasing and pickling operation to clean its surface. Then the core was heated to bonding temperature by immersion in a "duplex" bath of aluminum-silicon alloy (Al-Si) floating on lead. The core was preheated to brazing temperature by the lead layer and then pre-wet with the brazing alloy by brief agitation within the Al-Si layer. The core was then transferred to a heated AT-Si canning bath, where it was inserted into a preheated aluminum can and topped with an aluminum cap. After quenching, the fuel element was welded to create a continuous bond between the uranium core, the A1-Si braze, and the aluminum can. The braze layer was approximately 20 mils thick. Next, the ends of the fuel element were machined to the proper length and contour. Then, the exposed braze area was closed by a tungsten inert-gas weld bead. Finally, the completed fuel element was heated in an autoclave and inspected visually and by other non-destructive methods.

Table 4.37 ists the chemical inventory in the SPR currently stored at Hanford. This information was calculated using typical impurities of the materials in the SPR fuel elements found in fuel manufacturing documentation (HAPO 1955, HAPO 1958).

Table 4.3: Total Chemical Inventory in Single Pass Reactor Fuel Metals (All quantities in $\mathrm{kg}$ ) 
HNF-SD-SNF-TI-009, Rev. 1

\begin{tabular}{|c|c|c|c|}
\hline Impurity & $\frac{\text { Uranium }}{\text { A17oy 501 }}$ & A1 $\frac{\text { Aluminum }}{\mathrm{X} \text { loy }}$ & Al-Si Braze \\
\hline Boron & $\mathrm{NA}^{1}$ & $1.20 \mathrm{e}-03$ & NA \\
\hline Cadmium & NA & $3.60 \mathrm{e}-03$ & NA \\
\hline Carbon & $2.54 \mathrm{e}+00$ & NA & NA \\
\hline Chromium & $2.20 \mathrm{e}-01$ & NA & NA \\
\hline Cobalt & NA & $1.20 \mathrm{e}-03$ & NA \\
\hline Copper & NA & $1.77 \mathrm{e}-01$ & $9.30 e-03$ \\
\hline Iron & $5.07 e-01$ & $8.40 \mathrm{e}-01$ & $3.00 \mathrm{e}-02$ \\
\hline Lithium & NA & $9.60 \mathrm{e}-03$ & NA \\
\hline Magnesium & $8.45 \mathrm{e}-02$ & NA & NA \\
\hline Manganese & $8.45 e-02$ & NA & NA \\
\hline Nickel & $3.38 \mathrm{e}-01$ & $1.40 \mathrm{e}+00$ & NA \\
\hline Nitrogen & $3.38 \mathrm{e}-01$ & NA & NA \\
\hline Silicon & $2.54 \mathrm{e}-01$ & $2.05 e-01$ & NA \\
\hline Others; each & NA & $6.00 e-02$ & $3.00 \mathrm{e}-03$ \\
\hline Others, total & NA & $1.80 \mathrm{e}-01$ & $1.20 \mathrm{e}-02$ \\
\hline
\end{tabular}

\subsection{FUEL INVENTORY}

There are 3.38 metric tons [as total] heavy metal (MTHM) of SPR fuel at Hanford. The majority consists of 2.87 metric tons (MT) of highly depleted uranium and 8.7 kilograms of plutonium, contained in 779 fuel elements. This highly depleted SPR fuel, stored until 1995 at the PUREX facility, has been moved to the KW Basin. The highly depleted fuel is a portion of the fuel which was irradiated in the KE and KW Reactors between December 1966 and May 1968 to produce high ${ }^{240} \mathrm{Pu}$ content plutonium (WHC 1994b). The pre-irradiation ${ }^{235} \mathrm{U}$ content of the fuel was $0.14 \%$ and the fuel was irradiated to an average exposure of $3000 \mathrm{MWD} / \mathrm{MT}$. The post-irradiation ${ }^{235} \mathrm{U}$ content is $0.064 \%$ and the plutonium contains $26 \% 240 \mathrm{Pu}$.

The remaining 0.50 MTHM of the SPR fuel is natural or enriched uranium contained in 185 fuel elements; 0.40 MTHM in 138 elements within the KE Basin and 0.10 MTHM in 47 elements within the KW Basin (WHC 1991). The fuel is predominately the I\&E tru-Tine design. Most of this fuel is residual material from the KE and the KW Reactors. A small amount of fuel from the clean-out of the 105-C and the 105-D Storage Basins is also included in the 0.50 MTHM total. The specific types and numbers of fuel elements are listed below. 
HNF-SD-SNF-TI-009, Rev. 1

Table 4.4: Single Pass Reactor Fuel Elements Stored in the $K$ Basins

\section{Fuel Type}

C2N

$\mathrm{K} 4 \mathrm{~N}$

$\mathrm{K} 5 \mathrm{~N}$

$03 \mathrm{~N}$

C3E

$\mathrm{K} 5 \mathrm{E}$

$03 \mathrm{E}$

$\mathrm{K} 4 \mathrm{~W}$

Uncertain ${ }^{1}$
Basin

KE

KE

$\mathrm{KE}$

KE

KE

$\mathrm{KE}$

$\mathrm{KE}$

$\mathrm{KE}$

KW

\section{Quantity}

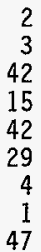

1) Existing records of these fuel elements do not indicate the specific. fuel type, however their ${ }^{3} \mathrm{U}$ enrichment does not exceed $1.25 \%$ (Larson 1990).

\subsection{RADIONUCLIDE CONTENT}

The radionuclide content of the depleted SPR fuel, estimated using the ORIGEN2 and WIMS-E computer codes, is shown in Table 4.5 (Schwinkendorf 1993). Radionuclide concentration and decay heat of the other SPR fuel stored in the $\mathrm{KE}$ and KW Basins are not available because of its small quantity, varied sources, and uncertain discharge and exposure history. However, nuclide concentrations and decay heat should be similar to that of $\mathrm{N}$ Reactor Mark IA fuel irradiated to a $6 \%{ }^{240} \mathrm{Pu}$ content because typical SPR fuel irradiation was less than 1000 MWD/MTU (HAPO 1944). It has been at least 20 years since the fuel was irradiated because the last SPR was shut down in 1971 .

Table 4.5: Total Activity of Selected Radionuclides in SPR Fuel (decayed to $1 / 1 / 94$ )

\begin{tabular}{cc} 
Radionuclide & Activity \\
\hline${ }^{3} \mathrm{H}$ & $7.03 \mathrm{e}+02$ \\
${ }^{63} \mathrm{Ni}$ & $6.76 \mathrm{e}+01$ \\
${ }^{85} \mathrm{Kr}$ & $7.33 \mathrm{e}+02$ \\
${ }^{90} \mathrm{Sr}$ & $1.36 \mathrm{e}+04$ \\
${ }^{90} \mathrm{Y}$ & $1.36 \mathrm{e}+04$ \\
${ }^{99} \mathrm{TC}$ & $6.67 \mathrm{e}+00$ \\
${ }^{113 \mathrm{~m}} \mathrm{Cd}$ & $1.69 \mathrm{e}+01$ \\
${ }^{134} \mathrm{Cs}$ & $6.76 \mathrm{e}+00$ \\
${ }^{137} \mathrm{Cs}$ & $3.48 \mathrm{e}+04$ \\
${ }^{137 \mathrm{~m}} \mathrm{Ba}$ & $3.30 \mathrm{e}+04$ \\
${ }^{151} \mathrm{Sm}$ & $4.06 \mathrm{e}+02$ \\
${ }^{154} \mathrm{Eu}$ & $4.70 \mathrm{e}+02$ \\
${ }^{155} \mathrm{Eu}$ & $1.15 \mathrm{e}+02$ \\
${ }^{238} \mathrm{Pu}$ & $1.45 \mathrm{e}+02$ \\
${ }^{239} \mathrm{Pu}$ & $4.06 \mathrm{e}+02$ \\
${ }^{240} \mathrm{Pu}$ & $6.42 \mathrm{e}+02$ \\
$241 \mathrm{Pu}$ & $1.69 \mathrm{e}+04$ \\
$241 \mathrm{Am}$ & $1.45 \mathrm{e}+03$ \\
\hline Total & $7.05 \mathrm{e}+04$
\end{tabular}




\subsection{FUEL STORAGE}

The majority of the SPR fuel was stored unti1 1995 at the PUREX storage basin, although smaller amounts were also stored at the $K$ Basins. As of September 1995, when the fuel from PUREX was transferred into the KW Basin, al1 SPR fuel has been located in the K Basins.

The fue 7 formerly stored at PUREX was stored in four buckets. Three of the four fuel buckets were briefly lifted out of the water so that the condition of the fuel could be observed and videotaped. The buckets were fu11 of fuel elements. There were several .7 arger elements that appeared to be either the 2 inch (5.1 centimeter) diameter fuel el ements or overpack containers. Tru-1ine end features could be seen on a few elements, al though. end features on most elements could not be seen. There appeared to be sludge or corrosion product on many of the fuel elements. 
HNF-SD-SNF-TI-009, Rev. 1

\subsection{5-K BASIN SLUDGE}

\section{I SLUDGE SOURCES}

Fuel handling operations initially caused some cladding damage in $\mathrm{N}-$ Reactor fuel. Subsequent fuel oxidation resulted in fuel and fission products accumulating in fuel canisters and on the fToor of the KE Basin discharge chute where fuel handling occurred. Aluminum oxide, iron oxide, concrete grit, and other materials have also accumulated and mixed with the fuel corrosion products to form a sludge on the basin floors.

The sludge on the KE Basin floor is being generated from a variety of sources and is moved through the basins by water circulation and necessary inpool operations. The sludge sources are:

- Fuel elements, which are oxidizing where cladding has been breached, thereby contributing uranium oxide and fission products to the sludge. Some oxidized fuel may have fallen to the floor of the basin through screens in the bottoms of some canisters (the Mark Os) in the basin.

- The KE Basin is an unlined concrete pool. As the facility ages, concrete grit comes loose from the walls and falls to the basin floor.

- The facility is not airtight. High winds cause dust and other pollutants (dirt, insects, tumbleweeds, etc.) from the outside environment to enter the facility, and ultimately, the storage pool.

- There are carbon steel storage racks sitting in the storage pool to hold the fuel canisters in place. As these racks age, they present a source of rust corrosion and paint chips:

- The aluminum canisters were corroded over a two year period when chlorine was used as a biological control agent.

Some of the canisters in the KE Basin have solid bottoms (the Mark 1 and Mark 2 canisters). Sludge accumulation is likely within those canisters as a result of fuel oxidation due to breached cladding.

Because all the canisters in the KW Basin are closed from the basin pool environment, any sludge that has resulted from fuel oxidation in breached fuel assemblies has been retained within the canisters. Some sludge is present on the $\mathrm{KW}$ Basin floor due to rusting storage racks and dust or other dirt that has entered the facility from the outside environment.

\subsection{SLUDGE LOCATION}

A schematic of the $K$ Basins is shown in Figure 5.1. The six pits connected to each basin are the Sandfilter Backwash Pit, the South Loadout Pit, the Wash Pit (also designated on drawings as the Dummy Elevator Pit), the Tech View Pit, the Weasel Pit, and the Discharge Chute. Figure 5.1 also indicates which areas of the basins contain sludge. 
The Sandfilter Backwash Pit, also designated on drawings as the North Loadout Pit, is a concrete pool (connected to the main basin by a closed-off fuel canister transfer channel) that is currently used to collect the backwash residues from the fuel pool sandfilter. This pit is isolated from the basin proper to provide a storage area for sludge that has been backwashed from the sand filter. This backwash process has deposited significant quantities of sludge into the pit.

The basin water is recirculated through the pool cooling and cleanup system in order to (WHC 1993):

(1) Remove the decay heat generated by the irradiated fuel stored in the basin.

(2) Maintain water quality and clarity.

(3) Control the concentration of soluble and particulate radioactive nuclides in the water to minimize personnel radiation exposure.

This recirculation of basin water results in sludge migration throughout the basin. In addition there is sufficient.decay heat from the fuel canisters to drive convection currents that further promote sludge migration.

Some intentional activities in the KE Basin have redistributed the basin sludge. The Fuel Segregation Campaign, which took place in the early 1980s, was initiated to separate the fuel according to enrichment. Fuel canisters were transported one by one from the main basin to the Discharge/Pickup Chute Area. There the canisters were emptied of their contents and repackaged. As the canisters were emptied, any sludge that had accumulated in the canister was also dumped into the Discharge Chute. Sludge was pumped from the Discharge Chute to the Weasel Pit in 1992, in order to clean up the Discharge Chute Area. Another sludge pumping campaign to move sludge from the Discharge Chute to the Weasel Pit was recently completed in order to prepare the basins for installation of barrier isolation doors to enhance the seismic integrity of the basins.

The back of the Weasel Pit is screened from the main basin by a 37 micron screen in order to retain most of the pumped sludge within the pit until it has had time to settle out. However, some fine particulate sludge still escapes back into the main basin, along with all dissolved material.

As a result of the sludge pumping activities, the Weasel Pit is expected to primarily contain fuel corrosion products (including fuel pieces $\leq{ }^{\alpha} \sigma \mathrm{mm}$ ) that originated in canisters containing fuel with breached cladding. Therefore, the Weasel Pit sludge composition is currently assumed to be characteristic of the siudge in fuel canisters with broken fuel. 

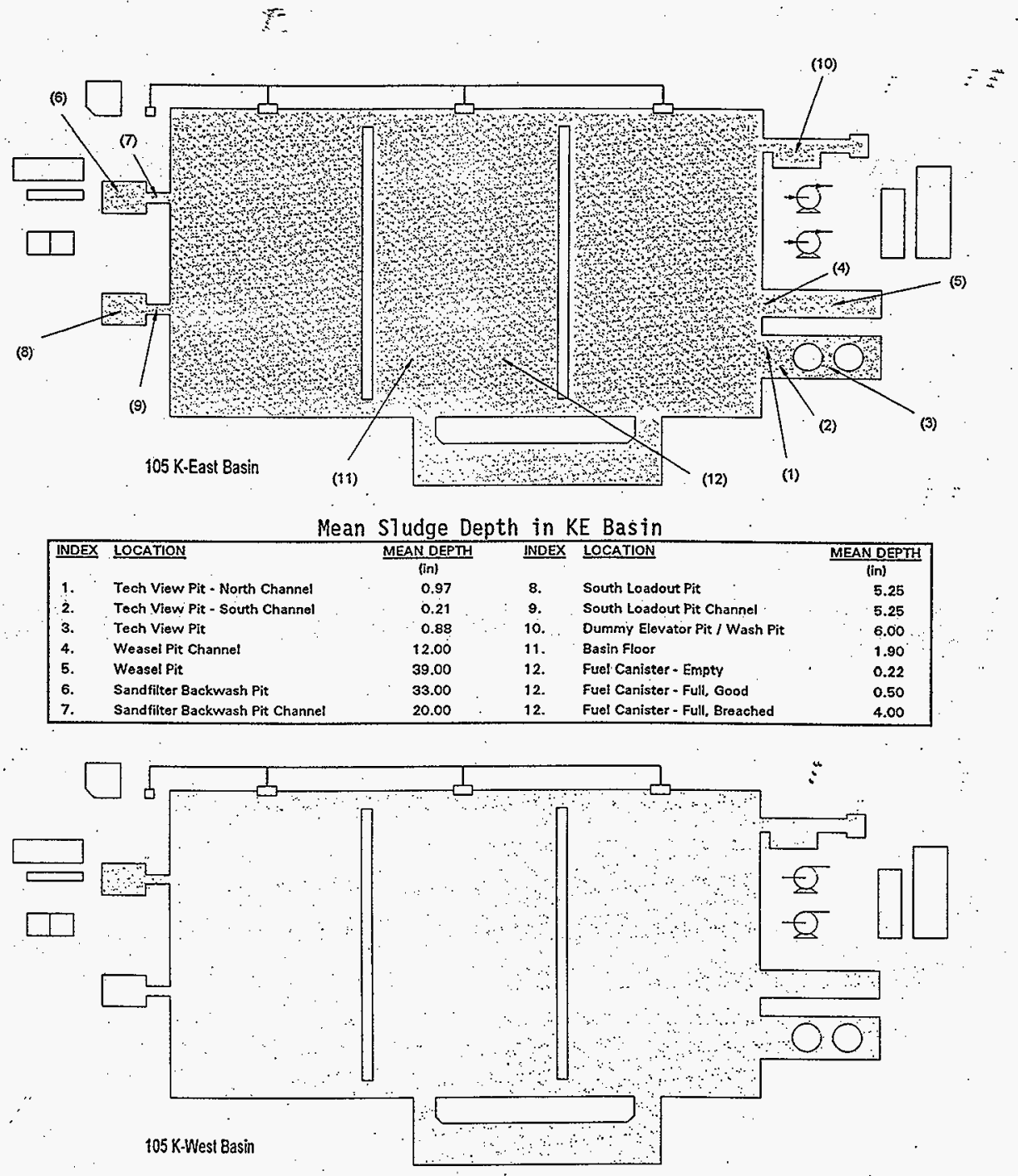


\subsection{SLUDGE DEPTH}

A series of measurements of depth of sludge in the KE Basin is presented in Sludge Measurement Results for $105 \mathrm{KE}$ Basin (Meling 1994). Data were obtained and recorded on video cassettes as well as on data sheets. The data provide physical measurements of sludge depth in the main basin and some pits, and a sampling of canister sludge depths. In the South Loadout Pit and Wash Pit, where the presence of debris made physical measurements infeasible, the sludge depth in the nearest main basin area was assigned to the area/pit in question. Using the depth measurements, sludge volume was estimated by analyzing the data with several different techniques (Meling 1994).

The Summary Status of $K$ Basins S7udge Characterization (Baker 1995) provided a qualitative summary of sludge characteristic observations from a review of videotapes. Based on this review, the KE Basin sludge was described as having a thin, light colored crust that contained lower layers of flocculent brown material.

The table in Figure 5.1 above presents a summary of the mean sludge depth reported for major KE Basin regions. Additional details on sludge depth measurements, including a description of the approximate depth measurement locations, are provided in the Baker document and in Sludge Measurement Results for $105 \mathrm{KE}$ Basin (Meling 1994).

Measurements of sludge depth were made recently in the $\mathrm{KW}$ Basin Sandfilter Backwash Pit and Transfer Channel. Brief reviews of the video tapes show the sludge in the Sandfilter Backwash Pit to be composed of a thin crust with underlying flocculent material. The top crust material settles fairly rapidly, while the underlying finer material tends to settle slowly. Differences noted between the sludge material in KE Basin and KW Basin include a darker, almost black appearance of the KW Basin flocculent sludge material, and a greater tendency to agglomerate (Baker 1995).

\subsection{CURRENT INVENTORY BASIS}

As shown on Figure 5.I, the basins can be divided into seven major areas for estimating the sludge inventory: Weasel Pit, Tech View Pit, Wash Pit, Sandfilter Backwash Pit, South Loadout Pit, Fuel. Canisters, and Basin Floor. Four sludge samples were taken from the KE Basin in May 1993 for analysis (Bechtold 1993). The samples were taken as follows:

Samplè S3-032-01

Samp le 53-032-02

Sample $53-032-03$

Sample S3-032-04*
West side of Weasel Pit screen

East side of Weasel Pit screen

Center of KE Basin (grating \#3718)

Channel of North Loadout Pit (Sandfilter Backwash Pit)

*Alternate samples analysis used, see explanation following.

Chemical analysis of the sludge was achieved by filtering sludge subsamples from the associated Tiquid, oven-drying, then digesting the residual solids in nitric acid solution. Chemical and radiochemical analysis produced results for the dried residual solids (see Appendix E, Tables E-1 and E-4).

Routine operational sampling of the Sandfilter Backwash Pit in May 1993 indicated that levels of plutonium had risen above allowable limits as a result of continuing corrosion of irradiated $\mathrm{N}$-Reactor fuel in the basin water. Consequently an Unreviewed Safety Question (USQ) was declared regarding continued sand filter backwash operation. A sampling and analysis 
plan was prepared that called for a sampling program to obtain sludge samples (Bechtold 1994). The results of this sample analysis were used to determine the chemical and radionuclide constituents in the Sandfilter Backwash Pit, as presented in Table 5.2.

Analyses of samples from the Tech View Pit, Wash Pit, South Loadout Pit, and Fuel Canisters are not currently available. Therefore, the current sludge inventory estimates are based on assuming sludge in these areas will be similar to, or bounded by, the composition of sludges from areas that have been sampled. Of the sample analyses available, the Weasel Pit sludge was found to contain the highest concentration of radionuclides. This result was expected based on the sludge pumping activities described in Section 5.2. Therefore, in order to bound the estimate of radionuclides in the sludge inventory, the Weasel Pit sludge composition is used to model sludge in the Tech View Pit, Wash Pit, and South Loadout Pit areas.

The Fuel Canisters have been separated into 1) empty canisters, 2) fuTl canisters containing unbreached fue1, and 3) full canisters containing breached fuel. The sludge contained in the empty canisters and full canisters with unbreached fuel is expected to be composed mainty of dust, concrete, and other environmental pollutants. Therefore, the Bas in Floor sludge sample is used to model the sludge composition in these areas. The sludge contained in the full canisters with breached fuel is expected to include corrosion products along with environmental pollutants. The Weasel Pit sample composition is used as a model of sludge in these canisters.

\subsection{5-K EAST BASIN SLUDGE}

The following table depicts the physical properties of the "wet" sludge (i.e., the sludige as it sits in the basin) in various areas of the KE Basin. These results are based on Summary Status of $K$ Basins S7udge Characterization (Baker 1995). The exception is the Sandfilter Backwash Pit; its sludge properties came from Safety Evaluation of the Plutonium and Uranium Content of the K East Basin Sandfilter Backwash Pit (Warner 1994), and the chemical and radionuclide constituent data came from Statistical Evaluation of the Data obtained from the $K$ East Basin Sandfilter Backwash Pit Samples (Welsh 1994). 
HNF-SD-SNF-TI-009, Rev. I

Table 5.1: Physical Properties of 105-K East Basin STudge

\begin{tabular}{|c|c|c|c|c|c|c|}
\hline & & $\begin{array}{c}\text { Volume } \\
\left(\mathrm{m}^{3}\right)\end{array}$ & $\begin{array}{c}\text { Mass }^{1} \\
(\mathrm{Mg})\end{array}$ & $\begin{array}{c}\text { Density } 1 \\
(g / m l)\end{array}$ & $\begin{array}{l}\text { Particle } \\
\text { size }(\mu \mathrm{m})\end{array}$ & $\begin{array}{c}\text { Solids } \\
\text { (weight \%) }\end{array}$ \\
\hline \multicolumn{2}{|c|}{ WEASEL PIT } & 11.86 & 18.20 & 1.535 & 1.53 & 51.29 \\
\hline \multicolumn{2}{|c|}{ TECH VIEW PIT } & 0.43 & 0.66 & 1.535 & 1.53 & 51.29 \\
\hline \multicolumn{2}{|l|}{ WASH PIT } & 1.37 & 2.11 & 1.535 & 1.53 & 51.29 \\
\hline \multicolumn{2}{|c|}{ SANDFILTER BACKWASH PIT } & 6.27 & 8.25 & 1.31 & 1.57 & 32.00 \\
\hline \multicolumn{2}{|c|}{ SOUTH LOADOUT PIT } & 1.09 & 1.67 & 1.535 & 1.53 & 51.29 \\
\hline \multirow{3}{*}{$\begin{array}{l}\text { FUEL } \\
\text { CANISTERS }\end{array}$} & Empty & 0.39 & 0.44 & 1.13 & 1.68 & 17.52 \\
\hline & Full, Good & 0.81 & 0.92 & 1.13 & 1.68 & 17.52 \\
\hline & Ful l, Breech & 6.64 & 10.19 & 1.535 & 1.53 & 51.29 \\
\hline \multicolumn{2}{|c|}{ BASIN FLOOR } & 21.65 & 24.46 & 1.13 & 1.68 & 17.52 \\
\hline & TOTAL & 50.51 & 66.90 & & & \\
\hline
\end{tabular}

1) Volume, mass, and density is of wet sludge, after settling.

2) Particle size is average size of all particles in sample.

Most particles are <2 $\mu \mathrm{m}$ diameter; over half of volume is in particles $>20-40 \mu \mathrm{m}$.

3) Weight percent of solids is the fractions of solids in the sludge (the remainder is water).

Table 6 in the Baker document includes a range of bounding sludge volumes. These estimates show that the total KE Basin sludge volume could be as high as $67 \mathrm{~m}^{3}$.

Inductively coupled plasma analysis, uranium analysis, gamma energy analysis (GEA), and radiochemical analysis. of the digestates produced chemical and radionuclide compositions of sludge samples on a dry bases. The average of the two Weasel Pit samples was used to characterize sludge in the Weasel Pit. Total component inventories were calculated for each area from compositions and total sludge mass in the area. These calculations are presented in Appendix E. In order to determine the inventory of chemical constituents in the basin, the mass of wet sludge in each basin area was multiplied by the component weight fraction as determined through chemical analysis, and then multiplied by the solids concentration of wet sludge versus dried sludge. The resultant chemical inventory for the KE Basin sludge is presented in Table 5.2. 
Table 5.2: Chemical Constituents in 105-K East Basin

\begin{tabular}{|c|c|c|c|c|c|c|c|c|}
\hline & $\begin{array}{c}\text { Weasel } \\
\text { Pit } \\
\text { (Kg) }\end{array}$ & $\begin{array}{l}\text { Tech } \\
\text { View } \\
\text { Pit } \\
(\mathrm{Kg}) \\
\end{array}$ & $\begin{array}{l}\text { Wash } \\
\text { Pit } \\
(\mathrm{Kg}) \\
\end{array}$ & $\begin{array}{c}\text { Sandfilter } \\
\text { Backwash } \\
\text { Pit } \\
(\mathrm{Kg}) \\
\end{array}$ & $\begin{array}{l}\text { South } \\
\text { Loadout } \\
\text { Pit } \\
(\mathrm{Kg}) \\
\end{array}$ & $\begin{array}{c}\text { Fuel }^{1} \\
\text { Canisters } \\
(\mathrm{Kg}) \\
\end{array}$ & $\begin{array}{l}\text { Basin } \\
\text { Floor } \\
(\mathrm{Kg}) \\
\end{array}$ & $\begin{array}{l}\text { Total } \\
(\mathrm{Kg})\end{array}$ \\
\hline $\begin{array}{l}\text { Al } \\
\text { As } \\
\text { Ba } \\
\text { Be }\end{array}$ & $\begin{array}{l}1.71 \mathrm{e}+02 \\
4.05 \mathrm{e}-01 \\
8.56 \mathrm{e}-01 \\
3.28 \mathrm{e}-02 \\
\end{array}$ & $\begin{array}{l}6.19 e+00 \\
1.47 e-02 \\
3.10 e-02 \\
1.19 e-03 \\
\end{array}$ & $\begin{array}{l}1.98 e+01 \\
4.70 e-02 \\
9.92 e-02 \\
3.80 e-03 \\
\end{array}$ & $\begin{array}{l}3.00 e+01 \\
4.01 e-01 \\
2.92 e-02 \\
\end{array}$ & $\begin{array}{l}1.57 \mathrm{e}+01 \\
3.72 \mathrm{e}-02 \\
7.85 \mathrm{e}-02 \\
3.01 \mathrm{e}-03 \\
\end{array}$ & $\begin{array}{l}1.01 e+02 \\
2.31 e-01 \\
4.92 e-01 \\
2.43 e-02 \\
\end{array}$ & $\begin{array}{l}8.91 \mathrm{e}+01 \\
7.11 \mathrm{e}-02 \\
2.30 \mathrm{e}-01 \\
1.06 \mathrm{e}-01 \\
\end{array}$ & $\begin{array}{l}4.32 \mathrm{e}+02 \\
8.06 \mathrm{e}-01 \\
2.19 \mathrm{e}+00 \\
2.00 \mathrm{e}-01 \\
\end{array}$ \\
\hline $\begin{array}{l}\mathrm{Ca} \\
\mathrm{Cd} \\
\mathrm{Co} \\
\mathrm{Cr} \\
\end{array}$ & $\begin{array}{l}3.19 \mathrm{e}+01 \\
7.19 \mathrm{e}-01 \\
2.06 \mathrm{e}-01 \\
8.64 \mathrm{e}+00 \\
\end{array}$ & $\begin{array}{l}1.16 \mathrm{e}+00 \\
2.61 \mathrm{e}-02 \\
7.46 \mathrm{e}-03 \\
3.13 \mathrm{e}-01 \\
\end{array}$ & $\begin{array}{l}3.70 \mathrm{e}+00 \\
8.34 \mathrm{e}-02 \\
2.39 \mathrm{e}-02 \\
1.00 \mathrm{e}+00 \\
\end{array}$ & $\begin{array}{l}2.27 \mathrm{e}+01 \\
2.06 \mathrm{e}-01 \\
4.94 \mathrm{e}-01 \\
\end{array}$ & $\begin{array}{l}2.93 \mathrm{e}+00 \\
6.60 \mathrm{e}-02 \\
1.89 \mathrm{e}-02 \\
7.93 \mathrm{e}-01 \\
\end{array}$ & $\begin{array}{l}1.80 e+01 \\
4.17 e-01 \\
1.17 e-01 \\
4.89 e+00 \\
\end{array}$ & $\begin{array}{l}2.97 e+00 \\
2.54 e-01 \\
3.75 e-02 \\
1.02 e+00 \\
\end{array}$ & $\begin{array}{l}8.34 \mathrm{e}+01 \\
1.77 \mathrm{e}+00 \\
4.11 \mathrm{e}-01 \\
1.72 \mathrm{e}+01 \\
\end{array}$ \\
\hline $\begin{array}{l}\mathrm{Cu} \\
\mathrm{Fe} \\
\mathrm{K} \\
\mathrm{Li}\end{array}$ & $\begin{array}{l}2.67 \mathrm{e}+00 \\
2.26 \mathrm{e}+03 \\
1.50 \mathrm{e}+00 \\
7.98 \mathrm{e}-01 \\
\end{array}$ & $\begin{array}{l}9.66 e-02 \\
8.21 e+01 \\
5.43 e-02 \\
2.89 e-02 \\
\end{array}$ & $\begin{array}{l}3.09 \mathrm{e}-01 \\
2.62 \mathrm{e}+02 \\
1.74 \mathrm{e}-01 \\
9.25 \mathrm{e}-02 \\
\end{array}$ & $\begin{array}{l}1.04 \mathrm{e}+00 \\
8.98 \mathrm{e}+01\end{array}$ & $\begin{array}{l}2.45 \mathrm{e}-01 \\
2.08 \mathrm{e}+02 \\
1.37 \mathrm{e}-01 \\
7.32 \mathrm{e}-02 \\
\end{array}$ & $\begin{array}{l}1.54 \mathrm{e}+00 \\
1.28 \mathrm{e}+03 \\
8.51 \mathrm{e}-01 \\
4.47 \mathrm{e}-01 \\
\end{array}$ & $\begin{array}{l}9.13 e-01 \\
3.15 e+02 \\
2.15 e-01 \\
4.84 e-03 \\
\end{array}$ & $\begin{array}{l}6.81 \mathrm{e}+00 \\
4.51 \mathrm{e}+03 \\
2.93 \mathrm{e}+00 \\
1.44 \mathrm{e}+00 \\
\end{array}$ \\
\hline $\begin{array}{l}\mathrm{Mg} \\
\mathrm{Mn} \\
\mathrm{Mo} \\
\mathrm{Na}\end{array}$ & $\begin{array}{l}7.85 \mathrm{e}+00 \\
2.81 \mathrm{e}+00 \\
3.45 \mathrm{e}-01 \\
1.09 \mathrm{e}+00 \\
\end{array}$ & $\begin{array}{l}2.85 \mathrm{e}-01 \\
1.02 \mathrm{e}-01 \\
1.25 \mathrm{e}-02 \\
3.95 \mathrm{e}-02 \\
\end{array}$ & $\begin{array}{l}9.10 \mathrm{e}-01 \\
3.26 \mathrm{e}-01 \\
4.00 \mathrm{e}-02 \\
1.26 \mathrm{e}-01 \\
\end{array}$ & $\begin{array}{l}2.86 \mathrm{e}+00 \\
1.24 \mathrm{e}+00 \\
1.63 \mathrm{e}+00 \\
\end{array}$ & $\begin{array}{l}7.20 \mathrm{e}-01 \\
2.58 \mathrm{e}-01 \\
3.17 \mathrm{e}-02 \\
1.00 \mathrm{e}-01 \\
\end{array}$ & $\begin{array}{l}4.46 \mathrm{e}+00 \\
1.61 \mathrm{e}+00 \\
1.97 \mathrm{e}-01 \\
6.21 \mathrm{e}-01 \\
\end{array}$ & $\begin{array}{l}1.29 \mathrm{e}+00 \\
6.69 \mathrm{e}-01 \\
6.43 \mathrm{e}-02 \\
1.89 \mathrm{e}-01\end{array}$ & $\begin{array}{l}1.84 \mathrm{e}+01 \\
7.02 \mathrm{e}+00 \\
6.91 \mathrm{e}-01 \\
3.80 \mathrm{e}+00 \\
\end{array}$ \\
\hline $\begin{array}{l}\mathrm{Nd} \\
\mathrm{Ni} \\
\mathrm{P} \\
\mathrm{Pb}\end{array}$ & $\begin{array}{l}1.22 \mathrm{e}+00 \\
8.70 \mathrm{e}-01 \\
3.87 \mathrm{e}+00 \\
4.55 \mathrm{e}+00\end{array}$ & $\begin{array}{l}4.43 \mathrm{e}-02 \\
3.16 \mathrm{e}-02 \\
1.40 \mathrm{e}-01 \\
1.65 \mathrm{e}-01 \\
\end{array}$ & $\begin{array}{l}1.42 \mathrm{e}-01 \\
1.01 \mathrm{e}-01 \\
4.49 \mathrm{e}-01 \\
5.27 \mathrm{e}-01 \\
\end{array}$ & $3.47 e-01$ & $\begin{array}{l}1.12 \mathrm{e}-01 \\
7.99 \mathrm{e}-02 \\
3.55 \mathrm{e}-01 \\
4.17 \mathrm{e}-01\end{array}$ & $\begin{array}{l}7.00 \mathrm{e}-01 \\
4.97 \mathrm{e}-01 \\
2.21 \mathrm{e}+00 \\
2.59 \mathrm{e}+00 \\
\end{array}$ & $\begin{array}{l}2.87 e-01 \\
1.73 e-01 \\
8.19 e-01 \\
8.36 e-01 \\
\end{array}$ & $\begin{array}{l}2.51 \mathrm{e}+00 \\
1.75 \mathrm{e}+00 \\
7.84 \mathrm{e}+00 \\
9.43 \mathrm{e}+00 \\
\end{array}$ \\
\hline $\begin{array}{l}s \\
s b \\
s i \\
s m \\
\end{array}$ & $\begin{array}{l}3.02 \mathrm{e}+00 \\
2.02 \mathrm{e}+00 \\
1.33 \mathrm{e}+01 \\
4.41 \mathrm{e}+00 \\
\end{array}$ & $\begin{array}{l}1.10 \mathrm{e}-01 \\
7.33 \mathrm{e}-02 \\
4.81 \mathrm{e}-01 \\
1.60 \mathrm{e}-01 \\
\end{array}$ & $\begin{array}{l}3.50 \mathrm{e}-01 \\
2.34 \mathrm{e}-01 \\
1.54 \mathrm{e}+00 \\
5.11 \mathrm{e}-01 \\
\end{array}$ & $3.44 \mathrm{e}+00$ & $\begin{array}{l}2.77 \mathrm{e}-01 \\
1.85 \mathrm{e}-01 \\
1.22 \mathrm{e}+00 \\
4.05 \mathrm{e}-01 \\
\end{array}$ & $\begin{array}{l}1.74 \mathrm{e}+00 \\
1.15 \mathrm{e}+00 \\
7.90 \mathrm{e}+00 \\
2.52 \mathrm{e}+00 \\
\end{array}$ & $\begin{array}{l}9.17 \mathrm{e}-01 \\
3.77 \mathrm{e}-01 \\
8.53 \mathrm{e}+00 \\
9.64 \mathrm{e}-01\end{array}$ & $\begin{array}{l}6.42 \mathrm{e}+00 \\
4.04 \mathrm{e}+00 \\
3.64 \mathrm{e}+01 \\
8.97 \mathrm{e}+00\end{array}$ \\
\hline $\begin{array}{l}\text { Sr } \\
\text { Tj } \\
\text { Tl } \\
V\end{array}$ & $\begin{array}{l}3.09 e-01 \\
1.32 e+00 \\
1.34 e+00 \\
3.45 e+00 \\
\end{array}$ & $\begin{array}{l}1.12 \mathrm{e}-02 \\
4.77 \mathrm{e}-02 \\
4.87 \mathrm{e}-02 \\
1.25 \mathrm{e}-01 \\
\end{array}$ & $\begin{array}{l}3.59 e-02 \\
1.53 e-01 \\
1.56 e-01 \\
4.00 e-01 \\
\end{array}$ & & $\begin{array}{l}2.84 \mathrm{e}-02 \\
1.21 \mathrm{e}-01 \\
1.23 \mathrm{e}-01 \\
3.16 \mathrm{e}-01\end{array}$ & $\begin{array}{l}1.76 \mathrm{e}-01 \\
7.48 \mathrm{e}-01 \\
7.75 \mathrm{e}-01 \\
1.97 \mathrm{e}+00\end{array}$ & $\begin{array}{l}4.89 \mathrm{e}-02 \\
1.92 \mathrm{e}-01 \\
4.29 \mathrm{e}-01 \\
7.07 \mathrm{e}-01 \\
\end{array}$ & $\begin{array}{l}6.10 \mathrm{e}-01 \\
2.58 \mathrm{e}+00 \\
2.87 \mathrm{e}+00 \\
6.97 \mathrm{e}+00 \\
\end{array}$ \\
\hline $\begin{array}{l}\mathrm{Zn} \\
\mathrm{Zr} \\
\mathrm{U} \\
\text { Pu } \\
\text { Other }\end{array}$ & $\begin{array}{l}9.27 e+00 \\
1.41 e+00 \\
6.97 e+02 \\
2.43 e+00 \\
6.09 e+03\end{array}$ & $\begin{array}{l}3.36 \mathrm{e}-01 \\
5.13 \mathrm{e}-02 \\
2.53 \mathrm{e}+01 \\
8.80 \mathrm{e}-02 \\
2.21 \mathrm{e}+02\end{array}$ & $\begin{array}{l}1.08 \mathrm{e}+00 \\
1.64 \mathrm{e}-01 \\
8.08 \mathrm{e}+01 \\
2.81 \mathrm{e}-01 \\
7.06 \mathrm{e}+02\end{array}$ & $\begin{array}{l}8.88 \mathrm{e}-01 \\
3.90 \mathrm{e}+01 \\
9.75 \mathrm{e}-02 \\
2.45 \mathrm{e}+03\end{array}$ & $\begin{array}{l}8.51 \mathrm{e}-01 \\
1.30 \mathrm{e}-01 \\
6.40 \mathrm{e}+01 \\
2.23 \mathrm{e}-01 \\
5.59 \mathrm{e}+02\end{array}$ & $\begin{array}{l}5.28 \mathrm{e}+00 \\
8.27 \mathrm{e}-01 \\
3.99 \mathrm{e}+02 \\
1.38 \mathrm{e}+00 \\
3.62 \mathrm{e}+03\end{array}$ & $\begin{array}{l}1.51 \mathrm{e}+00 \\
6.34 \mathrm{e}-01 \\
1.50 \mathrm{e}+02 \\
3.86 \mathrm{e}-01 \\
3.71 \mathrm{e}+03\end{array}$ & $\begin{array}{l}1.92 \mathrm{e}+01 \\
3.22 \mathrm{e}+00 \\
1.46 \mathrm{e}+03 \\
4.88 \mathrm{e}+00 \\
1.73 \mathrm{e}+04\end{array}$ \\
\hline $\begin{array}{l}\text { TOTAL } \\
\text { Dry } \\
\text { sludge }\end{array}$ & $9.33 \mathrm{e}+03$ & $3.39 \mathrm{e}+02$ & $1.08 \mathrm{e}+03$ & $2.64 \mathrm{e}+03$ & $8.57 e+02$ & $5.46 \mathrm{e}+03$ & $4.29 \mathrm{e}+03$ & $2.40 \mathrm{e}+04$ \\
\hline $\begin{array}{l}\text { Inter- } \\
\text { stitial } \\
\text { Water }\end{array}$ & $8.87 e+03$ & $3.21 \mathrm{e}+02$ & $1.03 e+03$ & $5.61 \mathrm{e}+03$ & $8.13 e+02$ & $6.09 \mathrm{e}+03$ & $2.02 \mathrm{e}+04$ & $4.29 e+04$ \\
\hline $\begin{array}{l}\text { TOTAL } \\
\text { Wet } \\
\text { Studge }\end{array}$ & $1.82 \mathrm{e}+04$ & $6.60 \mathrm{e}+02$ & $2.11 e+03$ & $8.25 e+03$ & $1.67 \mathrm{e}+03$ & $1.16 \mathrm{e}+04$ & $2.45 e+04$ & $6.69 \mathrm{e}+04$ \\
\hline
\end{tabular}

1) This column entitled "Fuel Canisters" is inclusive of all three categories of fuel canisters: the empty canisters, full canisters of unbreached fuel, and full canisters of breached fuel.

Radionuclides present in the KE Basin sludge were estimated by the same method used to estimate chemical components. The results are presented in Table 5.3, assuming the decay date basis for radionuclides is identical to the date data were reported. The exception is plutonium, whose activity was calculated based on the mass provided in Table 5.2. The Pu isotope mass fractions were taken from the Warner document. 
Table 5.3: Radionuclides in 105-K East Basin Sludge

(Decay Date: May 1993)

\begin{tabular}{|c|c|c|c|c|c|c|c|c|}
\hline & $\begin{array}{l}\text { WEASEL } \\
\text { PIT } \\
\text { ci }\end{array}$ & $\begin{array}{c}\text { TECH } \\
\text { VIEW PIT } \\
\text { Ci }\end{array}$ & $\begin{array}{c}\text { WASH PIT } \\
\text { Ci }\end{array}$ & $\begin{array}{c}\text { SANDFILTER } \\
\text { BACKWASH } \\
\text { PIT } \\
\text { Ci }\end{array}$ & $\begin{array}{c}\text { SOUTH } \\
\text { LOADOUT } \\
\text { PIT } \\
\mathrm{CI}\end{array}$ & $\begin{array}{c}\text { FUEL }^{1} \\
\text { CANISTERS }^{-1} \\
\mathrm{C}_{i}\end{array}$ & $\begin{array}{c}\text { BASIN } \\
\text { FLOOR } \\
\mathrm{Ci}\end{array}$ & $\begin{array}{c}\text { TOTAL } \\
\mathrm{Ci}\end{array}$ \\
\hline $\begin{array}{l}\text { Co } 60 \\
\text { Sr } 90 \\
\text { Y } 90 \\
\end{array}$ & $\begin{array}{l}1.10 \mathrm{e}+01 \\
5.51 \mathrm{e}+02 \\
5.51 \mathrm{e}+02 \\
\end{array}$ & $\begin{array}{l}3.99 \mathrm{e}-01 \\
2.00 \mathrm{e}+01 \\
2.00 \mathrm{e}+01 \\
\end{array}$ & $\begin{array}{l}1.28 \mathrm{e}+00 \\
6.39 \mathrm{e}+01 \\
6.39 \mathrm{e}+01 \\
\end{array}$ & $1.36 \mathrm{e}+00$ & $\begin{array}{l}1.01 \mathrm{e}+00 \\
5.06 \mathrm{e}+01 \\
5.06 \mathrm{e}+01\end{array}$ & $\begin{array}{l}6.56 \mathrm{e}+00 \\
3.26 \mathrm{e}+02 \\
3.26 \mathrm{e}+02 \\
\end{array}$ & $\begin{array}{l}6.99 \mathrm{e}+00 \\
3.21 \mathrm{e}+02 \\
3.21 \mathrm{e}+02 \\
\end{array}$ & $\begin{array}{l}2.86 e+01 \\
1.33 e+03 \\
1.33 e+03 \\
\end{array}$ \\
\hline $\begin{array}{ll}\text { Cs } & 137 \\
\text { Ba } 137 \mathrm{~m} \\
\text { Eu } 154 \\
\text { Eu } 155 \\
\end{array}$ & $\begin{array}{l}4.21 e+02 \\
3.99 e+02 \\
1.16 e+01 \\
6.57 e+00 \\
\end{array}$ & $\begin{array}{l}1.53 \mathrm{e}+01 \\
1.45 \mathrm{e}+01 \\
4.21 \mathrm{e}-01 \\
2.38 \mathrm{e}-01 \\
\end{array}$ & $\begin{array}{l}4.89 \mathrm{e}+01 \\
4.62 \mathrm{e}+01 \\
1.35 \mathrm{e}+00 \\
7.62 \mathrm{e}-01 \\
\end{array}$ & $\begin{array}{l}6.14 \mathrm{e}+01 \\
5.81 \mathrm{e}+01 \\
1.36 \mathrm{e}+00 \\
7.46 \mathrm{e}-01 \\
\end{array}$ & $\begin{array}{l}3.87 \mathrm{e}+01 \\
3.66 \mathrm{e}+01 \\
1.07 \mathrm{e}+00 \\
6.03 \mathrm{e}-01 \\
\end{array}$ & $\begin{array}{l}2.46 \mathrm{e}+02 \\
2.33 \mathrm{e}+02 \\
6.90 \mathrm{e}+00 \\
3.91 \mathrm{e}+00\end{array}$ & $\begin{array}{l}1.78 \mathrm{e}+02 \\
1.68 \mathrm{e}+02 \\
7.11 \mathrm{e}+00 \\
4.17 \mathrm{e}+00 \\
\end{array}$ & $\begin{array}{l}1.01 \mathrm{e}+03 \\
9.55 \mathrm{e}+02 \\
2.98 \mathrm{e}+01 \\
1.70 \mathrm{e}+01 \\
\end{array}$ \\
\hline $\begin{array}{l}\text { Pu } 238 \\
\text { Pu } 239 \\
\text { Pu } 240 \\
\text { Pu } 241\end{array}$ & $\begin{array}{l}3.28 \mathrm{e}+01 \\
1.29 \mathrm{e}+02 \\
7.10 \mathrm{e}+01 \\
2.81 \mathrm{e}+03\end{array}$ & $\begin{array}{l}1.19 \mathrm{e}+00 \\
4.69 \mathrm{e}+00 \\
2.57 \mathrm{e}+00 \\
1.02 \mathrm{e}+02 \\
\end{array}$ & $\begin{array}{l}3.81 \mathrm{e}+00 \\
1.50 \mathrm{e}+01 \\
8.23 \mathrm{e}+00 \\
3.26 \mathrm{e}+02 \\
\end{array}$ & $\begin{array}{l}1.32 \mathrm{e}+00 \\
5.20 \mathrm{e}+00 \\
2.85 \mathrm{e}+00 \\
1.13 \mathrm{e}+02 \\
\end{array}$ & $\begin{array}{l}3.01 \mathrm{e}+00 \\
1.19 \mathrm{e}+01 \\
6.51 \mathrm{e}+00 \\
2.58 \mathrm{e}+02 \\
\end{array}$ & $\begin{array}{l}1.87 e+01 \\
7.36 e+01 \\
4.04 e+01 \\
1.60 e+03\end{array}$ & $\begin{array}{l}5.22 \mathrm{e}+00 \\
2.06 \mathrm{e}+01 \\
1.13 \mathrm{e}+01 \\
4.47 \mathrm{e}+02 \\
\end{array}$ & $\begin{array}{l}6.60 \mathrm{e}+01 \\
2.60 \mathrm{e}+02 \\
1.43 \mathrm{e}+02 \\
5.66 \mathrm{e}+03 \\
\end{array}$ \\
\hline $\begin{array}{l}\text { Pu } 242 \\
\text { Am } 241 \\
\end{array}$ & $\begin{array}{l}2.17 \mathrm{e}-02 \\
2.50 \mathrm{e}+02 \\
\end{array}$ & $\begin{array}{l}7.86 \mathrm{e}-04 \\
9.06 \mathrm{e}+00 \\
\end{array}$ & $\begin{array}{l}2.51 \mathrm{e}-03 \\
2.90 \mathrm{e}+01 \\
\end{array}$ & $\begin{array}{l}8.71 e-04 \\
6.65 e+00 \\
\end{array}$ & $\begin{array}{l}1.99 \mathrm{e}-03 \\
2.29 \mathrm{e}+01\end{array}$ & $\begin{array}{r}1.23 e-02 \\
1.56 e+02 \\
\end{array}$ & $\begin{array}{l}3.44 \mathrm{e}-03 \\
2.95 \mathrm{e}+02 \\
\end{array}$ & $\begin{array}{l}4.36 \mathrm{e}-02 \\
7.69 \mathrm{e}+02 \\
\end{array}$ \\
\hline TOTAL. & $5.24 e+03$ & $1.90 \mathrm{e}+02$ & $6.08 \mathrm{e}+02$ & $2.52 \mathrm{e}+02$ & $4.82 \mathrm{e}+02$ & $3.04 \mathrm{e}+03$ & $1.79 \mathrm{e}+03$ & $1.16 e+04$ \\
\hline
\end{tabular}

1) This column entitled "Fuel canisters" is inclusive of all three categories of fuel canisters: the empty canisters, full canisters of unbreached fuel, and full canisters of breached fuel.

Table 5.4 provides an estimate of the total radionuclides for a composite of the 105-K East Basin sludge. The mass and heat generation rate of each isotope based on a decay date of 1/1/95 is derived from the activities estimated in Table 5.3, combined with specific activities and specific heat generation rates for the individual isotopes presented in Appendix $C$.

Table 5.4: 105-K East Basin Radionuclide Totals

\begin{tabular}{|c|c|c|c|c|}
\hline RADIONUCLIDE & $\begin{array}{c}\text { ACTIVITY } \\
\text { decay date: } \\
5 / 1 / 93 \\
\text { (Ci) } \\
\end{array}$ & $\begin{array}{c}\text { ACT IVITY } \\
\text { decay date: } \\
1 / 1 / 95 \\
\text { (Ci) } \\
\end{array}$ & $\begin{array}{c}\text { MASS } \\
\text { decay date: } \\
1 / 1 / 95 \\
(\mathrm{Kg}) \\
\end{array}$ & $\begin{array}{c}\text { HEAT } \\
\text { GENERATION } \\
\text { decay date: } 1 / 1 / 95 \\
\text { (BTU/hr) }\end{array}$ \\
\hline $\begin{array}{l}\text { Co } 60 \\
\text { Sr } 90 \\
\text { Y } 90\end{array}$ & $\begin{array}{l}2.86 \mathrm{e}+01 \\
1.33 \mathrm{e}+03 \\
1.33 \mathrm{e}+03\end{array}$ & $\begin{array}{l}2.30 \mathrm{e}+01 \\
1.28 \mathrm{e}+03 \\
1.28 \mathrm{e}+03\end{array}$ & $\begin{array}{l}2.03 e-05 \\
9.38 \mathrm{e}-03 \\
2.35 \mathrm{e}-06\end{array}$ & $\begin{array}{l}1.21 e+00 \\
5.07 e+00 \\
2.42 e+01 \\
\end{array}$ \\
\hline $\begin{array}{ll}\text { Cs } & 137 \\
\text { Ba } & 137 \mathrm{~m} \\
\text { Eu } & 154 \\
\text { Eu } & 155 \\
\end{array}$ & $\begin{array}{l}1.01 \mathrm{e}+03 \\
9.55 \mathrm{e}+02 \\
2.98 \mathrm{e}+01 \\
1.70 \mathrm{e}+01 \\
\end{array}$ & $\begin{array}{l}9.72 \mathrm{e}+02 \\
9.20 \mathrm{e}+02 \\
2.61 \mathrm{e}+01 \\
1.35 \mathrm{e}+01 \\
\end{array}$ & $\begin{array}{l}1.12 \mathrm{e}-02 \\
1.71 \mathrm{e}-09 \\
9.67 \mathrm{e}-05 \\
2.90 \mathrm{e}-05 \\
\end{array}$ & $\begin{array}{l}3.67 \mathrm{e}+00 \\
1.23 \mathrm{e}+01 \\
7.97 \mathrm{e}-01 \\
3.35 \mathrm{e}-02 \\
\end{array}$ \\
\hline $\begin{array}{l}\text { Pu } 238 \\
\text { Pu } 239 \\
\text { Pu } 240 \\
\text { Pu } 241 \\
\end{array}$ & $\begin{array}{l}6.60 \mathrm{e}+01 \\
2.60 \mathrm{e}+02 \\
1.43 \mathrm{e}+02 \\
5.66 \mathrm{e}+03 \\
\end{array}$ & $\begin{array}{l}6.51 \mathrm{e}+01 \\
2.60 \mathrm{e}+02 \\
1.43 \mathrm{e}+02 \\
5.22 \mathrm{e}+03 \\
\end{array}$ & $\begin{array}{l}3.86 \mathrm{e}-03 \\
4.18 \mathrm{e}+00 \\
6.28 \mathrm{e}-01 \\
5.50 \mathrm{e}-02 \\
\end{array}$ & $\begin{array}{l}7.47 \mathrm{e}+00 \\
2.74 \mathrm{e}+01 \\
1.52 \mathrm{e}+01 \\
5.99 \mathrm{e}-01 \\
\end{array}$ \\
\hline $\begin{array}{l}\text { Pu } 242 \\
\text { Am } 241 \\
\end{array}$ & $\begin{array}{r}4.36 e-02 \\
7.69 e+02 \\
\end{array}$ & $\begin{array}{l}4.36 \mathrm{e}-02 \\
7.82 \mathrm{e}+02 \\
\end{array}$ & $\begin{array}{r}1.15 \mathrm{e}-02 \\
2.28 \mathrm{e}-01 \\
\end{array}$ & $\begin{array}{r}4.39 e-03 \\
8.87 e+01 \\
\end{array}$ \\
\hline TOTAL & $1.16 e+04$ & $1.10 \mathrm{e}+04$ & $5.13 e+00$ & $1.87 \mathrm{e}+02$ \\
\hline
\end{tabular}




\subsection{5-K WEST BASIN SLUDGE}

Extensive information is not currently available on sludge in the $\mathrm{KW}$ Basin. The canisters in the KW Basin are all closed and therefore isolated from the basin environment. S7udge that has accumulated in this basin and related pits is expected to be from environmental pollutants such as dust, dirt, paint chips, etc. .

Table 5.5 presents information known at this time regarding sludge in the KW Basin. The volume of sludge in the Sandfilter Backwash Pit was obtained from integration of sludge depth measurements. It was also noted that significant sludge exists in the South Loadout Pit (from decapping canisters prior to shipment to PUREX) and the Tech View Pit (from changing filter cartridges) (Baker 1995).

Table 5.5: Physical Properties of 105-K West Basin Sludge

\begin{tabular}{|c|c|c|c|c|c|c|c|c|}
\hline & $\begin{array}{c}\text { WEASEL } \\
\text { PII }\end{array}$ & $\begin{array}{c}\text { TECH } \\
\text { VIEW PIT }\end{array}$ & WASH PIT & $\begin{array}{c}\text { SANDFILTER } \\
\text { BACKWASH } \\
\text { PIT }\end{array}$ & $\begin{array}{l}\text { SOUTH } \\
\text { LOADOUT } \\
\text { PIT }\end{array}$ & $\begin{array}{c}\text { FUEL } \\
\text { CANISTERS }\end{array}$ & $\begin{array}{l}\text { BASIN } \\
\text { FLOOR }\end{array}$ & TOTAL \\
\hline $\begin{array}{l}\text { Volume } \\
\left(\mathrm{m}^{3}\right)^{1}\end{array}$ & & & & 3.60 & & & & \\
\hline $\begin{array}{l}\text { Mass }{ }^{1} \\
(\mathrm{Mg})\end{array}$ & & & & & & & & \\
\hline $\begin{array}{l}\text { Density } \\
(\mathrm{g} / \mathrm{ml})\end{array}$ & & & & & & & & \\
\hline $\begin{array}{l}\text { Partjicle } \\
\text { size }(\mu \mathrm{m})^{2}\end{array}$ & & & & & & & & \\
\hline $\begin{array}{l}\text { Solids } 3 \\
\text { (wt. \%) }\end{array}$ & & & & & & & & \\
\hline
\end{tabular}

1) Volume, mass, and density is of wet sludge, after settling.

2) Particle size is average size of all particles in sample.

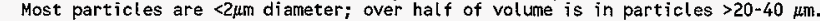

3) Weight percent of solids is the fractions of solids in the sludge (the remainder is water). 
HNF-SD-SNF-TI-009, Rev. I

\subsection{REFERENCES}

Baker, R. B., 1995, Summary Status of $K$ Basins Sludge Characterization, WHCSD-SNF-TI-006, Rev. 0, Westinghouse Hanford Company, Richland, Washington.

Bechtold, D. B., 1994, Report of Laboratory Test Plan for Analysis of KE Basin Backwash Pit Samples, WHC-SD-NR-TRP-021, Rev. O, Westinghouse Hanford Company, Richland, Washington.

Bechtold, D. B., 1993, Analysis of $105 \mathrm{KE}$ Basin S7udge Samp7es, (internal letter 12110-PCL93-069 to M. A. Meier, July 27), Westinghouse Hanford Company, Richland, Washington.

Cowan, R. G., 1995, MCo Proposed Description, (Internal Memo to W. L. Will is et a1, January 12), Westinghouse Hanford Company, Richland, Washington.

DOE, 1988, Internal Dose Conversion Factors for Calculation of Dose to the Pub7ic, DOE/EH-0071, United States Department of Energy, Washington, D.C.

DOE, 1994, Department of Energy Programmatic Spent Nuclear Fuel Management and Idaho National Engineering Laboratory Environmental Restoration and Waste Management Programs Draft Environmenta7 Impact Statement, DOE/EIS0203-D, United States Department of Energy, Washington, D.C.

DUN, 1967, Fuel Element Lot Identification and Component Codes, Document, DUN-117, Rev. 4, E. A. Weakley and K. C. Bowles, Douglas United Nuclear, Inc.

DUN, 1972, U. S. Atomic Energy Commission Nuclear Material Transaction Report,-Irradiated Special Depleted Uranium, Plutonium, and Neptunium, Nuclear Material Transaction Report, Douglas United Nuclear, Inc.

Gydesen, C. H., 1975, Functional Design Criteria Supplemental N-Reactor Fuel Storage 105-KW, UNI-410, Rev. 0, United Nuclear Industries, Inc., Richland, Washington.

Gydesen, C. H., 1977, Functional Design Criteria Supplementa7 N-Reactor Irradiated Fue7 Storage, 105-KE, UNI-108, Rev. 3, United Nuclear Industries, Inc., Richland, Washington.

HAP0, 1944, Hanford Engineering Works Technical Manual, Controlled Manual, HW-10475B, Hanford Atomic Products Operation, Richland, Washington.

HAP0, 1955, PUREX Technical Manual, Controlled Manual, HW-31000, Hanford Atomic Products Operation, Richland, Washington.

HAPO, 1958, Technology of the HAPO Lead Dip Fuel Element Canning Process, Supporting Document, $\mathrm{HW}-58115, \mathrm{E}$. A. Weakley, Hanford Atomic Products Operation, Richland; Washington.

HAP0, 1961, Reactor Physics Primer, Controlled Manual, H2-51856 Comp.,

E. H. Lockwood, Hanford Atomic Products Operation, Richland, Washington. 
HAP0, 1963a, Hazards Summary Report, Volume 2, Process Control and Technical Data, Hanford K Production Reactors, Supporting Document, HW-74905, Hanford Atomic Products Operation, Richland, Washington.

HAP0, 1963b, Hazards Summary Report, Volume 3, Process Control and Technical Data, Hanford $K$ Production Reactors, Supporting Document, HW74905, Hanford Atomic Products Operation, Richland, Washington.

Larson, 1990, SPR Fuel Va7ue Assignment, (Internal Memo), Westinghouse Hanford Company, Richland, Washington.

Meling, T. A., 1994, S7udge Measurement Results for 105 KE Basin, WHC-SD-WMANAL-037, Rev. 0, Westinghouse Hanford Company, Richland, Washington.

Pitner, A. L., 1995, KE Basin Underwater Visua.7 Fue7 Survey, WHC-SD-SNF-TI012, Rev. 0, Westinghouse Hanford Company, Richland, Washington.

PNL, 1991, A History of Major Hanford Facilities and Processes Involving Radioactive Material, PNL-6964 HEDR UC-707, M. Y. Ballinger and R. B. $\mathrm{Ha} 11$, Pacific Northwest Laboratory, Richland, Washington.

Roblyer 1995, K Basin Fue7 Decay Heating Characterization, (Internal Memorandum to J. J. Irwin, December 29), Westinghouse Hanford Company, Richland, Washington.

Schwarz, R. A., 1997, Modification to ORIGEN2 For Generating $N$ Reactor Source Terms, PNNL-11555 UC-610 (3 Volumes), Pacific Northwest Nationa? Laboratory, Richland, Washington.

Schwinkendorf, K. N., 1993, Source Terms in K Reactor Depleted Fuel, (Interna] Memorandum to W. G. Jasen, November 16), Westinghouse Hanford Company, Richland, Washington.

Schwinkendorf, K. N., S. P. Roblyer, and S. A. Parra, 1996, Use of the WIMS-E Lattice Code for Prediction of the Transuranic Source Term for Spent Fuel Dose Estimation, the SPECTRUM 96 International Topical Meeting on Nuclear and Hazardous Waste Management, Seattle, Washington, August 1823, 1996, Vol. 1, pp. 709-713.

Warner, R. D., 1994, Safety Evaluation of the Plutonium and Uranium Content of. the $K$ East Basin Sandfi7ter Backwash Pit, WHC-SD-WM-TA-152, Rev. 0, Westinghouse Hanford Company, Richland, Washington.

Weakley, 1994, Telephone conversation between the author and Everett Weakley, $\mathrm{N}$ Reactor fuel assembly area, November 10, 1994

Welsh, T. L., 1994, Statistical Evaluation of the Data Obtained from the $K$ East Basin Sandfilter Backwash Pit Samples, WHC-SD-SNF-TI-004, Rev. 0, Westinghouse Hanford Company, Richland, Washington. 
WHC, 1996, Westinghouse Hanford Company FY 1996 Materials Management P7an (MMP), WHC-SP-1177, Westinghouse Hanford Company, Rich1 and, Washington.

WHC, 1995a, Certification of RADNUC, WHC-SD-HWV-SWD-001, Rev. 1, Westinghouse Hanford Company, Richland, Washington.

WHC, I995b, K Basins Environmental Impact Statement Technical Input, WHC-SDSNF-TI-013, Rev. A, Westinghouse Hanford Company, Richland Washington.

WHC, 1995c, Integrated Process Strategy for K Basins Spent Nuclear Fue7, WHCSD-SNF-SP-005, Volume 1, Rev 0, Westinghouse Hanford Company, Richland Washington.

WHC, 1994a, Hanford Spent Nuclear Fuel Project Recommended Path Forward, Volume I: Recommended Path Forward, WHC-EP-0830, Vol. I, rev. 0, Westinghouse Hanford Company, Richland, Washington.

WHC, 1994b, Hanford Irradiated Fuel Inventory Baseline, WHC-SD-SNF-TI001 , Rev. 0, Westinghouse Hanford Company, Richland, Washington.

WHC, 1993a, Safety Analysis Irradiated N Reactor Fuel, WHC-SD-WM-SAR-062, Rev. 0 , Westinghouse Hanford Company, RichTand, Washington.

WHC, 1993b, Transport Mechanism of Radionuclides in 105-KE Fuel Storage Basin to Airborne Effluent Re7ease, WHC-SD-NR-ES-016, CoTumbia Energy and Environmental Services, Inc. for Westinghouse Hanford Company, Richland, Washington.

WHC, 1991, Fuel Metal Accountability, Internal Publication, WHC-IP-0069, Rev. 162, Westinghouse Hanford Company, Richland, Washington.

WHC, 1989, PUREX Technical Manual, Controlled Manual, WHC-CM-SP-0479, Westinghouse Hanford Company, Richland, Washington.

WHC, 1984, Engineering Specifications, Hanford N Reactor Fuel Elements, Controlled Manual, WHC-CM-5-17, (formerly DUN-4000, Vol. 3), Westinghouse Hanford Company, Richland, Washington.

Wittekind, W. D., 1997, Shippingport PWR Core 2 Source Term Calculation Using ORIGEN2, HNF-SD-SNF-TI-061, Fluor Daniel Northwest, Richland, Washington. 
HNF-SD-SNF-TI-009, ReV. 1

APPENDIX A

ACCOUNTABILITY DATA BASE FOR N REACTOR FUEL IN THE $K$ BASINS 
The following pages contain the database used in the development of the radionuclide tables in the document. The database includes the following 8 fields:

The first field is a location code a 108 in this field indicates the $105 \mathrm{~K}$-East Basin and a 107 indicates the $105 \mathrm{~K}$-West Basin.

- The second field is the key number which corresponds to the date the fuel was discharged from the reactor. The numbers are HAPO days and increase by one each day. HAPO day number one occurred September 26, 1944, the day that B Reactor achieved initial criticality.

A few records have key numbers in excess of 20000, (which correspond to dates no earlier than 1999) these few had 10000 added to differentiate fuel types with two different burnup rates discharged on the same day. 10000 was subtracted from the key date of a11 records with key dates in excess of 20000 when the database was converted into a data file.

- The third field is the fuet model, and was not used.

- The fourth field is the material type and this explains why there is from one to three lines for each record. The numbers are codes for uranium, plutonium, and neptunium as follows: $10=$ depleted uranium (contains less than $0: 71 \%{ }^{235} \mathrm{U}$ ); $20=$ enriched uranium (contains more than $0.71 \%{ }^{235} \mathrm{U}$ ); 50 = plutonium; $81=$ naturally occurring uranium (contains $0.71 \%{ }^{235} \mathrm{U}$ ); and $82=$ neptunium. most of the records contain a line for uranium, a line for plutonium, and a line for neptunium; some contain only uranium and plutonium; and a few contain only uranium.

- The fifth field is a sub ID code, and was not used.

- The sixth field is the fuet type, $V=$ mark IV fuel, and I = mark 1 A fuel.

- The seventh field contains isotopic breakdown information. In the uranium lines the seventh field is the post-irradiation ${ }^{235} \mathrm{U}$ content given as a percent of the total uranium. In the plutonium lines the seventh field is the ${ }^{240} \mathrm{Pu}$ content given as a percent of the total plutonium. The seventh field has no meaning in the neptunium $l$ ines.

- The eighth field is the discharge mass in metric tons. In the uranium line it is the total uranium mass, in the plutonium line it is the total plutonium mass. 
of the approximately 500 records in the accountability database, 9 records may be single pass reactor fuel. These 9 records account for 0.32 MTU or about $0.015 \%$ of the total inventory in the $K$ Basins. A11 9 records contain $5.49 \%{ }^{240} \mathrm{Pu}$ and are modeled as $\mathrm{N}$ Reactor Mark IV fuel. This fuel does not significantly impact either the chemical or radiological inventory of $\mathrm{N}$ Reactor fuel in the $\mathrm{K}$ Basins and therefore is modeled as $\mathrm{N}$ Reactor fuel. 
HNF-SD-SNF-TI-009, Rev. 1

\begin{tabular}{|c|c|c|c|c|c|c|}
\hline $\begin{array}{c}\text { Location } \\
\text { Code }\end{array}$ & Key Number & Fuel Model & $\begin{array}{c}\text { Material } \\
\text { Type }\end{array}$ & $\begin{array}{c}\text { sub ID } \\
\text { Code }\end{array}$ & Fuel Type & Isotopic Breakdown \\
\hline
\end{tabular}

\begin{tabular}{|c|c|c|c|c|c|c|c|}
\hline $\begin{array}{l}108 \\
108\end{array}$ & $\begin{array}{l}09621 \\
.09621\end{array}$ & $\begin{array}{l}\mathrm{C} 2 \mathrm{~N} \\
\mathrm{C} 2 \mathrm{~N}\end{array}$ & $\begin{array}{l}10 \\
50\end{array}$ & & $\begin{array}{l}v \\
v\end{array}$ & $\begin{array}{l}0.61 \\
5.94\end{array}$ & $\begin{array}{l}0.006668 \\
0.000005\end{array}$ \\
\hline $\begin{array}{l}108 \\
108\end{array}$ & $\begin{array}{l}09621 \\
09621\end{array}$ & $\begin{array}{l}\text { C3E } \\
\text { C3E }\end{array}$ & $\begin{array}{l}10 \\
50\end{array}$ & & $\begin{array}{l}v \\
v\end{array}$ & $\begin{array}{l}0.61 \\
5.94\end{array}$ & $\begin{array}{l}0.076639 \\
0.000055\end{array}$ \\
\hline $\begin{array}{l}108 \\
108\end{array}$ & $\begin{array}{l}09621 \\
09621\end{array}$ & $\begin{array}{l}\text { C3E } \\
\text { C3E }\end{array}$ & $\begin{array}{l}20 \\
50\end{array}$ & $\begin{array}{l}1 \\
1\end{array}$ & $\begin{array}{l}v \\
v\end{array}$ & $\begin{array}{l}0.84 \\
6.01\end{array}$ & $\begin{array}{r}0.023952 \\
0.00002\end{array}$ \\
\hline $\begin{array}{l}108 \\
108\end{array}$ & $\begin{array}{l}09621 \\
09621\end{array}$ & $\begin{array}{l}\text { K4N } \\
\text { K4N }\end{array}$ & $\begin{array}{l}10 \\
50\end{array}$ & & $\begin{array}{l}v \\
v\end{array}$ & $\begin{array}{l}0.62 \\
5.94\end{array}$ & $\begin{array}{l}0.009893 \\
0.000007\end{array}$ \\
\hline $\begin{array}{l}108 \\
108\end{array}$ & $\begin{array}{l}09621 \\
09621\end{array}$ & $\begin{array}{l}\mathrm{K} 4 \mathrm{~W} \\
\mathrm{~K} 4 \mathrm{~W}\end{array}$ & $\begin{array}{l}10 \\
50\end{array}$ & & $\begin{array}{l}v \\
v\end{array}$ & $\begin{array}{l}0.61 \\
5.94\end{array}$ & $\begin{array}{l}0.002372 \\
0.000002\end{array}$ \\
\hline $\begin{array}{l}108 \\
108\end{array}$ & $\begin{array}{l}09621 \\
09621\end{array}$ & $\begin{array}{l}\text { K5E } \\
\text { K5E }\end{array}$ & $\begin{array}{l}10 \\
50\end{array}$ & & v & $\begin{array}{l}0.61 \\
5.94\end{array}$ & $\begin{array}{l}0.072602 \\
0.000052\end{array}$ \\
\hline $\begin{array}{l}108 \\
108\end{array}$ & $\begin{array}{l}09621 \\
09621\end{array}$ & $\begin{array}{l}\text { K5N } \\
\text { K5N }\end{array}$ & $\begin{array}{l}10 \\
50\end{array}$ & & $v$ & $\begin{array}{l}0.61 \\
5.94\end{array}$ & $\begin{array}{l}0.149739 \\
0.000108\end{array}$ \\
\hline $\begin{array}{l}108 \\
108\end{array}$ & $\begin{array}{l}09621 \\
09621\end{array}$ & $\begin{array}{l}\text { O3E } \\
\text { O3E }\end{array}$ & $\begin{array}{l}10 \\
50\end{array}$ & & $\begin{array}{l}v \\
v\end{array}$ & $\begin{array}{l}0.61 \\
5.94\end{array}$ & $\begin{array}{l}0.009721 \\
0.000007\end{array}$ \\
\hline $\begin{array}{l}108 \\
108\end{array}$ & $\begin{array}{l}09621 \\
09621\end{array}$ & $\begin{array}{l}\text { O3N } \\
\text { O3N }\end{array}$ & $\begin{array}{l}10 \\
50\end{array}$ & & $\begin{array}{l}v \\
v\end{array}$ & $\begin{array}{l}0.61 \\
5.94\end{array}$ & $\begin{array}{l}0.050439 \\
0.000036\end{array}$ \\
\hline $\begin{array}{l}108 \\
108 \\
108\end{array}$ & $\begin{array}{l}10001 \\
10001 \\
10001\end{array}$ & $\begin{array}{l}\text { BogC } \\
\text { BO9C } \\
\text { BOgC }\end{array}$ & $\begin{array}{l}20 \\
50 \\
82\end{array}$ & & $\begin{array}{l}v \\
v \\
v\end{array}$ & $\begin{array}{r}0.79 \\
12.4 \\
0\end{array}$ & $\begin{array}{l}0.042041 \\
0.000078 \\
0.000001\end{array}$ \\
\hline $\begin{array}{l}108 \\
108 \\
108\end{array}$ & $\begin{array}{l}10001 \\
10001 \\
10001\end{array}$ & $\begin{array}{l}\text { Bo9s } \\
\text { Bo9s } \\
\text { Bogs }\end{array}$ & $\begin{array}{l}20 \\
50 \\
82\end{array}$ & & $\begin{array}{l}v \\
v \\
v\end{array}$ & $\begin{array}{r}0.73 \\
12.4 \\
0\end{array}$ & $\begin{array}{r}0.014875 \\
0.000027 \\
3.60 \mathrm{e}-07\end{array}$ \\
\hline $\begin{array}{l}108 \\
108 \\
108\end{array}$ & $\begin{array}{l}10001 \\
10001 \\
10001\end{array}$ & $\begin{array}{l}\times 09 A \\
\times 09 A \\
\times 09 A\end{array}$ & $\begin{array}{l}20 \\
50 \\
82\end{array}$ & & $\begin{array}{l}v \\
v \\
v\end{array}$ & $\begin{array}{r}0.79 \\
12.4 \\
0 \\
\end{array}$ & $\begin{array}{r}0.006627 \\
0.000012 \\
1.600-07\end{array}$ \\
\hline $\begin{array}{l}108 \\
108 \\
108\end{array}$ & $\begin{array}{l}10001 \\
10001 \\
10001\end{array}$ & $\begin{array}{l}\text { XogC } \\
\text { X09C } \\
\text { X09C }\end{array}$ & $\begin{array}{l}20 \\
50 \\
82\end{array}$ & & $\begin{array}{l}v \\
v \\
v\end{array}$ & $\begin{array}{r}0.79 \\
12.4 \\
0\end{array}$ & $\begin{array}{r}0.009892 \\
0.000018 \\
2.40 \mathrm{e}-07\end{array}$ \\
\hline $\begin{array}{l}108 \\
108 \\
108\end{array}$ & $\begin{array}{l}10001 \\
10001 \\
10001\end{array}$ & $\begin{array}{l}X 09 E \\
X 09 E \\
X 09 E \\
\end{array}$ & $\begin{array}{l}20 \\
50 \\
82 \\
\end{array}$ & & $\begin{array}{l}v \\
v \\
v\end{array}$ & $\begin{array}{r}0.73 \\
12.4 \\
0 \\
\end{array}$ & $\begin{array}{r}0.029876 \\
0.000055 \\
7.20 \mathrm{e}-07 \\
\end{array}$ \\
\hline $\begin{array}{l}108 \\
108 \\
108\end{array}$ & $\begin{array}{l}10001 \\
10001 \\
10001\end{array}$ & $\begin{array}{l}\text { X09s } \\
\text { X095 } \\
\text { X09s }\end{array}$ & $\begin{array}{l}20 \\
50 \\
82\end{array}$ & & $\begin{array}{l}v \\
v \\
v\end{array}$ & $\begin{array}{r}0.73 \\
12.4 \\
0\end{array}$ & $\begin{array}{r}0.035 \\
0.000065 \\
8.50 \mathrm{e}-07\end{array}$ \\
\hline $\begin{array}{l}108 \\
108 \\
108\end{array}$ & $\begin{array}{l}10201 \\
10201 \\
10201\end{array}$ & $\begin{array}{l}\text { A09A } \\
\text { A09A } \\
\text { A09A }\end{array}$ & $\begin{array}{l}20 \\
50 \\
82 \\
\end{array}$ & & $\begin{array}{l}v \\
v \\
v\end{array}$ & $\begin{array}{r}0.77 \\
9.09 \\
0\end{array}$ & $\begin{array}{r}1.073737 \\
0.001702 \\
0.00002 \\
\end{array}$ \\
\hline $\begin{array}{l}108 \\
108 \\
108\end{array}$ & $\begin{array}{l}10201 \\
10201 \\
10201\end{array}$ & $\begin{array}{l}\text { BO9E } \\
\text { BO9E } \\
\text { BO9E }\end{array}$ & $\begin{array}{l}20 \\
50 \\
82\end{array}$ & & $\begin{array}{l}v \\
v \\
v\end{array}$ & $\begin{array}{r}0.76 \\
9.09 \\
0\end{array}$ & $\begin{array}{l}0.365445 \\
0.000579 \\
0.000007\end{array}$ \\
\hline $\begin{array}{l}108 \\
108 \\
108\end{array}$ & $\begin{array}{l}10201 \\
10201 \\
10201\end{array}$ & $\begin{array}{l}\text { Bo9s } \\
\text { Bo9s } \\
\text { Bo9s }\end{array}$ & $\begin{array}{l}20 \\
50 \\
82\end{array}$ & & $\begin{array}{l}v \\
v \\
v\end{array}$ & $\begin{array}{r}0.77 \\
9.09 \\
0\end{array}$ & $\begin{array}{l}0.343367 \\
0.000544 \\
0.000006\end{array}$ \\
\hline $\begin{array}{l}108 \\
108 \\
108\end{array}$ & $\begin{array}{l}10201 \\
10201 \\
10201\end{array}$ & $\begin{array}{l}\text { NO9A } \\
\text { NO9A } \\
\text { NO9A }\end{array}$ & $\begin{array}{l}20 \\
50 \\
82\end{array}$ & & $\begin{array}{l}v \\
v \\
v\end{array}$ & $\begin{array}{r}0.8 \\
9.09 \\
0\end{array}$ & $\begin{array}{r}0.53617 \\
0.000849 \\
0.00001\end{array}$ \\
\hline $\begin{array}{l}108 \\
108 \\
108\end{array}$ & $\begin{array}{l}10201 \\
10201 \\
10201\end{array}$ & $\begin{array}{l}\text { XOgE } \\
\text { XO9E } \\
\text { XOgE }\end{array}$ & $\begin{array}{l}20 \\
50 \\
82\end{array}$ & & $\begin{array}{l}v \\
v \\
v\end{array}$ & $\begin{array}{r}0.8 \\
9.09 \\
0\end{array}$ & $\begin{array}{l}0.171798 \\
0.000272 \\
0.000003\end{array}$ \\
\hline
\end{tabular}


HNF-SD-SNF-TI-009, Rev. 1

\begin{tabular}{|c|c|c|c|c|c|c|}
\hline $\begin{array}{c}\text { Location } \\
\text { Code }\end{array}$ & Key Number & Fuel Model & $\begin{array}{c}\text { Material } \\
\text { Type }\end{array}$ & $\begin{array}{c}\text { sub ID } \\
\text { Code }\end{array}$ & Fuel Type & Isotopic Breakdown \\
\hline
\end{tabular}

\begin{tabular}{|c|c|c|c|c|c|c|}
\hline $\begin{array}{l}108 \\
108 \\
108\end{array}$ & $\begin{array}{l}10201 \\
10201 \\
10201\end{array}$ & $\begin{array}{l}\text { xogs } \\
\text { xo9s } \\
\text { x09s }\end{array}$ & $\begin{array}{l}20 \\
50 \\
82\end{array}$ & $\begin{array}{l}v \\
v \\
v\end{array}$ & $\begin{array}{r}0.78 \\
9.09 \\
0\end{array}$ & $\begin{array}{r}0.16156 \\
0.000256 \\
0.000003\end{array}$ \\
\hline $\begin{array}{l}108 \\
108 \\
108\end{array}$ & $\begin{array}{l}10259 \\
10259 \\
10259\end{array}$ & $\begin{array}{l}\text { A09A } \\
\text { A09A } \\
\text { A09A }\end{array}$ & $\begin{array}{l}20 \\
50 \\
82\end{array}$ & $\begin{array}{l}v \\
v \\
v\end{array}$ & $\begin{array}{r}0.76 \\
10.41 \\
0\end{array}$ & $\begin{array}{r}0.05052 \\
0.000091 \\
0.000001\end{array}$ \\
\hline $\begin{array}{l}108 \\
108 \\
108\end{array}$ & $\begin{array}{l}10259 \\
10259 \\
10259\end{array}$ & $\begin{array}{l}B 09 C \\
B 09 C \\
B 09 C\end{array}$ & $\begin{array}{l}20 \\
50 \\
82\end{array}$ & $\begin{array}{l}v \\
v \\
v\end{array}$ & $\begin{array}{r}0.76 \\
10.41 \\
0\end{array}$ & $\begin{array}{l}1.474138 \\
0.002666 \\
0.000034\end{array}$ \\
\hline $\begin{array}{l}108 \\
108 \\
108\end{array}$ & $\begin{array}{l}10259 \\
10259 \\
10259\end{array}$ & $\begin{array}{l}\text { BO9E } \\
\text { BO9E } \\
\text { BO9E }\end{array}$ & $\begin{array}{l}20 \\
50 \\
82\end{array}$ & $\begin{array}{l}v \\
v \\
v\end{array}$ & $\begin{array}{r}0.74 \\
10.41 \\
0\end{array}$ & $\begin{array}{l}12.32238 \\
0.022279 \\
0.000279\end{array}$ \\
\hline $\begin{array}{l}108 \\
108 \\
108\end{array}$ & $\begin{array}{l}10259 \\
10259 \\
10259\end{array}$ & $\begin{array}{l}\text { NO9A } \\
\text { NO9A } \\
\text { NO9A }\end{array}$ & $\begin{array}{l}20 \\
50 \\
82\end{array}$ & $\begin{array}{l}v \\
v \\
v\end{array}$ & $\begin{array}{r}0.78 \\
10.41 \\
0\end{array}$ & $\begin{array}{r}0.03153 \\
0.000057 \\
7.00 \mathrm{e}-07\end{array}$ \\
\hline $\begin{array}{l}108 \\
108 \\
108\end{array}$ & $\begin{array}{l}10259 \\
10259 \\
10259\end{array}$ & $\begin{array}{l}\text { Xo9C } \\
\times 09 C \\
\times 09 C\end{array}$ & $\begin{array}{l}20 \\
50 \\
82\end{array}$ & $\begin{array}{l}v \\
v \\
v\end{array}$ & $\begin{array}{r}0.79 \\
10.41 \\
0\end{array}$ & $\begin{array}{l}0.717121 \\
0.001296 \\
0.000016\end{array}$ \\
\hline $\begin{array}{l}108 \\
108 \\
108\end{array}$ & $\begin{array}{l}10259 \\
10259 \\
10259\end{array}$ & $\begin{array}{l}\text { XO9E } \\
\text { XO9E } \\
\text { XO9E }\end{array}$ & $\begin{array}{l}20 \\
50 \\
82\end{array}$ & $\begin{array}{l}v \\
v \\
v\end{array}$ & $\begin{array}{r}0.77 \\
10.41 \\
0\end{array}$ & $\begin{array}{l}5.748173 \\
0.010395 \\
0.000131\end{array}$ \\
\hline $\begin{array}{l}108 \\
108 \\
108\end{array}$ & $\begin{array}{l}10294 \\
10294 \\
10294\end{array}$ & $\begin{array}{l}A 07 B \\
A 07 B \\
A 07 B\end{array}$ & $\begin{array}{l}10 \\
50 \\
82\end{array}$ & $\begin{array}{l}v \\
v \\
v\end{array}$ & $\begin{array}{r}0.54 \\
8.94 \\
0\end{array}$ & $\begin{array}{r}0.032558 \\
0.000049 \\
6.000-07\end{array}$ \\
\hline $\begin{array}{l}108 \\
108 \\
108\end{array}$ & $\begin{array}{l}10294 \\
10294 \\
10294\end{array}$ & $\begin{array}{l}A 09 A \\
A 09 A \\
A 09 A\end{array}$ & $\begin{array}{l}20 \\
50 \\
82\end{array}$ & $\begin{array}{l}v \\
v \\
v\end{array}$ & $\begin{array}{r}0.74 \\
10.4 \\
0\end{array}$ & $\begin{array}{r}0.012625 \\
0.000023 \\
2.900-07\end{array}$ \\
\hline $\begin{array}{l}108 \\
108 \\
108\end{array}$ & $\begin{array}{l}10294 \\
10294 \\
10294\end{array}$ & $\begin{array}{l}\text { BO9C } \\
\text { BO9C } \\
\text { BogC }\end{array}$ & $\begin{array}{l}20 \\
50 \\
82\end{array}$ & $\begin{array}{l}v \\
v \\
v\end{array}$ & $\begin{array}{r}0.76 \\
10.4 \\
0\end{array}$ & $\begin{array}{l}0.810745 \\
0.001462 \\
0.000018\end{array}$ \\
\hline $\begin{array}{l}108 \\
108 \\
108\end{array}$ & $\begin{array}{l}10294 \\
10294 \\
10294\end{array}$ & $\begin{array}{l}\text { BO9E } \\
\text { BO9E } \\
\text { BO9E }\end{array}$ & $\begin{array}{l}20 \\
50 \\
82\end{array}$ & $\begin{array}{l}v \\
v \\
v\end{array}$ & $\begin{array}{r}0.74 \\
10.4 \\
0\end{array}$ & $\begin{array}{l}24.10676 \\
0.043476 \\
0.000546\end{array}$ \\
\hline $\begin{array}{l}108 \\
108 \\
108\end{array}$ & $\begin{array}{l}10294 \\
10294 \\
10294\end{array}$ & $\begin{array}{l}\text { Bo9s } \\
\text { BO9S } \\
\text { Bo9s }\end{array}$ & $\begin{array}{l}20 \\
50 \\
82\end{array}$ & $\begin{array}{l}v \\
v \\
v\end{array}$ & $\begin{array}{r}0.74 \\
10.4 \\
0\end{array}$ & $\begin{array}{l}0.760911 \\
0.001372 \\
0.000017\end{array}$ \\
\hline $\begin{array}{l}108 \\
108 \\
108\end{array}$ & $\begin{array}{l}10294 \\
10294 \\
10294\end{array}$ & $\begin{array}{l}\text { NO7B } \\
\text { NO7B } \\
\text { NO7B }\end{array}$ & $\begin{array}{l}10 \\
50 \\
82 \\
\end{array}$ & $\begin{array}{l}v \\
v \\
v \\
v\end{array}$ & $\begin{array}{r}0.56 \\
8.94 \\
0\end{array}$ & $\begin{array}{r}0.027111 \\
0.000041 \\
5.000-07\end{array}$ \\
\hline $\begin{array}{l}108 \\
108 \\
108\end{array}$ & $\begin{array}{l}10294 \\
10294 \\
10294\end{array}$ & $\begin{array}{l}\text { No9A } \\
\text { NO9A } \\
\text { NO9A }\end{array}$ & $\begin{array}{l}20 \\
50 \\
82\end{array}$ & $\begin{array}{l}v \\
v \\
v\end{array}$ & $\begin{array}{r}0.77 \\
10.4 \\
0\end{array}$ & $\begin{array}{r}0.006305 \\
0.000011 \\
1.40 \mathrm{e}-07\end{array}$ \\
\hline $\begin{array}{l}108 \\
108 \\
108\end{array}$ & $\begin{array}{l}10294 \\
10294 \\
10294\end{array}$ & $\begin{array}{l}\text { X09c } \\
\times 09 \mathrm{C} \\
\text { X09C }\end{array}$ & $\begin{array}{l}20 \\
50 \\
82\end{array}$ & $\begin{array}{l}v \\
v \\
v\end{array}$ & $\begin{array}{r}0.78 \\
10.4 \\
0\end{array}$ & $\begin{array}{l}0.380707 \\
0.000687 \\
0.000008\end{array}$ \\
\hline $\begin{array}{l}108 \\
108 \\
108\end{array}$ & $\begin{array}{l}10294 \\
10294 \\
10294\end{array}$ & $\begin{array}{l}\text { XO9E } \\
\text { XO9E } \\
\text { XO9E }\end{array}$ & $\begin{array}{l}20 \\
50 \\
82\end{array}$ & $\begin{array}{l}v \\
v \\
v\end{array}$ & $\begin{array}{r}0.77 \\
10.4 \\
0\end{array}$ & $\begin{array}{l}11.33217 \\
0.020432 \\
0.000258\end{array}$ \\
\hline $\begin{array}{l}108 \\
108 \\
108\end{array}$ & $\begin{array}{l}10294 \\
10294 \\
10294\end{array}$ & $\begin{array}{l}\text { xo9s } \\
\text { xo9s } \\
\text { xo9s }\end{array}$ & $\begin{array}{l}20 \\
50 \\
82\end{array}$ & $\begin{array}{l}v \\
v \\
v\end{array}$ & $\begin{array}{r}0.77 \\
10.4 \\
0\end{array}$ & $\begin{array}{r}0.344011 \\
0.00062 \\
0.000008\end{array}$ \\
\hline $\begin{array}{l}108 \\
108 \\
108\end{array}$ & $\begin{array}{l}10350 \\
10350 \\
10350\end{array}$ & $\begin{array}{l}\text { BO9C } \\
\text { BO9C } \\
\text { BO9C }\end{array}$ & $\begin{array}{l}20 \\
50 \\
82\end{array}$ & $\begin{array}{l}v \\
v \\
v\end{array}$ & $\begin{array}{r}0.77 \\
9.28 \\
0\end{array}$ & $\begin{array}{l}0.031594 \\
0.000051 \\
6.30 \mathrm{E}-07\end{array}$ \\
\hline
\end{tabular}


HNF-SD-SNF-TI-009, Rev. 1

\begin{tabular}{|c|c|c|c|c|c|c|}
\hline $\begin{array}{c}\text { Location } \\
\text { Code }\end{array}$ & Key Number & Fụel Model & $\begin{array}{c}\text { Material } \\
\text { Type }\end{array}$ & $\begin{array}{c}\text { sub ID } \\
\text { Code }\end{array}$ & Fuel Type & Isotopic Breakdown \\
\hline
\end{tabular}

\begin{tabular}{|c|c|c|c|c|c|c|}
\hline $\begin{array}{l}108 \\
108 \\
108\end{array}$ & $\begin{array}{l}10350 \\
10350 \\
10350\end{array}$ & $\begin{array}{l}\text { BO9E } \\
\text { BO9E } \\
\text { BO9E }\end{array}$ & $\begin{array}{l}20 \\
50 \\
82\end{array}$ & $\begin{array}{l}v \\
v \\
v\end{array}$ & $\begin{array}{r}0.77 \\
9.28 \\
0 \\
\end{array}$ & $\begin{array}{l}0.238337 \\
0.000386 \\
0.000005\end{array}$ \\
\hline $\begin{array}{l}108 \\
108 \\
108\end{array}$ & $\begin{array}{l}10350 \\
10350 \\
10350\end{array}$ & $\begin{array}{l}\text { Bo9s } \\
\text { Bo9s } \\
\text { Bo9s }\end{array}$ & $\begin{array}{l}20 \\
50 \\
82\end{array}$ & $\begin{array}{l}v \\
v \\
v\end{array}$ & $\begin{array}{r}0.77 \\
9.28 \\
0\end{array}$ & $\begin{array}{r}0.08958 \\
0.000145 \\
0.000002\end{array}$ \\
\hline $\begin{array}{l}108 \\
108 \\
108\end{array}$ & $\begin{array}{l}10350 \\
10350 \\
10350\end{array}$ & $\begin{array}{l}\text { Xo9c } \\
\text { x09C } \\
\text { xo9c }\end{array}$ & $\begin{array}{l}20 \\
50 \\
82\end{array}$ & $\begin{array}{l}v \\
v \\
v\end{array}$ & $\begin{array}{r}0.79 \\
9.28 \\
0\end{array}$ & $\begin{array}{r}0.014837 \\
0.000024 \\
3.00 \mathrm{e} .07\end{array}$ \\
\hline $\begin{array}{l}108 \\
108 \\
108\end{array}$ & $\begin{array}{l}10350 \\
10350 \\
10350\end{array}$ & $\begin{array}{l}\text { XO9E } \\
X 09 E \\
\text { XO9E }\end{array}$ & $\begin{array}{l}20 \\
50 \\
82\end{array}$ & $\begin{array}{l}v \\
v \\
v\end{array}$ & $\begin{array}{r}0.79 \\
9.28 \\
0\end{array}$ & $\begin{array}{r}0.11202 \\
0.000182 \\
0.000002\end{array}$ \\
\hline $\begin{array}{l}108 \\
108 \\
108\end{array}$ & $\begin{array}{l}10350 \\
10350 \\
10350\end{array}$ & $\begin{array}{l}\text { xo9s } \\
\text { xo9s } \\
\text { xogs }\end{array}$ & $\begin{array}{l}20 \\
50 \\
82\end{array}$ & $\begin{array}{l}v \\
v \\
v\end{array}$ & $\begin{array}{r}0.78 \\
9.28 \\
0\end{array}$ & $\begin{array}{r}0.042138 \\
0.000068 \\
8.40 e-07\end{array}$ \\
\hline $\begin{array}{l}108 \\
108 \\
108\end{array}$ & $\begin{array}{l}10385 \\
10385 \\
10385\end{array}$ & $\begin{array}{l}A 07 B \\
A 07 B \\
A 07 B\end{array}$ & $\begin{array}{l}10 \\
50 \\
82\end{array}$ & $\begin{array}{l}v \\
v \\
v\end{array}$ & $\begin{array}{r}0.51 \\
10.21 \\
0\end{array}$ & $\begin{array}{l}0.130147 \\
0.000234 \\
0.000003\end{array}$ \\
\hline $\begin{array}{l}108 \\
108 \\
108\end{array}$ & $\begin{array}{l}10385 \\
10385 \\
10385\end{array}$ & $\begin{array}{l}\text { B09A } \\
\text { B09A } \\
\text { B09A }\end{array}$ & $\begin{array}{l}20 \\
50 \\
82\end{array}$ & $\begin{array}{l}v \\
v \\
v\end{array}$ & $\begin{array}{r}0.72 \\
11.21 \\
0\end{array}$ & $\begin{array}{r}0.14074 \\
0.000274 \\
0.000004\end{array}$ \\
\hline $\begin{array}{l}108 \\
108 \\
108\end{array}$ & $\begin{array}{l}10385 \\
10385 \\
10385 \\
\end{array}$ & $\begin{array}{l}\text { BO9E } \\
\text { BO9E } \\
\text { BO9E }\end{array}$ & $\begin{array}{l}20 \\
50 \\
82 \\
\end{array}$ & $\begin{array}{l}v \\
v \\
v\end{array}$ & $\begin{array}{r}0.72 \\
11.21 \\
0\end{array}$ & $\begin{array}{l}23.76333 \\
0.046287 \\
0.000614\end{array}$ \\
\hline $\begin{array}{l}108 \\
108 \\
108\end{array}$ & $\begin{array}{l}10385 \\
10385 \\
\text { t0385 } \\
\end{array}$ & $\begin{array}{l}\text { Bo9s } \\
\text { Bo9s } \\
\text { B09S }\end{array}$ & $\begin{array}{l}20 \\
50 \\
82 \\
\end{array}$ & $\begin{array}{l}v \\
v \\
v\end{array}$ & $\begin{array}{r}0.73 \\
11.21 \\
0\end{array}$ & $\begin{array}{l}0.298316 \\
0.000581 \\
0.000008\end{array}$ \\
\hline $\begin{array}{l}108 \\
108 \\
108\end{array}$ & $\begin{array}{l}10385 \\
10385 \\
10385\end{array}$ & $\begin{array}{l}\text { NO7B } \\
\text { NO7B } \\
\text { NO7B }\end{array}$ & $\begin{array}{l}10 \\
50 \\
82\end{array}$ & $\begin{array}{l}v \\
v \\
v\end{array}$ & $\begin{array}{r}0.53 \\
10.21 \\
0\end{array}$ & $\begin{array}{l}0.075856 \\
0.000136 \\
0.000002\end{array}$ \\
\hline $\begin{array}{l}108 \\
108 \\
108\end{array}$ & $\begin{array}{l}10385 \\
10385 \\
10385\end{array}$ & $\begin{array}{l}X 09 A \\
\times 09 A \\
\times 09 A\end{array}$ & $\begin{array}{l}20 \\
50 \\
82\end{array}$ & $\begin{array}{l}v \\
v \\
v\end{array}$ & $\begin{array}{r}0.76 \\
11.21 \\
0\end{array}$ & $\begin{array}{l}0.059597 \\
0.000116 \\
0.000002\end{array}$ \\
\hline $\begin{array}{l}108 \\
108 \\
108\end{array}$ & $\begin{array}{l}10385 \\
10385 \\
10385\end{array}$ & $\begin{array}{l}\text { XO9E } \\
\times 09 E \\
\times 09 E \\
\end{array}$ & $\begin{array}{l}20 \\
50 \\
82 \\
\end{array}$ & $\begin{array}{l}v \\
v \\
v\end{array}$ & $\begin{array}{r}0.76 \\
11.21 \\
0\end{array}$ & $\begin{array}{l}11.15723 \\
0.021722 \\
0.000284\end{array}$ \\
\hline $\begin{array}{l}108 \\
108 \\
108\end{array}$ & $\begin{array}{l}10385 \\
10385 \\
10385\end{array}$ & $\begin{array}{l}\text { xogs } \\
\text { xogs } \\
\text { xogs }\end{array}$ & $\begin{array}{l}20 \\
50 \\
82\end{array}$ & $\begin{array}{l}v \\
v \\
v\end{array}$ & $\begin{array}{r}0.76 \\
11.21 \\
.0\end{array}$ & $\begin{array}{l}0.154433 \\
0.000301 \\
0.000004\end{array}$ \\
\hline $\begin{array}{l}108 \\
108 \\
108\end{array}$ & $\begin{array}{l}10456 \\
10456 \\
10456\end{array}$ & $\begin{array}{l}A 9 D \\
A 9 D \\
A 9 D\end{array}$ & $\begin{array}{l}20 \\
50 \\
82\end{array}$ & $\begin{array}{l}v \\
v \\
v\end{array}$ & $\begin{array}{r}0.72 \\
11.24 \\
0\end{array}$ & $\begin{array}{r}0.00953 \\
0.000018 \\
2.400-07\end{array}$ \\
\hline $\begin{array}{l}108 \\
108 \\
108\end{array}$ & $\begin{array}{l}10456 \\
10456 \\
10456\end{array}$ & $\begin{array}{l}\text { BO9E } \\
\text { BO9E } \\
\text { BO9E }\end{array}$ & $\begin{array}{l}20 \\
50 \\
82\end{array}$ & $\begin{array}{l}v \\
v \\
v\end{array}$ & $\begin{array}{r}0.88 \\
11.24 \\
0\end{array}$ & $\begin{array}{l}0.031856 \\
0.000061 \\
8.000-07\end{array}$ \\
\hline $\begin{array}{l}108 \\
108 \\
108\end{array}$ & $\begin{array}{l}10456 \\
10456 \\
10456\end{array}$ & $\begin{array}{l}\text { BXA } \\
\text { BXA } \\
\text { BXA }\end{array}$ & $\begin{array}{l}20 \\
50 \\
82\end{array}$ & $\begin{array}{l}v \\
v \\
v\end{array}$ & $\begin{array}{r}0.73 \\
11.24 \\
0\end{array}$ & $\begin{array}{l}0.413963 \\
0.000793 \\
0.000011\end{array}$ \\
\hline $\begin{array}{l}108 \\
108 \\
108\end{array}$ & $\begin{array}{l}10456 \\
10456 \\
10456 \\
\end{array}$ & $\begin{array}{l}\text { BXC } \\
\text { BXC } \\
\text { BXC }\end{array}$ & $\begin{array}{l}20 \\
50 \\
82\end{array}$ & $\begin{array}{l}v \\
v \\
v\end{array}$ & $\begin{array}{r}0.74 \\
11.24 \\
0\end{array}$ & $\begin{array}{l}1.345611 \\
0.002577 \\
0.000035\end{array}$ \\
\hline $\begin{array}{l}108 \\
108 \\
108\end{array}$ & $\begin{array}{l}10456 \\
10456 \\
10456\end{array}$ & $\begin{array}{l}\text { BXE } \\
\text { BXE } \\
\text { BXE }\end{array}$ & $\begin{array}{l}20 \\
50 \\
82\end{array}$ & $\begin{array}{l}v \\
v \\
v\end{array}$ & $\begin{array}{r}0.73 \\
11.24 \\
0\end{array}$ & $\begin{array}{l}21.40138 \\
0.040972 \\
0.000541\end{array}$ \\
\hline
\end{tabular}


HNF-SD-SNF-TI-009, Rev. I

\begin{tabular}{|c|c|c|c|c|c|c|}
\hline $\begin{array}{c}\text { Location } \\
\text { Code }\end{array}$ & Key Number & Fuel Model & $\begin{array}{c}\text { Material } \\
\text { Type }\end{array}$ & $\begin{array}{c}\text { sub ID } \\
\text { Code }\end{array}$ & Fuel Type & Isotopic Breakdown \\
\hline
\end{tabular}

\begin{tabular}{|c|c|c|c|c|c|c|}
\hline $\begin{array}{l}108 \\
108 \\
108\end{array}$ & $\begin{array}{l}10456 \\
10456 \\
10456\end{array}$ & $\begin{array}{l}\text { BXs } \\
\text { BXS } \\
\text { BXS }\end{array}$ & $\begin{array}{l}20 \\
50 \\
82\end{array}$ & $\begin{array}{l}v \\
v \\
v\end{array}$ & $\begin{array}{r}0.74 \\
11.24 \\
0\end{array}$ & $\begin{array}{r}3.180601 \\
0.00609 \\
0.000081\end{array}$ \\
\hline $\begin{array}{l}108 \\
108 \\
108\end{array}$ & $\begin{array}{l}10576 \\
10576 \\
10576\end{array}$ & $\begin{array}{l}\text { BXE } \\
\text { BXE } \\
\text { BXE }\end{array}$ & $\begin{array}{l}20 \\
50 \\
82\end{array}$ & $\begin{array}{l}v \\
v \\
v\end{array}$ & $\begin{array}{r}0.74 \\
11.09 \\
.0\end{array}$ & $\begin{array}{r}3.874377 \\
0.00738 \\
0.000098\end{array}$ \\
\hline $\begin{array}{l}108 \\
108 \\
108\end{array}$ & $\begin{array}{l}10576 \\
10576 \\
10576\end{array}$ & $\begin{array}{l}\text { BXs } \\
\text { BXs } \\
\text { BXs }\end{array}$ & $\begin{array}{l}20 \\
50 \\
82\end{array}$ & $\begin{array}{l}v \\
v \\
v \\
\end{array}$ & $\begin{array}{r}0.74 \\
11.09 \\
0\end{array}$ & $\begin{array}{l}0.043871 \\
0.000084 \\
0.000001\end{array}$ \\
\hline $\begin{array}{l}108 \\
108 \\
108\end{array}$ & $\begin{array}{l}10602 \\
10602 \\
10602 \\
\end{array}$ & $\begin{array}{l}\text { A7B } \\
\text { A7B } \\
\text { A7B }\end{array}$ & $\begin{array}{l}10 \\
50 \\
82\end{array}$ & $\begin{array}{l}v \\
v \\
v\end{array}$ & $\begin{array}{r}0.48 \\
13.75 \\
0 \\
\end{array}$ & $\begin{array}{l}0.081265 \\
0.000188 \\
0.000003\end{array}$ \\
\hline $\begin{array}{l}108 \\
708 \\
108\end{array}$ & $\begin{array}{l}10602 \\
10602 \\
10602\end{array}$ & $\begin{array}{l}\text { BO9E } \\
\text { BO9E } \\
\text { BO9E }\end{array}$ & $\begin{array}{l}20 \\
50 \\
82\end{array}$ & $\begin{array}{l}v \\
v \\
v \\
\end{array}$ & $\begin{array}{r}0.95 \\
11.09 \\
0 \\
\end{array}$ & $\begin{array}{r}0.031895 \\
0.00003 \\
4.000-07\end{array}$ \\
\hline $\begin{array}{l}108 \\
108 \\
108\end{array}$ & $\begin{array}{l}10602 \\
10602 \\
10602\end{array}$ & $\begin{array}{l}\text { BXA } \\
\text { BXA } \\
\text { BXA }\end{array}$ & $\begin{array}{l}10 \\
50 \\
82\end{array}$ & $\begin{array}{l}v \\
v \\
v\end{array}$ & $\begin{array}{r}0.69 \\
13.75 \\
0\end{array}$ & $\begin{array}{l}0.558238 \\
0.001293 \\
0.000019\end{array}$ \\
\hline $\begin{array}{l}108 \\
108 \\
108\end{array}$ & $\begin{array}{l}10602 \\
10602 \\
10602\end{array}$ & $\begin{array}{l}\text { BXC } \\
\text { BXC } \\
\text { BXC }\end{array}$ & $\begin{array}{l}20 \\
50 \\
82\end{array}$ & $\begin{array}{l}v \\
v \\
v\end{array}$ & $\begin{array}{r}.0 .74 \\
11.09 \\
0\end{array}$ & $\begin{array}{r}0.030929 \\
0.000029 \\
3.80 e-07\end{array}$ \\
\hline $\begin{array}{l}108 \\
108 \\
108\end{array}$ & $\begin{array}{l}10602 \\
10602 \\
10602\end{array}$ & $\begin{array}{l}\text { BXE } \\
\text { BXE } \\
\text { BXE }\end{array}$ & $\begin{array}{l}10 \\
50 \\
82\end{array}$ & $\begin{array}{l}v \\
v \\
v\end{array}$ & $\begin{array}{r}0.69 \\
13.75 \\
0\end{array}$ & $\begin{array}{l}24.73497 \\
0.057294 \\
0.000828\end{array}$ \\
\hline $\begin{array}{l}108 \\
108 \\
108\end{array}$ & $\begin{array}{l}10602 \\
10602 \\
10602\end{array}$ & $\begin{array}{l}\text { BXS } \\
\text { BXS } \\
\text { BXS }\end{array}$ & $\begin{array}{l}10 \\
50 \\
82 \\
\end{array}$ & $\begin{array}{l}v \\
v \\
v\end{array}$ & $\begin{array}{r}0.64 \\
13.75 \\
0\end{array}$ & $\begin{array}{l}1.225649 \\
0.002839 \\
0.000041\end{array}$ \\
\hline $\begin{array}{l}108 \\
108 \\
108\end{array}$ & $\begin{array}{l}10679^{\circ} \\
10679 \\
10679\end{array}$ & $\begin{array}{l}\text { A7B } \\
\text { A7B } \\
\text { A7B }\end{array}$ & $\begin{array}{l}10 \\
50 \\
82\end{array}$ & $\begin{array}{l}v \\
v \\
v\end{array}$ & $\begin{array}{r}0.48 \\
14.09 \\
0\end{array}$ & $\begin{array}{l}0.308771 \\
0.0007 .28 \\
0.000011\end{array}$ \\
\hline $\begin{array}{l}108 \\
108 \\
108\end{array}$ & $\begin{array}{l}10679 \\
10679 \\
10679\end{array}$ & $\begin{array}{l}\text { BO9A } \\
\text { BO9A } \\
\text { BO9A }\end{array}$ & $\begin{array}{l}20 \\
50 \\
82\end{array}$ & $\begin{array}{l}v \\
v \\
v\end{array}$ & $\begin{array}{r}0.83 \\
11.09 \\
0\end{array}$ & $\begin{array}{r}0.014109 \\
0.000027 \\
3.500-07\end{array}$ \\
\hline $\begin{array}{l}108 \\
108 \\
108\end{array}$ & $\begin{array}{l}10679 \\
10679 \\
10679\end{array}$ & $\begin{array}{l}\text { BXA } \\
\text { BXA } \\
\text { BXA }\end{array}$ & $\begin{array}{l}10 \\
50 \\
82\end{array}$ & $\begin{array}{l}v \\
v \\
v\end{array}$ & $\begin{array}{r}0.67 \\
14.09 \\
0\end{array}$ & $\begin{array}{l}0.123994 \\
0.000292 \\
0.000004\end{array}$ \\
\hline $\begin{array}{l}108 \\
108 \\
108\end{array}$ & $\begin{array}{l}10679 \\
10679 \\
10679\end{array}$ & $\begin{array}{l}\text { BXC } \\
\text { BXC } \\
\text { BXC }\end{array}$ & $\begin{array}{l}20 \\
50 \\
82\end{array}$ & $\begin{array}{l}v \\
v \\
v\end{array}$ & $\begin{array}{r}0.74 \\
11.09 \\
0\end{array}$ & $\begin{array}{l}1.252617 \\
0.002385 \\
0.000031\end{array}$ \\
\hline $\begin{array}{l}108 \\
108 \\
108\end{array}$ & $\begin{array}{l}10679 \\
10679 \\
10679\end{array}$ & $\begin{array}{l}\text { BXE } \\
\text { BXE } \\
\text { BXE }\end{array}$ & $\begin{array}{l}10 \\
50 \\
82\end{array}$ & $\begin{array}{l}v \\
v \\
v\end{array}$ & $\begin{array}{r}0.68 \\
14.09 \\
0\end{array}$ & $\begin{array}{l}22.91124 \\
0.054006 \\
0.000796\end{array}$ \\
\hline $\begin{array}{l}108 \\
108 \\
108\end{array}$ & $\begin{array}{l}10679 \\
10679 \\
10679\end{array}$ & $\begin{array}{l}\text { BXs } \\
\text { BXS } \\
\text { BXs }\end{array}$ & $\begin{array}{l}10 \\
50 \\
82 \\
\end{array}$ & $\begin{array}{l}v \\
v \\
v \\
\end{array}$ & $\begin{array}{r}0.71 \\
14.09 \\
0\end{array}$ & $\begin{array}{l}1.293334 \\
0.003049 \\
0.000045\end{array}$ \\
\hline $\begin{array}{l}108 \\
108 \\
108\end{array}$ & $\begin{array}{l}10742 \\
10742 \\
10742\end{array}$ & $\begin{array}{l}\text { BO9C } \\
\text { BO9C } \\
\text { BO9C }\end{array}$ & $\begin{array}{l}10 \\
50 \\
82\end{array}$ & $\begin{array}{l}v \\
v \\
v\end{array}$ & $\begin{array}{r}0.7 \\
14.25 \\
0\end{array}$ & $\begin{array}{l}1.167243 \\
0.002818 \\
0.000042\end{array}$ \\
\hline $\begin{array}{l}108 \\
108 \\
108\end{array}$ & $\begin{array}{l}10742 \\
10742 \\
10742\end{array}$ & $\begin{array}{l}\text { BO9E } \\
\text { BO9E } \\
\text { BO9E }\end{array}$ & $\begin{array}{l}10 \\
50 \\
82\end{array}$ & $\begin{array}{l}v \\
v \\
v\end{array}$ & $\begin{array}{r}0.66 \\
14.25 \\
0\end{array}$ & $\begin{array}{l}12.33092 \\
0.029774 \\
0.000443\end{array}$ \\
\hline $\begin{array}{l}108 \\
108 \\
108\end{array}$ & $\begin{array}{l}10742 \\
10742 \\
10742\end{array}$ & $\begin{array}{l}\text { Bogs } \\
\text { Bogs } \\
\text { Bo9s. }\end{array}$ & $\begin{array}{l}10 \\
50 \\
82\end{array}$ & $\begin{array}{l}v \\
v \\
v\end{array}$ & $\begin{array}{r}0.67 \\
14.25 \\
0\end{array}$ & $\begin{array}{l}0.461833 \\
0.001115 \\
0.000017\end{array}$ \\
\hline
\end{tabular}


HNF-SD-SNF-TI-009, Rev . 1

\begin{tabular}{|c|c|c|c|c|c|c|c|}
\hline $\begin{array}{c}\text { Location } \\
\text { Code }\end{array}$ & Key Number & Fuel Model & $\begin{array}{c}\text { Material } \\
\text { Type }\end{array}$ & $\begin{array}{c}\text { sub ID } \\
\text { Code }\end{array}$ & Fuel Type & Isotopic Breakdown & Discharge Mass \\
\hline
\end{tabular}

\begin{tabular}{|c|c|c|c|c|c|c|}
\hline $\begin{array}{l}108 \\
108 \\
108\end{array}$ & $\begin{array}{l}10742 \\
10742 \\
10742\end{array}$ & $\begin{array}{l}x 09 c \\
x 09 c \\
x 09 c\end{array}$ & $\begin{array}{l}20 \\
50 \\
82\end{array}$ & $\begin{array}{l}v \\
V \\
v\end{array}$ & $\begin{array}{r}0.74 \\
10.8 \\
0\end{array}$ & $\begin{array}{l}0.548368 \\
0.001091 \\
0.000017\end{array}$ \\
\hline $\begin{array}{l}108 \\
108 \\
108\end{array}$ & $\begin{array}{l}10742 \\
10742 \\
10742 \\
\end{array}$ & $\begin{array}{l}\text { XOgE } \\
X 09 E \\
\text { XO9E }\end{array}$ & $\begin{array}{l}10 \\
50 \\
82\end{array}$ & $\begin{array}{l}v \\
v \\
v\end{array}$ & $\begin{array}{r}0.71 \\
14.25 \\
0\end{array}$ & $\begin{array}{r}5.791929 \\
0.013986 \\
0.00021\end{array}$ \\
\hline $\begin{array}{l}108 \\
108 \\
108\end{array}$ & $\begin{array}{l}10742 \\
10742 \\
10742\end{array}$ & $\begin{array}{l}\text { xogs } \\
\text { xogs } \\
\text { xogs }\end{array}$ & $\begin{array}{l}20 \\
50 \\
82\end{array}$ & $\begin{array}{l}V \\
V \\
V\end{array}$ & $\begin{array}{r}0.72 \\
10.8 \\
0\end{array}$ & $\begin{array}{l}0.224427 \\
0.000447 \\
0.000007\end{array}$ \\
\hline 108 & 10764 & Bogs & 20 & $v$ & 0.95 & 0.052151 \\
\hline 108 & 10764 & B7E & 81 & $v$ & 0 & 0.04681 \\
\hline 108 & 10764 & BXA & 20 & $v$ & 0.95 & 0.446186 \\
\hline 108 & 10764 & BXE & 20 & $v$ & 0.95 & 0.365569 \\
\hline 108 & 10764 & BXR & 20 & $v$ & 0.95 & 0.373599 \\
\hline 108 & 10764 & BXS & 20 & $v$ & 0.95 & 0.681973 \\
\hline 108 & 10764 & $\mathrm{x} 09 \mathrm{~A}$ & 20 & $v$ & 0.93 & 0.00572 \\
\hline 108 & 10764 & XO9E & 20 & $v$ & 0.94 & 0.013134 \\
\hline 108 & 10764 & $\mathrm{XO9R}$ & 20 & $v$ & 0.95 & 0.00537 \\
\hline $\begin{array}{l}108 \\
108 \\
108 \\
\end{array}$ & $\begin{array}{l}10770 \\
10770 \\
10770 \\
\end{array}$ & $\begin{array}{l}\text { BXC } \\
\text { BXC } \\
\text { BXC }\end{array}$ & $\begin{array}{l}20 \\
50 \\
82 \\
\end{array}$ & $\begin{array}{l}v \\
v \\
v \\
\end{array}$ & $\begin{array}{r}0.73 \\
11.66 \\
0 \\
\end{array}$ & $\begin{array}{l}0.680305 \\
0.001345 \\
0.000018 \\
\end{array}$ \\
\hline $\begin{array}{l}108 \\
108 \\
108 \\
\end{array}$ & $\begin{array}{l}10770 \\
10770 \\
10770 \\
\end{array}$ & $\begin{array}{l}\text { BXE } \\
\text { BXE } \\
\text { BXE }\end{array}$ & $\begin{array}{l}10 \\
50 \\
82 \\
\end{array}$ & $\begin{array}{l}v \\
v \\
v\end{array}$ & $\begin{array}{r}0.69 \\
13.91 \\
0\end{array}$ & $\begin{array}{l}14.07941 \\
0.032713 \\
0.000489\end{array}$ \\
\hline $\begin{array}{l}108 \\
108 \\
108 \\
\end{array}$ & $\begin{array}{l}10770 \\
10770 \\
10770 \\
\end{array}$ & $\begin{array}{l}\text { BXS } \\
\text { BXS } \\
\text { BXS } \\
\end{array}$ & $\begin{array}{l}10 \\
50 \\
82 \\
\end{array}$ & $\begin{array}{l}v \\
v \\
v\end{array}$ & $\begin{array}{r}0.69 \\
13.91 \\
0\end{array}$ & $\begin{array}{l}4.426014 \\
0.010284 \\
0.000152\end{array}$ \\
\hline $\begin{array}{l}108 \\
108 \\
108 \\
\end{array}$ & $\begin{array}{l}10832 \\
10832 \\
10832 \\
\end{array}$ & $\begin{array}{l}\text { A7B } \\
\text { A7B } \\
\text { A7B }\end{array}$ & $\begin{array}{l}10 \\
50 \\
82\end{array}$ & $\begin{array}{l}v \\
v \\
v\end{array}$ & $\begin{array}{r}0.49 \\
13.65 \\
0\end{array}$ & $\begin{array}{r}0.260079 \\
0.0006 \\
0.000009\end{array}$ \\
\hline $\begin{array}{l}108 \\
108 \\
108\end{array}$ & $\begin{array}{l}10832 \\
10832 \\
10832 \\
\end{array}$ & $\begin{array}{l}\text { BXA } \\
\text { BXA } \\
\text { BXA }\end{array}$ & $\begin{array}{l}10 \\
50 \\
82 \\
\end{array}$ & $\begin{array}{l}v \\
v \\
v\end{array}$ & $\begin{array}{r}0.66 \\
13.65 \\
0 \\
\end{array}$ & $\begin{array}{l}0.041328 \\
0.000095 \\
0.000001\end{array}$ \\
\hline $\begin{array}{l}108 \\
108 \\
108\end{array}$ & $\begin{array}{l}10832 \\
10832 \\
10832\end{array}$ & $\begin{array}{l}\mathrm{BXC} \\
\mathrm{B} \times \mathrm{C} \\
\mathrm{BXC}\end{array}$ & $\begin{array}{l}10 \\
50 \\
82\end{array}$ & $\begin{array}{l}v \\
v \\
v\end{array}$ & $\begin{array}{r}0.71 \\
13.65 \\
0\end{array}$ & $\begin{array}{r}2.039846 \\
0.004703 \\
0.00007\end{array}$ \\
\hline $\begin{array}{l}108 \\
108 \\
108 \\
\end{array}$ & $\begin{array}{l}10832 \\
10832 \\
10832 \\
\end{array}$ & $\begin{array}{l}\text { BXE } \\
\text { BXE } \\
\text { BXE }\end{array}$ & $\begin{array}{l}10 \\
50 \\
82 \\
\end{array}$ & $\begin{array}{l}v \\
v \\
v\end{array}$ & $\begin{array}{r}0.69 \\
13.65 \\
0\end{array}$ & $\begin{array}{r}47.20901 \\
0.108844 \\
0.0016\end{array}$ \\
\hline $\begin{array}{l}108 \\
108 \\
108\end{array}$ & $\begin{array}{l}10832 \\
10832 \\
10832\end{array}$ & $\begin{array}{l}\text { BXS } \\
\text { BXS } \\
\text { BXS }\end{array}$ & $\begin{array}{l}10 \\
50 \\
82\end{array}$ & $\begin{array}{l}v \\
v \\
v\end{array}$ & $\begin{array}{r}0.66 \\
13.65 \\
0\end{array}$ & $\begin{array}{r}3.131132 \\
0.00722 \\
0.000106\end{array}$ \\
\hline $\begin{array}{l}108 \\
108 \\
108\end{array}$ & $\begin{array}{l}10982 \\
10982 \\
10982 \\
\end{array}$ & $\begin{array}{l}\text { A07B } \\
A 07 B \\
A 07 B\end{array}$ & $\begin{array}{l}10 \\
50 \\
82\end{array}$ & $\begin{array}{l}V \\
V \\
V\end{array}$ & $\begin{array}{r}0.48 \\
14.97 \\
0\end{array}$ & $\begin{array}{l}0.173428 \\
0.000433 \\
0.000007\end{array}$ \\
\hline $\begin{array}{l}108 \\
108 \\
108\end{array}$ & $\begin{array}{l}10982 \\
10982 \\
10982\end{array}$ & $\begin{array}{l}\text { BO9A } \\
\text { BO9A } \\
\text { BO9A }\end{array}$ & $\begin{array}{l}10 \\
50 \\
82\end{array}$ & $\begin{array}{l}v \\
v \\
v\end{array}$ & $\begin{array}{r}0.69 \\
14.97 \\
0\end{array}$ & $\begin{array}{l}0.126571 \\
0.000316 \\
0.000005 \\
\end{array}$ \\
\hline $\begin{array}{l}108 \\
108 \\
108\end{array}$ & $\begin{array}{l}10982 \\
.10982 \\
10982\end{array}$ & $\begin{array}{l}\text { Bo9C } \\
\text { Bo9C } \\
\text { Bo9C }\end{array}$ & $\begin{array}{l}20 \\
50 \\
82\end{array}$ & $\begin{array}{l}v \\
v \\
v\end{array}$ & $\begin{array}{r}0.71 \\
11.7 \\
0\end{array}$ & $\begin{array}{r}0.704745 \\
0.001436 \\
0.00002\end{array}$ \\
\hline
\end{tabular}


HNF-SD-SNF-TI-009, Rev. 1

\begin{tabular}{|c|c|c|c|c|c|c|}
\hline $\begin{array}{c}\text { Location } \\
\text { Code }\end{array}$ & Key Number & Fuel Model & $\begin{array}{c}\text { Material } \\
\text { Type }\end{array}$ & $\begin{array}{c}\text { sub ID } \\
\text { Code }\end{array}$ & Fuel Type & Isotopic Breakdown \\
\hline
\end{tabular}

\begin{tabular}{|c|c|c|c|c|c|c|}
\hline $\begin{array}{l}108 \\
108 \\
108\end{array}$ & $\begin{array}{l}10982 \\
10982 \\
10982\end{array}$ & $\begin{array}{l}\text { BO9E } \\
\text { BO9E } \\
\text { BO9E }\end{array}$ & $\begin{array}{l}10 \\
50 \\
82 \\
\end{array}$ & $\begin{array}{l}v \\
v \\
v\end{array}$ & $\begin{array}{r}0.65 \\
14.97 \\
0 \\
\end{array}$ & $\begin{array}{l}15.16333 \\
0.037897 \\
0.000584\end{array}$ \\
\hline $\begin{array}{l}108 \\
108 \\
108 \\
\end{array}$ & $\begin{array}{l}10982 \\
10982 \\
10982\end{array}$ & $\begin{array}{l}\text { Bo9s } \\
\text { Bo9s } \\
\text { Bo9s }\end{array}$ & $\begin{array}{l}10 \\
50 \\
82 \\
\end{array}$ & $\begin{array}{l}v \\
v \\
v\end{array}$ & $\begin{array}{r}0.67 \\
14.97 \\
0 \\
\end{array}$ & $\begin{array}{l}0.938379 \\
0.002345 \\
0.000036\end{array}$ \\
\hline $\begin{array}{l}108 \\
108 \\
108 \\
\end{array}$ & $\begin{array}{l}10982 \\
10982 \\
10982 \\
\end{array}$ & $\begin{array}{l}\text { NO7B } \\
\text { NO7B } \\
\text { NO7B } \\
\end{array}$ & $\begin{array}{l}10 \\
50 \\
82 \\
\end{array}$ & $\begin{array}{l}v \\
v \\
v\end{array}$ & $\begin{array}{r}0.52 \\
14.97 \\
0 \\
\end{array}$ & $\begin{array}{r}0.08666 \\
0.000217 \\
0.000003 \\
\end{array}$ \\
\hline $\begin{array}{l}108 \\
108 \\
108 \\
\end{array}$ & $\begin{array}{l}10982 \\
10982 \\
10982 \\
\end{array}$ & $\begin{array}{r}\text { X09A } \\
\text { X09A } \\
\times 09 A \\
\end{array}$ & $\begin{array}{l}20 \\
50 \\
82 \\
\end{array}$ & $\begin{array}{l}v \\
v \\
v\end{array}$ & $\begin{array}{r}0.76 \\
11.7 \\
0 \\
\end{array}$ & $\begin{array}{l}0.059598 \\
0.000122 \\
0.000002 \\
\end{array}$ \\
\hline $\begin{array}{l}108 \\
108 \\
108 \\
\end{array}$ & $\begin{array}{l}10982 \\
10982 \\
10982\end{array}$ & $\begin{array}{l}\text { xo9c } \\
\text { xo9c } \\
\text { xogc } \\
\end{array}$ & $\begin{array}{l}20 \\
50 \\
82 \\
\end{array}$ & $\begin{array}{l}v \\
v \\
v\end{array}$ & $\begin{array}{r}0.75 \\
11.7 \\
0\end{array}$ & $\begin{array}{l}0.331073 \\
0.000675 \\
0.000009\end{array}$ \\
\hline $\begin{array}{l}108 \\
108 \\
108\end{array}$ & $\begin{array}{l}10982 \\
10982 \\
10982\end{array}$ & $\begin{array}{l}\text { XO9E } \\
\text { XO9E } \\
\text { XO9E }\end{array}$ & $\begin{array}{l}10 \\
50 \\
82 \\
\end{array}$ & $\begin{array}{l}v \\
v \\
v\end{array}$ & $\begin{array}{r}0.7 \\
14.97 \\
0\end{array}$ & $\begin{array}{r}7.072527 \\
0.01768 \\
0.000275\end{array}$ \\
\hline $\begin{array}{l}108 \\
108 \\
108\end{array}$ & $\begin{array}{l}10982 \\
10982 \\
10982\end{array}$ & $\begin{array}{l}\text { xo9s } \\
\text { xo9s } \\
\text { xo9s } \\
\end{array}$ & $\begin{array}{l}20 \\
50 \\
82 \\
\end{array}$ & $\begin{array}{l}v \\
v \\
v\end{array}$ & $\begin{array}{r}0.72 \\
11.7 \\
0 \\
\end{array}$ & $\begin{array}{l}0.497909 \\
0.001015 \\
0.000014 \\
\end{array}$ \\
\hline $\begin{array}{l}108 \\
108 \\
108 \\
\end{array}$ & $\begin{array}{l}11036 \\
11036 \\
11036\end{array}$ & $\begin{array}{l}A 09 D \\
A 09 D \\
A 09 D \\
\end{array}$ & $\begin{array}{l}10 \\
50 \\
82 \\
\end{array}$ & $\begin{array}{l}v \\
v \\
v\end{array}$ & $\begin{array}{r}0.68 \\
14.37 \\
0 \\
\end{array}$ & $\begin{array}{r}0.006356 \\
0.000015 \\
2.30 \mathrm{e}-07 \\
\end{array}$ \\
\hline $\begin{array}{l}108 \\
108 \\
108 \\
\end{array}$ & $\begin{array}{l}11036 \\
11036 \\
11036\end{array}$ & $\begin{array}{l}\text { BO9C } \\
\text { BO9C } \\
\text { BO9C }\end{array}$ & $\begin{array}{l}20 \\
50 \\
82 \\
\end{array}$ & $\begin{array}{l}v \\
v \\
v \\
\end{array}$ & $\begin{array}{r}0.73 \\
13.31 \\
0 \\
\end{array}$ & $\begin{array}{l}0.326187 \\
0.000729 \\
0.000011 \\
\end{array}$ \\
\hline $\begin{array}{l}108 \\
108 \\
108 \\
\end{array}$ & $\begin{array}{l}11036 \\
11036 \\
11036 \\
\end{array}$ & $\begin{array}{l}\text { BO9E } \\
\text { BO9E } \\
\text { BO9E }\end{array}$ & $\begin{array}{l}10 \\
50 \\
82 \\
\end{array}$ & $\begin{array}{l}v \\
v \\
v\end{array}$ & $\begin{array}{r}0.66 \\
14.37 \\
0 \\
\end{array}$ & $\begin{array}{l}7.798047 \\
0.018824 \\
0.000285 \\
\end{array}$ \\
\hline $\begin{array}{l}108 \\
108 \\
108 \\
\end{array}$ & $\begin{array}{l}11036 \\
11036 \\
11036 \\
\end{array}$ & $\begin{array}{l}\text { Bogs } \\
\text { Bo9s } \\
\text { Bogs }\end{array}$ & $\begin{array}{l}10 \\
50 \\
82 \\
\end{array}$ & $\begin{array}{l}v \\
v \\
v\end{array}$ & $\begin{array}{r}0.65 \\
14.37 \\
0\end{array}$ & $\begin{array}{l}0.684893 \\
0.001654 \\
0.000025\end{array}$ \\
\hline $\begin{array}{l}108 \\
108 \\
108 \\
\end{array}$ & $\begin{array}{l}11036 \\
11036 \\
11036 \\
\end{array}$ & $\begin{array}{l}\text { NO9D } \\
\text { NO9D } \\
\text { N09D } \\
\end{array}$ & $\begin{array}{l}20 \\
50 \\
82 \\
\end{array}$ & $\begin{array}{l}v \\
v \\
v \\
\end{array}$ & $\begin{array}{r}0.73 \\
13.31 \\
0 \\
\end{array}$ & $\begin{array}{r}0.003169 \\
0.000007 \\
1.000-07 \\
\end{array}$ \\
\hline $\begin{array}{l}108 \\
108 \\
108 \\
\end{array}$ & $\begin{array}{l}11036 \\
11036 \\
11036 \\
\end{array}$ & $\begin{array}{l}X 09 A \\
\text { X09A } \\
X 09 A \\
\end{array}$ & $\begin{array}{l}10 \\
50 \\
82 \\
\end{array}$ & $\begin{array}{l}v \\
v \\
v \\
\end{array}$ & $\begin{array}{r}0.69 \\
14.37 \\
0 \\
\end{array}$ & $\begin{array}{r}0.013225 \\
0.000032 \\
4.800-07\end{array}$ \\
\hline $\begin{array}{l}108 \\
108 \\
108 \\
\end{array}$ & $\begin{array}{l}11036 \\
11036 \\
11036\end{array}$ & $\begin{array}{l}\text { X09c } \\
\text { Xo9c } \\
\text { Xo9c } \\
\end{array}$ & $\begin{array}{l}20 \\
50 \\
82 \\
\end{array}$ & $\begin{array}{l}v \\
v \\
v\end{array}$ & $\begin{array}{r}0.76 \\
.13 .31 \\
0 \\
\end{array}$ & $\begin{array}{l}0.123564 \\
0.000276 \\
0.000004 \\
\end{array}$ \\
\hline $\begin{array}{l}108 \\
108 \\
108\end{array}$ & $\begin{array}{l}11036 \\
11036 \\
11036\end{array}$ & $\begin{array}{l}\text { XO9E } \\
\text { XO9E } \\
\text { XO9E }\end{array}$ & $\begin{array}{l}10 \\
50 \\
82 \\
\end{array}$ & $\begin{array}{l}v \\
v \\
v\end{array}$ & $\begin{array}{r}0.71 \\
14.37 \\
0 \\
\end{array}$ & $\begin{array}{r}3.689834 \\
0.00891 \\
0.000134 \\
\end{array}$ \\
\hline $\begin{array}{l}108 \\
108 \\
108\end{array}$ & $\begin{array}{l}11036 \\
11036 \\
11036\end{array}$ & $\begin{array}{l}\text { xo9s } \\
\text { xo9s } \\
\text { xo9s. }\end{array}$ & $\begin{array}{l}10 \\
50 \\
82 \\
\end{array}$ & $\begin{array}{l}v \\
v \\
v \\
\end{array}$ & $\begin{array}{r}0.7 \\
14.37 \\
0\end{array}$ & $\begin{array}{l}0.329476 \\
0.000795 \\
0.000012\end{array}$ \\
\hline $\begin{array}{l}108 \\
108 \\
108\end{array}$ & $\begin{array}{l}11109 \\
11109 \\
11109\end{array}$ & $\begin{array}{l}\text { B09A } \\
\text { B09A } \\
\text { B09A } \\
\end{array}$ & $\begin{array}{l}10 \\
50 \\
82 \\
\end{array}$ & $\begin{array}{l}v \\
v \\
v \\
\end{array}$ & $\begin{array}{r}0.69 \\
14.62 \\
0 \\
\end{array}$ & $\begin{array}{r}0.16879 \\
0.000413 \\
0.000006 \\
\end{array}$ \\
\hline $\begin{array}{l}108 \\
108 \\
108\end{array}$ & $\begin{array}{l}11109 \\
11109 \\
11109\end{array}$ & $\begin{array}{l}\text { BogC } \\
\text { BogC } \\
\text { BogC }\end{array}$ & $\begin{array}{l}10 \\
50 \\
82\end{array}$ & $\begin{array}{l}v \\
v \\
v\end{array}$ & $\begin{array}{r}0.71 \\
14.62 \\
0 \\
\end{array}$ & $\begin{array}{l}0.673131 \\
0.001648 \\
0.000026\end{array}$ \\
\hline
\end{tabular}


HNF-SD-SNF-TI-009, Rev. 1

\begin{tabular}{|c|c|c|c|c|c|c|}
\hline $\begin{array}{c}\text { Location } \\
\text { Code }\end{array}$ & Key Number & Fuel Model & $\begin{array}{c}\text { Material } \\
\text { Type }\end{array}$ & $\begin{array}{c}\text { sub ID } \\
\text { Code }\end{array}$ & Fuel Type & Isotopic Breakdown \\
\hline
\end{tabular}

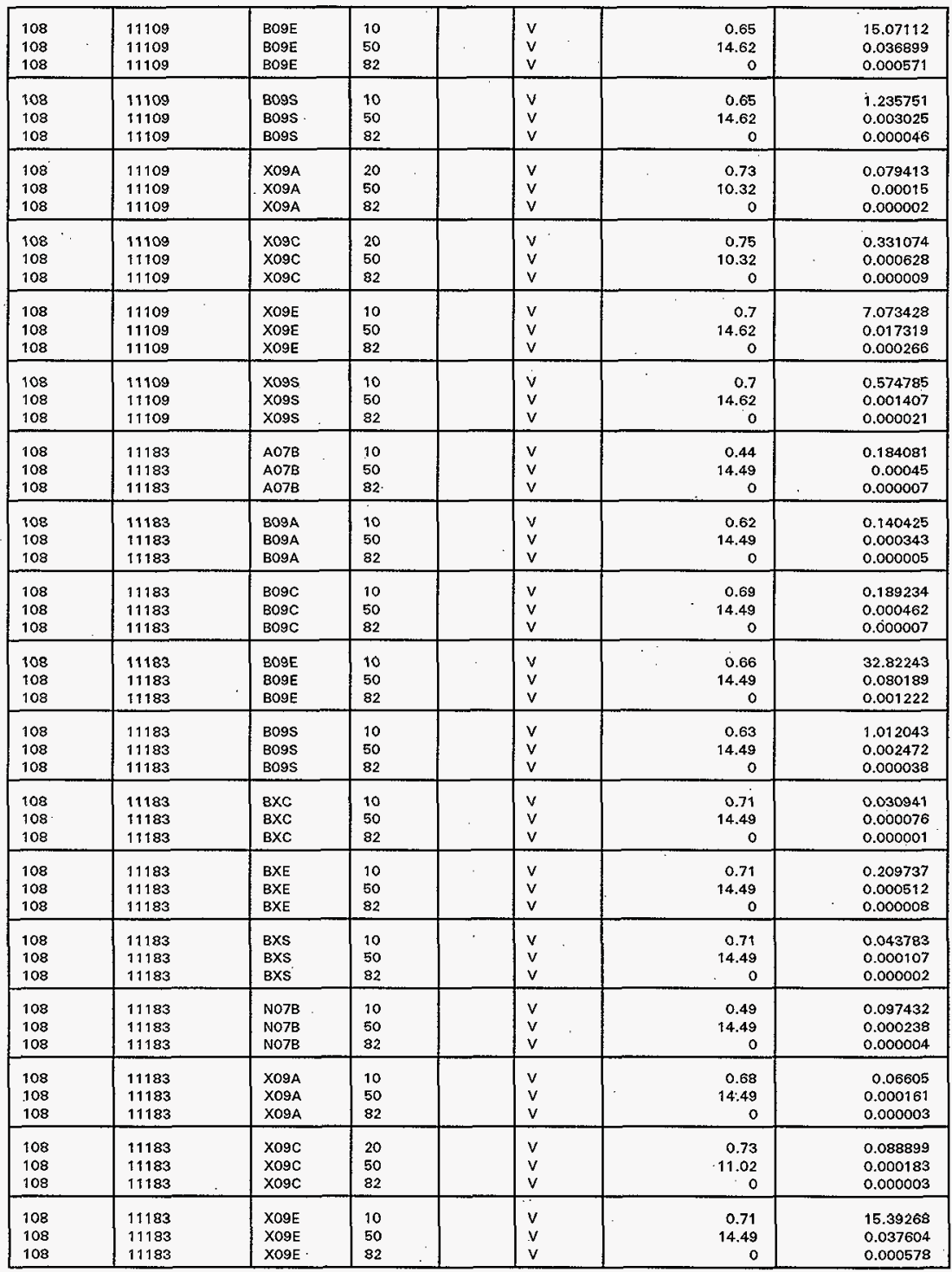


HNF-SD-SNF-TI-009, Rev. 1

\begin{tabular}{|c|c|c|c|c|c|c|}
\hline $\begin{array}{c}\text { Location } \\
\text { Code }\end{array}$ & Key Number & Fuel Model & $\begin{array}{c}\text { Material } \\
\text { Type }\end{array}$ & $\begin{array}{c}\text { sub ID } \\
\text { Code }\end{array}$ & Fuel Typo & Isotopic Broakdown \\
\hline
\end{tabular}

\begin{tabular}{|c|c|c|c|c|c|c|}
\hline $\begin{array}{l}108 \\
108 \\
108 \\
\end{array}$ & $\begin{array}{l}11183 \\
11183 \\
11183 \\
\end{array}$ & $\begin{array}{l}\text { Xo9s } \\
\text { xo9s } \\
\text { xo9s } \\
\end{array}$ & $\begin{array}{l}10 \\
50 \\
82 \\
\end{array}$ & $\begin{array}{l}v \\
v \\
v\end{array}$ & $\begin{array}{r}0.69 \\
14.49 \\
0 \\
\end{array}$ & $\begin{array}{r}0.49053 \\
0.001198 \\
0.000018 \\
\end{array}$ \\
\hline $\begin{array}{l}108 \\
108 \\
108 \\
\end{array}$ & $\begin{array}{l}11372 \\
11372 \\
11372\end{array}$ & $\begin{array}{l}A 07 B . \\
A 07 B \\
A 07 B\end{array}$ & $\begin{array}{l}10 \\
50 \\
82 \\
\end{array}$ & $\begin{array}{l}v \\
v \\
v\end{array}$ & $\begin{array}{r}0.47 \\
15.17 \\
0 \\
\end{array}$ & $\begin{array}{l}0.130046 \\
0.000323 \\
0.000005\end{array}$ \\
\hline $\begin{array}{l}108 \\
.108 \\
108\end{array}$ & $\begin{array}{l}11372 \\
11372 \\
11372 \\
\end{array}$ & $\begin{array}{l}\text { BO9A } \\
\text { B09A } \\
809 A \\
\end{array}$ & $\begin{array}{l}10 \\
50 \\
82 \\
\end{array}$ & $\begin{array}{l}v \\
v \\
v\end{array}$ & $\begin{array}{r}0.63 \\
15.17 \\
0 \\
\end{array}$ & $\begin{array}{l}0.042131 \\
0.000105 \\
0.000002 \\
\end{array}$ \\
\hline $\begin{array}{l}108 \\
108 \\
108 \\
\end{array}$ & $\begin{array}{l}11372 \\
11372 \\
11372 \\
\end{array}$ & $\begin{array}{l}\text { BO9C } \\
\text { BO9C } \\
\text { BO9C }\end{array}$ & $\begin{array}{l}10 \\
50 \\
82 \\
\end{array}$ & $\begin{array}{l}v \\
v \\
v\end{array}$ & $\begin{array}{r}0.69 \\
15.17 \\
0 \\
\end{array}$ & $\begin{array}{l}0.420552 \\
0.001044 \\
0.000016\end{array}$ \\
\hline $\begin{array}{l}108 \\
108 \\
108 \\
\end{array}$ & $\begin{array}{l}11372 \\
11372 \\
11372 \\
\end{array}$ & $\begin{array}{l}\text { BO9E } \\
\text { BO9E } \\
\text { BO9E }\end{array}$ & $\begin{array}{l}10 \\
50 \\
82 \\
\end{array}$ & $\begin{array}{l}v \\
v \\
v\end{array}$ & $\begin{array}{r}0.66 \\
15.17 \\
0 \\
\end{array}$ & $\begin{array}{r}19.86085 \\
0.04928 \\
0.000752 \\
\end{array}$ \\
\hline $\begin{array}{l}108 \\
108 \\
108 \\
\end{array}$ & $\begin{array}{l}11372 \\
11372 \\
11372 \\
\end{array}$ & $\begin{array}{l}\text { Bo9s } \\
\text { Bo9s } \\
\text { Bo9s }\end{array}$ & $\begin{array}{l}10 \\
50 \\
82 \\
\end{array}$ & $\begin{array}{l}v \\
V \\
V\end{array}$ & $\begin{array}{r}0.65 \\
15.17 \\
0 \\
\end{array}$ & $\begin{array}{l}0.684839 \\
0.001699 \\
0.000026 \\
\end{array}$ \\
\hline $\begin{array}{l}108 \\
108 \\
108 \\
\end{array}$ & $\begin{array}{l}11372 \\
11372 \\
11372 \\
\end{array}$ & $\begin{array}{l}\text { NO7B } \\
\text { NO7B } \\
\text { NO7B } \\
\end{array}$ & $\begin{array}{l}10 \\
50 \\
82 \\
\end{array}$ & $\begin{array}{l}v \\
v \\
v \\
\end{array}$ & $\begin{array}{r}0.51 \\
15.17 \\
0 \\
\end{array}$ & $\begin{array}{l}0.059569 \\
0.000148 \\
0.000002 \\
\end{array}$ \\
\hline $\begin{array}{l}108 \\
108 \\
108\end{array}$ & $\begin{array}{l}11372 \\
11372 \\
11372 \\
\end{array}$ & $\begin{array}{r}\times 09 A \\
\times 09 A \\
\times 09 A \\
\end{array}$ & $\begin{array}{l}20 \\
50 \\
82 \\
\end{array}$ & $\begin{array}{l}v \\
v \\
v \\
\end{array}$ & $\begin{array}{r}0.72 \\
12.05 \\
0 \\
\end{array}$ & $\begin{array}{r}0.019848 \\
0.000043 \\
6.60 \mathrm{e}-07 \\
\end{array}$ \\
\hline $\begin{array}{l}108 \\
108 \\
108 \\
\end{array}$ & $\begin{array}{l}11372 \\
11372 \\
11372 \\
\end{array}$ & $\begin{array}{l}\text { xogc } \\
\text { xogc } \\
\text { xo9c } \\
\end{array}$ & $\begin{array}{l}20 \\
50 \\
82 \\
\end{array}$ & $\begin{array}{l}v \\
v \\
v \\
\end{array}$ & $\begin{array}{r}0.74 \\
12.05 \\
0 \\
\end{array}$ & $\begin{array}{l}0.177825 \\
0.000388 \\
0.000006 \\
\end{array}$ \\
\hline $\begin{array}{l}108 \\
108 \\
108 \\
\end{array}$ & $\begin{array}{l}11372 \\
11372 \\
11372 \\
\end{array}$ & $\begin{array}{l}\text { XO9E } \\
\text { XO9E } \\
\text { XO9E }\end{array}$ & $\begin{array}{l}20 \\
50 \\
82 \\
\end{array}$ & $\begin{array}{l}v \\
v \\
v \\
\end{array}$ & $\begin{array}{r}0.71 \\
12.05 \\
0 \\
\end{array}$ & $\begin{array}{l}9.393451 \\
0.020513 \\
0.000315 \\
\end{array}$ \\
\hline $\begin{array}{l}108 \\
108 \\
108 \\
\end{array}$ & $\begin{array}{l}11372 \\
11372 \\
11372 \\
\end{array}$ & $\begin{array}{l}\text { xo9s } \\
\text { X09s } \\
\text { Xo9s } \\
\end{array}$ & $\begin{array}{l}10 \\
50 \\
82 \\
\end{array}$ & $\begin{array}{l}v \\
v \\
v\end{array}$ & $\begin{array}{r}0.7 \\
15.17 \\
0 \\
\end{array}$ & $\begin{array}{r}0.30841 \\
0.000765 \\
0.000011 \\
\end{array}$ \\
\hline $\begin{array}{l}108 \\
108 \\
108 \\
\end{array}$ & $\begin{array}{l}11449 \\
11449 \\
11449 \\
\end{array}$ & $\begin{array}{l}\text { BO9A } \\
\text { BO9A } \\
\text { BO9A }\end{array}$ & $\begin{array}{l}10 \\
50 \\
82 \\
\end{array}$ & $\begin{array}{l}v \\
v \\
v\end{array}$ & $\begin{array}{r}0.68 \\
14.37 \\
0 \\
\end{array}$ & $\begin{array}{l}0.196778 \\
0.000471 \\
0.000007\end{array}$ \\
\hline $\begin{array}{l}108 \\
108 \\
108 \\
\end{array}$ & $\begin{array}{l}11449 \\
11449 \\
11449 \\
\end{array}$ & $\begin{array}{l}\text { Bo9C } \\
\text { BogC } \\
\text { BogC }\end{array}$ & $\begin{array}{l}10 \\
50 \\
82 \\
\end{array}$ & $\begin{array}{l}v \\
v \\
v\end{array}$ & $\begin{array}{r}0.69 \\
14.37 \\
0 \\
\end{array}$ & $\begin{array}{l}0.094623 \\
0.000226 \\
0.000004\end{array}$ \\
\hline $\begin{array}{l}108 \\
108 \\
108 \\
\end{array}$ & $\begin{array}{l}11449 \\
11449 \\
11449 \\
\end{array}$ & $\begin{array}{l}\text { BO9E } \\
\text { BO9E } \\
\text { BO9E }\end{array}$ & $\begin{array}{l}10 \\
50 \\
82 \\
\end{array}$ & $\begin{array}{l}v \\
v \\
v\end{array}$ & $\begin{array}{r}0.66 \\
14.37 \\
0 \\
\end{array}$ & $\begin{array}{r}16.23012 \\
0.03882 \\
0.000594\end{array}$ \\
\hline $\begin{array}{l}108 \\
108 \\
108 \\
\end{array}$ & $\begin{array}{l}11449 \\
11449 \\
11449 \\
\end{array}$ & $\begin{array}{l}8095 \\
\text { Bogs } \\
\text { Bo9s }\end{array}$ & $\begin{array}{l}10 \\
50 \\
82 \\
\end{array}$ & $\begin{array}{l}v \\
v \\
v\end{array}$ & $\begin{array}{r}0.69 \\
14.37 \\
0 \\
\end{array}$ & $\begin{array}{l}3.353249 \\
0.008021 \\
0.000124 \\
\end{array}$ \\
\hline $\begin{array}{l}108 \\
108 \\
108 \\
\end{array}$ & $\begin{array}{l}11449 \\
11449 \\
11449 \\
\end{array}$ & $\begin{array}{l}\text { X09A } \\
\times 09 A \\
X 09 A \\
\end{array}$ & $\begin{array}{l}10 \\
50 \\
82 \\
\end{array}$ & $\begin{array}{l}v \\
v \\
v \\
\end{array}$ & $\begin{array}{r}0.71 \\
14.37 \\
0 \\
\end{array}$ & $\begin{array}{l}0.085984 \\
0.000206 \\
0.000003 \\
\end{array}$ \\
\hline $\begin{array}{l}108 \\
108 \\
108 \\
\end{array}$ & $\begin{array}{l}11449 \\
11449 \\
11449 \\
\end{array}$ & $\begin{array}{l}\text { XogC } \\
\text { XogC } \\
\text { Xogc } \\
\end{array}$ & $\begin{array}{l}20 \\
50 \\
82 \\
\end{array}$ & $\begin{array}{l}v \\
v \\
v\end{array}$ & $\begin{array}{r}0.74 \\
11.03 \\
0 \\
\end{array}$ & $\begin{array}{r}0.039517 \\
0.00008 \\
0.000001 \\
\end{array}$ \\
\hline $\begin{array}{l}108 \\
108 \\
108 \\
\end{array}$ & $\begin{array}{l}11449 \\
11449 \\
11449 \\
\end{array}$ & $\begin{array}{l}\text { XO9E } \\
\text { XO9E } \\
\text { XO9E }\end{array}$ & $\begin{array}{l}10 \\
50 \\
82 \\
\end{array}$ & $\begin{array}{l}v \\
v \\
v\end{array}$ & $\begin{array}{r}0.71 \\
14.37 \\
0\end{array}$ & $\begin{array}{l}7.611167 \\
0.018204 \\
0.000276\end{array}$ \\
\hline
\end{tabular}


HNF-SD-SNF-TI-009, Rev. 1

\begin{tabular}{|l|l|l|c|c|c|c|c|}
\hline $\begin{array}{c}\text { Location } \\
\text { Cọde }\end{array}$ & Key Number & Fuel Model & $\begin{array}{c}\text { Material } \\
\text { Type }\end{array}$ & $\begin{array}{c}\text { sub 10 } \\
\text { Code }\end{array}$ & Fuel Type & isotopic Breakdown & Discharge Mass \\
\hline
\end{tabular}

\begin{tabular}{|c|c|c|c|c|c|c|}
\hline $\begin{array}{l}108 \\
108 \\
108\end{array}$ & $\begin{array}{l}11449 \\
11449 \\
11449\end{array}$ & $\begin{array}{l}\text { xo9s } \\
\text { xo9s } \\
\text { xo9s }\end{array}$ & $\begin{array}{l}20 \\
50 \\
82 \\
\end{array}$ & $\begin{array}{l}v \\
v \\
v\end{array}$ & $\begin{array}{r}0.73 \\
11.03 \\
0\end{array}$ & $\begin{array}{l}1.613429 \\
0.003255 \\
0.000048\end{array}$ \\
\hline $\begin{array}{l}108 \\
108 \\
108\end{array}$ & $\begin{array}{l}11540 \\
11540 \\
11540\end{array}$ & $\begin{array}{l}A 07 B \\
A 07 B \\
A 07 B\end{array}$ & $\begin{array}{l}10 \\
50 \\
82\end{array}$ & $\begin{array}{l}v \\
V \\
v\end{array}$ & $\begin{array}{r}0.5 \\
11.66 \\
0\end{array}$ & $\begin{array}{r}0.151821 \\
0.0003 \\
0.000004\end{array}$ \\
\hline $\begin{array}{l}108 \\
108 \\
108\end{array}$ & $\begin{array}{l}11540 \\
11540 \\
11540\end{array}$ & $\begin{array}{l}\text { B09A } \\
\text { B09A } \\
809 A\end{array}$ & $\begin{array}{l}20 \\
50 \\
82\end{array}$ & $\begin{array}{l}v \\
v \\
v\end{array}$ & $\begin{array}{r}0.72 \\
11.3 \\
0\end{array}$ & $\begin{array}{l}0.140757 \\
0.000274 \\
0.000004\end{array}$ \\
\hline $\begin{array}{l}108 \\
108 \\
108\end{array}$ & $\begin{array}{l}11540 \\
11540 \\
11540\end{array}$ & $\begin{array}{l}\mathrm{B09C} \\
\mathrm{B} 09 \mathrm{C} \\
\mathrm{B} 09 \mathrm{C}\end{array}$ & $\begin{array}{l}20 \\
50 \\
82 \\
\end{array}$ & $\begin{array}{l}v \\
v \\
v\end{array}$ & $\begin{array}{r}0.72 \\
11.3 \\
0\end{array}$ & $\begin{array}{l}0.042084 \\
0.000082 \\
0.000001\end{array}$ \\
\hline $\begin{array}{l}108 \\
108 \\
108\end{array}$ & $\begin{array}{l}11540 \\
11540 \\
11540\end{array}$ & $\begin{array}{l}\text { BO9E } \\
\text { B09E } \\
\text { B09E }\end{array}$ & $\begin{array}{l}20 \\
50 \\
82\end{array}$ & $\begin{array}{l}v \\
v \\
v\end{array}$ & $\begin{array}{r}0.73 \\
11.3 \\
0\end{array}$ & $\begin{array}{l}7.588326 \\
0.014761 \\
0.000206\end{array}$ \\
\hline $\begin{array}{l}108 \\
108 \\
108\end{array}$ & $\begin{array}{l}11540 \\
11540 \\
11540\end{array}$ & $\begin{array}{l}\text { Bo9s } \\
\text { Bo9s } \\
\text { B09S }\end{array}$ & $\begin{array}{l}20 \\
50 \\
82\end{array}$ & $\begin{array}{l}v \\
v \\
v\end{array}$ & $\begin{array}{r}0.72 \\
11.3 \\
0\end{array}$ & $\begin{array}{l}0.596613 \\
0.001161 \\
0.000016\end{array}$ \\
\hline $\begin{array}{l}108 \\
108 \\
108 \\
\end{array}$ & $\begin{array}{l}11540 \\
11540 \\
11540 \\
\end{array}$ & $\begin{array}{l}\text { BXE } \\
\text { BXE } \\
\text { BXE }\end{array}$ & $\begin{array}{l}20 \\
50 \\
82 \\
\end{array}$ & $\begin{array}{l}v \\
v \\
v\end{array}$ & $\begin{array}{r}0.72 \\
11.3 \\
0\end{array}$ & $\begin{array}{l}0.980828 \\
0.001908 \\
0.000026\end{array}$ \\
\hline $\begin{array}{l}108 \\
108 \\
108\end{array}$ & $\begin{array}{l}11540 \\
11540 \\
11540\end{array}$ & $\begin{array}{l}\text { No7B } \\
\text { NO7B } \\
\text { No7B }\end{array}$ & $\begin{array}{l}10 \\
50 \\
82\end{array}$ & $\begin{array}{l}v \\
v \\
v\end{array}$ & $\begin{array}{r}0.53 \\
11.66 \\
-\quad 0\end{array}$ & $\begin{array}{r}0.075854 \\
0.00015 \\
0.000002\end{array}$ \\
\hline $\begin{array}{l}108 \\
108 \\
108 \\
\end{array}$ & $\begin{array}{l}11540 \\
11540 \\
11540\end{array}$ & $\begin{array}{l}X 09 A \\
X 09 A \\
X 09 A\end{array}$ & $\begin{array}{l}20 \\
50 \\
82 \\
\end{array}$ & $\begin{array}{l}v \\
v \\
v\end{array}$ & $\begin{array}{r}0.75 \\
11.3 \\
0\end{array}$ & $\begin{array}{r}0.072834 \\
0.000142 \\
.0 .000002\end{array}$ \\
\hline $\begin{array}{l}108 \\
108 \\
108\end{array}$ & $\begin{array}{l}11540 \\
11540 \\
11540\end{array}$ & $\begin{array}{l}\text { X09c } \\
\text { X09C } \\
\text { X09C }\end{array}$ & $\begin{array}{l}20 \\
50 \\
82 \\
\end{array}$ & $\begin{array}{l}v \\
v \\
v\end{array}$ & $\begin{array}{r}0.76 \\
11.3 \\
0\end{array}$ & $\begin{array}{r}0.02471 \\
0.000048 \\
6.50 \mathrm{e}-07\end{array}$ \\
\hline $\begin{array}{l}108 \\
108 \\
108\end{array}$ & $\begin{array}{l}11540 \\
11540 \\
11540 \\
\end{array}$ & $\begin{array}{l}\text { XO9E } \\
\text { XO9E } \\
\text { XO9E }\end{array}$ & $\begin{array}{l}20 \\
50 \\
82 \\
\end{array}$ & $\begin{array}{l}v \\
v \\
v\end{array}$ & $\begin{array}{r}0.76 \\
11.3 \\
0\end{array}$ & $\begin{array}{l}3.560047 \\
0.006926 \\
0.000095\end{array}$ \\
\hline $\begin{array}{l}108 \\
108 \\
108\end{array}$ & $\begin{array}{l}11540 \\
11540 \\
11540\end{array}$ & $\begin{array}{l}\text { xogs } \\
\text { xo9s } \\
\text { xo9s }\end{array}$ & $\begin{array}{l}20 \\
50 \\
82 \\
\end{array}$ & $\begin{array}{l}v \\
v \\
v\end{array}$ & $\begin{array}{r}0.75 \\
11.3 \\
0\end{array}$ & $\begin{array}{l}0.273709 \\
0.000532 \\
0.000007\end{array}$ \\
\hline $\begin{array}{l}108 \\
108 \\
108\end{array}$ & $\begin{array}{l}11733 \\
11733 \\
11733 \\
\end{array}$ & $\begin{array}{l}\text { BO9E } \\
\text { BO9E } \\
\text { BO9E }\end{array}$ & $\begin{array}{l}10 \\
50 \\
82\end{array}$ & $\begin{array}{l}\mathrm{v} \\
\mathrm{v} \\
\mathrm{v}\end{array}$ & $\begin{array}{r}0.7 \\
12.82 \\
0\end{array}$ & $\begin{array}{l}0.349069 \\
0.000762 \\
0.000011\end{array}$ \\
\hline $\begin{array}{l}108 \\
108 \\
108\end{array}$ & $\begin{array}{l}11733 \\
11733 \\
11733\end{array}$ & $\begin{array}{l}\text { Bo9s } \\
\text { Bo9s } \\
\text { Bo9s }\end{array}$ & $\begin{array}{l}10 \\
50 \\
82\end{array}$ & $\begin{array}{l}v \\
v \\
v\end{array}$ & $\begin{array}{r}0.7 \\
12.82 \\
0\end{array}$ & $\begin{array}{l}0.089444 \\
0.000195 \\
0.000003\end{array}$ \\
\hline $\begin{array}{l}108 \\
108 \\
108 \\
\end{array}$ & $\begin{array}{l}11733 \\
11733 \\
11733 \\
\end{array}$ & $\begin{array}{l}\text { XO9E } \\
\text { XO9E } \\
\text { XOSE }\end{array}$ & $\begin{array}{l}20 \\
50 \\
82 \\
\end{array}$ & $\begin{array}{l}v \\
v \\
v\end{array}$ & $\begin{array}{r}0.74 \\
10.36 \\
0 \\
\end{array}$ & $\begin{array}{l}0.156671 \\
0.000304 \\
0.000004\end{array}$ \\
\hline $\begin{array}{l}108 \\
108 \\
108 \\
\end{array}$ & $\begin{array}{l}11733 \\
11733 \\
11733 \\
\end{array}$ & $\begin{array}{l}\text { Xo9s } \\
\text { Xo9s } \\
\text { xoss }\end{array}$ & $\begin{array}{l}20 \\
50 \\
\mathbf{8 2}\end{array}$ & $\begin{array}{l}v \\
v \\
v\end{array}$ & $\begin{array}{r}0.74 \\
10.36 \\
0\end{array}$ & $\begin{array}{l}0.049116 \\
0.000095 \\
0.000001\end{array}$ \\
\hline $\begin{array}{l}108 \\
108 \\
108\end{array}$ & $\begin{array}{l}11806 \\
11806 \\
11806\end{array}$ & $\begin{array}{l}\text { A07B } \\
\text { A07B } \\
\text { A07B }\end{array}$ & $\begin{array}{l}10 \\
50 \\
82\end{array}$ & $\begin{array}{l}\text { V } \\
\text { V } \\
\text { V }\end{array}$ & $\begin{array}{r}0.47 \\
15.03 \\
0\end{array}$ & $\begin{array}{l}0.162563 \\
0.000399 \\
0.000006\end{array}$ \\
\hline $\begin{array}{l}108 \\
108 \\
108\end{array}$ & $\begin{array}{l}11806 \\
11806 \\
11806\end{array}$ & $\begin{array}{l}\text { B09A } \\
\text { B09A } \\
\text { B09A }\end{array}$ & $\begin{array}{l}20 \\
50 \\
82\end{array}$ & $\begin{array}{l}V \\
V \\
V\end{array}$ & $\begin{array}{r}0.73 \\
11.94 \\
0\end{array}$ & $\begin{array}{l}0.084459 \\
0.000181 \\
0.000003\end{array}$ \\
\hline
\end{tabular}


HNF-SD-SNF-TI-009, Rev. 1

\begin{tabular}{|c|c|c|c|c|c|c|}
\hline $\begin{array}{c}\text { Location } \\
\text { Code }\end{array}$ & Key Number & Fuel Model & $\begin{array}{c}\text { Material } \\
\text { Type }\end{array}$ & $\begin{array}{c}\text { sub ID } \\
\text { Code }\end{array}$ & Fuel Type & Isotopic Breakdown \\
\hline
\end{tabular}

\begin{tabular}{|c|c|c|c|c|c|c|}
\hline $\begin{array}{l}108 \\
108 \\
108\end{array}$ & $\begin{array}{l}11806 \\
11806 \\
11806\end{array}$ & $\begin{array}{l}\text { Bo9C } \\
\text { Bo9C } \\
\text { BO9C }\end{array}$ & $\begin{array}{l}20 \\
50 \\
82 \\
\end{array}$ & $\begin{array}{l}v \\
v \\
v\end{array}$ & $\begin{array}{r}0.74 \\
11.94 \\
0 \\
\end{array}$ & $\begin{array}{r}0.021051 \\
0.000045 \\
7.00 \mathrm{e}-07\end{array}$ \\
\hline $\begin{array}{l}108 \\
108 \\
108\end{array}$ & $\begin{array}{l}11806 \\
11806 \\
11806\end{array}$ & $\begin{array}{l}\text { BO9E } \\
\text { BO9E } \\
\text { BO9E }\end{array}$ & $\begin{array}{l}10 \\
50 \\
82\end{array}$ & $\begin{array}{l}V \\
v \\
v\end{array}$ & $\begin{array}{r}0.67 \\
15.03 \\
0\end{array}$ & $\begin{array}{l}18.21424 \\
0.044708 \\
0.000678\end{array}$ \\
\hline $\begin{array}{l}108 \\
108 \\
108\end{array}$ & $\begin{array}{l}11806 \\
11806 \\
11806\end{array}$ & $\begin{array}{l}\text { Bo9s } \\
\text { Bo9s } \\
\text { Bo9s }\end{array}$ & $\begin{array}{l}10 \\
50 \\
82\end{array}$ & $\begin{array}{l}v \\
v \\
v\end{array}$ & $\begin{array}{r}0.63 \\
15.03 \\
0\end{array}$ & $\begin{array}{r}0.267865 \\
0.000657 \\
0.00001\end{array}$ \\
\hline $\begin{array}{l}108 \\
108 \\
108\end{array}$ & $\begin{array}{l}11806 \\
11806 \\
11806\end{array}$ & $\begin{array}{l}\text { BXE } \\
\text { BXE } \\
\text { BXE }\end{array}$ & $\begin{array}{l}20 \\
50 \\
82\end{array}$ & $\begin{array}{l}v \\
v \\
v\end{array}$ & $\begin{array}{r}0.72 \\
11.94 \\
0\end{array}$ & $\begin{array}{r}0.326966 \\
0.0007 \\
0.000011\end{array}$ \\
\hline $\begin{array}{l}108 \\
108 \\
108\end{array}$ & $\begin{array}{l}11806 \\
11806 \\
11806\end{array}$ & $\begin{array}{l}\text { NO7B } \\
\text { NO7B } \\
\text { NO7B }\end{array}$ & $\begin{array}{l}10 \\
50 \\
82\end{array}$ & $\begin{array}{l}v \\
v \\
v\end{array}$ & $\begin{array}{r}0.51 \\
15.03 \\
0\end{array}$ & $\begin{array}{l}0.070407 \\
0.000173 \\
0.000003\end{array}$ \\
\hline $\begin{array}{l}108 \\
108 \\
108\end{array}$ & $\begin{array}{l}11806 \\
11806 \\
11806 \\
\end{array}$ & $\begin{array}{l}X 09 A \\
X 09 A \\
X 09 A\end{array}$ & $\begin{array}{l}20 \\
50 \\
82 \\
\end{array}$ & $\begin{array}{l}v \\
v \\
v\end{array}$ & $\begin{array}{r}0.76 \\
11.94 \\
0\end{array}$ & $\begin{array}{l}0.033111 \\
0.00007 t \\
0.000001\end{array}$ \\
\hline $\begin{array}{l}108 \\
108 \\
108\end{array}$ & $\begin{array}{l}11806 \\
11806 \\
11806\end{array}$ & $\begin{array}{l}\times 09 \mathrm{C} \\
\mathrm{X09C} \\
\mathrm{X09C}\end{array}$ & $\begin{array}{l}20 \\
50 \\
82\end{array}$ & $\begin{array}{l}v \\
v \\
v\end{array}$ & $\begin{array}{r}0.78 \\
11.94 \\
0\end{array}$ & $\begin{array}{r}0.009888 \\
0.000021 \\
3.20 \mathrm{e}-07\end{array}$ \\
\hline $\begin{array}{l}108 \\
108 \\
108\end{array}$ & $\begin{array}{l}11806 \\
11806 \\
11806\end{array}$ & $\begin{array}{l}\text { XO9E } \\
\text { XO9E } \\
\text { XO9E }\end{array}$ & $\begin{array}{l}20 \\
50 \\
82 \\
\end{array}$ & $\begin{array}{l}v \\
v \\
v\end{array}$ & $\begin{array}{r}0.72 \\
11.94 \\
0\end{array}$ & $\begin{array}{l}8.589093 \\
0.018397 \\
0.000288\end{array}$ \\
\hline $\begin{array}{l}108 \\
108 \\
108 \\
\end{array}$ & $\begin{array}{l}11806 \\
11806 \\
11806\end{array}$ & $\begin{array}{l}\text { xo9s } \\
\text { xo9s } \\
\text { xo9s } \\
\end{array}$ & $\begin{array}{l}10 \\
50 \\
82 \\
\end{array}$ & $\begin{array}{l}v \\
v \\
v \\
\end{array}$ & $\begin{array}{r}0.69 \\
15.03 \\
0 \\
\end{array}$ & $\begin{array}{r}0.126152 \\
0.00031 \\
0.000005 \\
\end{array}$ \\
\hline $\begin{array}{l}108 \\
108 \\
108\end{array}$ & $\begin{array}{l}11897 \\
11897 \\
11897\end{array}$ & $\begin{array}{l}\text { BO9C } \\
\text { BO9C } \\
\text { BO9C }\end{array}$ & $\begin{array}{l}20 \\
50 \\
82\end{array}$ & $\begin{array}{l}v \\
v \\
v\end{array}$ & $\begin{array}{r}0.72 \\
11.69 \\
0\end{array}$ & $\begin{array}{r}3.040089 \\
0.00602 \\
0.000084\end{array}$ \\
\hline $\begin{array}{l}108 \\
108 \\
108\end{array}$ & $\begin{array}{l}11897 \\
11897 \\
11897\end{array}$ & $\begin{array}{l}\text { BO9E } \\
\text { BO9E } \\
\text { BO9E }\end{array}$ & $\begin{array}{l}10 \\
50 \\
82\end{array}$ & $\begin{array}{l}v \\
v \\
v\end{array}$ & $\begin{array}{r}0.63 \\
15.47 \\
0\end{array}$ & $\begin{array}{l}20.32167 \\
0.053014 \\
0.000847\end{array}$ \\
\hline $\begin{array}{l}108 \\
108 \\
108\end{array}$ & $\begin{array}{l}11897 \\
11897 \\
11897\end{array}$ & $\begin{array}{l}\text { Bo9s } \\
\text { Bo9s } \\
\text { Bo9s }\end{array}$ & $\begin{array}{l}10 \\
50 \\
82\end{array}$ & $\begin{array}{l}v \\
v \\
v\end{array}$ & $\begin{array}{r}0.64 \\
15.47 \\
0\end{array}$ & $\begin{array}{l}1.607559 \\
0.004194 \\
0.000067\end{array}$ \\
\hline $\begin{array}{l}108 \\
108 \\
108\end{array}$ & $\begin{array}{l}11897 \\
11897 \\
11897\end{array}$ & $\begin{array}{l}\text { X09A } \\
\times 09 A \\
\times 09 A\end{array}$ & $\begin{array}{l}10 \\
50 \\
82 \\
\end{array}$ & $\begin{array}{l}v \\
v \\
v\end{array}$ & $\begin{array}{r}0.69 \\
15.47 \\
0 \\
\end{array}$ & $\begin{array}{r}0.006612 \\
0.000017 \\
2.80 \mathrm{e}-07\end{array}$ \\
\hline $\begin{array}{l}108 \\
108 \\
108\end{array}$ & $\begin{array}{l}11897 \\
11897 \\
11897\end{array}$ & $\begin{array}{l}\text { x09C } \\
\text { x09C } \\
\text { X09C }\end{array}$ & $\begin{array}{l}20 \\
50 \\
82\end{array}$ & $\begin{array}{l}v \\
v \\
v\end{array}$ & $\begin{array}{r}0.76 \\
11.69 \\
0\end{array}$ & $\begin{array}{r}1.428212 \\
0.002829 \\
0.00004\end{array}$ \\
\hline $\begin{array}{l}108 \\
108 \\
108 \\
\end{array}$ & $\begin{array}{l}11897 \\
11897 \\
11897\end{array}$ & $\begin{array}{l}\text { XO9E } \\
\text { XO9E } \\
\text { X09E } \\
\end{array}$ & $\begin{array}{l}10 \\
50 \\
82 \\
\end{array}$ & $\begin{array}{l}v \\
v \\
v\end{array}$ & $\begin{array}{r}0.69 \\
15.47 \\
0 \\
\end{array}$ & $\begin{array}{r}9.55962 \\
0.024942 \\
0.000398\end{array}$ \\
\hline $\begin{array}{l}108 \\
108 \\
108\end{array}$ & $\begin{array}{l}11897 \\
11897 \\
11897\end{array}$ & $\begin{array}{l}\text { xogs } \\
\text { xo9s } \\
\text { x09s }\end{array}$ & $\begin{array}{l}10 \\
50 \\
82\end{array}$ & $\begin{array}{l}v \\
v \\
v\end{array}$ & $\begin{array}{r}0.69 \\
15.47 \\
0\end{array}$ & $\begin{array}{l}0.749897 \\
0.001956 \\
0.000031\end{array}$ \\
\hline $\begin{array}{l}108 \\
108 \\
108\end{array}$ & $\begin{array}{l}11979 \\
11979 \\
11979\end{array}$ & $\begin{array}{l}A 7 B \\
A 7 B \\
A 7 B\end{array}$ & $\begin{array}{l}10 \\
50 \\
82\end{array}$ & $\begin{array}{l}v \\
v \\
v\end{array}$ & $\begin{array}{r}0.49 \\
15.34 \\
0\end{array}$ & $\begin{array}{l}0.081282 \\
0.000208 \\
0.000003\end{array}$ \\
\hline $\begin{array}{l}108 \\
108 \\
108\end{array}$ & $\begin{array}{l}11979 \\
11979 \\
11979\end{array}$ & $\begin{array}{l}\text { Bo9C } \\
\text { BO9C } \\
\text { BO9C }\end{array}$ & $\begin{array}{l}10 \\
50 \\
82\end{array}$ & $\begin{array}{l}v \\
v \\
v\end{array}$ & $\begin{array}{r}0.68 \\
15.34 \\
0\end{array}$ & $\begin{array}{l}1.849931 \\
0.004734 \\
0.000076\end{array}$ \\
\hline
\end{tabular}


HNF-SD-SNF-TI-009, Rev . I

\begin{tabular}{|c|c|c|c|c|c|c|}
\hline $\begin{array}{c}\text { Location } \\
\text { Code }\end{array}$ & Key Number & Fuel Model & $\begin{array}{c}\text { Material } \\
\text { Type }\end{array}$ & $\begin{array}{c}\text { sub ID } \\
\text { Code }\end{array}$ & Fuel Type & Isotopic Breakdown \\
\hline
\end{tabular}

\begin{tabular}{|c|c|c|c|c|c|c|}
\hline $\begin{array}{l}108 \\
108 \\
108\end{array}$ & $\begin{array}{l}11979 \\
11979 \\
11979\end{array}$ & $\begin{array}{l}\text { BO9E } \\
\text { BO9E } \\
\text { BO9E }\end{array}$ & $\begin{array}{l}10 \\
50 \\
82 \\
\end{array}$ & $\begin{array}{l}v \\
v \\
v\end{array}$ & $\begin{array}{r}0.63 \\
15.34 \\
\quad 0 \\
\end{array}$ & $\begin{array}{l}14.22384 \\
0.036396 \\
0.000584\end{array}$ \\
\hline $\begin{array}{l}108 \\
108 \\
108 \\
\end{array}$ & $\begin{array}{l}11979 \\
11979 \\
11979 \\
\end{array}$ & $\begin{array}{l}\text { Bogs } \\
\text { Bogs } \\
\text { Bogs }\end{array}$ & $\begin{array}{l}10 \\
50 \\
82 \\
\end{array}$ & $\begin{array}{l}v \\
v \\
v\end{array}$ & $\begin{array}{r}0.66 \\
15.34 \\
0 \\
\end{array}$ & $\begin{array}{l}1.921296 \\
0.004916 \\
0.000079\end{array}$ \\
\hline $\begin{array}{l}108 \\
108 \\
108\end{array}$ & $\begin{array}{l}11979 \\
11979 \\
11979 \\
\end{array}$ & $\begin{array}{l}\text { BXC } \\
\text { BXC } \\
\text { BXC }\end{array}$ & $\begin{array}{l}10 \\
50 \\
82 \\
\end{array}$ & $\begin{array}{l}v \\
v \\
v \\
\end{array}$ & $\begin{array}{r}0.69 \\
15.34 \\
0 \\
\end{array}$ & $\begin{array}{l}0.370705 \\
0.000949 \\
0.000015\end{array}$ \\
\hline $\begin{array}{l}108 \\
108 \\
108\end{array}$ & $\begin{array}{l}11979 \\
11979 \\
11979\end{array}$ & $\begin{array}{l}\text { BXE } \\
\text { BXE } \\
\text { BXE }\end{array}$ & $\begin{array}{l}10 \\
50 \\
82\end{array}$ & $\begin{array}{l}v \\
v \\
v\end{array}$ & $\begin{array}{r}0.66 \\
15.34 \\
0 \\
\end{array}$ & $\begin{array}{l}9.597243 \\
0.024559 \\
0.000391\end{array}$ \\
\hline $\begin{array}{l}108 \\
108 \\
108\end{array}$ & $\begin{array}{l}11979 \\
11979 \\
11979\end{array}$ & $\begin{array}{l}\text { BXs } \\
\text { BXS } \\
\text { BXs }\end{array}$ & $\begin{array}{l}10 \\
50 \\
82\end{array}$ & $\begin{array}{l}v \\
v \\
v\end{array}$ & $\begin{array}{r}0.67 \\
15.34 \\
0\end{array}$ & $\begin{array}{l}0.459883 \\
0.001177 \\
0.000019\end{array}$ \\
\hline $\begin{array}{l}108 \\
108 \\
108\end{array}$ & $\begin{array}{l}11979 \\
11979 \\
11979\end{array}$ & $\begin{array}{l}\text { xogc } \\
\text { xogc } \\
\text { xogc }\end{array}$ & $\begin{array}{l}20 \\
50 \\
82\end{array}$ & $\begin{array}{l}v \\
v . \\
v\end{array}$ & $\begin{array}{r}0.73 \\
11.7 \\
0\end{array}$ & $\begin{array}{l}0.893948 \\
0.001882 \\
0.000029\end{array}$ \\
\hline $\begin{array}{l}108 \\
108 \\
108\end{array}$ & $\begin{array}{l}11979 \\
11979 \\
11979\end{array}$ & $\begin{array}{l}X O 9 E \\
X O 9 E \\
X O 9 E\end{array}$ & $\begin{array}{l}10 \\
50 \\
82 \\
\end{array}$ & $\begin{array}{l}v \\
v \\
v\end{array}$ & $\begin{array}{r}0.69 \\
15.34 \\
0 \\
\end{array}$ & $\begin{array}{l}6.676392 \\
0.017087 \\
0.000269\end{array}$ \\
\hline $\begin{array}{l}108 \\
108 \\
108 \\
\end{array}$ & $\begin{array}{l}11979 \\
11979 \\
11979\end{array}$ & $\begin{array}{l}x 09 s \\
\text { Xogs } \\
\text { Xo9s }\end{array}$ & $\begin{array}{l}20 \\
50 \\
82\end{array}$ & $\begin{array}{l}v \\
v \\
v\end{array}$ & $\begin{array}{r}0.71 \\
11.7 \\
0\end{array}$ & $\begin{array}{l}0.890476 \\
0.001875 \\
0.000029\end{array}$ \\
\hline $\begin{array}{l}108 \\
108 \\
108 \\
\end{array}$ & $\begin{array}{l}12127 \\
12127 \\
12127 \\
\end{array}$ & $\begin{array}{l}A 7 B \\
\text { A7B } \\
\text { A7B } \\
\end{array}$ & $\begin{array}{l}10 \\
50 \\
82 \\
\end{array}$ & $\begin{array}{l}v \\
v \\
v \\
\end{array}$ & $\begin{array}{r}0.45 \\
14.73 \\
0 \\
\end{array}$ & $\begin{array}{l}0.146157 \\
0.000365 \\
0.000006\end{array}$ \\
\hline $\begin{array}{l}108 \\
108 \\
108\end{array}$ & $\begin{array}{l}12127 \\
12127 \\
12127\end{array}$ & $\begin{array}{l}\text { BXA } \\
\text { BXA } \\
\text { BXA }\end{array}$ & $\begin{array}{l}10 \\
50 \\
82\end{array}$ & $\begin{array}{l}v \\
v \\
v\end{array}$ & $\begin{array}{r}0.67 \\
14.73 \\
0\end{array}$ & $\begin{array}{l}0.496056 \\
0.001237 \\
0.000019\end{array}$ \\
\hline $\begin{array}{l}108 \\
108 \\
108 \\
\end{array}$ & $\begin{array}{l}12127 \\
12127 \\
12127\end{array}$ & $\begin{array}{l}\text { BXC } \\
\text { BXC } \\
\text { BXC } \\
\end{array}$ & $\begin{array}{l}10 \\
50 \\
82\end{array}$ & $\begin{array}{l}v \\
v \\
v\end{array}$ & $\begin{array}{r}0.69 \\
14.73 \\
0\end{array}$ & $\begin{array}{l}0.339818 \\
0.000848 \\
0.000013\end{array}$ \\
\hline $\begin{array}{l}108 \\
108 \\
108\end{array}$ & $\begin{array}{l}12127 \\
12127 \\
12127\end{array}$ & $\begin{array}{l}\text { BXE } \\
\text { BXE } \\
\text { BXE }\end{array}$ & $\begin{array}{l}10 \\
50 \\
82\end{array}$ & $\begin{array}{l}v \\
v \\
v\end{array}$ & $\begin{array}{r}0.67 \\
14.73 \\
0\end{array}$ & $\begin{array}{l}26.16562 \\
0.065269 \\
0.001022\end{array}$ \\
\hline $\begin{array}{l}108 \\
108 \\
108 \\
\end{array}$ & $\begin{array}{l}12127 \\
12127 \\
12127 \\
\end{array}$ & $\begin{array}{l}\text { BXs } \\
\text { BXs } \\
\text { BXs }\end{array}$ & $\begin{array}{l}10 \\
50 \\
82 \\
\end{array}$ & $\begin{array}{l}v \\
v \\
v\end{array}$ & $\begin{array}{r}0.66 \\
14.73 \\
0\end{array}$ & $\begin{array}{l}3.327976 \\
0.008302 \\
0.000129\end{array}$ \\
\hline $\begin{array}{l}108 \\
108 \\
108 \\
\end{array}$ & $\begin{array}{l}12201 \\
12201 \\
t 2201 \\
\end{array}$ & $\begin{array}{l}\text { A7B } \\
\text { A7B } \\
\text { A7B } \\
\end{array}$ & $\begin{array}{l}10 \\
50 \\
82 \\
\end{array}$ & $\begin{array}{l}v \\
v \\
v\end{array}$ & $\begin{array}{r}0.49 \\
13.98 \\
0\end{array}$ & $\begin{array}{l}0.130051 \\
0.000305 \\
0.000005\end{array}$ \\
\hline $\begin{array}{l}108 \\
108 \\
108 \\
\end{array}$ & $\begin{array}{l}12201 \\
12201 \\
12201\end{array}$ & $\begin{array}{l}\text { Bo9C } \\
\text { BogC } \\
\text { Bo9C }\end{array}$ & $\begin{array}{l}20 \\
50 \\
82\end{array}$ & $\begin{array}{l}v \\
v \\
v\end{array}$ & $\begin{array}{r}0.95 \\
11.38 \\
0 \\
\end{array}$ & $\begin{array}{r}0.01057 \\
0.000019 \\
2.708-07 \\
\end{array}$ \\
\hline $\begin{array}{l}108 \\
108 \\
108 \\
\end{array}$ & $\begin{array}{l}12201 \\
12201 \\
12201\end{array}$ & $\begin{array}{l}B \times C \\
B \times C \\
B \times C\end{array}$ & $\begin{array}{l}20 \\
50 \\
82\end{array}$ & $\begin{array}{l}v \\
v \\
v\end{array}$ & $\begin{array}{r}0.74 \\
11.38 \\
0\end{array}$ & $\begin{array}{l}0.448464 \\
0.000823 \\
0.000012\end{array}$ \\
\hline $\begin{array}{l}108 \\
108 \\
108 \\
\end{array}$ & $\begin{array}{l}12201 \\
12201 \\
12201\end{array}$ & $\begin{array}{l}\text { BXE } \\
\text { BXE } \\
\text { BXE }\end{array}$ & $\begin{array}{l}10 \\
50 \\
82\end{array}$ & $\begin{array}{l}v \\
v \\
v\end{array}$ & $\begin{array}{r}0.69 \\
13.98 \\
0\end{array}$ & $\begin{array}{r}15.898 \\
0.037237 \\
0.000566\end{array}$ \\
\hline $\begin{array}{l}108 \\
108 \\
108 \\
\end{array}$ & $\begin{array}{l}12201 \\
12201 \\
12201\end{array}$ & $\begin{array}{l}\text { BXS } \\
\text { BXS } \\
\text { BXS }\end{array}$ & $\begin{array}{l}10 \\
50 \\
82\end{array}$ & $\begin{array}{l}v \\
v \\
v\end{array}$ & $\begin{array}{r}0.68 \\
13.98 \\
0\end{array}$ & $\begin{array}{l}5.651549 \\
0.013238 \\
0.000201\end{array}$ \\
\hline
\end{tabular}


HNF-SD-SNF-TI-009, Rev. 1

\begin{tabular}{|c|c|c|c|c|c|c|}
\hline $\begin{array}{c}\text { Location } \\
\text { Code }\end{array}$ & Key Number & Fuel Model & $\begin{array}{c}\text { Material } \\
\text { Type }\end{array}$ & $\begin{array}{c}\text { sub ID } \\
\text { Code }\end{array}$ & Fuel Type & Isotopic Breakdown \\
\hline
\end{tabular}

\begin{tabular}{|c|c|c|c|c|c|c|}
\hline $\begin{array}{l}108 \\
108 \\
108 \\
\end{array}$ & $\begin{array}{l}12201 \\
12201 \\
12201 \\
\end{array}$ & $\begin{array}{l}X 09 \varepsilon \\
X 09 E \\
\text { XOSE } \\
\end{array}$ & $\begin{array}{l}20 \\
50 \\
82 \\
\end{array}$ & $\begin{array}{l}v \\
v \\
v\end{array}$ & $\begin{array}{r}0.96 \\
11.38 \\
0\end{array}$ & $\begin{array}{r}0.007493 \\
0.000014 \\
1.90 \mathrm{e}-07\end{array}$ \\
\hline $\begin{array}{l}108 \\
108 \\
108\end{array}$ & $\begin{array}{l}12240 \\
12240 \\
12240\end{array}$ & $\begin{array}{l}\text { BO9E } \\
\text { BO9E } \\
\text { BO9E }\end{array}$ & $\begin{array}{l}10 \\
50 \\
82\end{array}$ & $\begin{array}{l}v \\
v \\
v\end{array}$ & $\begin{array}{r}0.68 \\
14.51 \\
0\end{array}$ & $\begin{array}{l}0.063436 \\
0.000146 \\
0.000002\end{array}$ \\
\hline $\begin{array}{l}108 \\
108 \\
108\end{array}$ & $\begin{array}{l}12240 \\
12240 \\
12240\end{array}$ & $\begin{array}{l}\text { XO9E } \\
\text { XO9E } \\
\text { XO9E }\end{array}$ & $\begin{array}{l}20 \\
50 \\
82\end{array}$ & $\begin{array}{l}v \\
v \\
v\end{array}$ & $\begin{array}{r}0.73 \\
11.22 \\
0\end{array}$ & $\begin{array}{r}0.029835 \\
0.00006 \\
8.80 e-07\end{array}$ \\
\hline $\begin{array}{l}108 \\
108 \\
108\end{array}$ & $\begin{array}{l}12285 \\
12285 \\
12285\end{array}$ & $\begin{array}{l}\text { BO9A } \\
\text { BO9A } \\
\text { BO9A }\end{array}$ & $\begin{array}{l}10 \\
50 \\
82\end{array}$ & $\begin{array}{l}v \\
v \\
v\end{array}$ & $\begin{array}{r}0.64 \\
+4.45 \\
0\end{array}$ & $\begin{array}{r}0.014048 \\
0.000034 \\
5.30 e-07\end{array}$ \\
\hline $\begin{array}{l}108 \\
108 \\
108\end{array}$ & $\begin{array}{l}12285 \\
12285 \\
12285 \\
\end{array}$ & $\begin{array}{l}\text { BO9E } \\
\text { BO9E } \\
\text { BOSE }\end{array}$ & $\begin{array}{l}10 \\
50 \\
82 \\
\end{array}$ & $\begin{array}{l}v \\
v \\
v \\
\end{array}$ & $\begin{array}{r}0.67 \\
14.45 \\
0\end{array}$ & $\begin{array}{l}0.031693 \\
0.000077 \\
0.000001\end{array}$ \\
\hline $\begin{array}{l}108 \\
108 \\
108\end{array}$ & $\begin{array}{l}12285 \\
12285 \\
12285\end{array}$ & $\begin{array}{l}\text { BXC } \\
\text { BXC } \\
\text { BXC }\end{array}$ & $\begin{array}{l}20 \\
50 \\
82\end{array}$ & $\begin{array}{l}v \\
v \\
v\end{array}$ & $\begin{array}{r}0.72 \\
12.1 \\
0\end{array}$ & $\begin{array}{l}0.757435 \\
0.001555 \\
0.000022\end{array}$ \\
\hline $\begin{array}{l}108 \\
108 \\
108\end{array}$ & $\begin{array}{l}12285 \\
12285 \\
12285\end{array}$ & $\begin{array}{l}\text { BXE } \\
\text { BXE } \\
\text { BXE }\end{array}$ & $\begin{array}{l}10 \\
50 \\
82\end{array}$ & $\begin{array}{l}v \\
v \\
v\end{array}$ & $\begin{array}{r}0.67 \\
14.45 \\
0\end{array}$ & $\begin{array}{l}57.56088 \\
0.140543 \\
0.002174\end{array}$ \\
\hline $\begin{array}{l}108 \\
108 \\
108\end{array}$ & $\begin{array}{l}12285 \\
12285 \\
12285\end{array}$ & $\begin{array}{l}\text { BXS } \\
\text { BXS } \\
\text { BXS }\end{array}$ & $\begin{array}{l}10 \\
50 \\
82\end{array}$ & $\begin{array}{l}v \\
v \\
v\end{array}$ & $\begin{array}{r}0.66 \\
14.45 \\
0\end{array}$ & $\begin{array}{l}6.086724 \\
0.014859 \\
0.000228\end{array}$ \\
\hline $\begin{array}{l}108 \\
108 \\
108 \\
\end{array}$ & $\begin{array}{l}12285 \\
12285 \\
12285\end{array}$ & $\begin{array}{l}x 09 c \\
\text { xogc } \\
\text { xogc }\end{array}$ & $\begin{array}{l}20 \\
50 \\
82 \\
\end{array}$ & $\begin{array}{l}v \\
v \\
v\end{array}$ & $\begin{array}{r}0.95 \\
12.1 \\
0\end{array}$ & $\begin{array}{r}0.004962 \\
0.00001 \\
1.400-07\end{array}$ \\
\hline $\begin{array}{l}108 \\
108 \\
108\end{array}$ & $\begin{array}{l}12480 \\
12480 \\
12480\end{array}$ & $\begin{array}{l}\text { BXA } \\
\text { BXA } \\
\text { BXA }\end{array}$ & $\begin{array}{l}10 \\
50 \\
82\end{array}$ & $\begin{array}{l}v \\
v \\
v\end{array}$ & $\begin{array}{r}0.66 \\
14.29 \\
0\end{array}$ & $\begin{array}{l}0.578595 \\
0.001403 \\
0.000022\end{array}$ \\
\hline $\begin{array}{l}108 \\
108 \\
108\end{array}$ & $\begin{array}{l}12480 \\
12480 \\
12480\end{array}$ & $\begin{array}{l}B \times C \\
B \times C \\
B \times C\end{array}$ & $\begin{array}{l}20 \\
50 \\
82 \\
\end{array}$ & $\begin{array}{l}v \\
v \\
v\end{array}$ & $\begin{array}{r}0.72 \\
12.38 \\
0 \\
\end{array}$ & $\begin{array}{l}0.247324 \\
0.000509 \\
0.000007\end{array}$ \\
\hline $\begin{array}{l}108 \\
108 \\
108\end{array}$ & $\begin{array}{l}12480 \\
t 2480 \\
t 2480\end{array}$ & $\begin{array}{l}\text { BXE } \\
\text { BXE } \\
\text { BXE }\end{array}$ & $\begin{array}{l}10 \\
50 \\
82\end{array}$ & $\begin{array}{l}v \\
v \\
v\end{array}$ & $\begin{array}{r}0.68 \\
14.29 \\
0\end{array}$ & $\begin{array}{l}49.49961 \\
0.119985 \\
0.001848\end{array}$ \\
\hline $\begin{array}{l}108 \\
108 \\
108\end{array}$ & $\begin{array}{l}12480 \\
12480 \\
12480\end{array}$ & $\begin{array}{l}\text { BXs } \\
\text { BXS } \\
\text { BXS }\end{array}$ & $\begin{array}{l}10 \\
50 \\
82\end{array}$ & $\begin{array}{l}v \\
v \\
v\end{array}$ & $\begin{array}{r}0.67 \\
14.29 \\
0\end{array}$ & $\begin{array}{l}3.723296 \\
0.009025 \\
0.000138\end{array}$ \\
\hline $\begin{array}{l}108 \\
108 \\
108\end{array}$ & $\begin{array}{l}12565 \\
12565 \\
12565\end{array}$ & $\begin{array}{l}\text { BXA } \\
\text { BXA } \\
\text { BXA }\end{array}$ & $\begin{array}{l}10 \\
50 \\
82\end{array}$ & $\begin{array}{l}v \\
v \\
v\end{array}$ & $\begin{array}{r}0.69 \\
14.15 \\
0\end{array}$ & $\begin{array}{r}0.289463 \\
0.00069 \\
0.000011\end{array}$ \\
\hline $\begin{array}{l}108 \\
108 \\
108\end{array}$ & $\begin{array}{l}12565 \\
t 2565 \\
12565\end{array}$ & $\begin{array}{l}B \times C \\
B \times C \\
B \times C\end{array}$ & $\begin{array}{l}10 \\
50 \\
82 \\
\end{array}$ & $\begin{array}{l}v \\
v \\
v\end{array}$ & $\begin{array}{r}0.68 \\
14.15 \\
0\end{array}$ & $\begin{array}{r}0.13899 \\
0.000331 \\
0.000005\end{array}$ \\
\hline $\begin{array}{l}108 \\
108 \\
108 \\
\end{array}$ & $\begin{array}{l}12565 \\
12565 \\
12565\end{array}$ & $\begin{array}{l}\text { BXE } \\
\text { BXE } \\
\text { BXE }\end{array}$ & $\begin{array}{l}10 \\
50 \\
82 \\
\end{array}$ & $\begin{array}{l}v \\
v \\
v\end{array}$ & $\begin{array}{r}0.68 \\
14.15 \\
0\end{array}$ & $\begin{array}{l}34.70278 \\
0.082699 \\
0.001266\end{array}$ \\
\hline $\begin{array}{l}108 \\
108 \\
108\end{array}$ & $\begin{array}{l}12565 \\
12565 \\
12565\end{array}$ & $\begin{array}{l}\text { BXs } \\
\text { BXS } \\
\text { BXS }\end{array}$ & $\begin{array}{l}10 \\
50 \\
82\end{array}$ & $\begin{array}{l}v \\
v \\
v\end{array}$ & $\begin{array}{r}0.7 \\
14.15 \\
0\end{array}$ & $\begin{array}{r}3.637973 \\
0.00867 \\
0.000133\end{array}$ \\
\hline $\begin{array}{l}108 \\
108\end{array}$ & $\begin{array}{l}12565 \\
12565\end{array}$ & $\begin{array}{l}\text { XO9E } \\
\text { XOSE }\end{array}$ & $\begin{array}{l}20 \\
50\end{array}$ & $\begin{array}{l}v \\
v\end{array}$ & $\begin{array}{r}0.95 \\
0\end{array}$ & $\begin{array}{r}0.014986 \\
1.20 \mathrm{e}-07\end{array}$ \\
\hline
\end{tabular}


HNF-SD-SNF-TI-009, Rev. 1

\begin{tabular}{|c|c|c|c|c|c|c|}
\hline $\begin{array}{c}\text { Location } \\
\text { Code }\end{array}$ & Key Number & Fuel Model & $\begin{array}{c}\text { Material } \\
\text { Type }\end{array}$ & $\begin{array}{c}\text { sub ID } \\
\text { Code }\end{array}$ & Fuel Type & Isotopic Breakdown \\
\hline
\end{tabular}

\begin{tabular}{|c|c|c|c|c|c|c|}
\hline $\begin{array}{l}108 \\
108 \\
108 \\
\end{array}$ & $\begin{array}{r}12639 \\
12639 \\
12639 \\
\end{array}$ & $\begin{array}{l}\text { BO9E } \\
\text { BO9E } \\
\text { BO9E }\end{array}$ & $\begin{array}{l}10 \\
50 \\
82 \\
\end{array}$ & $\begin{array}{l}v \\
v \\
v\end{array}$ & $\begin{array}{r}0.69 \\
13.84 \\
0 \\
\end{array}$ & $\begin{array}{l}0.031703 \\
0.000074 \\
0.000001\end{array}$ \\
\hline $\begin{array}{l}108 \\
108 \\
108\end{array}$ & $\begin{array}{r}12639 \\
12639 \\
12639\end{array}$ & $\begin{array}{l}\text { B7E } \\
\text { B7E } \\
\text { B7E }\end{array}$ & $\begin{array}{l}10 \\
50 \\
82\end{array}$ & $\begin{array}{l}v \\
v \\
v\end{array}$ & $\begin{array}{r}0.55 \\
13.84 \\
0\end{array}$ & $\begin{array}{r}0.023035 \\
0.000054 \\
8.20 \mathrm{e}-07\end{array}$ \\
\hline $\begin{array}{l}108 \\
108 \\
108\end{array}$ & $\begin{array}{r}12639 \\
12639 \\
12639 \\
\end{array}$ & $\begin{array}{l}\text { BXE } \\
\text { BXE } \\
\text { BXE }\end{array}$ & $\begin{array}{l}10 \\
50 \\
82 \\
\end{array}$ & $\begin{array}{l}v \\
v \\
v\end{array}$ & $\begin{array}{r}0.69 \\
13.84 \\
0\end{array}$ & $\begin{array}{l}40.23534 \\
0.094447 \\
0.001415\end{array}$ \\
\hline $\begin{array}{l}108 \\
108 \\
108 \\
\end{array}$ & $\begin{array}{l}12639 \\
12639 \\
12639 \\
\end{array}$ & $\begin{array}{l}\text { BXS } \\
\text { BXS } \\
\text { BXS }\end{array}$ & $\begin{array}{l}10 \\
50 \\
82 \\
\end{array}$ & $\begin{array}{l}v \\
v \\
v\end{array}$ & $\begin{array}{r}0.67 \\
13.84 \\
0\end{array}$ & $\begin{array}{l}5.387353 \\
0.012647 \\
0.000192\end{array}$ \\
\hline $\begin{array}{l}108 \\
108 \\
108 \\
\end{array}$ & $\begin{array}{l}12852 \\
12852 \\
12852 \\
\end{array}$ & $\begin{array}{l}\text { BXE } \\
\text { BXE } \\
\text { BXE }\end{array}$ & $\begin{array}{r}20 \\
50 \\
82 \\
\end{array}$ & $\begin{array}{l}v \\
v \\
v \\
\end{array}$ & $\begin{array}{r}0.74 \\
11.43 \\
0 \\
\end{array}$ & $\begin{array}{l}2.520529 \\
0.004749 \\
0.000065\end{array}$ \\
\hline $\begin{array}{l}108 \\
108 \\
108\end{array}$ & $\begin{array}{l}13015 \\
13015 \\
13015\end{array}$ & $\begin{array}{l}\text { 8XC } \\
\text { BXC } \\
\text { BXC }\end{array}$ & $\begin{array}{l}20 \\
50 \\
82\end{array}$ & $\begin{array}{l}v \\
v \\
v\end{array}$ & $\begin{array}{r}0.72 \\
13.19 \\
0\end{array}$ & $\begin{array}{r}0.21617 \\
0.000428 \\
0.000006\end{array}$ \\
\hline $\begin{array}{l}108 \\
108 \\
108 .\end{array}$ & $\begin{array}{l}13015 \\
13015 \\
13015\end{array}$ & $\begin{array}{l}\text { BXE } \\
\text { BXE } \\
\text { BXE . }\end{array}$ & $\begin{array}{l}20 \\
50 \\
82\end{array}$ & $\begin{array}{l}v \\
v \\
v\end{array}$ & $\begin{array}{r}0.72 \\
13.19 \\
0\end{array}$ & $\begin{array}{l}0.652963 \\
0.001293 \\
0.000018\end{array}$ \\
\hline $\begin{array}{l}108 \\
108 \\
108 \\
\end{array}$ & $\begin{array}{l}13016 \\
13016 \\
13016 \\
\end{array}$ & $\begin{array}{l}\text { BXS } \\
\text { BXS } \\
\text { BXS }\end{array}$ & $\begin{array}{l}20 \\
50 \\
82\end{array}$ & $\begin{array}{l}v \\
v \\
v\end{array}$ & $\begin{array}{r}0.86 \\
5.63 \\
0\end{array}$ & $\begin{array}{r}0.021922 \\
0.000018 \\
2.100-07\end{array}$ \\
\hline $\begin{array}{l}108 \\
108 \\
108 \\
\end{array}$ & $\begin{array}{l}13371 \\
13371 \\
13371 \\
\end{array}$ & $\begin{array}{l}\text { BXE } \\
\text { BXE } \\
\text { BXE }\end{array}$ & $\begin{array}{l}20 \\
50 \\
82 \\
\end{array}$ & $\begin{array}{l}v \\
v \\
v\end{array}$ & $\begin{array}{r}0.84 \\
6.58 \\
0\end{array}$ & $\begin{array}{r}0.021108 \\
0.00002 \\
2.40 \mathrm{e}-07\end{array}$ \\
\hline $\begin{array}{l}108 \\
108 \\
108 \\
\end{array}$ & $\begin{array}{l}13649 \\
13649 \\
13649 \\
\end{array}$ & $\begin{array}{l}\text { B7E } \\
\text { B7E } \\
\text { B7E }\end{array}$ & $\begin{array}{l}10 \\
50 \\
82 \\
\end{array}$ & $\begin{array}{l}v \\
v \\
v\end{array}$ & $\begin{array}{r}0.57 \\
11.4 \\
0\end{array}$ & $\begin{array}{l}0.374046 \\
0.000631 \\
0.000008\end{array}$ \\
\hline $\begin{array}{l}108 \\
108 \\
108\end{array}$ & $\begin{array}{l}13649 \\
13649 \\
13649\end{array}$ & $\begin{array}{l}\text { BXC } \\
\text { BXC } \\
\text { BXC }\end{array}$ & $\begin{array}{l}20 \\
50 \\
82\end{array}$ & $\begin{array}{l}v \\
v \\
v\end{array}$ & $\begin{array}{r}0.72 \\
13.25 \\
0\end{array}$ & $\begin{array}{l}0.587287 \\
0.001159 \\
0.000017\end{array}$ \\
\hline $\begin{array}{l}108 \\
108 \\
108 \\
\end{array}$ & $\begin{array}{l}13649 \\
13649 \\
13649 \\
\end{array}$ & $\begin{array}{l}\text { BXE } \\
\text { BXE } \\
\text { BXE }\end{array}$ & $\begin{array}{l}20 \\
50 \\
82 \\
\end{array}$ & $\begin{array}{l}v \\
v \\
v\end{array}$ & $\begin{array}{r}0.72 \\
13.25 \\
0 \\
\end{array}$ & $\begin{array}{l}3.965021 \\
0.007825 \\
0.000116\end{array}$ \\
\hline $\begin{array}{l}108 \\
108 \\
108\end{array}$ & $\begin{array}{l}13685 \\
13685 \\
13685\end{array}$ & $\begin{array}{l}\text { BXE } \\
\text { BXE } \\
\text { BXE }\end{array}$ & $\begin{array}{l}20 \\
50 \\
82\end{array}$ & $\begin{array}{l}v \\
v \\
v\end{array}$ & $\begin{array}{r}0.72 \\
13.34 \\
0\end{array}$ & $\begin{array}{l}2.612148 \\
0.005193 \\
0.000077\end{array}$ \\
\hline $\begin{array}{l}108 \\
108 \\
108 \\
\end{array}$ & $\begin{array}{l}14065 \\
14065 \\
14065 \\
\end{array}$ & $\begin{array}{l}\text { XO9E } \\
\text { XO9E } \\
\text { XO9E } \\
\end{array}$ & $\begin{array}{l}20 \\
50 \\
82 \\
\end{array}$ & $\begin{array}{l}v \\
v \\
v \\
\end{array}$ & $\begin{array}{r}0.86 \\
5.62 \\
\quad 0 \\
\end{array}$ & $\begin{array}{r}0.023268 \\
0.000019 \\
2.400-07\end{array}$ \\
\hline $\begin{array}{l}108 \\
108 \\
108 \\
\end{array}$ & $\begin{array}{l}14355 \\
14355 \\
14355 \\
\end{array}$ & $\begin{array}{l}\text { BO9C } \\
\text { BO9C } \\
\text { BogC }\end{array}$ & $\begin{array}{l}10 \\
50 \\
82 \\
\end{array}$ & $\begin{array}{l}v \\
v \\
v\end{array}$ & $\begin{array}{r}0.66 \\
15.74 \\
0\end{array}$ & $\begin{array}{l}0.094561 \\
0.000253 \\
0.000004\end{array}$ \\
\hline $\begin{array}{l}108 \\
108 \\
108 \\
\end{array}$ & $\begin{array}{r}14355 \\
14355 \\
14355 \\
\end{array}$ & $\begin{array}{l}\text { BO9E } \\
\text { BO9E } \\
\text { BO9E }\end{array}$ & $\begin{array}{l}20 \\
50 \\
82 \\
\end{array}$ & $\begin{array}{l}v \\
v \\
v\end{array}$ & $\begin{array}{r}0.72 \\
12 \\
0\end{array}$ & $\begin{array}{l}6.189737 \\
0.012254 \\
0.000172\end{array}$ \\
\hline $\begin{array}{l}108 \\
108 \\
108 \\
\end{array}$ & $\begin{array}{l}14355 \\
14355 \\
14355 \\
\end{array}$ & $\begin{array}{l}\text { Bogs } \\
\text { 8095 } \\
\text { Bogs }\end{array}$ & $\begin{array}{l}10 \\
50 \\
82 \\
\end{array}$ & $\begin{array}{l}v \\
v \\
v\end{array}$ & $\begin{array}{r}0.61 \\
15.74 \\
0\end{array}$ & $\begin{array}{l}0.312363 \\
0.000836 \\
0.000013\end{array}$ \\
\hline $\begin{array}{l}108 \\
108 \\
108\end{array}$ & $\begin{array}{l}14355 \\
14355 \\
14355\end{array}$ & $\begin{array}{l}\text { Xo9c } \\
\text { xo9c } \\
\text { xo9C }\end{array}$ & $\begin{array}{l}10 \\
50 \\
82\end{array}$ & $\begin{array}{l}v \\
v \\
v\end{array}$ & $\begin{array}{r}0.71 \\
15.74 \\
0\end{array}$ & $\begin{array}{l}0.044429 \\
0.000119 \\
0.000002\end{array}$ \\
\hline
\end{tabular}


HNF-SD-SNF-TI-009, Rev. I

\begin{tabular}{|c|c|c|c|c|c|c|}
\hline $\begin{array}{c}\text { Location } \\
\text { Code }\end{array}$ & Key Number & Fuel Model & $\begin{array}{c}\text { Material } \\
\text { Type }\end{array}$ & $\begin{array}{c}\text { sub ID } \\
\text { Code }\end{array}$ & Fuel Type & Isotopio Breakdown \\
\hline
\end{tabular}

\begin{tabular}{|c|c|c|c|c|c|c|}
\hline $\begin{array}{l}108 \\
108 \\
108\end{array}$ & $\begin{array}{l}14355 \\
14355 \\
14355\end{array}$ & $\begin{array}{l}\text { XO9E } \\
\text { XO9E } \\
\text { XO9E }\end{array}$ & $\begin{array}{l}20 \\
50 \\
82\end{array}$ & $\begin{array}{l}v \\
v \\
v\end{array}$ & $\begin{array}{r}0.76 \\
12 \\
0\end{array}$ & $\begin{array}{r}2.910359 \\
0.00576 \\
0.000082\end{array}$ \\
\hline $\begin{array}{l}108 \\
108 \\
108\end{array}$ & $\begin{array}{l}14355 \\
14355 \\
14355\end{array}$ & $\begin{array}{l}\text { xo9s } \\
\text { X09S } \\
\text { X095 }\end{array}$ & $\begin{array}{l}10 \\
50 \\
82\end{array}$ & $\begin{array}{l}v \\
v \\
v\end{array}$ & $\begin{array}{r}0.67 \\
15.74 \\
0\end{array}$ & $\begin{array}{l}0.147105 \\
0.000394 \\
0.000006\end{array}$ \\
\hline $\begin{array}{l}108 \\
108 \\
108\end{array}$ & $\begin{array}{l}14356 \\
14356 \\
14356\end{array}$ & $\begin{array}{l}\text { A09A } \\
\text { A09A } \\
\text { A09A }\end{array}$ & $\begin{array}{l}20 \\
50 \\
82\end{array}$ & $\begin{array}{l}v \\
v \\
v\end{array}$ & $\begin{array}{r}0.81 \\
11.28 \\
0\end{array}$ & $\begin{array}{l}0.180411 \\
0.000283 \\
0.000003\end{array}$ \\
\hline $\begin{array}{l}108 \\
108 \\
108\end{array}$ & $\begin{array}{l}14356 \\
14356 \\
14356\end{array}$ & $\begin{array}{l}\text { A9A } \\
\text { A9A } \\
\text { A9A }\end{array}$ & $\begin{array}{l}20 \\
50 \\
82\end{array}$ & $\begin{array}{l}v \\
v \\
v\end{array}$ & $\begin{array}{r}0.81 \\
11.28 \\
0\end{array}$ & $\begin{array}{l}3.202667 \\
0.005031 \\
0.000059\end{array}$ \\
\hline $\begin{array}{l}108 \\
108 \\
108\end{array}$ & $\begin{array}{l}14356 \\
14356 \\
14356\end{array}$ & $\begin{array}{l}\text { Bo9s } \\
\text { Bo9s } \\
\text { Bo9s }\end{array}$ & $\begin{array}{l}20 \\
50 \\
82\end{array}$ & $\begin{array}{l}v \\
v \\
v\end{array}$ & $\begin{array}{r}0.78 \\
11.28 \\
0\end{array}$ & $\begin{array}{r}0.022 \\
0.000035 \\
4.000-07\end{array}$ \\
\hline $\begin{array}{l}108 \\
108 \\
108\end{array}$ & $\begin{array}{l}14356 \\
14356 \\
14356\end{array}$ & $\begin{array}{l}\text { BXA } \\
\text { BXA } \\
\text { BXA }\end{array}$ & $\begin{array}{l}20 \\
50 \\
82\end{array}$ & $\begin{array}{l}v \\
v \\
v\end{array}$ & $\begin{array}{r}0.75 \\
11.28 \\
0\end{array}$ & $\begin{array}{r}8.148949 \\
0.012802 \\
0.00015\end{array}$ \\
\hline $\begin{array}{l}108 \\
108 \\
108\end{array}$ & $\begin{array}{l}14356 \\
14356 \\
14356\end{array}$ & $\begin{array}{l}\text { BXE } \\
\text { BXE } \\
\text { BXE }\end{array}$ & $\begin{array}{l}20 \\
50 \\
82\end{array}$ & $\begin{array}{l}v \\
v \\
v\end{array}$ & $\begin{array}{r}0.76 \\
11.28 \\
0\end{array}$ & $\begin{array}{l}1.349992 \\
0.002121 \\
0.000025\end{array}$ \\
\hline $\begin{array}{l}108 \\
.108 \\
108\end{array}$ & $\begin{array}{l}14356 \\
14356 \\
14356\end{array}$ & $\begin{array}{l}\text { BXS } \\
\text { BXS } \\
\text { BXS }\end{array}$ & $\begin{array}{l}20 \\
50 \\
82\end{array}$ & $\begin{array}{l}v \\
v \\
v\end{array}$ & $\begin{array}{r}0.74 \\
11.28 \\
0\end{array}$ & $\begin{array}{l}0.371997 \\
0.000584 \\
0.000007\end{array}$ \\
\hline $\begin{array}{l}108 \\
108 \\
108\end{array}$ & $\begin{array}{l}14356 \\
14356 \\
14356\end{array}$ & $\begin{array}{l}\text { NO9A } \\
\text { NO9A } \\
\text { NO9A }\end{array}$ & $\begin{array}{l}20 \\
50 \\
82\end{array}$ & $\begin{array}{l}v \\
v \\
v\end{array}$ & $\begin{array}{r}0.81 \\
11.28 \\
0\end{array}$ & $\begin{array}{l}0.084899 \\
0.000133 \\
0.000002\end{array}$ \\
\hline $\begin{array}{l}108 \\
108 \\
108\end{array}$ & $\begin{array}{l}14356 \\
14356 \\
14356\end{array}$ & $\begin{array}{l}\text { XO9E } \\
\text { X09E } \\
\text { X09E }\end{array}$ & $\begin{array}{l}20 \\
50 \\
82\end{array}$ & $\begin{array}{l}v \\
v \\
v\end{array}$ & $\begin{array}{r}0.81 \\
11.28 \\
0\end{array}$ & $\begin{array}{r}0.1035 \\
0.000163 \\
0.000002\end{array}$ \\
\hline $\begin{array}{l}108 \\
108 \\
108\end{array}$ & $\begin{array}{l}14722 \\
14722 \\
14722\end{array}$ & $\begin{array}{l}\text { B7E } \\
\text { B7E } \\
\text { B7E }\end{array}$ & $\begin{array}{l}10 \\
50 \\
82\end{array}$ & $\begin{array}{l}v \\
v \\
v\end{array}$ & $\begin{array}{r}0.65 \\
5.05 \\
0 \\
\end{array}$ & $\begin{array}{r}0.068792 \\
0.00005 \\
5.40 e-07\end{array}$ \\
\hline $\begin{array}{l}108 \\
108 \\
108\end{array}$ & $\begin{array}{l}15204 \\
15204 \\
15204\end{array}$ & $\begin{array}{l}\text { BO9E } \\
\text { BO9E } \\
\text { BO9E }\end{array}$ & $\begin{array}{l}20 \\
50 \\
82\end{array}$ & $\begin{array}{l}v \\
v \\
v\end{array}$ & $\begin{array}{r}0.85 \\
6.01 \\
0\end{array}$ & $\begin{array}{r}0.015905 \\
0.000014 \\
1.60 e-07\end{array}$ \\
\hline $\begin{array}{l}108 \\
108 \\
108\end{array}$ & $\begin{array}{l}15204 \\
15204 \\
15204\end{array}$ & $\begin{array}{l}\text { B7E } \\
\text { B7E } \\
\text { B7E }\end{array}$ & $\begin{array}{l}10 \\
50 \\
82\end{array}$ & $\begin{array}{l}v \\
v \\
v\end{array}$ & $\begin{array}{r}0.65 \\
5.53 \\
0\end{array}$ & $\begin{array}{r}0.35096 \\
0.000281 \\
0.000003\end{array}$ \\
\hline $\begin{array}{l}108 \\
108 \\
108\end{array}$ & $\begin{array}{l}15204 \\
15204 \\
15204\end{array}$ & $\begin{array}{l}\text { BXA } \\
\text { BXA } \\
\text { BXA }\end{array}$ & $\begin{array}{l}20 \\
50 \\
82\end{array}$ & $\begin{array}{l}v \\
v \\
v\end{array}$ & $\begin{array}{r}0.85 \\
6.01 \\
0\end{array}$ & $\begin{array}{r}14.29324 \\
0.01245 \\
0.000145\end{array}$ \\
\hline $\begin{array}{l}108 \\
108 \\
108\end{array}$ & $\begin{array}{l}15204 \\
15204 \\
15204\end{array}$ & $\begin{array}{l}\text { BXC } \\
\text { BXC } \\
\text { BXC }\end{array}$ & $\begin{array}{l}20 \\
50 \\
82\end{array}$ & $\begin{array}{l}v \\
v \\
v\end{array}$ & $\begin{array}{r}0.85 \\
6.01 \\
0\end{array}$ & $\begin{array}{r}3.16191 \\
0.002754 \\
0.000033\end{array}$ \\
\hline $\begin{array}{l}108 \\
108 \\
108\end{array}$ & $\begin{array}{r}15204 \\
15204 \\
.15204\end{array}$ & $\begin{array}{l}\text { BXE } \\
\text { BXE } \\
\text { BXE }\end{array}$ & $\begin{array}{l}20 \\
50 \\
82\end{array}$ & $\begin{array}{l}v \\
v \\
v\end{array}$ & $\begin{array}{r}0.85 \\
6.01 \\
0\end{array}$ & $\begin{array}{r}59.433 \\
0.051786 \\
0.00061\end{array}$ \\
\hline $\begin{array}{l}108 \\
108 \\
108\end{array}$ & $\begin{array}{l}15204 \\
15204 \\
15204\end{array}$ & $\begin{array}{l}\text { BXs } \\
\text { BXs } \\
\text { BXs }\end{array}$ & $\begin{array}{l}20 \\
50 \\
82\end{array}$ & $\begin{array}{l}v \\
v \\
v\end{array}$ & $\begin{array}{r}0.85 \\
6.01 \\
0\end{array}$ & $\begin{array}{l}20.09126 \\
0.017503 \\
0.000201\end{array}$ \\
\hline $\begin{array}{l}108 \\
108 \\
108\end{array}$ & $\begin{array}{l}15204 \\
15204 \\
15204\end{array}$ & $\begin{array}{l}\text { XO9E } \\
\text { XO9E } \\
\text { XO9E }\end{array}$ & $\begin{array}{l}20 \\
50 \\
82\end{array}$ & $\begin{array}{l}v \\
v \\
v\end{array}$ & $\begin{array}{r}0.85 \\
6.01 \\
0\end{array}$ & $\begin{array}{r}0.007485 \\
0.000007 \\
8.00 \mathrm{e}-08\end{array}$ \\
\hline
\end{tabular}


HNF-SD-SNF-TI-009, Rev. 1

\begin{tabular}{|c|c|c|c|c|c|c|}
\hline $\begin{array}{c}\text { Location } \\
\text { Code }\end{array}$ & Key Number & Fuel Model & $\begin{array}{c}\text { Material } \\
\text { Type }\end{array}$ & $\begin{array}{c}\text { sub ID } \\
\text { Code }\end{array}$ & Fuel Type & Isotopic Breakdown \\
\hline
\end{tabular}

\begin{tabular}{|c|c|c|c|c|c|c|}
\hline $\begin{array}{l}108 \\
108 \\
108\end{array}$ & $\begin{array}{l}15240 \\
15240 \\
15240\end{array}$ & $\begin{array}{l}\text { BO9E } \\
\text { BO9E } \\
\text { BO9E }\end{array}$ & $\begin{array}{l}20 \\
50 \\
82\end{array}$ & $\begin{array}{l}v \\
v \\
v\end{array}$ & $\begin{array}{r}0.86 \\
5.6 \\
0\end{array}$ & $\begin{array}{r}0.015906 \\
0.000013 \\
1.400-07\end{array}$ \\
\hline $\begin{array}{l}108 \\
108 \\
108\end{array}$ & $\begin{array}{l}15240 \\
15240 \\
15240\end{array}$ & $\begin{array}{l}\text { B7E } \\
\text { B7E } \\
\text { B7E }\end{array}$ & $\begin{array}{l}10 \\
50 \\
82\end{array}$ & $\begin{array}{l}v \\
v \\
v\end{array}$ & $\begin{array}{r}0.65 \\
5.71 \\
0\end{array}$ & $\begin{array}{r}0.374369 \\
0.00043 \\
0.000005\end{array}$ \\
\hline $\begin{array}{l}108 \\
108 \\
108\end{array}$ & $\begin{array}{l}15240 \\
15240 \\
15240\end{array}$ & $\begin{array}{l}\text { BXS } \\
\text { BXS } \\
\text { BXS }\end{array}$ & $\begin{array}{l}20 \\
50 \\
82\end{array}$ & $\begin{array}{l}v \\
v \\
v\end{array}$ & $\begin{array}{r}0.86 \\
5.6 \\
0\end{array}$ & $\begin{array}{r}0.087938 \\
0.000069 \\
7.600-07\end{array}$ \\
\hline $\begin{array}{l}108 \\
108 \\
108\end{array}$ & $\begin{array}{l}15240 \\
15240 \\
15240\end{array}$ & $\begin{array}{l}X 09 A \\
\times 09 A \\
X 09 A\end{array}$ & $\begin{array}{l}20 \\
50 \\
82\end{array}$ & $\begin{array}{l}v \\
v \\
v\end{array}$ & $\begin{array}{r}0.87 \\
5.6 \\
0\end{array}$ & $\begin{array}{r}0.006639 \\
0.000005 \\
6.00 \mathrm{e}-08\end{array}$ \\
\hline $\begin{array}{l}108 \\
108 \\
108\end{array}$ & $\begin{array}{l}15240 \\
15240 \\
15240\end{array}$ & $\begin{array}{l}\text { xogs } \\
\text { xogs } \\
\text { xo9s }\end{array}$ & $\begin{array}{l}20 \\
50 \\
82\end{array}$ & $\begin{array}{l}v \\
v \\
v\end{array}$ & $\begin{array}{r}0.86 \\
5.6 \\
0\end{array}$ & $\begin{array}{r}0.007035 \\
0.000006 \\
6.00 e-08\end{array}$ \\
\hline $\begin{array}{l}108 \\
108 \\
108\end{array}$ & $\begin{array}{l}15316 \\
15316 \\
15316\end{array}$ & $\begin{array}{l}\text { BXA } \\
\text { BXA } \\
\text { BXA }\end{array}$ & $\begin{array}{l}20 \\
50 \\
82\end{array}$ & $\begin{array}{l}v \\
v \\
v\end{array}$ & $\begin{array}{r}0.85 \\
6.1 \\
0\end{array}$ & $\begin{array}{l}10.03809 \\
0.008775 \\
0.000106\end{array}$ \\
\hline $\begin{array}{l}108 \\
108 \\
108\end{array}$ & $\begin{array}{l}15316 \\
15316 \\
15316\end{array}$ & $\begin{array}{l}\text { BXC } \\
\text { BXC } \\
\text { BXC }\end{array}$ & $\begin{array}{l}20 \\
50 \\
82 \\
\end{array}$ & $\begin{array}{l}v \\
v \\
v\end{array}$ & $\begin{array}{r}0.86 \\
6.1 \\
0 \\
\end{array}$ & $\begin{array}{l}0.185878 \\
0.000163 \\
0.000002\end{array}$ \\
\hline $\begin{array}{l}108 \\
108 \\
108 \\
\end{array}$ & $\begin{array}{l}15316 \\
15316 \\
15316\end{array}$ & $\begin{array}{l}\text { BXE } \\
\text { BXE } \\
\text { BXE }\end{array}$ & $\begin{array}{l}20 \\
50 \\
82 \\
\end{array}$ & $\begin{array}{l}v \\
v \\
v\end{array}$ & $\begin{array}{r}0.85 \\
6.1 \\
0 \\
\end{array}$ & $\begin{array}{l}4.958521 \\
0.004338 \\
0.000053\end{array}$ \\
\hline $\begin{array}{l}108 \\
108 \\
108\end{array}$ & $\begin{array}{l}15316 \\
15316 \\
15316\end{array}$ & $\begin{array}{l}\text { BXS } \\
\text { BXS } \\
\text { BXS }\end{array}$ & $\begin{array}{l}20 \\
50 \\
82\end{array}$ & $\begin{array}{l}\mathrm{v} \\
\mathrm{v} \\
\mathrm{v}\end{array}$ & $\begin{array}{r}0.86 \\
6.1 \\
0\end{array}$ & $\begin{array}{l}4.330962 \\
0.003786 \\
0.000047\end{array}$ \\
\hline $\begin{array}{l}108 \\
108 \\
108\end{array}$ & $\begin{array}{l}15316 \\
15316 \\
15316\end{array}$ & $\begin{array}{l}\text { XO9E } \\
\times 09 E \\
X 09 E\end{array}$ & $\begin{array}{l}20 \\
50 \\
82 \\
\end{array}$ & $\begin{array}{l}v \\
v \\
v\end{array}$ & $\begin{array}{r}0.85 \\
6.1 \\
0\end{array}$ & $\begin{array}{r}0.007485 \\
0.000007 \\
8.00 \mathrm{e}-08 \\
\end{array}$ \\
\hline 108 & 15399 & BXE & 20 & $v$ & 0.95 & 0.374485 \\
\hline $\begin{array}{l}108 \\
108 \\
108\end{array}$ & $\begin{array}{l}15444 \\
15444 \\
15444\end{array}$ & $\begin{array}{l}\text { 8XA } \\
\text { BXA } \\
\text { BXA }\end{array}$ & $\begin{array}{l}20 \\
50 \\
82 \\
\end{array}$ & $\begin{array}{l}v \\
v \\
v\end{array}$ & $\begin{array}{r}0.88 \\
4.7 \\
0 \\
\end{array}$ & $\begin{array}{r}0.103645 \\
0.00006 \\
6.50 \mathrm{e}-07 \\
\end{array}$ \\
\hline $\begin{array}{l}108 \\
108 \\
108\end{array}$ & $\begin{array}{l}15444 \\
15444 \\
15444\end{array}$ & $\begin{array}{l}\text { BXE } \\
\text { BXE } \\
\text { BXE }\end{array}$ & $\begin{array}{l}20 \\
50 \\
82\end{array}$ & $\begin{array}{l}v \\
v \\
v\end{array}$ & $\begin{array}{r}0.89 \\
4.7 \\
0 \\
\end{array}$ & $\begin{array}{r}0.116888 \\
0.000068 \\
7.500-07\end{array}$ \\
\hline $\begin{array}{l}108 \\
108 \\
108\end{array}$ & $\begin{array}{l}15444 \\
15444 \\
15444\end{array}$ & $\begin{array}{l}\text { BXS } \\
\text { BXS } \\
\text { BXS }\end{array}$ & $\begin{array}{l}20 \\
50 \\
82\end{array}$ & $\begin{array}{l}\mathrm{v} \\
\mathrm{V} \\
\mathrm{V}\end{array}$ & $\begin{array}{r}0.89 \\
4.7 \\
0\end{array}$ & $\begin{array}{r}0.08789 \\
0.000051 \\
5.200-07\end{array}$ \\
\hline $\begin{array}{l}108 \\
108 \\
108\end{array}$ & $\begin{array}{l}15451 \\
15451 \\
15451\end{array}$ & $\begin{array}{l}\text { B7E } \\
\text { B7E } \\
\text { B7E }\end{array}$ & $\begin{array}{l}10 \\
50 \\
82\end{array}$ & $\begin{array}{l}v \\
V \\
V\end{array}$ & $\begin{array}{r}0.66 \\
4.97 \\
0\end{array}$ & $\begin{array}{r}1.496212 \\
0.000914 \\
0.00001\end{array}$ \\
\hline $\begin{array}{l}108 \\
108 \\
108\end{array}$ & $\begin{array}{l}15451 \\
15451 \\
15451\end{array}$ & $\begin{array}{l}\text { BXA } \\
\text { BXA } \\
\text { BXA }\end{array}$ & $\begin{array}{l}20 \\
50 \\
82 \\
\end{array}$ & $\begin{array}{l}v \\
v \\
v\end{array}$ & $\begin{array}{r}0.83 \\
6.79 \\
0 \\
\end{array}$ & $\begin{array}{l}6.792276 \\
0.007239 \\
0.000082\end{array}$ \\
\hline $\begin{array}{l}108 \\
108 \\
108\end{array}$ & $\begin{array}{l}15451 \\
15451 \\
15451\end{array}$ & $\begin{array}{l}\text { BXC } \\
\text { BXC } \\
\text { BXC }\end{array}$ & $\begin{array}{l}20 \\
50 \\
82 \\
\end{array}$ & $\begin{array}{l}v \\
v \\
v \\
\end{array}$ & $\begin{array}{r}0.83 \\
6.79 \\
0 \\
\end{array}$ & $\begin{array}{l}0.092584 \\
0.000099 \\
0.000001\end{array}$ \\
\hline $\begin{array}{l}108 \\
108 \\
108\end{array}$ & $\begin{array}{l}15451 \\
15451 \\
15451\end{array}$ & $\begin{array}{l}\text { BXS } \\
\text { BXS } \\
\text { BXS }\end{array}$ & $\begin{array}{l}20 \\
50 \\
82 \\
\end{array}$ & $\begin{array}{l}v \\
v \\
v \\
\end{array}$ & $\begin{array}{r}0.9 \\
6.79 \\
0 \\
\end{array}$ & $\begin{array}{r}0.04396 \\
0.000047 \\
5.40 \mathrm{e}-07 \\
\end{array}$ \\
\hline $\begin{array}{l}108 \\
108 \\
108\end{array}$ & $\begin{array}{l}15455 \\
15455 \\
15455\end{array}$ & $\begin{array}{l}\text { BXA } \\
\text { BXA } \\
\text { BXA }\end{array}$ & $\begin{array}{l}20 \\
50 \\
82\end{array}$ & $\begin{array}{l}v \\
v \\
v\end{array}$ & $\begin{array}{r}0.86 \\
4.94 \\
0\end{array}$ & $\begin{array}{l}0.372934 \\
0.000225 \\
0.000002\end{array}$ \\
\hline
\end{tabular}


HNF-SD-SNF-TI-009, Rev . 1

\begin{tabular}{|c|c|c|c|c|c|c|c|}
\hline $\begin{array}{c}\text { Location } \\
\text { Code }\end{array}$ & Key Number & Fuel Model & $\begin{array}{c}\text { Material } \\
\text { Type }\end{array}$ & $\begin{array}{c}\text { sub ID } \\
\text { Code }\end{array}$ & Fuel Type & Isotopic Breakdown & Discharge Mass \\
\hline
\end{tabular}

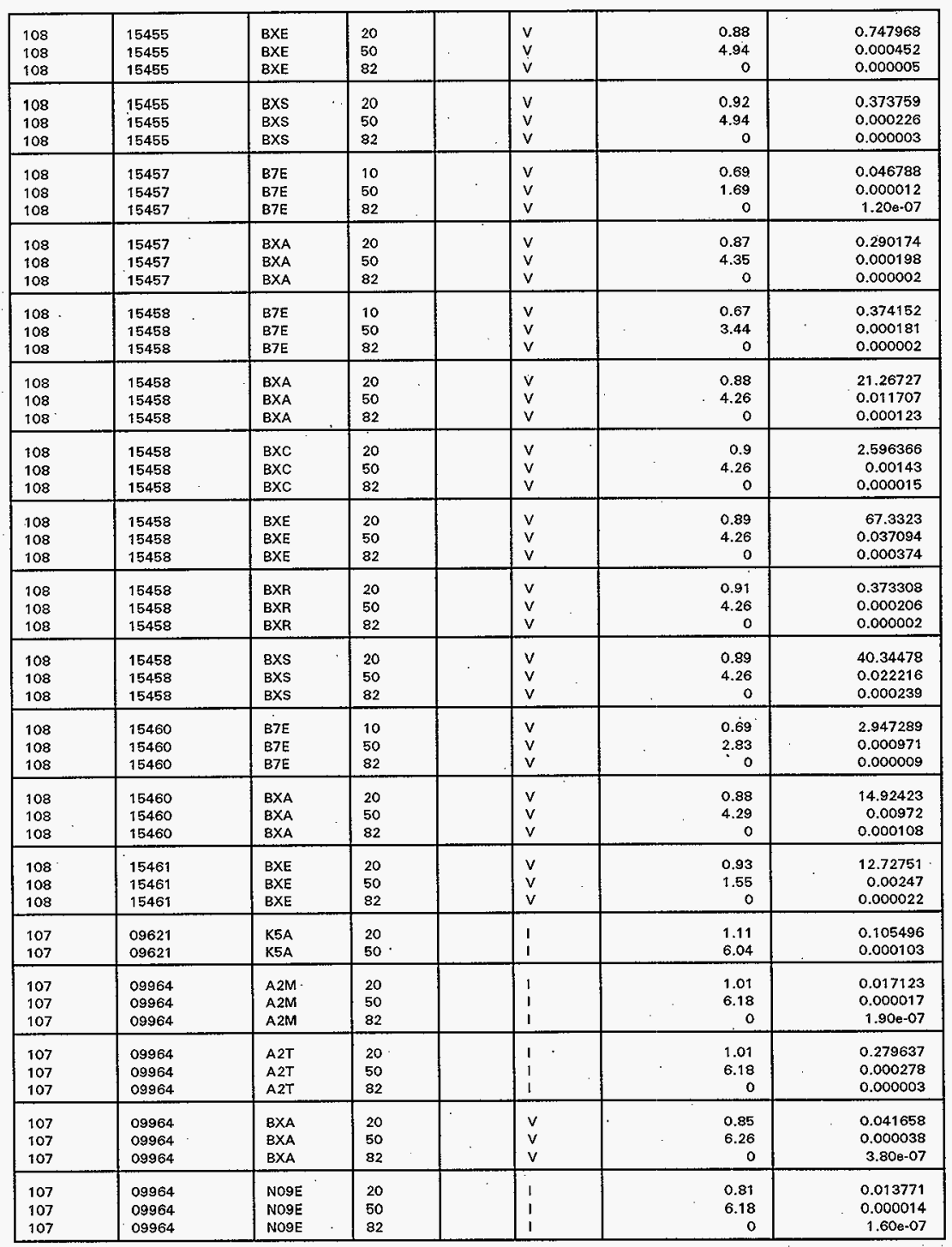


HNF-SD-SNF-TI-009, Rev. 1

\begin{tabular}{|c|c|c|c|c|c|c|}
\hline $\begin{array}{c}\text { Location } \\
\text { Code }\end{array}$ & Key Number & Fuel Model & $\begin{array}{c}\text { Material } \\
\text { Type }\end{array}$ & $\begin{array}{c}\text { sub to } \\
\text { Code }\end{array}$ & Fuel Typo & Isotopic Breakdown \\
\hline
\end{tabular}

\begin{tabular}{|c|c|c|c|c|c|c|}
\hline $\begin{array}{l}107 \\
107 \\
107\end{array}$ & $\begin{array}{l}09964 \\
09964 \\
09964\end{array}$ & $\begin{array}{l}\text { NO9F } \\
\text { NO9F } \\
\text { NO9F }\end{array}$ & $\begin{array}{l}20 \\
50 \\
82 \\
\end{array}$ & $\begin{array}{l}1 \\
1 \\
1\end{array}$ & $\begin{array}{r}0.81 \\
6.18 \\
0\end{array}$ & $\begin{array}{r}0.003879 \\
0.000004 \\
4.000-08\end{array}$ \\
\hline $\begin{array}{l}107 \\
107 \\
107\end{array}$ & $\begin{array}{l}09964 \\
09964 \\
09964\end{array}$ & $\begin{array}{l}\text { NOSM } \\
\text { NOSM } \\
\text { NOSM }\end{array}$ & $\begin{array}{l}20 \\
50 \\
82\end{array}$ & $\begin{array}{l}1 \\
1 \\
1\end{array}$ & $\begin{array}{r}0.81 \\
6.18 \\
0\end{array}$ & $\begin{array}{r}0.00548 \\
0.000005 \\
6.00 \mathrm{e}-08\end{array}$ \\
\hline $\begin{array}{l}107 \\
107 \\
107\end{array}$ & $\begin{array}{l}09964 \\
09964 \\
09964\end{array}$ & $\begin{array}{l}X 09 A \\
X 09 A \\
X 09 A\end{array}$ & $\begin{array}{l}20 \\
50 \\
82\end{array}$ & $\begin{array}{l}v \\
v \\
v\end{array}$ & $\begin{array}{r}0.85 \\
6.26 \\
0\end{array}$ & $\begin{array}{l}0.03334 \\
0.00003 \\
3.00 \mathrm{e}-07\end{array}$ \\
\hline $\begin{array}{l}107 . \\
107 \\
107\end{array}$ & $\begin{array}{l}09993 \\
09993 \\
09993\end{array}$ & $\begin{array}{l}\text { A2F } \\
\text { A2F } \\
\text { A2F }\end{array}$ & $\begin{array}{l}20 \\
50 \\
82\end{array}$ & $\begin{array}{l}1 \\
1 \\
1\end{array}$ & $\begin{array}{r}0.91 \\
10.29 \\
0\end{array}$ & $\begin{array}{l}0.246184 \\
0.000405 \\
0.000005\end{array}$ \\
\hline $\begin{array}{l}107 \\
107 \\
107\end{array}$ & $\begin{array}{l}09993 \\
09993 \\
09993\end{array}$ & $\begin{array}{l}\text { A2M } \\
\text { A2M } \\
\text { A2M }\end{array}$ & $\begin{array}{l}20 \\
50 \\
82\end{array}$ & $\begin{array}{l}1 \\
1 \\
1\end{array}$ & $\begin{array}{r}0.91 \\
10.29 \\
0\end{array}$ & $\begin{array}{l}4.636134 \\
0.007627 \\
0.000104\end{array}$ \\
\hline $\begin{array}{l}107 \\
107 \\
107\end{array}$ & $\begin{array}{l}09993 \\
09993 \\
09993\end{array}$ & $\begin{array}{l}\text { A2T } \\
\text { A2T } \\
\text { A2T }\end{array}$ & $\begin{array}{l}20 \\
50 \\
82 \\
\end{array}$ & $\begin{array}{l}1 \\
1 \\
1\end{array}$ & $\begin{array}{r}0.91 \\
10.29 \\
0\end{array}$ & $\begin{array}{l}3.566373 \\
0.005865 \\
0.000078\end{array}$ \\
\hline $\begin{array}{l}107 \\
107 \\
107 \\
\end{array}$ & $\begin{array}{l}10001 \\
10001 \\
10001 \\
\end{array}$ & $\begin{array}{l}\text { BO9C } \\
\text { BO9C } \\
\text { BO9C } \\
\end{array}$ & $\begin{array}{l}10 \\
50 \\
82 \\
\end{array}$ & $\begin{array}{l}v \\
v \\
v \\
\end{array}$ & $\begin{array}{r}0.71 \\
13.59 \\
0 \\
\end{array}$ & $\begin{array}{r}0.03156 \\
0.000064 \\
9.00 e-07\end{array}$ \\
\hline $\begin{array}{l}107 \\
107 \\
107\end{array}$ & $\begin{array}{l}10001 \\
10001 \\
10001\end{array}$ & $\begin{array}{l}\text { BO9E } \\
\text { BO9E } \\
\text { BO9E }\end{array}$ & $\begin{array}{l}10 \\
50 \\
82\end{array}$ & $\begin{array}{l}v \\
v \\
v\end{array}$ & $\begin{array}{r}0.71 \\
13.59 \\
0\end{array}$ & $\begin{array}{r}0.03169 \\
0.000064 \\
9.008-07\end{array}$ \\
\hline $\begin{array}{l}107 \\
107 \\
107\end{array}$ & $\begin{array}{l}10001 \\
10001 \\
10001 \\
\end{array}$ & $\begin{array}{l}\text { BO9R } \\
\text { BO9R } \\
\text { BO9R }\end{array}$ & $\begin{array}{l}20 \\
50 \\
82 \\
\end{array}$ & $\begin{array}{l}v \\
v \\
v \\
\end{array}$ & $\begin{array}{r}0.88 \\
5.61 \\
0 \\
\end{array}$ & $\begin{array}{r}0.013353 \\
0.000011 \\
1.30 \mathrm{e}-07\end{array}$ \\
\hline $\begin{array}{l}107 \\
107 \\
107 \\
\end{array}$ & $\begin{array}{l}10001 \\
10001 \\
10001 \\
\end{array}$ & $\begin{array}{l}\text { Bogs } \\
\text { Bogs } \\
\text { Bogs }\end{array}$ & $\begin{array}{l}10 \\
50 \\
82 \\
\end{array}$ & $\begin{array}{l}v \\
v \\
v\end{array}$ & $\begin{array}{r}0.71 \\
13.59 \\
0 \\
\end{array}$ & $\begin{array}{r}0.029772 \\
0.00006 \\
8.60 \mathrm{e} \cdot 07\end{array}$ \\
\hline $\begin{array}{l}107 \\
107 \\
107\end{array}$ & $\begin{array}{l}10001 \\
10001 \\
10001\end{array}$ & $\begin{array}{l}\text { BXE } \\
\text { BXE } \\
\text { BXE }\end{array}$ & $\begin{array}{l}10 \\
50 \\
82 \\
\end{array}$ & $\begin{array}{l}v \\
v \\
v\end{array}$ & $\begin{array}{r}0.71 \\
13.59 \\
0 \\
\end{array}$ & $\begin{array}{r}0.72243 \\
0.001455 \\
0.00002\end{array}$ \\
\hline $\begin{array}{l}107 \\
107 \\
107 \\
\end{array}$ & $\begin{array}{l}10001 \\
10001 \\
10001\end{array}$ & $\begin{array}{l}\text { BXR } \\
\text { BXR } \\
\text { BXR } \\
\end{array}$ & $\begin{array}{l}20 \\
50 \\
82 \\
\end{array}$ & $\begin{array}{l}v \\
v \\
v\end{array}$ & $\begin{array}{r}0.88 \\
5.61 \\
-\quad 0 \\
\end{array}$ & $\begin{array}{r}0.019638 \\
0.000016 \\
1.900 .07\end{array}$ \\
\hline $\begin{array}{l}107 \\
107 \\
107\end{array}$ & $\begin{array}{l}10001 \\
10001 \\
10001\end{array}$ & $\begin{array}{l}\text { BXs } \\
\text { BXS } \\
\text { BXs }\end{array}$ & $\begin{array}{l}20 \\
50 \\
82 \\
\end{array}$ & $\begin{array}{l}v \\
v \\
v\end{array}$ & $\begin{array}{r}0.86 \\
5.61 \\
0\end{array}$ & $\begin{array}{r}0.021922 \\
0.000018 \\
2.10 e \cdot 07\end{array}$ \\
\hline $\begin{array}{l}107 \\
107 \\
107 \\
\end{array}$ & $\begin{array}{l}10001 \\
10001 \\
10001\end{array}$ & $\begin{array}{l}\text { XOgE } \\
\text { XOSE } \\
\text { XOSE }\end{array}$ & $\begin{array}{l}10 \\
50 \\
82 \\
\end{array}$ & $\begin{array}{l}v \\
v \\
v\end{array}$ & $\begin{array}{r}0.7 \\
13.59 \\
0 \\
\end{array}$ & $\begin{array}{r}0.007459 \\
0.000015 \\
2.10 e-07 \\
\end{array}$ \\
\hline $\begin{array}{l}107 \\
107 \\
107 \\
\end{array}$ & $\begin{array}{l}10001 \\
10001 \\
10001 \\
\end{array}$ & $\begin{array}{l}\text { XO9R } \\
\text { XO9R } \\
\text { XO9R } \\
\end{array}$ & $\begin{array}{l}20 \\
50 \\
82 \\
\end{array}$ & $\begin{array}{l}v \\
v \\
v\end{array}$ & $\begin{array}{r}0.88 \\
5.61 \\
0\end{array}$ & $\begin{array}{r}0.006284 \\
0.000005 \\
6.006-08\end{array}$ \\
\hline $\begin{array}{l}107 \\
107 \\
107 \\
\end{array}$ & $\begin{array}{l}10001 \\
10001 \\
10001 \\
\end{array}$ & $\begin{array}{l}\text { xo9s } \\
\text { xo9s } \\
\text { xo9s } \\
\end{array}$ & $\begin{array}{l}10 \\
50 \\
82 \\
\end{array}$ & $\begin{array}{l}v \\
v \\
v\end{array}$ & $\begin{array}{r}0.71 \\
13.59 \\
0 \\
\end{array}$ & $\begin{array}{r}0.01401 \\
0.000028 \\
4.00 e-07 \\
\end{array}$ \\
\hline $\begin{array}{l}107 \\
107 \\
107\end{array}$ & $\begin{array}{l}10201 \\
10201 \\
10201\end{array}$ & $\begin{array}{l}\text { A2E } \\
\text { A2E } \\
\text { A2E }\end{array}$ & $\begin{array}{l}20 \\
50 \\
82\end{array}$ & $\begin{array}{l}1 \\
1 \\
1\end{array}$ & $\begin{array}{r}0.94 \\
9.22 \\
0 \\
\end{array}$ & $\begin{array}{r}0.24942 \\
0.000368 \\
0.000005\end{array}$ \\
\hline $\begin{array}{l}107 \\
107 \\
107\end{array}$ & $\begin{array}{l}10201 \\
10201 \\
10201\end{array}$ & $\begin{array}{l}\text { A2F } \\
\text { A2F } \\
\text { A2F }\end{array}$ & $\begin{array}{l}20 \\
50 \\
82\end{array}$ & $\begin{array}{l}1 \\
1 \\
1\end{array}$ & $\begin{array}{r}0.94 \\
9.22 \\
0\end{array}$ & $\begin{array}{l}0.489995 \\
0.000723 \\
0.000009\end{array}$ \\
\hline
\end{tabular}


HNF-SD-SNF-TI-009, Rev. 1

\begin{tabular}{|c|c|c|c|c|c|c|}
\hline $\begin{array}{c}\text { Location } \\
\text { Code }\end{array}$ & Key Number & Fuel Model & $\begin{array}{c}\text { Material } \\
\text {-Type }\end{array}$ & $\begin{array}{c}\text { sub ID } \\
\text { Code }\end{array}$ & Fuel Type & Isotopic Breakdown \\
\hline
\end{tabular}

\begin{tabular}{|c|c|c|c|c|c|c|}
\hline $\begin{array}{l}107 \\
107 \\
107\end{array}$ & $\begin{array}{l}10201 \\
10201 \\
10201\end{array}$ & $\begin{array}{l}\text { A2M } \\
\text { A2M } \\
\text { A2M }\end{array}$ & $\begin{array}{l}20 \\
50 \\
82\end{array}$ & $\begin{array}{l}1 \\
1 \\
1\end{array}$ & $\begin{array}{r}0.94 \\
9.22 \\
0\end{array}$ & $\begin{array}{l}12.12241 \\
0.017897 \\
0.000228\end{array}$ \\
\hline $\begin{array}{l}107 \\
107 \\
107\end{array}$ & $\begin{array}{l}10201 \\
10201 \\
10201\end{array}$ & $\begin{array}{l}\text { A2T } \\
\text { A2T } \\
\text { A2T }\end{array}$ & $\begin{array}{l}20 \\
50 \\
82\end{array}$ & $\begin{array}{l}1 \\
1 \\
1\end{array}$ & $\begin{array}{r}0.94 \\
9.22 \\
0\end{array}$ & $\begin{array}{l}1.234542 \\
0.001822 \\
0.000023\end{array}$ \\
\hline $\begin{array}{l}107 \\
107 \\
107\end{array}$ & $\begin{array}{l}10259 \\
10259 \\
10259\end{array}$ & $\begin{array}{l}\text { A2F } \\
\text { A2F } \\
\text { A2F }\end{array}$ & $\begin{array}{l}20 \\
50 \\
82\end{array}$ & $\begin{array}{l}1 \\
1 \\
1\end{array}$ & $\begin{array}{r}0.91 \\
10.35 \\
0\end{array}$ & $\begin{array}{l}0.734838 \\
0.001217 \\
0.000016\end{array}$ \\
\hline $\begin{array}{l}107 \\
107 \\
107\end{array}$ & $\begin{array}{l}10259 \\
10259 \\
10259\end{array}$ & $\begin{array}{l}\text { A2M } \\
\text { A2M } \\
\text { A2M }\end{array}$ & $\begin{array}{l}20 \\
50 \\
82\end{array}$ & $\begin{array}{l}1 \\
1 \\
1\end{array}$ & $\begin{array}{r}0.91 \\
10.35 \\
0\end{array}$ & $\begin{array}{r}2.225036 \\
0.003683 \\
0.00005\end{array}$ \\
\hline $\begin{array}{l}107 \\
107 \\
107 \\
\end{array}$ & $\begin{array}{l}10294 \\
10294 \\
10294\end{array}$ & $\begin{array}{l}\text { A2M } \\
\text { A2M } \\
\text { A2M }\end{array}$ & $\begin{array}{l}20 \\
50 \\
82 \\
\end{array}$ & $\begin{array}{l}1 \\
1 \\
1 \\
\end{array}$ & $\begin{array}{r}0.93 \\
9.8 \\
0 \\
\end{array}$ & $\begin{array}{r}19.05676 \\
0.02994 \\
0.000393 \\
\end{array}$ \\
\hline $\begin{array}{l}107 \\
107 \\
107 \\
\end{array}$ & $\begin{array}{l}10294 \\
10294 \\
10294 \\
\end{array}$ & $\begin{array}{l}\mathrm{A} 2 \mathrm{~T} \\
\mathrm{~A} 2 \mathrm{~T} \\
\mathrm{~A} 2 \mathrm{~T}\end{array}$ & $\begin{array}{l}20 \\
50 \\
82 \\
\end{array}$ & $\begin{array}{l}1 \\
1 \\
1\end{array}$ & $\begin{array}{r}0.93 \\
9.8 \\
0 \\
\end{array}$ & $\begin{array}{r}0.06176 \\
0.000097 \\
0.000001 \\
\end{array}$ \\
\hline $\begin{array}{l}107 \\
107 \\
107 \\
\end{array}$ & $\begin{array}{l}10350 \\
10350 \\
10350 \\
\end{array}$ & $\begin{array}{l}\text { A } 12 M \\
\text { A12M } \\
\text { A12M }\end{array}$ & $\begin{array}{l}20 \\
50 \\
82 \\
\end{array}$ & $\begin{array}{l}1 \\
1 \\
1 \\
\end{array}$ & $\begin{array}{r}0.9 \\
10.65 \\
0 \\
\end{array}$ & $\begin{array}{r}0.01099 \\
0.000019 \\
2.60 e-07 \\
\end{array}$ \\
\hline $\begin{array}{l}107 \\
107 \\
107 \\
\end{array}$ & $\begin{array}{l}10350 \\
10350 \\
10350 \\
\end{array}$ & $\begin{array}{l}\text { A2F } \\
\text { A2F } \\
\text { A2F }\end{array}$ & $\begin{array}{l}20 \\
50 \\
82 \\
\end{array}$ & $\begin{array}{l}1 \\
1 \\
1\end{array}$ & $\begin{array}{r}0.9 \\
10.65 \\
0 \\
\end{array}$ & $\begin{array}{l}1.306433 \\
0.002225 \\
0.000031 \\
\end{array}$ \\
\hline $\begin{array}{l}107 \\
107 \\
107\end{array}$ & $\begin{array}{l}10350 \\
10350 \\
10350\end{array}$ & $\begin{array}{l}\text { A2M } \\
\text { A2M } \\
\text { A2M }\end{array}$ & $\begin{array}{l}20 \\
50 \\
82\end{array}$ & $\begin{array}{l}1 \\
1 \\
1 \\
\end{array}$ & $\begin{array}{r}0.9 \\
10.65 \\
0 \\
\end{array}$ & $\begin{array}{l}13.56264 \\
0.023102 \\
0.000313 \\
\end{array}$ \\
\hline $\begin{array}{l}107 \\
107 \\
107\end{array}$ & $\begin{array}{l}10350 \\
10350 \\
10350\end{array}$ & $\begin{array}{l}\text { A2T } \\
\text { A2T } \\
\text { A2T }\end{array}$ & $\begin{array}{l}20 \\
50 \\
82\end{array}$ & $\begin{array}{l}1 \\
1 \\
1\end{array}$ & $\begin{array}{r}0.9 \\
10.65 \\
0 \\
\end{array}$ & $\begin{array}{l}0.895177 \\
0.001524 \\
0.000021\end{array}$ \\
\hline $\begin{array}{l}107 \\
107 \\
107\end{array}$ & $\begin{array}{l}10350 \\
10350 \\
10350\end{array}$ & $\begin{array}{l}\text { NO9M } \\
\text { NO9M } \\
\text { NO9M } \\
\end{array}$ & $\begin{array}{l}20 \\
50 \\
82 \\
\end{array}$ & $\begin{array}{l}1 \\
1 \\
1\end{array}$ & $\begin{array}{r}0.9 \\
10.65 \\
0 \\
\end{array}$ & $\begin{array}{r}0.005494 \\
0.000009 \\
1.30 \mathrm{e} \cdot 07 \\
\end{array}$ \\
\hline $\begin{array}{l}107 \\
107 \\
107\end{array}$ & $\begin{array}{l}10385 \\
10385 \\
10385\end{array}$ & $\begin{array}{l}A 12 M \\
A 12 M \\
A 12 M\end{array}$ & $\begin{array}{l}20 \\
50 \\
82\end{array}$ & $\begin{array}{l}1 \\
1 \\
1\end{array}$ & $\begin{array}{r}0.91 \\
10.42 \\
0\end{array}$ & $\begin{array}{r}0.011208 \\
0.000019 \\
2.506-07\end{array}$ \\
\hline $\begin{array}{l}107 \\
107 \\
107\end{array}$ & $\begin{array}{l}10385 \\
10385 \\
10385\end{array}$ & $\begin{array}{l}\text { A2M } \\
\text { A2M } \\
\text { A2M }\end{array}$ & $\begin{array}{l}20 \\
50 \\
82\end{array}$ & $\begin{array}{l}1 \\
1 \\
1\end{array}$ & $\begin{array}{r}0.91 \\
10.42 \\
0 \\
\end{array}$ & $\begin{array}{l}7.481947 \\
0.012467 \\
0.000168 \\
\end{array}$ \\
\hline $\begin{array}{l}107 \\
107 \\
107 \\
\end{array}$ & $\begin{array}{l}10385 \\
10385 \\
10385 \\
\end{array}$ & $\begin{array}{l}\text { A2T } \\
\text { A2T } \\
\text { A2T }\end{array}$ & $\begin{array}{l}20 \\
50 \\
82 \\
\end{array}$ & $\begin{array}{l}i \\
i \\
1\end{array}$ & $\begin{array}{r}0.91 \\
10.42 \\
0 \\
\end{array}$ & $\begin{array}{l}0.740783 \\
0.001235 \\
0.000017 \\
\end{array}$ \\
\hline $\begin{array}{l}107 \\
107 \\
107\end{array}$ & $\begin{array}{l}10456 \\
.10456 \\
10456\end{array}$ & $\begin{array}{l}\text { A2M } \\
\text { A2M } \\
\text { A2M }\end{array}$ & $\begin{array}{l}20 \\
50 \\
82 \\
\end{array}$ & $\begin{array}{l}1 \\
1 \\
1\end{array}$ & $\begin{array}{r}0.89 \\
11.37 \\
0\end{array}$ & $\begin{array}{l}15.58376 \\
0.028304 \\
0.000407 \\
\end{array}$ \\
\hline $\begin{array}{l}107 \\
107 \\
107 \\
\end{array}$ & $\begin{array}{l}10456 \\
10456 \\
10456 \\
\end{array}$ & $\begin{array}{l}\mathrm{A} 2 \mathrm{~T} \\
\mathrm{~A} 2 \mathrm{~T} \\
\mathrm{~A} 2 \mathrm{~T}\end{array}$ & $\begin{array}{l}20 \\
50 \\
82 \\
\end{array}$ & $\begin{array}{l}1 \\
1 \\
1\end{array}$ & $\begin{array}{r}0.89 \\
11.37 \\
0 \\
\end{array}$ & $\begin{array}{l}0.956295 \\
0.001737 \\
0.000025\end{array}$ \\
\hline $\begin{array}{l}107 \\
107 \\
107\end{array}$ & $\begin{array}{l}10602 \\
10602 \\
10602\end{array}$ & $\begin{array}{l}\text { A12M } \\
\text { A12M } \\
\text { A12M }\end{array}$ & $\begin{array}{l}20 \\
50 \\
82\end{array}$ & $\begin{array}{l}\text { I } \\
\text { I }\end{array}$ & $\begin{array}{r}0.89 \\
11.11 \\
0\end{array}$ & $\begin{array}{r}0.011218 \\
0.00002 \\
2.800-07\end{array}$ \\
\hline $\begin{array}{l}107 \\
107 \\
107\end{array}$ & $\begin{array}{l}10602 \\
10602 \\
10602\end{array}$ & $\begin{array}{l}\text { A2M } \\
\text { A2M } \\
\text { A2M }\end{array}$ & $\begin{array}{l}20 \\
50 \\
82\end{array}$ & $\begin{array}{l}1 \\
1 \\
1\end{array}$ & $\begin{array}{r}0.89 \\
11.11 \\
0\end{array}$ & $\begin{array}{l}13.84097 \\
0.024583 \\
0.000344\end{array}$ \\
\hline
\end{tabular}


HNF-SD-SNF-TI-009, Rev, 1

\begin{tabular}{|c|c|c|c|c|c|c|}
\hline $\begin{array}{c}\text { Location } \\
\text { Code }\end{array}$ & Key Number & Fuel Model & $\begin{array}{c}\text { Material } \\
\text { Type }\end{array}$ & $\begin{array}{c}\text { sub ID } \\
\text { Code }\end{array}$ & Fuel Type & Isotopic Breakdown \\
\hline
\end{tabular}

\begin{tabular}{|c|c|c|c|c|c|c|}
\hline $\begin{array}{l}107 \\
107 \\
107 \\
\end{array}$ & $\begin{array}{l}10602 \\
10602 \\
10602 \\
\end{array}$ & $\begin{array}{l}\text { A } 2 T \\
\text { A2T } \\
\text { A2T }\end{array}$ & $\begin{array}{l}20 \\
50 \\
82\end{array}$ & $\begin{array}{l}1 \\
1 \\
1\end{array}$ & $\begin{array}{r}0.89 \\
11.11 \\
0 \\
\end{array}$ & $\begin{array}{r}0.64864 \\
0.001152 \\
0.000016\end{array}$ \\
\hline $\begin{array}{l}107 \\
107 \\
107\end{array}$ & $\begin{array}{l}10679 \\
10679 \\
10679\end{array}$ & $\begin{array}{l}\text { A2F } \\
\text { A2F } \\
\text { A2F }\end{array}$ & $\begin{array}{l}20 \\
50 \\
82 \\
\end{array}$ & $\begin{array}{l}1 \\
1 \\
1\end{array}$ & $\begin{array}{r}0.87 \\
11.76 \\
0 \\
\end{array}$ & $\begin{array}{l}0.163593 \\
0.000308 \\
0.000004\end{array}$ \\
\hline $\begin{array}{l}107 \\
107 \\
107\end{array}$ & $\begin{array}{l}10679 \\
10679 \\
10679 \\
\end{array}$ & $\begin{array}{l}\text { A2M } \\
\text { A2M } \\
\text { A2M }\end{array}$ & $\begin{array}{l}20 \\
50 \\
82 \\
\end{array}$ & $\begin{array}{l}1 \\
1 \\
1\end{array}$ & $\begin{array}{r}0.87 \\
11.76 \\
0 \\
\end{array}$ & $\begin{array}{r}7.750192 \\
0.01457 \\
0.000212 \\
\end{array}$ \\
\hline $\begin{array}{l}107 \\
107 \\
107\end{array}$ & $\begin{array}{l}10679 \\
10679 \\
10679 \\
\end{array}$ & $\begin{array}{l}\text { A2T } \\
\text { A2T } \\
\text { A2T }\end{array}$ & $\begin{array}{l}20 \\
50 \\
82 \\
\end{array}$ & $\begin{array}{l}1 \\
1 \\
1\end{array}$ & $\begin{array}{r}0.87 \\
11.76 \\
0 \\
\end{array}$ & $\begin{array}{l}3.551796 \\
0.006677 \\
0.000097\end{array}$ \\
\hline $\begin{array}{l}107 \\
107 \\
107 \\
\end{array}$ & $\begin{array}{l}10742 \\
10742 \\
10742 \\
\end{array}$ & $\begin{array}{l}\text { A12F } \\
\text { A12F } \\
\text { A12F }\end{array}$ & $\begin{array}{l}20 \\
50 \\
82 \\
\end{array}$ & $\begin{array}{l}1 \\
1 \\
1\end{array}$ & $\begin{array}{r}0.85 \\
12.77 \\
0 \\
\end{array}$ & $\begin{array}{r}0.007946 \\
0.000016 \\
2.50 \mathrm{e}-07 \\
\end{array}$ \\
\hline $\begin{array}{l}107 \\
107 \\
107\end{array}$ & $\begin{array}{l}10742 \\
10742 \\
10742\end{array}$ & $\begin{array}{l}\text { A2F } \\
\text { A2F } \\
\text { A2F }\end{array}$ & $\begin{array}{l}20 \\
50 \\
82\end{array}$ & $\begin{array}{l}1 \\
1 \\
1\end{array}$ & $\begin{array}{r}0.85 \\
12.77 \\
0\end{array}$ & $\begin{array}{r}0.21033 \\
0.000428 \\
0.000007\end{array}$ \\
\hline $\begin{array}{l}107 \\
107 \\
107\end{array}$ & $\begin{array}{l}10742 \\
10742 \\
10742 \\
\end{array}$ & $\begin{array}{l}\text { A2M } \\
\text { A2M } \\
\text { A2M }\end{array}$ & $\begin{array}{l}20 \\
50 \\
82\end{array}$ & $\begin{array}{l}1 \\
1 \\
1\end{array}$ & $\begin{array}{r}0.85 \\
12.77 \\
\quad 0 \\
\end{array}$ & $\begin{array}{l}3.642564 \\
0.007417 \\
0.000115\end{array}$ \\
\hline $\begin{array}{l}107 \\
107 \\
107\end{array}$ & $\begin{array}{l}10742 \\
10742 \\
10742 \\
\end{array}$ & $\begin{array}{l}\text { A2T } \\
\text { A2T } \\
\text { A2T }\end{array}$ & $\begin{array}{l}20 \\
50 \\
82 \\
\end{array}$ & $\begin{array}{l}1 \\
1 \\
1\end{array}$ & $\begin{array}{r}0.85 \\
12.77 \\
0 \\
\end{array}$ & $\begin{array}{l}2.777783 \\
0.005657 \\
0.000086 \\
\end{array}$ \\
\hline $\begin{array}{l}107 \\
107 \\
107 \\
\end{array}$ & $\begin{array}{l}10742 \\
10742 \\
10742 \\
\end{array}$ & $\begin{array}{l}\text { No9M } \\
\text { No9M } \\
\text { No9M } \\
\end{array}$ & $\begin{array}{l}20 \\
50 \\
82 \\
\end{array}$ & $\begin{array}{l}1 \\
1 \\
1 \\
\end{array}$ & $\begin{array}{r}0.85 \\
12.77 \\
\quad 0 \\
\end{array}$ & $\begin{array}{r}0.005274 \\
0.000011 \\
1.700-07 \\
\end{array}$ \\
\hline 107 & 10764 & A2M & 20 & 1 & 1.15 & 0.016656 \\
\hline 107 & 10764 & BXE & 20 & $v$ & 0.95 & 0.304268 \\
\hline $\begin{array}{l}107 \\
107 \\
107\end{array}$ & $\begin{array}{l}10770 \\
10770 \\
10770\end{array}$ & $\begin{array}{l}\text { A1 2T } \\
\text { A12T } \\
\text { A12T }\end{array}$ & $\begin{array}{l}20 \\
50 \\
82 .\end{array}$ & $\begin{array}{l}1 \\
1 \\
1\end{array}$ & $\begin{array}{r}0.84 \\
13.16 \\
0\end{array}$ & $\begin{array}{r}0.010337 \\
0.000022 \\
3.40 \mathrm{e}-07\end{array}$ \\
\hline $\begin{array}{l}107 \\
107 \\
107 \\
\end{array}$ & $\begin{array}{l}10770 \\
10770 \\
10770 \\
\end{array}$ & $\begin{array}{l}\text { A2M } \\
\text { A2M } \\
\text { A2M }\end{array}$ & $\begin{array}{l}20 \\
50 \\
82 \\
\end{array}$ & $\begin{array}{l}1 \\
1 \\
1\end{array}$ & $\begin{array}{r}0.84 \\
13.16 \\
0 \\
\end{array}$ & $\begin{array}{l}6.146783 \\
0.012896 \\
0.000201 \\
\end{array}$ \\
\hline $\begin{array}{l}107 \\
107 \\
107\end{array}$ & $\begin{array}{l}10770 \\
10770 \\
10770\end{array}$ & $\begin{array}{l}\text { A2T } \\
\text { A2T } \\
\text { A2T }\end{array}$ & $\begin{array}{l}20 \\
50 \\
82\end{array}$ & $\begin{array}{l}1 \\
1 \\
1\end{array}$ & $\begin{array}{r}0.84 \\
13.16 \\
0 \\
\end{array}$ & $\begin{array}{l}2.005478 \\
0.004206 \\
0.000066\end{array}$ \\
\hline $\begin{array}{l}107 \\
107 \\
107\end{array}$ & $\begin{array}{l}10770 \\
10770 \\
10770\end{array}$ & $\begin{array}{l}\text { NO9T } \\
\text { NO9T } \\
\text { NO9T }\end{array}$ & $\begin{array}{l}20 \\
50 \\
82\end{array}$ & $\begin{array}{l}1 \\
1 \\
1\end{array}$ & $\begin{array}{r}0.86 \\
13.16 \\
0\end{array}$ & $\begin{array}{r}0.005095 \\
0.000011 \\
1.70 e-07\end{array}$ \\
\hline $\begin{array}{l}107 \\
107 \\
107\end{array}$ & $\begin{array}{l}10832 \\
10832 \\
10832\end{array}$ & $\begin{array}{l}\text { A2M } \\
\text { A2M } \\
\text { A2M }\end{array}$ & $\begin{array}{l}20 \\
50 \\
82\end{array}$ & $\begin{array}{l}1 \\
1 \\
1\end{array}$ & $\begin{array}{r}0.84 \\
12.92 \\
0\end{array}$ & $\begin{array}{r}13.05217 \\
0.02688 \\
0.00042\end{array}$ \\
\hline $\begin{array}{l}107 \\
107 \\
107 \\
\end{array}$ & $\begin{array}{l}10832 \\
10832 \\
10832 \\
\end{array}$ & $\begin{array}{l}\text { A2T } \\
\text { A2T } \\
\text { A2T }\end{array}$ & $\begin{array}{l}20 \\
50 \\
82 \\
\end{array}$ & $\begin{array}{l}1 \\
1 \\
1\end{array}$ & $\begin{array}{r}0.84 \\
12.92 \\
0 \\
\end{array}$ & $\begin{array}{r}3.6888 \\
0.007598 \\
0.00012 \\
\end{array}$ \\
\hline $\begin{array}{l}107 \\
107 \\
107\end{array}$ & $\begin{array}{l}10982 \\
10982 \\
10982 \\
\end{array}$ & $\begin{array}{l}\text { A1 } 2 \mathrm{~T} \\
\text { A12T } \\
\text { A12T }\end{array}$ & $\begin{array}{l}20 \\
50 \\
82\end{array}$ & $\begin{array}{l}1 \\
1 \\
1\end{array}$ & $\begin{array}{r}0.82 \\
13.73 \\
0 \\
\end{array}$ & $\begin{array}{r}0.020936 \\
0.000046 \\
7.40 \mathrm{e}-07 \\
\end{array}$ \\
\hline $\begin{array}{l}107 \\
107 \\
107\end{array}$ & $\begin{array}{l}10982 \\
10982 \\
10982\end{array}$ & $\begin{array}{l}\text { A2F } \\
\text { A2F } \\
\text { A2F }\end{array}$ & $\begin{array}{l}20 \\
50 \\
82\end{array}$ & $\begin{array}{l}1 \\
1 \\
1\end{array}$ & $\begin{array}{r}0.82 \\
13.73 \\
0\end{array}$ & $\begin{array}{r}0.023339 \\
0.000051 \\
8.200-07\end{array}$ \\
\hline
\end{tabular}


HNF-SD-SNF-TI-009, Rev. 1

\begin{tabular}{|c|c|c|c|c|c|c|}
\hline $\begin{array}{c}\text { Location } \\
\text { Code }\end{array}$ & Key Number & Fuel Model & $\begin{array}{c}\text { Material } \\
\text { Type }\end{array}$ & $\begin{array}{c}\text { sub ID } \\
\text { Code }\end{array}$ & Fuel Type & Isotopic Breakdown \\
\hline
\end{tabular}

\begin{tabular}{|c|c|c|c|c|c|c|}
\hline $\begin{array}{l}107 \\
107 \\
107\end{array}$ & $\begin{array}{l}10982 \\
10982 \\
10982\end{array}$ & $\begin{array}{l}\mathrm{A} 2 \mathrm{M} \\
\mathrm{A} 2 \mathrm{M} \\
\mathrm{A} 2 \mathrm{M}\end{array}$ & $\begin{array}{l}20 \\
50 \\
82\end{array}$ & 1 & $\begin{array}{r}0.82 \\
13.73 \\
0\end{array}$ & $\begin{array}{l}16.45954 \\
0.036006 \\
0.000581\end{array}$ \\
\hline $\begin{array}{l}107 \\
107 \\
107\end{array}$ & $\begin{array}{l}10982 \\
10982 \\
10982 \\
\end{array}$ & $\begin{array}{l}\text { A2T } \\
\text { A2T } \\
\text { A2T }\end{array}$ & $\begin{array}{l}20 \\
50 \\
82\end{array}$ & $\begin{array}{l}1 \\
1 \\
1\end{array}$ & $\begin{array}{r}0.82 \\
13.73 \\
0\end{array}$ & $\begin{array}{r}0.692735 \\
.0 .001515 \\
0.000024\end{array}$ \\
\hline $\begin{array}{l}107 \\
107 \\
107\end{array}$ & $\begin{array}{l}10982 \\
10982 \\
10982\end{array}$ & $\begin{array}{l}\text { NO9M } \\
\text { No9M } \\
\text { NO9M }\end{array}$ & $\begin{array}{l}20 \\
50 \\
82\end{array}$ & $\begin{array}{l}1 \\
1 \\
1\end{array}$ & $\begin{array}{r}0.82 \\
13.73 \\
0\end{array}$ & $\begin{array}{r}0.010524 \\
0.000023 \\
3.80 e-07\end{array}$ \\
\hline $\begin{array}{l}107 \\
107 \\
107\end{array}$ & $\begin{array}{l}11036 \\
11036 \\
11036\end{array}$ & $\begin{array}{l}\text { A2M } \\
\text { A2M } \\
\text { A2M }\end{array}$ & $\begin{array}{l}20 \\
50 \\
82\end{array}$ & $\begin{array}{l}1 \\
1 \\
1\end{array}$ & $\begin{array}{r}0.82 \\
13.6 \\
0\end{array}$ & $\begin{array}{r}7.596712 \\
0.01647 \\
0.000263\end{array}$ \\
\hline $\begin{array}{l}107 \\
107 \\
107\end{array}$ & $\begin{array}{l}11109 \\
11109 \\
11109\end{array}$ & $\begin{array}{l}\text { A2F } \\
\text { A2F } \\
\text { A2F }\end{array}$ & $\begin{array}{l}20 \\
50 \\
82\end{array}$ & $\begin{array}{l}1 \\
1 \\
1\end{array}$ & $\begin{array}{r}0.82 \\
13.7 \\
0 \\
\end{array}$ & $\begin{array}{r}0.467032 \\
0.00102 \\
0.000016 \\
\end{array}$ \\
\hline $\begin{array}{l}107 \\
107 \\
107\end{array}$ & $\begin{array}{l}11109 \\
11109 \\
11109\end{array}$ & $\begin{array}{l}\text { A2M } \\
\text { A2M } \\
\text { A2M }\end{array}$ & $\begin{array}{l}20 \\
50 \\
82\end{array}$ & $\begin{array}{l}1 \\
1 \\
1\end{array}$ & $\begin{array}{r}0.82 \\
13.7 \\
0 \\
\end{array}$ & $\begin{array}{l}14.60046 \\
0.031879 \\
0.000524\end{array}$ \\
\hline $\begin{array}{l}107 \\
107 \\
107\end{array}$ & $\begin{array}{l}11109 \\
11109 \\
11109\end{array}$ & $\begin{array}{l}\text { NO9M } \\
\text { NO9M } \\
\text { NO9M }\end{array}$ & $\begin{array}{l}20 \\
50 \\
82\end{array}$ & $\begin{array}{l}1 \\
1 \\
1 \\
\end{array}$ & $\begin{array}{r}0.82 \\
13.7 \\
0 \\
\end{array}$ & $\begin{array}{r}0.005263 \\
0.000011 \\
1.90 \mathrm{e}-07\end{array}$ \\
\hline $\begin{array}{l}107 \\
107 \\
107\end{array}$ & $\begin{array}{l}11183 \\
11183 \\
11183\end{array}$ & $\begin{array}{l}A 12 M \\
A 12 M \\
A 12 M\end{array}$ & $\begin{array}{l}20 \\
50 \\
82\end{array}$ & $\begin{array}{l}1 \\
1 \\
1\end{array}$ & $\begin{array}{r}0.83 \\
13.31 \\
0\end{array}$ & $\begin{array}{r}0.022046 \\
0.000047 \\
7.60 \theta-07\end{array}$ \\
\hline $\begin{array}{l}107 \\
107 \\
107\end{array}$ & $\begin{array}{l}11183 \\
11183 \\
11183\end{array}$ & $\begin{array}{l}\text { A2F } \\
\text { A2F } \\
\text { A2F }\end{array}$ & $\begin{array}{l}20 \\
50 \\
82\end{array}$ & $\begin{array}{l}1 \\
1 \\
1\end{array}$ & $\begin{array}{r}0.83 \\
13.31 \\
0\end{array}$ & $\begin{array}{l}0.677131 \\
0.001439 \\
0.000023\end{array}$ \\
\hline $\begin{array}{l}107 \\
107 \\
107\end{array}$ & $\begin{array}{l}11183 \\
11183 \\
11183\end{array}$ & $\begin{array}{l}\text { A2M } \\
\text { A2M } \\
\text { A2M }\end{array}$ & $\begin{array}{l}20 \\
50 \\
82 \\
\end{array}$ & $\begin{array}{l}1 \\
1 \\
1\end{array}$ & $\begin{array}{r}0.83 \\
13.31 \\
0\end{array}$ & $\begin{array}{l}9.341152 \\
0.019857 \\
0.000318\end{array}$ \\
\hline $\begin{array}{l}107 \\
107 \\
107\end{array}$ & $\begin{array}{l}11183 \\
11183 \\
11183\end{array}$ & $\begin{array}{l}\mathrm{A} 2 \mathrm{~T} \\
\mathrm{~A} 2 \mathrm{~T} \\
\mathrm{~A} 2 \mathrm{~T}\end{array}$ & $\begin{array}{l}20 \\
50 \\
82 \\
\end{array}$ & $\begin{array}{l}1 \\
1 \\
1\end{array}$ & $\begin{array}{r}0.83 \\
13.31 \\
0 \\
\end{array}$ & $\begin{array}{l}0.246348 \\
0.000524 \\
0.000008\end{array}$ \\
\hline $\begin{array}{l}107 \\
107 \\
107\end{array}$ & $\begin{array}{l}11183 \\
11183 \\
11183\end{array}$ & $\begin{array}{l}\text { NO9M } \\
\text { NO9M } \\
\text { NO9M }\end{array}$ & $\begin{array}{l}20 \\
50 \\
82\end{array}$ & $\begin{array}{l}1 \\
1 \\
1\end{array}$ & $\begin{array}{r}0.83 \\
13.31 \\
0\end{array}$ & $\begin{array}{r}0.010858 \\
0.000023 \\
3.600-07\end{array}$ \\
\hline $\begin{array}{l}107 \\
107 \\
107\end{array}$ & $\begin{array}{l}11372 \\
11372 \\
11372 \\
\end{array}$ & $\begin{array}{l}\text { A2F } \\
\text { A2F } \\
\text { A2F }\end{array}$ & $\begin{array}{l}20 \\
50 \\
82\end{array}$ & $\begin{array}{l}1 \\
1 \\
1\end{array}$ & $\begin{array}{r}0.82 \\
13.77 \\
0\end{array}$ & $\begin{array}{l}0.688631 \\
0.001513 \\
0.000025 \\
\end{array}$ \\
\hline $\begin{array}{l}107 \\
107 \\
107\end{array}$ & $\begin{array}{l}11372 \\
11372 \\
11372\end{array}$ & $\begin{array}{l}\text { A2M } \\
\text { A2M } \\
\text { A2M }\end{array}$ & $\begin{array}{l}20 \\
50 \\
82\end{array}$ & $\begin{array}{l}1 \\
1 \\
1\end{array}$ & $\begin{array}{r}0.82 \\
13.77 \\
0\end{array}$ & $\begin{array}{l}18.52989 \\
0.040707 \\
0.000665\end{array}$ \\
\hline $\begin{array}{l}107 \\
107 \\
107\end{array}$ & $\begin{array}{l}11372 \\
11372 \\
11372\end{array}$ & $\begin{array}{l}\text { A2T } \\
\text { A2T } \\
\text { A2T }\end{array}$ & $\begin{array}{l}20 \\
50 \\
82\end{array}$ & $\begin{array}{l}1 \\
1 \\
1\end{array}$ & $\begin{array}{r}0.82 \\
13.77 \\
0 \\
\end{array}$ & $\begin{array}{l}0.708117 \\
0.001556 \\
0.000026\end{array}$ \\
\hline $\begin{array}{l}107 \\
107 \\
107\end{array}$ & $\begin{array}{l}11449 \\
11449 \\
11449 \\
\end{array}$ & $\begin{array}{l}\text { A2F } \\
\text { A2F } \\
\text { A2F }\end{array}$ & $\begin{array}{l}20 \\
50 \\
82\end{array}$ & $\begin{array}{l}1 \\
1 \\
1\end{array}$ & $\begin{array}{r}0.83 \\
13.45 \\
0\end{array}$ & $\begin{array}{l}0.105028 \\
0.000226 \\
0.000004\end{array}$ \\
\hline $\begin{array}{l}107 \\
107 \\
107\end{array}$ & $\begin{array}{l}11449 \\
11449 \\
11449\end{array}$ & $\begin{array}{l}\text { A2M } \\
\text { A2M } \\
\text { A2M }\end{array}$ & $\begin{array}{l}20 \\
50 \\
82\end{array}$ & $\begin{array}{l}1 \\
1 \\
1\end{array}$ & $\begin{array}{r}0.83 \\
13.45 \\
0\end{array}$ & $\begin{array}{l}18.54239 \\
0.039825 \\
0.000641\end{array}$ \\
\hline $\begin{array}{l}107 \\
107 \\
107\end{array}$ & $\begin{array}{l}11449 \\
11449 \\
11449\end{array}$ & $\begin{array}{l}\text { A2T } \\
\text { A2T } \\
\text { A2T }\end{array}$ & $\begin{array}{l}20 \\
50 \\
82\end{array}$ & $\begin{array}{l}1 \\
1 \\
1\end{array}$ & $\begin{array}{r}0.83 \\
13.45 \\
0\end{array}$ & $\begin{array}{l}1.295873 \\
0.002783 \\
0.000045\end{array}$ \\
\hline
\end{tabular}


HNF-SD-SNF-TI-009; Rev. 1

\begin{tabular}{|c|c|c|c|c|c|c|c|}
\hline $\begin{array}{c}\text { Location } \\
\text { Code }\end{array}$ & Key Number & Fuel Model & $\begin{array}{c}\text { Material } \\
\text { Type }\end{array}$ & $\begin{array}{l}\text { sub ID } \\
\text { Code }\end{array}$ & Fual Type & Isotopic Breakdown & Discharge Mass \\
\hline
\end{tabular}

\begin{tabular}{|c|c|c|c|c|c|c|}
\hline $\begin{array}{l}107 \\
107 \\
107\end{array}$ & $\begin{array}{l}11540 \\
11540 \\
11540\end{array}$ & $\begin{array}{l}\text { A2M } \\
\text { A2M } \\
\text { A2M }\end{array}$ & $\begin{array}{l}20 \\
50 \\
82 \\
\end{array}$ & $\begin{array}{l}1 \\
1 \\
1\end{array}$ & $\begin{array}{r}0.83 \\
\cdot 13.26 \\
0\end{array}$ & $\begin{array}{l}12.46058 \\
0.026407 \\
0.000423\end{array}$ \\
\hline $\begin{array}{l}107 \\
107 \\
107\end{array}$ & $\begin{array}{l}11806 \\
11806 \\
11806\end{array}$ & $\begin{array}{l}\text { A2F } \\
\text { A2F } \\
\text { A2F }\end{array}$ & $\begin{array}{l}20 \\
50 \\
82\end{array}$ & $\begin{array}{l}1 \\
1 \\
1\end{array}$ & $\begin{array}{r}0.82 \\
13.86 \\
0\end{array}$ & $\begin{array}{l}0.209843 \\
0.000465 \\
0.000008\end{array}$ \\
\hline $\begin{array}{l}107 \\
107 \\
107 \\
\end{array}$ & $\begin{array}{l}11806 \\
11806 \\
11806 \\
\end{array}$ & $\begin{array}{l}\text { A2M } \\
\text { A2M } \\
\text { A2M }\end{array}$ & $\begin{array}{l}20 \\
50 \\
82 \\
\end{array}$ & $\begin{array}{l}1 \\
1 \\
1 \\
\end{array}$ & $\begin{array}{r}0.82 \\
13.86 \\
0 \\
\end{array}$ & $\begin{array}{l}19.19476 \\
0.042523 \\
0.000699\end{array}$ \\
\hline $\begin{array}{l}107 \\
107 \\
107 \\
\end{array}$ & $\begin{array}{l}11806 \\
11806 \\
11806 \\
\end{array}$ & $\begin{array}{l}\text { A2T } \\
\text { A2T } \\
\text { A2T }\end{array}$ & $\begin{array}{l}20 \\
50 \\
82\end{array}$ & $\begin{array}{l}1 \\
1 \\
1\end{array}$ & $\begin{array}{r}0.82 \\
13.86 \\
0\end{array}$ & $\begin{array}{r}0.539924 \\
0.001196 \\
0.00002\end{array}$ \\
\hline $\begin{array}{l}107 \\
107 \\
107\end{array}$ & $\begin{array}{l}11897 \\
11897 \\
11897\end{array}$ & $\begin{array}{l}A 12 F \\
A 12 F \\
A \mid 2 F\end{array}$ & $\begin{array}{l}20 \\
50 \\
82 \\
\end{array}$ & $\begin{array}{l}1 \\
1 \\
1 \\
\end{array}$ & $\begin{array}{r}0.8 \\
14.4 \\
0 \\
\end{array}$ & $\begin{array}{r}0.023429 \\
0.000054 \\
9.30 e \cdot 07\end{array}$ \\
\hline $\begin{array}{l}107 \\
107 \\
107\end{array}$ & $\begin{array}{l}11897 \\
11897 \\
11897 \\
\end{array}$ & $\begin{array}{l}\text { A2F } \\
\text { A2F } \\
\text { A2F }\end{array}$ & $\begin{array}{l}20 \\
50 \\
82 \\
\end{array}$ & $\begin{array}{l}1 \\
1 \\
1\end{array}$ & $\begin{array}{r}0.8 \\
14.4 \\
0 \\
\end{array}$ & $\begin{array}{l}1.981819 \\
0.004559 \\
0.000078\end{array}$ \\
\hline $\begin{array}{l}107 \\
107 \\
107\end{array}$ & $\begin{array}{l}11897 \\
11897 \\
11897 \\
\end{array}$ & $\begin{array}{l}A 2 M \\
\text { A2M } \\
\text { A2M }\end{array}$ & $\begin{array}{r}20 \\
.50 \\
82 \\
\end{array}$ & $\begin{array}{l}1 \\
1 \\
1 \\
\end{array}$ & $\begin{array}{r}0.8 \\
14.4 \\
0 \\
\end{array}$ & $\begin{array}{r}17.6565 \\
0.040607 \\
0.000697 \\
\end{array}$ \\
\hline $\begin{array}{l}107 \\
107 \\
107\end{array}$ & $\begin{array}{l}11897 \\
11897 \\
11897\end{array}$ & $\begin{array}{l}\text { NO9F } \\
\text { NO9F } \\
\text { NO9F }\end{array}$ & $\begin{array}{l}20 \\
50 \\
82 \\
\end{array}$ & $\begin{array}{l}1 \\
1 \\
1\end{array}$ & $\begin{array}{r}0.8 \\
14.4 \\
0 \\
\end{array}$ & $\begin{array}{r}0.003847 \\
0.000009 \\
1.506-07\end{array}$ \\
\hline $\begin{array}{l}107 \\
107 \\
107 \\
\end{array}$ & $\begin{array}{l}11979 \\
11979 \\
11979 \\
\end{array}$ & $\begin{array}{l}\text { A12F } \\
\text { A12F } \\
\text { A1 } 2 \mathrm{~F}\end{array}$ & $\begin{array}{l}20 \\
50 \\
82 \\
\end{array}$ & $\begin{array}{l}1 \\
1 \\
1\end{array}$ & $\begin{array}{r}0.8 \\
14.27 \\
0 \\
\end{array}$ & $\begin{array}{r}0.007963 \\
0.000018 \\
3.10 \mathrm{e}-07 \\
\end{array}$ \\
\hline $\begin{array}{l}107 \\
107 \\
107\end{array}$ & $\begin{array}{l}11979 \\
11979 \\
11979\end{array}$ & $\begin{array}{l}A 12 M \\
\text { A12M } \\
\text { A12M }\end{array}$ & $\begin{array}{l}20 \\
50 \\
82 \\
\end{array}$ & $\begin{array}{l}1 \\
1 \\
1\end{array}$ & $\begin{array}{r}0.8 \\
14.27 \\
0\end{array}$ & $\begin{array}{r}0.011208 \\
0.000026 \\
4.30 e-07\end{array}$ \\
\hline $\begin{array}{l}107 \\
107 \\
107\end{array}$ & $\begin{array}{l}11979 \\
11979 \\
11979\end{array}$ & $\begin{array}{l}A 12 T \\
A 12 T \\
\text { A12T }\end{array}$ & $\begin{array}{l}20 \\
50 \\
82\end{array}$ & 1. & $\begin{array}{r}0.8 \\
14.27 \\
0\end{array}$ & $\begin{array}{r}0.010483 \\
0.000024 \\
4.108-07\end{array}$ \\
\hline $\begin{array}{l}107 \\
107 \\
107\end{array}$ & $\begin{array}{l}11979 \\
11979 \\
11979 \\
\end{array}$ & $\begin{array}{l}\mathrm{A} 2 \mathrm{~F} \\
\mathrm{~A} 2 \mathrm{~F} \\
\mathrm{~A} 2 \mathrm{~F}\end{array}$ & $\begin{array}{l}20 \\
50 \\
82 \\
\end{array}$ & $\begin{array}{l}1 \\
1 \\
1\end{array}$ & $\begin{array}{r}0.8 \\
14.27 \\
0 \\
\end{array}$ & $\begin{array}{l}1.947591 \\
0.004442 \\
0.000075\end{array}$ \\
\hline $\begin{array}{l}107 \\
107 \\
107\end{array}$ & $\begin{array}{l}11979 \\
11979 \\
11979\end{array}$ & $\begin{array}{l}\text { A2M } \\
\text { A2M } \\
\text { A2M }\end{array}$ & $\begin{array}{l}20 \\
50 \\
82 \\
\end{array}$ & $\begin{array}{l}1 \\
1 \\
1\end{array}$ & $\begin{array}{r}0.8 \\
14.27 \\
0\end{array}$ & $\begin{array}{l}14.46003 \\
0.032986 \\
0.000553\end{array}$ \\
\hline $\begin{array}{l}107 \\
107 \\
107 \\
\end{array}$ & $\begin{array}{l}11979 \\
11979 \\
11979 \\
\end{array}$ & $\begin{array}{l}\mathrm{A} 2 \mathrm{~T} \\
\mathrm{~A} 2 \mathrm{~T} \\
\mathrm{~A} 2 \mathrm{~T}\end{array}$ & $\begin{array}{l}20 \\
50 \\
82 \\
\end{array}$ & $\begin{array}{r}1 \\
1 \\
1\end{array}$ & $\begin{array}{r}0.8 \\
14.27 \\
0 \\
\end{array}$ & $\begin{array}{l}8.864286 \\
0.020223 \\
0.000345 \\
\end{array}$ \\
\hline $\begin{array}{l}107 \\
107 \\
107 .\end{array}$ & $\begin{array}{l}11979 \\
11979 \\
11979 .\end{array}$ & $\begin{array}{l}\text { No9M } \\
\text { No9M } \\
\text { No9M } \\
\end{array}$ & $\begin{array}{l}20 \\
50 \\
82 \\
\end{array}$ & $\begin{array}{l}1 \\
1 \\
1\end{array}$ & $\begin{array}{r}0.8 \\
14.27 \\
0\end{array}$ & $\begin{array}{r}0.010706 \\
0.000024 \\
4.20 e-07\end{array}$ \\
\hline $\begin{array}{l}1.07 \\
107 \\
107\end{array}$ & $\begin{array}{l}12127 \\
12127 \\
12127\end{array}$ & $\begin{array}{l}\text { A2F } \\
\text { A2F } \\
\text { A2F }\end{array}$ & $\begin{array}{l}20 \\
50 \\
82 \\
\end{array}$ & $\begin{array}{l}1 \\
1 \\
1\end{array}$ & $\begin{array}{r}0.81 \\
14.22 \\
. \quad 0 \\
\end{array}$ & $\begin{array}{r}0.980225 \\
0.00223 \\
0.000037\end{array}$ \\
\hline $\begin{array}{l}107 \\
107 \\
107\end{array}$ & $\begin{array}{l}12127 \\
12127 \\
12127 \\
\end{array}$ & $\begin{array}{l}\text { A2M } \\
\text { A2M } \\
\text { A2M }\end{array}$ & $\begin{array}{l}20 \\
50 \\
82 \\
\end{array}$ & $\begin{array}{l}1 \\
1 \\
1\end{array}$ & $\begin{array}{r}0.81 \\
14.22 \\
0\end{array}$ & $\begin{array}{l}13.29014 \\
0.030238 \\
0.000508\end{array}$ \\
\hline $\begin{array}{l}107 \\
107 \\
107\end{array}$ & $\begin{array}{l}12127 \\
12127 \\
12127\end{array}$ & $\begin{array}{l}\text { A2T } \\
\text { A2T } \\
\text { A2T }\end{array}$ & $\begin{array}{l}20 \\
50 \\
82\end{array}$ & $\begin{array}{l}\text { I } \\
\text { I }\end{array}$ & $\begin{array}{r}0.81 \\
14.22 \\
0\end{array}$ & $\begin{array}{r}1.47972 \\
0.003366 \\
0.000057\end{array}$ \\
\hline
\end{tabular}


HNF-SD-SNF-TI-009, Rev, I

\begin{tabular}{|c|c|c|c|c|c|c|}
\hline $\begin{array}{c}\text { Location } \\
\text { Code }\end{array}$ & Key Number & Fuel Model & $\begin{array}{c}\text { Material } \\
\text { Type }\end{array}$ & $\begin{array}{c}\text { sub ID } \\
\text { Code }\end{array}$ & Fuel Type & Isotopic Breakdown \\
\hline
\end{tabular}

\begin{tabular}{|c|c|c|c|c|c|c|}
\hline $\begin{array}{l}107 \\
107 \\
107\end{array}$ & $\begin{array}{l}12201 \\
12201 \\
12201\end{array}$ & $\begin{array}{l}\text { A2F } \\
\text { A2F } \\
\text { A2F }\end{array}$ & $\begin{array}{l}20 \\
50 \\
82 \\
\end{array}$ & $\begin{array}{l}1 \\
1 \\
1\end{array}$ & $\begin{array}{r}0.83 \\
13.24 \\
0\end{array}$ & $\begin{array}{l}0.746713 \\
0.001585 \\
0.000026\end{array}$ \\
\hline $\begin{array}{l}107 \\
107 \\
107\end{array}$ & $\begin{array}{l}12201 \\
12201 \\
12201\end{array}$ & $\begin{array}{l}\mathrm{A} 2 \mathrm{M} \\
\mathrm{A} 2 \mathrm{M} \\
\mathrm{A} 2 \mathrm{M}\end{array}$ & $\begin{array}{l}20 \\
50 \\
82 \\
\end{array}$ & $\begin{array}{l}1 \\
1 \\
1\end{array}$ & $\begin{array}{r}0.83 \\
13.24 \\
0 \\
\end{array}$ & $\begin{array}{r}24.3225 \\
0.051616 \\
0.000827 \\
\end{array}$ \\
\hline $\begin{array}{l}107 \\
107 \\
107\end{array}$ & $\begin{array}{l}12285 \\
12285 \\
12285\end{array}$ & $\begin{array}{l}\text { A2F } \\
\text { A2F } \\
\text { A2F }\end{array}$ & $\begin{array}{l}20 \\
50 \\
82 \\
\end{array}$ & $\begin{array}{l}1 \\
1 \\
1\end{array}$ & $\begin{array}{r}0.84 \\
13.17 \\
0 \\
\end{array}$ & $\begin{array}{l}0.245655 \\
0.000519 \\
0.000008 \\
\end{array}$ \\
\hline $\begin{array}{l}107 \\
107 \\
107\end{array}$ & $\begin{array}{l}12285 \\
12285 \\
12285\end{array}$ & $\begin{array}{l}\text { A2M } \\
\text { A2M } \\
\text { A2M }\end{array}$ & $\begin{array}{l}20 \\
50 \\
82 \\
\end{array}$ & $\begin{array}{l}1 \\
1 \\
1\end{array}$ & $\begin{array}{r}0.84 \\
13.17 \\
0 \\
\end{array}$ & $\begin{array}{r}19.5256 \\
0.04124 \\
0.000662 \\
\end{array}$ \\
\hline $\begin{array}{l}107 \\
107 \\
107\end{array}$ & $\begin{array}{l}12480 \\
12480 \\
12480\end{array}$ & $\begin{array}{l}\mathrm{A} 12 \mathrm{M} \\
\mathrm{A} 12 \mathrm{M} \\
\mathrm{A} 12 \mathrm{M}\end{array}$ & $\begin{array}{l}20 \\
50 \\
82 \\
\end{array}$ & $\begin{array}{l}1 \\
1 \\
1 \\
\end{array}$ & $\begin{array}{r}0.82 \\
13.78 \\
0 \\
\end{array}$ & $\begin{array}{r}0.022123 \\
0.000049 \\
8.00 \mathrm{e}-07 \\
\end{array}$ \\
\hline $\begin{array}{l}107 \\
107 \\
107\end{array}$ & $\begin{array}{l}12480 \\
12480 \\
12480\end{array}$ & $\begin{array}{l}\text { A2M } \\
\text { A2M } \\
\text { A2M }\end{array}$ & $\begin{array}{l}20 \\
50 \\
82\end{array}$ & $\begin{array}{l}1 \\
1 \\
1\end{array}$ & $\begin{array}{r}0.82 \\
13.78 \\
0\end{array}$ & $\begin{array}{l}19.38647 \\
0.042851 \\
0.000704\end{array}$ \\
\hline $\begin{array}{l}107 \\
107 \\
107\end{array}$ & $\begin{array}{l}12565 \\
12565 \\
12565\end{array}$ & $\begin{array}{l}A 12 M \\
\text { A12M } \\
\text { At2M }\end{array}$ & $\begin{array}{l}20 \\
50 \\
82\end{array}$ & $\begin{array}{l}1 \\
1 \\
1\end{array}$ & $\begin{array}{r}0.82 \\
13.7 \\
0\end{array}$ & $\begin{array}{r}0.017067 \\
0.000024 \\
4.000-07\end{array}$ \\
\hline $\begin{array}{l}107 \\
107 \\
107 \\
\end{array}$ & $\begin{array}{l}12565 \\
12565 \\
12565 \\
\end{array}$ & $\begin{array}{l}\text { A2M } \\
\text { A2M } \\
\text { A2M }\end{array}$ & $\begin{array}{l}20 \\
50 \\
82 \\
\end{array}$ & $\begin{array}{l}1 \\
1 \\
1 \\
\end{array}$ & $\begin{array}{r}0.82 \\
13.7 \\
0\end{array}$ & $\begin{array}{l}25.18379 \\
0.055373 \\
0.000915\end{array}$ \\
\hline $\begin{array}{l}107 \\
107 \\
107\end{array}$ & $\begin{array}{l}12639 \\
12639 \\
12639 \\
\end{array}$ & $\begin{array}{l}A 12 M \\
A 12 M \\
A 12 M\end{array}$ & $\begin{array}{l}20 \\
50 \\
82 \\
\end{array}$ & $\begin{array}{l}1 \\
1 \\
1\end{array}$ & $\begin{array}{r}0.84 \\
13.06 \\
0 \\
\end{array}$ & $\begin{array}{r}0.011071 \\
0.000023 \\
3.700-07\end{array}$ \\
\hline $\begin{array}{l}107 \\
107 \\
107\end{array}$ & $\begin{array}{l}12639 \\
12639 \\
12639\end{array}$ & $\begin{array}{l}\text { A2M } \\
\text { A2M } \\
\text { A2M }\end{array}$ & $\begin{array}{l}20 \\
50 \\
82\end{array}$ & $\begin{array}{l}1 \\
1 \\
1\end{array}$ & $\begin{array}{r}0.84 \\
13.06 \\
0 \\
\end{array}$ & $\begin{array}{l}23.55778 \\
0.049425 \\
0.000799\end{array}$ \\
\hline $\begin{array}{l}107 \\
107 \\
107\end{array}$ & $\begin{array}{l}12639 \\
12639 \\
12639\end{array}$ & $\begin{array}{l}\text { NO9M } \\
\text { NO9M } \\
\text { NO9M }\end{array}$ & $\begin{array}{l}20 \\
50 \\
82 \\
\end{array}$ & $\begin{array}{l}1 \\
1 \\
1\end{array}$ & $\begin{array}{r}0.84 \\
13.06 \\
0\end{array}$ & $\begin{array}{r}0.005453 \\
0.000011 \\
1.800-07\end{array}$ \\
\hline $\begin{array}{l}107 \\
107 \\
107\end{array}$ & $\begin{array}{l}12823 \\
12823 \\
12823\end{array}$ & $\begin{array}{l}\text { A2M } \\
\text { A2M } \\
\text { A2M }\end{array}$ & $\begin{array}{l}20 \\
50 \\
82\end{array}$ & $\begin{array}{l}1 \\
1 \\
1\end{array}$ & $\begin{array}{r}0.83 \\
13.17 \\
0\end{array}$ & $\begin{array}{l}7.198119 \\
0.015247 \\
0.000244\end{array}$ \\
\hline $\begin{array}{l}107 \\
107 \\
107 \\
\end{array}$ & $\begin{array}{l}12823 \\
12823 \\
12823\end{array}$ & $\begin{array}{l}\mathrm{A} 2 \mathrm{~T} \\
\mathrm{~A} 2 \mathrm{~T} \\
\text { A2T }\end{array}$ & $\begin{array}{l}20 \\
50 \\
82\end{array}$ & $\begin{array}{l}1 \\
1 \\
1\end{array}$ & $\begin{array}{r}0.83 \\
13.17 \\
0\end{array}$ & $\begin{array}{l}0.635473 \\
0.001346 \\
0.000022\end{array}$ \\
\hline $\begin{array}{l}107 \\
107 \\
107 \\
\end{array}$ & $\begin{array}{l}1,2852 \\
12852 \\
12852 \\
\end{array}$ & $\begin{array}{l}\text { A2M } \\
\text { A2M } \\
\text { A2M }\end{array}$ & $\begin{array}{l}20 \\
50 \\
82 \\
\end{array}$ & $\begin{array}{l}1 \\
1 \\
1\end{array}$ & $\begin{array}{r}0.84 \\
13.01 \\
\quad 0 \\
\end{array}$ & $\begin{array}{r}10.83763 \\
0.022663 \\
0.00036 \\
\end{array}$ \\
\hline $\begin{array}{l}107 \\
107 \\
107\end{array}$ & $\begin{array}{l}12852 \\
12852 \\
12852\end{array}$ & $\begin{array}{l}\mathrm{A} 2 \mathrm{~T} \\
\mathrm{~A} 2 \mathrm{~T} \\
\mathrm{~A} 2 \mathrm{~T}\end{array}$ & $\begin{array}{l}20 \\
50 \\
82 \\
\end{array}$ & $\begin{array}{l}1 \\
1 \\
1\end{array}$ & $\begin{array}{r}0.84 \\
13.01 \\
0 \\
\end{array}$ & $\begin{array}{r}2.868037 \\
0.006 \\
0.000096\end{array}$ \\
\hline $\begin{array}{l}107 \\
107 \\
107\end{array}$ & $\begin{array}{l}12852 \\
12852 \\
12852\end{array}$ & $\begin{array}{l}\text { BO9E } \\
\text { BO9E } \\
\text { BO9E }\end{array}$ & $\begin{array}{l}20 \\
50 \\
82\end{array}$ & $\begin{array}{l}v \\
v \\
v\end{array}$ & $\begin{array}{r}0.72 \\
13.42 \\
0\end{array}$ & $\begin{array}{l}0.047572 \\
0.000095 \\
0.000001\end{array}$ \\
\hline $\begin{array}{l}107 \\
107 \\
107\end{array}$ & $\begin{array}{l}12852 \\
12852 \\
12852\end{array}$ & $\begin{array}{l}\text { BXE } \\
\text { BXE } \\
\text { BXE }\end{array}$ & $\begin{array}{l}20 \\
50 \\
82\end{array}$ & $\begin{array}{l}v \\
v \\
v\end{array}$ & $\begin{array}{r}0.72 \\
13.42 \\
0\end{array}$ & $\begin{array}{l}66.47092 \\
0.132468 \\
0.001881\end{array}$ \\
\hline $\begin{array}{l}107 \\
107 \\
107\end{array}$ & $\begin{array}{l}12852 \\
12852 \\
12852\end{array}$ & $\begin{array}{l}\text { BXS } \\
\text { BXS } \\
\text { BXS }\end{array}$ & $\begin{array}{l}20 \\
50 \\
82\end{array}$ & $\begin{array}{l}v \\
v \\
v\end{array}$ & $\begin{array}{r}0.72 \\
13.42 \\
0\end{array}$ & $\begin{array}{l}0.372719 \\
0.000743 \\
0.000011\end{array}$ \\
\hline
\end{tabular}


HNF-SD-SNF-TI-009, Rev, 1

\begin{tabular}{|c|c|c|c|c|c|c|}
\hline $\begin{array}{c}\text { Location } \\
\text { Code }\end{array}$ & Key Number & Fuel Model & $\begin{array}{c}\text { Material } \\
\text { Type }\end{array}$ & $\begin{array}{c}\text { sub ID } \\
\text { Code }\end{array}$ & Fuel Type & Isotopic Breakdown \\
\hline
\end{tabular}

\begin{tabular}{|c|c|c|c|c|c|c|}
\hline $\begin{array}{l}107 \\
107 \\
107 \\
\end{array}$ & $\begin{array}{l}12852 \\
12852 \\
12852 \\
\end{array}$ & $\begin{array}{l}\text { XO9E } \\
\text { XO9E } \\
\text { XO9E } \\
\end{array}$ & $\begin{array}{l}20 \\
50 \\
82 \\
\end{array}$ & $\begin{array}{l}v \\
v \\
v\end{array}$ & $\begin{array}{r}0.72 \\
13.42 \\
0 \\
\end{array}$ & $\begin{array}{r}0.022379 \\
0.000045 \\
6.300-07\end{array}$ \\
\hline $\begin{array}{l}107 \\
107 \\
107\end{array}$ & $\begin{array}{l}12942 \\
12942 \\
12942\end{array}$ & $\begin{array}{l}\mathrm{A} 2 \mathrm{~F} \\
\mathrm{~A} 2 \mathrm{~F} \\
\mathrm{~A} 2 \mathrm{~F}\end{array}$ & $\begin{array}{l}20 \\
50 \\
82\end{array}$ & $\begin{array}{l}1 \\
1 \\
1\end{array}$ & $\begin{array}{r}0.84 \\
13.03 \\
0\end{array}$ & $\begin{array}{r}0.739118 \\
0.00155 \\
0.000025\end{array}$ \\
\hline $\begin{array}{l}107 \\
107 \\
107\end{array}$ & $\begin{array}{l}12942 \\
12942 \\
12942\end{array}$ & $\begin{array}{l}\text { A2M } \\
\text { A2M } \\
\text { A2M }\end{array}$ & $\begin{array}{l}20 \\
50 \\
82\end{array}$ & $\begin{array}{l}1 \\
1 \\
1\end{array}$ & $\begin{array}{r}0.84 \\
13.03 \\
0\end{array}$ & $\begin{array}{l}17.40925 \\
0.036494 \\
0.000589\end{array}$ \\
\hline $\begin{array}{l}107 \\
107 \\
107\end{array}$ & $\begin{array}{l}12942 \\
12942 \\
12942 \\
\end{array}$ & $\begin{array}{l}\text { A2T } \\
\text { A2T } \\
\text { A2T }\end{array}$ & $\begin{array}{l}20 \\
50 \\
82\end{array}$ & $\begin{array}{l}1 \\
1 \\
1\end{array}$ & $\begin{array}{r}0.84 \\
13.03 \\
0\end{array}$ & $\begin{array}{r}2.246109 \\
0.00471 \\
0.000075\end{array}$ \\
\hline $\begin{array}{l}107 \\
107 \\
107 \\
\end{array}$ & $\begin{array}{l}12942 \\
12942 \\
12942 \\
\end{array}$ & $\begin{array}{l}\text { B7E } \\
\text { B7E } \\
\text { B7E }\end{array}$ & $\begin{array}{r}10 \\
50 \\
.82 \\
\end{array}$ & $\begin{array}{l}v \\
v \\
v\end{array}$ & $\begin{array}{r}0.56 \\
12.1 \\
0 \\
\end{array}$ & $\begin{array}{l}0.373946 \\
0.000671 \\
0.000009\end{array}$ \\
\hline $\begin{array}{l}107 \\
107 \\
107 \\
\end{array}$ & $\begin{array}{l}12942 \\
12942 \\
12942 \\
\end{array}$ & $\begin{array}{l}\text { BXA } \\
\text { BXA } \\
\text { BXA } \\
\end{array}$ & $\begin{array}{l}20 \\
50 \\
82 \\
\end{array}$ & $\begin{array}{l}v \\
v \\
v \\
\end{array}$ & $\begin{array}{r}0.73 \\
12.82 \\
0 \\
\end{array}$ & $\begin{array}{r}0.369594 \\
0.000702 \\
0.00001 \\
\end{array}$ \\
\hline $\begin{array}{l}107 \\
107 \\
107 \\
\end{array}$ & $\begin{array}{r}12942 \\
12942 \\
12942 \\
\end{array}$ & $\begin{array}{l}\text { BXC } \\
\text { BXC } \\
\text { BXC } \\
\end{array}$ & $\begin{array}{l}20 \\
50 \\
82 \\
\end{array}$ & $\begin{array}{l}v \\
v \\
v \\
\end{array}$ & $\begin{array}{r}0.73 \\
12.82 \\
0 \\
\end{array}$ & $\begin{array}{l}0.556128 \\
0.001057 \\
0.000015 \\
\end{array}$ \\
\hline $\begin{array}{l}107 \\
107 \\
107\end{array}$ & $\begin{array}{l}12942 \\
12942 \\
12942\end{array}$ & $\begin{array}{l}\text { BXE } \\
\text { BXE } \\
\text { BXE }\end{array}$ & $\begin{array}{l}20 \\
50 \\
82\end{array}$ & $\begin{array}{l}v \\
v \\
v\end{array}$ & $\begin{array}{r}0.73 \\
12.82 \\
0\end{array}$ & $\begin{array}{r}50.04592 \\
0.095109 \\
0.00133\end{array}$ \\
\hline $\begin{array}{l}107 \\
107 \\
107\end{array}$ & $\begin{array}{l}12942 \\
12942 \\
12942 \\
\end{array}$ & $\begin{array}{l}\text { BXS } \\
\text { BXS } \\
\text { BXS }\end{array}$ & $\begin{array}{l}20 \\
50 \\
82 \\
\end{array}$ & $\begin{array}{l}v \\
v \\
v\end{array}$ & $\begin{array}{r}0.73 \\
12.82 \\
0 \\
\end{array}$ & $\begin{array}{r}1.468644 \\
0.002791 \\
0.00004\end{array}$ \\
\hline $\begin{array}{l}107 \\
107 \\
107\end{array}$ & $\begin{array}{l}13015 \\
13015 \\
13015\end{array}$ & $\begin{array}{l}\text { Bo9C } \\
\text { Bo9C } \\
\text { Bo9C }\end{array}$ & $\begin{array}{l}20 \\
50 \\
82\end{array}$ & $\begin{array}{l}v \\
v \\
v\end{array}$ & $\begin{array}{r}0.72 \\
13.19 \\
\quad 0\end{array}$ & $\begin{array}{r}0.010503 \\
0.000021 \\
2.90 \mathrm{e}-07\end{array}$ \\
\hline $\begin{array}{l}107 \\
107 \\
107 \\
\end{array}$ & $\begin{array}{l}13015 \\
13015 \\
13015 \\
\end{array}$ & $\begin{array}{l}\text { B7E } \\
\text { B7E } \\
\text { B7E }\end{array}$ & $\begin{array}{l}10 \\
50 \\
82 \\
\end{array}$ & $\begin{array}{l}v \\
v \\
v\end{array}$ & $\begin{array}{r}0.56 \\
12.13 \\
0 \\
\end{array}$ & $\begin{array}{l}0.373937 \\
0.000673 \\
0.000009\end{array}$ \\
\hline $\begin{array}{l}107 \\
107 \\
107\end{array}$ & $\begin{array}{l}13015 \\
13015 \\
13015\end{array}$ & $\begin{array}{l}B \times C \\
B \times C \\
B \times C\end{array}$ & $\begin{array}{l}20 \\
50 \\
82\end{array}$ & $\begin{array}{l}v \\
v \\
v\end{array}$ & $\begin{array}{r}0.72 \\
13.19 \\
0 \\
\end{array}$ & $\begin{array}{l}4.585912 \\
0.009088 \\
0.000128\end{array}$ \\
\hline $\begin{array}{l}107 \\
107 \\
107\end{array}$ & $\begin{array}{l}13015 \\
13015 \\
13015\end{array}$ & $\begin{array}{l}\text { BXE } \\
\text { BXE } \\
\text { BXE }\end{array}$ & $\begin{array}{l}20 \\
50 \\
82\end{array}$ & $\begin{array}{l}v \\
v \\
v\end{array}$ & $\begin{array}{r}0.72 \\
13.19 \\
0\end{array}$ & $\begin{array}{r}36.5893 \\
0.072519 \\
0.00102\end{array}$ \\
\hline $\begin{array}{l}107 \\
107 \\
107\end{array}$ & $\begin{array}{l}13015 \\
13015 \\
13015\end{array}$ & $\begin{array}{l}\text { BXS } \\
\text { BXS } \\
\text { BXs }\end{array}$ & $\begin{array}{l}20 \\
50 \\
82\end{array}$ & $\begin{array}{l}v \\
v \\
v\end{array}$ & $\begin{array}{r}0.72 \\
13.19 \\
0 \\
\end{array}$ & $\begin{array}{l}2.609064 \\
0.005172 \\
0.000074\end{array}$ \\
\hline $\begin{array}{l}107 \\
107 \\
107 \\
\end{array}$ & $\begin{array}{l}13015 \\
13015 \\
13015 \\
\end{array}$ & $\begin{array}{l}\text { xo9c } \\
\text { Xo9c } \\
\text { X09C } \\
\end{array}$ & $\begin{array}{l}20 \\
50 \\
82 \\
\end{array}$ & $\begin{array}{l}v \\
v \\
v\end{array}$ & $\begin{array}{r}0.72 \\
13.19 \\
0 \\
\end{array}$ & $\begin{array}{r}0.004942 \\
0.00001 \\
1.40 e-07 \\
\end{array}$ \\
\hline $\begin{array}{l}107 \\
107 \\
107 \\
\end{array}$ & $\begin{array}{l}13016 \\
13016 \\
13016\end{array}$ & $\begin{array}{l}\text { A2F } \\
\text { A2F } \\
\text { A2F }\end{array}$ & $\begin{array}{l}20 \\
50 \\
82 \\
\end{array}$ & $\begin{array}{l}1 \\
1 \\
\end{array}$ & $\begin{array}{r}0.83 \\
13.18 \\
0 \\
\end{array}$ & $\begin{array}{l}0.762811 \\
0.001639 \\
0.000026\end{array}$ \\
\hline $\begin{array}{l}107 \\
107 \\
107\end{array}$ & $\begin{array}{l}13016 \\
13016 \\
13016 \\
\end{array}$ & $\begin{array}{l}\text { A2M } \\
\text { A2M } \\
\text { A2M }\end{array}$ & $\begin{array}{l}20 \\
50 \\
82 \\
\end{array}$ & $\begin{array}{l}1 \\
1 \\
1\end{array}$ & $\begin{array}{r}0.83 \\
13.18 \\
0\end{array}$ & $\begin{array}{l}19.57218 \\
0.042032 \\
0.000674\end{array}$ \\
\hline $\begin{array}{l}107 \\
107 \\
107\end{array}$ & $\begin{array}{l}13016 \\
13016 \\
13016\end{array}$ & $\begin{array}{l}\text { A2T } \\
\text { A2T } \\
\text { A2T }\end{array}$ & $\begin{array}{l}20 \\
50 \\
82\end{array}$ & $\begin{array}{l}1 \\
1 \\
1\end{array}$ & $\begin{array}{r}0.83 \\
13.18 \\
0\end{array}$ & $\begin{array}{l}0.247751 \\
0.000532 \\
0.000008\end{array}$ \\
\hline
\end{tabular}


HNF-SD-SNF-TI-009, Rev. I

\begin{tabular}{|c|c|c|c|c|c|c|}
\hline $\begin{array}{c}\text { Location } \\
\text { Code }\end{array}$ & Key Number & Fuel Model & $\begin{array}{c}\text { Material } \\
\text { Type }\end{array}$ & $\begin{array}{c}\text { sub ID } \\
\text { Code }\end{array}$ & Fuel Typo & Isotopic Breakdown \\
\hline
\end{tabular}

\begin{tabular}{|c|c|c|c|c|c|c|}
\hline $\begin{array}{l}107 \\
107 \\
107\end{array}$ & $\begin{array}{l}13016 \\
13016 \\
13016\end{array}$ & $\begin{array}{l}\text { No9M } \\
\text { No9M } \\
\text { No9M }\end{array}$ & $\begin{array}{l}20 \\
50 \\
82 \\
\end{array}$ & $\begin{array}{l}1 \\
1 \\
1\end{array}$ & $\begin{array}{r}0.83 \\
13.18 \\
0 \\
\end{array}$ & $\begin{array}{r}0.005235 \\
0.000011 \\
1.800-07\end{array}$ \\
\hline $\begin{array}{l}107 \\
107 \\
107\end{array}$ & $\begin{array}{l}13016 \\
13016 \\
13016\end{array}$ & $\begin{array}{l}\text { NO9T } \\
\text { NO9T } \\
\text { NO9T }\end{array}$ & $\begin{array}{l}20 \\
50 \\
82\end{array}$ & $\begin{array}{l}1 \\
1 \\
1\end{array}$ & $\begin{array}{r}-0.83 \\
13.18 \\
0\end{array}$ & $\begin{array}{r}0.015329 \\
0.000033 \\
5.400-07\end{array}$ \\
\hline $\begin{array}{l}107 \\
107 \\
107\end{array}$ & $\begin{array}{l}13017 \\
13017 \\
13017\end{array}$ & $\begin{array}{l}\text { BXC } \\
\text { BXC } \\
\text { BXC }\end{array}$ & $\begin{array}{l}20 \\
50 \\
82\end{array}$ & $\begin{array}{l}v \\
v \\
v\end{array}$ & $\begin{array}{r}0.76 \\
11.39 \\
0\end{array}$ & $\begin{array}{l}1.129932 \\
0.001898 \\
0.000025\end{array}$ \\
\hline $\begin{array}{l}107 \\
107 \\
107\end{array}$ & $\begin{array}{l}13017 \\
13017 \\
13017\end{array}$ & $\begin{array}{l}\text { BXE } \\
\text { BXE } \\
\text { BXE }\end{array}$ & $\begin{array}{l}20 \\
50 \\
82\end{array}$ & $\begin{array}{l}v \\
v \\
v\end{array}$ & $\begin{array}{r}0.76 \\
11.39 \\
0\end{array}$ & $\begin{array}{l}25.38336 \\
0.042626 \\
0.000565\end{array}$ \\
\hline $\begin{array}{l}107 \\
107 \\
107\end{array}$ & $\begin{array}{l}13017 \\
13017 \\
13017\end{array}$ & $\begin{array}{l}\text { BXS } \\
\text { BXS } \\
\text { BXS }\end{array}$ & $\begin{array}{l}20 \\
50 \\
82 \\
\end{array}$ & $\begin{array}{l}v \\
v \\
v\end{array}$ & $\begin{array}{r}0.76 \\
11.39 \\
0 \\
\end{array}$ & $\begin{array}{l}0.373695 \\
0.000627 \\
0.000008\end{array}$ \\
\hline $\begin{array}{l}107 \\
107 \\
107\end{array}$ & $\begin{array}{l}13371 \\
13371 \\
13371\end{array}$ & $\begin{array}{l}\mathrm{A} 12 \mathrm{~F} \\
\mathrm{~A} 12 \mathrm{~F} \\
\mathrm{~A} 12 \mathrm{~F}\end{array}$ & $\begin{array}{l}20 \\
50 \\
82 \\
\end{array}$ & $\begin{array}{l}1 \\
1 \\
1\end{array}$ & $\begin{array}{r}0.84 \\
12.95 \\
0\end{array}$ & $\begin{array}{r}0.015875 \\
0.0000033 \\
5.400 .07 \\
\end{array}$ \\
\hline $\begin{array}{l}107 \\
107 \\
107\end{array}$ & $\begin{array}{l}13371 \\
13371 \\
13371 \\
\end{array}$ & $\begin{array}{l}\mathrm{A} 2 \mathrm{~F} \\
\text { A2F } \\
\text { A2F }\end{array}$ & $\begin{array}{l}20 \\
50 \\
82 \\
\end{array}$ & $\begin{array}{l}1 \\
1 \\
1 \\
\end{array}$ & $\begin{array}{r}0.84 \\
12.95 \\
0 \\
\end{array}$ & $\begin{array}{l}0.245132 \\
0.000511 \\
0.000008\end{array}$ \\
\hline $\begin{array}{l}107 \\
107 \\
107\end{array}$ & $\begin{array}{l}13371 \\
13371 \\
13371\end{array}$ & $\begin{array}{l}\text { A2M } \\
\text { A2M } \\
\text { A2M }\end{array}$ & $\begin{array}{l}20 \\
50 \\
82 \\
\end{array}$ & $\begin{array}{l}1 \\
1 \\
1\end{array}$ & $\begin{array}{r}0.84 \\
12.95 \\
0 \\
\end{array}$ & $\begin{array}{l}4.713549 \\
0.009835 \\
0.000162 \\
\end{array}$ \\
\hline $\begin{array}{l}107 \\
107 \\
107\end{array}$ & $\begin{array}{l}13371 \\
13371 \\
13371\end{array}$ & $\begin{array}{l}\text { NO9T } \\
\text { NO9T } \\
\text { NO9T }\end{array}$ & $\begin{array}{l}20 \\
50 \\
82 \\
\end{array}$ & $\begin{array}{l}1 \\
1 \\
1\end{array}$ & $\begin{array}{r}0.84 \\
12.95 \\
0 \\
\end{array}$ & $\begin{array}{r}0.010219 \\
0.000021 \\
3.60 \mathrm{e}-07 \\
\end{array}$ \\
\hline $\begin{array}{l}107 \\
107 \\
107\end{array}$ & $\begin{array}{l}13372 \\
13372 \\
13372\end{array}$ & $\begin{array}{l}\text { Bogs } \\
\text { Bogs } \\
\text { Bogs }\end{array}$ & $\begin{array}{l}20 \\
50 \\
82 \\
\end{array}$ & $\begin{array}{l}v \\
v \\
v\end{array}$ & $\begin{array}{r}0.72 \\
13.02 \\
0 \\
\end{array}$ & $\begin{array}{r}0.014931 \\
0.000029 \\
4.20 e-07 \\
\end{array}$ \\
\hline $\begin{array}{l}107 \\
107 \\
107\end{array}$ & $\begin{array}{l}13372 \\
13372 \\
13372\end{array}$ & $\begin{array}{l}B \times C \\
B \times C \\
B \times C\end{array}$ & $\begin{array}{l}20 \\
50 \\
82\end{array}$ & $\begin{array}{l}v \\
v \\
v\end{array}$ & $\begin{array}{r}0.72 \\
13.02 \\
0\end{array}$ & $\begin{array}{r}3.170657 \\
0.006132 \\
0.00009\end{array}$ \\
\hline $\begin{array}{l}107 \\
107 \\
107\end{array}$ & $\begin{array}{l}13372 \\
13372 \\
13372\end{array}$ & $\begin{array}{l}\text { BXE } \\
\text { BXE } \\
\text { BXE }\end{array}$ & $\begin{array}{l}20 \\
50 \\
82\end{array}$ & $\begin{array}{l}v \\
v \\
v\end{array}$ & $\begin{array}{r}0.72 \\
13.02 \\
0\end{array}$ & $\begin{array}{l}11.76885 \\
0.022756 \\
0.000333\end{array}$ \\
\hline $\begin{array}{l}107 \\
107 \\
107\end{array}$ & $\begin{array}{l}13372 \\
13372 \\
13372 \\
\end{array}$ & $\begin{array}{l}\text { BXS } \\
\text { BXS } \\
\text { BXS }\end{array}$ & $\begin{array}{l}20 \\
50 \\
82 \\
\end{array}$ & $\begin{array}{l}v \\
v \\
v\end{array}$ & $\begin{array}{r}0.72 \\
13.02 \\
0 \\
\end{array}$ & $\begin{array}{l}4.324834 \\
0.008363 \\
0.000122 \\
\end{array}$ \\
\hline $\begin{array}{l}107 \\
107 \\
107\end{array}$ & $\begin{array}{l}13372 \\
13372 \\
13372\end{array}$ & $\begin{array}{l}\text { xo9c } \\
\text { xo9c } \\
\text { xo9c }\end{array}$ & $\begin{array}{l}20 \\
50 \\
82\end{array}$ & $\begin{array}{l}v \\
v \\
v\end{array}$ & $\begin{array}{r}0.72 \\
13.02 \\
0 \\
\end{array}$ & $\begin{array}{r}0.004951 \\
0.00001 \\
1.40 \mathrm{e}-07\end{array}$ \\
\hline $\begin{array}{l}107 \\
107 \\
107\end{array}$ & $\begin{array}{l}13524 \\
13524 \\
13524\end{array}$ & $\begin{array}{l}\text { BXA } \\
B X A \\
B X A\end{array}$ & $\begin{array}{l}20 \\
50 \\
82 \\
\end{array}$ & $\begin{array}{l}v \\
v \\
v\end{array}$ & $\begin{array}{r}0.72 \\
13.13 \\
0 \\
\end{array}$ & $\begin{array}{l}4.098228 \\
0.008005 \\
0.000117\end{array}$ \\
\hline $\begin{array}{l}107 \\
107 \\
107\end{array}$ & $\begin{array}{l}13524 \\
13524 \\
13524\end{array}$ & $\begin{array}{l}\mathrm{BXC} \\
\mathrm{BXC} \\
\mathrm{BXC}\end{array}$ & $\begin{array}{l}20 \\
50 \\
82\end{array}$ & $\begin{array}{l}v \\
v \\
v\end{array}$ & $\begin{array}{r}0.72 \\
13.13 \\
0\end{array}$ & $\begin{array}{l}2.923896 \\
0.005712 \\
0.000083\end{array}$ \\
\hline $\begin{array}{l}107 \\
107 \\
107\end{array}$ & $\begin{array}{l}13524 \\
13524 \\
13524\end{array}$ & $\begin{array}{l}\text { BXE } \\
\text { BXE } \\
\text { BXE }\end{array}$ & $\begin{array}{l}20 \\
50 \\
82\end{array}$ & $\begin{array}{l}v \\
v \\
v\end{array}$ & $\begin{array}{r}0.72 \\
13.13 \\
0\end{array}$ & $\begin{array}{l}25.92515 \\
0.050638 \\
0.000744\end{array}$ \\
\hline $\begin{array}{l}107 \\
107 . \\
107\end{array}$ & $\begin{array}{l}13524 \\
13524 \\
13524\end{array}$ & $\begin{array}{l}\text { BXS } \\
\text { BXS } \\
\text { BXS }\end{array}$ & $\begin{array}{l}20 \\
50 \\
82\end{array}$ & $\begin{array}{l}v \\
V \\
V\end{array}$ & $\begin{array}{r}0.72 \\
13.13 \\
0\end{array}$ & $\begin{array}{l}4.630184 \\
0.009046 \\
0.000133\end{array}$ \\
\hline
\end{tabular}




\begin{tabular}{|c|c|c|c|c|c|c|c|}
\hline $\begin{array}{c}\text { Location } \\
\text { Code }\end{array}$ & Key Number & Fuel Mode! & $\begin{array}{c}\text { Material } \\
\text { Type }\end{array}$ & $\begin{array}{l}\text { sub ID } \\
\text { Code }\end{array}$ & Fuel Type & Isotopic Breakdown & Discharge Mass \\
\hline
\end{tabular}

\begin{tabular}{|c|c|c|c|c|c|c|c|}
\hline $\begin{array}{l}107 \\
107 \\
107 \\
\end{array}$ & $\begin{array}{l}13525 \\
13525 \\
13525 \\
\end{array}$ & $\begin{array}{l}\text { A2F } \\
\text { A2F } \\
\text { A2F }\end{array}$ & $\begin{array}{l}20 \\
50 \\
82 \\
\end{array}$ & . & $\begin{array}{l}1 \\
1 \\
1\end{array}$ & $\begin{array}{r}0.82 \\
13.52 \\
0 \\
\end{array}$ & $\begin{array}{l}1.217087 \\
0.002653 \\
0.000045\end{array}$ \\
\hline $\begin{array}{l}107 \\
107 \\
107 \\
\end{array}$ & $\begin{array}{l}13525 \\
13525 \\
13525 \\
\end{array}$ & $\begin{array}{l}\text { A2M } \\
\text { A2M } \\
\text { A2M }\end{array}$ & $\begin{array}{l}20 \\
50 \\
82\end{array}$ & & $\begin{array}{l}1 \\
1 \\
1\end{array}$ & $\begin{array}{r}0.82 \\
.13 .52 \\
0\end{array}$ & $\begin{array}{l}16.33464 \\
0.035608 \\
0.000613\end{array}$ \\
\hline $\begin{array}{l}107 \\
107 \\
107\end{array}$ & $\begin{array}{l}13648 \\
13648 \\
13648\end{array}$ & $\begin{array}{l}\text { A2M } \\
\text { A2M } \\
\text { A2M }\end{array}$ & $\begin{array}{l}20 \\
50 \\
82\end{array}$ & & $\begin{array}{l}1 \\
1 \\
1\end{array}$ & $\begin{array}{r}0.88 \\
11.67 \\
0\end{array}$ & $\begin{array}{r}0.032513 \\
0.000061 \\
9.40 \mathrm{e}-07\end{array}$ \\
\hline $\begin{array}{l}107 \\
107 \\
107\end{array}$ & $\begin{array}{l}13650 \\
13650 \\
13650\end{array}$ & $\begin{array}{l}\text { A2F } \\
\text { A2F } \\
\text { A2F }\end{array}$ & $\begin{array}{l}20 \\
50 \\
82\end{array}$ & & $\begin{array}{l}1 . \\
1 \\
1\end{array}$ & $\begin{array}{r}0.83 \\
13.41 \\
0\end{array}$ & $\begin{array}{l}1.435141 \\
0.003108 \\
0.000053\end{array}$ \\
\hline $\begin{array}{l}107 \\
107 \\
107\end{array}$ & $\begin{array}{l}13650 \\
13650 \\
13650\end{array}$ & $\begin{array}{l}\mathrm{A} 2 \mathrm{M} \\
\mathrm{A} 2 \mathrm{M} \\
\mathrm{A} 2 \mathrm{M}\end{array}$ & $\begin{array}{l}20 \\
50 \\
82 \\
\end{array}$ & & $\begin{array}{l}1 \\
1 \\
1 .\end{array}$ & $\begin{array}{r}0.83 \\
13.41 \\
0 \\
\end{array}$ & $\begin{array}{l}12.39377 \\
0.026841 \\
0.000451 \\
\end{array}$ \\
\hline $\begin{array}{l}107 \\
107 \\
107\end{array}$ & $\begin{array}{l}13650 \\
13650 \\
13650\end{array}$ & $\begin{array}{l}\mathrm{A} 2 \mathrm{~T} \\
\mathrm{~A} 2 \mathrm{~T} \\
\mathrm{~A} 2 \mathrm{~T}\end{array}$ & $\begin{array}{l}20 \\
50 \\
82 \\
\end{array}$ & & $\begin{array}{l}1 \\
1 \\
1\end{array}$ & $\begin{array}{r}0.83 \\
13.41 \\
0\end{array}$ & $\begin{array}{r}2.7182 \\
0.005885 \\
0.000099 \\
\end{array}$ \\
\hline $\begin{array}{l}107 \\
107 \\
107\end{array}$ & $\begin{array}{l}13686 \\
13686 \\
13686\end{array}$ & $\begin{array}{l}\mathrm{A} 2 \mathrm{~F} \\
\text { A2F } \\
\text { A2F }\end{array}$ & $\begin{array}{l}20 \\
50 \\
82\end{array}$ & . & $\begin{array}{l}1 \\
1 \\
1\end{array}$ & $\begin{array}{r}0.86 \\
12.41 \\
0\end{array}$ & $\begin{array}{r}0.023339 \\
0.000047 \\
7.60 \mathrm{e}-07\end{array}$ \\
\hline $\begin{array}{l}107 \\
107 \\
107 \\
\end{array}$ & $\begin{array}{l}13686 \\
13686 \\
13686 \\
\end{array}$ & $\begin{array}{l}\mathrm{A} 2 \mathrm{M} \\
\mathrm{A} 2 \mathrm{M} \\
\mathrm{A} 2 \mathrm{M}\end{array}$ & $\begin{array}{l}20 \\
50 \\
82 \\
\end{array}$ & & $\begin{array}{l}1 \\
1 \\
1 \\
\end{array}$ & $\begin{array}{r}0.86 \\
12.41 \\
0 \\
\end{array}$ & $\begin{array}{r}17.5855 \\
0.035252 \\
0.000564\end{array}$ \\
\hline $\begin{array}{l}107 \\
107 \\
107\end{array}$ & $\begin{array}{l}13686 \\
13686 \\
13686\end{array}$ & $\begin{array}{l}\text { A2T } \\
\text { A2T } \\
\text { A2T }\end{array}$ & $\begin{array}{l}20 \\
50 \\
82 \\
\end{array}$ & & $\begin{array}{l}1 \\
1 \\
1 \\
\end{array}$ & $\begin{array}{r}0.86 \\
12.41 \\
\quad 0 \\
\end{array}$ & $\begin{array}{l}0.247249 \\
0.000496 \\
0.000008\end{array}$ \\
\hline $\begin{array}{l}107 \\
107 \\
107\end{array}$ & $\begin{array}{l}13724 \\
13724 \\
13724\end{array}$ & $\begin{array}{l}\text { A2T } \\
\text { A2T } \\
\text { A2T }\end{array}$ & $\begin{array}{l}20 \\
50 \\
82 \\
\end{array}$ & & $\begin{array}{l}1 \\
1 \\
1\end{array}$ & $\begin{array}{r}1.02 \\
5.99 \\
0 \\
\end{array}$ & $\begin{array}{r}0.015508 \\
0.000015 \\
1.80 \mathrm{e}-07\end{array}$ \\
\hline $\begin{array}{l}107 \\
107 \\
107\end{array}$ & $\begin{array}{l}13858 \\
13858 \\
13858 \\
\end{array}$ & $\begin{array}{l}\text { B7E } \\
\text { B7E } \\
\text { B7E } \\
\end{array}$ & $\begin{array}{l}10 \\
50 \\
82\end{array}$ & & $\begin{array}{l}v \\
v \\
v\end{array}$ & $\begin{array}{r}0.56 \\
12.01 \\
0\end{array}$ & $\begin{array}{l}0.373955 \\
0.000668 \\
0.000009\end{array}$ \\
\hline $\begin{array}{l}107 \\
107 \\
107\end{array}$ & $\begin{array}{l}13858 \\
13858 \\
13858 \\
\end{array}$ & $\begin{array}{l}\text { BXC } \\
\text { BXC } \\
\text { BXC }\end{array}$ & $\begin{array}{l}20 \\
50 \\
82\end{array}$ & & $\begin{array}{l}v \\
v \\
v\end{array}$ & $\begin{array}{r}0.74 \\
12.04 \\
0\end{array}$ & $\begin{array}{l}3.122185 \\
0.005575 \\
0.000077\end{array}$ \\
\hline $\begin{array}{l}107 \\
107 \\
107\end{array}$ & $\begin{array}{l}13858 \\
13858 \\
13858\end{array}$ & $\begin{array}{l}\text { BXE } \\
\text { BXE } \\
\text { BXE } \\
\end{array}$ & $\begin{array}{l}20 \\
50 \\
82\end{array}$ & & $\begin{array}{l}v \\
v \\
v\end{array}$ & $\begin{array}{r}0.74 \\
12.04 \\
0\end{array}$ & $\begin{array}{r}48.26557 \\
0.086215 \\
0.00122 \\
\end{array}$ \\
\hline $\begin{array}{l}107 \\
107 \\
107\end{array}$ & $\begin{array}{l}13858 \\
13858 \\
13858\end{array}$ & $\begin{array}{l}\text { BXs } \\
\text { BXs } \\
\text { BXs }\end{array}$ & $\begin{array}{l}20 \\
50 \\
82\end{array}$ & & $\begin{array}{l}v \\
v \\
v\end{array}$ & $\begin{array}{r}0.74 \\
12.04 \\
0 \\
\end{array}$ & $\begin{array}{l}1.009438 \\
0.001803 \\
0.000026\end{array}$ \\
\hline $\begin{array}{l}107 \\
107 \\
107\end{array}$ & $\begin{array}{l}13858 \\
13858 \\
13858\end{array}$ & $\begin{array}{l}x 09 \mathrm{C} \\
\times 09 \mathrm{C} \\
\text { xo9c }\end{array}$ & $\begin{array}{l}20 \\
50 \\
82\end{array}$ & & $\begin{array}{l}v \\
v \\
v\end{array}$ & $\begin{array}{r}0.74 \\
12.04 \\
0 \\
\end{array}$ & $\begin{array}{r}0.004946 \\
0.000009 \\
1.20 \mathrm{e}-07 \\
\end{array}$ \\
\hline $\begin{array}{l}107 \\
107 \\
107 \\
\end{array}$ & $\begin{array}{l}13859 \\
13859 \\
13859 \\
\end{array}$ & $\begin{array}{l}\text { A1 2F } \\
\text { A1 2F } \\
\text { A1 2F }\end{array}$ & $\begin{array}{l}20 \\
50 \\
82\end{array}$ & & $\begin{array}{l}1 \\
1 \\
1\end{array}$ & $\begin{array}{r}0.86 \\
12.28 \\
0 \\
\end{array}$ & $\begin{array}{r}0.007911 \\
0.000016 \\
2.50 \mathrm{e}-07\end{array}$ \\
\hline $\begin{array}{l}107 \\
107 \\
107\end{array}$ & $\begin{array}{l}13859 \\
13859 \\
13859\end{array}$ & $\begin{array}{l}\text { A2F } \\
\text { A2F } \\
\text { A2F }\end{array}$ & $\begin{array}{l}20 \\
50 \\
82\end{array}$ & & $\begin{array}{l}1 \\
1 \\
1\end{array}$ & $\begin{array}{r}0.86 \\
12.28 \\
0\end{array}$ & $\begin{array}{r}0.011634 \\
0.000023 \\
3.70 e-07\end{array}$ \\
\hline $\begin{array}{l}107 \\
107 \\
107\end{array}$ & $\begin{array}{l}13859 \\
13859 \\
13859\end{array}$ & $\begin{array}{l}\mathrm{A} 2 \mathrm{M} \\
\mathrm{A} 2 \mathrm{M} \\
\mathrm{A} 2 \mathrm{M}\end{array}$ & $\begin{array}{l}20 \\
50 \\
82\end{array}$ & & $\begin{array}{l}1 \\
1 \\
1\end{array}$ & $\begin{array}{r}0.86 \\
12.28 \\
. \quad 0\end{array}$ & $\begin{array}{l}25.82511 \\
0.051268 \\
0.000829\end{array}$ \\
\hline
\end{tabular}


HNF-SD-SNF-TI-009, Rev. 1

\begin{tabular}{|c|c|c|c|c|c|c|}
\hline $\begin{array}{c}\text { Location } \\
\text { Code }\end{array}$ & $\cdot$ Key Number & Fuel Model & $\begin{array}{c}\text { Material } \\
\text { Type }\end{array}$ & $\begin{array}{c}\text { sub ID } \\
\text { Code }\end{array}$ & Fuel Type & Isotopic Breakdown \\
\hline
\end{tabular}

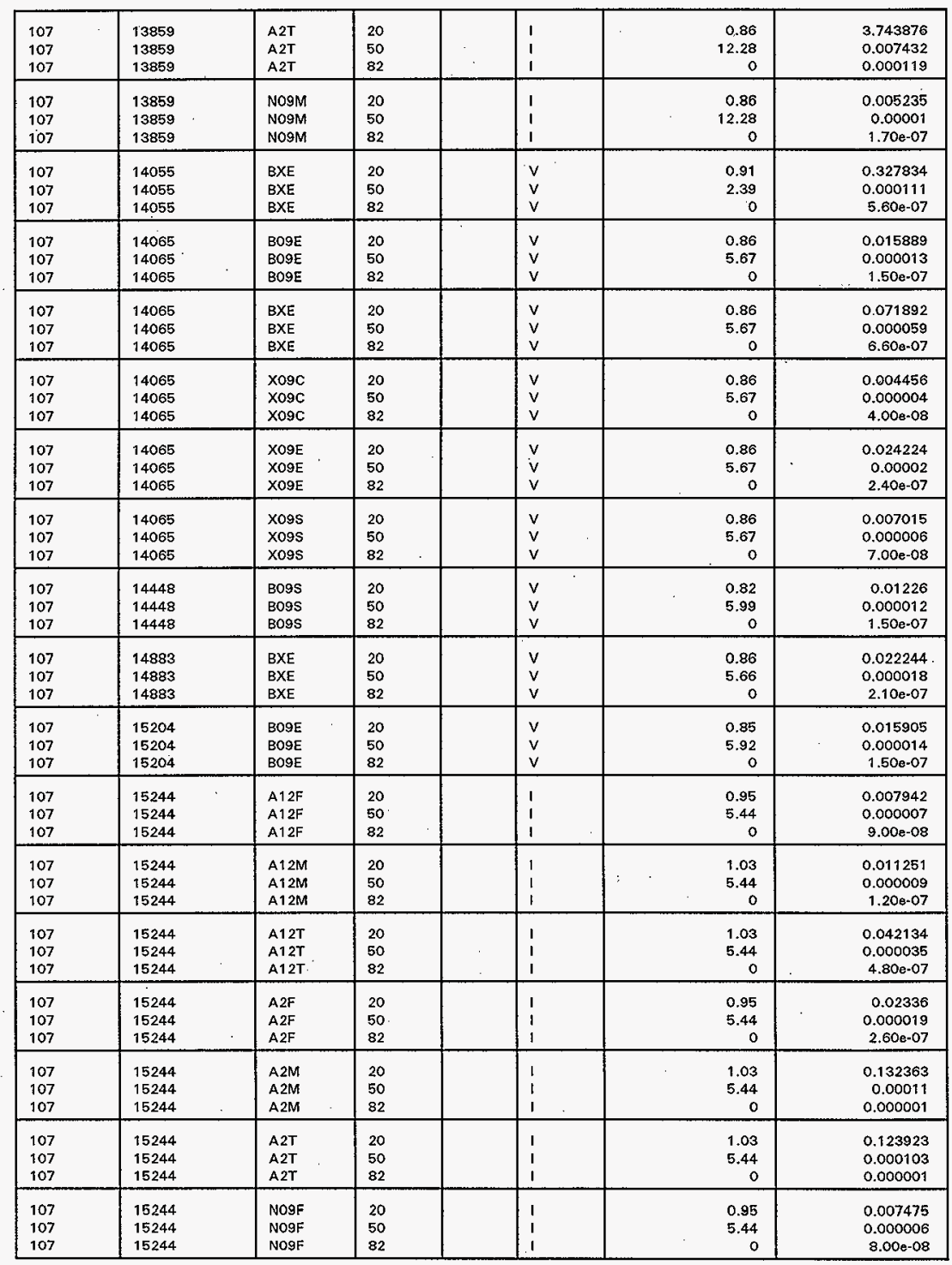


HNF-SD-SNF-TI-009, Rev. 1

\begin{tabular}{|c|c|c|c|c|c|c|}
\hline $\begin{array}{c}\text { Location } \\
\text { Cade }\end{array}$ & Key Number & Fuel Model & $\begin{array}{c}\text { Material } \\
\text { Type }\end{array}$ & $\begin{array}{c}\text { sub ID } \\
\text { Code }\end{array}$ & Fuel Type & Isotopic Breakdown \\
\hline
\end{tabular}

\begin{tabular}{|c|c|c|c|c|c|c|}
\hline $\begin{array}{l}107 \\
107 \\
107 \\
\end{array}$ & $\begin{array}{l}15244 \\
15244 \\
15244 \\
\end{array}$ & $\begin{array}{l}\text { NO9T } \\
\text { NO9T } \\
\text { NO9T } \\
\end{array}$ & $\begin{array}{l}20 \\
50 \\
82 \\
\end{array}$ & $\begin{array}{l}1 \\
1 \\
1\end{array}$ & $\begin{array}{r}1.03 \\
5.44 \\
0 \\
\end{array}$ & $\begin{array}{r}0.004957 \\
0.000004 \\
5.000-08\end{array}$ \\
\hline $\begin{array}{l}107 \\
107 \\
107 \\
\end{array}$ & $\begin{array}{l}15244 \\
15244 \\
15244 \\
\end{array}$ & $\begin{array}{l}\text { xogs } \\
\text { xogs } \\
\text { xogs } \\
\end{array}$ & $\begin{array}{l}10 \\
50 \\
82 \\
\end{array}$ & $\begin{array}{l}v \\
v \\
v\end{array}$ & $\begin{array}{r}0.71 \\
13.58 \\
0 \\
\end{array}$ & $\begin{array}{r}0.007005 \\
0.000014 \\
2.00 e-07\end{array}$ \\
\hline $\begin{array}{l}107 \\
107 \\
107 \\
\end{array}$ & $\begin{array}{l}15347 \\
15347 \\
15347 \\
\end{array}$ & $\begin{array}{l}\text { A1 } 2 F \\
\text { A12F } \\
\text { A12F }\end{array}$ & $\begin{array}{l}20 \\
50 \\
82 \\
\end{array}$ & $\begin{array}{l}1 \\
1 \\
1 \\
\end{array}$ & $\begin{array}{r}0.95 \\
6.16 \\
0 \\
\end{array}$ & $\begin{array}{r}0.007941 \\
0.000008 \\
1.00 e-07\end{array}$ \\
\hline $\begin{array}{l}107 \\
107 \\
107 \\
\end{array}$ & $\begin{array}{l}15347 \\
15347 \\
15347 \\
\end{array}$ & $\begin{array}{l}\mathrm{A} 2 \mathrm{~F} \\
\mathrm{~A} 2 \mathrm{~F} \\
\mathrm{~A} 2 \mathrm{~F}\end{array}$ & $\begin{array}{l}20 \\
50 \\
82 \\
\end{array}$ & $\begin{array}{l}1 \\
1 \\
1 \\
\end{array}$ & $\begin{array}{r}0.95 \\
6.16 \\
0 \\
\end{array}$ & $\begin{array}{r}0.011679 \\
0.000011 \\
1.500-07 \\
\end{array}$ \\
\hline $\begin{array}{l}107 \\
107 \\
107 \\
\end{array}$ & $\begin{array}{l}15347 \\
15347 \\
15347 \\
\end{array}$ & $\begin{array}{l}\mathrm{A} 2 \mathrm{M} \\
\mathrm{A} 2 \mathrm{M} \\
\mathrm{A} 2 \mathrm{M}\end{array}$ & $\begin{array}{r}20 \\
50 \\
82 \\
\end{array}$ & $\begin{array}{l}1 \\
1 \\
1 \\
\end{array}$ & $\begin{array}{r}1.02 \\
6.16 \\
0 \\
\end{array}$ & $\begin{array}{r}0.083087 \\
0.00008 \\
0.000001 \\
\end{array}$ \\
\hline $\begin{array}{l}107 \\
107 \\
107 \\
\end{array}$ & $\begin{array}{l}15347 \\
15347 \\
15347 \\
\end{array}$ & $\begin{array}{l}\mathrm{A} 2 \mathrm{~T} \\
\mathrm{~A} 2 \mathrm{~T} \\
\mathrm{~A} 2 \mathrm{~T}\end{array}$ & $\begin{array}{l}20 \\
50 \\
82 \\
\end{array}$ & $\begin{array}{l}1 \\
1 \\
1 \\
\end{array}$ & $\begin{array}{r}1.02 \\
6.16 \\
0 \\
\end{array}$ & $\begin{array}{r}0.031107 \\
0.00003 \\
4.20 \mathrm{e}-07 \\
\end{array}$ \\
\hline $\begin{array}{l}107 \\
107 \\
107 \\
\end{array}$ & $\begin{array}{l}15347 \\
15347 \\
15347 \\
\end{array}$ & $\begin{array}{l}\text { NO9M } \\
\text { NO9M } \\
\text { NO9M }\end{array}$ & $\begin{array}{l}20 \\
50 \\
82 \\
\end{array}$ & $\begin{array}{l}1 \\
1 \\
1\end{array}$ & $\begin{array}{r}1.02 \\
6.16 \\
0 \\
\end{array}$ & $\begin{array}{r}0.010635 \\
0.00001 \\
1.40 \mathrm{e}-07 \\
\end{array}$ \\
\hline $\begin{array}{l}107 \\
107 \\
107 \\
\end{array}$ & $\begin{array}{l}15445 \\
15445 \\
15445 \\
\end{array}$ & $\begin{array}{l}\text { A2M } \\
\text { A2M } \\
\text { A2M }\end{array}$ & $\begin{array}{l}20 \\
50 \\
82 \\
\end{array}$ & $\begin{array}{l}1 \\
1 \\
1 \\
\end{array}$ & $\begin{array}{r}1.05 \\
5.23 \\
0 \\
\end{array}$ & $\begin{array}{l}1.296922 \\
0.000984 \\
0.000012\end{array}$ \\
\hline $\begin{array}{l}107 \\
107 \\
107 \\
\end{array}$ & $\begin{array}{l}15445 \\
15445 \\
15446 \\
\end{array}$ & $\begin{array}{l}\text { A2T } \\
\text { A2T } \\
\text { A2T }\end{array}$ & $\begin{array}{l}20 \\
50 \\
82 \\
\end{array}$ & $\begin{array}{l}1 \\
1 \\
1 \\
\end{array}$ & $\begin{array}{r}1.03 \\
5.23 \\
0 \\
\end{array}$ & $\begin{array}{l}0.668979 \\
0.000508 \\
0.000006 \\
\end{array}$ \\
\hline $\begin{array}{l}107 \\
107 \\
107 \\
\end{array}$ & $\begin{array}{l}15448 \\
15448 \\
15448 \\
\end{array}$ & $\begin{array}{l}\mathrm{A} 12 \mathrm{~F} \\
\mathrm{~A} 12 \mathrm{~F} \\
\mathrm{~A} 12 \mathrm{~F}\end{array}$ & $\begin{array}{l}20 \\
50 \\
82 \\
\end{array}$ & $\begin{array}{l}1 \\
1 \\
1 \\
\end{array}$ & $\begin{array}{r}1.02 \\
4.54 \\
0 \\
\end{array}$ & $\begin{array}{r}0.007997 \\
0.000005 \\
7.000-08 \\
\end{array}$ \\
\hline $\begin{array}{l}107 \\
107 \\
107 \\
\end{array}$ & $\begin{array}{l}15448 \\
15448 \\
15448 \\
\end{array}$ & $\begin{array}{l}\text { A2T } \\
\text { A2T } \\
\text { A2T }\end{array}$ & $\begin{array}{l}20 \\
50 \\
82 \\
\end{array}$ & $\begin{array}{l}1 \\
1 \\
1 \\
\end{array}$ & $\begin{array}{r}1.03 \\
4.54 \\
0 \\
\end{array}$ & $\begin{array}{r}0.015801 \\
0.000011 \\
1.30 \mathrm{e}-07 \\
\end{array}$ \\
\hline $\begin{array}{l}107 \\
107 \\
107 \\
\end{array}$ & $\begin{array}{l}15448 \\
15448 \\
15448 \\
\end{array}$ & $\begin{array}{l}\text { NO9F } \\
\text { NOGF } \\
\text { NO9F }\end{array}$ & $\begin{array}{l}20 \\
50 \\
82 \\
\end{array}$ & $\begin{array}{l}1 \\
1 \\
1\end{array}$ & $\begin{array}{r}1.02 \\
4.54 \\
0 \\
\end{array}$ & $\begin{array}{r}0.003763 \\
0.000003 \\
3.000-08 \\
\end{array}$ \\
\hline $\begin{array}{l}107 \\
107 \\
107 \\
\end{array}$ & $\begin{array}{l}15448 \\
15448 \\
15448 \\
\end{array}$ & $\begin{array}{l}\text { No9M } \\
\text { No9M } \\
\text { NO9M }\end{array}$ & $\begin{array}{l}20 \\
50 \\
82 \\
\end{array}$ & $\begin{array}{l}1 \\
1 \\
1 \\
\end{array}$ & $\begin{array}{r}1.07 \\
4.54 \\
0 \\
\end{array}$ & $\begin{array}{r}0.005323 \\
0.000004 \\
4.008-08 \\
\end{array}$ \\
\hline $\begin{array}{l}107 \\
107 \\
107 \\
\end{array}$ & $\begin{array}{l}15451 \\
15451 \\
15451 \\
\end{array}$ & $\begin{array}{l}\text { A2M } \\
\text { A2M } \\
\text { A2M } \\
\end{array}$ & $\begin{array}{l}20 \\
50 \\
82 \\
\end{array}$ & $\begin{array}{l}1 \\
1 \\
1\end{array}$ & $\begin{array}{r}1.04 \\
5.31 \\
0 \\
\end{array}$ & $\begin{array}{l}0.465448 \\
0.000387 \\
0.000005\end{array}$ \\
\hline $\begin{array}{l}107 \\
107 \\
107\end{array}$ & $\begin{array}{l}15457 \\
15457 \\
15457\end{array}$ & $\begin{array}{l}\text { A2M } \\
\text { A.2M } \\
\text { A2M }\end{array}$ & $\begin{array}{l}20 \\
50 \\
82 \\
\end{array}$ & $\begin{array}{l}1 \\
1 \\
1 \\
\end{array}$ & $\begin{array}{r}1.09 \\
2.85 \\
\quad 0 \\
\end{array}$ & $\begin{array}{r}0.033277 \\
0.000015 \\
1.80 \mathrm{e}-07 \\
\end{array}$ \\
\hline $\begin{array}{l}107 \\
107 \\
107 \\
\end{array}$ & $\begin{array}{l}15459 \\
15459 \\
15459 \\
\end{array}$ & $\begin{array}{l}\text { A2M } \\
\text { A2M } \\
\text { A2M }\end{array}$ & $\begin{array}{l}20 \\
50 \\
82 \\
\end{array}$ & 1 & $\begin{array}{r}1.07 \\
4.06 \\
.0 \\
\end{array}$ & $\begin{array}{r}25.26509 \\
0.01519 \\
0.000182 \\
\end{array}$ \\
\hline $\begin{array}{l}107 \\
107 \\
107 \\
\end{array}$ & $\begin{array}{l}15459 \\
15459 \\
15459 \\
\end{array}$ & $\begin{array}{l}\text { A2T } \\
\text { A2T } \\
\text { A2T }\end{array}$ & $\begin{array}{l}20 \\
50 \\
82 \\
\end{array}$ & $\begin{array}{l}1 \\
1 \\
1 \\
\end{array}$ & $\begin{array}{r}1.07 \\
4.06 \\
0 \\
\end{array}$ & $\begin{array}{r}8.655769 \\
0.00521 \\
0.000067 \\
\end{array}$ \\
\hline $\begin{array}{l}107 \\
107 \\
107\end{array}$ & $\begin{array}{l}15460 \\
15460 \\
15460\end{array}$ & $\begin{array}{l}\mathrm{A} 2 \mathrm{M} \\
\mathrm{A} 2 \mathrm{M} \\
\mathrm{A} 2 \mathrm{M}\end{array}$ & $\begin{array}{l}20 \\
50 \\
82\end{array}$ & $\begin{array}{l}1 \\
1 \\
1\end{array}$ & $\begin{array}{r}1.08 \\
3.32 \\
0 \\
\end{array}$ & $\begin{array}{l}2.096243 \\
0.001042 \\
0.000011\end{array}$ \\
\hline
\end{tabular}


HNF-SD-SNF-TI-009, Rev, 1

\begin{tabular}{|c|c|c|c|c|c|c|c|}
\hline $\begin{array}{c}\text { Location } \\
\text { Code }\end{array}$ & Key Number & Fuel Model & $\begin{array}{c}\text { Material } \\
\text { Type }\end{array}$ & $\begin{array}{l}\text { sub ID } \\
\text { Code }\end{array}$ & Fuel Type & Isotopic Breakdown & Discharge Mass \\
\hline
\end{tabular}

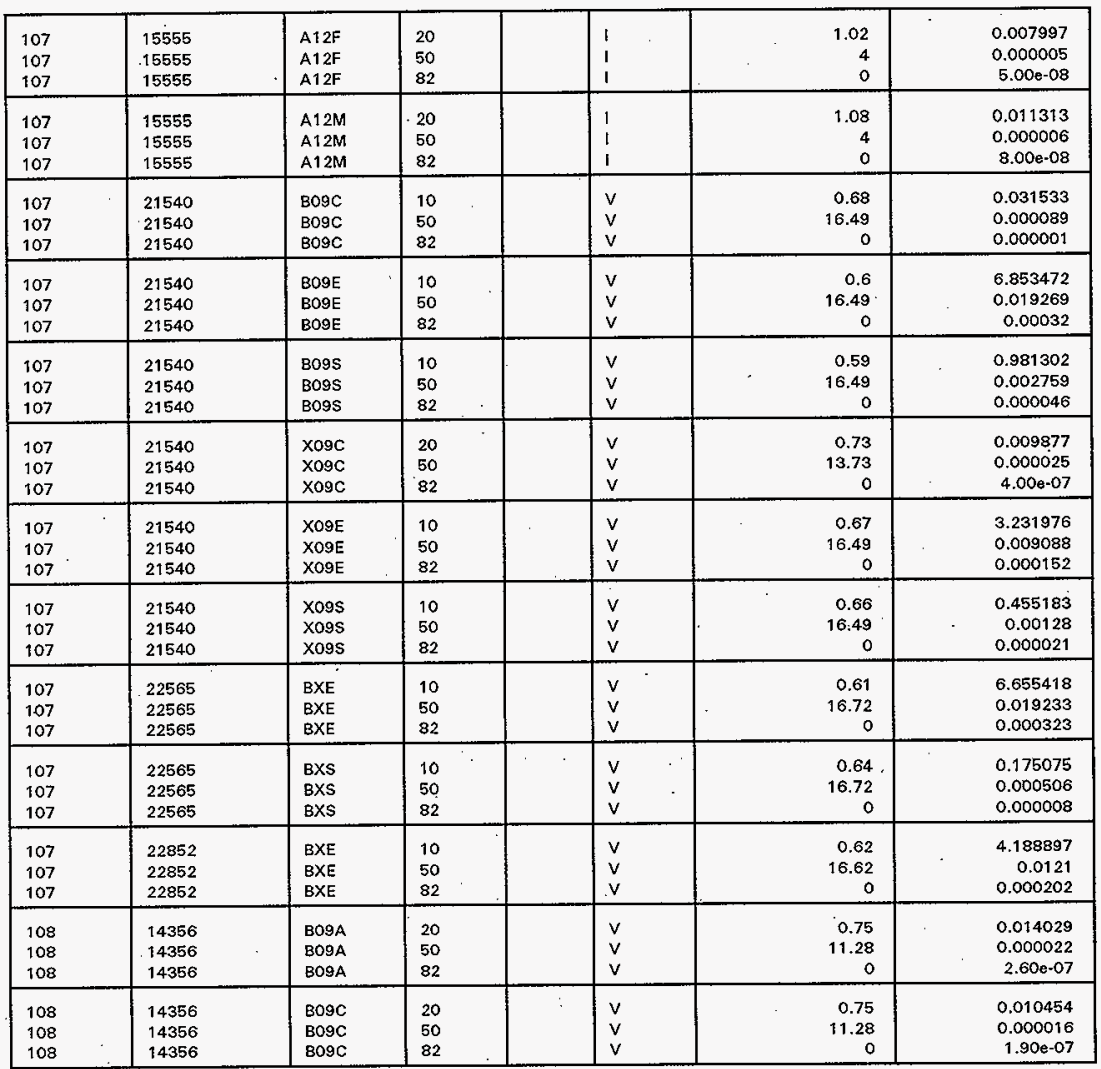


HNF-SD-SNF-TI-009, Rev . 1

APPENDIX B

RADNUC INPUT AND OUTPUT FILES 
Selected information was taken from the accountability database (Appendix A) to develop the following data files which were used as input files in the RADNUC program. Five separate data files were used; one for the combined basins, one for K-East alone, one for K-West alone, one for the shielding basis, and one for the safety/regulatory assessment basis. Eleven keys in the $\mathrm{K}$ East Basin (2.38 MTU) and two keys in the $K$ West Basin (0.32 MTU) in the accountability database were un-irradiated fuel, these keys are not included in the RADNUC input files. The uranium from the keys not included in the RADNUC input is added to the uranium mass, activity, and heat generation tables within the document.

The first four lines of the data files are used to identify the information, and are ignored by RADNUC. RADNUC uses the information following the first four 1 ines to estimate the radionuclide content. Each 1 ine represents one record from the accountability database, and contains the following information:

- First Field

- Second Field

- Third Field The first field is the Key Number. This is the date (HAPO day) that the fuel was discharged from the reactor.

The second field is the grade and is ignored by RADNUC. The grade corresponds to the percent ${ }^{240} \mathrm{Pu}$ of the total plutonium.

The third field is the type fuel, and indicates the initial ${ }^{235} \mathrm{U}$ enrichment. This field contains either a 1 corresponding to mark $1 \mathrm{~A}$ fuel or a 4 corresponding to mark 4 fuel.

- Fourth Field The fourth field is the number of elements in the record. This field is ignored by RADNUC.

- Fifth Field The fifth field is the percent ${ }^{240} \mathrm{Pu}$ of the total plutonium.

- Sixth Field

The sixth field is the combined masses of uranium and plutonium from the accountability database. The intent is to estimate the pre-irradiation uranium content of the fuel this will be a slight underestimation of the pre-irradiation uranium because it does not account for fission product mass.

- Seventh Field The seventh field is the month the fuel was processed in PUREX. It is important to note that the RADNUC program was written to estimate radionuclides in tank waste. The numbers used in the seventh and eighth fields is described in the eighth fields definition below.

- Eighth Field The eighth field is the year the fuel was processed in PUREX. The seventh and eighth fields were set to 12 and 99 corresponding to december 1999, a date 1 ater than $1 / 1 / 1995$ (decay date). 
HNF-SD-SNF-TI-009, Rev. 1

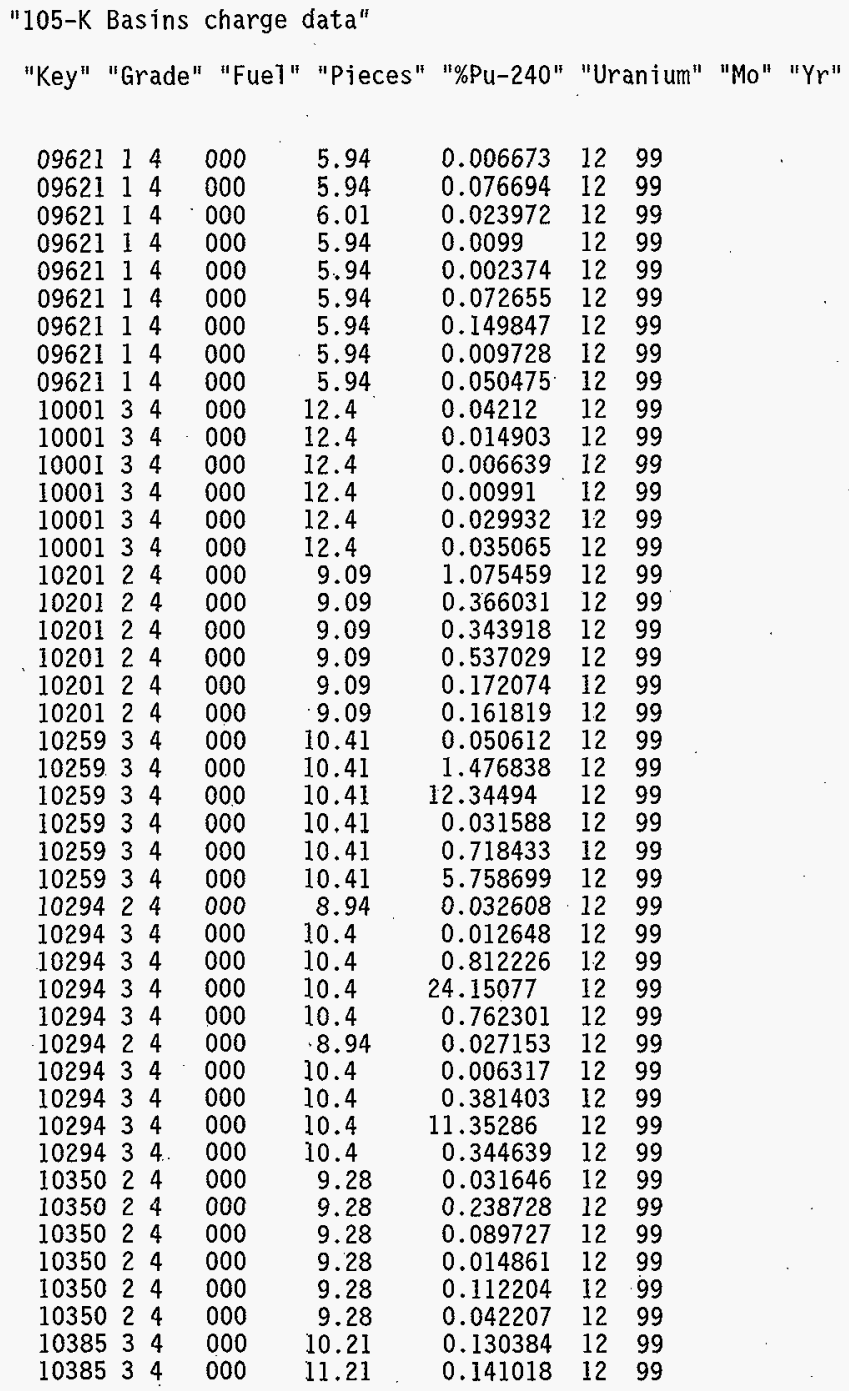


HNF-SD-SNF-TI-009, Rev . 1

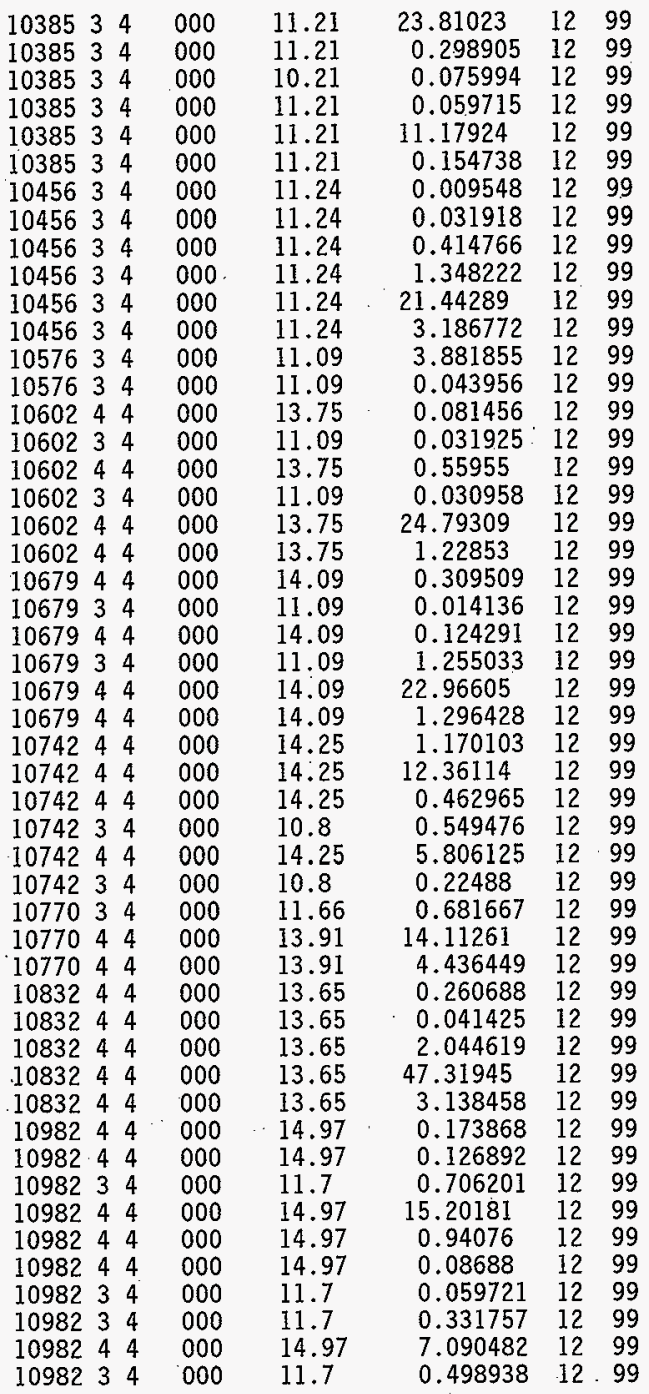


HNF-SD-SNF-TI-009, Rev. I

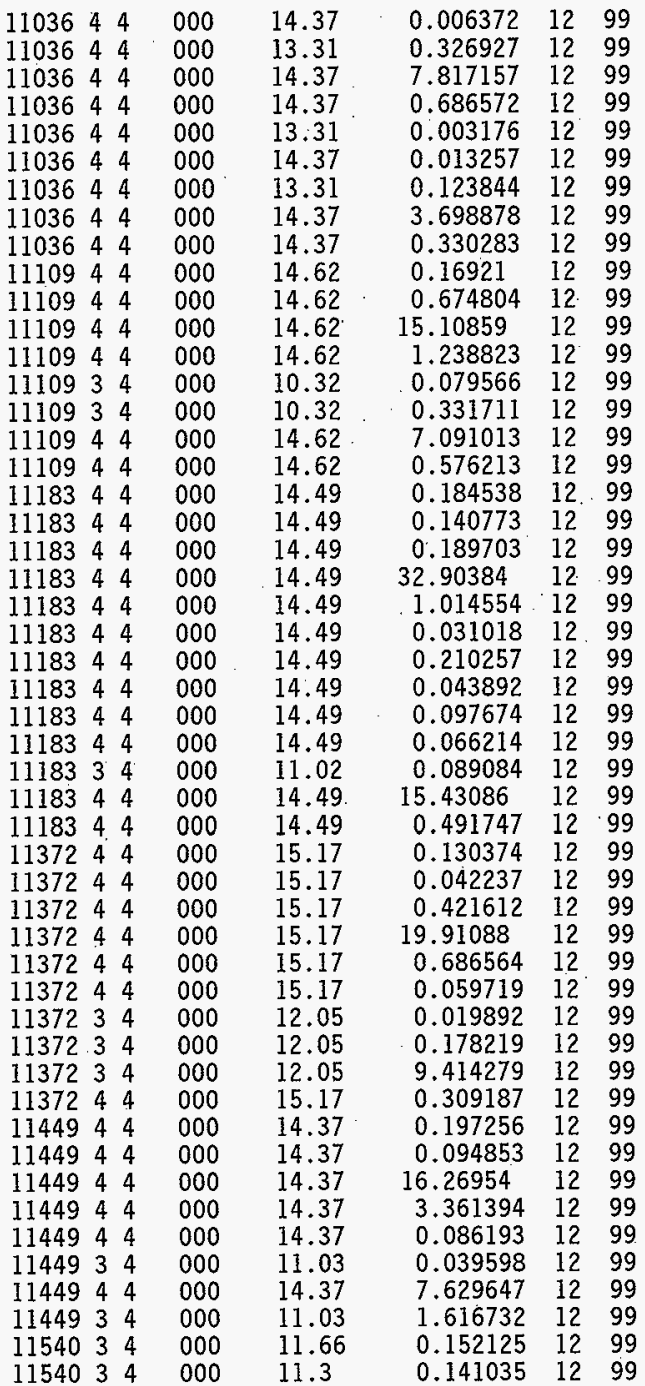




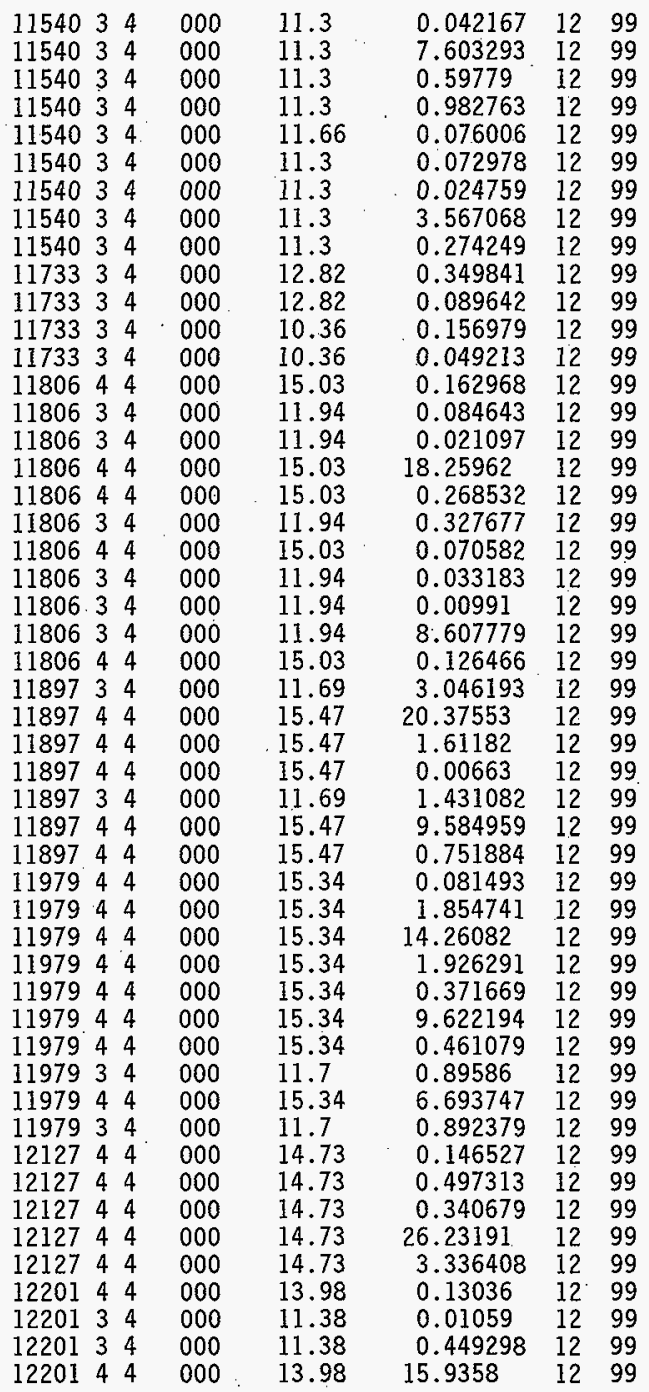




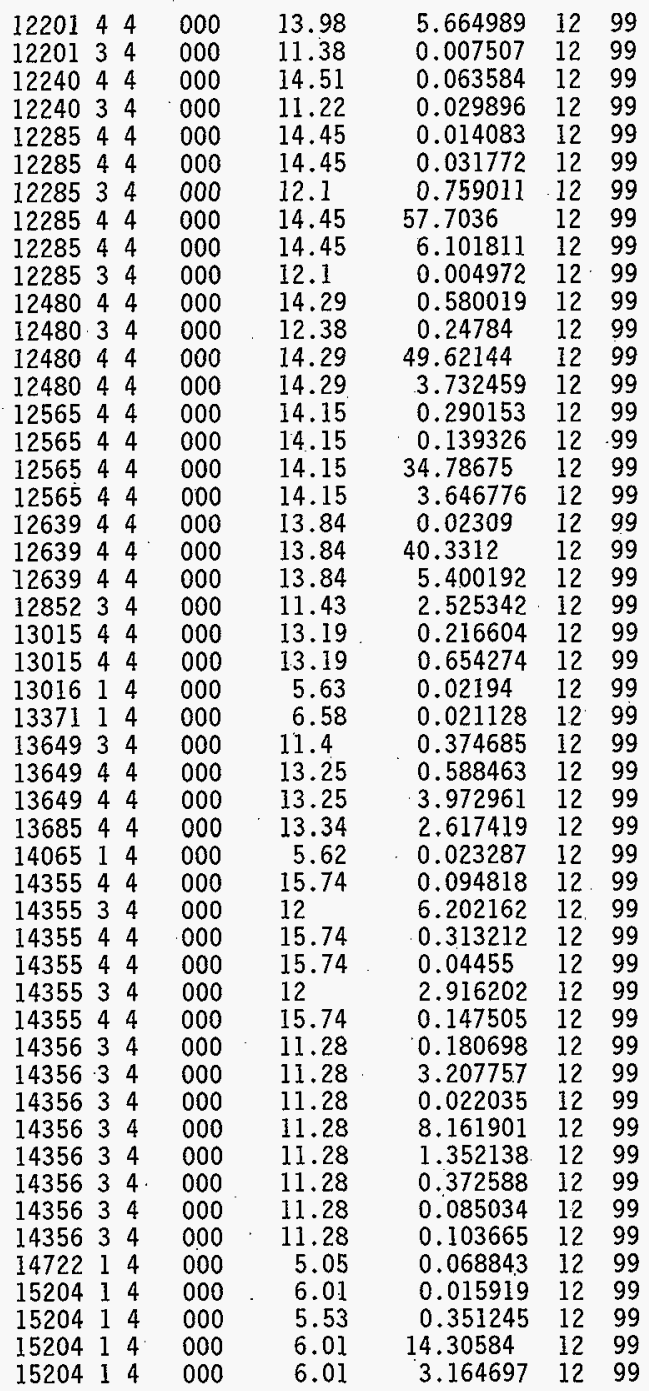


HNF-SD-SNF-TI-009, Rev. I

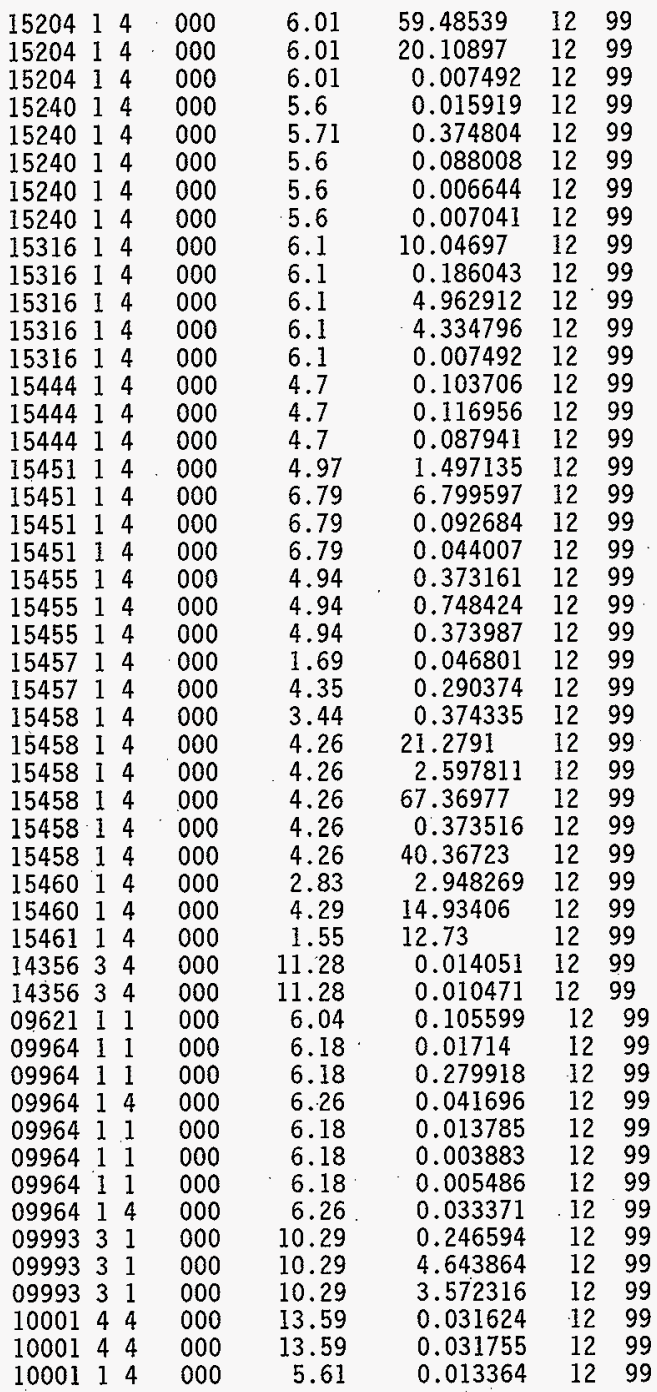


HNF-SD-SNF-TI-009, Rev. 1

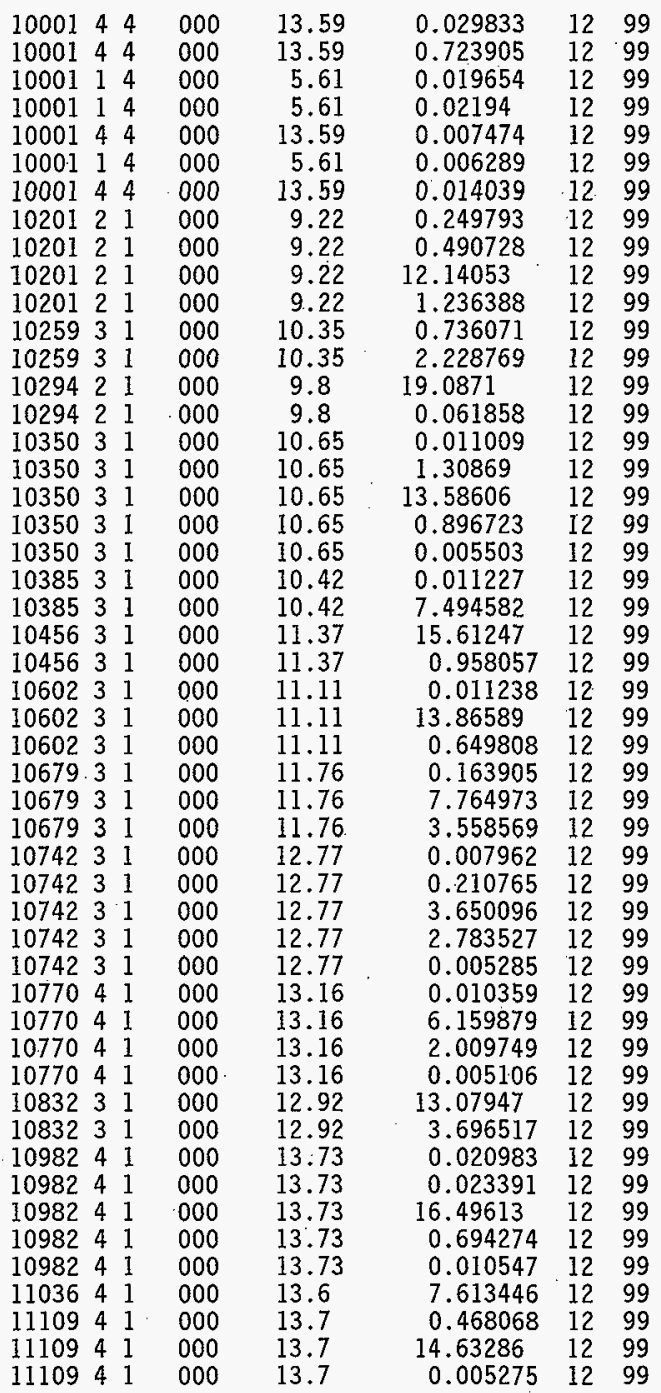


HNF-SD-SNF-TI-009, Rev. 1

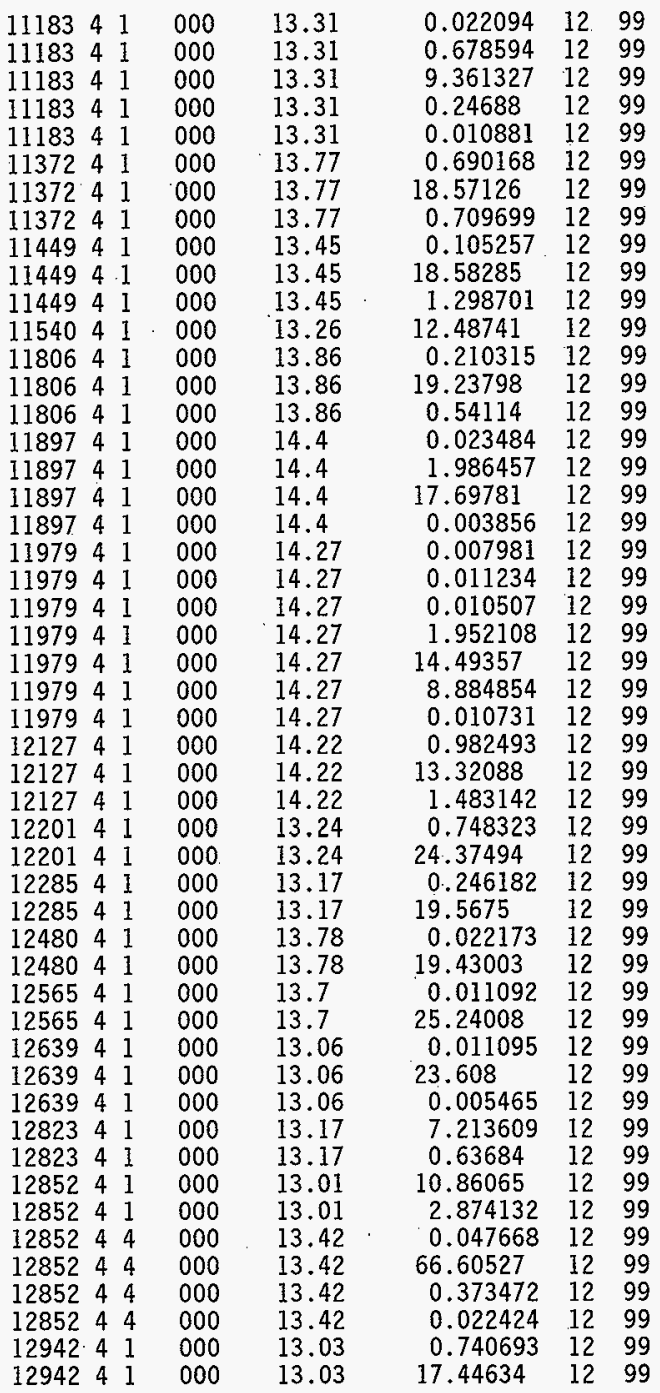




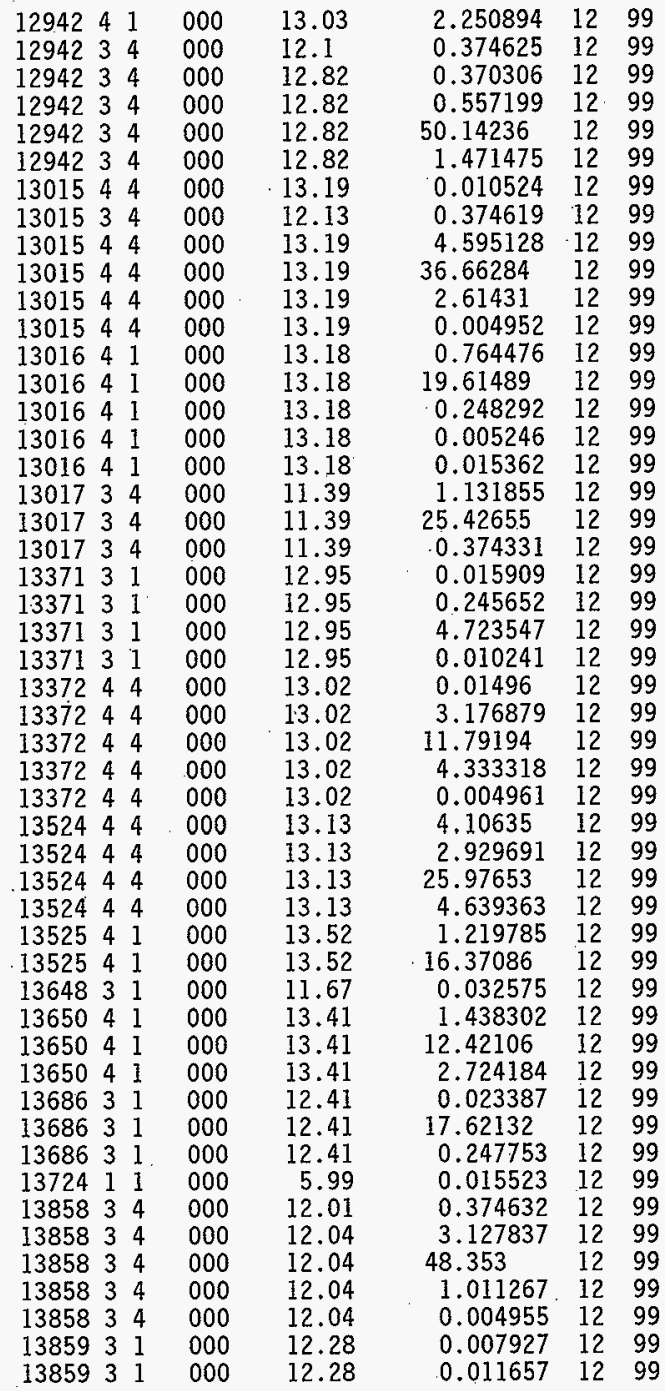




$\begin{array}{llllrcrl}13859 & 3 & 1 & 000 & 12.28 & 25.87721 & 12 & 99 \\ 13859 & 3 & 1 & 000 & 12.28 & 3.751426 & 12 & 99 \\ 13859 & 3 & 1 & 000 & 12.28 & 0.005246 & 12 & 99 \\ 14055 & 1 & 4 & 000 & 2.39 & 0.327945 & 12 & 99 \\ 14065 & 1 & 4 & 000 & 5.67 & 0.015902 & 12 & 99 \\ 14065 & 1 & 4 & 000 & 5.67 & 0.071951 & 12 & 99 \\ 14065 & 1 & 4 & 000 & 5.67 & 0.00446 & 12 & 99 \\ 14065 & 1 & 4 & 000 & 5.67 & 0.024244 & 12 & 99 \\ 14065 & 1 & 4 & 000 & 5.67 & 0.007021 & 12 & 99 \\ 14448 & 1 & 4 & 000 & 5.99 & 0.012272 & 12 & 99 \\ 14883 & 1 & 4 & 000 & 5.66 & 0.022262 & 12 & 99 \\ 15204 & 1 & 4 & 000 & 5.92 & 0.015919 & 12 & 99 \\ 15244 & 1 & 1 & 000 & 5.44 & 0.007949 & 12 & 99 \\ 15244 & 1 & 1 & 000 & 5.44 & 0.01126 & 12 & 99 \\ 15244 & 1 & 1 & 000 & 5.44 & 0.042169 & 12 & 99 \\ 15244 & 1 & 1 & 000 & 5.44 & 0.02338 & 12 & 99 \\ 15244 & 1 & 1 & 000 & 5.44 & 0.132474 & 12 & 99 \\ 15244 & 1 & 1 & 000 & 5.44 & 0.124027 & 12 & 99 \\ 15244 & 1 & 1 & 000 & 5.44 & 0.007481 & 12 & 99 \\ 15244 & 1 & 1 & 000 & 5.44 & 0.004961 & 12 & 99 \\ 15244 & 4 & 4 & 000 & 13.58 & 0.007019 & 12 & 99 \\ 15347 & 1 & 1 & 000 & 6.16 & 0.007949 & 12 & 99 \\ 15347 & 1 & 1 & 000 & 6.16 & 0.01169 & 12 & 99 \\ 15347 & 1 & 1 & 000 & 6.16 & 0.083168 & 12 & 99 \\ 15347 & 1 & 1 & 000 & 6.16 & 0.031137 & 12 & 99 \\ 15347 & 1 & 1 & 000 & 6.16 & 0.010645 & 12 & 99 \\ 15445 & 1 & 1 & 000 & 5.23 & 1.297919 & 12 & 99 \\ 15445 & 1 & 1 & 000 & 5.23 & 0.669493 & 12 & 99 \\ 15448 & 1 & 1 & 000 & 4.54 & 0.008002 & 12 & 99 \\ 15448 & 1 & 1 & 000 & 4.54 & 0.015812 & 12 & 99 \\ 15448 & 1 & 1 & 000 & 4.54 & 0.003766 & 12 & 99 \\ 15448 & 1 & 1 & 000 & 4.54 & 0.005327 & 12 & 99 \\ 15451 & 1 & 1 & 000 & 5.31 & 0.46584 & 12 & 99 \\ 15457 & 1 & 1 & 000 & 2.85 & 0.033293 & 12 & 99 \\ 15459 & 1 & 1 & 000 & 4.06 & 25.28046 & 12 & 99 \\ 15459 & 1 & 1 & 000 & 4.06 & 8.661046 & 12 & 99 \\ 15460 & 1 & 1 & 000 & 3.32 & 2.097296 & 12 & 99 \\ 15555 & 1 & 1 & 000 & 4 & 0.008002 & 12 & 99 \\ 15555 & 1 & 1 & 000 & 4 & 0.01132 & 12 & 99 \\ 11540 & 4 & 4 & 000 & 16.49 & 0.031623 & 12 & 99 \\ 11540 & 4 & 4 & 000 & 16.49 & 6.873061 & 12 & 99 \\ 11540 & 4 & 4 & 000 & 16.49 & 0.984106 & 12 & 99 \\ 11540 & 4 & 4 & 000 & 13.73 & 0.009902 & 12 & 99 \\ 11540 & 4 & 4 & 000 & 16.49 & 3.241216 & 12 & 99 \\ 11540 & 4 & 4 & 000 & 16.49 & 0.456485 & 12 & 99 \\ 12565 & 4 & 4 & 000 & 16.72 & 6.674973 & 12 & 99 \\ 12565 & 4 & 4 & 000 & 16.72 & 0.175589 & 12 & 99 \\ 12852 & 4 & 4 & 000 & 16.62 & 4.201198 & 12 & 99 \\ & & & & & & & \end{array}$


"06/02/1997 RADNUC2A run for combined K Basins "

"Results decayed to 05/31/1998"

if Total MTU " 2099.1

If Total Curies" $5.50 E+07$

if Total BTU " $5.49 \mathrm{E}+05$

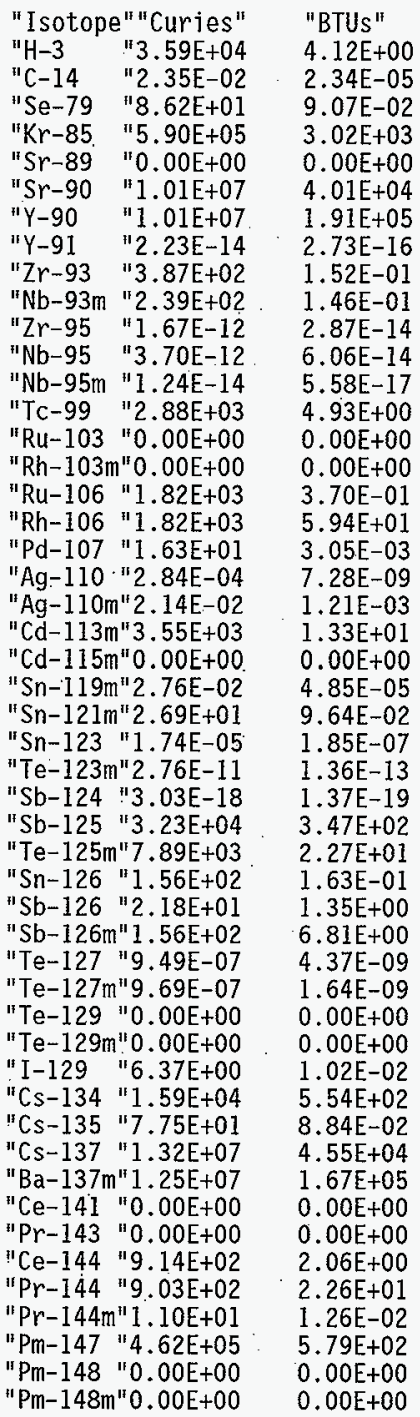




\begin{tabular}{|c|c|c|}
\hline 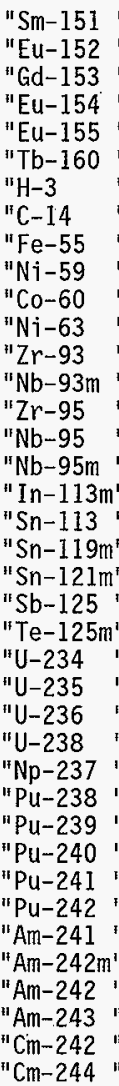 & $\begin{array}{l}\text { "1.76E+05 } \\
" 9.45 \mathrm{E}+02 \\
" 1.28 \mathrm{E}-04 \\
" 1.07 \mathrm{E}+05 \\
" 2.21 \mathrm{E}+04 \\
" 2.77 \mathrm{E}-15 \\
" 7.24 \mathrm{E}+02 \\
" 6.93 \mathrm{E}+02 \\
" 1.84 \mathrm{E}+03 \\
" 4.10 \mathrm{E}+01 \\
" 3.96 \mathrm{E}+03 \\
" 4.49 \mathrm{E}+03 \\
" 1.32 \mathrm{E}+01 \\
" 8.18 \mathrm{E}+00 \\
" 1.64 \mathrm{E}-14 \\
" 3.63 \mathrm{E}-14 \\
" 1.21 \mathrm{E}-16 \\
1 " 2.14 \mathrm{E}-07 \\
" 2.14 \mathrm{E}-07 \\
1 " 2.69 \mathrm{E}-01 \\
1 " 5.27 \mathrm{E}+01 \\
" 1.19 \mathrm{E}+03 \\
" 12.89 \mathrm{E}+02 \\
" 8.74 \mathrm{E}+02 \\
" 3.37 \mathrm{E}+01 \\
" 1.27 \mathrm{E}+02 \\
" 6.96 \mathrm{E}+02 \\
" 5.72 \mathrm{E}+01 \\
" 1.11 \mathrm{E}+05 \\
" 2.51 \mathrm{E}+05 \\
" 1.44 \mathrm{E}+05 \\
" 6.68 \mathrm{E}+06 \\
" 5.49 \mathrm{E}+01 \\
" 3.75 \mathrm{E}+05 \\
" 1.96 \mathrm{E}+02\end{array}$ & $\begin{array}{l}7.02 \mathrm{E}+01 \\
1.46 \mathrm{E}+01 \\
3.94 \mathrm{E}-07 \\
3.29 \mathrm{E}+03 \\
5.45 \mathrm{E}+01 \\
7.55 \mathrm{E}-17 \\
8.31 \mathrm{E}-02 \\
6.91 \mathrm{E}-01 \\
2.09 \mathrm{E}-01 \\
5.55 \mathrm{E}-03 \\
2.08 \mathrm{E}+02 \\
1.55 \mathrm{E}+00 \\
5.20 \mathrm{E}-03 \\
5.00 \mathrm{E}-03 \\
2.81 \mathrm{E}-16 \\
5.94 \mathrm{E}-16 \\
5.47 \mathrm{E}-19 \\
1.69 \mathrm{E}-09 \\
1.21 \mathrm{E}-10 \\
4.73 \mathrm{E}-04 \\
1.89 \mathrm{E}-01 \\
1.27 \mathrm{E}+01 \\
8.32 \mathrm{E}-01 \\
8.44 \mathrm{E}+01 \\
3.12 \mathrm{E}+00 \\
1.16 \mathrm{E}+01 \\
5.92 \mathrm{E}+01 \\
5.63 \mathrm{E}+00 \\
1.24 \mathrm{E}+04 \\
2.62 \mathrm{E}+04 \\
1.51 \mathrm{E}+04 \\
7.07 \mathrm{E}+02 \\
5.45 \mathrm{E}+00 \\
4.19 \mathrm{E}+04 \\
1.02 \mathrm{E}+00 \\
5.53 \mathrm{E}+00 \\
1.30 \mathrm{E}+01 \\
2.00 \mathrm{E}+0 \mathrm{I} \\
1.69 \mathrm{E}+02\end{array}$ \\
\hline
\end{tabular}


HNF-SD-SNF-TI-009, Rev. 1

\begin{tabular}{|c|c|c|c|c|c|c|c|}
\hline "Key" & "Gra & " $\mathrm{F}$ & "Pieces" & $" " \% P u-240 "$ & "Uranium" & "Mo" & $" Y r "$ \\
\hline 09621 & 14 & 000 & 5.94 & 0.006673 & 1299 & & \\
\hline 09621 & 14 & 000 & 5.94 & 0.076694 & 12 & & \\
\hline 09621 & 14 & 000 & 6.01 & 0.023972 & 12 & & \\
\hline 09621 & 14 & 000 & 5.94 & 0.0099 & 12 & & \\
\hline 09621 & 14 & 000 & 5.94 & 0.002374 & 12 & & \\
\hline 09621 & 14 & 000 & 5.94 & 0.072655 & 12 & & \\
\hline 09621 & 14 & 000 & 5.94 & 0.149847 & 12 & & \\
\hline 09621 & 14 & 000 & 5.94 & 0.009728 & 12 & & \\
\hline 09621 & 14 & 000 & 5.94 & 0.050475 & 12 & & \\
\hline 10001 & 3.4 & 000 & 12.4 & 0.04212 & 12 & & \\
\hline 10001 & 34 & 000 & 12.4 & 0.014903 & 12 & & \\
\hline 10001 & 34 & 000 & 12.4 & 0.006639 & 12 & & \\
\hline 10001 & 34 & 000 & 12.4 & 0.00991 & 12 & & \\
\hline 10001 & 34 & 000 & 12.4 & 0.029932 & 12 & & \\
\hline 10001 & 34 & 000 & 12.4 & 0.035065 & 12 & & \\
\hline 10201 & 24 & 000 & 9.09 & 1.075459 & 12 & & \\
\hline 10201 & 24 & 000 & 9.09 & 0.366031 & 12 & & \\
\hline 10201 & 24 & 000 & 9.09 & 0.343918 & 12 & & \\
\hline 10201 & 24 & 000 & 9.09 & 0.537029 & 12 & & \\
\hline 10201 & 24 & 000 & 9.09 & 0.172074 & 12 & & \\
\hline 10201 & 24 & 000 & 9.09 & 0.161819 & 12 & & \\
\hline 10259 & 34 & 000 & 10.41 & 0.050612 & 12 & & \\
\hline 10259 & 34 & 000 & 10.41 & 1.476838 & 12 & & \\
\hline 10259 & 34 & 000 & 10.41 & 12.34494 & 12 & & \\
\hline 10259 & 34 & 000 & 10.41 & 0.031588 & 12 & & \\
\hline 10259 & 34 & 000 & 10.41 & 0.718433 & 12 & & \\
\hline 10259 & 34 & 000 & 10.41 & 5.758699 & 12 & & \\
\hline 10294 & 24 & 000 & 8.94 & 0.032608 & 12 & & \\
\hline 10294 & 34 & 000 & 10.4 & 0.012648 & $\cdot 12$ & & \\
\hline 10294 & 34 & 000 & 10.4 & 0.812226 & 12 & & \\
\hline 10294 & 34 & 000 & 10.4 & 24.15077 & 12 & & \\
\hline 10294 & 34 & 000 & 10.4 & 0.762301 & 12 & & \\
\hline 10294 & 24 & 000 & 8.94 & 0.027153 & 12 & & \\
\hline 10294 & 34 & 000 & 10.4 & 0.006317 & 12 & & \\
\hline 10294 & 34 & 000 & 10.4 & 0.381403 & 12 & & \\
\hline 10294 & 34 & 000 & 10.4 & 11.35286 & 12 & & \\
\hline 10294 & 34 & 000 & 10.4 & 0.344639 & 12 & & \\
\hline 10350 & 24 & 000 & 9.28 & 0.031646 & 12 & & \\
\hline 10350 & 24 & 000 & 9.28 & 0.238728 & 12 & & \\
\hline 10350 & 24 & 000 & 9.28 & 0.089727 & 12 & & \\
\hline 10350 & 24 & 000 & 9.28 & 0.014861 & 12 & & \\
\hline 10350 & 24 & 000 & 9.28 & 0.112204 & 12 & & \\
\hline 10350 & 24 & 000 & 9.28 & 0.042207 & 12 & & \\
\hline 10385 & 34 & 000 & 10.21 & 0.130384 & 12 & & \\
\hline 10385 & 34 & 000 & 11.21 & 0.141018 & 12 & & \\
\hline 10385 & 34 & 000 & 11.21 & 23.81023 & 12 & & \\
\hline 10385 & 34 & 000 & 11.21 & 0.298905 & 12 & & \\
\hline 10385 & 34 & 000 & 10.21 & 0.075994 & 12 & & \\
\hline 10385 & 34 & 000 & $11.2 \mathrm{I}$ & 0.059715 & 12 & & \\
\hline 10385 & 34 & 000 & 11.21 & 11.17924 & 12 & & \\
\hline 10385 & 34 & 000 & 11.21 & 0.154738 & 12 & & \\
\hline 10456 & 34 & 000 & 11.24 & 0.009548 & 12 & & \\
\hline 10456 & 34 & 000 & 11.24 & 0.031918 & 12 & & \\
\hline 104 & 34 & 000 & 11.24 & 0.414766 & 12 & & \\
\hline & 34 & 000 & 11.24 & 1.348222 & 12 & & \\
\hline & 34 & 000 & 11.24 & 21.44289 & 12 & & \\
\hline
\end{tabular}


HNF-SD-SNF-TI-009, Rev. I

\begin{tabular}{|c|c|c|c|c|c|c|}
\hline 10456 & 34 & 000 & 11.24 & 3.186772 & 12 & 99 \\
\hline 10576 & 34 & 000 & 11.09 & 3.881855 & 12 & \\
\hline 10576 & 34 & 000 & 11.09 & 0.043956 & 12 & \\
\hline 10602 & 44 & 000 & 13.75 & 0.081456 & 12 & \\
\hline 10602 & 34 & 000 & 11.09 & 0.031925 & 12 & \\
\hline 10602 & 44 & 000 & 13.75 & 0.55955 & 12 & \\
\hline 10602 & 34 & 000 & 11.09 & 0.030958 & 12 & \\
\hline 10602 & 44 & 000 & 13.75 & 24.79309 & 12 & \\
\hline 10602 & 44 & 000 & 13.75 & 1.22853 & 12 & \\
\hline 10679 & 44 & 000 & 14.09 & 0.309509 & 12 & \\
\hline 10679 & 34 & 000 & 11.09 & 0.014136 & 12 & \\
\hline 10679 & 44 & 000 & 14.09 & 0.124291 & 12 & \\
\hline 10679 & 34 & 000 & 11.09 & 1.255033 & 12 & \\
\hline 10679 & 44 & 000 & 14.09 & 22.96605 & 12 & \\
\hline 10679 & 44 & 000 & 14.09 & 1.296428 & 12 & \\
\hline 10742 & 44 & 000 & .25 & 1.170103 & 12 & \\
\hline 10742 & 44 & 000 & .25 & 12.36114 & 12 & \\
\hline 10742 & 44 & 000 & 14.25 & 0.462965 & 12 & \\
\hline 10742 & 34 & 000 & 10.8 & 0.549476 & 12 & \\
\hline 10742 & 44 & 000 & 14.25 & 5.806125 & 12 & \\
\hline 10742 & 34 & 000 & 10.8 & 0.22488 & 12 & \\
\hline 10770 & 34 & 000 & 11.66 & 0.681667 & 12 & \\
\hline 10770 & 44 & 000 & 13.91 & 14.11261 & 12 & \\
\hline 10770 & 44 & 000 & 13.91 & 4.436449 & 12 & \\
\hline 10832 & 44 & 000 & 13.65 & 0.260688 & 12 & \\
\hline 10832 & 44 & 000 & .65 & 0.041425 & 12 & \\
\hline 10832 & 44 & 000 & 13 & 2.044619 & 12 & \\
\hline 10832 & 44 & 000 & 13 & 47.31945 & 12 & \\
\hline 10832 & 44 & 000 & & 3.138458 & 12 & \\
\hline 10982 & 44 & 000 & & 0.173868 & 12 & \\
\hline 10982 & 44 & 000 & & 0.126892 & 12 & \\
\hline 10982 & 34 & 000 & & 0.706201 & 12 & \\
\hline 10982 & 44 & 000 & 97 & 15.20181 & 12 & \\
\hline 10982 & 44 & 000 & & 0.94076 & 12 & \\
\hline 10982 & 44 & 000 & 97 & 8688 & 12 & \\
\hline 10982 & 34 & 000 & 11 & 59721 & 12 & \\
\hline 10982 & 34 & 000 & 11 & 31757 & 12 & \\
\hline 10982 & 44 & 000 & .97 & 90482 & 12 & \\
\hline 10 & 34 & 000 & & 938 & 12 & \\
\hline 110 & 44 & 000 & & 6372 & 12 & \\
\hline & 44 & 0.00 & & 26927 & 12 & \\
\hline & 44 & 000 & & 7157 & 12 & \\
\hline & 44 & 000 & & 572 & 12 & \\
\hline & 44 & 000 & & 176 & 12 & \\
\hline & 44 & 000 & & 57 & 12 & \\
\hline & 44 & 000 & & 844 & 12 & \\
\hline & 44 & 000 & & 878 & 12 & \\
\hline & 44 & 000 & & 283 & 12 & \\
\hline 11 & 44 & 000 & & 5921 & 12 & \\
\hline & 44 & 000 & & 4804 & 12 & \\
\hline & 44 & 000 & & 0859 & 12 & \\
\hline & 44 & 000 & & 38823 & 12 & \\
\hline & 34 & 000 & & 79566 & 12. & \\
\hline & 34 & 000 & & 31711 & 12 & \\
\hline & 44 & 000 & & 91013 & 12 & \\
\hline & 44 & 000 & & & 12 & \\
\hline & 44 & 000 & & & 12 & \\
\hline & & 000 & & 0.140773 & 12 & \\
\hline
\end{tabular}


HNF-SD-SNF-TI-009, Rev . 1

\begin{tabular}{|c|c|c|c|c|c|c|}
\hline 11183 & 44 & 000 & 14.49 & 0.189703 & 12 & 95 \\
\hline 11183 & 44 & 000 & 14.49 & 32.90384 & 12 & \\
\hline 11183 & 44 & 000 & 14.49 & 1.014554 & 12 & \\
\hline 11183 & 44 & 000 & 14.49 & 0.031018 & 12 & \\
\hline 11183 & 44 & 000 & 14.49 & 0.210257 & 12 & \\
\hline 11183 & 44 & 000 & 14.49 & 0.043892 & 12 & \\
\hline 11183 & 44 & 000 & 14.49 & 0.097674 & 12 & \\
\hline 11183 & 44 & 000 & 14.49 & 0.066214 & 12 & \\
\hline 11183 & 34 & 000 & 11.02 & 0.089084 & 12 & \\
\hline & 44 & 000 & 14.49 & 15.43086 & 12 & \\
\hline 11183 & 44 & 000 & 14.49 & 0.491747 & 12 & \\
\hline & 44 & 000 & 15.17 & 0.130374 & 12 & \\
\hline & 44 & 000 & 15.17 & 0.042237 & 12 & \\
\hline & 44 & 000 & 15.17 & 0.421612 & 12 & \\
\hline 72 & 4.4 & 000 & .17 & 19.91088 & 12 & \\
\hline & 44 & 000 & .17 & 0.686564 & 12 & \\
\hline & 44 & 000 & 15.17 & 0.059719 & 12 & \\
\hline & 34 & 000 & .05 & 0.019892 & 12 & \\
\hline & 34 & 000 & 12.05 & 0.178219 & 12 & \\
\hline & 34 & 000 & 12.05 & 9.414279 & 12 & \\
\hline & 44 & 000 & 15.17 & 0.309187 & 12 & \\
\hline 49 & 44 & 000 & 14.37 & 0.197256 & 12 & \\
\hline 49 & 44 & 000 & 14.37 & 0.094853 & 12 & \\
\hline 49 & 44 & 000 & 14.37 & 16.26 & 12 & \\
\hline 116 & 44 & 000 & 14.37 & 3.36 & 12 & \\
\hline 49 & 44 & 000 & 14.37 & 0.086193 & 12 & \\
\hline 49 & 34 & 000 & 11.03 & 598 & 12 & \\
\hline & 44 & 000 & 14.37 & 7. & 12 & \\
\hline & 34 & 000 & 11.03 & 1. & 12 & \\
\hline & 34 & 000 & 11.66 & 0. & 12 & \\
\hline & 34 & 000 & 11.3 & 0.14 & 12 & \\
\hline & 34 & 000 & 11.3 & 0.042167 & 12 & \\
\hline & 34 & 000 & 11.3 & 7.60 & 12 & \\
\hline & 34 & 000 & 11.3 & 0.59779 & 12 & \\
\hline & 34 & 000 & 11.3 & 0.982763 & 12 & \\
\hline & 34 & 000 & 11.66 & 0.076006 & 12 & \\
\hline & 34 & 000 & 11.3 & 0.072978 & 12 & \\
\hline & 34 & 000 & 11.3 & 0.0247 & 12 & \\
\hline & 34 & 000 & 11.3 & 3.567068 & 12 & \\
\hline & 34 & 000 & 11.3 & 0.274 & 12 & \\
\hline & 34 & 000 & 12.82 & 0.349841 & 12 & \\
\hline & 34 & 000 & 12.82 & 0. & 12 & \\
\hline & 34 & 000 & 10.36 & 0.15 & 12 & \\
\hline & 34 & 000 & 10.36 & 0.049213 & 12 & \\
\hline & 44 & 000 & 15.03 & 0.1 & 12 & \\
\hline & 34 & 000 & .94 & 84643 & 12 & \\
\hline & 34 & 000 & 11.94 & 0.021097 & 12 & \\
\hline & 44 & 000 & .03 & 18.2596 & 12 & \\
\hline & 44 & 000 & 15.03 & 68532 & 12 & \\
\hline & 34 & 000 & & 0. & 12 & \\
\hline & 44 & 000 & .03 & 170582 & 12 & \\
\hline & 34 & 000 & & 33183 & 12 & \\
\hline & 34 & 000 & 11.94 & 0.00991 & 12 & \\
\hline & 34 & 000 & .94 & 8.607779 & 12 & \\
\hline & 44 & 000 & & 0.126466 & 12 & \\
\hline & 34 & 000 & 11.69 & 3.046193 & 12 & \\
\hline & 44 & 00 & & 20.37553 & 12 & \\
\hline & 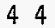 & 000 & & 1.61182 & 12 & \\
\hline
\end{tabular}


HNF-SD-SNF-TI-009, Rev. I

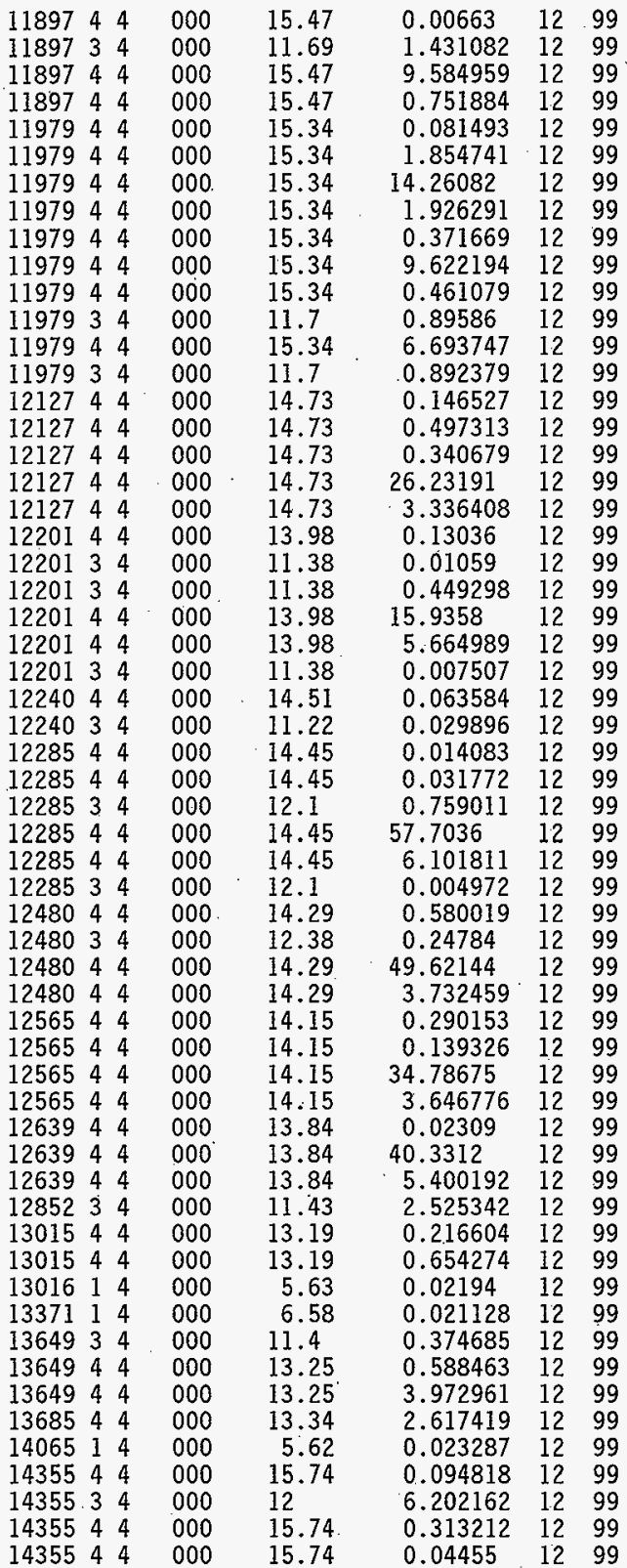


HNF-SD-SNF-TI-009, Rev. 1

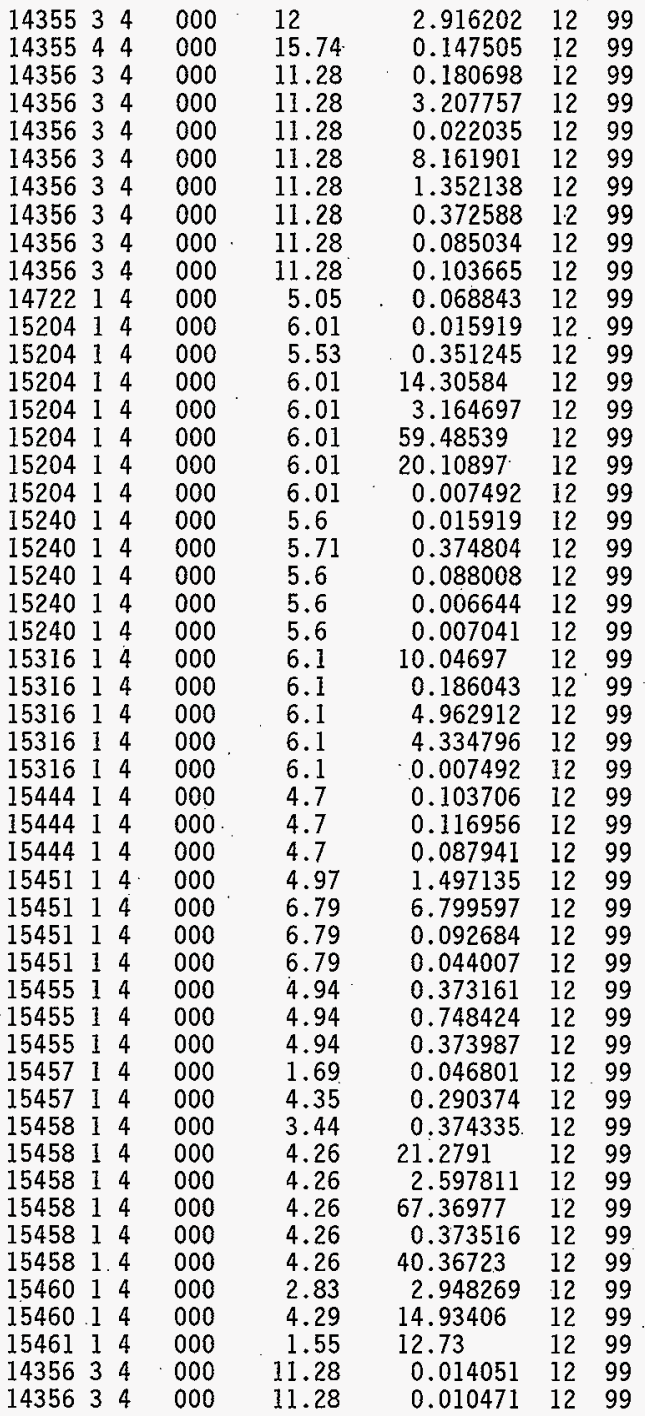


"06/02/1997 RADNUC2A run for K-EAST "

"Results decayed to 05/31/1998"

"Total MTU" 1146.0

"Total Curies" 2.73E+07

"Total BTU" $2.75 \mathrm{E}+05$

\begin{tabular}{|c|c|}
\hline 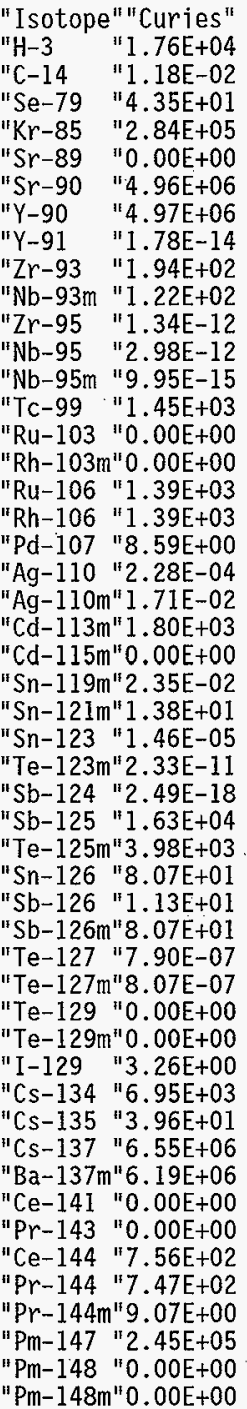 & $\begin{array}{l}\text { "BTUS" } \\
2.02 \mathrm{E}+00 \\
1.18 \mathrm{E}-05 \\
4.57 \mathrm{E}-02 \\
1.45 \mathrm{E}+03 \\
0.00 \mathrm{E}+00 \\
1.97 \mathrm{E}+04 \\
9.37 \mathrm{E}+04 \\
2.18 \mathrm{E}-16 \\
7.60 \mathrm{E}-02 \\
7.43 \mathrm{E}-02 \\
2.31 \mathrm{E}-14 \\
4.87 \mathrm{E}-14 \\
4.48 \mathrm{E}-17 \\
2.48 \mathrm{E}+00 \\
0.00 \mathrm{E}+00 \\
0.00 \mathrm{E}+00 \\
2.82 \mathrm{E}-01 \\
4.52 \mathrm{E}+01 \\
1.61 \mathrm{E}-03 \\
5.83 \mathrm{E}-09 \\
9.70 \mathrm{E}-04 \\
6.77 \mathrm{E}+00 \\
0.00 \mathrm{E}+00 \\
4.13 \mathrm{E}-05 \\
4.94 \mathrm{E}-02 \\
1.56 \mathrm{E}-07 \\
1.15 \mathrm{E}-13 \\
1.12 \mathrm{E}-19 \\
1.75 \mathrm{E}+02 \\
1.14 \mathrm{E}+01 \\
8.46 \mathrm{E}-02 \\
6.98 \mathrm{E}-01 \\
3.53 \mathrm{E}+00 \\
3.64 \mathrm{E}-09 \\
1.36 \mathrm{E}-09 \\
0.00 \mathrm{E}+00 \\
0.00 \mathrm{E}+00 \\
5.20 \mathrm{E}-03 \\
2.42 \mathrm{E}+02 \\
4.52 \mathrm{E}-02 \\
2.26 \mathrm{E}+04 \\
8.29 \mathrm{E}+04 \\
0.00 \mathrm{E}+00 \\
0.00 \mathrm{E}+00 \\
1.70 \mathrm{E}+00 \\
1.87 \mathrm{E}+01 \\
1.04 \mathrm{E}-02 \\
3.07 \mathrm{E}+02 \\
0.00 \mathrm{E}+00 \\
0.00 \mathrm{E}+00\end{array}$ \\
\hline
\end{tabular}




\begin{tabular}{|c|c|c|}
\hline $\begin{array}{l}\text { "Sm-151 } \\
\text { "Eu-152 } \\
\text { "Gd-153 } \\
\text { "Eu-154 } \\
\text { "Eu-155 } \\
\text { "Tb-160 } \\
\text { "H-3 } \\
\text { "C-14 } \\
\text { "Fe-55 } \\
\text { "Ni-59 } \\
\text { "Co-60 } \\
\text { "Ni-63 } \\
\text { "Zr-93 } \\
\text { "Nb-93m } \\
\text { "Zr-95 } \\
\text { "Nb-95 } \\
\text { "Nb-95m } \\
\text { "In-113m } \\
\text { "Sn-113 } \\
\text { "Sn-119m } \\
\text { "Sn-121m } \\
\text { "Sb-125 } \\
\text { "Te-125m } \\
\text { "U-234 } \\
\text { "U-235 } \\
\text { "U-236 } \\
\text { "U-238 } \\
\text { "Np-237 } \\
\text { "Pu-238 } \\
\text { "Pu-239 } \\
\text { "Pu-240 } \\
\text { "Pu-241 } \\
\text { "Pu-242 } \\
\text { "Am-241 } \\
\text { "Am-242m } \\
\text { "Am-242 } \\
\text { "Am-243 } \\
\text { "Cm-242 } \\
\text { "Cm-244 }\end{array}$ & $\begin{array}{l}" 8.92 \mathrm{E}+04 \\
" 4.67 \mathrm{E}+02 \\
" 9.59 \mathrm{E}-05 \\
" 5.30 \mathrm{E}+04 \\
" 1.12 \mathrm{E}+04 \\
" 2.29 \mathrm{E}-15 \\
" 3.75 \mathrm{E}+02 \\
" 3.62 \mathrm{E}+02 \\
" 9.64 \mathrm{E}+02 \\
" 2.11 \mathrm{E}+01 \\
" 1.86 \mathrm{E}+03 \\
" 2.30 \mathrm{E}+03 \\
" 6.58 \mathrm{E}+00 \\
" 4.13 \mathrm{E}+00 \\
" 1.31 \mathrm{E}-14 \\
" 2.91 \mathrm{E}-14 \\
" 9.73 \mathrm{E}-17 \\
1 " 1.77 \mathrm{E}-07 \\
" 1.77 \mathrm{E}-07 \\
1 " 2.26 \mathrm{E}-01 \\
1 " 2.63 \mathrm{E}+01 \\
" 5.96 \mathrm{E}+02 \\
1 " 1.45 \mathrm{E}+02 \\
" 4.66 \mathrm{E}+02 \\
" 1.77 \mathrm{E}+01 \\
" 6.61 \mathrm{E}+01 \\
" 3.80 \mathrm{E}+02 \\
" 3.02 \mathrm{E}+01 \\
" 6.05 \mathrm{E}+04 \\
" 1.32 \mathrm{E}+05 \\
" 7.64 \mathrm{E}+04 \\
" 3.42 \mathrm{E}+06 \\
" 3.07 \mathrm{E}+01 \\
" 2.06 \mathrm{E}+05 \\
1 " 1.14 \mathrm{E}+02 \\
" 1.13 \mathrm{E}+02 \\
" 7.12 \mathrm{E}+01 \\
" 9.40 \mathrm{E}+01 \\
" 8.71 \mathrm{E}+02\end{array}$ & $\begin{array}{l}3.56 \mathrm{E}+01 \\
7.21 \mathrm{E}+00 \\
2.95 \mathrm{E}-07 \\
1.62 \mathrm{E}+03 \\
2.77 \mathrm{E}+01 \\
6.25 \mathrm{E}-17 \\
4.30 \mathrm{E}-02 \\
3.61 \mathrm{E}-01 \\
1.10 \mathrm{E}-01 \\
2.86 \mathrm{E}-03 \\
9.76 \mathrm{E}+01 \\
7.95 \mathrm{E}-01 \\
2.59 \mathrm{E}-03 \\
2.53 \mathrm{E}-03 \\
2.26 \mathrm{E}-16 \\
4.77 \mathrm{E}-16 \\
4.39 \mathrm{E}-19 \\
1.40 \mathrm{E}-09 \\
1.00 \mathrm{E}-10 \\
3.97 \mathrm{E}-04 \\
9.41 \mathrm{E}-02 \\
6.39 \mathrm{E}+00 \\
4.18 \mathrm{E}-01 \\
4.51 \mathrm{E}+01 \\
1.64 \mathrm{E}+00 \\
6.03 \mathrm{E}+00 \\
3.23 \mathrm{E}+01 \\
2.97 \mathrm{E}+00 \\
6.73 \mathrm{E}+03 \\
1.38 \mathrm{E}+04 \\
7.98 \mathrm{E}+03 \\
3.62 \mathrm{E}+02 \\
3.05 \mathrm{E}+00 \\
2.30 \mathrm{E}+04 \\
5.95 \mathrm{E}-01 \\
3.22 \mathrm{E}+00 \\
7.68 \mathrm{E}+00 \\
1.16 \mathrm{E}+01 \\
1.02 \mathrm{E}+02 \\
\end{array}$ \\
\hline
\end{tabular}


HNF-SD-SNF-TI-009, Rev. 1

"150-K WEST charge data"

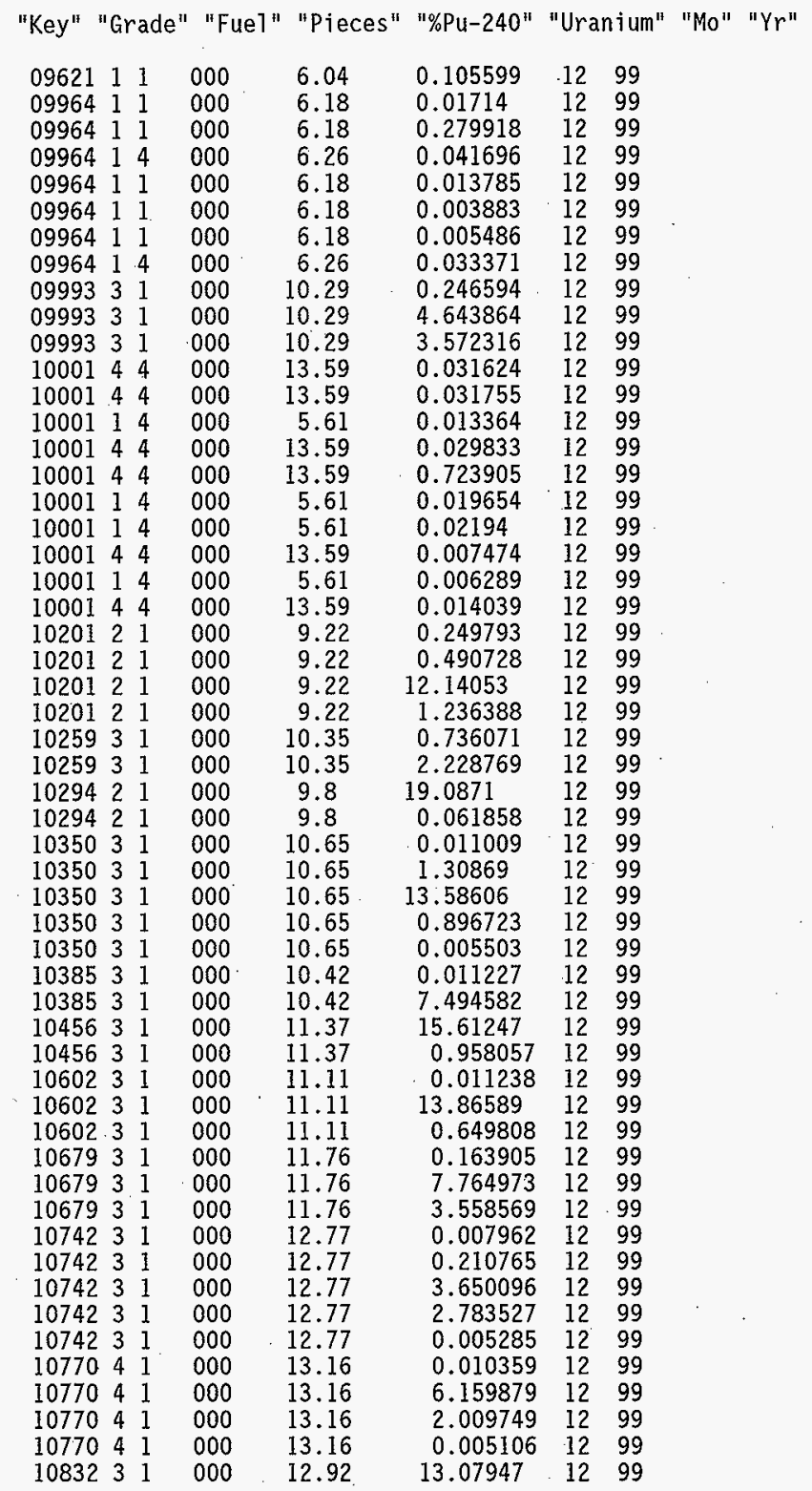


HNF-SD-SNF-TI-009, Rev. 1

\begin{tabular}{|c|c|c|c|c|c|c|}
\hline 10832 & 31 & 000 & 12.92 & 3.696517 & 12 & 99 \\
\hline 10982 & 41 & 000 & 13.73 & 0.020983 & 12 & 99 \\
\hline 10982 & 41 & 000 & 13.73 & 0.023391 & 12 & 99 \\
\hline 10982 & 41 & 000 & 13.73 & 16.49613 & 12 & 99 \\
\hline 10982 & 41 & 000 & 13.73 & 0.694274 & 12 & 99 \\
\hline 10982 & 41 & 000 & 13.73 & 0.010547 & 12 & 99 \\
\hline 11036 & 41 & 000 & 13.6 & 7.613446 & 12 & 99 \\
\hline 11109 & 41 & 000 & 13.7 & 0.468068 & 12 & 99 \\
\hline 11109 & 41 & 000 & 13.7 & 14.63286 & 12 & 99 \\
\hline 11109 & $4 i$ & 000 & 13.7 & 0.005275 & 12 & 99 \\
\hline 11183 & 41 & 000 & 13.31 & 0.022094 & 12 & 99 \\
\hline 11183 & 41 & 000 & 13.31 & 0.678594 & 12 & 99 \\
\hline 11183 & 41 & 000 & 13.31 & 9.361327 & 12 & 99 \\
\hline 11183 & 41 & 000 & 13.31 & 0.24688 & 12 & 99 \\
\hline 11183 & 4. 1 & 000 & 13.31 & 0.010881 & 12 & 99 \\
\hline 11372 & 41 & 000 & 13.77 & 0.690168 & 12 & 99 \\
\hline 11372 & 41 & 000 & 13.77 & 18.57126 & 12 & 99 \\
\hline 11372 & 41 & 000 & 13.77 & 0.709699 & 12 & 99 \\
\hline 11449 & 41 & 000 & 13.45 & 0.105257 & 12 & 99 \\
\hline 11449 & 41 & 000 & 13.45 & 18.58285 & 12 & 99 \\
\hline 11449 & 41 & 000 & 13.45 & 1.298701 & 12 & 99 \\
\hline 11540 & 41 & 000 & 13.26 & 12.48741 & 12 & 99 \\
\hline 11805 & 41 & 000 & 13.86 & 0.210315 & 12 & 99 \\
\hline 11806 & 41 & 000 & 13.86 & 19.23798 & 12 & 99 \\
\hline 11806 & 41 & 000 & 13.86 & 0.54114 & 12 & 99 \\
\hline 11897 & 41 & 000 & 14.4 & 0.023484 & 12 & 99 \\
\hline 11897 & 41 & 000 & 14.4 & 1.986457 & 12 & 99 \\
\hline 11897 & 41 & 000 & 14.4 & 17.69781 & 12 & 99 \\
\hline 11897 & 41. & 000 & 14.4 & 0.003856 & 12 & 99 \\
\hline 11979 & 41 & 000 & 14.27 & 0.007981 & 12 & 99 \\
\hline 11979 & 41 & 000 & 14.27 & 0.011234 & 12 & 99 \\
\hline 11979 & 41 & 000 & 14.27 & 0.010507 & 12 & 99 \\
\hline 11979 & 41 & 000 & 14.27 & 1.952108 & 12 & 99 \\
\hline 11979 & 41 & 000 & 14.27 & 14.49357 & 12 & 99 \\
\hline 1979 & 41 & 000 & 14.27 & 8.884854 & 12 & 99 \\
\hline 11 & 41 & 000 & 14.27 & 0.010731 & 12 & 99 \\
\hline 121 & 41 & 000 & 14.22 & 0.982493 & 12 & 99 \\
\hline 12127 & 4.1 & 000 & 14.22 & 13.32088 & 12 & 9 \\
\hline 12127 & 41 & 000 & 14.22 & 1.483142 & 12 & 99 \\
\hline 12201 & 41 & 000 & 13.24 & 0.748323 & 12 & 99 \\
\hline & 41 & 000 & 13.24 & 24.37494 & 12 & 99 \\
\hline & 41 & 000 & 13.17 & 0.246182 & 12 & 99 \\
\hline & 41 & 000 & 13.17 & 19.5675 & 12 & 99 \\
\hline 124 & 41 & 000 & $13.78^{\circ}$ & 0.022173 & 12 & 99 \\
\hline & 41 & 000 & $13: 78$ & 19.43003 & 12 & 99 \\
\hline & 41 & 000 & 13.7 & 0.011092 & 12 & 99 \\
\hline & 41 & 000 & 13.7 & 25.24008 & 12 & 99 \\
\hline & 41 & 000 & 13.06 & 0.011095 & 12 & 99 \\
\hline & 41 & 000 & 13.06 & 23.608 & 12 & 99 \\
\hline & 41 & 000 & 13.06 & 0.005465 & 12 & \\
\hline & 41 & 000 & .17 & 7.213609 & 12 & 99 \\
\hline & 41 & 000 & .17 & 0.63684 & 12 & 99 \\
\hline & 41 & 000 & .01 & 10.86065 & 12 & 99 \\
\hline & & 000 & & 2.874132 & 12 & 99 \\
\hline & 44 & 000 & 42 & 0.047668 & 12 & 99 \\
\hline & 44 & 000 & 42 & 66.60527 & 12 & 99 \\
\hline & 44 & 000 & 42 & 0.373472 & 12 & 99 \\
\hline & & 000 & 13.42 & 0.022424 & 12 & 99 \\
\hline
\end{tabular}


HNF-SD-SNF-TI-009, Rev. 1

\begin{tabular}{|c|c|c|c|c|c|c|}
\hline 129424 & 41 & 000 & 13.03 & 0.740693 & 12 & 99 \\
\hline 129424 & 41 & 000 & 13.03 & 17.44634 & 12 & 99 \\
\hline 129424 & 41 & 000 & 13.03 & 2.250894 & 12 & 99 \\
\hline 129423 & 34 & 000 & 12.1 & 0.374625 & 12 & 99 \\
\hline 129423 & 34 & 000 & 12.82 & 0.370306 & 12 & 99 \\
\hline 129423 & 34 & 000 & 12.82 & 0.557199 & 12 & 99 \\
\hline 12942 & 34 & 000 & 12.82 & 50.14236 & 12 & 99 \\
\hline 129423 & 34 & 000 & 12.82 & 1.471475 & 12 & 99 \\
\hline 130154 & 44 & 000 & 13.19 & 0.010524 & 12 & 99 \\
\hline 130153 & 34 & 000 & 12.13 & 0.374619 & 12 & 99 \\
\hline 130154 & 44 & 000 & 13.19 & 4.595128 & 12 & 99 \\
\hline 130154 & 44 & 000 & 13.19 & 36.66284 & 12 & 99 \\
\hline 130154 & 44 & 000 & 13.19 & 2.61431 & 12 & 99 \\
\hline 130154 & 44 & 000 & 13.19 & 0.004952 & 12 & 99 \\
\hline 130164 & 41 & 000 & 13.18 & 0.764476 & 12 & 99 \\
\hline 130164 & 41 & 000 & 13.18 & 19.61489 & 12 & 99 \\
\hline 130164 & 41 & 000 & 13.18 & 0.248292 & 12 & 99 \\
\hline 130164 & 41 & 000 & 13.18 & 0.005246 & 12 & 99 \\
\hline 130164 & 41 & 000 & 13.18 & 0.015362 & 12 & 99 \\
\hline 130173 & 34 & 000 & 11.39 & 1.131855 & 12 & 99 \\
\hline 13017 & 34 & 000 & 11.39 & 25.42655 & 12 & 99 \\
\hline 130173 & 34 & 000 & 11.39 & 0.374331 & 12 & 99 \\
\hline 13371 & 31 & 000 & 12.95 & 0.015909 & 12 & 99 \\
\hline 133713 & 31 & 000 & 12.95 & 0.245652 & 12 & 99 \\
\hline 13371 & 31 & 000 & 12.95 & 4.723547 & 12 & 99 \\
\hline 13371 & 31 & 000 & 12.95 & 0.010241 & 12 & 99 \\
\hline 133724 & 44 & 000 & 13.02 & 0.01496 & 12 & 99 \\
\hline 133724 & 44 & 000 & 13.02 & 3.176879 & 12 & 99 \\
\hline 133724 & 44 & 000 & 13.02 & 11.79194 & 12 & 99 \\
\hline 133724 & 44 & 000 & 13.02 & 4.333318 & 12 & 99 \\
\hline 13372 & 44 & 000 & 13.02 & 0.004961 & 12 & 99 \\
\hline 135244 & 44 & 000 & 13.13 & 4.10635 & 12 & 99 \\
\hline 135244 & 44 & 000 & 13.13 & 2.929691 & 12 & 99 \\
\hline 13524 & 44 & 000 & 13.13 & 25.97653 & 12 & 99 \\
\hline 13524 & 44 & 000 & 13.13 & 4.639363 & 12 & 99 \\
\hline 13525 & 41 & 000 & 13.52 & 1.219785 & 12 & 99 \\
\hline 135254 & 41 & 000 & 13.52 & 16.37086 & 12 & 99 \\
\hline 136483 & 31 & 000 & 11.67 & 0.032575 & 12 & 99 \\
\hline 13650 & $4 i$ & 000 & & 1.438302 & 12 & 99 \\
\hline 13650 & 41 & 000 & 13.41 & 12.42106 & 12 & 9 \\
\hline 13650 & 41 & 000 & & 2.724184 & 12 & \\
\hline 13686 & 1 & 000 & 12.41 & 0.023387 & 12 & 9 \\
\hline 13 & 1 & 000 & 12.41 & 17.62132 & 12 & 99 \\
\hline 136863 & 31 & 000 & 12.41 & 0.247753 & 12 & 99 \\
\hline 137 & 11 & 000 & 5.99 & 0.015523 & 12 & 99 \\
\hline 138583 & 34 & 000 & 12.01 & 0.374632 & 12 & 99 \\
\hline 583 & 34 & 000 & 12.04 & 3.127837 & 12 & 99 \\
\hline 138583 & 34 & 000 & 12.04 & 48.353 & 12 & 99 \\
\hline 138583 & 34 & 000 & 12.04 & 1.011267 & 12 & 9.9 \\
\hline 583 & 34 & 000 & 12.04 & 0.004955 & 12 & 99 \\
\hline 138 & 31 & 000 & 12.28 & 0.007927 & 12 & 99 \\
\hline & 31 & 000 & 12.28 & 0.011657 & 12 & 99 \\
\hline 138 & 31 & 000 & 12.28 & 25.87721 & 12 & 99 \\
\hline & 31 & 000 & 12.28 & 3.751426 & 12 & 99 \\
\hline & 31 & 000 & 12.28 & 0.005246 & 12 & 99 \\
\hline & 14 & 000 & 2.39 & 0.327945 & 12 & 99 \\
\hline 14 & 14 & 000 & 5.67 & 0.015902 & 12 & 99 \\
\hline 140651 & 14 & 000 & 5.67 & 0.07 .1951 & 12 & 99 \\
\hline
\end{tabular}


HNF-SD-SNF-TI-009, Rev. 1

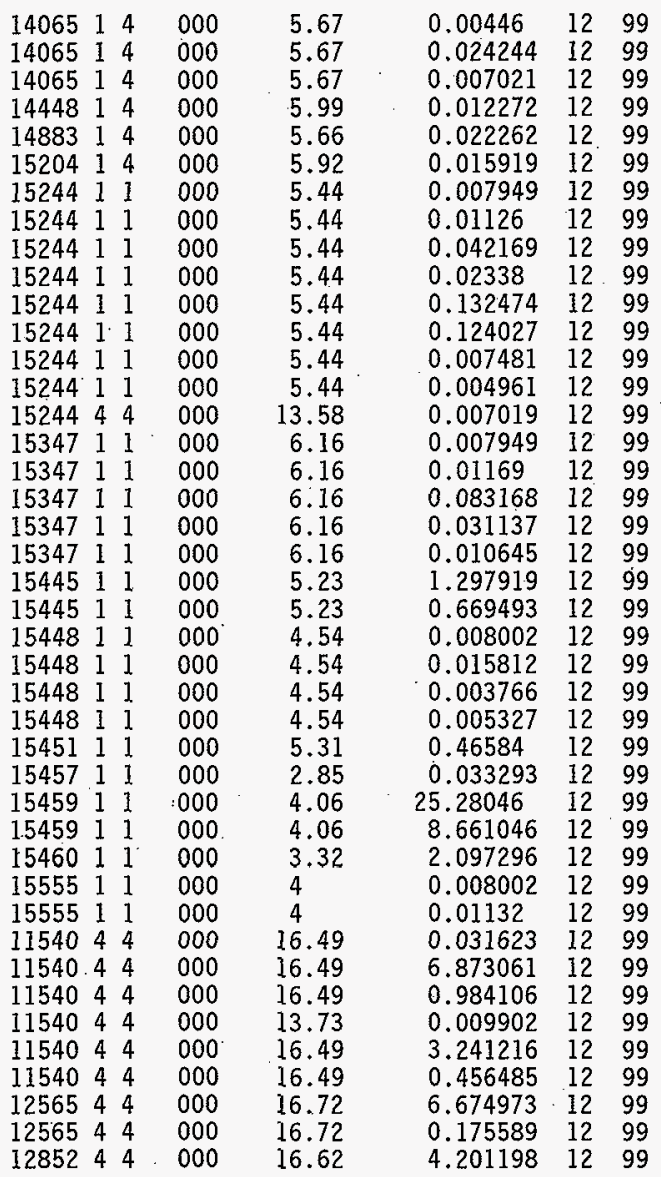


"06/02/1997 RADNUC2A run for K-WEST

"Results decayed to 05/31/1998"

"Total MTU " 953.1

"Total Curies " 2.77E+07

"Total BTU " 2.74E+05

\begin{tabular}{|c|c|c|}
\hline \multicolumn{2}{|c|}{ 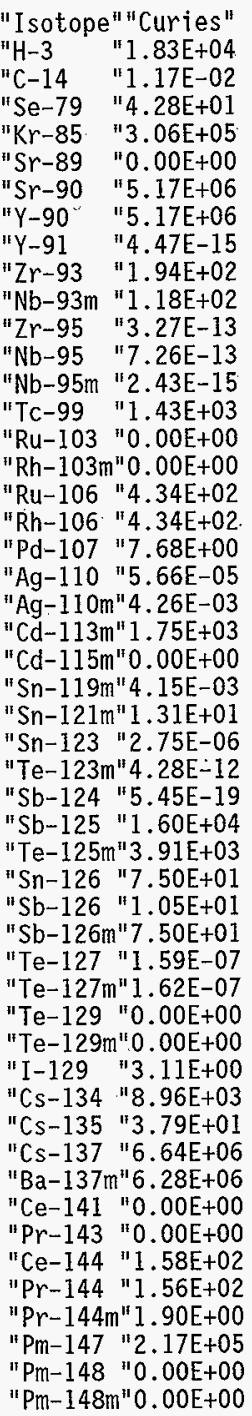 } & $\begin{array}{l}\text { "BTUs" } \\
2.09 \mathrm{E}+00 \\
1.16 \mathrm{E}-05 \\
4.50 \mathrm{E}-02 \\
1.57 \mathrm{E}+03 \\
0.00 \mathrm{E}+00 \\
2.05 \mathrm{E}+04 \\
9.76 \mathrm{E}+04 \\
5.46 \mathrm{E}-17 \\
7.60 \mathrm{E}-02 \\
7.20 \mathrm{E}-02 \\
5.62 \mathrm{E}-15 \\
1.19 \mathrm{E}-14 \\
1.09 \mathrm{E}-17 \\
2.45 \mathrm{E}+00 \\
0.00 \mathrm{E}+00 \\
0.00 \mathrm{E}+00 \\
8.81 \mathrm{E}-02 \\
1.41 \mathrm{E}+01 \\
1.44 \mathrm{E}-03 \\
1.45 \mathrm{E}-09 \\
2.41 \mathrm{E}-04 \\
6.56 \mathrm{E}+00 \\
0.00 \mathrm{E}+00 \\
7.29 \mathrm{E}-06 \\
4.70 \mathrm{E}-02 \\
2.93 \mathrm{E}-08 \\
2.12 \mathrm{E}-14 \\
2.46 \mathrm{E}-20 \\
1.72 \mathrm{E}+02 \\
1.12 \mathrm{E}+01 \\
7.86 \mathrm{E}-02 \\
6.49 \mathrm{E}-01 \\
3.28 \mathrm{E}+00 \\
7.31 \mathrm{E}-10 \\
2.74 \mathrm{E}-10 \\
0.00 \mathrm{E}+00 \\
0.00 \mathrm{E}+00 \\
4.98 \mathrm{E}-03 \\
3.12 \mathrm{E}+02 \\
4.32 \mathrm{E}-02 \\
2.29 \mathrm{E}+04 \\
8.41 \mathrm{E}+04 \\
0.00 \mathrm{E}+00 \\
0.00 \mathrm{E}+00 \\
3.56 \mathrm{E}-01 \\
3.91 \mathrm{E}+00 \\
2.18 \mathrm{E}-03 \\
2.72 \mathrm{E}+02 \\
0.00 \mathrm{E}+00 \\
0.00 \mathrm{E}+00\end{array}$ \\
\hline
\end{tabular}




\begin{tabular}{|c|c|c|}
\hline 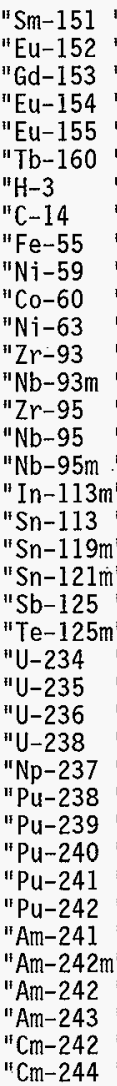 & $\begin{array}{l}" 8.66 \mathrm{E}+04 \\
" 4.77 \mathrm{E}+02 \\
" 3.23 \mathrm{E}-05 \\
" 5.44 \mathrm{E}+04 \\
" 1.08 \mathrm{E}+04 \\
" 4.77 \mathrm{E}-16 \\
" 3.49 \mathrm{E}+02 \\
" 3.31 \mathrm{E}+02 \\
" 8.75 \mathrm{E}+02 \\
" 1.99 \mathrm{E}+01 \\
" 2.10 \mathrm{E}+03 \\
" 2.19 \mathrm{E}+03 \\
" 6.65 \mathrm{E}+00 \\
" 4.04 \mathrm{E}+00 \\
" 3.23 \mathrm{E}-15 \\
" 7.18 \mathrm{E}-15 \\
" 2.40 \mathrm{E}-17 \\
" 3.74 \mathrm{E}-08 \\
" 3.74 \mathrm{E}-08 \\
\text { " } 4.33 \mathrm{E}-02 \\
\text { " } " 2.64 \mathrm{E}+01 \\
" 5.91 \mathrm{E}+02 \\
n " 1.44 \mathrm{E}+02 \\
" 4.08 \mathrm{E}+02 \\
" 1.60 \mathrm{E}+01 \\
" 6.11 \mathrm{E}+01 \\
" 3.16 \mathrm{E}+02 \\
" 2.70 \mathrm{E}+01 \\
" 5.10 \mathrm{E}+04 \\
" 1.19 \mathrm{E}+05 \\
" 6.77 \mathrm{E}+04 \\
" 3.26 \mathrm{E}+06 \\
" 2.42 \mathrm{E}+01 \\
" 1.69 \mathrm{E}+05 \\
" 8.19 \mathrm{E}+01 \\
" 8.15 \mathrm{E}+01 \\
" 4.89 \mathrm{E}+01 \\
" 6.76 \mathrm{E}+01 \\
" 5.72 \mathrm{E}+02\end{array}$ & $\begin{array}{l}3.46 \mathrm{E}+01 \\
7.36 \mathrm{E}+00 \\
9.92 \mathrm{E}-08 \\
1.67 \mathrm{E}+03 \\
2.68 \mathrm{E}+01 \\
1.30 \mathrm{E}-17 \\
4.00 \mathrm{E}-02 \\
3.30 \mathrm{E}-01 \\
9.95 \mathrm{E}-02 \\
2.69 \mathrm{E}-03 \\
1.10 \mathrm{E}+02 \\
7.54 \mathrm{E}-01 \\
2.61 \mathrm{E}-03 \\
2.47 \mathrm{E}-03 \\
5.57 \mathrm{E}-17 \\
1.17 \mathrm{E}-16 \\
1.08 \mathrm{E}-19 \\
2.95 \mathrm{E}-10 \\
2.12 \mathrm{E}-11 \\
7.62 \mathrm{E}-05 \\
9.48 \mathrm{E}-02 \\
6.33 \mathrm{E}+00 \\
4.14 \mathrm{E}-01 \\
3.94 \mathrm{E}+01 \\
1.48 \mathrm{E}+00 \\
5.57 \mathrm{E}+00 \\
2.68 \mathrm{E}+01 \\
2.66 \mathrm{E}+00 \\
5.68 \mathrm{E}+03 \\
1.24 \mathrm{E}+04 \\
7.07 \mathrm{E}+03 \\
3.45 \mathrm{E}+02 \\
2.40 \mathrm{E}+00 \\
1.89 \mathrm{E}+04 \\
4.28 \mathrm{E}-01 \\
2.3 .1 \mathrm{E}+00 \\
5.27 \mathrm{E}+00 \\
8.35 \mathrm{E}+00 \\
6.71 \mathrm{E}+01\end{array}$ \\
\hline
\end{tabular}


HNF-SD-SNF-TI-009, Rev. I

"105-K Basins shielding basis charge data"

"Key" "Grade" "Fuel" "Pieces" "\%u-240". "Uranium" "Mo" "Yr"

$\begin{array}{lllllll}1470744 & 000 & 16.00 & 1.000000 & 12 & 99\end{array}$

$\begin{array}{lllllll}1470744 & 000 & 16.00 & 1.000000 & 12 & 99\end{array}$

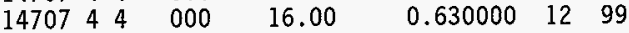


"06/02/1997 RADNUC2A run for shielding basis "

"Results decayed to 05/31/1998"

$\begin{array}{lc}\text { "Total MTU " } & 2.6 \\ \text { "Total Curies " } & 1.32 \mathrm{E}+05 \\ \text { "Total BTU " } & 1.2 \mathrm{~L}+03\end{array}$

"Isotope" "Curies" "BTUs"

"H-3 "1.02E+02 1.17E-02

"C-14 "4.45E-05 4.44E-08

"Se-79 "1.62E-01 1.71E-04

$" \mathrm{Kr}-85 \quad " 1.62 \mathrm{E}+03 \quad 8.28 \mathrm{E}+00$

"Sr-89, "0.00E+00 $0.00 \mathrm{E}+00$

"Sr-90 "2.13E+04 8.43E+01

"Y-90 "2.13E+04 4.02E+02

"Y-91 "0.00E+00 $0.00 \mathrm{E}+00$

"Zr-93 "7.10E-01 2.79E-04

"Nb-93m" 3.47E-01 2.12E-04

"Zr-95 "1.08E-17 1.86E-19

"Nb-95 "2.40E-17. 3.93E-19

"Nb-95m "8.03E-20 3.62E-22

"Tc-99 "5.42E+00 9.28E-03

"Ru-103 "0.00E+00 $0.00 E+00$

"Rh-103m" $0.00 E+00 \quad 0.00 E+00$

"Ru-106 "2.44E+01 4.96E-03

"Rh-106" "2.44E+01 $\cdot 7.96 \mathrm{E}-01$

"Pd-107"3.75E-02 7.05E-06

"Ag-110 "1.08E-05 2.76E-10

"Ag-110m"8.11E-04 4.60E-05

"Cd-113m"1.03E+01 3.86E-02

"Cd-115m"0.00E+00 $0.00 E+00$

"Sn-119m" $1.28 \mathrm{E}-04 \quad 2.25 \mathrm{E}-07$

" $\mathrm{S} n-121 \mathrm{~m}^{11} 6.39 \mathrm{E}-02 \quad 2.29 \mathrm{E}-04$

"Sn-123"1.06E-08 1.12E-10

"Te-123m"3.10E-13 1.53E-15

"Sb-124"0.00E+00 $0.00 \mathrm{E}+00$

"Sb-125 "2.48E+02 $2.65 E+00$

"Te-125m" $6.04 \mathrm{E}+01 \quad 1.74 \mathrm{E}-01$

"Sn-126 "3.18E-01 3.33E-04

"Sb-126" $4.45 \mathrm{E}-02 \quad 2.75 \mathrm{E}-03$

"Sb-126m" 3. 18E-01 1.39E-02

"Te-127 "3.02E-10 1.39E-12

"Te-127m"3.09E-10 5.22E-13

"Te-129"0.00E+00 $0.00 \mathrm{E}+00$

"Te-129m"0.00E+00 $0.00 \mathrm{E}+00$

"I-129 "1.27E-02 2.03E-05

"CS-134" $2.79 \mathrm{E}+02 \quad 9.72 \mathrm{E}+00$

"CS-135 "1.50E-01 $1.71 \mathrm{E}-04$

"Cs-137 "2.93E+04 1.01E+02

"Ba-137m"2.77E+04 3.71E+02

"Ce-141" $0.00 \mathrm{E}+00 \quad 0.00 \mathrm{E}+00$

" $\mathrm{Pr}-143$ "0.00E+00 $0.00 \mathrm{E}+00$

"Ce-144" $4.55 \mathrm{E}+00 \quad 1.02 \mathrm{E}-02$

"Pr-144"4.49E+00 1.12E-01

"Pr-144m" 5.45E-02 6.26E-05

. Pm-147"2.75E+03 $3.44 \mathrm{E}+00$

${ }^{17} \mathrm{Pm}-148$ "0.00E+00 $0.00 \mathrm{E}+00$

"Pm-148m" $0.00 E+00 \quad 0.00 E+00$ 


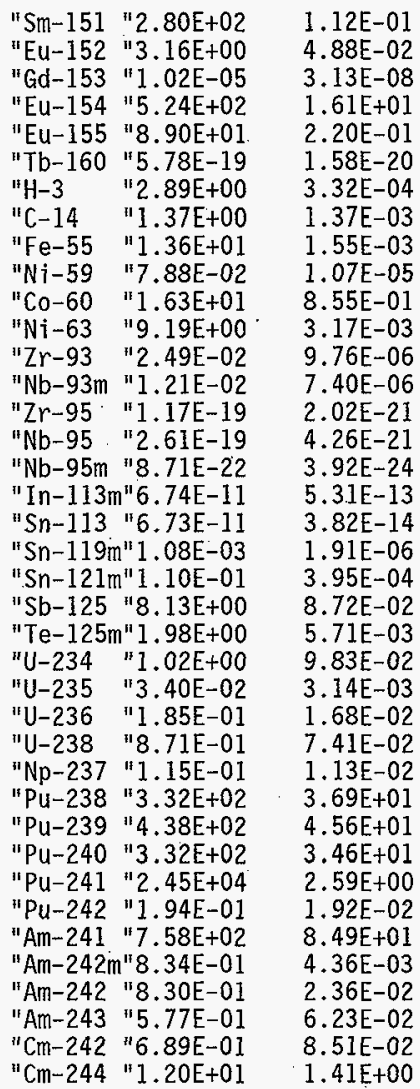


"105-K Basins Maximum Pu-240 charge data safety/regulatory assessment basis" "Key" "Grade" "Fuel" "Pieces" "\%u-240" "Uranium" "Mo" "Yr"

\begin{tabular}{|c|c|}
\hline 25654 & 000 \\
\hline
\end{tabular}

$\begin{array}{lllllll}12565 & 4.4 & 000 & 16.72 & 0.175589 & 12 & 99\end{array}$


"06/02/1997 RADNUC2A run for Safety Basis

"Results decayed to 05/31/1998 "

"Total MTU" 11.6

"Total Curies" 4.77E+05

"Total BTU " $4.84 \mathrm{E}+03$

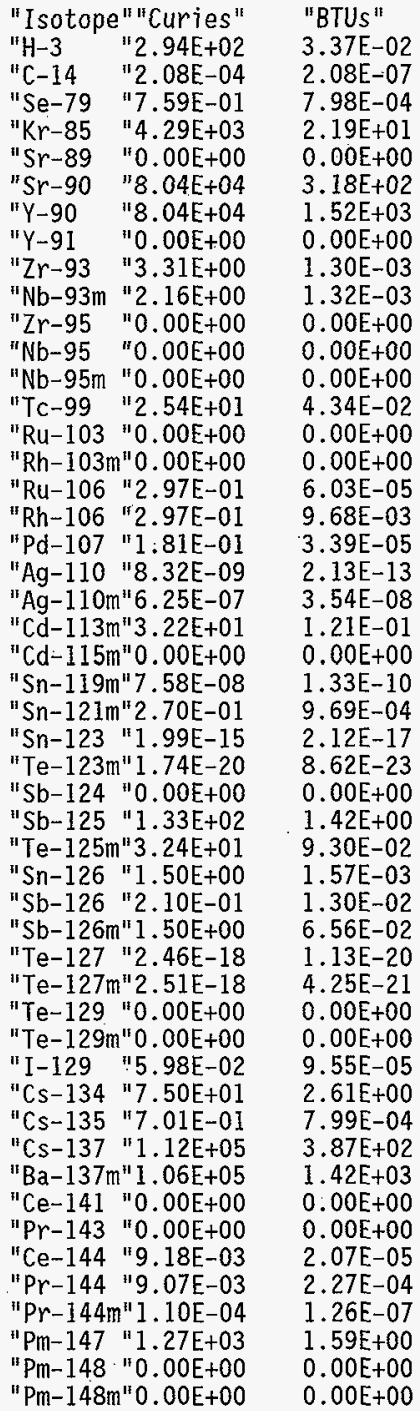




\begin{tabular}{|c|c|c|}
\hline 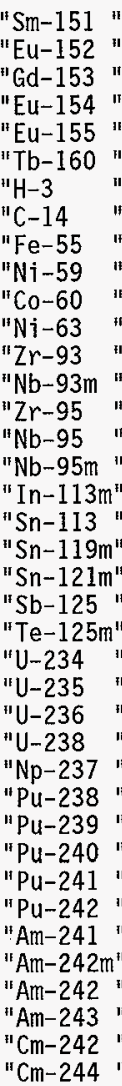 & $\begin{array}{l}" 1.18 \mathrm{E}+03 \\
" 9.80 \mathrm{E}+00 \\
" 6.02 \mathrm{E}-09 \\
" 1.31 \mathrm{E}+03 \\
" 1.23 \mathrm{E}+02 \\
" 0.00 \mathrm{E}+00 \\
" 8.78 \mathrm{E}+00 \\
" 6.42 \mathrm{E}+00 \\
" 6.28 \mathrm{E}+00 \\
" 3.69 \mathrm{E}-01 \\
" 2.43 \mathrm{E}+01 \\
" 4.03 \mathrm{E}+01 \\
" 1.17 \mathrm{E}-01 \\
" 7.61 \mathrm{E}-02 \\
" 0.00 \mathrm{E}+00 \\
" 0.00 \mathrm{E}+00 \\
" 0.00 \mathrm{E}+00 \\
" 1.58 \mathrm{E}-18 \\
" 1.58 \mathrm{E}-18 \\
" 6.37 \mathrm{E}-07 \\
14.57 \mathrm{E}-01 \\
" 4.32 \mathrm{E}+00 \\
" 1.05 \mathrm{E}+00 \\
" 4.46 \mathrm{E}+00 \\
" 1.47 \mathrm{E}-01 \\
" 8.31 \mathrm{E}-01 \\
" 3.84 \mathrm{E}+00 \\
" 5.40 \mathrm{E}-01 \\
" 1.54 \mathrm{E}+03 \\
" 2.01 \mathrm{E}+03 \\
" 1.59 \mathrm{E}+03 \\
" 7.91 \mathrm{E}+04 \\
" 1.01 \mathrm{E}+00 \\
" 5.03 \mathrm{E}+03 \\
" 4.32 \mathrm{E}+00 \\
" 4.30 \mathrm{E}+00 \\
" 3.23 \mathrm{E}+00 \\
" 3.57 \mathrm{E}+00 \\
" 5.19 \mathrm{E}+01\end{array}$ & $\begin{array}{l}4.71 \mathrm{E}-01 \\
1.51 \mathrm{E}-01 \\
1.85 \mathrm{E}-11 \\
4.00 \mathrm{E}+01 \\
3.03 \mathrm{E}-01 \\
0.00 \mathrm{E}+00 \\
1.01 \mathrm{E}-03 \\
6.40 \mathrm{E}-03 \\
7.14 \mathrm{E}-04 \\
5.00 \mathrm{E}-05 \\
1.28 \mathrm{E}+00 \\
1.39 \mathrm{E}-02 \\
4.58 \mathrm{E}-05 \\
4.65 \mathrm{E}-05 \\
0.00 \mathrm{E}+00 \\
0.00 \mathrm{E}+00 \\
0.00 \mathrm{E}+00 \\
1.24 \mathrm{E}-20 \\
8.93 \mathrm{E}-22 \\
1.12 \mathrm{E}-09 \\
1.64 \mathrm{E}-03 \\
4.64 \mathrm{E}-02 \\
3.03 \mathrm{E}-03 \\
4.31 \mathrm{E}-01 \\
1.36 \mathrm{E}-02 \\
7.58 \mathrm{E}-02 \\
3.26 \mathrm{E}-01 \\
5.31 \mathrm{E}-02 \\
1.72 \mathrm{E}+02 \\
2.09 \mathrm{E}+02 \\
1.66 \mathrm{E}+02 \\
8.37 \mathrm{E}+00 \\
1.01 \mathrm{E}-01 \\
5.63 \mathrm{E}+02 \\
2.26 \mathrm{E}-02 \\
1.22 \mathrm{E}-01 \\
3.49 \mathrm{E}-01 \\
4.41 \mathrm{E}-01\end{array}$ \\
\hline
\end{tabular}


"06/04/1997 RADNUC2A run for safety basis fuel (40"

"Results decayed to 05/31/2038"

"Total MTU " 6.9

"Total Curies" $1.13 E+05$

"Total BTU " 1.72E+03

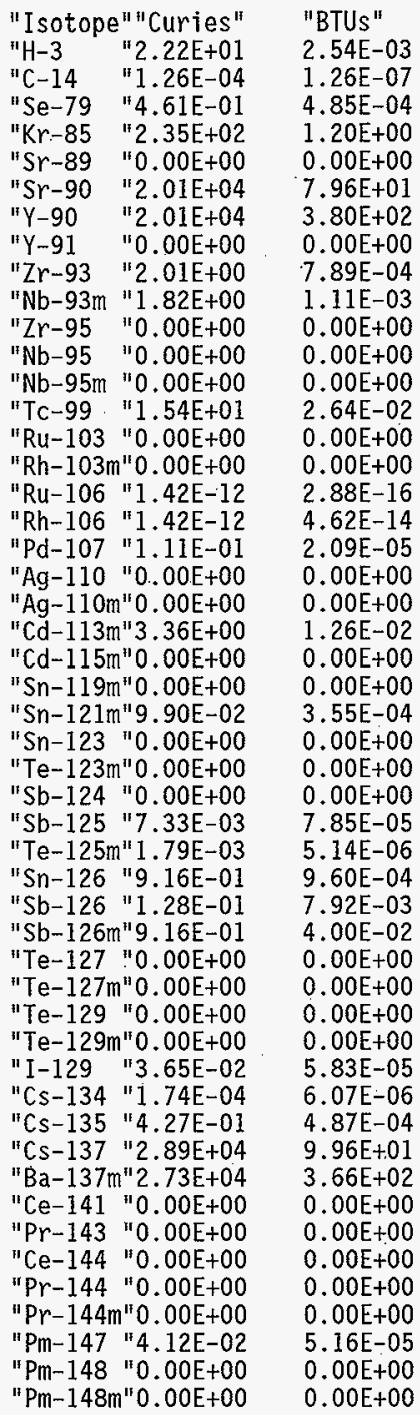




\begin{tabular}{|c|c|c|}
\hline 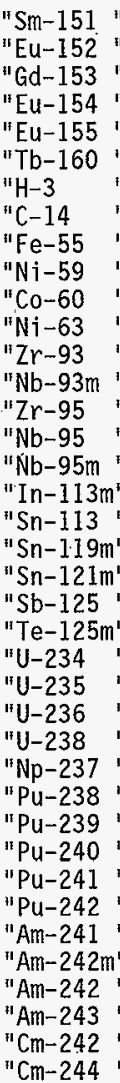 & $\begin{array}{l}" 5.29 \mathrm{E}+02 \\
" 9.09 \mathrm{E}-01 \\
" 0.00 \mathrm{E}+00 \\
" 4.09 \mathrm{E}+01 \\
" 4.10 \mathrm{E}-01 \\
" 0.00 \mathrm{E}+00 \\
" 6.79 \mathrm{E}-01 \\
" 3.89 \mathrm{E}+00 \\
" 1.88 \mathrm{E}-04 \\
" 2.24 \mathrm{E}-01 \\
" 1.11 \mathrm{E}-01 \\
" 1.85 \mathrm{E}+01 \\
" 7.10 \mathrm{E}-02 \\
" 6.43 \mathrm{E}-02 \\
" 0.00 \mathrm{E}+00 \\
" 0.00 \mathrm{E}+00 \\
" 0.00 \mathrm{E}+00 \\
1 " 0.00 \mathrm{E}+00 \\
" 0.00 \mathrm{E}+00 \\
1 " 0.00 \mathrm{E}+00 \\
1 " 1.66 \mathrm{E}-01 \\
" 2.38 \mathrm{E}-04 \\
1 " 5.81 \mathrm{E}-05 \\
" 2.63 \mathrm{E}+00 \\
" 8.61 \mathrm{E}-02 \\
" 4.96 \mathrm{E}-01 \\
" 2.27 \mathrm{E}+00 \\
" 3.29 \mathrm{E}-01 \\
" 7.20 \mathrm{E}+02 \\
" 1.21 \mathrm{E}+03 \\
" 9.75 \mathrm{E}+02 \\
" 8.22 \mathrm{E}+03 \\
" 6.48 \mathrm{E}-01 \\
" 4.26 \mathrm{E}+03 \\
" 2.37 \mathrm{E}+00 \\
" 2.36 \mathrm{E}+00 \\
" 2.13 \mathrm{E}+00 \\
" 1.96 \mathrm{E}+00 \\
" 8.55 \mathrm{E}+00\end{array}$ & $\begin{array}{l}2.11 \mathrm{E}-01 \\
1.40 \mathrm{E}-02 \\
0.00 \mathrm{E}+00 \\
1.25 \mathrm{E}+00 \\
1.01 \mathrm{E}-03 \\
0.00 \mathrm{E}+00 \\
7.78 \mathrm{E}-05 \\
3.88 \mathrm{E}-03 \\
2.14 \mathrm{E}-08 \\
3.04 \mathrm{E}-05 \\
5.82 \mathrm{E}-03 \\
6.39 \mathrm{E}-03 \\
2.79 \mathrm{E}-05 \\
3.93 \mathrm{E}-05 \\
0.00 \mathrm{E}+00 \\
0.00 \mathrm{E}+00 \\
0.00 \mathrm{E}+00 \\
0.00 \mathrm{E}+00 \\
0.00 \mathrm{E}+00 \\
0.00 \mathrm{E}+00 \\
5.96 \mathrm{E}-04 \\
2.55 \mathrm{E}-06 \\
1.67 \mathrm{E}-07 \\
2.54 \mathrm{E}-01 \\
7.96 \mathrm{E}-03 \\
4.53 \mathrm{E}-02 \\
1.93 \mathrm{E}-01 \\
3.23 \mathrm{E}-02 \\
8.01 \mathrm{E}+01 \\
1.26 \mathrm{E}+02 \\
1.02 \mathrm{E}+02 \\
8.69 \mathrm{E}-01 \\
6.44 \mathrm{E}-02 \\
4.77 \mathrm{E}+02 \\
1.24 \mathrm{E}-02 \\
6.70 \mathrm{E}-02 \\
2.30 \mathrm{E}-01 \\
2.42 \mathrm{E}-01 \\
1.00 \mathrm{E}+00\end{array}$ \\
\hline
\end{tabular}


HNF-SD-SNF-TI-009, Rev. 1

This page intentionally left blank. 
HNF-SD-SNF-TI-009, Rev. 1

APPENDIX C

HALF-LIFE, SPECIFIC ACTIVITY, AND SPECIFIC HEAT FOR SELECTED RADIONUCLIDES

C-1 
HNF-SD-SNF-TI-009, Rev. 1

\begin{tabular}{|c|c|c|c|c|c|c|}
\hline \multicolumn{7}{|c|}{$\begin{array}{c}\text { Specific Activity and Decay Heat Generation } \\
\text { Rates for Selected Radionucljdes. }\end{array}$} \\
\hline \multirow{2}{*}{$\begin{array}{l}\text { Radio- } \\
\text { nuclide }\end{array}$} & \multirow{2}{*}{$\begin{array}{l}\text { Atomic } \\
\text { Weight }\end{array}$} & \multirow[t]{2}{*}{ Half-life } & & \multirow{2}{*}{$\begin{array}{c}\text { Specific } \\
\text { Activity } \\
\text { (Ci/g) }\end{array}$} & \multicolumn{2}{|c|}{$\begin{array}{l}\text { Decay Heat } \\
\text { Generation Rate }\end{array}$} \\
\hline & & & & & $(W / C i)$ & $(W / g)$ \\
\hline $\begin{array}{l}\mathrm{H}-3 \\
\mathrm{C}-14 \\
\mathrm{Fe}-55 \\
\mathrm{Co}-60 \\
\end{array}$ & $\begin{array}{r}3 \\
14 \\
55 \\
60 \\
\end{array}$ & $\begin{array}{l}3.897 \mathrm{e}+08 \\
1.808 \mathrm{e}+11 \\
2.600 \mathrm{e}+00 \\
1.663 \mathrm{e}+08 \\
\end{array}$ & $\begin{array}{l}s \\
s \\
y \\
s\end{array}$ & $\begin{array}{l}9.651 \mathrm{e}+03 \\
4.458 \mathrm{e}+00 \\
2.500 \mathrm{e}+03 \\
1.131 \mathrm{e}+03\end{array}$ & $\begin{array}{l}3.367 \mathrm{e}-05 \\
2.933 \mathrm{e}-04 \\
3.379 \mathrm{e}-05 \\
1.542 \mathrm{e}-02\end{array}$ & $\begin{array}{l}3.250 \mathrm{e}-01 \\
1.307 \mathrm{e}-03 \\
8.448 \mathrm{e}-02 \\
1.744 \mathrm{e}+01 \\
\end{array}$ \\
\hline $\begin{array}{l}\mathrm{Ni}-59 \\
\mathrm{Ni}-63 \\
\mathrm{Se}-79 \\
\mathrm{Kr}-85 \\
\end{array}$ & $\begin{array}{l}59 \\
63 \\
79 \\
85 \\
\end{array}$ & $\begin{array}{l}8.000 \mathrm{e}+01 \\
9.200 \mathrm{e}+01 \\
2.050 \mathrm{e}+12 \\
3.383 \mathrm{e}+08 \\
\end{array}$ & $\begin{array}{l}\text { ky } \\
\text { y } \\
\text { s } \\
\text { s } \\
\end{array}$ & $\begin{array}{l}7.575 \mathrm{e}-02 \\
6.169 \mathrm{e}+01 \\
6.967 \mathrm{e}-02 \\
3.924 \mathrm{e}+02 \\
\end{array}$ & $\begin{array}{l}3.972 \mathrm{e}-05 \\
3.972 \mathrm{e}-04 \\
2.490 \mathrm{e}-04 \\
1.498 \mathrm{e}-03\end{array}$ & $\begin{array}{l}3.009 \mathrm{e}-06 \\
2.450 \mathrm{e}-02 \\
1.735 \mathrm{e}-05 \\
5.878 \mathrm{e}-01 \\
\end{array}$ \\
\hline $\begin{array}{l}S r-89 \\
S r-90 \\
Y-90 \\
Y-91 \\
\end{array}$ & $\begin{array}{l}89 \\
90 \\
90 \\
91 \\
\end{array}$ & $\begin{array}{l}4.363 e+06 \\
9.190 e+08 \\
2.304 e+05 \\
5.055 e+06 \\
\end{array}$ & $\begin{array}{l}s \\
s \\
s \\
s\end{array}$ & $\begin{array}{l}2.906 \mathrm{e}+04 \\
1.364 \mathrm{e}+02 \\
5.441 \mathrm{e}+05 \\
2.453 \mathrm{e}+04 \\
\end{array}$ & $\begin{array}{l}3.457 \mathrm{e}-03 \\
1.161 \mathrm{e}-03 \\
5.543 \mathrm{e}-03 \\
3.592 \mathrm{e}-03 \\
\end{array}$ & $\begin{array}{l}1.005 e+02 \\
1.583 e-01 \\
3.016 e+03 \\
8.810 e+01 \\
\end{array}$ \\
\hline $\begin{array}{l}\mathrm{Zr}-93 \\
\mathrm{Zr}-95 \\
\mathrm{Nb}-93 \mathrm{~m} \\
\mathrm{Nb}-95\end{array}$ & $\begin{array}{l}93 \\
95 \\
93 \\
95\end{array}$ & $\begin{array}{l}4.828 e+13 \\
5.528 e+06 \\
4.292 e+08 \\
3.037 e+06\end{array}$ & $\begin{array}{l}s \\
s \\
s \\
s\end{array}$ & $\begin{array}{l}2.513 \mathrm{e}-03 \\
2.148 \mathrm{e}+04 \\
2.827 \mathrm{e}+02 \\
3.911 \mathrm{e}+04\end{array}$ & $\begin{array}{l}1.162 \mathrm{e}-04 \\
5.066 \mathrm{e}-03 \\
1.772 \mathrm{e}-04 \\
4.797 \mathrm{e}-03\end{array}$ & $\begin{array}{l}2.920 e-07 \\
1.088 e+02 \\
5.009 e-02 \\
1.876 e+02\end{array}$ \\
\hline $\begin{array}{l}\mathrm{Nb}-95 \mathrm{~m} \\
\mathrm{Tc}-99 \\
\mathrm{Ru}-103 \\
\mathrm{Ru}-106\end{array}$ & $\begin{array}{r}95 \\
99 \\
103 \\
106 \\
\end{array}$ & $\begin{array}{l}3.118 e+05 \\
6.722 e+12 \\
3.394 e+06 \\
3.181 e+07 \\
\end{array}$ & $\begin{array}{l}\mathrm{s} \\
\mathrm{s} \\
\mathrm{s} \\
\mathrm{s}\end{array}$ & $\begin{array}{l}3.809 \mathrm{e}+05 \\
1.695 \mathrm{e}-02 \\
3.228 \mathrm{e}+04 \\
3.346 \mathrm{e}+03 \\
\end{array}$ & $\begin{array}{l}1.390 \mathrm{e}-03 \\
5.015 \mathrm{e}-04 \\
3.346 \mathrm{e}-03 \\
5.946 \mathrm{e}-05 \\
\end{array}$ & $\begin{array}{l}5.293 \mathrm{e}+02 \\
8.503 \mathrm{e}-06 \\
1.080 \mathrm{e}+02 \\
1.990 \mathrm{e}-01 \\
\end{array}$ \\
\hline $\begin{array}{l}\mathrm{Rh}-103 \mathrm{~m} \\
\mathrm{Rh}-106 \\
\mathrm{Pd}-107 \\
\mathrm{Ag}-110 \\
\end{array}$ & $\begin{array}{l}103 \\
106 \\
107 \\
110 \\
\end{array}$ & $\begin{array}{l}3.367 \mathrm{e}+03 \\
2.990 \mathrm{e}+01 \\
2.050 \mathrm{e}+14 \\
2.460 \mathrm{e}+01 \\
\end{array}$ & $\begin{array}{l}\mathrm{s} \\
\mathrm{s} \\
\mathrm{s} \\
\mathrm{s}\end{array}$ & $\begin{array}{l}3.253 \mathrm{e}+07 \\
3.560 \mathrm{e}+09 \\
5.144 \mathrm{e}-04 \\
4.170 \mathrm{e}+09 \\
\end{array}$ & $\begin{array}{l}2.302 \mathrm{e}-04 \\
9.592 \mathrm{e}-03 \\
5.928 \mathrm{e}-05 \\
7.185 \mathrm{e}-03 \\
\end{array}$ & $\begin{array}{l}7.489 e+03 \\
3.415 e+07 \\
3.049 e-08 \\
2.996 e+07 \\
\end{array}$ \\
\hline $\begin{array}{l}\mathrm{Ag}-110 \mathrm{~m} \\
\mathrm{Cd}-113 \mathrm{~m} \\
\mathrm{Cd}-115 \mathrm{~m} \\
\mathrm{In}-113 \mathrm{~m} \\
\end{array}$ & $\begin{array}{l}110 \\
113 \\
115 \\
113 \\
\end{array}$ & $\begin{array}{l}2.159 e+07 \\
4.604 e+08 \\
3.853 e+06 \\
5.969 e+03 \\
\end{array}$ & $\begin{array}{l}\mathrm{s} \\
\mathrm{s} \\
\mathrm{s} \\
\mathrm{s}\end{array}$ & $\begin{array}{l}4.751 \mathrm{e}+03 \\
2.169 \mathrm{e}+02 \\
2.546 \mathrm{e}+04 \\
1.673 \mathrm{e}+07 \\
\end{array}$ & $\begin{array}{l}1.670 \mathrm{e}-02 \\
1.684 \mathrm{e}-03 \\
3.730 \mathrm{e}-03 \\
2.330 \mathrm{e}-03 \\
\end{array}$ & $\begin{array}{l}7.934 \mathrm{e}+01 \\
3.651 \mathrm{e}-01 \\
9.498 \mathrm{e}+01 \\
3.897 \mathrm{e}+04\end{array}$ \\
\hline $\begin{array}{l}\mathrm{Sn}-113 \\
\mathrm{Sn}-119 \mathrm{~m} \\
\mathrm{Sn}-121 \mathrm{~m} \\
\mathrm{Sn}-123 \\
\end{array}$ & $\begin{array}{l}113 \\
119 \\
121 \\
123 \\
\end{array}$ & $\begin{array}{l}9.945 e+06 \\
2.117 e+07 \\
1.577 e+09 \\
1.116 e+07 \\
\end{array}$ & $\begin{array}{l}\mathrm{s} \\
\mathrm{s} \\
\mathrm{s} \\
\mathrm{s}\end{array}$ & $\begin{array}{l}1.004 \mathrm{e}+04 \\
4.479 \mathrm{e}+03 \\
5.913 \mathrm{e}+01 \\
8.220 \mathrm{e}+03 \\
\end{array}$ & $\begin{array}{l}1.666 \mathrm{e}-04 \\
5.169 \mathrm{e}-04 \\
2.004 \mathrm{e}-03 \\
3.124 \mathrm{e}-03 \\
\end{array}$ & $\begin{array}{l}1.672 \mathrm{e}+00 \\
2.315 \mathrm{e}+00 \\
1.185 \mathrm{e}-01 \\
2.567 \mathrm{e}+01 \\
\end{array}$ \\
\hline $\begin{array}{l}S n-126 \\
S b-124 \\
S b-125 \\
S b-126 \\
\end{array}$ & $\begin{array}{l}126 \\
124 \\
125 \\
126 \\
\end{array}$ & $\begin{array}{l}3.156 \mathrm{e}+12 \\
5.201 \mathrm{e}+06 \\
8.741 \mathrm{e}+07 \\
1.071 \mathrm{e}+06 \\
\end{array}$ & $\begin{array}{l}\mathrm{s} \\
\mathrm{s} \\
\mathrm{s} \\
\mathrm{s}\end{array}$ & $\begin{array}{l}2.837 \mathrm{e}-02 \\
1.750 \mathrm{e}+04 \\
1.033 \mathrm{e}+03 \\
8.361 \mathrm{e}+04 \\
\end{array}$ & $\begin{array}{l}1.247 \mathrm{e}-03 \\
1.328 \mathrm{e}-02 \\
3.126 \mathrm{e}-03 \\
1.848 \mathrm{e}-02 \\
\end{array}$ & $\begin{array}{l}3.539 \mathrm{e}-05 \\
2.323 \mathrm{e}+02 \\
3.229 \mathrm{e}+00 \\
1.545 \mathrm{e}+03 \\
\end{array}$ \\
\hline $\begin{array}{l}\text { Sb-126m } \\
\text { Te-125m } \\
\text { Te-127 } \\
\text { Te-127m }\end{array}$ & $\begin{array}{l}126 \\
125 \\
127 \\
127 \\
\end{array}$ & $\begin{array}{l}1.140 \mathrm{e}+03 \\
5.011 \mathrm{e}+06 \\
3.366 \mathrm{e}+04 \\
9.418 \mathrm{e}+06\end{array}$ & $\begin{array}{l}s \\
s \\
s \\
s\end{array}$ & $\begin{array}{l}7.855 e+07 \\
1.801 e+04 \\
2.639 e+06 \\
9.433 e+03\end{array}$ & $\begin{array}{l}1.273 \mathrm{e}-02 \\
8.406 \mathrm{e}-04 \\
1.350 \mathrm{e}-03 \\
5.379 \mathrm{e}-04\end{array}$ & $\begin{array}{l}1.000 \mathrm{e}+06 \\
1.514 \mathrm{e}+01 \\
3.564 \mathrm{e}+03 \\
5.074 \mathrm{e}+00\end{array}$ \\
\hline
\end{tabular}


HNF-SD-SNF-TI-009, Rev. 1

\begin{tabular}{|c|c|c|c|c|c|c|}
\hline \multicolumn{7}{|c|}{$\begin{array}{l}\text { Specific Activity and Decay Heat Generation } \\
\text { Rates for Selected Radionuclides. }\end{array}$} \\
\hline \multirow{2}{*}{$\begin{array}{l}\text { Radio- } \\
\text { nuclide }\end{array}$} & \multirow{2}{*}{$\begin{array}{l}\text { Atomic } \\
\text { Wejght }\end{array}$} & \multirow[t]{2}{*}{ Half-life } & & \multirow{2}{*}{$\begin{array}{l}\text { Specific } \\
\text { Activity } \\
(C i / g)\end{array}$} & \multicolumn{2}{|c|}{$\begin{array}{l}\text { Decay Heat } \\
\text { Generation Rate }\end{array}$} \\
\hline & & & & & $(\mathrm{W} / \mathrm{C} \mathrm{i})$ & $(W / g)$ \\
\hline $\begin{array}{l}\text { Te-129 } \\
\text { Te-129m } \\
\mathrm{I}-129 \\
\mathrm{Cs}-134 \\
\end{array}$ & $\begin{array}{l}129 \\
129 \\
129 \\
134 \\
\end{array}$ & $\begin{array}{l}4.176 e+03 \\
2.903 e+06 \\
4.954 e+14 \\
6.507 e+07 \\
\end{array}$ & $\begin{array}{l}\mathrm{s} \\
\mathrm{s} \\
\mathrm{s} \\
\mathrm{s}\end{array}$ & $\begin{array}{l}2.094 \mathrm{e}+07 \\
3.013 \mathrm{e}+04 \\
1.766 \mathrm{e}-04 \\
1.294 \mathrm{e}+03 \\
\end{array}$ & $\begin{array}{l}3.573 \mathrm{e}-03 \\
1.754 \mathrm{e}-03 \\
4.626 \mathrm{e}-04 \\
1.018 \mathrm{e}-02 \\
\end{array}$ & $\begin{array}{l}7.483 e+04 \\
5.283 e+01 \\
8.168 \mathrm{e}-08 \\
1.317 \mathrm{e}+01 \\
\end{array}$ \\
\hline $\begin{array}{l}\mathrm{Cs}-135 \\
\mathrm{Cs}-137 \\
\mathrm{Ba}-137 \mathrm{~m} \\
\mathrm{Ce}-141 \\
\end{array}$ & $\begin{array}{l}135 \\
137 \\
137 \\
141 \\
\end{array}$ & $\begin{array}{l}7.258 \mathrm{e}+13 \\
9.467 \mathrm{e}+08 \\
1.531 \mathrm{e}+02 \\
2.809 \mathrm{e}+06 \\
\end{array}$ & $\begin{array}{l}s \\
s \\
s \\
s\end{array}$ & $\begin{array}{l}1.152 \mathrm{e}-03 \\
8.699 \mathrm{e}+01 \\
5.379 \mathrm{e}+08 \\
2.849 \mathrm{e}+04 \\
\end{array}$ & $\begin{array}{l}3.338 \mathrm{e}-04 \\
1.106 \mathrm{e}-03 \\
3.927 \mathrm{e}-03 \\
1.464 \mathrm{e}-03 \\
\end{array}$ & $\begin{array}{l}3.843 \mathrm{e}-07 \\
9.623 \mathrm{e}-02 \\
2.112 \mathrm{e}+06 \\
4.171 \mathrm{e}+01 \\
\end{array}$ \\
\hline $\begin{array}{l}\mathrm{Ce}-144 \\
\mathrm{Pr}-143 \\
\mathrm{Pr}-144 \\
\mathrm{Pr}-144 \mathrm{~m}\end{array}$ & $\begin{array}{l}144 \\
143 \\
144 \\
144 \\
\end{array}$ & $\begin{array}{l}2.456 \mathrm{e}+07 \\
1.172 \mathrm{e}+06 \\
1.037 \mathrm{e}+03 \\
4.320 \mathrm{e}+02 \\
\end{array}$ & $\begin{array}{l}\mathrm{s} \\
\mathrm{s} \\
\mathrm{s} \\
\mathrm{s}\end{array}$ & $\begin{array}{l}3.190 \mathrm{e}+03 \\
6.732 \mathrm{e}+04 \\
7.556 \mathrm{e}+07 \\
1.814 \mathrm{e}+08\end{array}$ & $\begin{array}{l}6.634 \mathrm{e}-04 \\
1.863 \mathrm{e}-03 \\
7.351 \mathrm{e}-03 \\
3.422 \mathrm{e}-04 \\
\end{array}$ & $\begin{array}{l}2.116 e+00 \\
1.254 \mathrm{e}+02 \\
5.554 \mathrm{e}+05 \\
6.206 \mathrm{e}+04 \\
\end{array}$ \\
\hline $\begin{array}{l}P m-147 \\
P m-148 \\
P m-148 m \\
S m-151 \\
\end{array}$ & $\begin{array}{l}147 \\
148 \\
148 \\
151 \\
\end{array}$ & $\begin{array}{l}8.279 \mathrm{e}+07 \\
4.640 \mathrm{e}+05 \\
3.568 \mathrm{e}+06 \\
2.840 \mathrm{e}+09 \\
\end{array}$ & $\begin{array}{l}s \\
s \\
s \\
s \\
\end{array}$ & $\begin{array}{l}9.271 \mathrm{e}+02 \\
1.643 \mathrm{e}+05 \\
2.137 \mathrm{e}+04 \\
2.631 \mathrm{e}+01 \\
\end{array}$ & $\begin{array}{l}3.587 \mathrm{e}-04 \\
7.701 \mathrm{e}-03 \\
1.268 \mathrm{e}-02 \\
1.173 \mathrm{e}-04 \\
\end{array}$ & $\begin{array}{l}3.326 \mathrm{e}-01 \\
1.265 \mathrm{e}+03 \\
2.709 \mathrm{e}+02 \\
3.085 \mathrm{e}-03 \\
\end{array}$ \\
\hline $\begin{array}{l}\mathrm{Eu}-152 \\
\mathrm{Eu}-154 \\
\mathrm{Eu}-155 \\
\mathrm{Gd}-153 \\
\mathrm{~Tb}-160 \\
\end{array}$ & $\begin{array}{l}152 \\
154 \\
155 \\
153 \\
160 \\
\end{array}$ & $\begin{array}{l}4.292 e+08 \\
2.714 e+08 \\
1.565 e+08 \\
2.091 e+07 \\
6.247 e+06\end{array}$ & $\begin{array}{l}\mathrm{s} \\
\mathrm{s} \\
\mathrm{s} \\
\mathrm{s} \\
\mathrm{s}\end{array}$ & $\begin{array}{l}1.730 \mathrm{e}+02 \\
2.700 \mathrm{e}+02 \\
4.651 \mathrm{e}+02 \\
3.527 \mathrm{e}+03 \\
1.129 \mathrm{e}+04\end{array}$ & $\begin{array}{l}7.564 \mathrm{e}-03 \\
8.946 \mathrm{e}-03 \\
7.274 \mathrm{e}-04 \\
9.034 \mathrm{e}-04 \\
8.145 \mathrm{e}-03\end{array}$ & $\begin{array}{l}1.308 \mathrm{e}+00 \\
2.415 \mathrm{e}+00 \\
3.383 \mathrm{e}-01 \\
3.186 \mathrm{e}+00 \\
9.195 \mathrm{e}+01\end{array}$ \\
\hline $\begin{array}{l}U-234 \\
U-235 \\
U-236 \\
U-238 \\
\end{array}$ & $\begin{array}{l}234 \\
235 \\
236 \\
238 \\
\end{array}$ & $\begin{array}{l}7.716 \mathrm{e}+12 \\
2.221 \mathrm{e}+16 \\
7.389 \mathrm{e}+14 \\
1.410 \mathrm{e}+17 \\
\end{array}$ & $\begin{array}{l}\mathrm{s} \\
\mathrm{s} \\
\mathrm{s} \\
\mathrm{s}\end{array}$ & $\begin{array}{l}6.249 \mathrm{e}-03 \\
2.162 \mathrm{e}-06 \\
6.470 \mathrm{e}-05 \\
3.362 \mathrm{e}-07 \\
\end{array}$ & $\begin{array}{l}2.880 \mathrm{e}-02 \\
2.619 \mathrm{e}-02 \\
2.709 \mathrm{e}-02 \\
2.537 \mathrm{e}-02 \\
\end{array}$ & $\begin{array}{l}1.800 \mathrm{e}-04 \\
5.662 \mathrm{e}-08 \\
1.753 \mathrm{e}-06 \\
8.529 \mathrm{e}-09 \\
\end{array}$ \\
\hline $\begin{array}{l}\mathrm{Np}-237 \\
\mathrm{Pu}-238 \\
\mathrm{Pu}-239 \\
\mathrm{Pu}-240 \\
\end{array}$ & $\begin{array}{l}237 \\
238 \\
239 \\
240 \\
\end{array}$ & $\begin{array}{l}6.753 \mathrm{e}+13 \\
2.769 \mathrm{e}+09 \\
7.594 \mathrm{e}+11 \\
2.063 \mathrm{e}+11 \\
\end{array}$ & $\begin{array}{l}\mathrm{s} \\
\mathrm{s} \\
\mathrm{s} \\
\mathrm{s}\end{array}$ & $\begin{array}{l}7.050 \mathrm{e}-04 \\
1.712 \mathrm{e}+01 \\
6.217 \mathrm{e}-02 \\
2.279 \mathrm{e}-01 \\
\end{array}$ & $\begin{array}{l}3.057 \mathrm{e}-02 \\
3.314 \mathrm{e}-02 \\
3.082 \mathrm{e}-02 \\
3.114 \mathrm{e}-02 \\
\end{array}$ & $\begin{array}{l}2.155 \mathrm{e}-05 \\
5.675 \mathrm{e}-01 \\
1.916 \mathrm{e}-03 \\
7.096 \mathrm{e}-03 \\
\end{array}$ \\
\hline $\begin{array}{l}\mathrm{Pu}-241 \\
\mathrm{Pu}-242 \\
\mathrm{Am}-241 \\
\mathrm{Am}-242 \\
\end{array}$ & $\begin{array}{l}241 \\
242 \\
241 \\
242 \\
\end{array}$ & $\begin{array}{l}4.544 e+08 \\
1.221 e+13 \\
1.364 e+10 \\
5.767 e+04 \\
\end{array}$ & $\begin{array}{l}\mathrm{S} \\
\mathrm{S} \\
\mathrm{S} \\
\mathrm{S}\end{array}$ & $\begin{array}{l}1.030 \mathrm{e}+02 \\
3.819 \mathrm{e}-03 \\
3.432 \mathrm{e}+00 \\
8.085 \mathrm{e}+05 \\
\end{array}$ & $\begin{array}{l}3.100 \mathrm{e}-05 \\
2.953 \mathrm{e}-02 \\
3.322 \mathrm{e}-02 \\
1.135 \mathrm{e}-03 \\
\end{array}$ & $\begin{array}{l}3.194 \mathrm{e}-03 \\
1.128 \mathrm{e}-04 \\
1.140 \mathrm{e}-01 \\
9.178 \mathrm{e}+02 \\
\end{array}$ \\
\hline $\begin{array}{l}\mathrm{Am}-242 \mathrm{~m} \\
\mathrm{Am}-243 \\
\mathrm{Cm}-242 \\
\mathrm{Cm}-244 \\
\end{array}$ & $\begin{array}{l}242 \\
243 \\
242 \\
244 \\
\end{array}$ & $\begin{array}{l}4.797 e+09 \\
2.329 e+11 \\
1.410 e+07 \\
5.715 e+08 \\
\end{array}$ & $\begin{array}{l}s \\
s \\
S \\
s\end{array}$ & $\begin{array}{l}9.719 \mathrm{e}+00 \\
1.994 \mathrm{e}-01 \\
3.307 \mathrm{e}+03 \\
8.091 \mathrm{e}+01 \\
\end{array}$ & $\begin{array}{l}3.950 \mathrm{e}-04 \\
3.215 \mathrm{e}-02 \\
3.685 \mathrm{e}-02 \\
3.498 \mathrm{e}-02 \\
\end{array}$ & $\begin{array}{l}3.840 \mathrm{e}-03 \\
6.409 \mathrm{e}-03 \\
1.218 \mathrm{e}+02 \\
2.830 \mathrm{e}+00 \\
\end{array}$ \\
\hline \multicolumn{7}{|c|}{$\begin{array}{l}\text { Time abbreviations are as follows: "Gy" gigayears, "My" megayears, } \\
\text { "Ky" kiloyears, "y" years, "d" days, "h" hours, "m" minutes, and } \\
\text { "s" seconds. }\end{array}$} \\
\hline
\end{tabular}


HNF-SD-SNF-TI-009, Rev. 1

This page intentionally left blank.

C-4 
HNF-SD-SNF-TI-009, Rev. 1

APPENDIX D

ENABLING ASSUMPTIONS 


\section{ENABLING ASSUMPTIONS}

The following is a list of the assumptions that were made to enable the development of this document. This list indicates the Timitations of the data that have been developed. A projected method of validation is presented for each assumption. It is anticipated that a decision will be made on the need to validate each assumption, comparing the cost of validation with the uncertainty associated with retaining the assumption invalidated.

\section{- Nuclear Accountability Database}

The assumption is that the database is an accurate reflection of the fuel that is stored in the $K$ Basins. There are at least two such databases: the one used here, and another known as Reconstructed SCATS which was developed in parallel with the Nuclear Accountability database. The Reconstructed SCATS database was used in the development of the safety analysis which was done totally independently of the feed basis. The results of feed development in this document are within about $10 \%$ of those presented in the safety documentation for ${ }^{137} \mathrm{Cs}$ and ${ }^{241} \mathrm{Am}$, two important isotopes for shielding and safety basis calculations.

The Nuclear Accountability database was used because it represents the official accepted numbers for tracking special nuclear materials. Because the Nuclear Accountability data contains the official plutonium inventory for the Hanford site, the plutonium isotopes reported in tables 2.2, 2.4, 3.5, 3.6, and 3.7 come directly from the database (WHC 1996).

For the purpose of this development, the most important aspects of the database are: the type of fuel (Mark 1A or Mark IV); the date irradiation of the fuel ended, 1isted here as a key date (date of discharge from the reactor); the percentage ${ }^{240} \mathrm{Pu}$ in the fue 1 ; and the mass of uranium in the fuel. Validation of the database, for these factors, could be obtained by direct measurement of the beta/gamma energy levels emitted by the fue 1 and the use those energies to estimate concentrations of particular nuclides. With knowledge of the nuclide concentrations in the fuel, time since discharge and ${ }^{240} \mathrm{Pu}$ content could be estimated accurately. The mass of uranium, at least for the undamaged elements, could be obtained by weighing the fuel, and then adjusting the weight to account for the cladding, fission, activation, and actinide products. This activity would be difficult and costly.

\section{- ORIGEN2}

The assumption is that ORIGEN2 accurately predicts fission, activation, and actinide products in irradiated $\mathrm{N}$-Reactor fuel, when correct input information is used. There is reason to suspect that some impurities in the fuel were inadequately defined, and that activation products from those impurities may become important for shielding and/or safety basis definition.

The ${ }^{60} \mathrm{Co}$ amounts were specifically changed in RADNUC from those predicted in ORIGEN2 because of higher than expected ${ }^{60} C_{0}$ concentrations in tank waste samples. It is important to note that radionuclides in the tank waste originated in irradiated $N$ Reactor fuel processed at the PUREX PTant. Subsequent samples showed somewhat lower cobalt concentrations, and RADNUC was changed to reflect these lower numbers. In the development work done here, the ${ }^{60} \mathrm{Co}$ concentrations as predicted by RADNUC produced about half the dose rates resulting from the ${ }^{137} \mathrm{Cs}$ and therefore shielding basis is derived by cesium, and not cobalt. For the present the shielding design basis should be as 7 isted here. 
Another potentially important isotope is ${ }^{14} \mathrm{C}$ which results from the activation of nitrogen in the fuel or cladding, and as a fission product. Activation of nitrogen produces orders of magnitude more ${ }^{14} \mathrm{C}$ than fission. As in the case of cobalt, the ${ }^{14} \mathrm{C}$ amounts in RADNUC were changed to reflect higher than expected concentrations in tank waste samples.

Validation of ORIGEN2 for $N$ Reactor would need to be done by analysis of a statistically meaningful sampling of irradiated $N$ Reactor fuels. The analysis results would need to be compared with ORIGEN2 predictions.

Levels of activation products in the fuel and cladding will depend on impurity levels in the unirradiated fuel. Since the fuel was fabricated using many different shipments of uranium and zircaloy 2, it is possible that impurity levels varied significantly over time.

\section{- RADNUC}

The assumption is that RADNUC accurately predicts nuclide concentrations in $\mathrm{N}$ Reactor fuel. RADNUC was originally written to predict nuclides in tank waste. The nuclides in tank waste however, originated in the irradiated fuel. Therefore, RADNUC was written to determine fission, activation, and actinide products in the fuel. As originally written, RADNUC gave the user the option of removing some of the actinides and fission products to simulate processing activities at PUREX and other facilities. RADNUC was recently changed to allow the user to specify fuel or tank waste in the case of fuel, no nuclides are removed.

RADNUC uses ORIGEN2 runs for Mark $1 \mathrm{~A}$ and Mark IV $N$ Reactor fuel as the basis for estimating radionuclide amounts. Output from ORIGEN2 runs for $6 \%$, $9 \%, 12 \%$, and $16 \%{ }^{240} \mathrm{Pu}$ are included in the RADNUC code. It is important to note that a]though the runs are referred to as $6 \%, 9 \%, 12 \%$, and $16 \%{ }^{240} \mathrm{Pu}$ runs, ORIGEN2 input files only include burnup information and were iterated to arrive at the desired ${ }^{240} \mathrm{Pu}$ content. In. the case of the "16\% ${ }^{240} \mathrm{Pu}$ " run the actual ${ }^{240} \mathrm{Pu}$ content is only slightiy over $15 \%$ at discharge and actually drops below $15 \%$ at 120 days after discharge. This apparent weakness in the available ORIGEN2 runs was factored into the RADNUC code however, and should not present a problem in the predictions.

RADNUC reads the ${ }^{240} \mathrm{Pu}$ content from the input data file and interpolates the radionuclide per MTU content from the 2 nearest ORIGEN2 runs. For ${ }^{240} \mathrm{Pu}$ contents between $0 \%$ and $6 \%$ a direct 1 inear interpolation scheme is used, for ${ }^{240} \mathrm{Pu}$ contents between $6 \%$ and $15 \%$ the $\log$ of ${ }^{240} \mathrm{Pu}$ content is interpolated, and for ${ }^{240} \mathrm{Pu}$ contents above $15 \%$, the $10 \mathrm{~g}$ of the ${ }^{240} \mathrm{Pu}$ content is used to extrapolate the nuclides. Each of the 88 isotopes are interpolated or extrapolated for each entry in the input data file. Each of the nuclides are summed to arrive at total for each of the 88 for the entire data file. For fission and activation products, the concentration of nuclides in the fuel is nearly Tinear with ${ }^{240} \mathrm{Pu}$ content, and therefore should be predicted we 17 by RADNUC. Actinides are somewhat less linear, and therefore accurate prediction by interpolation is 1 imited to the range weil covered by the availabie data. Fortunately, the maximum ${ }^{240} \mathrm{Pu}$ content is only slightly above $16 \%$.

RADNUC has been validated by comparison with ORIGEN2 runs for identical ${ }^{240} \mathrm{Pu}$ content fuels. This validation was performed and documented as part of the changes to the RADNUC code.

- Fuel vs STudge 
The assumption is that all the fuel in the $K$ Basins is intact, and contains all of the nuclides within its cladding. In fact this assumption is not correct, much of the fue 1 in the basins has damaged, and in some cases severely damaged, cladding which has allowed the uranium to corrode and release fission, activation, and actinide products into the surrounding basin as either gases, soluble materials, or solids (sludge). Some of this material $\left({ }^{85} \mathrm{Kr}\right.$ and $\left.{ }^{3} \mathrm{H}\right)$ has been released to the environment, and some has been removed from the basin water in the treatment systems (filtration and ion exchange). It is difficult to account for the exact origin of the radionuclides in the basin sludge, filtration systems, ion exchange columns, and other basin systems because of the long history of fuel storage in the basins.

Extensive analyses would be required to determine the origin of radionuclides in: sludge or other basin systems; ion exchange columns; or environmental releases. These analyses are not recommended because of the high cost and small likelihood that any such results would cause significant changes to fuel storage or treatment systems. A conservative approach is to assume that the radionuclides in basin sludge, basin water systems, and any which may have been released to the environment, originated in fuel not currently stored in the basins. At the same time the most conservative assumption is that a 11 nuclides which originated in the fuel currently in storage remain with the fuel. 
HNF-SD-SNF-TI-009, Rev. 1

This page intentionally left blank. 
HNF-SD-SNF-TI-009, Rev . I

APPENDIX E

CALCULATION OF SLUDGE COMPONENT INVENTORY 
Table E-1 contains the raw sample data from 105-K East Basin samples (Bechtold 1993). The unit conversion columns show the change in units for further use.

Table E-2 shows conversion of the raw data into a sludge component inventory by multiplying the component weight fraction (obtained from Table E1) by the total sludge mass and solids weight fraction in a Basin area from which the sample was obtained.

Since limited sample data were available, extrapolation was required to obtain sludge component inventory for the remaining pits and fuel canisters. Since the Weasel Pit sludge contains the highest amount of radionuclides due to sludge pumping activities, the sludge in this area is used to estimate the component inventory in the Tech View Pit, Wash Pit, South Loadout Pit, and breached fuel canisters. For the empty fuel canisters and fuel canisters with unbreached fuel, the Basin Floor sludge composition was used to model the sludge in these areas. These calculated values are provided in Table E-3.

Similar information on the radionuclide inventory in the sludge is provided in Tables E-4 through E- 6 . The final sludge radionuclide inventory calculations are the same as described above for the chemical components. 


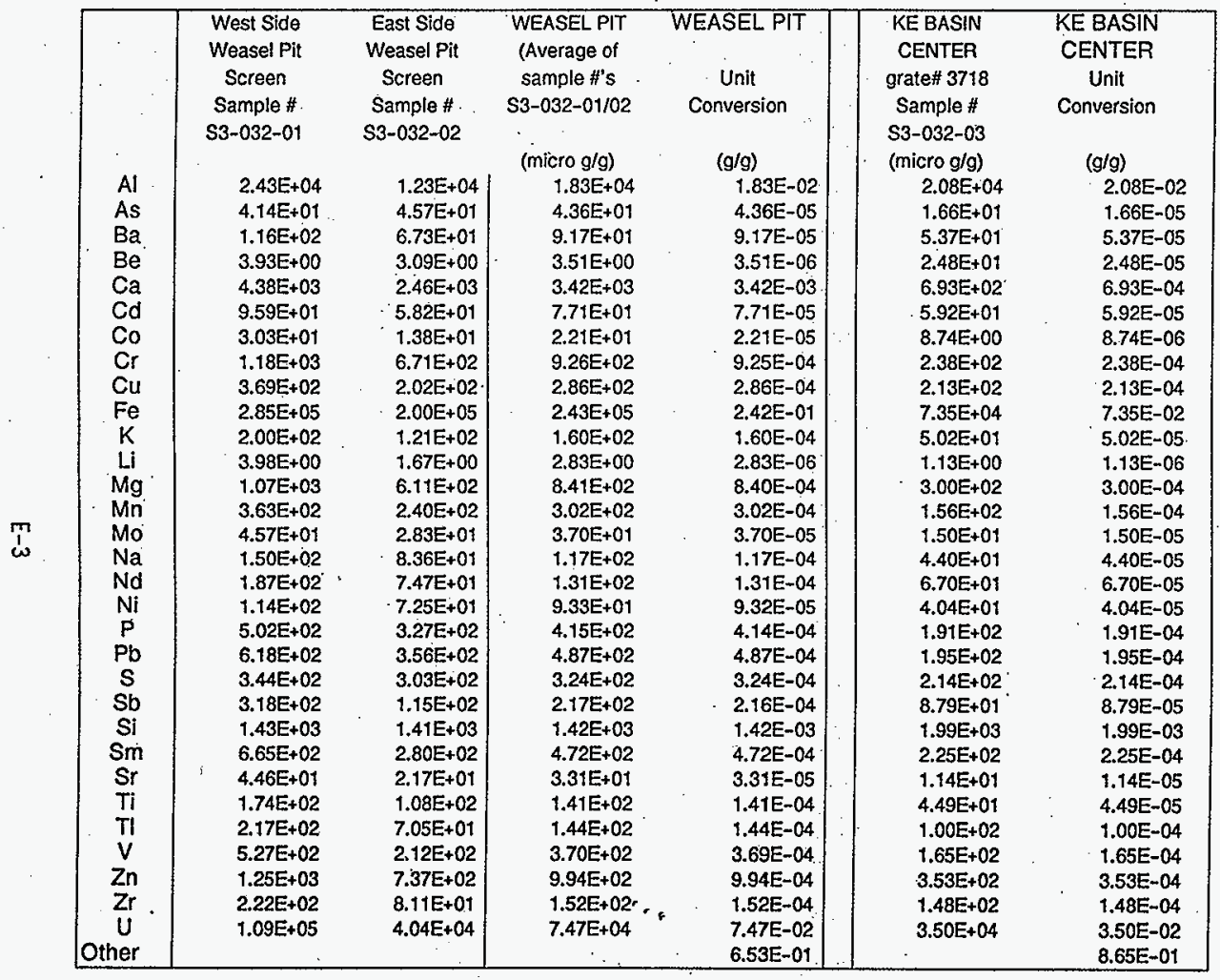




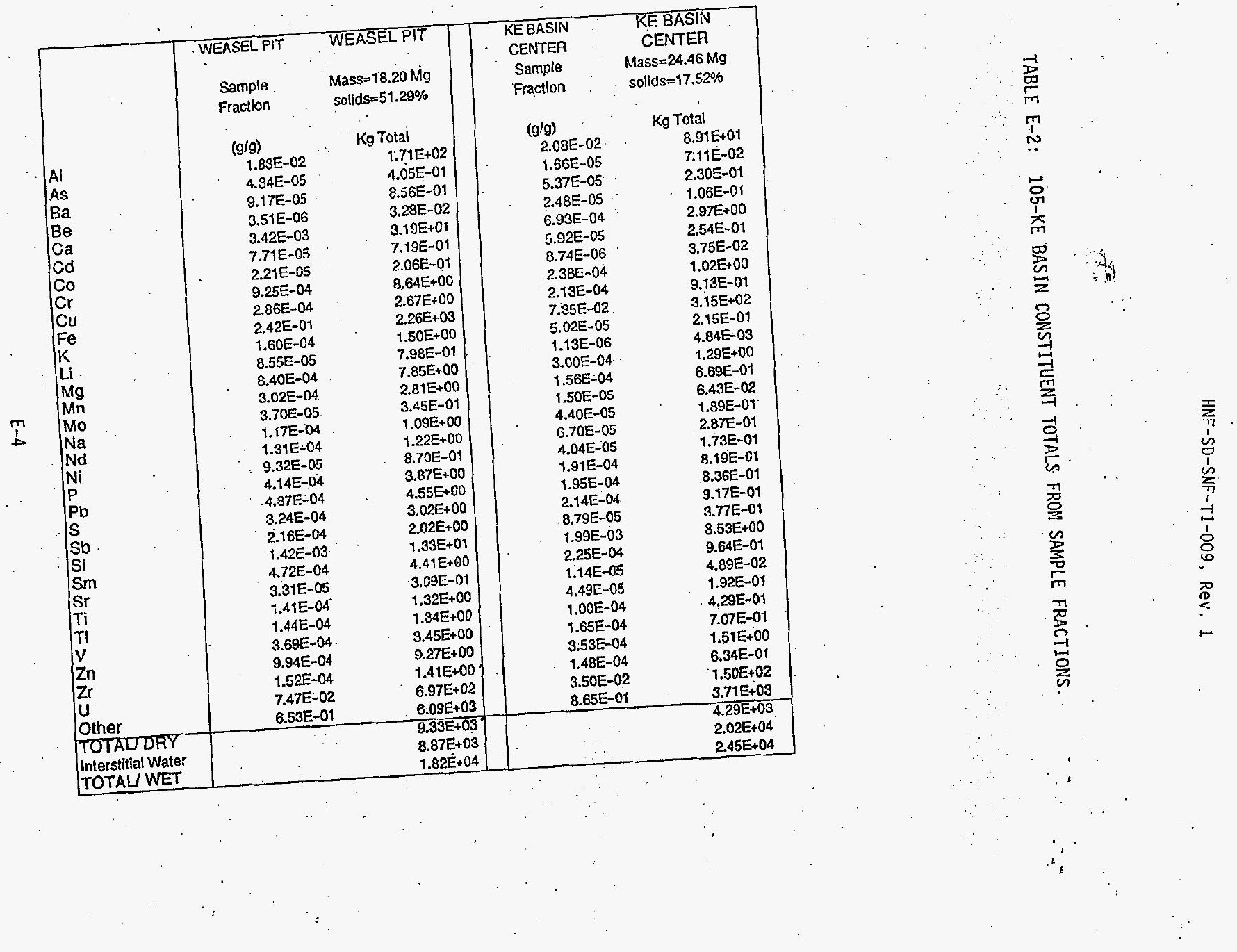




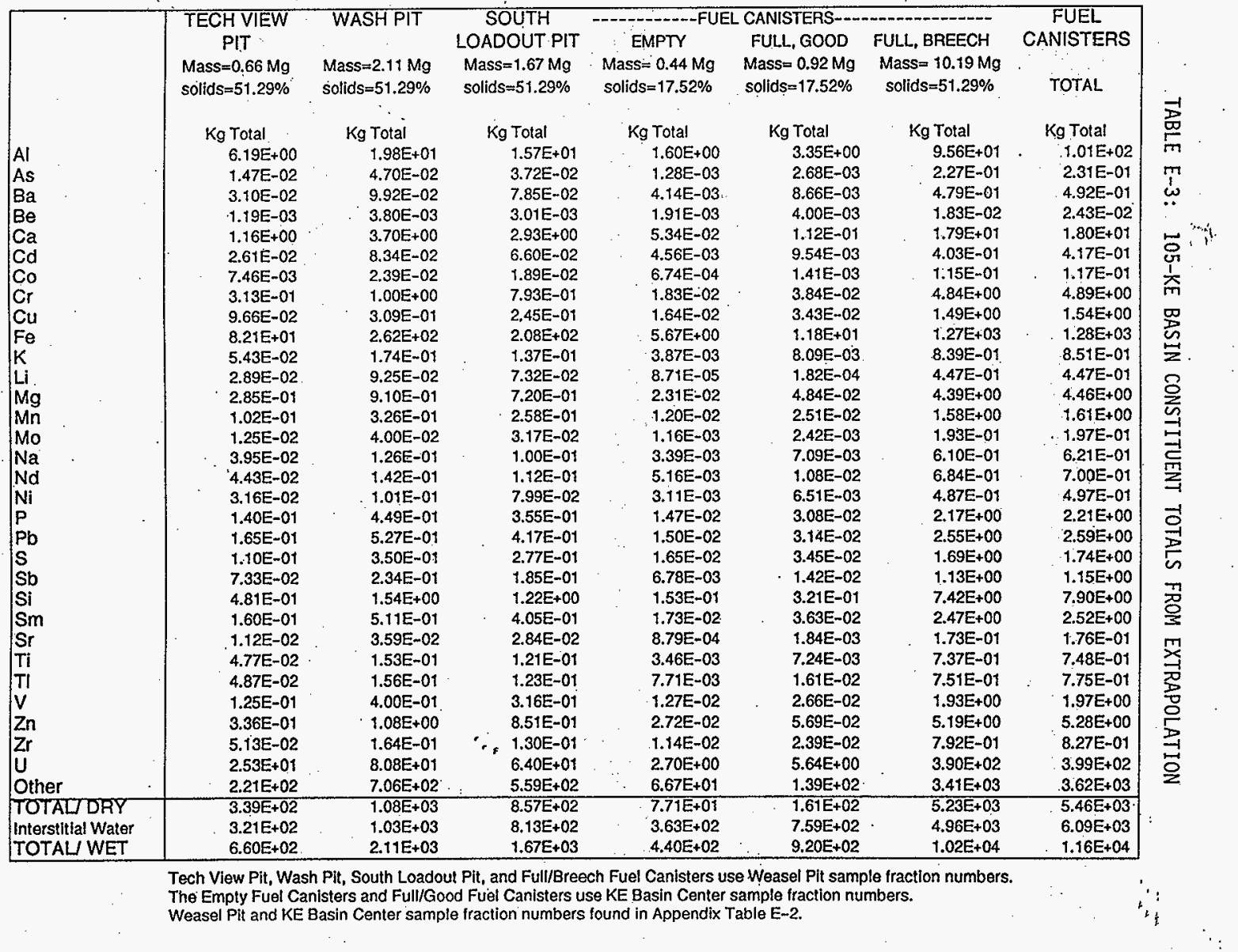




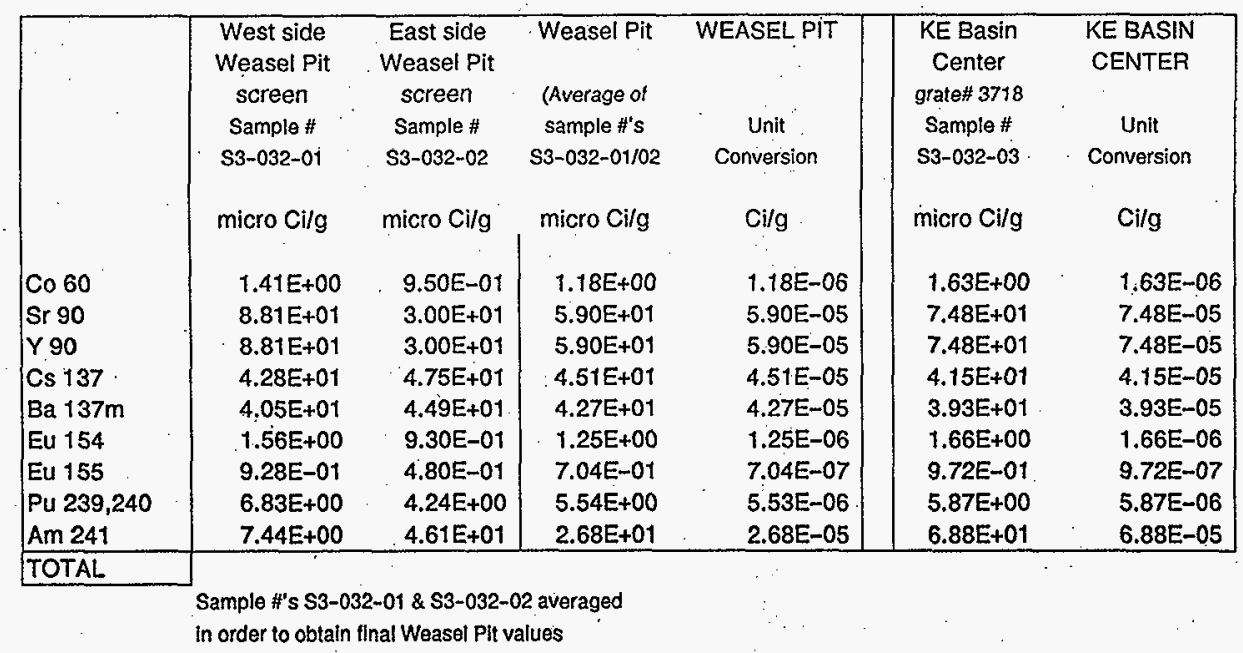




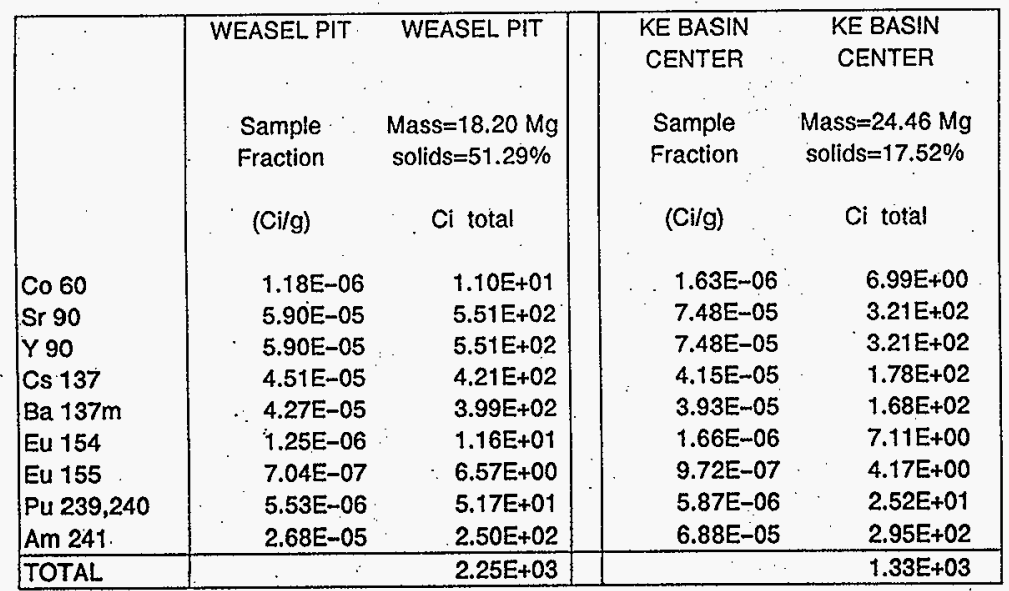

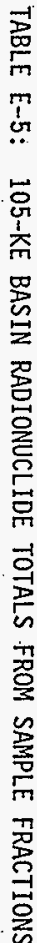




\begin{tabular}{|c|c|c|c|c|c|c|c|}
\hline \multirow{2}{*}{. } & \multirow{3}{*}{$\begin{array}{c}\text { TECH VIEW } \\
\text { PIT } \\
\text { Mass }=0.66 \mathrm{Mg} \\
\text { solids }=51.29 \%\end{array}$} & \multirow[t]{2}{*}{ WASH PIT } & \multirow{2}{*}{$\begin{array}{c}\text { SOUTH } \\
\text { LOADOUT PIT }\end{array}$} & \multicolumn{3}{|c|}{--- FUEL CANISTERS $-\cdots$} & \multirow{2}{*}{$\begin{array}{c}\text { FUEL } \\
\text { CANISTERS }\end{array}$} \\
\hline & & & & EMPTY & FULL, GOOD & FULL, BREECH & \\
\hline & & $\begin{array}{l}\text { Mass }=2.11 \mathrm{Mg} \\
\text { solids }=51.29 \%\end{array}$ & $\begin{array}{l}\text { Mass }=1.67 \mathrm{Mg} \\
\text { solids }=51.29 \%\end{array}$ & $\begin{array}{l}\text { Mass }=0.44 \mathrm{Mg} \\
\text { sollds }=17.52 \%\end{array}$ & $\begin{array}{l}\text { Mass }=0.92 \mathrm{Mg} \\
\text { solids }=17.52 \%\end{array}$ & $\begin{array}{c}\text { Mass }=10.19 \mathrm{Mg} \\
\text { solids }=51.29 \%\end{array}$ & TOTAL. \\
\hline & Ci total & Ci total & Ci total & Ci total & Ci total & Ci total & Ci total \\
\hline $\begin{array}{l}\text { H } 3 \\
\text { Co } 60\end{array}$ & $3.99 E-01$ & $1.28 E+00$ & $1.01 E+00$ & $1,26 \mathrm{E}-01$ & $2.63 \mathrm{E}-01$ & $6.17 E+00$ & $6.56 \mathrm{E}+00$ \\
\hline Sr 90 & $2.00 E+01$ & $6.39 E+01$ & $5.06 E+01$ & $5.77 E+00$ & $1.21 E+01$ & $3.09 E+02$ & $3.26 E+02$ \\
\hline Y 90 & $2.00 E+01$ & $6.39 E+01$ & $5.06 \mathrm{E}+01$ & $5.77 E+00$ & $1.21 E+01$ & $3.09 E+02$ & $3.26 \mathrm{E}+02$ \\
\hline Cs 137 . & $1.53 E+01$ & $4.89 E+01$ & 3.87E+01 & $3.20 E+00$ & $6.69 E+00$ & $2.36 E+02$ & $2.46 \mathrm{E}+02$ \\
\hline $\mathrm{Ba} 137 \mathrm{~m}$ & $1.45 E+01$ & $4.62 E+01$ & $3.66 \mathrm{E}+01$ & $3.03 E+00$ & $6.33 E+00$ & $2.23 E+02$ & $2.33 E+02$ \\
\hline Eu 154 & $4.21 E-01$ & $1.35 E+\infty 0$ & $1.07 E+00$ & $1.28 \mathrm{E}-01$ & $2.68 \mathrm{E}-01$ & $6.51 E+00$ & $6.90 E+00$ \\
\hline Eu 155 & 2.38E-01 & 7.62E-01 & $6.03 E-01$ & $7.49 \mathrm{E}-02$ & 1.57E-01 & $3.68 E+00$ & $3.91 E+00$ \\
\hline Pu 239,240 & $1.87 E+00$ & $5.99 E+00$ & $4.74 E+00$ & 4.53E-01 & $9.46 E-01$ & $2.89 E+01$ & $3.03 E+01$ \\
\hline Am 241 & $9.06 E+00$ & $2.90 \mathrm{E}+01$ & $2.29 E+01$ & $5.30 E+00$ & $1.11 E+01$ & $1.40 \mathrm{E}+02$ & $1.56 E+02$ \\
\hline TOTAL & $8.17 E+01$ & $2.61 E+02$ & $2.07 E+02$ & & & & $1.34 E+03$ \\
\hline
\end{tabular}

Tech View Pit, Wash Pit, South Loadout Pit, and Full/Breech Fuel Canisters use Weasel Pit sample fraction numbers. The Empty Fuel Canisters and Full/Good Fuel Canisters use KE Basin Center sample fraction numbers. Weasel PIt and KE Basin Center sample fraction numbers found in Appendlx Table E-5. 
HNF-SD-SNF-TI-009, Rev . 1

APPENDIX F

SAFETY/REGULATORY ASSESSMENT BASIS METHODOLOGY 
The Safety/Regulatory assessment basis was selected by estimating a relative dose commitment to people resulting from an accidental release. The dose rates were estimated using "Internal Dose Conversion Factors for Calculation of Dose to the Public" (DOE 1988), which includes tables for radionuclides. The tables give the dose rate per unit. intake of the radionuclide for ingestion and inhalation pathways to various organs and a total dose known as a cumulative effective dose equivalent or CEDE.

For a release of irradiated fuel, the total dose to people per unit mass released, is dominated by only a few nuclides. The dose results from a product of the activity/unit mass of fuel, and the CEDE (REM/unit activity). ${ }^{241} \mathrm{Am}$, with a CEDE of $520 \mathrm{rem} / \mu \mathrm{C} i$ for the inhalation pathway and a total of $315,000 \mathrm{Ci}$ in the $\mathrm{K}$ Basins, results in the largest potential dose from a single nuclide in a release. Plutonium isotopes, with CEDE's of $330 \mathrm{rem} / \mu \mathrm{Cj}$

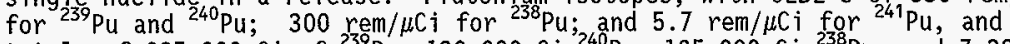
totals of $225,000 \mathrm{Ci}$ of ${ }^{239} \mathrm{Pu}, 130,000 \mathrm{Ci}{ }^{240} \mathrm{Pu}, 125,000 \mathrm{Ci}{ }^{238} \mathrm{Pu}$, and $7,380,000$ $\mathrm{Ci}{ }^{241} \mathrm{Pu}$ in the $\mathrm{K}$ Basins, also result in significant potential dose in comparison to ${ }^{241} \mathrm{Am}$. ${ }^{90} \mathrm{Sr}$, with a CEDE of $1.3 \mathrm{rem} / \mu \mathrm{Ci}$, and a total of $10,500,000 \mathrm{Ci}$ in the $\mathrm{K}$ Basins, al so results in a significant potential dose in comparison with ${ }^{241} \mathrm{Am}$. ${ }^{137} \mathrm{Cs}$, the isotope with the largest activity $(13,500,000 \mathrm{Ci}$ in the $\mathrm{K}$ Basins), and with a CEDE of $0.032 \mathrm{rem} / \mu \mathrm{C} j$ results in a dose about 2.5 orders of magnitude less than the ${ }^{241} \mathrm{Am}$. The dose resulting from other nuclides in the fuel is negligible in comparison to those above because of their lower abundance and smalier CEDE.

The fuel in the $K$ basins containing the mix of these isotopes per unit mass of fuel with the 1argest potential dose consequence is used to establish a safety envelope. ${ }^{241} \mathrm{Am}$ with a half 1 ife of approximately 433 years results in the fuel primarily from the decay of ${ }^{241} \mathrm{Pu}$. Because of the difference in half 1 ives, ${ }^{241} \mathrm{Pu}$ has a half $1 \mathrm{ife}$ of approximately 14 years, the concentration of ${ }^{241} \mathrm{Am}$ in the fuel increases for approximately 60 years following discharge from the reactor. ${ }^{241} \mathrm{Am}$ concentrations are increasing in both singie pass and $\mathrm{N}$ Reactor fuels. The most important plutonium isotopes from a safety/regulatory assessment standpoint are ${ }^{239} \mathrm{Pu}$ and ${ }^{240} \mathrm{Pu}$ with half 7 ives of 24,100 and 6,560 years respectively. Over a fifty year 7 ife, the concentrations of ${ }^{239} \mathrm{Pu}$ and ${ }^{240} \mathrm{Pu}$ will not change appreciably in the fuel. The concentrations of ${ }^{90} \mathrm{Sr},{ }^{137} \mathrm{Cs},{ }^{238} \mathrm{Pu}$, and ${ }^{241} \mathrm{Pu}$ a 71 change significantly over a fifty year facility life.

Two factors are important in determining which fuel to use in determining the safety/regulatory assessment design basis: burn-up, and time since discharge from the reactor. The safety/regulatory assessment basis should be the highest burn-up fuel in the basins. Time since discharge is also an important factor. As a first guess, the highest burn-up fuel $N$ Reactor fuel (16.72\% ${ }^{240} \mathrm{Pu}$ MK IV fuel discharged from $\mathrm{N}$ Reactor $\left.2 / 20 / 1995\right)$ is used as a starting point in the determination. Tables F.1 and F.2 show the concentrations of the safety basis nuclides in this fuel on $1 / 1 / 1995$, and $1 / 1 / 2015$ respective1y.

Figures F.3 and F.4 are $16.49 \%{ }^{240} \mathrm{Pu}$ fuel discharged from $\mathrm{N}$ Reactor on May 1 , 1976. Figure F.5 is single Pass reactor fuel with $26 \%{ }^{240} \mathrm{Pu}$ content. Note that the dose equivalent for the lower burn-up $N$ reactor fuel and for SPR fuel is lower than for the $16.72 \%{ }^{240} \mathrm{Pu}$ fuel in all cases. 
HNF-SD-SNF-TI-009, Rev. 1

Table F.1: Maximum ${ }^{240} \mathrm{Pu}$ Content $\mathrm{N}$ Reactor Fuel in the $\mathrm{K}$ Basins As of $1 / 1 / 1995$

\begin{tabular}{|c|c|c|c|}
\hline Isotope & $\begin{array}{l}\text { Activity } \\
\text { (Ci/MTU) }\end{array}$ & $\begin{array}{c}\text { CEDE } \\
(r e m / u C i)\end{array}$ & $\begin{array}{c}\text { Dose Equivalent } \\
\text { (rem/MTU) }\end{array}$ \\
\hline Sr-90 & $7.84 \mathrm{e}+03$ & $1.30 \mathrm{e}+00$ & $1.02 \mathrm{e}+10$ \\
\hline Cs-137 & $1.08 e+04$ & $3.20 \mathrm{e}-02$ & $3.46 \mathrm{e}+08$ \\
\hline $\mathrm{Pu}-238$ & $1.71 \mathrm{e}+02$ & $3.00 \mathrm{e}+02$ & $5.13 e+10$ \\
\hline $\mathrm{Pu}-239$ & $1.58 \mathrm{e}+02$ & $3.30 \mathrm{e}+02$ & $5.21 e+10$ \\
\hline Pu-240 & $1.28 \mathrm{e}+02$ & $3.30 \mathrm{e}+02$ & $4.22 e+10$ \\
\hline $\mathrm{Pu}-241$ & $9.25 \mathrm{e}+03$ & $5.70 \mathrm{e}+00$ & $5.27 \mathrm{e}+10$ \\
\hline $\mathrm{Pu}-242$ & $1.05 \mathrm{e}-01$ & $3.10 \mathrm{e}+02$ & $3.25 \mathrm{e}+07$ \\
\hline Am-241 & $3.58 \mathrm{e}+02$ & $5.20 \mathrm{e}+02$ & $1.86 \mathrm{e}+11$ \\
\hline \multicolumn{4}{|c|}{ Total Dose Equivalent (rem/MTU) $3.95 \mathrm{e}+11$} \\
\hline \multicolumn{4}{|c|}{$\begin{array}{c}\text { RADNUC } 2.0 \text { run } 3 / 7 / 1995 \text { for Maximum Pu-240 content } K \text { Basin fuel } \\
\text { Results decayed to 01/01/1995. Total mass in run } 6.90 \mathrm{e}+00 \mathrm{MTU} \text {. Total } \\
\text { Activity in run } 3.35 \mathrm{e}+05 \mathrm{Ci} .\end{array}$} \\
\hline
\end{tabular}

Table F.2: Maximum ${ }^{240} \mathrm{Pu}$ Content $\mathrm{N}$. Reactor Fue 7 in the $\mathrm{K}$ Basins As of $1 / 1 / 2015$

\begin{tabular}{|c|c|c|c|}
\hline Isotope & $\begin{array}{l}\text { Activity } \\
\text { (Ci/MTU) }\end{array}$ & $\begin{array}{l}\text { C.E.D.E. } \\
\text { (rem/uCi) }\end{array}$ & $\begin{array}{c}\text { Dose Equivalent } \\
\text { (rem/MTU) }\end{array}$ \\
\hline Sr-90 & $4.87 e+03$ & $1.30 \mathrm{e}+00$ & $6.33 e+09$ \\
\hline Cs-137 & $6.81 e+03$ & $3.20 \mathrm{e}-02$ & $2.18 \mathrm{e}+08$ \\
\hline $\mathrm{Pu}-238$ & $1.46 \mathrm{e}+02$ & $3.00 \mathrm{e}+02$ & $4.39 \mathrm{e}+10$ \\
\hline Pu-239 & $1.58 \mathrm{e}+02$ & $3.30 \mathrm{e}+02$ & $5.21 \mathrm{e}+10$ \\
\hline $\mathrm{Pu}-240$ & $1.28 \mathrm{e}+02$ & $3.30 \mathrm{e}+02$ & $4.21 \mathrm{e}+10$ \\
\hline $\mathrm{Pu}-241$ & $3.54 \mathrm{e}+03$ & $5.70 \mathrm{e}+00$ & $2.02 e+10$ \\
\hline $\mathrm{Pu}-242$ & $1.05 \mathrm{e}-01$ & $3.10 \mathrm{e}+02$ & $3.25 \mathrm{e}+07$ \\
\hline Am-241 & $5.33 \mathrm{e}+02$ & $5.20 \mathrm{e}+02$ & $2.77 \mathrm{e}+11$ \\
\hline \multicolumn{4}{|c|}{ Total Dose Equivalent (rem/MTU) $4.42 \mathrm{e}+1 \mathrm{l}$} \\
\hline
\end{tabular}


HNF-SD-SNF-TI-009, Rev. 1

Table F.3: $\quad 16.49 \%{ }^{240} \mathrm{Pu}$ Fuel Discharged from N Reactor 5/1/1976 as of $1 / 1 / 1995$

\begin{tabular}{||c|c|c|c||}
\hline Isotope & $\begin{array}{c}\text { Activity } \\
\text { (Ci/MTU) }\end{array}$ & $\begin{array}{c}\text { CEDE } \\
\text { (rem/uCi) }\end{array}$ & $\begin{array}{c}\text { Dose Equivalent } \\
\text { (rem/MTU) }\end{array}$ \\
\hline $\mathrm{Sr}-90$ & $7.20 \mathrm{e}+03$ & $1.30 \mathrm{e}+00$ & $9.36 \mathrm{e}+09$ \\
\hline $\mathrm{Cs}-137$ & $9.91 \mathrm{e}+03$ & $3.20 \mathrm{e}-02$ & $3.17 \mathrm{e}+08$ \\
\hline $\mathrm{Pu}-238$ & $1.59 \mathrm{e}+02$ & $3.00 \mathrm{e}+02$ & $4.76 \mathrm{e}+10$ \\
\hline $\mathrm{Pu}-239$ & $1.56 \mathrm{e}+02$ & $3.30 \mathrm{e}+02$ & $5.15 \mathrm{e}+10$ \\
\hline $\mathrm{Pu}-240$ & $1.24 \mathrm{e}+02$ & $3.30 \mathrm{e}+02$ & $4.10 \mathrm{e}+10$ \\
\hline $\mathrm{Pu}-241$ & $7.72 \mathrm{e}+03$ & $5.70 \mathrm{e}+00$ & $4.40 \mathrm{e}+10$ \\
\hline $\mathrm{Pu}-242$ & $9.74 \mathrm{e}-02$ & $3.10 \mathrm{e}+02$ & $3.02 \mathrm{e}+07$ \\
\hline $\mathrm{Am}-241$ & $3.78 \mathrm{e}+02$ & $5.20 \mathrm{e}+02$ & $1.96 \mathrm{e}+11$ \\
\hline \hline \multicolumn{4}{|c|}{ Total Equivalent Dose (rem/MTU) 3.90e+11 } \\
\hline \hline \multicolumn{2}{|c|}{$\begin{array}{c}\text { RADNUC 2.0 run } 1 / 26 / 1995 \text { for Safety Basis Fue1 Results decayed to } \\
\text { 01/01/1995. Total Mass 1.16e+01 MTU. Total Activity 5.04e+05 Ci. }\end{array}$} \\
\hline
\end{tabular}

Table F.4: $\quad 16.49 \%{ }^{240} \mathrm{Pu}$ Fuel Discharged from N Reactor 5/1/1976 as of $1 / 1 / 2015$

\begin{tabular}{|c|c|c|c|}
\hline Isotope & $\begin{array}{l}\text { Activity } \\
\text { (Ci/MTU) }\end{array}$ & $\begin{array}{c}\text { CEDE } \\
\text { (rem/MTU) }\end{array}$ & $\begin{array}{c}\text { Dose Equivalent } \\
\text { (rem/MTU) }\end{array}$ \\
\hline $5 r-90$ & $4.47 e+03$ & $1.30 \mathrm{e}+00$ & $5.82 e+09$ \\
\hline $\mathrm{Cs}-137$ & $6.25 e+03$ & $3.20 \mathrm{e}-02$ & $2.00 \mathrm{e}+08$ \\
\hline $\mathrm{Pu}-238$ & $1.35 \mathrm{e}+02$ & $3.00 \mathrm{e}+02$ & $4.06 \mathrm{e}+10$ \\
\hline $\mathrm{Pu}-239$ & $1.56 \mathrm{e}+02$ & $3.30 \mathrm{e}+02$ & $5.15 \mathrm{e}+10$ \\
\hline $\mathrm{Pu}-240^{\circ}$ & $1.23 \mathrm{e}+02$ & $3.30 \mathrm{e}+02$ & $4.07 e+10$ \\
\hline $\mathrm{Pu}-241$ & $2.95 e+03$ & $5.70 \mathrm{e}+00$ & $1.68 \mathrm{e}+10$ \\
\hline $\mathrm{Pu}-242$ & $9.74 \mathrm{e}-02$ & $3.10 \mathrm{e}+02$ & $3.02 \mathrm{e}+07$ \\
\hline Am-241 & $5.22 e+02$ & $5.20 \mathrm{e}+02$ & $2.72 \mathrm{e}+11$ \\
\hline \multicolumn{4}{|c|}{ Total Dose Equivalent (rem/MTU) $4.27 \mathrm{e}+11$} \\
\hline \multicolumn{4}{|c|}{$\begin{array}{l}\text { RADNUC } 2.0 \text { run } 3 / 7 / 1995 \text { for } 1 / 1 / 1995 \text { Safety Basis. Results decayed to } \\
01 / 01 / 2015 \text {. Total Mass this run } 1.16 \mathrm{e}+01 \mathrm{MTU} \text {. Total Activity this run } \\
2.93 \mathrm{e}+05 \mathrm{Ci} .\end{array}$} \\
\hline
\end{tabular}


HNF-SD-SNF-TI-009, Rev. 1

Table F.5: $26 . \%{ }^{240} \mathrm{Pu}$ SPR Fuel Currently in storage at PUREX

\begin{tabular}{||c|c|c|c||}
\hline Isotope & $\begin{array}{c}\text { Activity } \\
(\mathrm{Ci} / \mathrm{MTU})\end{array}$ & $\begin{array}{c}\text { CEDE } \\
\text { (rem/uCi) }\end{array}$ & $\begin{array}{c}\text { Dose Equivalent } \\
\text { (rem/MTU) }\end{array}$ \\
\hline $\mathrm{Sr}-90$ & $4.03 \mathrm{e}+03$ & $1.30 \mathrm{e}+00$ & $5.24 \mathrm{e}+09$ \\
\hline $\mathrm{Cs}-137$ & $1.03 \mathrm{e}+04$ & $3.20 \mathrm{e}-02$ & $3.30 \mathrm{e}+08$ \\
\hline $\mathrm{Pu}-238$ & $4.30 \mathrm{e}+01$ & $3.00 \mathrm{e}+02$ & $1.29 \mathrm{e}+10$ \\
\hline $\mathrm{Pu}-239$ & $1.20 \mathrm{e}+02$ & $3.30 \mathrm{e}+02$ & $3.96 \mathrm{e}+10$ \\
\hline $\mathrm{Pu}-240$ & $1.90 \mathrm{e}+02$ & $3.30 \mathrm{e}+02$ & $6.27 \mathrm{e}+10$ \\
\hline $\mathrm{Pu}-241$ & $5.00 \mathrm{e}+03$ & $5.70 \mathrm{e}+00$ & $2.85 \mathrm{e}+10$ \\
\hline $\mathrm{Pu}-242$ & not available & $3.10 \mathrm{e}+02$ & $\mathrm{~N} / \mathrm{A}$ \\
\hline $\mathrm{Am}-241$ & $4.30 \mathrm{e}+02$ & $5.20 \mathrm{e}+02$ & $2.24 \mathrm{e}+11$ \\
\hline \hline \multicolumn{4}{|c|}{ Total Dose Equivalent (rem/MTU) $3.73 \mathrm{e}+11$} \\
\hline \hline
\end{tabular}

The $16.72 \%{ }^{240} \mathrm{Pu}$ fuel is the safety/regulatory assessment basis fuel. 
HNF-SD-SNF-TI-009, Rev . I

APPENDIX G

INDEPENDENT REVIEW 
Appendix G

\section{INDEPENDENT REVIEW}

\section{PURPOSE}

The purpose of this appendix is to assess whether the design basis feed types defined in this document are appropriate for developing path forward processes and facilities development and whether the design basis feeds are sufficiently accurate.

\section{SCOPE}

This appendix uses the main body of this report and its other appendices to assess whether:

1. The design basis feeds encompass the needs of process and facilities development.

2. The design basis feeds are sufficiently and conservatively described.

This report relies on the Accountability Data Base and the Origen 2 computer program to determine the inventories and their isotopic contents that will be included in the path forward. This data base and this computer program have been validated prior to preparation of this report; their assessment is outside the scope of this appendix. 


\section{SUMMARY}

This appendix teviews three design basis feeds described in the main part of this report:

- Shielding Design Basis

- Safety/Regulatory Design Basis

- Heat Generation Design Basis

The reviews conclude that these design bases are appropriate and conservative.

This appendix also reviews Section 5 , Sludge Sources. The review concludes that the data in Section 5 is appropriate and conservative except that Section 5 is based on nominal sludge volumes reported in Table 4, Baker 1995. However, Table 6, Baker 1995 , observes that the sludge volumes could be approximately $50 \%$ higher if uncertainty is considered. A caveat has been added to Section 5 to note this difference between Tables 4 and 6 in Baker 1995.

The next revision of this document should address this issue.

Review of the remaining design bases, Criticality and Operational Variability, will be completed later when the sections of this report addressing these design bases are completed. 


\section{DISCUSSION}

\section{Review of Design Basis Feeds}

Table 1.1 defines five design feeds and their basis. The purpose of the five feeds is to provide material quantities and isotopic content need to support the activities . required for development of processes and facilities needed for the Spent Nuclear Fuel Project recommended path forward. Although details of the path forward process and facilities are not finalized, information is available in the body of this report and the Independent Technical Assessment (ITA) team report (WHC 1994a) to determine the major activities required to develop processes and facilities. These are summarized below:

1. Facility Development: These activities include design, evaluations and construction of the facilities required for the path forward. Major facilities to be developed include:

- Multiple canister overpacks (MCOs) used during SNF transportation, conditioning and interim storage.

- Modifications in the K Basin to prepare SNF, load it into MCOs and load MCOs into transfer casks.

- A conditioning station where the MCOs will be dewatered, the fuel dehydrided and passivated, and the MCO will be inerted and sealed for interim storage:

- An interim storage facility where the MCO containing dry and inerted SNF will be stored for an extended period of time.

\section{Process Development}

- Processes to dewater the MCOS

- Processes to dry, dehydride and passivate the SNF

- Processes to inert and seal the MCOS

The above facility and process development and operation tasks will require several types of activities: 
1. Design of facilities and process equipment including construction drawings and specifications.

2. Design analysis including shielding, criticality, stress and thermal effects.

3. Safety evaluations including SARs, SERs and EISs.

The five design basis feeds described in Table 1.1. address the activities listed above. These design basis feeds are sufficient for the scope of design, analysis and safety evaluation described above provided that conditions described in Table 1.1 and the following are met:

1. Using the definitions in Table 1.1, the shielding design basis should include the significant $\gamma$ emitting isotopes. On the other hand, isotopes that emit only $\alpha$ and $\beta$ need not be part of this design basis since they have no penetrating power and do not control shielding thickness.

2. The thermal design basis should include all significant radioactive isotopes including $\gamma$ as well as $\alpha$ and $\beta$ emitters, on the basis that the latter particles will be stopped and release their energy within the source and the conservative assumption that the $\gamma^{2} s$ will also be stopped and release their energy within the source.

3. The dose to personnel assessment used to develop the Safety/Regulatory design basis is based on DOE methodology. The dose methodology is contained in the reference (DOE, 1988). This document assigns values of committed effective dose equivalents (CEDEs) to radioactive isotopes. CEDEs are in units of rem/curie and, when multiplied by the curie level of an isotope, result in the radioactive intensity of the isotope in rem. 


\section{Assessment Spreadsheets}

The main part of this report uses the program Origen 2 to calculate $N$ Reactor spent fuel isotopes for various amounts of fuel burnup in megawatt-days/ton (MWD/T) for both MKIV and MKIA fuel elements. The amount of burnup used in Origen 2 was that estimated to produce Pu240 contents of 6, 9,12 and 16 percent of total Pu. The output of Origen 2 is a complete lists of weights (grams/MTU), radioactivity (curies/MTU), and heat generation (watts/MTU) for both radioactive isotopes and elements. Only data for the significant isotopes were used for this report. Origen 2. output in the form of electronic media was made available to Mollerus Engineering Corporation (MEC) for this independent review. The Origen 2 output was for the following conditions:

For MKIV Fuel

\begin{tabular}{|c|r|r|r|r|}
\hline $\begin{array}{c}\text { Nominal Pu240, } \\
\%\end{array}$ & $\begin{array}{l}\text { Burnup, } \\
\text { MDW/T }\end{array}$ & $\begin{array}{c}\text { Total Pu, } \\
\text { grams/MTU }\end{array}$ & $\begin{array}{c}\text { Pu240, } \\
\text { grams/MTU }\end{array}$ & \multicolumn{1}{c|}{ Pu240 } \\
\hline 6 & 1188 & 965.7 & 62.5 & 6.469 \\
\hline 9 & 1979 & 1503 & 139.8 & 9.301 \\
\hline 12 & 2970 & 2079 & 253.9 & 12.184 \\
\hline 16 & later & 2758 & $: 417.8$ & 15.159 \\
\hline
\end{tabular}

For MKIA Fuel

\begin{tabular}{|c|r|r|r|r|}
\hline $\begin{array}{c}\text { Nominal Pu240, } \\
\%\end{array}$ & $\begin{array}{c}\text { Burnup, } \\
\text { MDW/t }\end{array}$ & $\begin{array}{c}\text { Total Pu, } \\
\text { grams/MTU }\end{array}$ & $\begin{array}{c}\text { Pu240, } \\
\text { grams/MTU }\end{array}$ & Pu240 \\
\hline 6 & 1010 & 970 & 62.3 & 6.42 \\
\hline 9 & 1670 & 1510 & 143.0 & 9.48 \\
\hline 12 & 2510 & 2090 & 262.0 & 12.58 \\
\hline 16 & 3620 & 2760 & 439.0 & 15.88 \\
\hline
\end{tabular}

The above data indicates that, for the same burnup, there is little difference in Pu240 and total Pu produced in the two fuel designs stored in the $\mathrm{K}$ Basins. However, the $\mathrm{Pu}$ content (and other isotopes) is very much a linear function of burnup.

Origen 2 is a well documented and validated national laboratory computer program for calculating isotopic content of irradiated nuclear fuel. Independent review of Origen 2 and it's application to Hanford's spent fuel inventory is not part of the scope of the independent review described in this appendix. Rather, the scope of this 
review is the application of the output of Origen 2 as described below.

As noted above, the output of Origen 2 is based on a pre-selected MWD/T burnup with an estimate of Pu240 content and pre-programmed decay periods since fuel discharge. However, the spent fuel stored at Hanford has a wide variety of Pu240 content and decay times since discharge from $N$ Reactor. The approach used in other parts of this report is to use the program RADNUC to derive data for conditions different than those developed using Origen 2. The independent review described in this appendix does not use RADNUC. Instead, the Origen 2 output showing significant isotopic content after $71 / 2$ years of radioactive decay has taken place has been placed into the following EXCEL based spreadsheets.

IVFUELWA.xIs
Spreadsheet for MKIV fuel heat generation
IAFUELU.xls Spreadsheet for MKIV fuel radioactivity
IAFUELCU.xls

Tables G-1 and G-2 show the significant isotopic weights, radioactivity and heat sources calculated to exist in the MKIV and MKIA fuel after $71 / 2$ years of radioactive decay following discharge from $N$ Reactor (a period of time slightly less than the decay time associated with the last fuel to be discharged from $N$ Reactor ). Typically, the isotopic content is a nonlinear function of Pu240. The nonlinear data has been curve fitted using the equation form:

$$
Y=\frac{C \cdot 1+C ; 5 * X}{1+C 2 * X+C 4 * X^{2}}
$$

where $\mathrm{X}$ is the Pu240 content in fraction of total Pu. Coefficients for both radioactivity (curies/MTU) and heat generation (watts/MTU) have been calculated and added to the spreadsheets. Equations were then added to the spreadsheets to calculate radioactivity and heat generation as a function of Pu240 fraction.

Next, the spreadsheets were modified to include table of half lives, CEDE's and gamma energy data for each of the isotopes. Table G-3 shows this data. Equations were then added to the spreadsheets to calculate radioactivity and heat generation as a function of time using 


0
0
$\therefore$

where

$$
\begin{aligned}
& X_{0}=\text { the } 71 / 2 \text { year radioactivity or heat generation value } \\
& \lambda=\underline{0.693} \\
& t=\text { time after } 71 / 2 \text { years in seconds }
\end{aligned}
$$

This feature gives the spreadsheet the capability to calculate radioactivity and heat generation values for decay periods greater than $71 / 2$ years.

Next, the IVFUELCU.xls and IAFUELCU.xls spreadsheets were modified to multiply the radioactivity (curies/MTU) by both gamma energy and the CEDE for each significant isotope. This is used later to evaluate each isotope in terms of safety and shielding impact.

Finally, regions of the spreadsheets were set up to allow transfer of data using the COPY/SPECIAL PASTE/DATA feature of EXCEL. Data can be sorted in descending order to evaluate the impact of each of the isotopes. Areas of the spreadsheet have been set up to print portions of the sorted data that are considered to be significant.

In summary, the spreadsheets provide the capability to evaluate MKIV and MKIA fuels in terms of:

Pu2 240 content

Radioactive decay period

Heat generation

CEDE and shielding impacts

Table G-4 provides a roadmap of spreadsheet tables, calculation and sorting regions. 


\section{Analysis of Design Basis Feeds}

\section{Shielding Design Basis}

Heavy shielding is needed to reduce gamma radiation. Alpha and Beta tadiation can be stopped by protective clothing and relatively thin-walled structures and enclosures. A measure of the shielding load of spent fuel is it's curies content and the energy in the gamma radiation. Therefore, the shielding design basis feed should include those isotopes with the combination of highest activity and highest gamma energy, i.e. (curies $\times \mathrm{Kev}$ ). According to the Accountability Data Base contained in Appendix B the following appear to be key numbers with the highest Pu240 and shortest decay periods:

\begin{tabular}{|c|c|c|r|r|}
\hline Key Number & Discharge Date & $\begin{array}{c}\text { Decay period, } \\
\text { years }\end{array}$ & $\begin{array}{c}\text { Pu240, } \\
\%\end{array}$ & (Curies*Kev) \\
\hline 14355 & $\operatorname{Jan} 1984$ & 11 & 15.74 & $3.16 \mathrm{E}+07$ \\
\hline 15244 & $\operatorname{Jun} 1986$ & 8.5 & 13.58 & $2.73 \mathrm{E}+07$ \\
\hline 12565 & $\operatorname{Jan} 1979$ & 16 & 16.72 & $1.76 \mathrm{E}+07$ \\
\hline
\end{tabular}

Key number 14355 has the highest (Curie*Kev) loading. Table G-5 shows the significant heat generating isotopes for Key Number 14355 using the IVFUELCU.xls spread sheet. The values shown in Table 2.5 are higher, indicating that the basis used for Table 2.5, 16\% Pu240 and 10 year decay, is conservative.

\section{Safety/Regulatory Assessment Design Basis}

Most safety assessments deal with the impact of the release of activation products, fission products and daughter isotopes on human health. A measure of these impact is the DOE committed effective dose equivalent (CEDE) methodology where the CEDE units are rem per curie. Table G-3 lists the CEDEs used in this appendix and the spreadsheets. The total CEDE content of $N$ Reactor fuel increases in proportion to burnup and exponentially with Pu240 content while it decreases with decay time." According to the Accountability Data Base contained in Appendix B the following appear to be key numbers with the highest Pu240 and shortest decay periods: 


\begin{tabular}{|c|c|c|c|c|}
\hline Key Number & Discharge Date & $\begin{array}{c}\text { Decay period, } \\
\text { years }\end{array}$ & \multicolumn{1}{|c|}{$\begin{array}{c}\text { PU240, } \\
\%\end{array}$} & $\begin{array}{c}\text { CEDE*Curies } \\
\text { rem/MTU }\end{array}$ \\
\hline 12565 & Jun 1979 & 16 & 16.72 & $1.95 \mathrm{E}+05$ \\
\hline 14355 & Jan 1984 & 11 & 15.74 & $1.89 \mathrm{E}+05$ \\
\hline 15244 & Jun 1986 & 8.5 & 13.58 & $1.40 \mathrm{E}+05$ \\
\hline
\end{tabular}

Key number 12565 has the highest rem/MTU loading. Table G-6 shows the significant heat generating isotopes for Key Number 12565 using the IVFUELCU.xls spread sheet. The values shown in Table 2.8 are higher, indicating that the basis used for Table $2.8,16.72 \%$ Pu240 and 16 year decay, is conservative.

\section{Heat Generation Design Basis}

The heat generation rate in $N$ Reactor fuel increases in proportion to burnup and exponentially with Pu240 content while it decreases with decay time. According to the Accountability Data Base contained in Appendix B, the following appear to be key numbers with the highest Pu240 and shortest decay periods:

\begin{tabular}{|c|c|c|c|r|}
\hline Key Number & Discharge Date & $\begin{array}{c}\text { Decay period, } \\
\text { years }\end{array}$ & $\begin{array}{c}\text { PU240, } \\
\%\end{array}$ & Watts/MTU \\
\hline 14355 & Jan 1984 & 11 & 15.74 & 127.24 \\
\hline 12565 & Jun 1979 & 16 & 16.72 & 123.79 \\
\hline 15244 & Jun 1986 & 8.5 & 13.58 & 109.04 \\
\hline
\end{tabular}

Key number 14355 has the highest watts/MTU loading. Table G-7 shows the significant heat generating isotopes for Key Number 14355 using the IVFUELWA.xls spread sheet. The values shown in Table 2.10 are higher, indicating that the basis used for Table $2.10,16 \%$ Pu240 and 10 year decay, is conservative. 


\section{Criticality Design \\ Later \\ 5. Operational Variability Design Basis \\ Later}

\section{Sludge Sources}

Section 5 notes that metallic oxides, concrete grit, and other loose material has accumulated and mixed with spent fuel corrosion product to form sludge. Most of the sludge is on the basin floors; a small amount is in the open $105 \mathrm{KE}$ canisters and the closed $105 \mathrm{KW}$ canisters. Present plans call for the sludge to be dried, passivated, and loaded into MCO's using the processes and facilities provided for spent fuel. It is anticipated that, due to dilution with metallic oxides, concrete grit and other nonfuel material, the chemical and radioactive loading of sludge will be less than the spent fuel loading described in Sections 3 and 4 and reviewed above. This section of the appendix reviews the data contained in Section 5 and Appendix E.

The sludge design basis described in Section 5 relies on test data and visual observations to bracket the volumes and both chemical and isotopic content of the sludge. This methodology is appropriate since a purely analytical approach is not appropriate to a problem that is highly empirical and dependent on basin water chemistry and temperature conditions that varied widely over a long period of time. Basically, Section 5 multiplied observed sludge volumes by reported results from. chemical and isotopic analysis of sludge samples. Sludge samples are limited and do not cover all parts of the $\mathrm{K}$ East Basin. The higher measured values have been applied to the entire basin. Sources of input used to develop the data in Tables 5.1 through 5.5 are

- Sludge volumes: Baker 1995 except Warner 1994 for the Sandfilter Backwash Pit

- Chemical and radionuclide constituent data: Welsh 1994 and Baker 1995

These sources appear to be appropriate and are the most current.

This appendix is not a review of these documents, which were reviewed by other procedures prior to their publication. Rather, this appendix reviews application of the data in these references to generate the information in Section 5.

The approach taken and the data used to develop Section 5 appear to be appropriate. 
However the results may not conservatively bracket total siudge volumes, weights, and isotopic content since Section 5 is based on sludge volumes reported in Table 4, Baker 1995. However, Table 6, Baker 1995, reports maximum volumes that are approximately $50 \%$ higher. Baker repoits these to be estimated based on conservative uncertainty factors. 
HNF-SD-SNF-TI-009, Rev. 1

Appendix $\mathrm{G}$

is Engineering Corporation Independent Review

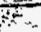

APPENDIX $G$

TABLES 
HNF-SD-SNF-TI-009, REV. 1

THIS PAGE INTENTIONALLY LEFT BLANK

G-13 


\begin{tabular}{|c|c|c|c|c|}
\hline SB126 & 0 & 01 & 0 & 0 \\
\hline SB126M & 0 & 0 & 0 & 0 \\
\hline TE123M & $5.818 \mathrm{E}-11$ & $2.607 E-10$ & $8.061 \mathrm{E}-10$ & $2.199 \mathrm{E}-09$ \\
\hline TE125M & 0.8592 & 1.414 & 2.055 & 2.876 \\
\hline TE127 & $3.753 \mathrm{E}-14$ & $2.009 E-13$ & $8.048 \mathrm{E}-13$ & $2.06 \mathrm{E}-12$ \\
\hline TE127M & $3.831 \mathrm{E}-14$ & $2.051 \mathrm{E}-13$ & $8.217 \mathrm{E}-13$ & $2.103 E-12$ \\
\hline & & & & \\
\hline TOTALS & 0.064688827 & 0.093013972 & 0.121837422 & 0.151486584 \\
\hline & 0.09561 & 0.26211 & 0.565 & 1.132 \\
\hline & & & & \\
\hline ACTIVATION PRODUCTS & & & Therm & nal power, watts \\
\hline & & & & \\
\hline Nominal Pu 240 & MKIV 6\% & MKIV 9\% & MKIV 12\% Pu & MKIV 16\% Pu \\
\hline & & & & \\
\hline H3 & 0.000003219 & 0.000008823 & 0.00001902 & 0.00003813 \\
\hline C14 & 0.00003501 & 0.00005912 & 0.00008887 & \\
\hline EE55 & 0.0002209 & 0.0003631 & 0.0005277 & 0.0007369 \\
\hline $\mathrm{CO60}$ & 0.0432 & 0.07175 & 0.1057 & 0.1502 \\
\hline NI59 & $2.826 \mathrm{E}-07$ & $4.734 \mathrm{E}-07$ & $7.048 \mathrm{E}-07$ & 0.000001016 \\
\hline N163 & 0.0003367 & 0.0005668 & 0.000849 & 0.001233 \\
\hline SR89 & $9: 34 \mathrm{E}-19$ & $1.149 \mathrm{E}-18$ & $1.272 \mathrm{E}-18$ & $1.324 \mathrm{E}-18$ \\
\hline SR90 & $2.594 \mathrm{E}-09$ & $6.559 \mathrm{E}-09$ & $1.334 \mathrm{E}-08$ & $2.583 \mathrm{E}-08$ \\
\hline Y90 & $1.239 \mathrm{E}-08$ & $3.133 E-08$ & $6.374 \mathrm{E}-08$ & $1.234 \mathrm{E}-07$ \\
\hline$Y 91$ & $3.993 \mathrm{E}-16$ & $5.03 \mathrm{E}-16$ & $5.646 \mathrm{E}-16$ & $5.934 \mathrm{E}-16$ \\
\hline ZR93 & 0.000000252 & $4.252 \mathrm{E}-07$ & $6.389 \mathrm{E}-07$ & 0.000000932 \\
\hline ZR95 & $2.19 \mathrm{E}-12$ & $2.798 \mathrm{E}-12$ & $3.17 \mathrm{IE}-12$ & $3.358 \mathrm{E}-12$ \\
\hline NB93M & 0.000000118 & $2.013 \mathrm{E}-07$ & $3.066 \mathrm{E}-07$ & $4: 553 \mathrm{E}-07$ \\
\hline NB95 & $4.603 E-12$ & $5.884 \mathrm{E}-12$ & $6.666 \mathrm{E}-12$ & $7.059 \mathrm{E}-12$ \\
\hline NB95M & $4.456 \mathrm{E}-15$ & $5.695 \mathrm{E}-15$ & $6.452 \mathrm{E}-15$ & $6.833 \mathrm{E}-15$ \\
\hline TC99. & $3.322 \mathrm{E}-10$ & $5.589 \mathrm{E}-10$ & $8.366 \mathrm{E}-10$ & $1.214 \mathrm{E}-09$ \\
\hline AG110 & $2.179 \mathrm{E}-14$ & $9.251 \mathrm{E}-14$ & $2.744 \mathrm{E}-13$ & $6.89 \mathrm{E}-13$ \\
\hline AGI10M & $3.809 \mathrm{E}-12$ & $1.617 \mathrm{E}-11$ & $4.796 \mathrm{E}-11$ & $1.204 \mathrm{E}-10$ \\
\hline CD115M & $1.41 E-22$ & $1.72 \mathrm{E}-22$ & $1.884 \mathrm{E}-22$ & $1.945 \mathrm{E}-22$ \\
\hline IN113M & $1.337 \mathrm{E}-08$ & $1.876 \mathrm{E}-08$ & $2.292 \mathrm{E}-08$ & 0.000000026 \\
\hline SN113 & $9.554 \mathrm{E}-10$ & $1.34 \mathrm{E}-09$ & $1.638 \mathrm{E}-09$ & $1.858 \mathrm{E}-09$ \\
\hline SN119M & 0.0000342 & 0.00005242 & 0.00007019 & 0.00008833 \\
\hline SN121M & 0.00002093 & 0.0000353 & 0.00005299 & 0.00007721 \\
\hline SN123 & $2.758 \mathrm{E}-08$ & $3.935 E-08$ & $4.887 \mathrm{E}-08$ & $5.644 \mathrm{E}-08$ \\
\hline SB124 & $6.176 \mathrm{E}-18$ & $2.225 E-17$ & $5.529 \mathrm{E}-17$ & $1.152 \mathrm{E}-16$ \\
\hline SB125 & 0.01101 & 0.01812 & 0.02633 & 0.03686 \\
\hline SB126 & 0 & - & 0 & 0 \\
\hline SB126M & 0 & 0 & 0 & 0 \\
\hline TE123M & $8.473 \mathrm{E}-14$ & $3.797 \mathrm{E}-13$ & $1.174 \mathrm{E}-12$ & $3.202 \mathrm{E}-12$ \\
\hline TE125M & 0.0007222 & 0.001189 & 0.001728 & 0.002418 \\
\hline \multirow[t]{2}{*}{ TE127 } & $5.067 \mathrm{E}-17$ & $2.712 \mathrm{E}-16$ & $1.087 \mathrm{E}-15$ & $2.782 \mathrm{E}-15$ \\
\hline & & & & \\
\hline
\end{tabular}




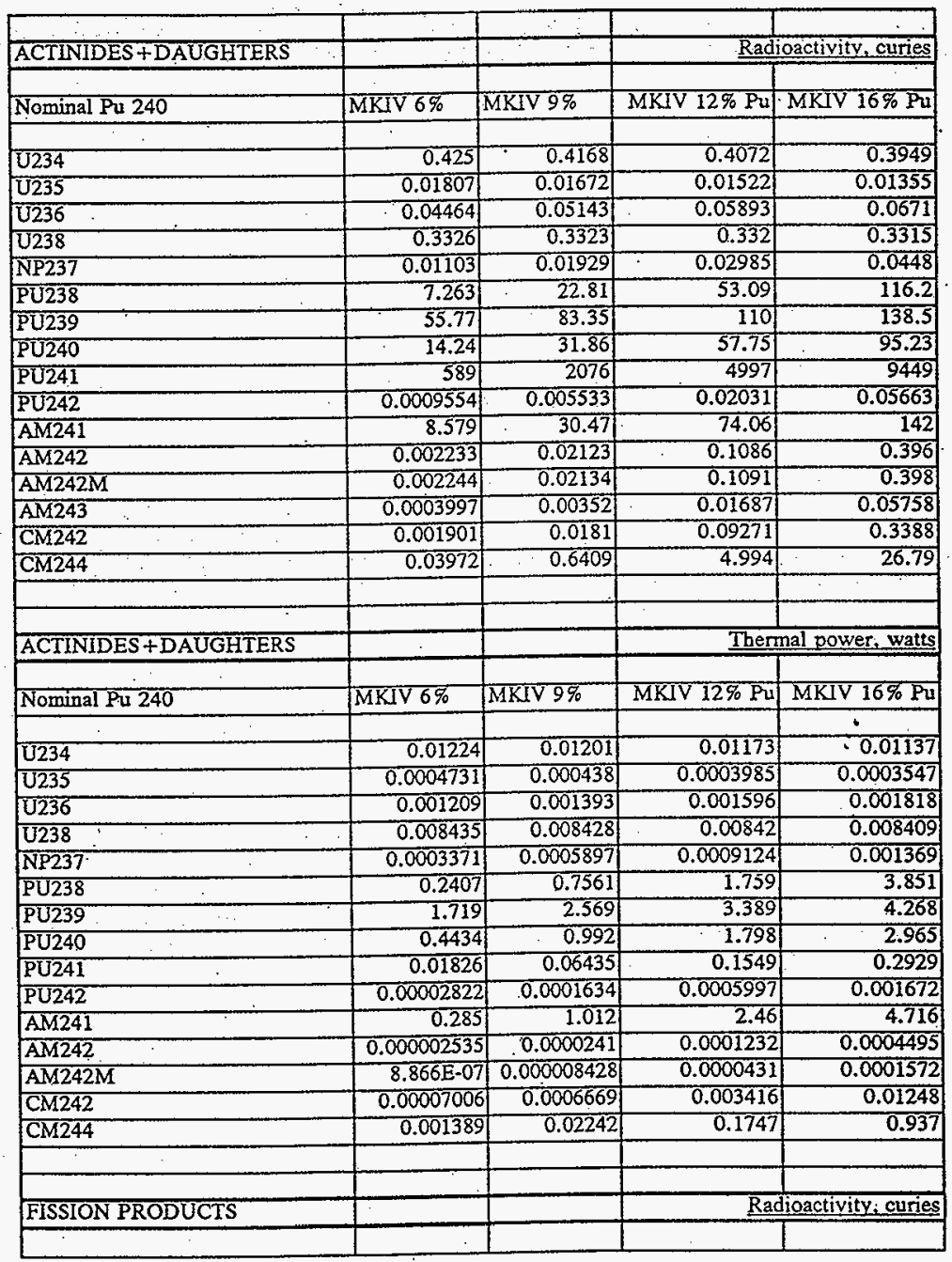




\begin{tabular}{|c|c|c|c|c|}
\hline Nominal Pu 240 & MKIV 6\% & MKIV 9\%. & MKIV $12 \%$ Pu & MKIV $16 \%$ Pu \\
\hline & & & & \\
\hline $\mathrm{H3}$ & 11.58 & 19.74 & 30.31 & 44.25 \\
\hline C14 & 0.000003926 & 0.00000654 & 0.000009852 & 0.00001411 \\
\hline SE79 & 0.01459 & 0.02418 & 0.03616 & 0.05143 \\
\hline $\mathrm{KR} 85$ & 244.2 & 391.4 & 565.5 & 771.7 \\
\hline SR89 & $1.247 E-11$ & $1.401 \mathrm{E}-11$ & $1.427 E-11$ & $1.333 \mathrm{E}-11$ \\
\hline SR90 & 2540 & 4060 & 5857 & 7986 \\
\hline Y90 & 2540 & 4061 & 5859 & 7988 \\
\hline Y91 & $2.5 \mathrm{E}-09$ & $2.908 \mathrm{E}-09$ & $3.04 \mathrm{E}-09$ & $2.901 \mathrm{E}-09$ \\
\hline ZR93 & 0.06846 & 0.1114 & 0.1638 & 0.2284 \\
\hline NB93M & 0.02106 & 0.03468 & 0.05176 & 0.07357 \\
\hline ZR95 & $4.467 \mathrm{E}-08$ & $5.452 \mathrm{E}-08$ & 5.975E-08 & $5.996 \mathrm{E}-08$ \\
\hline NB95 & $9.917 \mathrm{E}-08$ & 0.000000121 & $1.326 \mathrm{E}-07$ & $1.331 E-07$ \\
\hline NB95M & $3.314 \mathrm{E}-10$ & $4.044 \mathrm{E}-10$ & $4.432 \mathrm{E}-10$ & $4.448 \mathrm{E}-10$ \\
\hline TC99 & 0.4865 & 0.8076 & 1.211 & 1.723 \\
\hline RU103 & $2.744 \mathrm{E}-16$ & $3.419 \mathrm{E}-16$ & $3.943 \mathrm{E}-16$ & $4.226 \mathrm{E}-16$ \\
\hline $\mathrm{RH} 103 \mathrm{M}$ & $2.474 \mathrm{E}-16$ & $3.082 \mathrm{E}-16$ & $3.554 \mathrm{E}-16$ & $3.81 \mathrm{E}-16$ \\
\hline RU106 & 91.73 & 174.2 & 287.1 & 435.1 \\
\hline RHIO6 & 91.73 & 174.2 & 287.1 & 435.1 \\
\hline PD107 & 0.001681 & 0.003516 & 0.006385 & 0.01082 \\
\hline AG110 & 0.00005647 & 0.0001924 & 0.0004961 & 0.001121 \\
\hline AG110M & 0.004246 & 0.01447 & 0.0373 & 0.08427 \\
\hline CD113M & 0.9142 & 1.633 & 2.609 & 4.038 \\
\hline CD115M & $1.086 \mathrm{E}-16$ & $1.371 \mathrm{E}-16$ & $1.571 \mathrm{E}-16$ & $1.695 \mathrm{E}-16$ \\
\hline SN119M & 0.006528 & 0.01033 & 0.01435 & 0.01871 \\
\hline SN121M & 0.003969 & 0.007625 & 0.01298 & 0.0207 \\
\hline SN123 & 0.0001755 & 0.0002573 & 0.0003303 & 0.0003912 \\
\hline TE123M & $4.944 \mathrm{E}-10$ & $2.254 \mathrm{E}-09$ & $7.125 \mathrm{E}-09$ & $1.979 \mathrm{E}-08$ \\
\hline SB124 & $2.042 \mathrm{E}-13$ & $4.82 \mathrm{E}-13$ & $9.125 \mathrm{E}-13$ & $1.557 \mathrm{E}-12$ \\
\hline SB125 & 85.55 & 148 & 228.6 & .333 .5 \\
\hline TE125M & . 20.87 & 36.12 & 55.78 & 81.36 \\
\hline SN126 & 0.02274 & 0.04016 & 0.06347 & 0.09602 \\
\hline SB126 & 0.003183 & 0.005622 & 0.008885 & 0.01344 \\
\hline SB126M & 0.02274 & 0.04016 & 0.06347 & 0.09602 \\
\hline TE127 & 0.00004109 & 0.00006122 & 0.00008019 & 0.00009596 \\
\hline TE127M & 0.00004195 & 0.0000625 & 0.00008187 & 0.00009797 \\
\hline TE129 & $1.757 \mathrm{E}-21$ & $2.133 \mathrm{E}-21$ & $2.415 \mathrm{E}-21$ & $2.55 \mathrm{E}-21$ \\
\hline TE129M & $2.699 \mathrm{E}-21$ & $3.277 \mathrm{E}-21$ & $3.71 \mathrm{E}-21$ & $3: 917 \mathrm{E}-21$ \\
\hline 1129 & 0.0009641 & 0.001678 & 0.002627 & 0.00391 \\
\hline CS134. & 41.55 & 126.7 & 282.2 & 566.5 \\
\hline CS135 & 0.01319 & 0.02163 & 0.03255 & 0.04651 \\
\hline CS137. & 2957 & 4931 & 7431 & 10640 \\
\hline BA137M & 2797 & 4664 & 7030 & 10060 \\
\hline CE141 & $1.838 \mathrm{E}-20$ & $2.042 \mathrm{E}-20$ & $2.143 \mathrm{E}-20$ & $2.108 E-20$ \\
\hline PR143 & $8.456 \mathrm{E}-56$ & $8.693 \mathrm{E}-56$ & $8.674 E-56$ & $8.355 \mathrm{E}-56$ \\
\hline CE144 & 124.6 & 186.6 & 247.8 & 302.7 \\
\hline
\end{tabular}




\begin{tabular}{|c|c|c|c|c|}
\hline PR144 & 124.6 & 186.6 & 247.8 & 302.7 \\
\hline PR144M & 1.495 & 2.239 & 2.973 & 3.632 \\
\hline PM147 & 1833 & 2752 & 3646 & 4439 \\
\hline PM148 & $1.323 \mathrm{E}-18$ & $2.439 \mathrm{E}-18$ & $3.431 \mathrm{E}-18$ & $4.295 \mathrm{E}-18$ \\
\hline PM148M & $2.349 \mathrm{E}-17$ & $4.33 \mathrm{E}-17$ & $6.091 E-17$ & $7.625 \mathrm{E}-17$ \\
\hline SM151 & 55.96 & 74.22 & 89.09 & 100.8 \\
\hline EU152 & 0.112 & 0.34 & 0.7188 & 1.208 \\
\hline GD153 & 0.00002641 & 0.0001441 & 0.000484 & 0.001213 \\
\hline EU154 & 14.91 & 44.1 & 103.8 & 224.5 \\
\hline EU155 & 28.31 & 37.17 & 48.46 & 65.43 \\
\hline TB160 & $1.227 \mathrm{E}-11$ & $3.594 \mathrm{E}-11$ & $8.12 \mathrm{E}-11$ & $1.607 \mathrm{E}-10$ \\
\hline & & & & \\
\hline & & & & \\
\hline 3 & - & & & \\
\hline FISSION PRODUCTS & & & \multicolumn{2}{|c|}{ Thermal power, watts } \\
\hline Nominal Pu 240 & MKIV 6\% & MKIV $9 \%$ & MRIV 12\% Pu & MKIV 16\% Pu \\
\hline H3 & & & 000102 & 00000 \\
\hline C14 & $1.151 \mathrm{E}-09$ & $1.918 \mathrm{E}-09$ & $2.889 \mathrm{E}-09$ & $\frac{0.00149}{4.138 \mathrm{E}-09}$ \\
\hline SE79 & 0.000003633 & 0.000006019 & 0.000009003 & 0.0000128 \\
\hline KR85 & 0.3658 & 0.5862 & 0.8471 & 1.156 \\
\hline SR89 & $4.31 \mathrm{E}-14$ & $4.842 \mathrm{E}-14$ & $4.934 E-14$ & $4.607 \mathrm{E}-14$ \\
\hline SR90 & 2.948 & 4.712 & .6 .798 & 9.269 \\
\hline Y90 & 14.08 & 22.51 & 32.47 & 44.27 \\
\hline Y91 & $8.978 \mathrm{E}-12$ & $1.044 \mathrm{E}-11$ & $1.092 \mathrm{E}-11$ & $1.042 \mathrm{E}-11$ \\
\hline ZRO3 & 0.000007954 & 0.00001294 & 0.00001903 & 0.00002653 \\
\hline NB93M & 0.000003731 & 0.000006144 & 0.000009171 & 0.00001304 \\
\hline ZR95 & $2.263 \mathrm{E}-10$ & $2.762 E-10$ & $3.026 \mathrm{E}-10$ & $3.037 \mathrm{E}-10$ \\
\hline NB95 & $4.757 \mathrm{E}-10$ & $5.806 \mathrm{E}-10$ & $6.363 \mathrm{E}-10$ & $6.385 \mathrm{E}-10$ \\
\hline $\mathrm{NB} 95 \mathrm{M}$ & $4.604 \mathrm{E}-13$ & $5.62 \mathrm{E}-13$ & $6.159 \mathrm{E}-13$ & $6.18 \mathrm{E}-13$ \\
\hline TC99. & 0.000244 & 0.000405 & 0.0006073 & 0.000864 \\
\hline RU103 & $9.181 \mathrm{E}-19$ & $1.144 \mathrm{E}-18$ & $1.319 \mathrm{E}-18$ & $1.414 \mathrm{E}-18$ \\
\hline RHI03M & $5.694 \mathrm{E}-20$ & $7.094 \mathrm{E}-20$ & $8.181 \mathrm{E}-20$ & $8.77 \mathrm{E}-20$ \\
\hline RU106 & 0.005454 & 0.01036 & 0.01707 & 0.02587 \\
\hline RH106 & 0.8798 & 1.671 & 2.754 & 4.173 \\
\hline PD107 & $9.964 \mathrm{E}-08$ & $2.084 \mathrm{E}-07$ & $3.785 \mathrm{E}-07$ & $6.413 \mathrm{E}-07$ \\
\hline AG110 & $4.057 \mathrm{E}-07$ & 0.000001383 & 0.000003564 & 0.000008052 \\
\hline AGIIOM & 0.0000709 & 0.0002416 & 0.0006228 & 0.001407 \\
\hline CD113M & 0.001539 & 0.002749 & 0.004392 & 0.006798 \\
\hline SN119M & 0.000003374 & 0.00000534 & 0.000007418 & 0.00000967 \\
\hline SN121M & 0.000007952 & 0.00001528 & 0.000026 & 0.00004148 \\
\hline SN123 & 0.000000548 & $8.036 \mathrm{E}-07$ & 0.000001032 & 0.000001222 \\
\hline TE123M & $7.2 \mathrm{E}-13$ & $3.283 \mathrm{E}-12$ & $1.038 \mathrm{E}-11$ & $2.883 \mathrm{E}-11$ \\
\hline SB124 & $2.711 \mathrm{E}-15$ & $6.4 \mathrm{E}-15$ & $1.212 \mathrm{E}-14$ & $2.067 \mathrm{E}-14$ \\
\hline SB125 & 0.2674 & 0.4628 & 0.7147 & 1.042 \\
\hline TE125M & 0.01754 & 0.03036 & 0.04689 & 0.06839 \\
\hline
\end{tabular}




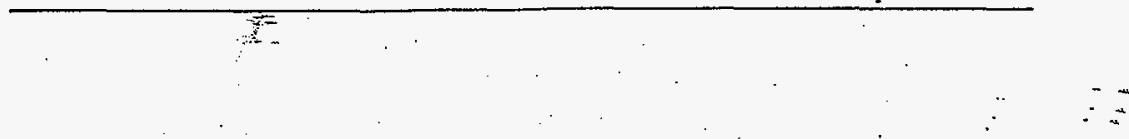

\begin{tabular}{|l|r|r|r|r|}
\hline SN126 & 0.00002836 & 0.00005009 & 0.00007915 & 0.0001198 \\
\hline SB126 & 0.00005882 & 0.0001039 & 0.0001642 & 0.0002484 \\
\hline SB126M & 0.0002895 & 0.0005113 & 0.0008081 & 0.001223 \\
\hline TE127 & $5.549 \mathrm{E}-08$ & $8.267 \mathrm{E}-08$ & $1.083 \mathrm{E}-07$ & $1.296 \mathrm{E}-07$ \\
\hline TE127M & $2.257 \mathrm{E}-08$ & $3.362 \mathrm{E}-08$ & $4.403 \mathrm{E}-08$ & $5.269 \mathrm{E}-08$ \\
\hline TE129 & $6.275 \mathrm{E}-24$ & $7.62 \mathrm{E}-24$ & $8.628 \mathrm{E}-24$ & $9.11 \mathrm{E}-24$ \\
\hline TE129M & $4.732 \mathrm{E}-24$ & $5.745 \mathrm{E}-24$ & $6.506 \mathrm{E}-24$ & $6.869 \mathrm{E}-24$ \\
\hline I129 & 0.000000446 & $7.762 \mathrm{E}-07$ & 0.000001215 & 0.000001809 \\
\hline CS134 & 0.4229 & 1.29 & 2.872 & 5.766 \\
\hline CS135 & 0.000004403 & 0.00000722 & 0.00001086 & 0.00001552 \\
\hline CS137 & 3.271 & 5.454 & 8.22 & 11.77 \\
\hline BA137M & 10.98 & 18.31 & 27.6 & 39.51 \\
\hline CE141 & $2.691 \mathrm{E}-23$ & $2.99 \mathrm{E}-23$ & $3.137 \mathrm{E}-23$ & $3.086 \mathrm{E}-23$ \\
\hline PR143 & $1.575 \mathrm{E}-58$ & $1.619 \mathrm{E}-58$ & $1.616 \mathrm{E}-58$ & $1.557 \mathrm{E}-58$ \\
\hline CE144 & 0.08265 & 0.1237 & 0.1643 & 0.2008 \\
\hline PR144 & 0.9159 & 1.371 & 1.821 & 2.225 \\
\hline PR144M & 0.0005116 & 0.000766 & 0.001017 & 0.001243 \\
\hline PM147 & 0.6575 & 0.987 & 1.308 & 1.592 \\
\hline PM148 & $1.019 \mathrm{E}-20$ & $1.878 \mathrm{E}-20$ & $2.642 \mathrm{E}-20$ & $3.307 \mathrm{E}-20$ \\
\hline PM148M & $2.978 \mathrm{E}-19$ & $5.49 \mathrm{E}-19$ & $7.723 \mathrm{E}-19$ & $9.667 \mathrm{E}-19$ \\
\hline SM151 & 0.006561 & 0.008703 & 0.01045 & 0.01182 \\
\hline EU152 & 0.000847 & 0.002572 & 0.005437 & 0.009136 \\
\hline GD153 & $2.386 \mathrm{E}-08$ & $1.301 \mathrm{E}-07$ & $4.372 \mathrm{E}-07$ & 0.000001096 \\
\hline EU154 & 0.1334 & 0.3945 & 0.9285 & 2.008 \\
\hline EU155 & 0.02059 & 0.02703 & 0.03524 & 0.04759 \\
\hline TB160 & $9.994 \mathrm{E}-14$ & $2.927 \mathrm{E}-13$ & $6.614 \mathrm{E}-13$ & $1.308 \mathrm{E}-12$ \\
\hline
\end{tabular}


Table G-2

ORIGEN II BASED DATA FOR MKIA FUEL (7.5 YEARS DECAY)

(Data shown in Units per Metric Ton of Uranium)

\begin{tabular}{|c|c|c|c|c|}
\hline PLUTONIUTM & - & & \multicolumn{2}{|c|}{ Concentrations, grams } \\
\hline Pli240 file & MK126\% Pu & MKIa $9 \%$ Pu & MKla12\% Pu & MKJa16\% Pu \\
\hline & & & & \\
\hline Pu, gm & $9.70 \mathrm{E}+02$ & $1.51 \mathrm{E}+03$ & $2.09 \mathrm{E}+03$ & $2.76 \mathrm{E}+03$ \\
\hline Pu240, gm & $6.23 \mathrm{E}+01$ & $1.43 \mathrm{E}+02$ & $2.62 \mathrm{E}+02$ & $4.39 \mathrm{E}+02$ \\
\hline Pi1240, \% & $6.42 \%$ & $9.48 \%$ & $12.58 \%$ & \\
\hline & & & & \\
\hline & & & & \\
\hline ACTIVATION PRODUCTS & & & Radic & activity, curies \\
\hline & & & & \\
\hline Pu240 file & $\mathrm{MKIa} 6 \% \mathrm{Pu}$ & $\mathrm{MKla} 9 \% \mathrm{Pu}$ & MKla12\% Pu. & MKJa16\% Pu \\
\hline & & & & \\
\hline $\mathrm{H3}$ & $9.86 \mathrm{E}-02$ & $2.68 \mathrm{E}-01$ & $5.81 \mathrm{E}-01$ & $1.17 \mathrm{E}+00$ \\
\hline $\mathrm{C14}$ & $1.27 \mathrm{E}-01$ & $2.13 \mathrm{E}-01$ & $3.21 \mathrm{E}-01$ & $4.71 \mathrm{E}-01$ \\
\hline FESS & $7.06 \mathrm{E}+00$ & $1.16 \mathrm{E}+01$ & $1.69 \mathrm{E}+01$ & $2.37 \mathrm{E}+01$ \\
\hline FE59 & $2.88 \mathrm{E}-18$ & $3.46 \mathrm{E}-18$ & $1.69 \mathrm{E}+01$ & $3.99 \mathrm{E}-18$ \\
\hline $\mathrm{CO} 60$ & $3.50 \mathrm{E}+00$ & $5.78 \mathrm{E}+00$ & $8.55 \mathrm{E}+00$ & $1.22 \mathrm{E}+01$ \\
\hline N159 & $7.89 \mathrm{E}-03$ & $1.32 \mathrm{E}-02$ & $1.97 E-02$ & $2.84 E-02$ \\
\hline N163 & $9.38 \mathrm{E}-01$ & $1.57 \mathrm{E}+00$ & $2.37 \mathrm{E}+00$ & $3.45 \mathrm{E}+00$ \\
\hline SR89 & $3.27 \mathrm{E}-16$ & $4.00 \mathrm{E}-16$ & $4.45 E-16$ & $4.65 \mathrm{E-16}$ \\
\hline SR90 & $2.69 \mathrm{E}-06$ & $6.76 \mathrm{E}-06$ & $1.39 \mathrm{E}-05$ & $2.72 \mathrm{E}-05$ \\
\hline Y90 & $2.69 \mathrm{E}-06$ & $6.76 \mathrm{E}-06$ & 1.39E-05 & $2.72 \mathrm{E}-05$ \\
\hline Y91 & $1.35 \mathrm{E}-13$ & $1.68 \mathrm{E}-13$ & $1.90 \mathrm{E}-13$ & $2.01 \mathrm{E}-13$ \\
\hline ZR93 & $2.68 E-03$ & $4.51 \mathrm{E}-03$ & $6.80 \mathrm{E}-03$ & $9.96 \mathrm{E}-03$ \\
\hline ZR95 & $5.29 \mathrm{E}-10$ & $6.72 \mathrm{E}-10$ & $7.66 \mathrm{E}-10$ & $8.15 \mathrm{E}-10$ \\
\hline NB93M & $8.23 \mathrm{E}-04$ & $1.40 \mathrm{E}-03$ & $2.14 \mathrm{E}-03$ & $3.19 \mathrm{E}-03$ \\
\hline NB95 & $1.17 \mathrm{E}-09$ & $1.49 \mathrm{E}-09$ & $1.70 \mathrm{E}-09$ & $1.81 \mathrm{E}-09$ \\
\hline NB95M & $3.92 \mathrm{E}-12$ & $4.98 \mathrm{E}-12$ & $5.68 \mathrm{E}-12$ & $6.05 \mathrm{E}-12$ \\
\hline TC99 & $7.96 \mathrm{E}-07$ & $1.33 \mathrm{E}-06$ & $2.01 \mathrm{E}-06$ & $2.92 \mathrm{E}-06$ \\
\hline AG110 & 3.11E-12 & $1.31 \mathrm{E}-11$ & $3.92 \mathrm{E}-11$ & $9.92 \mathrm{E}-11$ \\
\hline AG110M & $2.34 \mathrm{E}-10$ & $9.85 \mathrm{E}-10$ & $2,95 \mathrm{E}-09$ & $7: 46 \mathrm{E}-09$ \\
\hline CD115M & $3.87 \mathrm{E}-20$ & $4.68 \mathrm{E}-20$ & $5.16 \mathrm{E}-2,0$ & $5.34 \mathrm{E}-20$ \\
\hline IN113M & $6.90 \mathrm{E}-06$ & $9.63 \mathrm{E}-06$ & $1.18 \mathrm{E}-05$ & $1.35 \mathrm{E}-05$ \\
\hline SN113 & $6.89 \mathrm{E}-06$ & $9.62 \mathrm{E}-06$ & $1.18 \mathrm{E}-05$ & $1.35 \mathrm{E}-05$ \\
\hline SN119M & $7.87 \mathrm{E}-02$ & $1.20 \mathrm{E}-01$ & $1.62 \mathrm{E}-01$ & $2.04 \mathrm{E}-01$ \\
\hline SN12IM & $1.25 \mathrm{E}-02$ & $2.10 \mathrm{E}-02$ & $3.17 \mathrm{E}-02$ & $4.63 \mathrm{E}-02$ \\
\hline SN123 & $1.08 \mathrm{E}-05$ & $1.54 \mathrm{E}-05$ & $1.92 \mathrm{E}-05$ & $2.23 \mathrm{E}-05$ \\
\hline SB124 & $5.63 \mathrm{E}-16$ & $2.01 \mathrm{E}-15$ & $5.04 \mathrm{E}-15$ & $1.06 \mathrm{E}-14$ \\
\hline
\end{tabular}




\begin{tabular}{|c|c|c|c|c|}
\hline SB125 & $4.21 \mathrm{E}+00$ & $6.89 \mathrm{E}+00$ & $1.01 \mathrm{E}+011$ & $1.41 E+01$ \\
\hline SB126 & $0.00 \mathrm{E}+00$ & $0.00 \mathrm{E}+00$ & $0.00 \mathrm{E}+00$ & $0.00 \mathrm{E}+00$ \\
\hline $\mathrm{SB126M}$ & $0.00 \mathrm{E}+00$ & $0.00 \mathrm{E}+00$ & $0.00 \mathrm{E}+00$ & $0.00 E+00$ \\
\hline TE.123M & $6.82 \mathrm{E}-11$ & $3,02 \mathrm{E}-10$ & 9.49E-10 & $2.63 \mathrm{E}-09$ \\
\hline TE125M & $1.03 \mathrm{E}+00$ & $1.68 \mathrm{E}+00$ & $2.46 \mathrm{E}+00$ & $3.45 \mathrm{E}+00$ \\
\hline TE127 & $4.38 \mathrm{E}-14$ & $2.32 \mathrm{E}-13$ & $9.43 \mathrm{E}-13$ & $2 . \overline{45 E-12}$ \\
\hline TE127M & $4.47 \mathrm{E}-14$ & $2.36 \mathrm{E}-13$ & $9.63 \mathrm{E}-13$ & $2.50 \mathrm{E}-12$ \\
\hline & & & & \\
\hline TOTAL & $\begin{array}{r}6.42 \% \\
9.86 \bar{c}-02\end{array}$ & $\begin{array}{r}9.48 \% \\
2.68 \mathrm{E}-01\end{array}$ & $\begin{array}{r}12.58 \% \\
5.81 \mathrm{E}-01\end{array}$ & $\begin{array}{r}15.88 \% \\
1.17 \mathrm{E}+00\end{array}$ \\
\hline & & & & \\
\hline & & & & \\
\hline ACTIVATION PRODUCTS & & & \multicolumn{2}{|c|}{ Thermal power, watts } \\
\hline & & & & \\
\hline Pu240 file & $\mathrm{MKIa} 6 \% \mathrm{Pu}$ & MKIa 9\% Pu & MKlal2\% Pu & MKIa16\% Pu \\
\hline$\overline{\mathrm{H3}}$ & & & $196 \mathrm{E}-05$ & \\
\hline$\frac{\mathrm{H} 3}{\mathrm{C} 14}$ & $\frac{3.32 E-06}{3.71 E-05}$ & $\frac{9.01 \mathrm{E}-00}{6.24 \mathrm{E}-05}$ & $\frac{1.90 \mathrm{E}-05}{9.42 \mathrm{E}-05}$ & $\frac{3,94 \mathrm{E}-05}{1.38 \mathrm{E}-04}$ \\
\hline $\begin{array}{l}\text { C14 } \\
\text { FE55 }\end{array}$ & $2.39 \mathrm{E}-04$ & $3.90 \mathrm{E}-04$ & $5.70 \mathrm{E}-04$ & $7.99 \mathrm{E}-04$ \\
\hline C060 & $5.39 \mathrm{E}-02$ & $8.91 \mathrm{E}-02$ & $1.32 \mathrm{E}-01$ & $1.88 \mathrm{E}-01$ \\
\hline Ni59 & $3.13 \mathrm{E}-07$ & $5.23 \mathrm{E}-07$ & $7.81 \mathrm{E}-07$ & $1.13 \mathrm{E}-06$ \\
\hline NI63 & $3.73 \mathrm{E}-04$ & $6.24 \mathrm{E}-04$ & $9.40 \mathrm{E}-04$ & $1.37 \mathrm{E}-03$ \\
\hline SR89 & $1.13 \mathrm{E}-18$ & $1.38 \mathrm{E}-18$ & $1.54 \mathrm{E}-18$ & $1.61 \mathrm{E}-18$ \\
\hline SR90 & $3.12 \mathrm{E}-09$ & $7.85 E-09$ & $1.62 \mathrm{E}-08$ & $3.16 \mathrm{E}-08$ \\
\hline Y90 & $1.49 \mathrm{E}-08$ & $3.75 \mathrm{E}-08$ & $7.72 \mathrm{E}-08$ & $1.51 \mathrm{E}-07$ \\
\hline Y91 & $4,83 \mathrm{E}-16$ & $6.05 \mathrm{E}-16$ & $6.83 \mathrm{E}-16$ & $7.21 \mathrm{E}-16$ \\
\hline ZR93 & $3.11 \mathrm{E}-07$ & $5.23 \mathrm{E}-07$ & $7.90 \mathrm{E}-07$ & $116 \mathrm{E}-06$ \\
\hline ZR9S & $2.68 \mathrm{E}-12$ & $3.40 \mathrm{E}-12$ & $3.88 \mathrm{E}-12$ & $4.13 \mathrm{E}-12$ \\
\hline$\overline{\mathrm{NB}} \mathrm{3} \mathrm{M}$ & 1.46E-07 & $2.48 \mathrm{E}-07$ & $3.79 \mathrm{E}-07$ & $5.65 \mathrm{E}-07$ \\
\hline NB95 & $5.63 \mathrm{E}-12$ & $7.15 \mathrm{E}-12$ & $8.16 \mathrm{E}-12$ & $8.68 \mathrm{E}-12$ \\
\hline NB95M & $5.45 \mathrm{E}-15$ & $6.92 E-15$ & $7.89 \mathrm{E}-15$ & $8.40 \mathrm{E}-15$ \\
\hline TC99 & $3.99 \mathrm{E}-10$ & $6.69 E-10$ & $1.01 \mathrm{E}-09$ & $1.46 \mathrm{E}-09$ \\
\hline AG110 & $2.24 \mathrm{E}-14$ & $9.41 \mathrm{E}-14$ & $2.82 \mathrm{E}-13$ & $7.13 \mathrm{E}-13$ \\
\hline AG110M & $3.91 \mathrm{E}-12$ & $1.65 \mathrm{E}-11$ & $4.93 \mathrm{E}-11$ & $1.25 \mathrm{E}-10$ \\
\hline CD115M & $1.44 \mathrm{E}-22$ & $1.75 \mathrm{E}-22$ & $1.92 \mathrm{E}-22$ & $1.99 \mathrm{E}-22$ \\
\hline IN113M & $1.61 \mathrm{E}-08$ & $2.24 \mathrm{E}-08$ & $2.76 \mathrm{E}-08$ & $3.14 \mathrm{E}-08$ \\
\hline SN113 & $1.15 \mathrm{E}-09$ & $1.60 \mathrm{E}-09$ & $1.97 \varepsilon-09$ & $2.25 E-09$ \\
\hline SN119M & $4.07 E-05$ & $6.21 E-05$ & $8.35 E-05$ & $1.06 \mathrm{E}-04$ \\
\hline SN121M & $2.51 \mathrm{E}-05$ & $4.21 \mathrm{E}-05$ & $6.35 \mathrm{E}-05$ & $9.28 \mathrm{E}-05$ \\
\hline SN123 & $3.38 \mathrm{E}-08$ & $4.79 \mathrm{E}-08$ & $5.99 \mathrm{E}-08$ & $6.95 \mathrm{E}-08$ \\
\hline SB124 & $7.47 \mathrm{E}-18$ & $2.67 \mathrm{E}-17$ & $6.70 \mathrm{E}-17$ & $1.41 \mathrm{E}-16$ \\
\hline SB125 & $1.32 \mathrm{E}-02$ & $2.16 \mathrm{E}-02$ & $3.15 E-02$ & $4.42 \mathrm{E}-02$ \\
\hline SB126 & $0.00 \mathrm{E}+\infty$ & $0.00 \mathrm{E}+00$ & $0.00 \mathrm{E}+00$ & $0.00 \mathrm{E}+00$ \\
\hline SB126M & $0.00 \mathrm{E}+00$ & $0.00 \mathrm{E}+00$ & $0.00 \mathrm{E}+00$ & $0.00 \mathrm{E}+00$ \\
\hline TE123M & $9.93 \mathrm{E}-14$ & $4.40 \mathrm{E}-13$ & $1.38 \mathrm{E}-12$ & $3.82 \mathrm{E}-12$ \\
\hline TE125M & $8.63 \mathrm{E}-04$ & $1.41 \mathrm{E}-03$ & $2.06 \mathrm{E}-03$ & $2.90 \mathrm{E}-03$ \\
\hline TE127 & $5.91 \mathrm{E}-17$ & $3.13 \mathrm{E}-16$ & $1.27 \mathrm{E}-15$ & $3.31 \mathrm{E}-15$ \\
\hline
\end{tabular}




\begin{tabular}{|c|c|c|c|c|}
\hline & & & & . \\
\hline & & & & \\
\hline ACTINIDES + DAUGHTERS & & & \multicolumn{2}{|c|}{ Radioactivity, curies } \\
\hline Pu240 file & MKIa $6 \%$ Pu & MKla 9\% Pu & MKJa12\% Pu & MKla16\% Pu \\
\hline \\
\hline U234 & $4.66 \mathrm{E}-01$ & $4.57 \mathrm{E}-01$ & $4.46 \mathrm{E}-01$ & $4.33 E-01$ \\
\hline U235 & $2.18 \mathrm{E}-02$ & $2.01 E-02$ & $1.82 \mathrm{E}-02$ & $1.60 \mathrm{E}-02$ \\
\hline $\mathrm{U} 236$ & $4.76 \mathrm{E}-02$ & $5.63 E-02$ & $6.59 \mathrm{E}-02$ & $7.66 \mathrm{E}=02$ \\
\hline $\mathrm{U} 238$ & $3.32 E-01$ & $3.32 \mathrm{E}-01$ & $3.31 \mathrm{E}-01$ & $3.31 \mathrm{E}-01$ \\
\hline NP237 & $1.12 \mathrm{E}-02$ & $1.98 \mathrm{E}-02$ & $3.11 \mathrm{E}-02$ & $4.74 \mathrm{E}-02$ \\
\hline PU238 & $7.35 E+00$ & $2.33 E+01$ & $5.55 E+01$ & $1.24 E+02$ \\
\hline PU239 & $5.60 \mathrm{E}+01$ & $8.33 \mathrm{E}+01$ & $1.10 \mathrm{E}+02$ & $1.37 \mathrm{E}+02$ \\
\hline PU240 & $1.42 \mathrm{E}+01$ & $3.25 E+01$ & $5.98 \mathrm{E}+01$ & $1.00 \mathrm{E}+02$ \\
\hline PU241 & $5.80 \mathrm{E}+02$ & $2.07 \mathrm{E}+03$ & $5.04 \mathrm{E}+03$ & $9.83 \mathrm{E}+03$ \\
\hline PU242 & $9.40 E-04$ & $5.65 \mathrm{E}-03$ & $2.13 \mathrm{E}-02$ & $6.24 \mathrm{E}-02$ \\
\hline AM241 & $8.44 E+00$ & $3.04 \mathrm{E}+01$ & $7.47 \mathrm{E}+01$ & $1.48 \mathrm{E}+02$ \\
\hline AM242 & $2.19 \mathrm{E}-03$ & $2.09 \mathrm{E}-02$ & $1.08 \mathrm{E}-01$ & $4.05 \mathrm{E}-01$ \\
\hline AM242M & $2.20 \mathrm{E}-03$ & $2.10 \mathrm{E}=02$ & $1.09 \mathrm{E}-01$ & $4.07 \mathrm{E}-01$ \\
\hline AMि243 & $3.95 \mathrm{E}-04$ & 3.55E-03 & $1.76 \mathrm{E}-02$ & $6.29 \mathrm{E}-02$ \\
\hline CM242 & $1.86 \mathrm{E}-03$ & $1.78 \mathrm{E}-02$ & $9.26 \mathrm{E}-02$ & $3.47 \mathrm{E}-01$ \\
\hline \multirow[t]{2}{*}{ CM244 } & $3.89 \mathrm{E}-02$ & $6.33 \mathrm{E}-01$ & $5.12 \mathrm{E}+00$ & $2.88 \mathrm{E}+01$ \\
\hline & & & & \\
\hline \multirow[t]{2}{*}{ ACTINIDES + DAUGHTERS } & & & \multicolumn{2}{|c|}{ Thermal power, watts } \\
\hline & & & & \\
\hline Pu240 file & $\mathrm{MKIa}$ 6\% Pu & $\mathrm{MKJa} 9 \% \mathrm{Pu}$ & MKIa12\% Pu & MKIV16\% Pu \\
\hline$\overline{\mathrm{U} 234}$ & $134 \mathrm{E}-02$ & $1.32 \mathrm{E}-02$ & $1.29 \mathrm{E}-02$ & $1.25 \mathrm{E}-02$ \\
\hline $\mathrm{U} 235$ & $5.72 \mathrm{E}-04$ & $5.27 \mathrm{E}-04$ & $\frac{1.76 \mathrm{E}-04}{4.7}$ & $4.18 \mathrm{E}-04$ \\
\hline $\mathrm{U} 236$ & $1.29 \mathrm{E}-03$ & $1.53 \mathrm{E}-03$ & $1.79 \mathrm{E}-03$ & $2.08 \mathrm{E}-03$ \\
\hline $\begin{array}{l}\mathrm{U} 238 \\
\mathrm{NP237}\end{array}$ & $8.42 \mathrm{E}-03$ & $8.41 \mathrm{E}-03$ & $8.40 E-03$ & $8.39 \mathrm{E}-03$ \\
\hline NP237 & $3.42 \mathrm{E}-04$ & $6.04 \mathrm{E}-04$ & $9.50 \mathrm{E}-04$ & $1.45 \mathrm{E}-03$ \\
\hline $\begin{array}{l}\text { PU238 } \\
\text { PU239 }\end{array}$ & $2.43 \mathrm{E}-01$ & $7.73 \mathrm{E}-01$ & $1.84 \mathrm{E}+00$ & $4.12 \mathrm{E}+00$ \\
\hline$\frac{\text { PU239 }}{\text { PU240 }}$ & $1.73 E+\infty 0$ & $2.57 \mathrm{E}+00$ & $3.38 \mathrm{E}+00$ & $4.22 \mathrm{E}+\infty 0$ \\
\hline PU240 & $4.42 \mathrm{E}-01$ & $1.01 \mathrm{E} \div 00$ & $1.86 \mathrm{E}+00$ & $3.11 E+00$ \\
\hline \multirow{2}{*}{$\begin{array}{l}\text { PU241 } \\
\text { PU242 }\end{array}$} & $1.80 \mathrm{E}=02$ & $6.42 \mathrm{E}-02$ & $1.56 \mathrm{E}-01$ & $3.05 \mathrm{E}-01$ \\
\hline & $2.78 \mathrm{E}-05$ & $1.67 \mathrm{E}-04$ & $6.29 \mathrm{E}-04$ & $1.84 \mathrm{E}-03$ \\
\hline AM241 & $2.80 \mathrm{E}-01$ & $1.01 \mathrm{E}+00$ & $2.48 \mathrm{E}+00$ & $4.90 \mathrm{E}+00$ \\
\hline AM242 & $2.48 \mathrm{E}-06$ & $2.37 E-05$ & $1.23 \mathrm{E}-04$ & $4.60 \mathrm{E}-04$ \\
\hline AM242M & $8.68 \mathrm{E}-07$ & $8.30 \mathrm{E}-06$ & $4.31 \mathrm{E}-05$ & $1.61 \mathrm{E}-04$ \\
\hline $\mathrm{CM} 242$ & $6.86 \mathrm{E}-05$ & $6.57 \mathrm{E}-04$ & $3.41 \mathrm{E}-03$ & $1.28 \mathrm{E}-02$ \\
\hline \multirow[t]{2}{*}{ CM244 } & $1.36 \mathrm{E}-03$ & $2.22 \mathrm{E}-02$ & $1.79 \mathrm{E}-01$ & $1.01 E+00$ \\
\hline & & & & \\
\hline \multirow[t]{2}{*}{ FISSION PRODUCTS } & & & \multicolumn{2}{|c|}{ Radidoactivity, curies } \\
\hline & & & & \\
\hline
\end{tabular}




\begin{tabular}{|c|c|c|c|c|}
\hline Pu240 file & $\mathrm{MKIa} 6 \%$ Pu & $\mathrm{MKJa} 9 \%$ Pu & MKla12\% Pu & MKJa16\% PI \\
\hline & & & & \\
\hline H3 & $1.36 \mathrm{E}+01$ & $2.31 \mathrm{E}+01$ & $3.54 \mathrm{E}+01$ & $5.17 E+01$ \\
\hline C14 & $4.72 \mathrm{E}-06$ & $7.85 \mathrm{E}-06$ & $1.18 \mathrm{E}-05$ & $1.69 \mathrm{E}-05$ \\
\hline SE79 & $1.75 \mathrm{E}-02$ & $2.89 \mathrm{E}-02$ & $4.32 \mathrm{E}-02$ & $6.15 \mathrm{E}-02$ \\
\hline KR85 & $2.98 \mathrm{E}+02$ & $4.79 \mathrm{E}+02$ & $6.93 E+02$ & $9.49 \mathrm{E}+02$ \\
\hline SR89 & $1.53 \mathrm{E}-11$ & $1.73 E-11$ & $1.77 \mathrm{E}-12$ & $1.66 \mathrm{E}-11$ \\
\hline SROO & $3.11 E+03$ & $4.99 E+03$ & $7.22 E+03$ & $9.89 \bar{E}+03$ \\
\hline Y90. & $3.11 \mathrm{E}+03$ & $4.99 E+03$ & $7.22 \mathrm{E}+03$ & $9.89 \bar{E}+03$ \\
\hline Y91 & $3.06 \mathrm{E}-09$ & $3.57 \mathrm{E}-09$ & $3.75 \mathrm{E}-09$ & $3.60 \mathrm{E}-09$ \\
\hline ZR93 & $8.31 \mathrm{E}-02$ & $1.36 \mathrm{E}-01$ & $1.99 \mathrm{E}-01$ & $2.79 E-01$ \\
\hline NB93M & $2.56 \mathrm{E}-02$ & $4.22 \mathrm{E}-02$ & $6.30 \mathrm{E}-02$ & $8.98 \mathrm{E}-02$ \\
\hline ZR95 & 5.40E-08 & $6.60 \mathrm{E}-08$ & $7.23 \mathrm{E}-08$ & $7.27 \mathrm{E}-08$ \\
\hline NB95 & $1.20 \mathrm{E}-07$ & $1.47 \mathrm{E}-07$ & $1.61 \mathrm{E}-07$ & $1.62 \mathrm{E}-07$ \\
\hline NB95M & $4.01 \mathrm{E}-10$ & $4.90 \mathrm{E}-10$ & $5,36 \mathrm{E}-10$ & $5.40 \mathrm{E}-10$ \\
\hline TC99 & $5.84 \mathrm{E}-01$ & $9.69 \mathrm{E}-01$ & $1.45 \mathrm{E}+00$ & $2.06 \bar{E}+00$ \\
\hline RU103 & $3.20 \mathrm{E}-16$ & $3.95 \mathrm{E}-16$ & $4.53 E-16$ & $4.88 \mathrm{E}-16$ \\
\hline RH103M & $2.88 \mathrm{E}-16$ & $3.56 \mathrm{E}-16$ & $4.09 \mathrm{E}-16$ & $4.40 \overline{E-16}$ \\
\hline RU106 & $9.96 \mathrm{E}+0 \mathrm{I}$ & $1.88 \mathrm{E}+02$ & $3.10 \mathrm{E}+02$ & $4.75 E+02$ \\
\hline RH106 & $9.96 \mathrm{E}+01$ & $1.88 \mathrm{E}+02$ & $3.10 \mathrm{E}+02$ & $4.75 E+02$ \\
\hline PD107 & $1.79 \mathrm{E}-03$ & $3.74 \mathrm{E}-03$ & $6: 81 \mathrm{E}-03$ & $1.17 \mathrm{E}-02$ \\
\hline AG110 & $6.03 \mathrm{E}-05$ & $2.04 \mathrm{E}-04$ & $5.30 \mathrm{E}-04$ & 1.22E-03 \\
\hline AG110M & $4.54 \mathrm{E}-03$ & $1.53 \mathrm{E}-02$ & $3.98 \mathrm{E}-02$ & $9.15 \mathrm{E}-02$ \\
\hline CD113M & $9.88 \mathrm{E}-01$ & $1.75 \mathrm{E}+00$ & $2.80 \mathrm{E}+00$ & $4.35 E+00$ \\
\hline $\mathrm{CD} 115 \mathrm{M}$ & $1.17 \mathrm{E}-16$ & $1.46 \mathrm{E}-16$ & $1.68 \mathrm{E}-16$ & $1.82 \mathrm{E}-16$ \\
\hline SN119M & $7.10 \overline{\mathrm{E}}-03$ & $1.12 \mathrm{E}-02$ & $1.55 \mathrm{E}-02$ & $2.03 E-02$ \\
\hline SN121M & $4.52 \mathrm{E}-03$ & 8.60 E-03 & $1.46 \mathrm{E}-02$ & $2.33 \mathrm{E}-02$ \\
\hline SN123 & $1.95 \mathrm{E}-04$ & $2.84 \mathrm{E}-04$ & $3.64 \mathrm{E}-04$ & $4.32 \mathrm{E}-04$ \\
\hline TE123M & $5.34 \mathrm{E}-10$ & $2.40 \mathrm{E}-09$ & $7.68 \mathrm{E}-09$ & $2.16 \mathrm{E}-08$ \\
\hline SB124 & $2.24 \mathrm{E}-13$ & $5.20 \mathrm{E}-13$ & $9.91 \mathrm{E}-13$ & 1.70E-12 \\
\hline SB125 & $9.39 \mathrm{E}+01$ & $1.62 E+02$ & $2.49 \mathrm{E}+02$ & $3.64 E+02$ \\
\hline TE125M & $2.29 \mathrm{E}+01$ & $3.94 \mathrm{E}+01$ & $6.08 \mathrm{E}+01$ & $8.89 \mathrm{E}+01$ \\
\hline SN126 & $2.55 \mathrm{E}-02$ & $4.47 \mathrm{E}-02$ & $7.05 \mathrm{E}-02$ & $1.07 \mathrm{E}-01$ \\
\hline SB126 & $3.56 \mathrm{E}-03$ & $6.25 \mathrm{E}-03$ & $9.87 E-03$ & $1.50 \mathrm{E}-02$ \\
\hline SB126M & $2.55 \mathrm{E}-02$ & $4.47 \mathrm{E}-02$ & $7.05 E-02$ & $1.07 \mathrm{E}-01$ \\
\hline TEY27 & $4.64 \mathrm{E}-05$ & $6.86 \mathrm{E}-05$ & $8.96 \mathrm{E}-05$ & $1.08 E-04$ \\
\hline TE127M & $4.73 \mathrm{E}-05$ & $7.00 \mathrm{E}-05$ & 9.15E-05 & $1.10 \mathrm{E}-04$ \\
\hline TE129 & $2.04 \mathrm{E}-21$ & $2.46 \mathrm{E}-2 \mathrm{I}$ & $2.77 \mathrm{E}-21$ & $2.94 \mathrm{E}-21$ \\
\hline TE129M & $3.14 \overline{\mathrm{E}}-21$ & $3.78 \mathrm{E}-21$ & $4.26 \mathrm{E}-21$ & $4.51 \mathrm{E}-21$ \\
\hline II 29 & $1.12 \mathrm{E}-03$ & $1.95 \mathrm{E}-03$ & $3.04 \mathrm{E}-03$ & $4.52 \mathrm{E}-03$ \\
\hline $\mathrm{CS134}$ & $5.13 \mathrm{E}+01$ & $1.55 \mathrm{E}+02$ & $3.45 \mathrm{E}+02$ & $6.97 \mathrm{E}+02$ \\
\hline CS135 & $1.53 \mathrm{E}-02$ & $2.51 \mathrm{E}-02$ & $3.76 \mathrm{E}-02$ & $5.36 \mathrm{E}-02$ \\
\hline CS137 & $3.55 E+03$ & $5.92 \mathrm{E}+03$ & $8.89 E+03$ & $1.28 \mathrm{E}+04$ \\
\hline $\mathrm{BA137M}$ & $3.36 \mathrm{E}+03$ & $5.60 \mathrm{E}+03$ & $8.41 \mathrm{E}+03$ & $1.21 \mathrm{E}+04$ \\
\hline CE14I & $2.22 \mathrm{E}-20$ & $2.46 \mathrm{E}-20$ & $2.57 E-20$ & $2.54 \mathrm{E}-20$ \\
\hline PR143 & $1.02 \mathrm{E}-55$ & $1.05 \mathrm{E}-55$ & $1.04 \mathrm{E}-55$ & $1.01 E-55$ \\
\hline CE144 & $1.51 \mathrm{E}+02$ & $2.26 \mathrm{E}+02$ & $3.01 E+02$ & $3.68 \mathrm{E}+02$ \\
\hline
\end{tabular}




\begin{tabular}{|c|c|c|c|c|}
\hline PR144 & $1.51 \mathrm{E}+02$ & $2.26 \mathrm{E}+02$ & $3.01 \mathrm{E}+02$ & $3.68 \mathrm{E}+02$ \\
\hline PR144M & $1.81 \mathrm{E}+00$ & $2.72 \mathrm{E}+00$ & $3.61 E+00$ & $4.42 \mathrm{E}+00$ \\
\hline PM147 & $2.20 \mathrm{E}+03$ & $3.30 \mathrm{E}+03$ & $4.33 \mathrm{E}+03$ & $5.26 \mathrm{E}+03$ \\
\hline PM148 & $1.60 \mathrm{E}-18$ & $2.93 \mathrm{E}-18$ & $4.08 \mathrm{E}-18$ & $5.10 \mathrm{E}-18$ \\
\hline PM148M & $2.85 \mathrm{E}-17$ & 5.21E-17 & $7.25 \mathrm{E}-17$ & $9.06 \mathrm{E}-17$ \\
\hline SM151 & $6.40 E+01$ & $8.41 \mathrm{E}+01$ & $9.96 \mathrm{E}+01$ & $1.12 \mathrm{E}+02$ \\
\hline EU152 & $1.32 \mathrm{E}-0 \mathrm{II}$ & $3.95 \mathrm{E}-01$ & $8.24 \mathrm{E}-01$ & $1.37 \mathrm{E}+00$ \\
\hline GD153 & $3.16 \mathrm{E}-05$ & $1.67 \mathrm{E}-04$ & $5.60 \mathrm{E}-04$ & $1.40 \mathrm{E}-03$ \\
\hline EU154 & $1.78 \mathrm{E}+0 \mathrm{~T}$ & $5.20 \mathrm{E}+01$ & $1.23 E+02$ & $2.66 \mathrm{E}+02$ \\
\hline EU155 & $3.07 \mathrm{E}+01$ & $4.04 \mathrm{E}+01$ & $5.29 \mathrm{E}+01$ & $7.29 \mathrm{E}+01$ \\
\hline TB160 & $1.31 \mathrm{E}-11$ & $3.78 \mathrm{E}-11$ & $8.60 \mathrm{E}-11$ & $1.73 \mathrm{E}-10$ \\
\hline & & & & \\
\hline & & & & \\
\hline FISSION PRODUCTS & & & \multicolumn{2}{|c|}{ Thermal power, watts } \\
\hline Pu240 file & MKIa $6 \%$ Pu & MKIa 9\% Pu & $\mathrm{MKla} 12 \% \mathrm{Pu}$ & MCla16\% Pu \\
\hline & & & & \\
\hline $\mathrm{H} 3$ & $4.59 \mathrm{E}-04$ & $7.79 E-04$ & $1.19 \mathrm{E}-03$ & $1.74 \mathrm{E}-03$ \\
\hline C14 & $1.38 \mathrm{E}-09$ & $2.30 \mathrm{E}-09$ & $3.46 \mathrm{E}-09$ & $4.96 \mathrm{E}-09$ \\
\hline SE79 & $4.35 \mathrm{E}-06$ & $7.20 \mathrm{E}-06$ & $1.08 \mathrm{E}-05$ & $1.53 \mathrm{E}-05$ \\
\hline KR85 & $4.46 \mathrm{E}-01$ & $7.17 \mathrm{E}-01$ & $1.04 \mathrm{E}+00$ & $1.42 \mathrm{E}+00$ \\
\hline SR 89 & $5.28 \mathrm{E}-14$ & $5.97 \mathrm{E}-14$ & $6.11 E-14$ & $5.74 \mathrm{E}-14$ \\
\hline SR90 & $3.61 \mathrm{E}+00$ & $5.79 E+00$ & $8.38 \mathrm{E}+00$ & $1.15 E+01$ \\
\hline Y90 & $1.72 \mathrm{E}+01$ & $2.77 \mathrm{E}+01$ & $4.00 \mathrm{E}+01$ & $5.48 \mathrm{E}+01$ \\
\hline$Y 91$ & $1.10 \mathrm{E}-11$ & $1.28 \mathrm{E}-11$ & $1.35 \mathrm{E}-11$ & $1.29 \mathrm{E}-11$ \\
\hline ZRO3 & $9.66 \mathrm{E}-06$ & $1.58 \mathrm{E}-05$ & $2.32 \mathrm{E}-05$ & $3.24 E-05$ \\
\hline NB93M & $4.53 \mathrm{E}-06$ & $7.48 \mathrm{E}-06$ & $1.12 \mathrm{E}-05$ & $4.59 \mathrm{E}-05$ \\
\hline ZRQ5 & $2.74 \mathrm{E}-10$ & $3.34 \mathrm{E}-10$ & $3.66 \mathrm{E}-10$ & $3.68 \mathrm{E}-10$ \\
\hline NB95 & $5.75 \mathrm{E}-10$ & $7.03 \mathrm{E}-10$ & $7.70 \mathrm{E}-10$ & $7.75 \mathrm{E}-10$ \\
\hline NB95M & $5.57 \mathrm{E}-13$ & $6.80 \mathrm{E}-13$ & $7.45 \mathrm{E}-13$ & $7.50 \mathrm{E}-13$ \\
\hline TC99. & $2.93 \mathrm{E}-04$ & $4.86 \mathrm{E}-04$ & $7.27 E-04$ & $1.04 \mathrm{E}-03$ \\
\hline RU103 & $1.07 E-18$ & $1.32 \mathrm{E}-18$ & $1.52 \mathrm{E}+18$ & $1.63 \bar{E}-18$ \\
\hline RH103M & $6.63 \mathrm{E}-20$ & $8.20 \mathrm{E}-20$ & $9.41 \mathrm{E}-20$ & $1.01 \mathrm{E}-19$ \\
\hline RU106 & $5.92 \mathrm{E}-03$ & $1.12 \mathrm{E}-02$ & $1.85 \mathrm{E}-02$ & $2.83 \mathrm{E}-02$ \\
\hline RH106. & $9.55 \mathrm{E}-01$ & $1.81 \mathrm{E}+00$ & $2.98 \mathrm{E}+00$ & $4.56 \mathrm{E}+00$ \\
\hline PD107 & $1.06 \mathrm{E}-07$ & $2.22 \mathrm{E}-07$ & $4.04 \mathrm{E}-07$ & $6.92 \mathrm{E}-07$ \\
\hline AG110 & $4.33 \mathrm{E}-07$ & $1.46 \mathrm{E}-06$ & 3.81E-06 & $8.75 \mathrm{E}-06$ \\
\hline AG110M & $7.58 \mathrm{E}-05$ & $2.56 \mathrm{E}-04$ & $6.65 \mathrm{E}-04$ & $1.53 \mathrm{E}-03$ \\
\hline CD113M & $1.66 \mathrm{E}-03$ & $2.95 \mathrm{E}-03$ & $4.72 \mathrm{E}-03$ & $7.33 \mathrm{E}-03$ \\
\hline SNI19M & $3.67 \mathrm{E}-06$ & $5.77 \mathrm{E}-06$ & $8.02 \mathrm{E}-06$ & $1.05 \mathrm{E}-05$ \\
\hline SN121M & $9.05 \mathrm{E}-06$ & $1.72 \mathrm{E}-05$ & $2.92 \mathrm{E}-05$ & $4.67 \mathrm{E}-05$ \\
\hline SN123 & $6.09 \mathrm{E}-07$ & $8.86 E-07$ & $1.14 \mathrm{E}-06$ & $1.35 \mathrm{E}-06$ \\
\hline TE123M & $7.78 \mathrm{E}-13$ & $3.49 \mathrm{E}-12$ & $1.12 \mathrm{E}-11$ & $3.14 \mathrm{E}-11$ \\
\hline SB124 & $2.97 \mathrm{E}-15$ & $6.91 \mathrm{E}-15$ & $1.32 \mathrm{E}-14$ & $2.26 \mathrm{E}-14$ \\
\hline SB125 & $2.94 \mathrm{E}-01$ & $5.05 \mathrm{E}-01$ & $7.79 \mathrm{E}-01$ & $1.14 \mathrm{E}+00$ \\
\hline TE12SM & $1.93 \mathrm{E}-02$ & $3.31 \mathrm{E}-02$ & $5.11 \mathrm{E}-02$ & $7.47 \mathrm{E}-02$ \\
\hline SN126 & $3.17 \mathrm{E}-05$ & $5.57 \mathrm{E}-05$ & $8.79 E-05$ & $1.33 \mathrm{E}-04$ \\
\hline
\end{tabular}




\begin{tabular}{|c|c|c|c|c|}
\hline SB126 & $6.58 \mathrm{E}-05$ & $1.16 \mathrm{E}-04$ & $1.82 \mathrm{E}-04$ & $2.76 \mathrm{E}-04$ \\
\hline SB126M & $3.24 \mathrm{E}-04$ & $5.69 \mathrm{E}-04$ & $8.97 \mathrm{E}-04$ & $1.36 \mathrm{E}-03$ \\
\hline TE127 & $6.26 E-08$ & $9.26 \mathrm{E}-08$ & $1.21 \mathrm{E}-07$ & $1.45 \mathrm{E}-07$ \\
\hline IE127M & $2.55 \mathrm{E}-08$ & $3.77 E-08$ & $4.92 \mathrm{E}-08$ & $5.91 \mathrm{E}-08$ \\
\hline TE129 & $7.29 \mathrm{E}-24$ & $8.79 \mathrm{E}-24$ & $9.90 \mathrm{E}-24$ & $1.05 \mathrm{E}-23$ \\
\hline TE129M & $5.50 \mathrm{E}-24$ & $6.62 \mathrm{E}-24$ & $7.47 \mathrm{E}-24$ & $7.91 \mathrm{E}-24$ \\
\hline 1129 & $5.20 \mathrm{E}-07$ & $9.01 \mathrm{E}-07$ & $1.40 \mathrm{E}-06$ & $2.09 E-06$ \\
\hline CS134 & $5.22 \mathrm{E}-01$ & $1.57 \mathrm{E}+00$ & $3.52 \mathrm{E}+00$ & $7.09 \mathrm{E}+00$ \\
\hline CS135 & $5.10 \mathrm{E}-06$ & $8.38 \mathrm{E}-06$ & $1.25 \mathrm{E}-05$ & $1.79 \mathrm{E}-05$ \\
\hline CS137 & $3.93 \mathrm{E}+00$ & $6.55 \mathrm{E}+00$ & $9.84 \mathrm{E}+00$ & $1.41 \mathrm{E}+01$ \\
\hline BA137M & $1.32 \mathrm{E}+01$ & $2.20 \mathrm{E}+01$ & $3.30 \mathrm{E}+0 \mathrm{~d}$ & $4.73 E+01$ \\
\hline CE141 & $3.24 \mathrm{E}-23$ & $3.60 \mathrm{E}-23$ & $3.77 \mathrm{E}-23$ & $3.71 \mathrm{E}-23$ \\
\hline PRI43 & $1.90 \mathrm{E}-58$ & $1.96 \mathrm{E}-58$ & $1.95 \mathrm{E}-58$ & $1.88 \mathrm{E}-58$ \\
\hline CE144 & $1.00 \mathrm{E}-01$ & $1.50 \mathrm{E}-01$ & $1.99 \mathrm{E}-01$ & $2.44 \mathrm{E}-01$ \\
\hline PR144. & $1.11 E+00$ & $1.66 \mathrm{E}+00$ & $2.21 \mathrm{E}+00$ & $2.71 \mathrm{E}+00$ \\
\hline PR144M & $6.20 \mathrm{E}-04$ & $9.30 \mathrm{E}-04$ & $1.23 \mathrm{E}-03$ & $1.51 \mathrm{E}-03$ \\
\hline PM147 & $7.88 \mathrm{E}-01$ & $1.18 \mathrm{E}+00$ & $1.55 \mathrm{E}+00$ & $1.89 E+00$ \\
\hline PM148 & $1.23 \mathrm{E}-20$ & $2.26 \mathrm{E}-20$ & $3.14 \mathrm{E}-20$ & $3.93 \mathrm{E}-20$ \\
\hline PM148M & $3.61 \mathrm{E}-19$ & $6.60 \mathrm{E}-19$ & $9.19 \mathrm{E}-19$ & $1.15 \mathrm{E}-18$ \\
\hline SM151 & $7.50 \mathrm{E}-03$ & $9.86 \mathrm{E}-03$ & $1.17 \mathrm{E}-02$ & $1.32 \mathrm{E}-02$ \\
\hline EU152 & $1.00 \mathrm{E}-03$ & $2.99 \mathrm{E}-03$ & $6.23 \mathrm{E}-03$ & $1.04 \mathrm{E}-02$ \\
\hline GD153 & $2.85 \mathrm{E}-08$ & $1.51 \mathrm{E}-07$ & $5.06 \mathrm{E}-07$ & $1.26 \mathrm{E}-06$ \\
\hline EU154 & $1.59 \mathrm{E}-0 \mathrm{I}$ & $4.65 \mathrm{E}-01$ & $1.10 \mathrm{E}+00$ & $2.38 \mathrm{E}+00$ \\
\hline EU155 & $2.23 \mathrm{E}-02$ & $2.94 \mathrm{E}-02$ & $3.84 \mathrm{E}-02$ & $5.30 \mathrm{E}-02$ \\
\hline TB160 & $1.07 \mathrm{E}-13$ & $3.08 E-13$ & $7.00 \mathrm{E}-13$ & $1.41 \mathrm{E}-12$ \\
\hline
\end{tabular}


Table G-3

ISOTOPE DATA

\begin{tabular}{|c|c|c|c|c|c|}
\hline ISOTOPE & CEDE & HALF-LIFE & See footnotes & $\frac{\text { HALF-LIFE }}{\text { SECONDS }}$ & $\frac{\text { GAMMA }}{\mathrm{KeV}}$ \\
\hline H3 & 0.000063 & 12.3 & a & $3.88 \mathrm{E}+08$ & 0 \\
\hline C14 & 0.0021 & 5730 & $\overline{\mathbf{a}}$ & $1.81 \mathrm{E}+11$ & 0 \\
\hline FE55 & 0.0026 & 2.73 & $\bar{a}$ & 86093280 & 0 \\
\hline FE59 & 0.015 & 44.51 & d & 3845664 & $\overline{1291.6}$ \\
\hline $\mathrm{CO} 60$ & 0.03 & 5.271 & $\bar{a}$ & $1.66 \mathrm{E}+08$ & 1332.5 \\
\hline N159 & 0.0027 & 76000 & $a$ & $2.4 \mathrm{E}+12$ & 0 \\
\hline N163 & 0.0063 & 100 & $a$ & $3.15 E+09$ & 0 \\
\hline SE79 & 0.0039 & 65000 & $a$ & $2.05 \mathrm{E}+12$ & 0 \\
\hline KR85 & 0 & 10.73 & $\bar{a}$ & $3.38 \mathrm{E}+08$ & 514 \\
\hline SR89 & 0.037 & 50.52 & d & 4364928 & 909.2 \\
\hline SR90 & 1.3 & 29.1 & $\mathrm{a}$ & $9.18 \mathrm{E}+08$ & 0 \\
\hline Y90 & 0.0082 & 2.67 & d - SR90 & $9.18 \mathrm{E}+08$ & 479.5 \\
\hline Y91 & 0.044 & 58.5 & $\mathrm{~d}$ & 5054400 & 1205 \\
\hline ZR93 & 0.32 & 1500000 & $\mathrm{a}$ & $4.73 \mathrm{E}+13$ & 30.4 \\
\hline ZR95 & 0.019 & 64.02 & d & 5531328 & 756.7 \\
\hline NB93M & 0.028 & 16.1 & a-ZR93** & $5.08 \mathrm{E}+08$ & 30.4 \\
\hline NB95 & 0.0045 & 34.97 & $\mathrm{~d}-\mathrm{ZR} 95^{* * *}$ & 3021408 & 765.8 \\
\hline NB95M & 0.0022 & 3.61 & d-2R95** & 311904 & 235.7 \\
\hline TC99 & 0.0075 & 213000 & $a$ & $6.72 E+12$ & 89.7 \\
\hline RU103 & 0.0078 & 39.27 & $d$ & 3392928 & .497 .1 \\
\hline $\mathrm{RH} 103 \mathrm{M}$ & $4.8 \mathrm{E}-06$ & 56.12 & $\mathrm{~m}-\mathrm{RU} 103 \mathrm{~m}$ & 3392928 & 39.8 \\
\hline RU106 & 0.44 & 1.02 & 2 & 32166720 & \\
\hline RH106 & 0.00039 & 2.18 & h-RU106 & 32166720 & 1045.8 \\
\hline PD107 & 0.013 & 650000 & $\mathbf{a}$ & $2.05 E+13$ & \\
\hline AG110 & 0 & 24.6 & $s$ & 24.6 & 657.8 \\
\hline AG110M & 0.053 & 249.8 & ह & 21582720 & 884.7 \\
\hline CD113M & 0.42 & 14.1 & $a$ & $4.45 \mathrm{E}+08$ & 263.7 \\
\hline CD115M & 0.065 & 44.6 & $d$ & 3853440 & 1290.6 \\
\hline INI13M & 0.0001 & 1.658 & $\mathrm{~h}-\mathrm{CD} 113 \mathrm{M}$ & $4.45 \mathrm{E}+08$ & 391.7 \\
\hline SN113 & 0.0039 & 115.1 &.$d$ & 9944640 & 391:7 \\
\hline SN119M & 0.0053 & 293 & d & 25315200 & 65.7 \\
\hline SN121M & 0.0063 & 55 & 2 & $1.73 \mathrm{E}+09$ & 6.3 \\
\hline SN123 & 0.03 & 129.2 & $d$ & 11162880 & 1088.6 \\
\hline TE123M & 0.0096 & 119.7 & d & 10342080 & 159 \\
\hline SB124 & 0.021 & 60.2 & d & 5201280 & 1691 \\
\hline$S B 125$ & 0.0093 & 2.76 & $a$ & 87039360 & 635.9 \\
\hline TE125M & 0.0067 & 58 & d-SB125 & 87039360 & 109.3 \\
\hline SN126 & 0.086 & 100000 & $a$ & $3.15 E+12$ & 87.6 \\
\hline SB126 & 0.01 & 12.4 & $\mathrm{~d}-\$ 126$ & $3.15 E+12$ & 694.9 \\
\hline
\end{tabular}




\begin{tabular}{|c|c|c|c|c|c|}
\hline SB126M & 0.000073 & 11 & $s-5126$ & $3.15 \mathrm{E}+12$ & 22.7 \\
\hline IE127 & 0.00069 & 9.4 & $\mathrm{~h}$ & $\cdot 33840$ & 417.9 \\
\hline TE127M & 0.019 & 109 & $\mathrm{~d}$ & 9417600 & 88.3 \\
\hline TE129 & 0.00019 & 1.16 & $\mathrm{~h}-\mathrm{I129**}$ & 4176 & 459.6 \\
\hline $\mathrm{TE} 129 \mathrm{M}$ & 0.02 & 33.6 & $d-1129^{* *}$ & 2903040 & 695.9 \\
\hline 1129 & 0.28 & 15700000 & a & $4.95 \mathrm{E}+14$ & 39.6 \\
\hline CS134 & 0.074 & 2.065 & a & 65121840 & 795.9 \\
\hline$\overline{\mathrm{CS} 135}$ & 0.0071 & 2.356 & $a$ & 74298816 & \\
\hline CS137 & 0.05 & 30.17 & $a-B A 137 M$ & $9.51 E+08$ & 661.7 \\
\hline BA137M & of & 2.552 & m & $9.51 \mathrm{E}+08$ & 661.7 \\
\hline CE141 & 0.0085 & 32.5 & $d$ & 2808000 & 145.1 \\
\hline PR143 & 0.0073 & 13.57 & $d$ & 1172448 & 742 \\
\hline CE144 & 0.36 & 284.5 & $d$ & 24580800 & 133.5 \\
\hline PR144 & 0.00011 & 7.2 & $m-\mathrm{CE} 144$ & 24580800 & 696.5 \\
\hline PR144M & 0 & 17.28 & m-CE144 & 24580800 & 2187.5 \\
\hline PM147 & 0.034 & 2.634 & $a$ & 83065824 & 121.3 \\
\hline PM148 & 0.01 & 41.3 & d & 3568320 & 630 \\
\hline PM148M & 0.017 & 5.37 & d & 463968 & 1465.1 \\
\hline SM151 - & 0.029 & 90 & $\mathbf{a}$ & $2.84 \mathrm{E}+09$ & 21.5 \\
\hline EU152 & 0.22 & 13.48 & 2 & $4.25 \mathrm{E}+08$ & 1408 \\
\hline GD153 & 0.06747 & 241.4 & d & 20856960 & 103.2 \\
\hline EU154 & 0.28 & 8.59 & $a$ & $2.71 \mathrm{E}+08$ & 1274.5 \\
\hline EU155 & 0.039 & 4.71 & $\mathrm{a}$ & $1.49 \mathrm{E}+08$ & 105.3 \\
\hline TB160 & 3.12 & 72.3 & d & 6246720 & 966.2 \\
\hline U234 & 130 & 246000 & $\mathrm{a}$ & $7.76 \mathrm{E}+12$ & \\
\hline U235 & 120 & $7.04 \mathrm{E}+08$ & $a$ & $2.22 \mathrm{E}+16$ & \\
\hline U236 & 120 & 23420000 & a & $7.39 \mathrm{E}+14$ & 7 \\
\hline U238 & 120 & 44700000 & a & $1.41 \mathrm{E}+15$ & $\div$ \\
\hline NP237 & 4.9 & 2140000 & $\mathrm{a}$ & $6.75 \mathrm{E}+13$ & \\
\hline PU238 & 300 & 87.7 & a & $2.77 \mathrm{E}+09$ & \\
\hline PU239 & 330 & 24100 & 2 & $7.6 \mathrm{E}+11$ & \\
\hline PU240 & 330 & 6560 & $a$ & $2.07 \mathrm{E}+11$ & \\
\hline PU241 & 5.7 & 14.4 & 2 & $4.54 \mathrm{E}+08$ & \\
\hline PU242 & 310 & 375000 & 3 & $1.18 \mathrm{E}+13$ & \\
\hline AM241 & 0.1027 & 432.7 & 2 & $1.36 \mathrm{E}+10$ & \\
\hline AM242 & 0.061 & 16.02 & h & 57672 & \\
\hline AM242M & 510 & 141 & $\mathrm{a}$ & $4.45 E+09$ & \\
\hline AM243 & 520 & 7370 & $\mathrm{a}$ & $2.32 \mathrm{E}+11$ & \\
\hline CM242 & 17 & 162.8 & d & 14065920 & \\
\hline CM244 & 270 & 18.1 & a & $5.71 E+08$ & \\
\hline
\end{tabular}

Time Symbols
$\mathrm{a}=$ years
1 year $=31536000$ seconds
$\mathrm{d}=$ days
1 day $=86400$ seconds
$\mathbf{h}=$ hours
1 hour $=3600$ seconds

An isotope symbol shown next to a time symbol idicates this isotope is a daughter of the isotope listed 
HNF-SD-SNF-TI-009, Rev. 1 .

Mollerus Engineering Corporation

Appendix $\mathbf{G}$

Independent Review $\sqrt{2+2}$

in the left column. 
Table G-4

\section{PROGRAM IVFUEL.XIS ROADMPA}

\begin{tabular}{|c|c|}
\hline AI & Roadmap \\
\hline$\overline{A 100}$ & Isotope data (CEDE, half-life, gamma, beta, alpha) \\
\hline A200 & Curve fitting data (from IVFUELWA.XLS \\
\hline A.200 & $\begin{array}{l}\text { Curve fitted curies, curie* } \overline{\mathrm{Kev}} \text { and Cunie }{ }^{*} \mathrm{CEDE} \text { by isotope } \\
\text { Cure fitted watts by isotope }\end{array}$ \\
\hline$\overline{\mathrm{BA} 200}$ & Isotope/watts sorting area \\
\hline $\mathrm{BA300}$ & Print sumimary tables \\
\hline
\end{tabular}


Table G-5

SIGNIFICANT ISOTOPES SORTED BY CURIES $\times$ KeV

Radioactivity in MKIV Fuel

Pu240 $=$

Time after Discharge $=$
15.74 percent

11 years
Values shown are per MTU

\begin{tabular}{|c|c|c|c|c|c|c|}
\hline \multicolumn{2}{|c|}{ Individual Isotope } & & & \multicolumn{2}{|c|}{ Cumulative, $\%$ of Total } & \\
\hline Isotope & Curies & $\mathrm{Cu} * \mathrm{Kev}$ & Cu*CEDE & Curies & $\mathrm{Cu}^{*} \mathrm{Kev}$ & Cu*CEDE \\
\hline $\operatorname{cs} 137$ & 10490.88 & 6941817.698 & 524.5441815 & 0.215703878 & 0.377940217 & 0.002812907 \\
\hline BA137M & 9916.094 & $6 5 6 \longdiv { 1 4 7 9 . 6 6 4 }$ & 0 & 0.419589471 & 0.735173315 & 0.002812907 \\
\hline Y90. & $7 \overline{771.321}$ & 3726348.605 & 63.72483538 & 0.579376217 & 0.938050582 & 0.003154637 \\
\hline$\overline{\mathrm{KR} 85}$ & 651.0065 & 334617.3564 & 0 & 0.592761613 & 0.956268484 & 0.003154637 \\
\hline EU154 & 193.9723 & 247217.6783 & 54.31224005 & 0.596749893 & 0.969727999 & 0.00344589 \\
\hline PM147 & 1821.639 & 220964.7564 & 61.93571077 & 0.634204745 & 0.981758201 & 0.003778025 \\
\hline CS134 & 198.4937 & 157981.1259 & 14.68853288 & 0.638285989 & 0.990359323 & 0.003856793 \\
\hline SB125 & 153.6475 & 97704.46075 & 1.428921977 & 0.641445148 & 0.995678743 & 0.003864456 \\
\hline RH106 & 43,36999 & 45356.3331 & 0.016914295 & 0.642336882 & 0.998148123 & 0.003864547 \\
\hline$\overline{\mathrm{PR} 144}$ & 13.89067 & 9674.854598 & 0.001527974 & 0.642622489 & 0.998674861 & 0.003864555 \\
\hline $\mathrm{CO} 60$ & 6.582655 & 8771.387454 & 0.197479642 & 0.642757836 & 0.99915241 & 0.003865614 \\
\hline EU155 & 41.79158 & 4400.653394 & 1.629871627 & 0.643617116 & 0.999391999 & 0.003874354 \\
\hline TE125M & 37.48302 & 4096.894102 & 0.251136235 & 0.644387807 & 0.99961505 & 0.003875701 \\
\hline SM151 & 100.0078 & 2150.167644 & 2.900226125 & 0.646444075 & 0.999732114 & 0.003891254 \\
\hline CE144 & 13.89067 & 1854.405009 & 5.000642721 & 0.646729682 & 0.999833075 & 0.00391807 \\
\hline EU152 & 1.082745 & 1524.504645 & 0.238203851 & 0.646751945 & 0.999916075 & 0.003919347 \\
\hline CD113M & 3.704964 & 976.9991244 & 1.556085067 & 0.646828123 & 0.999969267 & 0.003927692 \\
\hline PR144M & 0.16668 & 364.6123852 & 0 & 0.64683155 & 0.999989118 & 0.003927692 \\
\hline TC99 & 1.83837 & 164.9018068 & 0.013787776 & 0.646869349 & 0.999998096 & 0.003927766 \\
\hline SB126 & 0.014543 & 10.10625547 & 0.000145435 & 0.646869648 & 0.999998646 & 0.003927767 \\
\hline & & & 186477.59 & & & \\
\hline & & & & & & \\
\hline
\end{tabular}




\section{SIGNIFICANT ISOTOPES SORTED BY CURIES $\times$ CEDE}

Radioactivity in MKIV Fuel

$\mathrm{Pu} 240=$

Time after discharge $=$
16.72 percent 16 years
Values shown are per MTU

\begin{tabular}{|l|r|r|r|r|r|r|}
\hline Individual Isotope & & & \multicolumn{1}{|c|}{ Cumulative, \% of Total } & \\
\hline Isotope & Curies & Cu*Kev & Cu*CEDE & Curies & Cu*KeV & Cu*CEDE \\
\hline PU239 & 154.8357 & $0.00 \mathrm{E}+00$ & $5.11 \mathrm{E}+04$ & $0.343 \%$ & $0.000 \%$ & $26.229 \%$ \\
\hline PU238 & 161.5706 & $0.00 \mathrm{E}+00$ & $4.85 \mathrm{E}+04$ & $0.701 \%$ & $0.000 \%$ & $51.111 \%$ \\
\hline PU241 & 7557.049 & $0.00 \mathrm{E}+00$ & $4.31 \mathrm{E}+04$ & $17.448 \%$ & $0.000 \%$ & $73.223 \%$ \\
\hline PU240 & 119.8451 & $0.00 \mathrm{E}+00$ & $3.95 \mathrm{E}+04$ & $17.714 \%$ & $0.000 \%$ & $93.525 \%$ \\
\hline SR90 & 7539.69 & $0.00 \mathrm{E}+00$ & $9.80 \mathrm{E}+03$ & $34.422 \%$ & $0.000 \%$ & $98.556 \%$ \\
\hline CM244 & 6.782464 & $0.00 \mathrm{E}+00$ & $1.83 \mathrm{E}+03$ & $34.437 \%$ & $0.000 \%$ & $99.496 \%$ \\
\hline CS137 & 10405.87 & $6.89 \mathrm{E}+06$ & $5.20 \mathrm{E}+02$ & $57.497 \%$ & $39.085 \%$ & $99.764 \%$ \\
\hline AM242M & 0.289204 & $0.00 \mathrm{E}+00$ & $1.47 \mathrm{E}+02$ & $57.498 \%$ & $39.085 \%$ & $99.839 \%$ \\
\hline Y90 & 7540.417 & $3.62 \mathrm{E}+06$ & $6.18 \mathrm{E}+01$ & $74.208 \%$ & $59.609 \%$ & $99.871 \%$ \\
\hline U234 & 0.386429 & $0.00 \mathrm{E}+00$ & $5.02 \mathrm{E}+01$ & $74.208 \%$ & $59.609 \%$ & $99.897 \%$ \\
\hline EU154 & 158.9324 & $2.03 \mathrm{E}+05$ & $4.45 \mathrm{E}+01$ & $74.561 \%$ & $60.759 \%$ & $99.920 \%$ \\
\hline U238 & 0.33128 & $0.00 \mathrm{E}+00$ & $3.98 \mathrm{E}+01$ & $74.561 \%$ & $60.759 \%$ & $99.940 \%$ \\
\hline AM241 & 340.3458 & $0.00 \mathrm{E}+00$ & $3.50 \mathrm{E}+01$ & $75.316 \%$ & $60.759 \%$ & $99.958 \%$ \\
\hline AM243 & 0.047683 & $0.00 \mathrm{E}+00$ & $2.48 \mathrm{E}+01$ & $75.316 \%$ & $60.759 \%$ & $99.971 \%$ \\
\hline PU242 & 0.061705 & $0.00 \mathrm{E}+00$ & $1.91 \mathrm{E}+01$ & $75.316 \%$ & $60.759 \%$ & $99.980 \%$ \\
\hline PM147 & 51.0072 & $6.20 \mathrm{E}+04$ & $1.74 \mathrm{E}+01$ & $76.448 \%$ & $61.110 \%$ & $99.989 \%$ \\
\hline U236 & 0.071531 & $0.00 \mathrm{E}+00$ & $8.58 \mathrm{E}+00$ & $76.448 \%$ & $61.110 \%$ & $99.994 \%$ \\
\hline CS134 & 45.13431 & $3.59 \mathrm{E}+04$ & $3.34 \mathrm{E}+00$ & $76.548 \%$ & $61.314 \%$ & $99.996 \%$ \\
\hline SM151 & 98.99248 & $2.13 \mathrm{E}+03$ & $2.87 \mathrm{E}+00$ & $76.768 \%$ & $61.326 \%$ & $99.997 \%$ \\
\hline U235 & 0.012616 & $0.00 \mathrm{E}+00$ & $1.51 \mathrm{E}+00$ & $76.768 \%$ & $61.326 \%$ & $99.998 \%$ \\
\hline & & & & & & \\
\hline TOTAI & $4.51 \mathrm{E}+04$ & $1.76 \mathrm{E}+07$ & $1.95 \mathrm{E}+05$ & & & \\
\hline & & & & & & \\
\hline
\end{tabular}


Table G-7

\section{HEAT GENERATION IN MKIV FUEL}

Pu $240=$

Time after discharge $=11$ years

\begin{tabular}{|l|r|r|r|r|}
\hline \multicolumn{1}{|c|}{ Individual Isotope } & \multicolumn{3}{c|}{ Cumulative } \\
\hline \multicolumn{1}{|c|}{ Isotope } & Watts/MTU & \% of TOTAL & Watts/MTU & \% of TOTAI \\
\hline H3 & $1.35 \mathrm{E}-03$ & $0.00 \%$ & 0.001 & $0.00 \%$ \\
\hline C14 & $-8.19 \mathrm{E}-06$ & $0.00 \%$ & 0.001 & $0.00 \%$ \\
\hline FE55 & $3.23 \mathrm{E}-04$ & $0.00 \%$ & 0.002 & $0.00 \%$ \\
\hline CO60 & $1.02 \mathrm{E}-01$ & $0.08 \%$ & 0.103 & $0.08 \%$ \\
\hline NI59 & $1.10 \mathrm{E}-06$ & $0.00 \%$ & 0.103 & $0.08 \%$ \\
\hline N163 & $1.30 \mathrm{E}-03$ & $0.00 \%$ & 0.104 & $0.08 \%$ \\
\hline SE79 & $1.37 \mathrm{E}-05$ & $0.00 \%$ & 0.104 & $0.08 \%$ \\
\hline KR85 & $9.75 \mathrm{E}-01$ & $0.77 \%$ & 1.080 & $0.85 \%$ \\
\hline SR89 & $1.10 \mathrm{E}-21$ & $0.00 \%$ & 1.080 & $0.85 \%$ \\
\hline SR90 & $9.02 \mathrm{E}+00$ & $7.09 \%$ & 10.097 & $7.94 \%$ \\
\hline Y90 & $4.31 \mathrm{E}+01$ & $33.85 \%$ & 53.169 & $41.79 \%$ \\
\hline Y91 & $2.72 \mathrm{E}-18$ & $0.00 \%$ & 53.169 & $41.79 \%$ \\
\hline ZR93 & $2.92 \mathrm{E}-05$ & $0.00 \%$ & 53.169 & $41.79 \%$ \\
\hline ZR95 & $3.00 \mathrm{E}-16$ & $0.00 \%$ & 53.169 & $41.79 \%$ \\
\hline NB93M & $1.24 \mathrm{E}-05$ & $0.00 \%$ & 53.169 & $41.79 \%$ \\
\hline NB95 & $0.00 \mathrm{E}+00$ & $0.00 \%$ & 53.169 & $41.79 \%$ \\
\hline NB95M & $0.00 \mathrm{E}+00$ & $0.00 \%$ & 53.169 & $41.79 \%$ \\
\hline TC99 & $9.22 \mathrm{E}-04$ & $0.00 \%$ & 53.170 & $41.79 \%$ \\
\hline RU103 & $0.00 \mathrm{E}+00$ & $0.00 \%$ & 53.170 & $41.79 \%$ \\
\hline RH103M & $0.00 \mathrm{E}+00$ & $0.00 \%$ & 53.170 & $41.79 \%$ \\
\hline & & & & \\
\hline TOTAI & $1.27 \mathrm{E}+02$ & & & \\
\hline
\end{tabular}


DISTRIBUTION SHEET

\begin{tabular}{|c|c|c|c|c|c|}
\hline \multirow{2}{*}{$\begin{array}{l}\text { To } \\
\text { Distribution }\end{array}$} & \multirow{2}{*}{\multicolumn{3}{|c|}{$\begin{array}{l}\text { From } \\
\text { Process Engineering }\end{array}$}} & \multicolumn{2}{|l|}{ Page 1 of 1} \\
\hline & & & & \multicolumn{2}{|l|}{ Date $1 / 6 / 98$} \\
\hline \multicolumn{4}{|l|}{ Project Title/Work Order } & \multicolumn{2}{|l|}{ EDT No. } \\
\hline \multicolumn{4}{|c|}{$\begin{array}{l}\text { 105-K Basin Material Design Basis Feed Description for Spent } \\
\text { Nuclear Fuel Project Facilities }\end{array}$} & \multicolumn{2}{|c|}{ ECN No. 645037} \\
\hline Name & MSIN & $\begin{array}{l}\text { Text } \\
\text { With All } \\
\text { Attach. }\end{array}$ & Text Only & $\begin{array}{l}\text { Attach./ } \\
\text { Appendix } \\
\text { Only }\end{array}$ & $\begin{array}{l}\text { EDT/ECN } \\
\text { Only }\end{array}$ \\
\hline
\end{tabular}

\section{DE\&S Hanford}

C. J. Alderman

R. B. Baker

D. E. Ball

D. W. Bergman

K. H. Bergsman

C. Defigh-Price

J. I. Dieh1

D. R. Duncan

J. R. Frederickson

R. G. Gant

L. H. Goldmann

J. W. Osborne

A. T. Kee

P. G. LeRoy

M. K. Mahaffey

R. H. Meichle

R. P. Omberg

K. L. Pearce

A. N. Praga

W. H. Rasin

M. A. Reilly

R. P. Ruth

E. J. Shen

D. L. Sherre11

D. W. Smith

K. E. Smith

J.. A. Swenson .

C. A. Thompson

J. E. Turnbaugh

Centrat FiTes (orig. + 1)

SNF Project Files

\section{FDH}

W. D. Gallo

E. W. Gerber:

R. L. McCormack

\section{FDNW}

R. D. Crowe

L. J. Garvin

D. A. Smith

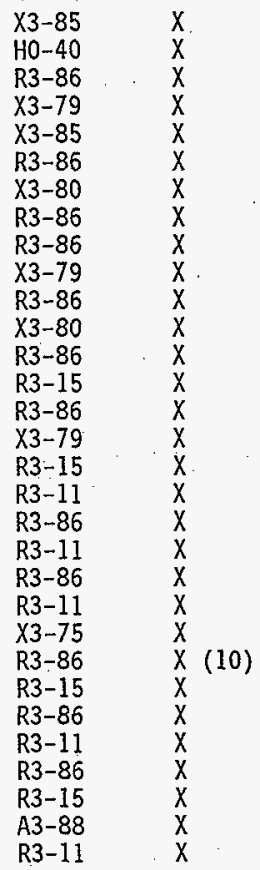

R3-11

R3-11

R3-86.

$x$

$x$
R3-11

R3-11

R3-11 $x$
$X$
$x$ 
NHC

G. D. Bazinet

S8-06

R3-86

R3-86

H5-49

J. P. Sloughter

H5-61

$X$
$X$
$X$
$X$
$X$

RFSH

F. M. Coony.

H6-06

$X$

SGN Eurisys

A. L. Pajunen

R3-86

X

XWEST

B.D. Lorenz

R3-I1 X 